UNIVERSIDADE DE SÃO PAULO

FACULDADE DE FILOSOFIA, LETRAS E CIÊNCIAS HUMANAS

ARIANE DUTRA FANTE GODOY

Dicionário multilíngue de termos

do setor feirístico: português, inglês, francês e italiano 


\title{
Dicionário multilíngue de termos do setor feirístico: português, inglês, francês e italiano
}

\author{
Versão Corrigida
}

Tese apresentada à Faculdade de Filosofia, Letras e Ciências Humanas da Universidade de São Paulo como pré-requisito para a obtenção do título de Doutora em Letras.

Área de Concentração: Estudos da Tradução

Orientadora: Profa. Dra. Adriana Zavaglia 
Autorizo a reprodução e divulgação total ou parcial deste trabalho, por qualquer meio convencional ou eletrônico, para fins de estudo e pesquisa, desde que citada a fonte.

Catalogação na Publicação

Serviço de Biblioteca e Documentação

Faculdade de Filosofia, Letras e Ciências Humanas da Universidade de São Paulo

G588d Godoy, Ariane Dutra Fante

Dicionário multilíngue de termos do setor

feirístico: português, inglês, francês e italiano/

Ariane Dutra Fante Godoy ; orientadora Adriana

Zavaglia. - São Paulo, 2019.

$340 \mathrm{f}$

Tese (Doutorado) - Faculdade de Filosofia, Letras e Ciências Humanas da Universidade de São Paulo. Departamento de Letras Modernas. Área de concentração: Estudos da Tradução.

1. terminologia. 2. tradução. 3. feiras. 4. comércio exterior. 5. variação. I. Zavaglia, Adriana, orient. II. Título. 


\section{ENTREGA DO EXEMPLAR CORRIGIDO DA TESE}

\section{Termo de Ciência e Concordância da orientadora}

Nome da aluna: Ariane Dutra Fante Godoy

Data da defesa: 24/ 05/ 2019

Nome da Profa. Orientadora: Profa. Dra. Adriana Zavaglia

Nos termos da legislação vigente, declaro ESTAR CIENTE do conteúdo deste EXEMPLAR CORRI GI DO elaborado em atenção às sugestões dos membros da comissão Julgadora na sessão de defesa do trabalho, manifestando-me plenamente favorável ao seu encaminhamento e publicação no Portal Digital de Teses da USP.

São Paulo, 24/07/2019

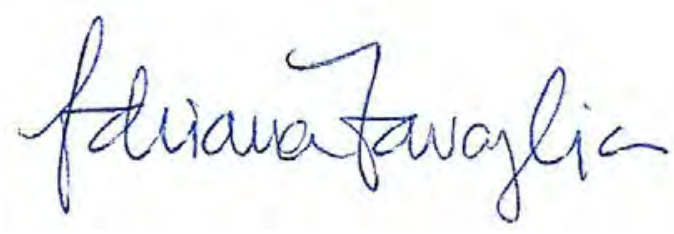

(Assinatura da Orientadora) 
GODOY, Ariane Dutra Fante. Dicionário multilíngue de termos do setor feirístico: português, inglês, francês e italiano. 2019. 340 f. Tese (Doutorado em Estudos da Tradução) - Faculdade de Filosofia, Letras e Ciências Humanas, Universidade de São Paulo, São Paulo, 2019.

Aprovado em: 24 de maio de 2019.

Banca Examinadora

Profa. Dra.: Ieda Maria Alves

Instituição: Universidade de São Paulo (USP)

Julgamento: Aprovada

Assinatura:

Profa. Dra.: Maria da Graça Krieger

Instituição: Universidade do Vale do Rio dos Sinos (UNISINOS)

Julgamento: Aprovada

Assinatura:

Profa. Dra.: Tinka Reichmann

Instituição: Universidade Leipzig

Julgamento: Aprovada

Assinatura: 
DEDICATÓRIA

Ao Creador que nos proporcionou mais esta realização. 


\section{AGRADECIMENTOS}

À Profa. Dra. Adriana Zavaglia pela orientação, dedicação, doação, apoio, ajuda e sábios ensinamentos; sem ela este trabalho não teria chegado onde chegou;

Às Professoras Ieda Maria Alves, Maria da Graça Krieger e Tinka Reichmann pela participação na banca e valiosas contribuições no exame de qualificação;

Aos Professores dos estágios de pesquisa no exterior: Ana Frankenberg-Garcia (University of Surrey, UK), Isabelle Oliveira (Université Sorbonne Nouvelle Paris 3, Paris) e, especialmente, Silvia Bernardini, Eros Zanchetta e Claudia Lecci (Università di Bolonha, Forlì, Itália);

Aos Professores do Programa de Pós-Graduação em Estudos da Tradução, em especial ao Prof. Dr. John Milton pela oportunidade, generosidade e gentileza em revisar o projeto de estágio de pesquisa no exterior para o inglês; à Profa. Dra. Lenita Esteves pela supervisão do Estágio de Docência PAE e à Profa. Dra. Angela Zucchi pela atenção e bons conselhos, quando ainda não era aluna do Doutorado;

À Coordenação de Aperfeiçoamento de Pessoal de Nível Superior (CAPES) pelo auxílio financeiro nos primeiros oito meses de pesquisa;

À Fundação de Amparo à Pesquisa do Estado de São Paulo (FAPESP) pelo apoio financeiro (processo $\mathrm{n}^{\circ}$ 2015/06562-6) e Bolsa de Estágio de Pesquisa no Exterior (processo $\mathrm{n}^{\circ}$ 2016/20172-9);

Às organizadoras de feiras no Brasil e no exterior que gentilmente me cederam tempo e compartilharam conhecimentos contribuindo com o resultado da pesquisa;

Ao Paul Filkin que gentilmente me ajudou a recuperar o dicionário quando o SDL MultiTerm parou de funcionar;

Aos funcionários do DLM e da FFLCH que sempre responderam prontamente às solicitações;

À minha mãe, Maria das Graças da Silva Pedro, pelo apoio incondicional e incentivo durante todo o percurso;

Ao Creador pela oportunidade de amadurecimento espiritual por meio das inúmeras experiências vivenciadas durante este trabalho;

À minha família e a todos que colaboraram, direta ou indiretamente, para a concretização deste trabalho, minha gratidão e amor... 


\section{RESUMO}

O Setor Feirístico tem grande relevância no cenário econômico nacional e internacional e está em constante expansão. Desse modo, a participação em feiras internacionais tornou-se o portão de entrada de produtos brasileiros no mercado externo por meio das exportações. Durante pesquisa realizada em nível de mestrado (GODOY, 2014), elaboramos um glossário bilíngue português-inglês/inglês-português dos termos fundamentais do setor feirístico. Dando continuidade a esse trabalho, o objetivo geral da pesquisa de doutorado é analisar a terminologia multilíngue português-inglês-francês-italiano desse setor, mais especificamente dos termos utilizados durante o processo de preparação, participação e pós-feira, tendo como objetivo específico a elaboração de um dicionário terminológico multilíngue para uso de profissionais, pesquisadores, estudantes das áreas de comércio exterior e relações internacionais e, especialmente, tradutores e intérpretes. A pesquisa está fundamentada nos conceitos e princípios da Terminologia, mais especificamente da Terminologia Multilíngue e Equivalência Terminológica (DUBUC, 1985, 1992), da Teoria Comunicativa da Terminologia (CABRÉ, 1993, 1999), da Socioterminologia (GAUDIN, 1993), com especial atenção para a Variação Terminológica (FAULSTICH, 1998, 2001), e da Linguística de Corpus (SINCLAIR, 1966) com apoio em BERBER SARDINHA (2004). Para desenvolver este trabalho, reunimos corpora em português, inglês, francês e italiano (livros, artigos e revistas especializados, estudo de mercado das feiras, guias e manuais do expositor, trabalhos acadêmicos, manuais de participação em feiras produzidos por órgãos públicos e privados e leis sobre feiras). Para a coleta dos termos utilizamos o software para tratamento de corpora WordSmith tools (versão 6.0), desenvolvido por Mike Scott (2012), e os armazenamos em fichas terminológicas criadas com o apoio das ferramentas computacionais Access (2010) e SDL MultiTerm (2017). Os 311 termos estudados em cada língua foram analisados em seus contextos de uso e os ganchos terminológicos levantados para a busca e o estabelecimento das equivalências nas quatro línguas. Considerando a relevância da participação em feiras nacionais e internacionais para o crescimento da economia interna e para a expansão das exportações, nosso trabalho será útil tanto para os profissionais do setor quanto para pesquisadores, estudantes, tradutores e intérpretes que produzam textos nas línguas alvo de nosso estudo.

PALAVRAS-CHAVE: Terminologia Multilíngue; Tradução; Feiras; Comércio Exterior 


\begin{abstract}
The trade show sector is of considerable importance in the Brazilian and international economic environment and it is constantly expanding. Therefore, participation in international trade shows has become the gateway for Brazilian products to reach foreign markets through exports. In an MA study (GODOY, 2014) we developed a bilingual glossary (portugueseenglish/english-portuguese) of key terms of the trade show sector. Following on from this study, the overall aim of this $\mathrm{PhD}$ is to analyze the multilingual terminology (portuguese-englishfrench-italian) of this sector, more specifically the terms used during the process of preparation, participation and post-show, with the specific goal of compiling a terminological dictionary to be used by professionals, researchers, students of foreign trade and international relations areas as well as translators and interpreters. The study is based on Terminology concepts and principles, specifically the Multilingual Terminology and Terminological Equivalence (DUBUC 1985, 1992), the Communicative Theory of Terminology (CABRÉ, 1993, 1999), Socioterminology (GAUDIN, 1993), with special attention to Terminological Variation (FAUSTICH, 1998, 2001), and Corpus Linguistics (SINCLAIR, 1966; BERBER SARDINHA, 2004). To develop this work, we gathered corpora in portuguese, english, french and italian (books, specialized articles and magazines, market studies of trade shows, guides and manuals for exhibitors, academic papers, trade show manuals produced by public and private agencies and legislation on trade). To collect the terms WordSmith software (version 6.0) developed by Mike Scott (2012) was used and the key terms were stored in terminological records created from Microsoft Access (2010) and SDL MultiTerm (2017). The 311 terms studied in each language were analyzed in their contexts of use and terminological links used in the pursuit and establishment of equivalences in the four languages. This study emphasises the importance of participating in national and international trade shows for the growth of the domestic economy and the expansion of exports and helps professionals who work in this field, researchers, students, translators and interpreters who produce texts and translate from or into the languages of this study.
\end{abstract}

KEYWORDS: Multilingual Terminology; Translation; Trade Show; Foreign Trade 


\section{RÉSUMÉ EN FRANÇAIS}

Le secteur feiristique revêt une grande importance dans le scénario économique national et international et est en expansion constante. De cette manière, la participation à des foires internationales est devenue la porte d'entrée des produits brésiliens sur le marché étranger par le biais des exportations. Au cours de recherches menées au niveau de Master (GODOY, 2014), nous avons développé un glossaire bilingue portugais-anglais/anglais-portugais de termes fondamentaux du secteur feiristique. Poursuivant ce travail, l'objectif général de la recherche de Doctorat est analyser la terminologie multilingue portugais-anglais-français-italien de ce secteur, plus spécifiquement les termes utilisés au cours du processus de préparation, de participation et d'après foire, avec l'objectif spécifique d'élaborer un dictionnaire terminologique multilingue pour l'utilisation des professionnels, chercheurs, étudiants dans les domaines du commerce extérieur et relations internationales et des traducteurs et interprètes. La recherche est basée sur les concepts et les principes de la Terminologie, plus spécifiquement la Terminologie Multilingue et Équivalence Terminologique (DUBUC, 1985, 1992), de la Théorie Communicative de la Terminologie (CABRÉ, 1993, 1999), de la Socioterminologie (GAUDIN, 1993), avec une attention particulière à la Variation Terminologique (FAULSTICH, 1998, 2001), et de la Linguistique de Corpus (SINCLAIR, 1966) avec soutien à BERBER SARDINHA (2004). Pour développer ce travail, nous avons assemblé des corpus en portugais, anglais, français et italien (livres, articles et magazines spécialisés, études de marché des foires, manuels des exposants, papiers académiques, manuels de participation à des foires produites par des organismes publics et privés et lois sur les foires). Pour la collection des termes, nous avons utilisé le software WordSmith tools (version 6.0), développé par Mike Scott (2012), et nous avons les stocké dans des fichiers terminologiques créés à l'aide de Access (2010) et SDL MultiTerm (2017). Les 311 termes étudiés dans chaque langue ont été analysés dans leurs contextes d'utilisation et les crochets terminologiques soulevés pour la recherche et l'établissement des équivalences dans le quatre langues. Considérant la pertinence de la participation à des foires nationales et internationales pour la croissance de l'économie nationale et expansion des exportations, notre travail sera utile à la fois aux professionnels du secteur et aux chercheurs, étudiants, traducteurs et interprètes qui produisent des textes dans les langues cibles de notre étude.

MOTS-CLÉS : Terminologie Multilingue; Traduction; Foires; Commerce Extérieur 


\section{L’ABSTRACT IN ITALIANO}

Il settore fieristico ha una grande rilevanza nello scenario economico nazionale ed internazionale ed è in costante espansione. In questo modo, la partecipazione a fiere internazionale divenne la porta di accesso dei prodotti brasiliani al mercato estero attraverso le esportazioni. Durante la ricerca condotta a livello di Master (GODOY, 2014) abbiamo sviluppato un glossario bilingue portoghese-inglese/inglese-portoghese dei termini fondamentali del settore fieristico. Continuando questo lavoro, l'obiettivo generale della ricerca di Dottorato è analizzare la terminologia multilingue portoghese-inglese-francese-italiano di questo settore più specificamente i termini usati durante il processo di preparazione, partecipazione e post-fiera, con l'obiettivo specifico di elaborare un dizionario terminologico plurilingue per l'uso di professionisti del settore, ricercatori e studenti delle aree del commercio estero e delle relazioni internazionali e dei traduttori ed interpreti. La ricerca si basa sui concetti e sui principi di Terminologia più specificamente la Terminologia Multilingue ed Equivalenza Terminologica (DUBUC, 1985, 1992), la Teoria Comunicativa della Terminologia (CABRÉ, 1993, 1999), la Socioterminologia (GAUDIN, 1993), con particolare attenzione alla Variazione Terminologica (FAULSTICH, 1998, 2001), e la Corpus Linguistica (SINCLAIR, 1966) con supporto in BERBER SARDINHA (2004). Per sviluppare questo lavoro, abbiamo riunito i corpora in portoghese, inglese, francese ed italiano (libri, articoli e riviste specializzati, studio di mercato delle fiere, manuali degli espositori, documenti accademici, manuali di partecipazione alle fiere prodotti da enti pubblici e privati e leggi sulle fiere). Per la raccolta dei termini abbiamo utilizzato il software per il trattamento dei corpora WordSmith tools (versione 6.0), sviluppato da Mike Scott (2012) e li abiamo archiviati in fogli terminologici creati con il supporto di Access 2010 e SDL MultiTerm (2017). I 311 termini studiati in ciascuna lingua sono stati analizzati nei loro contesti di utilizzo ed i ganci terminologici sollevati per la ricerca e la costituzione delle equivalenze nelle quatro lingue. Considerando l'importanza della partecipazione alle fiere nazionali ed internazionali per la crescita dell'economia domestica e per l'espansione delle esportazioni, il nostro lavoro sarà utile sia ai professionisti del settore che ai ricercatori, studenti, traduttori ed interpreti che producono testi nelle lingue di destinazione del nostro studio.

PAROLE CHIAVE: Terminologia Multilingue; Traduzione; Fiere; Commercio Estero 


\section{LISTA DE FIGURAS}

Figura 1: Feiras e Exposições realizadas por ano na França .............................................. 31

Figura 2: Porcentagem de expositores que realizam negócios em feiras e exposições ........ 33

Figura 3: Estudos de Tradução: Pura e Aplicada ..................................................................... 48

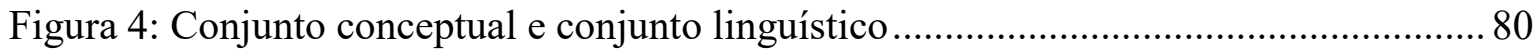

Figura 5: Sistema organizacional das feiras em português............................................ 120

Figura 6: Relação hiperonímia/hiponímia/co-hiponímia.................................................. 148

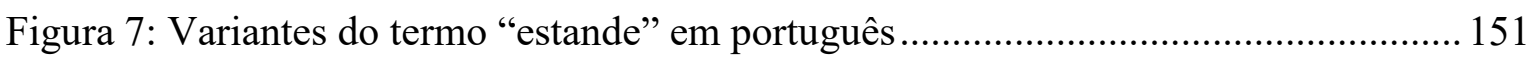

Figura 8: Variantes do termo stand em inglês ............................................................... 152

Figura 9: Variantes do termo stand em francês ................................................................... 153

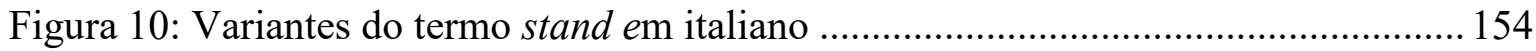

Figura 11: Relação hiperonímia-hiponímia-sinonímia em 3 níveis ................................. 161

Figura 12: Relação hiperonímia-hiponímia-sinonímia em 2 níveis ............................... 162

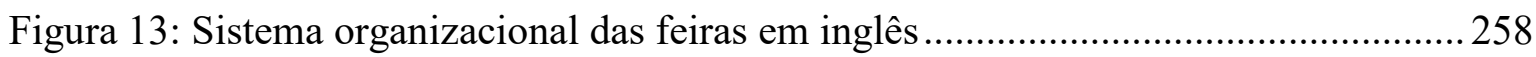

Figura 14: Sistema organizacional das feiras em francês ................................................ 258

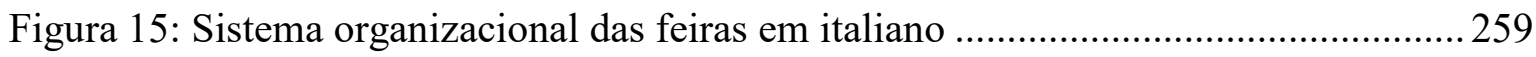




\section{LISTA DE GRÁFICOS}

Gráfico 1: Relação entre o orçamento utilizado e a participação em feiras ........................ 35

Gráfico 2: Número de feiras italianas no exterior em 2014 por país ................................... 39

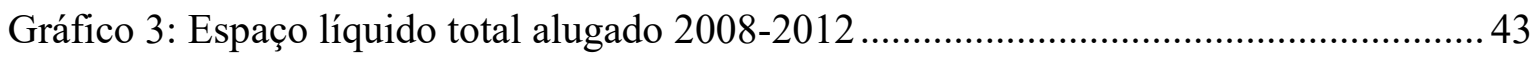




\section{LISTA DE TABELAS}

Tabela 1: 15 países responsáveis por $80 \%$ do espaço de exposição coberto mundial......... 40

Tabela 2: Principais feiras realizadas na Itália e França.......................................................... 41

Tabela 3: Espaço líquido total alugado pelos 10 principais mercados ................................ 42

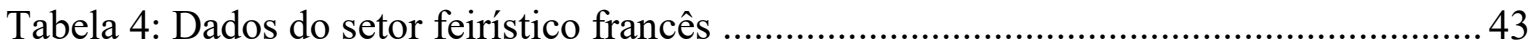

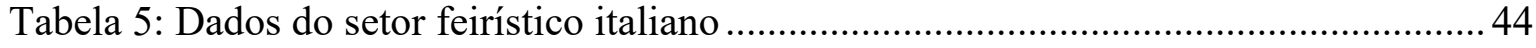

Tabela 6: Total de exposições realizadas na América Latina por país ................................. 45

Tabela 7: Informações sobre os corpora de estudo em inglês ......................................... 107

Tabela 8: Word Sketch - Colocados do termo stand I ................................................... 108

Tabela 9: Word Sketch - Colocados do termo stand II................................................... 109

Tabela 10: Word Sketch - Colocados do termo stand III ............................................. 110

Tabela 11: Informações sobre os corpora de estudo em italiano ...................................... 111

Tabela 12: Word Sketch - Colocados para o termo fiera ................................................ 112

Tabela 13: Informações sobre os corpora de estudo em francês ...................................... 113

Tabela 14: Sketch Engine - lista de termos simples e complexos em francês I................. 114

Tabela 15: Sketch Engine - lista de termos simples e complexos em francês II .............. 115

Tabela 16: Sketch Engine - lista de termos simples e complexos em francês III .............. 116 


\section{LISTA DE QUADROS}

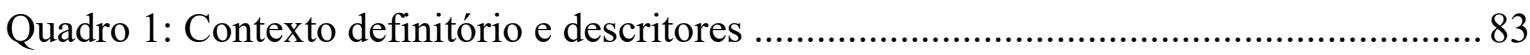

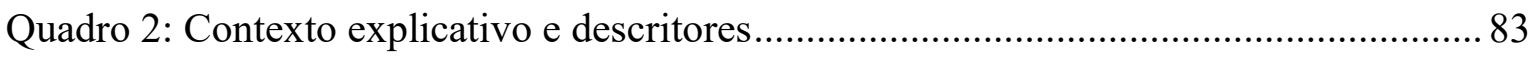

Quadro 3: Modelo de microestrutura de verbete preferencial ......................................... 121

Quadro 4: Modelo de microestrutura de verbete remissivo ........................................... 122

Quadro 5: Quadro-resumo da metodologia utilizada na pesquisa ................................... 124

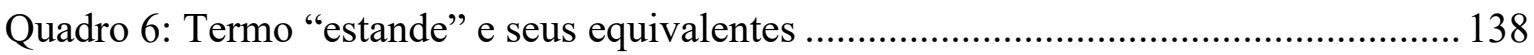

Quadro 7: Termo "área livre” e seus equivalentes .......................................................... 138

Quadro 8: Termo "estande coletivo" e seus equivalentes ............................................... 139

Quadro 9: Termo "estande com mezanino" e seus equivalentes ...................................... 139

Quadro 10: Termo "estande com piso superior" ........................................................... 139

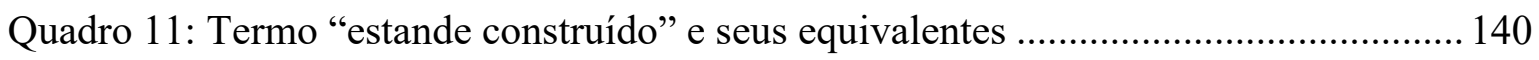

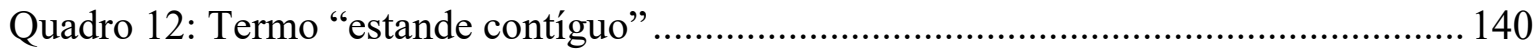

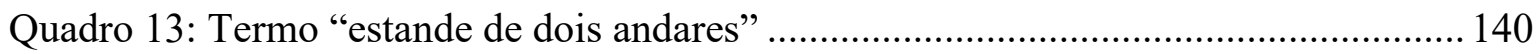

Quadro 14: Termo "estande de esquina" e seus equivalentes ....................................... 140

Quadro 15: Termo "estande ilha" e seus equivalentes .................................................... 141

Quadro 16: Estrangeirismos encontrados em português ................................................ 143

Quadro 17: Estrangeirismos encontrados em francês...................................................... 143

Quadro 18: Estrangeirismos encontrados em italiano ................................................... 143

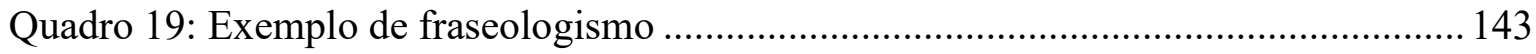

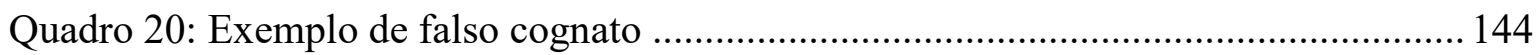

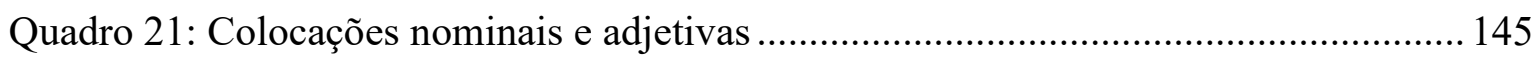

Quadro 22: Estrutura morfossintática e léxico-semântica dos termos .............................. 145

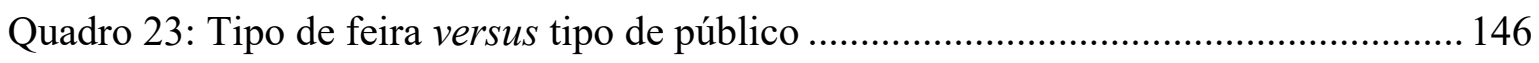

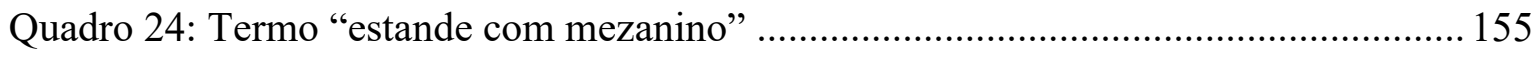

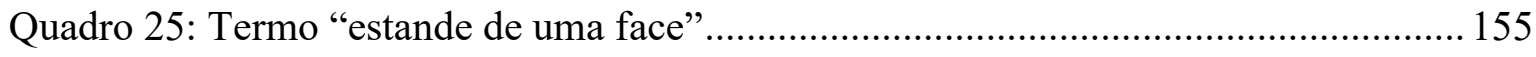

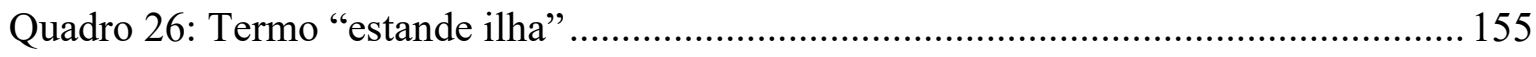

Quadro 27: Variantes coocorrentes (sinônimos) ……...................................................... 156

Quadro 28: Constituição interna das unidades fraseológicas em português....................... 164

Quadro 29: Constituição interna das unidades fraseológicas em inglês........................... 164

Quadro 30: Constituição interna das unidades fraseológicas em francês........................... 164

Quadro 31: Constituição interna das unidades fraseológicas em italiano ......................... 165

Quadro 32: Ficha terminológica nas quatro línguas ........................................................256 
INTRODUÇÃO.............................................................................................................................18

\section{A IMPORTÂNCIA DA PARTICIPAÇÃO EM FEIRAS DE NEGÓCIOS NACIONAIS}

E INTERNACIONAIS: ASPECTOS GERAIS E DADOS ESPECÍFICOS

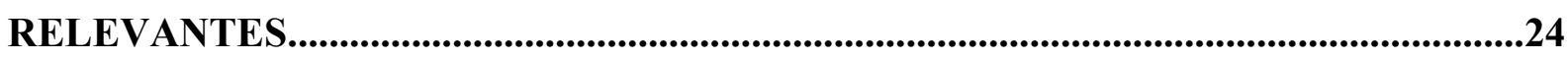

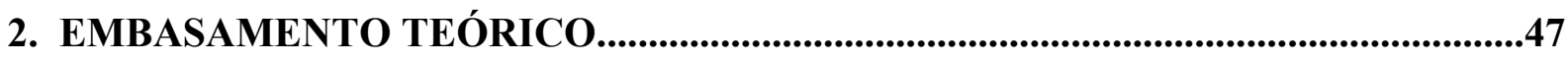

2.1 Tradução e Terminologia: o lugar e as bases da pesquisa ........................................... 47

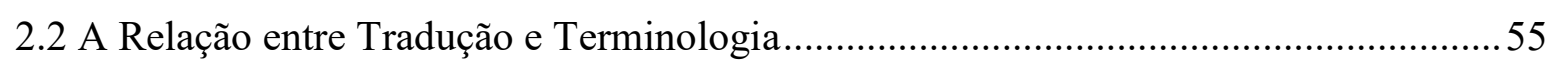

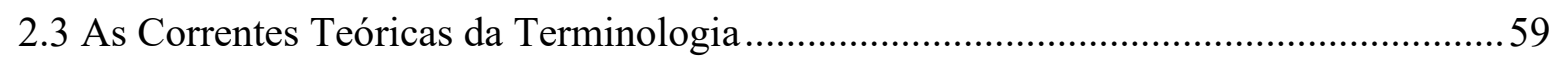

2.4 As Obras Terminográficas: Os Dicionários Terminológicos Multilíngues....................68

2.5 A Terminologia Multilíngue e a Equivalência Terminológica.................................... 77

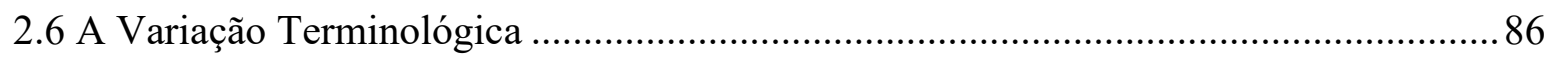

2.7 A Contribuição da Linguística de Corpus ................................................................ 91

2.8 As Unidades Fraseológicas nas Feiras de Negócios.................................................. 98

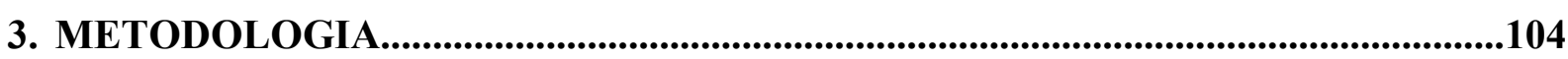

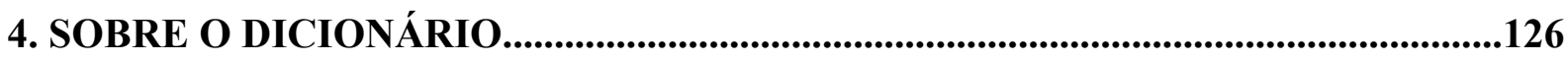

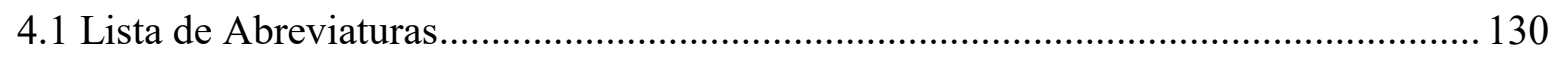

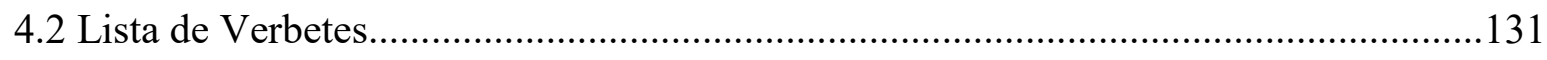

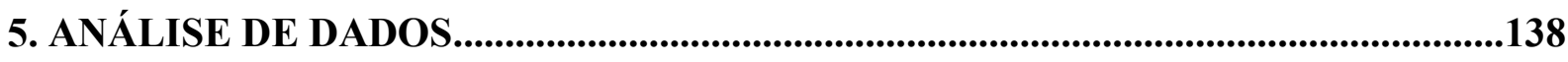

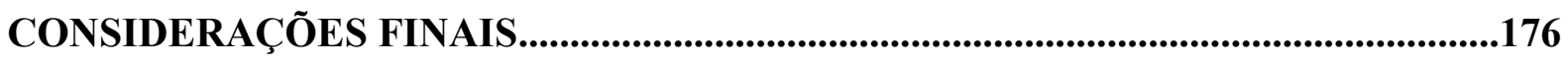

REFERÊNCIAS BIBLIOGRÁFICAS......................................................................182

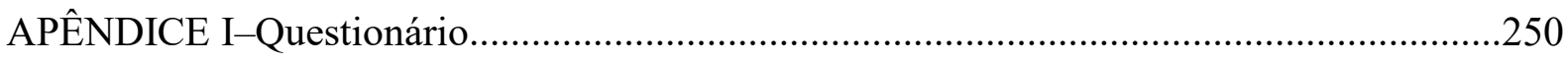

APÊNDICE II-Ficha terminológica nas quatro línguas................................................ 256

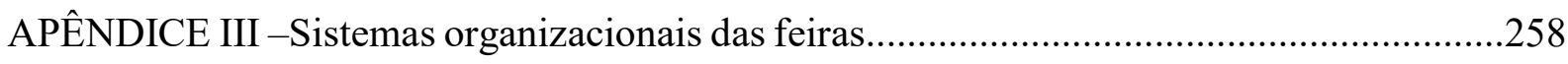

APÊNDICE IV-Ganchos terminológicos nas quatro línguas...........................................260

APÊNDICE V-Definições elaboradas antes da análise dos ganchos terminológicos............. 288

APÊNDICE VI-Aprimoramento das definições após a análise dos ganchos terminológicos..289 
APÊNDICE VII- Reformulação das definições após a defesa.

APÊNDICE VIII-Apresentação do dicionário no formato SDL MultiTerm.......................... 293

APÊNDICE IX-Amostra de 1 verbete extraído da primeira versão do dicionário.

APÊNDICE X-Fotos tiradas durante as pesquisas de campo na Inglaterra, França e Itália....304 


\section{INTRODUÇÃO}

O setor feirístico tem grande relevância no cenário econômico nacional e internacional e está em constante expansão, oferecendo oportunidades para as empresas tornarem-se conhecidas, expandirem seus negócios, gerarem empregos e aumentarem as suas receitas.

Tal contexto se dá numa perspectiva multilíngue, uma vez que a comunicação se realiza entre expositores de diversos países e, evidentemente, diversas línguas. Essa realidade implica o surgimento de diferentes materiais escritos em diferentes línguas, como os manuais do expositor, e, consequentemente, a demanda por traduções. Ainda que seja uma área forte no Brasil e no mundo, não se encontram materiais terminográficos disponíveis para os profissionais envolvidos, sejam eles expositores, organizadores, promotores e visitantes ou tradutores e intérpretes. Assim, nossa pesquisa de doutorado vem contribuir para preencher essa lacuna com a proposta da elaboração de um Dicionário multilíngue de termos do setor feirístico.

Em nível de mestrado (GODOY, 2014) ${ }^{1}$, elaboramos um glossário bilíngue portuguêsinglês/inglês-português de termos fundamentais do setor feirístico. O presente trabalho, em seguimento à pesquisa anterior, tem como objetivo geral analisar a terminologia multilíngue português-inglês-francês-italiano do referido domínio, mais especificamente dos termos utilizados durante o processo de preparação, participação e pós-feira, tendo como objetivo específico a elaboração de um dicionário terminológico multilíngue para uso de profissionais da área, pesquisadores e estudantes das áreas de comércio exterior e relações internacionais, tradutores e intérpretes.

\footnotetext{
${ }^{1}$ Glossário Bilíngue dos Termos Fundamentais do Setor Feirístico: Busca de Equivalências em Inglês. Dissertação de Mestrado apresentada ao Programa de Pós-Graduação em Estudos Linguísticos da Universidade Estadual Paulista "Júlio de Mesquita Filho", Campus de São José do Rio Preto, sob a orientação do Prof. Dr. Maurizio Babini e apoio financeiro da Fundação de Apoio à Pesquisa do Estado de São Paulo (FAPESP), processo n ${ }^{\circ}$ 2012/09499-5.
} 
A ideia de trabalhar com esse tema surgiu de um curso de Especialização lato sensu em Negócios Internacionais. Para a monografia final ${ }^{2}$, elaboramos um estudo sobre a importância da participação de empresas brasileiras em feiras de negócios no exterior. Como resultado, comprovamos a relevância de participar de uma feira ou exposição no exterior para a conquista de novos mercados e o aumento das vendas por meio das exportações. Todavia, embora tenha seu germe nessa especialização, a presente pesquisa tem como base o estudo da terminologia das feiras de negócios. Trata-se de uma pesquisa terminológica multilíngue envolvendo o estudo dos termos em português, inglês, francês e italiano para a elaboração de um dicionário mutilíngue de termos do setor feirístico. Os verbetes do dicionário são constituídos da definição dos termos-entrada em português, seus equivalentes em inglês, em francês e em italiano e suas variantes, seguidos dos respectivos contextos de uso e fontes.

Além do seu caráter original e inovador, já que não existem estudos acerca da terminologia do setor feirístico e tampouco materiais terminográficos sobre essa temática disponíveis no mercado, a presente pesquisa de doutorado poderá culminar em parcerias, para além dos muros acadêmicos, com câmaras de comércio, associações organizadoras de feiras e empresários do setor privado, que se mostraram interessados no produto final deste trabalho.

Afinal, o que é uma feira de negócios? É um grande evento promocional no qual as empresas expositoras alugam estandes com o intuito de expor seus produtos ou oferecer seus serviços para um público específico, no caso das feiras profissionais e especializadas, ou para o grande público, no caso das feiras gerais. Uma feira, portanto, é um local onde o expositor pode apresentar e demonstrar um novo produto, trocar informações sobre os produtos, conhecer os produtos da concorrência, conversar com potenciais clientes, fazer pesquisa de mercado e contatar agentes, no caso de feiras internacionais; enfim, estar presente em uma feira de negócios significa realizar novas parcerias, abrir novas carteiras de clientes e tornar a sua marca conhecida naquele mercado em particular.

As feiras fazem parte de um dos elementos do marketing mix ${ }^{3}$, a promoção. De acordo com Boone e Kurtz (1998, p. 392), a promoção "tem a função de informar, persuadir, influenciar as decisões de compra dos consumidores e despertar o interesse para o produto ou serviço". Kotler (1998, p. 578) compartilha dessa visão, acrescentando que "as feiras estão entre

\footnotetext{
${ }^{2}$ Um estudo exploratório sobre a importância da participação das indústrias paulistas de alimentos em promoções na Flórida para a abertura do mercado norte-americano. Monografia apresentada ao Programa de Pós-graduação lato sensu da Universidade Presbiteriana Mackenzie, São Paulo, 2006.

${ }^{3}$ Conjunto de decisões voltadas para o preço, o produto, a propaganda e a distribuição, com os quais a empresa pretende atingir o mercado, ou seja, o segmento de consumidores escolhidos como alvo (CORTINAS LOPES, 2010, p. 25).
} 
as principais ferramentas de promoção destinadas à força de vendas e ao negócio". Os expositores, segundo este autor, esperam vários benefícios de sua participação em uma feira, tais como: o estabelecimento de novos negócios, o follow up com clientes, a apresentação de novos produtos, entre outros (KOTLER, 2006, p. 589). Para Pipkin uma feira é um instrumento de promoção comercial singular que possibilita a apresentação de um produto ao vivo no estande para o possível comprador que pode tocar, cheirar, sentir e provar o produto (PIPKIN, 2000, p. 107). Do mesmo modo, Nickels e Wood enfatizam que em uma feira de negócios as empresas expõem seus produtos tanto para consumidores atuais como para consumidores potenciais, sendo, inclusive, mais barato iniciar relações comerciais em uma feira do que por meio de visitas de vendas pessoais (NICKELS; WOOD, 1999, p. 364-365). Este é, aliás, um dos motivos pelos quais empresas de pequeno e médio porte incluem a participação em feiras em seu budget anual, uma vez que o custo-benefício e os resultados de sua participação nesses eventos são bastante favoráveis e lucrativos.

Do exposto, Kotabe e Helsen (2000, p. 419) confirmam que as feiras "têm impacto direto e indireto sobre as vendas do expositor". Isso significa que a participação em uma feira pode resultar em vendas feitas no estande (impacto direto) ou pode resultar em visitantes mais interessados pelos produtos, o que poderá gerar vendas no futuro (impacto indireto). Por conseguinte, podemos afirmar que a participação em feiras tornou-se o portão de entrada de produtos nacionais no mercado externo e de produtos estrangeiros no mercado brasileiro e é, portanto, o gatilho das exportações. Essa informação pode, também, ser comprovada no artigo "A importância das feiras no aumento das exportações", publicado pela revista Brazil Export, que diz:

no atual mercado externo, não basta apenas ser competitivo -embora isso seja fundamental- é preciso ser também conhecido internacionalmente com um forte trabalho de divulgação. Neste contexto, as feiras de negócios tornam-se um dos instrumentos mais poderosos de divulgação de produtos no mercado externo e, consequentemente, de ampliação das exportações, principalmente em relação aos produtos industrializados (Brazil Export Magazine, 2011).

Logo, é aconselhável a uma empresa que pretenda internacionalizar-se e exportar seus produtos para o exterior, a princípio, divulgá-los no mercado escolhido por meio da participação em feiras para, desse modo, tornar sua marca conhecida pelos compradores locais. Essa é a maneira mais segura e confiável de penetração em um mercado externo.

Os dados do Ministério do Desenvolvimento, Indústria e Comércio Exterior revelam que no acumulado janeiro-outubro de 2016 as exportações brasileiras apresentaram valor de US\$ 153,086 bilhões. Para chegar a esse resultado, as empresas brasileiras tiveram que investir 
muito em promoção comercial no exterior, apresentar seus produtos em muitas feiras e, desse modo, engordar as estatísticas da balança comercial brasileira.

Considerando a relevância da participação em feiras nacionais e internacionais para o crescimento da economia interna e para a expansão das exportações, nosso dicionário terminológico multilíngue será útil tanto para os profissionais do setor feirístico quanto para pesquisadores, estudantes, intérpretes e tradutores que produzam textos nas línguas de nosso estudo.

Pretendemos, portanto, com a pesquisa, contribuir com a área feirística e com o desenvolvimento dos estudos terminológicos, elaborando um material terminográfico multilíngue que colaborará com a redução de possíveis falhas de comunicação no setor e facilitará os processos de preparação, participação e pós-feira nos quatro idiomas estudados, confirmando, portanto, a dimensão social e pragmática dos estudos terminológicos e sua interface com o mundo corporativo, empresarial e de negócios. Para tanto, fizemos uso de uma combinação metodológica, "sócio-corpus-linguística", baseada nos corpora de estudo e em entrevistas com usuários dessa terminologia. A seguir, apresentamos os objetivos de nossa pesquisa.

\section{Objetivo geral:}

Identificar a terminologia multilíngue (português brasileiro, inglês britânico/americano, francês da França e italiano) do domínio das feiras com a finalidade de elaborar um dicionário terminológico unidirecional do português para o inglês, o francês e o italiano de termos do setor feirístico.

\section{Objetivos Específicos:}

1) Identificar os termos da área de feira de negócios nas línguas portuguesa, inglesa, francesa e italiana,

2) Verificar como eles se apresentam do ponto de vista dos sintagmas especificadores (adjetivo ou sintagma preposicionado),

3) Verificar a melhor maneira de estruturá-los unidirecionalmente do português para as outras línguas num dicionário multilíngue,

4) Verificar se os termos são equivalentes/correspondentes,

5) Identificar os principais problemas encontrados na busca das equivalências, descrevendo-os em relação à tradução,

6) Verificar o modo como cada língua designa as relações semânticas num mesmo 
paradigma (por exemplo, os tipos de estande),

7) Verificar como se dá a variação nas quatro línguas.

Para alcançar esses objetivos, seguimos as seguintes etapas metodológicas:

- Elaboração da definição dos termos preferenciais em português coletados durante a pesquisa de mestrado

- Aprofundamento das pesquisas bibliográficas em francês e italiano e aperfeiçoamento da bibliografia em português e inglês

- Constituição de dois corpora de textos sobre o domínio das feiras em francês e italiano e aperfeiçoamento dos corpora em português e inglês

- Coleta dos termos em francês e italiano e preenchimento das fichas terminológicas e aperfeiçoamento dos termos e fichas terminológicas em português e inglês

- Organização desses termos em quatro sistemas organizacionais das feiras

- Comparação dos sistemas organizacionais das feiras nas quatro línguas estudadas e estabelecimento das equivalências, por meio da análise dos ganchos terminológicos coletados nas quatro línguas

- Elaboração da macroestrutura, microestrutura e sistema de remissivas do dicionário.

Quanto à organização da tese, no Capítulo 1, apresentamos algumas características do setor feirístico e a importância da participação em feiras de negócios nacionais e internacionais para a expansão do mercado interno e para o aumento das exportações. No Capítulo 2, trazemos a fundamentação teórica que consiste nos conceitos e aplicações dos Estudos da Tradução, a Relação Tradução e Terminologia, a Terminologia e os Tipos de termos, as Correntes Teóricas da Terminologia, a Terminologia Multilíngue e a Equivalência Terminológica, a Variação Terminológica, a Linguística de Corpus e as Unidades Fraseológicas nas feiras de negócios. No Capítulo 3, apresentamos os procedimentos metodológicos adotados para a realização de nossa pesquisa: a criação da base de dados textual, a criação da base de dados terminológicos, a apresentação das fichas terminológicas e dos sistemas organizacionais das feiras. No Capítulo 4, trazemos as informações referentes ao dicionário, a macro e a microestrutura, os grupos temáticos, a lista de abreviaturas e a lista de verbetes. No Capítulo 5, expomos as análises dos termos em português e a busca de seus equivalentes em inglês, francês e italiano, a partir da análise dos ganchos terminológicos; apresentamos alguns exemplos de termos correspondentes, termos homônimos, estrangeirismos e falsos cognatos encontrados na terminologia do setor feirístico nas quatro línguas; a análise da estrutura morfossintática e léxico-semântica dos 
termos; o conjunto de variantes e suas relações de hiperonímia, hiponímia e sinonímia; a variação e a insconsistência terminológica na área; a constituição interna das unidades fraseológicas; os problemas de tradução encontrados na busca pelas equivalências e as reflexões acerca dos estágios no exterior. Sucessivamente, trazemos as considerações finais, as referências bibliográficas utilizadas na pesquisa e os apêndices. 


\section{A IMPORTÂNCIA DA PARTICIPAÇÃO EM FEIRAS DE NEGÓCIOS NACIONAIS E INTERNACIONAIS: ASPECTOS GERAIS E DADOS ESPECÍFICOS RELEVANTES}

Os motivos pelos quais as empresas planejam a sua participação em feiras de negócios e se preparam com antecedência para o evento são variados; desde uma participação mais simples, com um estande básico, para coletar informações sobre o mercado, conhecer a concorrência e avaliar a aceitabilidade de seus produtos, até uma participação mais agressiva, com um estande maior e personalizado, com o intuito de se destacar no pavilhão e atrair o maior número possível de visitantes para, assim, alavancar as vendas, conquistar novos clientes e negócios e fechar contratos.

Em relação às feiras internacionais, é comum um expositor participar primeiramente como visitante para se familiarizar com o mercado em que deseja atuar, conhecer e conversar com agentes locais, verificar se o seu produto atende às exigências e necessidades daquele público e se está adequado e de acordo com as normas dos órgãos de fiscalização locais; enfim, fazer "o dever de casa" e uma boa pesquisa de mercado. Num segundo momento, o expositor já se sentirá mais confiante para alugar um estande dentro do pavilhão e poderá contar com o auxílio dos agentes locais para lhe apresentar possíveis compradores para seus produtos.

Penetrar em um mercado estrangeiro não é uma tarefa fácil. É preciso trabalhar duro e ter muita calma e paciência. É necessário estar presente em várias feiras, apresentar o seu produto ao maior número de pessoas possível, ouvir o que os agentes e os potenciais clientes estão falando sobre os seus produtos, fazer as adequações necessárias, levar a literatura promocional na língua do país onde está acontecendo a feira e também um intérprete, caso não domine o idioma para conversar e negociar com os visitantes. Em termos de trabalho pós-feira, é importante manter contato com os clientes abertos durante a feira, por meio de visitas comerciais e envio de amostras e informações sobre os produtos, a empresa e suas atividades.

Uma vez obtido um potencial comprador para o seu produto e a oportunidade de demonstrá-lo para os seus clientes em sua loja, o expositor, caso a aceitabilidade do seu produto seja boa, poderá ter o seu primeiro pedido de compra; terá sido dado, portanto, o primeiro passo para a internacionalização de sua marca.

Em Godoy (2006), elaboramos um questionário (cf. Apêndice I) para avaliar a importância da participação das indústrias de alimentos paulistas em feiras e eventos comerciais nos EUA, para a abertura do mercado norte-americano. Na ocasião, cerca de 2000 indústrias 
alimentícias de São Paulo foram convidadas a responder esse questionário, cujo tema era "O Estudo da viabilidade da participação em promoção comercial nos EUA". O objetivo específico era avaliar o resultado da participação dessas empresas em promoções na Flórida e a contribuição dessa prática para a expansão de seus negócios no mercado norte-americano e em seus históricos de vendas (GODOY, 2006, p. 110).

Para a coleta dos dados foi contatada a empresa Fispal, especializada na organização de feiras de negócios nacionais e internacionais. Esta empresa, cujos eventos promocionais proporcionam em média de um a três clientes a seus partipantes, organizou duas edições da feira de alimentos Fispal Latino nos EUA. O departamento de marketing da Fispal recebeu o nosso questionário e o encaminhou para todos os participantes das duas edições da referida feira. Além disso, enviamos o mesmo questionário para os clientes da Oxford Group, consultoria americana especializada em feiras nos EUA.

Em seguida, fizemos a análise dos questionários recebidos e comprovou-se que a participação em promoção comercial nos EUA constitui um excelente meio de abertura do mercado norte-americano, já que a presença local faz toda a diferença nesse mercado tão competitivo e cheio de exigências.

Dos resultados obtidos, percebeu-se que as feiras e os representantes ${ }^{4}$ ocupam o primeiro lugar na preferência das empresas para se inserirem no mercado norte-americano, em segundo lugar, a participação em missões comerciais e, em terceiro, os showrooms ${ }^{5}$. É principalmente o aumento do faturamento das empresas que identifica o resultado das ações realizadas para a entrada em mercados internacionais. No referido questionário, empresas citaram um aumento em torno de $20 \%$. Além disso, declararam que, além do incremento de seu market share ${ }^{6}$, também melhorou bastante o reconhecimento de suas marcas no mercado interno (GODOY, 2006, p. 127-129).

Além do evidente desejo das empresas de ampliar suas receitas, muitos são os motivos para participar de uma feira. Siskind (2009, p. 26-28), especialista em feiras e exposições, apresenta 100 deles, dos quais citamos os principais:

- Vender produtos e serviços

- Introduzir novos produtos e serviços em um mercado

- Demonstrar novos produtos e serviços

\footnotetext{
${ }^{4}$ Os representantes são contratados pelo expositor para auxiliá-lo no processo de penetração de seus produtos em um mercado externo.

${ }^{5}$ Locais onde os produtos são expostos para a venda.

${ }^{6}$ Participação de uma empresa dentro de um ramo de atuação, ou seja, a fatia desse mercado que a empresa detém.
} 
- Abrir novos mercados

- Obter feedback de produtos, novos e já existentes

- Fazer pesquisa de mercado

- Encontrar comerciantes, representantes e agentes

- Reforçar a imagem da empresa

- Criar uma base de dados de clientes

- Distribuir amostras de produtos

- Conduzir um encontro de vendas

- Reposicionar sua empresa no mercado

- Conhecer novas tendências setoriais

- Estabelecer relacionamentos de negócios com compradores internacionais

- Influenciar as atitudes dos clientes

- Encontrar novas oportunidades de negócios

- Apresentar novos métodos de produção

- Ter influência direta sobre os tomadores de decisões

- Incentivar a força de vendas

- Dar ao cliente em potencial a oportunidade de experimentar seu produto e/ou serviço

- Realizar vendas imediatas

- Aumentar a lucratividade corporativa, entre outros.

Assim, como podemos perceber, participar de uma feira nacional ou internacional é uma excelente oportunidade para as empresas se tornarem conhecidas, expandirem seus negócios, gerarem empregos e aumentarem as suas receitas.

O especialista afirma, ademais, que as pessoas vão às feiras para experimentar produtos e serviços com todos os sentidos possíveis. Quando a pessoa interessada é envolvida na demonstração ou degustação, sua necessidade de experimentar o produto foi satisfeita. Quando a demonstração ou degustação está em curso, o envolvimento de sua plateia é um fator importante. Permita que as pessoas toquem, experimentem, cheirem, vejam e sintam, por exemplo, ao segurar o produto ou tocar um teclado. Pode ser a oferta de um biscoito que acaba de sair do forno, ou pedir para que alguém aperte um botão [...] (SISKIND, 2009, p. 214).

É exatamente isso o que faz de uma feira de negócios um local tão peculiar e atrativo, ou seja, ela proporciona a oportunidade de participar da demonstração de um novo produto, da degustação de uma criação culinária, do manuseio de uma novidade tecnológica, de um equipamento doméstico moderno ou de uma inovação do mundo têxtil. Essa imensidão de 
possibilidades pode ser experienciada dentro de um único local: o pavilhão de exposições. É lá que, ao expor seus produtos no chamado marketing face a face, surge a oportunidade de o expositor encontrar e conversar com muitos clientes alvo em um curto espaço de tempo e ainda coletar informações com especialistas, membros de associações, concorrentes e demais expositores durante a feira (SISKIND, 2009, p. 259; 305-306).

Desse modo, a participação em feiras e eventos comerciais internacionais consolidouse como o principal portão de entrada de produtos brasileiros no mercado externo pelo aumento consequente das vendas através das exportações. No período de janeiro a julho de 2016, entre os 20 principais países de destino das exportações brasileiras, com a China em primeiro lugar e os Estados Unidos em segundo, estão a Itália, na $9^{\text {a }}$ posição, o Reino Unido, na $13^{\text {a }}$ posição, e a França, na $17^{\mathrm{a}}$ posição (MDIC, 2016), países de interesse de nossa pesquisa. Além disso, os dados do comércio bilateral entre o Brasil, o Reino Unido, a França e a Itália confirmam que o aumento das exportações brasileiras para esses países está diretamente relacionado à participação das empresas em feiras internacionais.

No que diz respeito ao Reino Unido, a UK Trade \& Investment (UKTI) ${ }^{7}$ afirma que as feiras podem ser "uma das melhores maneiras de promover seus produtos" ao "explorar o modo como se pode ter sucesso exportando para o Brasil". Segundo o guia Doing business in Brazil elaborado pela UKTI,

o Reino Unido tem uma relação comercial forte e histórica com o Brasil, que remonta a mais de 200 anos. É o maior parceiro comercial do Reino Unido na América Latina, com um comércio bilateral de bens no valor de 5,1 bilhões de libras. Isso cresceu 3,5\% em 2013. Ao longo dos últimos 4 anos, as exportações do Reino Unido para o Brasil cresceram $20 \%$, chegando a 2,5 bilhões de libras em $2013^{9}$ (UKTI, 2014).

Essa realidade se confirma ainda hoje, visto que o comércio bilateral entre os dois países continua forte, uma vez que o Reino Unido ocupa a $13^{\mathrm{a}}$ posição entre os países de destino das exportações brasileiras em 2016, com US\$ 2.406 bilhões em exportações e a $13^{\mathrm{a}}$ posição também entre os países de origem das importações brasileiras, com US\$ 1.971 bilhões em

\footnotetext{
${ }^{7}$ UKTI é uma organização governamental que trabalha com empresas sediadas no Reino Unido para garantir seu sucesso nos mercados internacionais por meio de exportações. Nós encorajamos e apoiamos as empresas estrangeiras a olharem para o Reino Unido como o melhor lugar para se instalar ou expandir seus negócios. A $U K$ Trade \& Investment foi substituída pelo Department for International Trade em julho de 2016.

${ }^{8}$ One of the best ways to promote your products; be sure to explore how you can have exporting success in Brazil (UKTI, Gateway to South America, 2014). As traduções de todas as citações e notas foram elaboradas pela autora do trabalho.

9 The UK has a strong and historic trading relationship with Brazil, going back over 200 years. It is the UK's largest trading partner in Latin America with a bilateral trade in goods worth $£ 5.1$ billion. This grew by $3.5 \%$ in 2013. Over the last 4 years, UK exports to Brazil have grown by $20 \%$, reaching $£ 2.5$ billion in 2013 (UKTI, 2014).
} 
importações, no período de janeiro a outubro (MDIC, 2016).

Em conformidade com o Estudo de Comércio Exterior da Série "Como Exportar" publicado pelo Ministério das Relações Exteriores (MRE), o Brasil é, entre os países da América do Sul, o maior destinatário de investimentos britânicos e o Reino Unido, por sua vez, é um dos parceiros mais antigos do Brasil no comércio exterior (MRE, 2009, p. 30 e 34). Esse estudo conclui também que

no tocante à ampliação da penetração de produtos brasileiros no mercado britânico, haveria duas opções para ampliar o fluxo de exportações de produtos e serviços do Brasil para o Reino Unido. A primeira delas seria a ampliação do volume dos produtos já exportados, e a outra alternativa seria conquistar mercado para novos produtos, o que demandaria a implementação de ações focadas e esforço mais integrado de promoção comercial no mercado britânico (MRE, 2009, p. $35)$.

Assim, a participação efetiva em feiras e exposições no Reino Unido é a forma ideal de conquistar mercado para novos produtos, promover os produtos brasileiros nesse mercado, conquistar novos clientes e, consequentemente, aumentar as exportações para esses países (Inglaterra, Irlanda do Norte, Escócia e País de Gales).

De acordo com o Centro Brasileiro Britânico $(\mathrm{CBB})^{10}$, o Consulado Geral Britânico, sede da UK Trade and Investment no Brasil,

dá suporte a empresas britânicas interessadas em oferecer produtos e serviços ao mercado brasileiro ou investir no Brasil, e orienta empresas brasileiras que queiram internacionalizar seus negócios investindo e montando operações no Reino Unido. Para aproximar empresas dos dois países, a equipe da UK Trade and Investment organiza participação em feiras e missões comerciais, promove seminários e desenvolve uma rede de contatos para trocar informações sobre oportunidades de negócios (CBB, 2010).

Desse modo, o auxílio e suporte das organizações governamentais são essenciais nesse processo de aproximação das empresas de ambos os países, principalmente no que diz respeito à organização de feiras e missões comerciais internacionais. Como vimos, a participação em feiras é muito importante para o networking, o contato face to face, a apresentação de produtos e serviços e, principalmente, para a expansão dos negócios.

Um outro estudo publicado pela UKTI sugere que as empresas que queiram fazer negócios no Brasil devem participar de feiras e exposições que acontecem no Brasil durante o

\footnotetext{
${ }^{10}$ Inaugurado em 2000, o Centro Brasileiro Britânico foi idealizado pela Cultura Inglesa de São Paulo para reunir, em um só endereço, todas as instituições e atividades relacionadas a cultura, educação, lazer e comércio entre Brasil e Reino Unido.
} 
ano todo, pois são "uma excelente maneira para encontrar clientes potenciais pessoalmente"11 (UKTI, 2012). Segundo esse estudo, é possível que a empresa precise adaptar o seu produto de acordo com as exigências brasileiras para poder vendê-lo, já que ignorar a legislação, o gosto e a cultura locais seria uma receita para o fracasso (UKTI, 2012). Desse modo, no intercâmbio entre os países, os aspectos culturais também são, e devem ser, considerados.

Conforme dados do Ministério das Relações Exteriores, houve uma considerável evolução do intercâmbio comercial Brasil-Reino Unido no período de 2005 a 2014, com um aumento de 47,4\% nas exportações e 136,8\% nas importações (MRE, abril de 2015). No período de janeiro a maio de 2015 as exportações brasileiras para o Reino Unido representaram 9,3\% do total exportado pelo Brasil (MRE, junho de 2015). Podemos atribuir essa evolução do comércio entre os dois países à intensa promoção comercial praticada por ambos baseada também no cuidado às diferenças culturais.

Em relação à França, a Confederação Nacional da Indústria (CNI) destaca que

o Brasil e a França têm fortes laços comerciais e diplomáticos. Em 2014, o fluxo de comércio bilateral foi de US\$ 8,6 bilhões, colocando a França na $13^{\mathrm{a}}$ posição entre os principais parceiros brasileiros. Até 2013, o estoque de investimentos franceses no Brasil era de US\$ 37 bilhões - o quinto país com maior volume de recursos, enquanto as empresas brasileiras aplicaram US\$ 1,2 bilhão na França. A Europa é o principal destino das mercadorias exportadas pelo Brasil. O presidente da Medef Internacional, Jean Burelle, lembrou que o comércio entre as nações cresceu, em média, $5 \%$ ao ano na última década, e que hoje existem cerca de 850 entidades francesas no Brasil, entre empresas e instituições. Ele frisou, também, a posição estratégica de seu país para a indústria brasileira. A França é a porta de entrada para a Europa (CNI, 2015).

Os laços comerciais e diplomáticos entre o Brasil e a França seguem sólidos. Em 2016 a França ocupa a $17^{\mathrm{a}}$ posição entre os países de destino das exportações brasileiras, com US\$ 1.950 bilhões em exportações, e a $6^{\text {a }}$ posição entre os países de origem das importações brasileiras, com US\$ 3.153 bilhões em importações, no período de janeiro a outubro (MDIC, 2016).

Um estudo ${ }^{12}$ realizado pela Médiamétrie, empresa francesa que trabalha com pesquisa de mercado, em parceira com o Ministério francês da Economia, o DGE (Direction Général

\footnotetext{
${ }^{11}$ An excellent way to meet potential customers face to face (UKTI, 2012).

${ }^{12}$ Estudo intitulado Salons et Foires en France: un puissant outil de développement pour les entreprises, publicado em 2015 pela Médiamétrie.
} 
des Entreprises) ${ }^{13}$, a UNIMEV (Union Française des Métiers de l'Evénement) ${ }^{14}$, a Câmara de Comércio e Indústria de Paris Île-de-France e o Comitê de Exposições de Paris, apresenta, pela primeira vez,

uma avaliação fiável e robusta do volume de operações realizadas na França e no exterior pelos expositores que participam nas feiras e exposições em nosso país. Esse estudo- realizado pela Médiamétrie compartilhado entre o governo e a indústria é o primeiro do mundo, apresenta cifras proeminentes e demonstra o enorme efeito de alavancagem que as feiras e as exposições representam em termos de negócios gerados e de desenvolvimento para as empresas (MÉDIAMÉTRIE, 2015, p. 5) ${ }^{15}$.

Realmente, esse é um estudo muito completo que traz um panorama muito positivo sobre as feiras e valida, portanto, o nosso objetivo de demonstrar e comprovar a importância da participação em feiras e exposições para a expansão dos negócios e a internacionalização das empresas em nível global.

Nesse estudo, 3319 empresas francesas ou estrangeiras que expõem em feiras ou exposições na França foram entrevistadas. Como podemos observar na figura abaixo, as feiras e exposições na França são um poderoso instrumento de desenvolvimento para as empresas:

\footnotetext{
13 Sob a autoridade do Ministério da Economia e da Indústria, a DGE tem por missão desenvolver a competitividade e o crescimento das empresas, indústrias e serviços na França.

${ }^{14}$ União Francesa das Profissões de Eventos é a única organização profissional representativa do conjunto de atores de eventos profissionais: organizadores de feiras, exposições, congressos e eventos, gestores de sites e prestadores de serviços.

${ }^{15}$ Une évaluation fiable et robuste du volume de transactions réalisé en France et à l'export par les exposants qui participent aux Salons et Foires dans notre pays. Cette étude, - réalisée par Médiamétrie - partagée entre les pouvoirs publics et la filière et qui constitue une première mondiale, présente des chiffres remarquables et démontre le formidable effet de levier que les Salons et Foires représentent en termes de business généré et de développement pour les entreprises (MÉDIAMÉTRIE, 2015, p. 5).
} 
Figura 1: Feiras e Exposições realizadas por ano na França

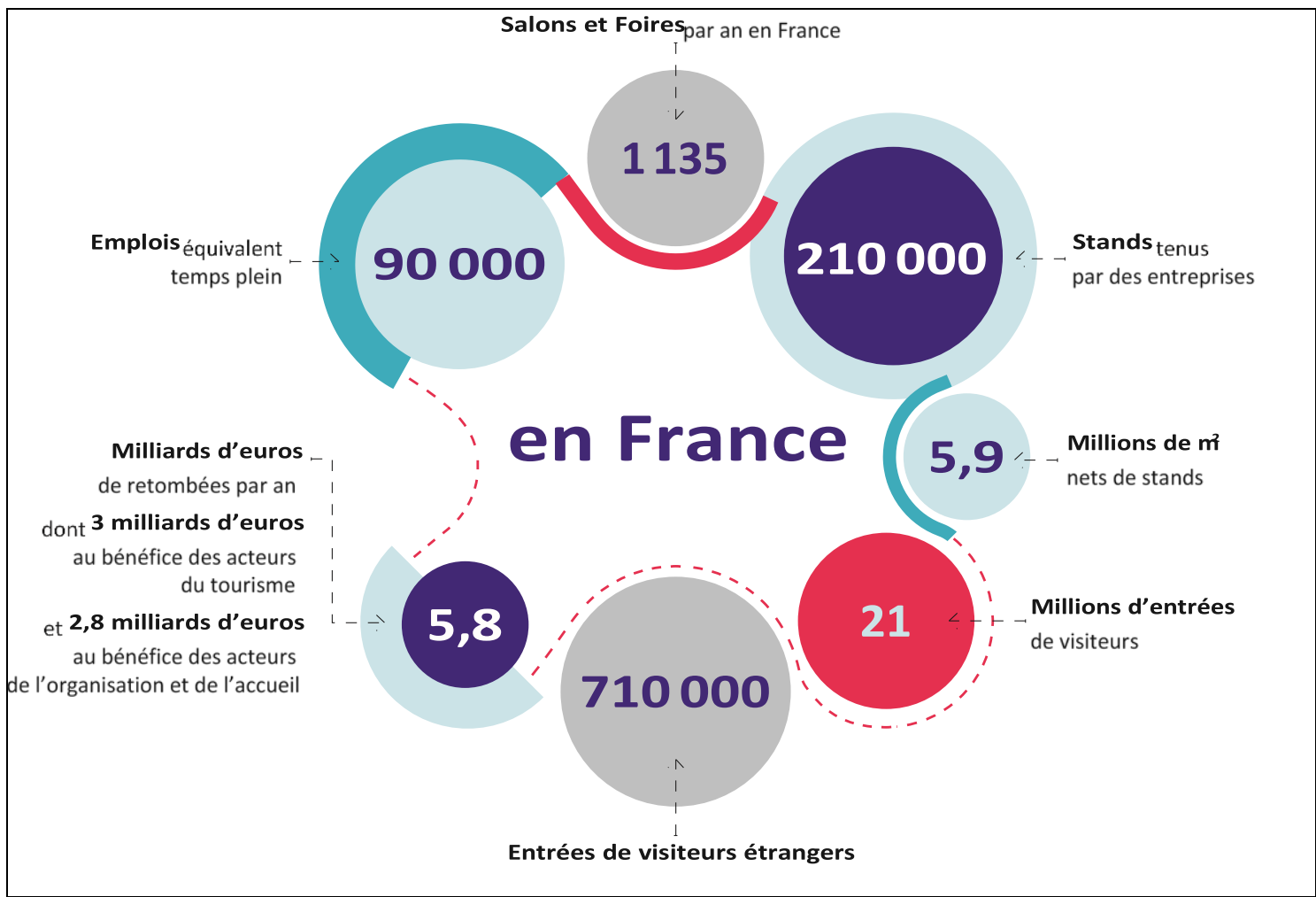

Fonte: Estudo realizado pela empresa Médiamétrie e publicado em 2015

Assim, conforme dados apresentados acima, temos:

- 1135 feiras e exposições na França anualmente

- 5,9 milhões de $\mathrm{m}^{2}$ em estandes

- $\quad$ 5,8 bilhões de euros em benefícios por ano, dos quais 3 bilhões de euros em benefício das entidades ligadas ao turismo e 2,8 bilhões de euros em benefício das entidades da organização e da hospedagem

- 210000 estandes ocupados por empresas

- 90000 postos de traballho em tempo integral

- 710000 visitantes estrangeiros

- 21 milhões de visitantes.

Os dados demonstram, portanto, o grande volume de negócios, postos de trabalho e fluxo de visitantes gerados, por ano, na França, devido ao setor feirístico que movimenta quase 6 bilhões de euros, em 1135 feiras e exposições que acontecem durante o ano.

De acordo com esse estudo, apesar da crise econômica, as feiras e exposições 
continuaram a desempenhar um papel central e essencial para os setores industriais e de serviços [...]. Algumas empresas ou PME, que viram a sua atividade diminuir significativamente durante esse período tiveram um melhor amortecimento dos efeitos da crise graças às vendas e às encomendas assumidas nas Feiras e Exposições ${ }^{16}$.

Mais uma vez, podemos constatar aqui o importante papel da participação das empresas em feiras e exposições, principalmente em períodos de crise econômica, no sentido de atenuar os seus efeitos negativos, por meio dos contratos assinados e vendas realizadas nos estandes durante esses eventos.

Assim, verificou-se que as Feiras e Exposições na França são geradoras de receitas para as empresas que nelas expõem, o que significa:

- $\quad 17,7$ milhões de contratos assinados

- 30,5 bilhões de euros em receitas

- $1 / 4$ (da receita) realizada durante o evento e 3/4 nos meses que seguem

- Um retorno sobre o investimento de $8^{17}$.

Além desse retorno significativo em termos de contratos assinados e volume de negócios, as empresas que participam em feiras e exposições na França têm, principalmente, objetivos comerciais, tais como: "prospectar e recrutar novos clientes, manter relações comerciais com os clientes existentes, vender e receber pedidos, lançar um novo produto ou desenvolver-se em um mercado"18, e também objetivos de imagem, a saber:

- Desenvolver a imagem junto aos jornalistas e concorrentes

- Observar e analisar a concorrência e o mercado

- Desenvolver ou estabelecer parcerias

- Tirar proveito do impacto mediático da exposição para anunciar a assinatura de importantes contratos ${ }^{19}$.

\footnotetext{
${ }^{16}$ Malgré une crise économique durable, les Salons et Foires ont continué de jouer un rôle central et essentiel pour les filières industrielles et de services [...]. Certaines entreprises ou PME qui voyaient leur activité diminuer sensiblement au cours de la période ont mieux amorti les effets de la crise grâce aux ventes et aux carnets de commandes pris sur les Salons et les Foires auxquels elles participaient et continuent de participer (MÉDIAMÉTRIE, 2015, p. 5).

${ }^{17}$ (Ibid., p. 7).

${ }^{18}$ Prospecter et recruters de nouveaux clientes; entretenir la relation commerciale avec les clients existants, vendre et prendre des commandes (pendant l'événement), lancer un nouveau produit ou vous développer sur un nouveau marché (Ibid.,p. 9).

${ }^{19}$ Développer votre image auprès des journalistes et des concurrents; observer et analyser la concurrence/ le marché; développer ou nouer des partenariats; profiter de l'impact médiatique du salon pour y annoncer la signature d'importants contrats $(I d$.$) .$
} 
Portanto, considerando os objetivos comerciais e de imagem citados acima e os 30,5 bilhões de euros em volume de negócios gerados (sendo 17,5 bilhões só em Paris e Île-deFrance), concluímos que a participação empresarial em eventos dessa natureza é muito significativa, visto que $84 \%$ dos expositores realizam transações comerciais durante a sua participação em feiras e exposições na França (MÉDIAMÉTRIE, 2015, p. 10), conforme descrito na imagem abaixo:

Figura 2: Porcentagem de expositores que realizam negócios em feiras e exposições

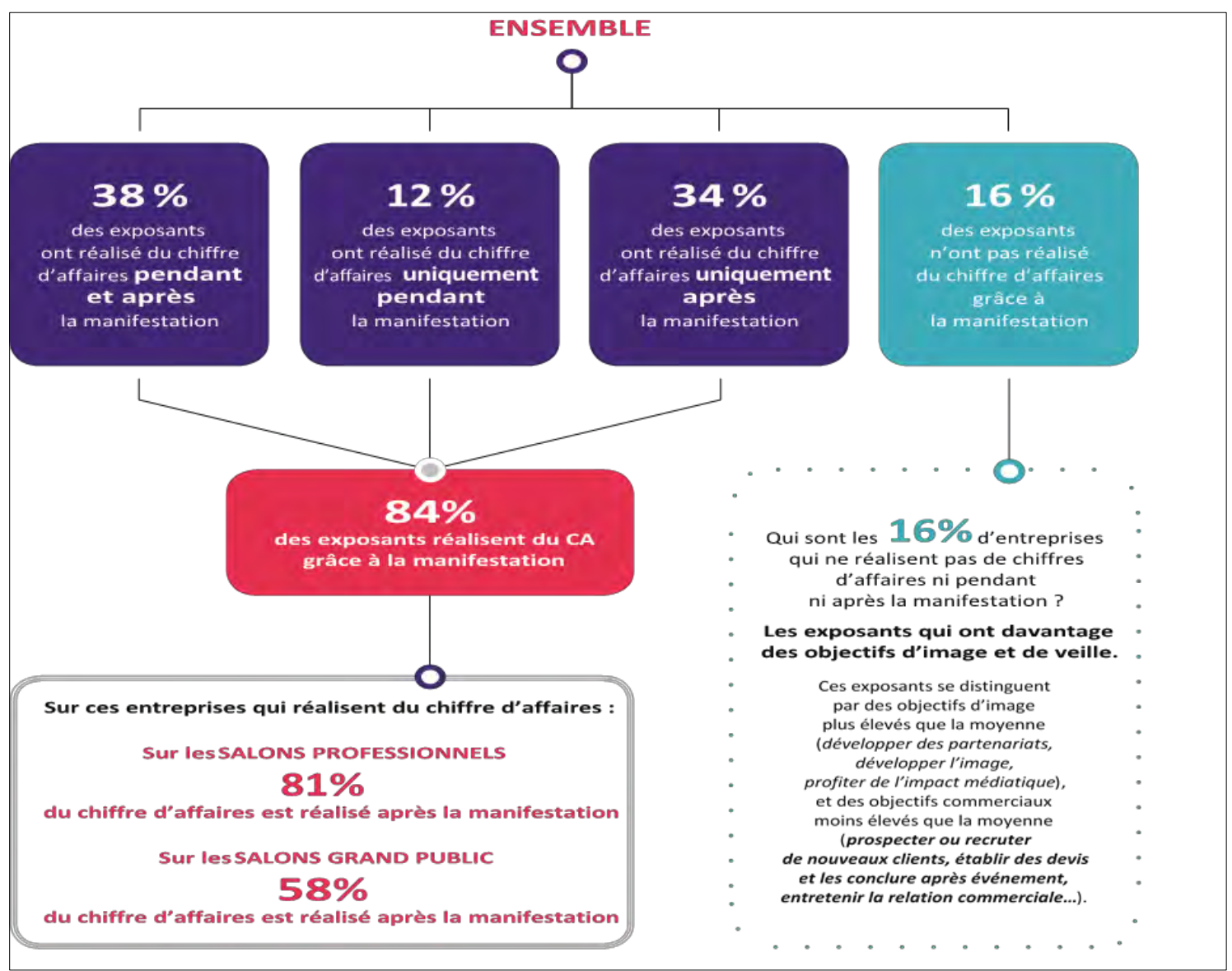

Fonte: Estudo realizado pela empresa Médiamétrie e publicado em 2015

Dessa maneira, de acordo com os dados apresentados, temos:

- $38 \%$ de expositores alcançaram vendas durante e após o evento

- $12 \%$ dos expositores alcançaram vendas unicamente durante o evento

- $34 \%$ dos expositores alcançaram vendas unicamente após o evento

- $84 \%$ dos expositores alcançaram vendas com o evento

- $16 \%$ dos expositores não alcançaram vendas no evento. Quem são os $16 \%$ das empresas que não alcançaram vendas durante ou depois do evento? Expositores que têm 
primeiramente objetivos de imagem. Esses expositores se distinguem pelos objetivos de imagem mais elevados do que a média (desenvolver parcerias, desenvolver a imagem, tirar proveito do impacto mediático) e objetivos comerciais menos elevados do que a média (prospectar ou recrutar novos clientes, estabelecer orçamentos e conclui-los após o evento, manter o relacionamento comercial...)

- Nas exposições profissionais, $81 \%$ do volume de negócios é feito após o evento

- Nas exposições para o grande público, 58\% do volume de negócios é feito após o evento.

Podemos constatar, portanto, que apenas $16 \%$ das empresas que participaram de eventos de promoção comercial na França não alcançaram vendas, ao passo que $84 \%$ delas alçancaram seus objetivos comerciais com a participação nesses eventos.

As feiras e exposições na França funcionam também como centros de comércio internacional, sendo que 1/3 da receita é gerada por empresas estrangeiras (MÉDIAMÉTRIE, 2015, p. 7), e são, portanto, o primeiro passo em direção à exportação. Logo, $32 \%$ do volume de negócios gerados são realizados por expositores estrangeiros que representam $20 \%$ dos expositores e os contratos assinados por empresas francesas junto a clientes estrangeiros equivalem a 12\% do volume de transações (MÉDIAMÉTRIE, 2015, p. 16), o que significa que o mercado francês está de portas abertas para produtos estrangeiros. Basta, portanto, que as empresas brasileiras saibam aproveitar essa oportunidade e invistam na participação em feiras e exposições na França.

De acordo com dados da Business France "das 120 mil empresas francesas exportadoras, 1 em cada 6 , ou seja 18 mil e 500 empresas, realizam vendas no exterior graças às feiras e exposições"20. Desse modo, podemos concluir que, de fato, a participação nesses eventos de promoção comercial na França é o primeiro passo para a exportação para as micro, pequena e média empresas francesas (MÉDIAMÉTRIE, 2015, p. 14). Assim, esse estudo permitiu determinar

o perfil dessas 42.000 empresas que utilizam a ferramenta feiras e exposições na França e que participam em média de 5 eventos por ano. Maduras, fiéis, essas empresas são, principalmente, PME (pequena e média empresa) e TPE (micro-empresa) que contam com esta ferramenta para alcançar volume de negócios, prospectar e se desenvolver ${ }^{21}$.

\footnotetext{
${ }^{20}$ Sur 120000 entreprises françaises exportatrices (source Business France), 1 sur 6, soit 18500 entreprises, réalise du chiffre d'affaires à l'export grâce aux Salons et Foires (MÉDIAMÉTRIE, 2015, p. 17).

${ }^{21}$ Cette étude a permis de dresser le portrait de ces 42000 entreprises qui utilisent l'outil Salons et Foires en France et qui participent en moyenne à 5 manifestations par an. Matures, fidèles, ces entreprises sont principalement des PME et TPE qui font confiance à cet outil pour réaliser du chiffre d'affaires, prospecter et se developer (Ibid., $p$. $18)$.
} 
Isso mostra a maturidade das empresas francesas que acreditam nessa ferramenta como meio para alavancar suas vendas e atingir novos mercados. Para tanto, reconhecem que não é suficiente estarem presentes para atingir o volume de negócios em feiras e exposições, elas sabem que é necessário investir realmente na sua participação e realizar um excelente trabalho pós-feira, ou seja, o follow-up dos clientes contatados durante o evento (MÉDIAMÉTRIE, 2015, p. 18).

O estudo nos revela também que para muitos expositores,

as feiras e exposições desempenham um papel central na sua estratégia de desenvolvimento. $60 \%$ deles gastam mais de $15 \%$ do seu orçamento de promoção e marketing na participação em feiras e exposições. E para $13 \%$ dos expositores, mais de $75 \%$ desse orçamento é dedicado a esses eventos ${ }^{22}$.

Esses dados podem ser observados no gráfico a seguir, cujo título é “A porcentagem de empresas que atingem mais de 50\% do seu volume de negócios anuais, graças a sua participação em feiras e exposições, de acordo com o seu orçamento de marketing dedicado a essa ferramenta" 23 :

Gráfico 1: Relação entre o orçamento utilizado e a participação em feiras

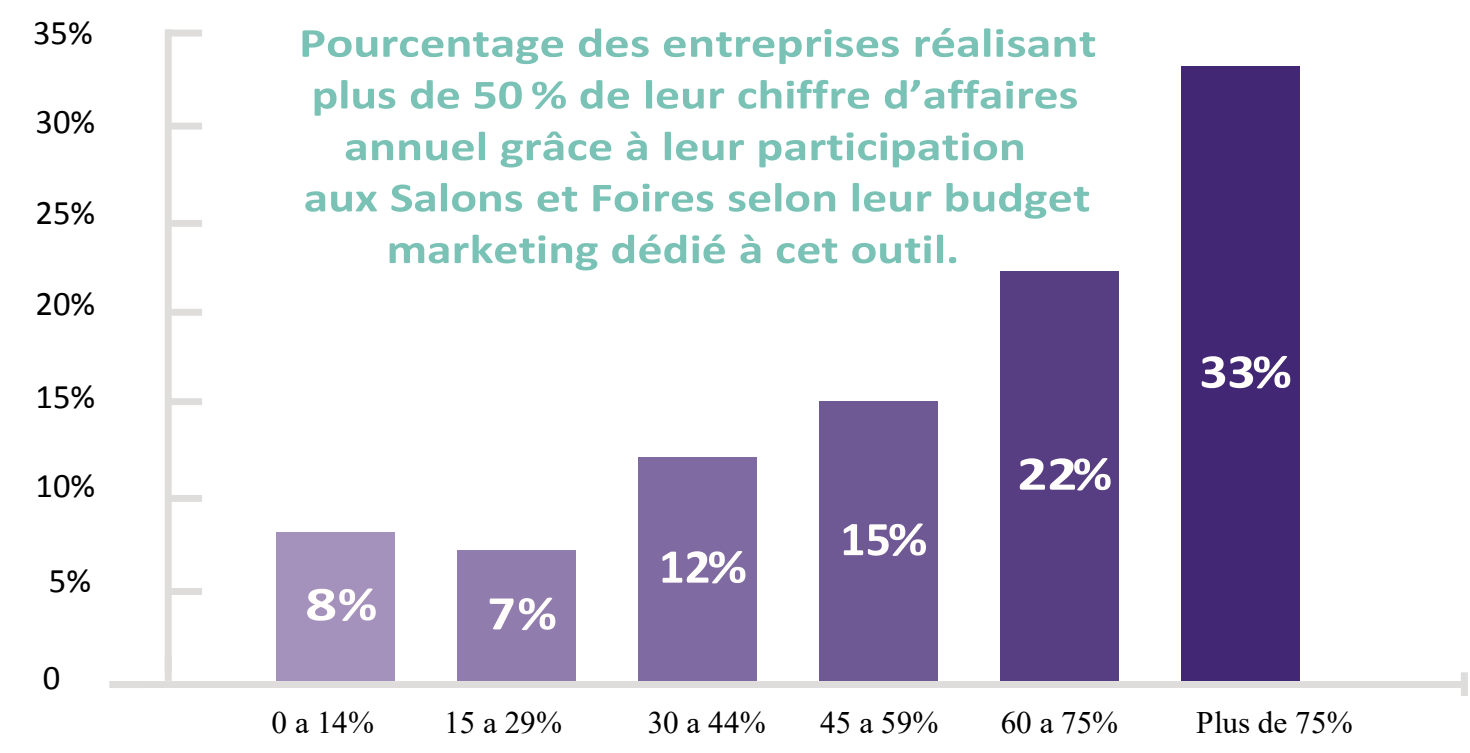

Fonte: Estudo realizado pela empresa Médiamétrie, publicado em 2015

\footnotetext{
${ }^{22}$ Pour de nombreux exposants, les Salons et Foires jouent un rôle central dans leur stratégie de développement. $60 \%$ d'entre eux consacrent plus de 15\% de leur budget marketing-promotion à la participation aux Salons et Foires. Et pour $13 \%$ des exposants, plus de $75 \%$ de ce budget est consacré à ces événements (MÉDIAMÉTRIE, 2015, p. 18).

${ }^{23}$ Pourcentage des entreprises réalisant plus de $50 \%$ de leur chiffre d'affaires annuel grâce à leur participation aux Salons et Foires selon leur budget marketing dédié à cet outil (Ibid., p. 19).
} 
Desse modo, há uma sólida correlação entre a percentagem do orçamento de marketing dedicado a feiras e exposições e a quantidade de volume de negócios anuais gerados, bem como a quantidade de novos clientes abertos, ou seja, quanto maior o orçamento disponibilizado, mais as feiras e exposições contribuem para o volume de negócios anuais da empresa, e maior é o número de clientes novos descobertos nesses eventos (MÉDIAMÉTRIE, 2015, p. 19).

As 42.000 empresas que expõem em feiras e exposições na França as colocam "na primeira posição dentre as ferramentas de promoção em termos de custo-benefício" 24 , como pode ser observado nos dados abaixo:

- Feiras e exposições: $29 \%$

- Internet: $25 \%$

- Visitas de vendedores/representantes: $22 \%$

- Marketing direto: $13 \%$

- Eventos específicos: relações com a mídia, relações públicas, outros eventos (que você organiza): $7 \%$

- Meios de publicidade (imprensa, rádio, TV, outdoors): $4 \%{ }^{25}$.

Assim, 29\% das empresas consideram que as feiras e exposições são as melhores ferramentas de promoção e marketing, à frente até mesmo da internet e das visitas comerciais.

No que tange à Itália, o Ministério do Desenvolvimento, Indústria e Comércio Exterior (MDIC) afirma que

em maio de 2014 o Brasil exportou para a Itália US\$ 433,62 milhões, o que representa um aumento de $4,75 \%$ em comparação com maio de 2013. No mesmo período, o Brasil importou da Itália US\$ 526,1 milhões, o que corresponde a um aumento de $3,52 \%$ em relação a abril de 2014 e de 5,19\% sobre maio de 2013. A balança comercial entre os dois países revelou aumento da corrente de comércio em $1,26 \%$ em relação a abril, atingindo US\$ 959,73 milhões. As vendas de produtos importantes da pauta de exportações brasileira para a Itália cresceram significativamente (MDIC, 2014).

As relações comerciais entre o Brasil e a Itália continuaram a crescer em 2016, já que a Itália ocupa a $9^{a}$ posição entre os países de destino das exportações brasileiras, com US\$2.808 bilhões em exportações, e a $7^{\mathrm{a}}$ posição entre os países de origem das importações brasileiras,

\footnotetext{
${ }^{24}$ Citent les Salons et Foires à la première position des outils de promotion en termes de coût-efficacité (MÉDIAMÉTRIE, 2015, p. 21).

${ }^{25}$ Foire et salons: 29\%; internet: 25\%; visites de vendeurs/commerciaux: 22\%; marketing direct: 13\%; événements spécifiques: relations presse, relations publiques, autres événements (que vous organisez): 7\%; publicité médias (presse, radio, TV, affichage: $4 \%$ (Id.).
} 
com US\$ 3.100 bilhões em importações, no período de janeiro a outubro de 2016 (MDIC, 2016).

De acordo com um estudo realizado pelo Ministério do Desenvolvimento Econômico ${ }^{26}$, a Agência para a Promoção no Exterior e a Internacionalização das Empresas Italianas (ICE) ${ }^{27}$ e a Associação das Exposições e Feiras Italianas (AEFI) ${ }^{28}$, as feiras são "uma ferramenta de promoção, marketing e internacionalização insubstituível para as empresas, um canal privilegiado para o contato direto com o mercado"29. Eles afirmam também que o sistema feirístico italiano

representa uma realidade extremamente significativa pela importância dos centros de exposições, a quantidade e a qualidade dos expositores e os resultados que são alcançados a cada ano. Todos os anos são organizados na Itália cerca de 1.000 eventos por meio dos quais os 200.000 expositores apresentam a 22 milhões de visitantes novidades, produtos, filosofia empresarial e habilidades ${ }^{30}$.

Nesse sentido, podemos concluir que o mercado italiano de feiras é bastante desenvolvido e constitui-se em ferramenta de fundamental importância para as empresas que queiram promover seus produtos e/ou tornar sua marca mundialmente conhecida.

O referido estudo destaca que durante as feiras são realizados 60 bilhões de euros em negócios, dos quais se originam 50\% das exportações nacionais e que $75 \%$ das empresas industriais e $88,5 \%$ das PME reconhecem a feira como principal ferramenta de promoção comercial (AEFI, 2015a, p. 6).

O sistema feirístico italiano conta com o apoio de importantes associações e instituições governamentais: o Ministério de Desenvolvimento Econômico que administra os principais setores da economia italiana, em termos de promoção, desenvolvimento da competitividade da produção nacional e supervisão do mercado interno; o ICE (Agência para a promoção e a internacionalização das empresas italianas) que trabalha ao lado de empresas italianas para garantir o seu êxito nos mercados internacionais, promover a internacionalização e incentivar as empresas estrangeiras a olharem para a Itália como um parceiro global fiável; a AEFI (Associação de Exposições e Feiras Italianas) que desenvolve programas de treinamento,

\footnotetext{
${ }^{26}$ Ministero dello sviluppo economico. Disponível em: http://sviluppoeconomico.gov.it/index.php/it/.

${ }^{27}$ ICE-Agenzia per la promozione all'estero e l'internazionalizzazione delle imprese italiane. Disponível em: https://www.ice.it/it/chi-siamo.

${ }^{28}$ Associazione esposizioni e fiere italiane. Disponível em: http://www.aefi.it/Aefi/site/it/associazione/chi-siamo.

${ }^{29}$ Uno strumento di promozione, marketing e internazionalizzazione insostituibile per le imprese, un canale privilegiato per il contatto diretto con il mercato (AEFI, 2015a, p. 6).

${ }^{30}$ Il sistema fieristico italiano rappresenta una realtà estremamente significativa per l'importanza dei quartieri, la quantità e qualità degli espositori e i risultati che vengono ogni anno conseguiti. Ogni anno si organizzano in Italia quasi 1.000 manifestazioni attraverso cui 200.000 espositori presentano a 22 milioni di visitatori novità, prodotti, filosofia aziendale e competenze (Id.).
} 
marketing, promoção e pesquisa, além de prestar serviços para feiras e exposições, com 35 centros de exposições associados e uma área de exposição total de 4,2 milhões de metros quadrados (AEFI, 2015a, p. 7).

Ettore Riello, ex-presidente da AEFI, afirma que os mercados externos

constituem certamente uma oportunidade imperdível para as empresas italianas, e as feiras, de onde se originam $50 \%$ das exportações, desempenham um papel importante para o "feito na Itália" no exterior. Para $75 \%$ das PME italianas, de fato, o instrumento "feira" representa o único meio de promoção no exterior para produtos de alta qualidade e com alto valor agregado ${ }^{31}$.

Essa declaração de Riello atesta a relevância das feiras para a divulgação e a venda de produtos italianos no mercado internacional, principalmente de produtos com alto valor agregado produzidos por pequenas e médias empresas. A seguir, trazemos os números do setor feirístico italiano, de acordo com a AEFI:

- Centros de exposições: $65^{*}$

- Área de exposição: 4.200.000 metros quadrados, dos quais 2,27 milhões são cobertos

- Eventos em 2014: Total: 962; Internacional:190; Nacional: 280; Regional/Local: 400*; Organizados no exterior: $92 *$

- Eventos internacionais em 2014: 190

Referem-se principalmente ao setor têxtil (18\%); esportes, hobbies, entretenimento e arte (13\%); alimentos, bebidas e hospitalidade (10\%); mecânica (10\%)

- Total de expositores: 200.000

- Expositores eventos internacionais: 98.000 , cerca de $28 \%$ vêm do exterior

- Total de visitantes: 22.000 .000

- Visitantes eventos internacionais: 13.000 .000 , dos quais $10 \%$ vêm do exterior

- Negócios de 60 bilhões de euros celebrados todos os anos durante as feiras

- $50 \%$ das exportações vêm de contatos provenientes de participação em exposições

- $75,3 \%$ das empresas veem as feiras como uma ferramenta-chave para o seu próprio desenvolvimento, útil para o contato direto com o mercado e a comunicação da competência empresarial no processo de busca ativa de potencial comprador ${ }^{32}$.

\footnotetext{
${ }^{31}$ I mercati stranieri costituiscono certamente un'occasione irrinunciabile per le aziende italiane e e le fiere, da cui origina il 50\% dell'export, ricoprono un ruolo di primo piano per il made in Italy all'estero. Per il $75 \%$ delle Pmi italiane, infatti, lo strumento "fiera" rappresenta l'unico mezzo di promozione oltre confine per prodotti di elevata qualitá a grande valore aggiunto (Revista Largo Consumo n.1/2015, p. 72).
}

${ }^{32}$ AEFI: I numeri del settore fieristico italiano, 2015b. 
(*) Valores estimados

Como podemos perceber pela expressividade dos números, 65 centros de exposições construídos na Itália, mais de 4 milhões de metros quadrados em área de exposição, 200 mil expositores, 22 milhões de visitantes, 60 bilhões de euros em receitas arrecadados durante as feiras, $50 \%$ das exportações provenientes de feiras e exposições, todos esses fatores reforçam o quão estruturado e bem desenvolvido é o setor feirístico italiano, como pôde ser observado na prática durante as pequisas de campo realizadas em Bolonha, Milão, Verona, Roma, Rimini, Nápoles, etc. A seguir, apresentamos um gráfico com o número de feiras italianas realizadas em 2014 no exterior, por país:

Gráfico 2: Número de feiras italianas realizadas no exterior em 2014 por país

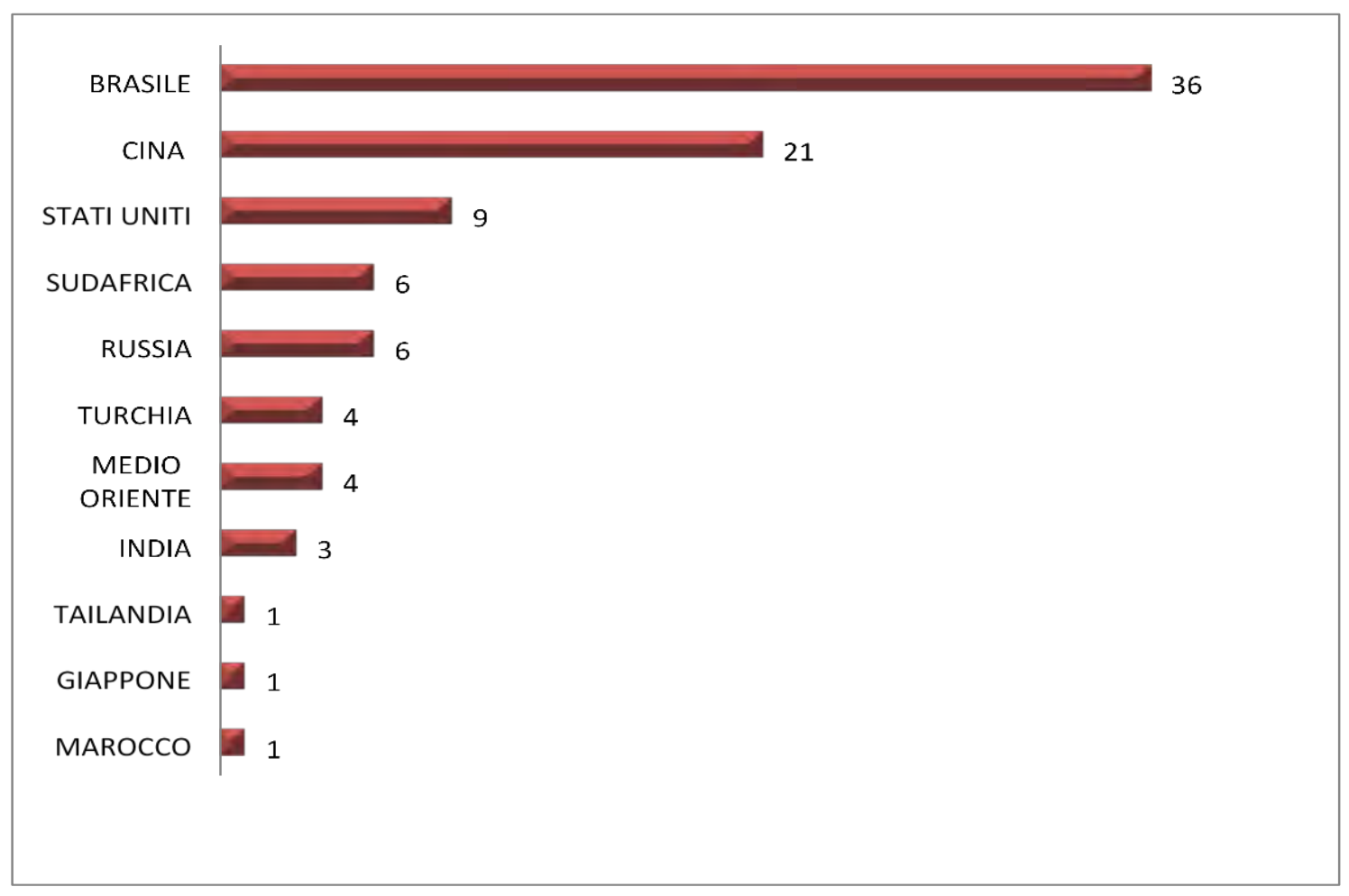

Fonte: AEFI, 2015b

Como podemos observar, em 2014, a Itália participou de 36 feiras e exposições no Brasil, seguida dos EUA com 9 participações e o Sul da África e Rússia com 6 participações. Assim, podemos concluir que a participação de feiras no Brasil representou 39\% do total de feiras em que a Itália esteve presente no exterior. Esses dados foram retirados do estudo "Os Números do Setor Feirístico Italiano” produzido e publicado pela AEFI em 2015.

A seguir, apresentamos os 15 países responsáveis por $80 \%$ do espaço de exposição 
coberto mundial, em 2011, de acordo com a UFI (The Global Association of the Exhibition Industry) ${ }^{33}$ :

Tabela 1: 15 países responsáveis por $80 \%$ do espaço de exposição coberto mundial

\begin{tabular}{lcc} 
& TOTAL (in sqm) & WORLD \% \\
\hline USA & 6712342 & $21 \%$ \\
\hline China & 4755102 & $15 \%$ \\
\hline Germany & 3377821 & $10 \%$ \\
\hline Italy & 2227304 & $7 \%$ \\
\hline France & 2094554 & $6 \%$ \\
\hline Spain & 1548057 & $5 \%$ \\
\hline The Netherlands & 960530 & $2 \%$ \\
\hline Brazil & 701882 & $2 \%$ \\
\hline United Kingdom & 701857 & $2 \%$ \\
\hline Canada & 684175 & $2 \%$ \\
\hline Russia & 566777 & $2 \%$ \\
\hline Switzerland & 500570 & $1 \%$ \\
\hline Belgium & 448265 & $1 \%$ \\
\hline Turkey & 433904 & 231761 \\
\hline Mexico & $43 \%$ \\
\hline
\end{tabular}

Fonte: UFI - Global Exhibition Industry Statistics March 2014, p. 07

Como podemos perceber pela tabela acima, o Brasil é responsável por $2 \%$ do total mundial de espaço de exposição coberto, assim como o Reino Unido que possui 701.857 metros quadrados em espaço de exposição e também contribui com $2 \%$ do total mundial.

Nesse cenário, a Itália está em quarto lugar com 2.227.304 metros quadrados de espaço de exposição, o que representa 7\% do total global, seguida da França, em quinto lugar, com 2.094.554 metros quadrados em espaço de exposição, o que equivale a $6 \%$ do total.

Neste sentido, podemos concluir que a Itália, a França, o Brasil e o Reino Unido têm

\footnotetext{
${ }^{33}$ UFI é a associação dos principais organizadores de feiras do mundo e donos de parques de exposições, bem como das principais associações de exposições nacionais e internacionais, e parceiros seletos da indústria de exposições. Disponível em: https://www.ufi.org/.
} 
uma participação ativa no cenário mundial no que diz respeito à organização e à participação em feiras de negócios, o que justifica, mais uma vez, a nossa escolha em elaborar um dicionário terminológico multilíngue do setor.

Destacamos a seguir, os principais centros de exposições na Itália e na França que oferecem no mínimo 200.000 metros quadrados de espaço de exposição coberto. São eles: Fiera Milano e Bologna Fiere, na Itália, Paris Nord Villepinte e Paris Porte de Versailles, na França, conforme pode ser observado nos dados abaixo:

Tabela 2: Principais centros de exposições na Itália e na França

\begin{tabular}{l|l|l} 
FEIRA & LOCAL & $\begin{array}{l}\text { ESPAÇO } \\
\text { EXPOSIÇÃO (m }\end{array}$ \\
\hline Messe Frankfurt & Frankfurt/Main (Germany) & 345697 \\
\hline Fiera Milano & Milano (Italy) & 345000 \\
\hline Pazhou Complex & Guangzhou (China) & 338000 \\
\hline Koelnmesse & Cologne (Germany) & 284000 \\
\hline Messe Duesseldorf & Duesseldorf (Germany) & 262704 \\
\hline Paris Nord Villepinte & Paris (France) & 241582 \\
\hline McCormick Place & Chicago (USA) & 241524 \\
\hline Feria Valencia & Valencia (Spain) & 230602 \\
\hline Paris Porte de Versailles & Paris (France) & 228211 \\
\hline Crocus International & Moscow (Russia) & 226399 \\
\hline Fiera de Barcelona & Barcelona (Spain) & 205000 \\
\hline Bologna Fiere & Bologna (Italy) & 200000 \\
\hline Feria de Madrid & Madrid (Spain) & 200000
\end{tabular}

Fonte: UFI -Global Exhibition Industry Statistics March 2014, p. 9

Durante os estágios de pesquisa no exterior tivemos a oportunidade de conhecer esses importantes centros de exposições na Itália e na França, destacados na tabela acima. Feiras organizadas na Fiera Milano, Bologna Fiere, Paris Nord Villepinte e Paris Porte de Versailles fazem parte de nossos corpora de estudo, cujos manuais do expositor estão disponíveis online para a orientação dos expositores em sua participação nesses eventos nos dois países.

Em relação aos 10 principais mercados e o espaço líquido total alugado em milhões de metros quadrados em 2012, temos: 
Tabela 3: Espaço líquido total alugado pelos 10 principais mercados

\begin{tabular}{c|c} 
USA & 41,1 \\
\hline China & 13,7 \\
\hline Germany & 8,7 \\
\hline Italy & 5,9 \\
\hline France & 5,7 \\
\hline Japan & 3,2 \\
\hline Brazil & 3,0 \\
\hline Russia & 2,9 \\
\hline Spain & 2,8 \\
\hline UK & 2,8 \\
\hline &
\end{tabular}

Fonte: UFI - Global Exhibition Industry Statistics March 2014, p. 17

Como podemos verificar na tabela acima, o Brasil está entre os principais mercados e alugou em 2012, 3 milhões de metros quadrados em espaços de exposição. A Itália, por sua vez, está na quarta posição com 5,9 milhões de metros quadrados em espaço de exposição alugados, seguida da França com 5,7 milhões e do Reino Unido com 2,8 milhões. Esses dados mais uma vez comprovam a utilização pelos países das feiras de negócios como poderosa ferramenta de marketing e vendas.

Ao considerar esses valores no período de 2008 a 2012, podemos observar no gráfico abaixo que o Brasil está na primeira posição com um crescimento contínuo entre 2008 e 2010 e um crescimento acelerado entre 2010 e 2012, chegando a 120 milhões de metros quadrados em espaço líquido total alugado.

A França, por sua vez sofreu um declínio em espaço líquido total alugado entre 2008 e 2010, caindo de 100 milhões para pouco mais de 90 milhões, e atingindo pouco menos de 100 milhões em 2012.

A Itália teve uma queda brusca em espaço líquido total alugado entre 2008 e 2012, caindo de 100 para 90 milhões de metros quadrados e o Reino Unido apresentou um declínio em 2010 de cerca de 5 milhões de metros quadrados, em comparação com 2008, caindo de 100 para 95 milhões, atingindo em 2012 uma média de 93 milhões de metros quadrados em espaço líquido total alugado, como podemos visualizar a seguir: 
Gráfico 3: Espaço líquido total alugado 2008-2012

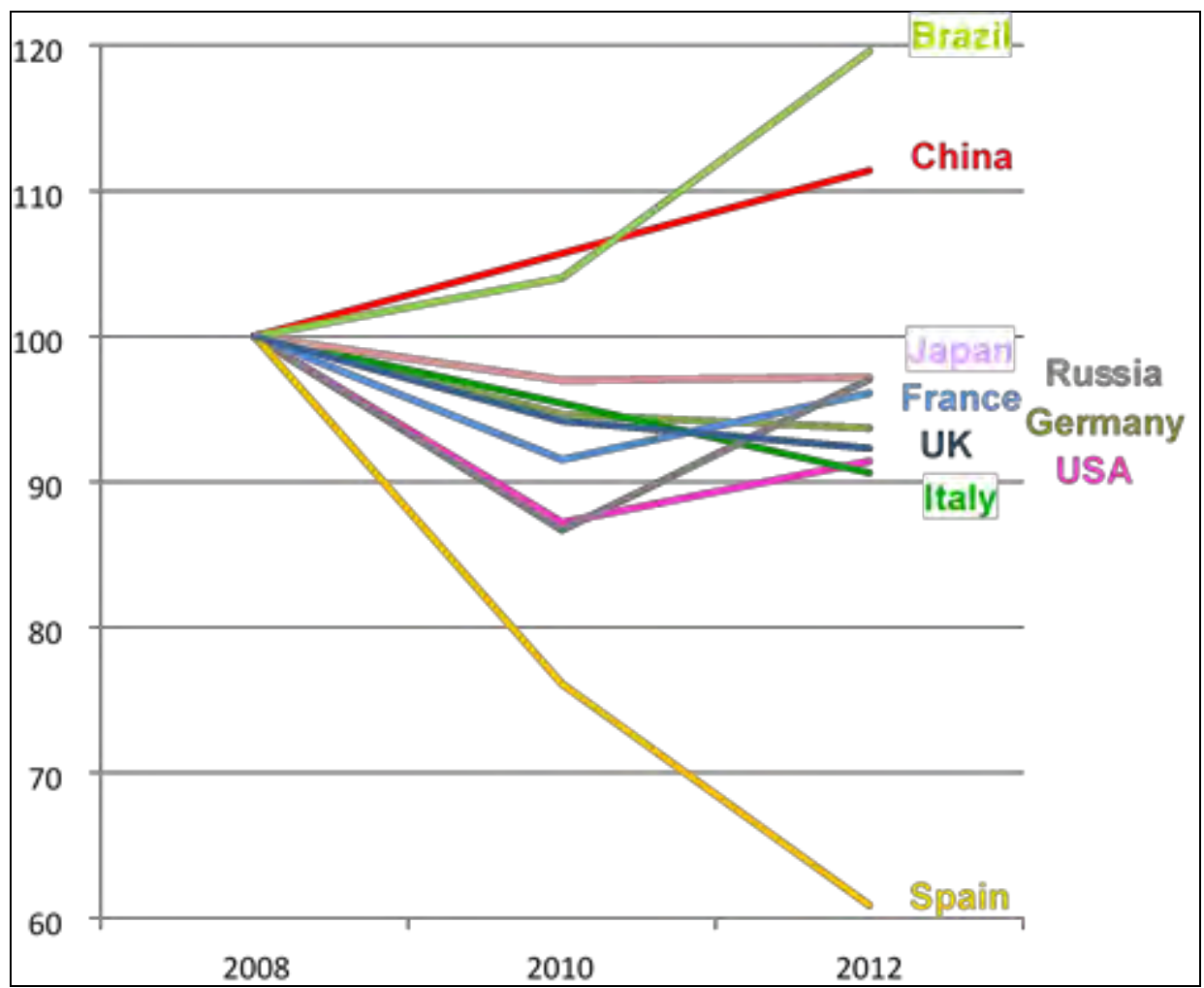

Fonte: UFI - Global Exhibition Industry Statistics March 2014, p. 17

Nesse sentido, podemos concluir que o Brasil foi o país que obteve melhor performance no que diz respeito à quantidade de metros quadrados em espaço de exposição alugados entre 2008 e 2012, confirmando a posição privilegiada do nosso país no ranking do marketing de exposições, ferramenta poderosa para a expansão dos negócios e vendas de produtos no mercado externo.

A seguir, apresentamos alguns dados relativos ao tipo de evento e ao tipo de público em feiras e exposições na França e na Itália em 2011. Vale ressaltar que esse estudo foi publicado pela UFI em março de 2014, tendo como referência o ano de 2011. Em relação à França, temos:

Tabela 4: Dados do setor feirístico francês

\begin{tabular}{|c|rrr|r|}
\cline { 2 - 5 } \multicolumn{1}{c|}{} & Public & Trade only & $\begin{array}{c}\text { Trade \& } \\
\text { Public }\end{array}$ & TOTAL \\
\hline Number of exhibitions & 60 & 178 & 15 & 253 \\
Total net space rented (in sqm) & 498442 & 2470377 & 356872 & 3325691 \\
\hline Total number of exhibitors & 17330 & 84293 & 6085 & 107708 \\
Total number of foreign exhibitors & 4039 & 39861 & 2259 & 46159 \\
\% of foreign exhibitors & $23 \%$ & $47 \%$ & $37 \%$ & $43 \%$ \\
\hline
\end{tabular}




\begin{tabular}{|c|rrr|r|}
\hline Total number of visitors & 2556964 & 3334682 & 2160119 & 8051765 \\
Total number of foreign visitors & 67725 & 1002752 & 23393 & 1093870 \\
$\%$ of foreign visitors & $3 \%$ & $30 \%$ & $1 \%$ & $14 \%$ \\
\hline
\end{tabular}

Fonte: UFI - Global Exhibition Industry Statistics March 2014, p. 59

Assim, como nos mostra a tabela acima, temos o número de exposições ocorridas na França de acordo com o tipo de evento: público (60), especializado (178) e misto (15); o espaço líquido total alugado em metros quadrados; o número total de expositores; o número total de expositores estrangeiros; o número total de visitantes e o número total de visitantes estrangeiros em cada evento. Em relação à Italia, temos:

Tabela 5: Dados do setor feirístico italiano

\begin{tabular}{|c|c|c|c|c|}
\hline ITALY & Public & Trade only & $\begin{array}{l}\text { Trade \& } \\
\text { Public }\end{array}$ & TOTAL \\
\hline Number of exhibitions & 9 & 130 & 36 & 175 \\
\hline Total net space rented (in sqm) & 353795 & 2564954 & 1024751 & 3943499 \\
\hline Total number of exhibitors & 6184 & 52606 & 15376 & 74166 \\
\hline Total number of foreign exhibitors & 1679 & 13459 & 4254 & 19392 \\
\hline$\%$ of foreign exhibitors & $27 \%$ & $26 \%$ & $28 \%$ & $26 \%$ \\
\hline Total number of visitors & 4081152 & 2940377 & 2386748 & 9408277 \\
\hline Total number of foreign visitors & 421634 & 682176 & 434074 & 1537884 \\
\hline$\%$ of foreign visitors & $10 \%$ & $23 \%$ & $18 \%$ & $16 \%$ \\
\hline
\end{tabular}

Fonte: UFI - Global Exhibition Industry Statistics March 2014, p. 60

Do mesmo modo, a tabela acima nos indica o número de exposições ocorridas na Itália de acordo com o tipo de evento: público (9), especializado (130) e misto (36); o espaço líquido total alugado em metros quadrados; o número total de expositores; o número total de expositores estrangeiros; o número total de visitantes e o número total de visitantes estrangeiros em cada evento.

Assim, podemos perceber que, em ambos os países, os eventos especializados direcionados ao público comprador (e não ao público geral) são mais numerosos. Na França, os expositores estrangeiros representam $43 \%$ do total, enquanto que na Itália eles equivalem a $26 \%$ do total. Entretanto, as feiras italianas são as que recebem mais visitantes estrangeiros, mais de um milhão e meio de visitantes, ao passo que a França recebe pouco mais de um milhão de visitantes estrangeiros nas suas feiras e exposições. 
No que diz respeito à indústria de feiras e exposições da América Latina, a lista abaixo nos mostra o número total de exposições identificadas por países no calendário de exposições 2012-2013-2014 da UFI:

Tabela 6: Total de exposições realizadas na América Latina por país

\begin{tabular}{|c|r|}
\hline Country & $\begin{array}{r}\text { Number of } \\
\text { exhibitions }\end{array}$ \\
\hline Brasil & 548 \\
México & 449 \\
Argentina & 197 \\
Colombia & 185 \\
Chile & 94 \\
Ecuador & 86 \\
Perú & 68 \\
Venezuela & 42 \\
Bolivia & 35 \\
Uruguay & 30 \\
Guatemala & 29 \\
Panamá & 23 \\
Costa Rica & 21 \\
El Salvador & 20 \\
Paraguay & 18 \\
Cuba & 14 \\
Honduras & 12 \\
Republica Dominicana & 6 \\
Nicaragua & 5 \\
\hline TOTAL & 1882 \\
\hline
\end{tabular}

Fonte: UFI - Global Exhibition Industry Statistics March 2014, p. 63

Como podemos visualizar na tabela acima, o Brasil está em primeiro lugar entre os países das Américas Central e Sul em número de exposições realizadas no período. Foram 548, o que representa 29\% do total de feiras e exposições realizadas na América Latina.

Assim, considerando os dados do comércio bilateral entre o Brasil, o Reino Unido, a França e a Itália, podemos assegurar que o aumento das exportações brasileiras está diretamente relacionado à participação das empresas em feiras internacionais que se consolidaram como importante mecanismo para a penetração de produtos brasileiros no mercado externo, a 
internacionalização da marca, o fechamento de contratos e negócios e a consequente expansão das vendas por meio das exportações. A seguir, apresentamos o referencial teórico da pesquisa. 


\section{EMBASAMENTO TEÓRICO}

Após discorrermos sobre a importância da participação em feiras de negócios nacionais e internacionais, apresentamos, neste Capítulo, os conceitos que fundamentam a nossa pesquisa, provenientes dos Estudos da Tradução, da Terminologia e da Linguística de Corpus. Para tanto, trataremos do lugar que nosso estudo ocupa nos Estudos da Tradução, passando pela relação entre Tradução e Terminologia, pelas correntes teóricas da Terminologia, com especial atenção a aspectos ligados à Terminologia Multilíngue, à Equivalência e Variação Terminológica, até às ferramentas da Linguística de Corpus e às Unidades Fraseológicas.

\subsection{Tradução e Terminologia: o lugar e as bases da pesquisa}

Os Estudos da Tradução são uma área de pesquisa que investiga a tradução e o processo de traduzir em seus aspectos teóricos e práticos. As bases dessa disciplina, ou seja, a criação da terminologia e a concepção de sua estrutura, foram sistematizadas por James S. Holmes em 1972 no artigo intitulado The Name and Nature of Translation Studies (O Nome e a Natureza dos Estudos da Tradução), apresentado na Terceira Conferência Internacional de Linguística Aplicada realizada em Copenhague.

Anteriormente, a tradução era estudada como parte da literatura comparada, da linguística contrastiva e do ensino de línguas (MUNDAY, 2001, p. 17). Entretanto, a partir da década de 1970, com a virada pragmática, os Estudos da Tradução surgiram como disciplina independente (SNELL-HORNBY, 2005, p. 47) e foram estruturados em dois grandes blocos: Estudos de Tradução Pura e Estudos de Tradução Aplicada.

$\mathrm{O}$ primeiro bloco diz respeito à teoria e aos estudos de tradução descritivos. Holmes destaca que "os objetivos da pesquisa pura são descrever os fenômenos de traduzir e da tradução como eles se manifestam no mundo da nossa experiência, e estabelecer os princípios gerais por meio dos quais esses fenômenos podem ser explicados e previstos"34 (HOLMES, 1988, p. 71). Em outras palavras, envolve o estudo da tradução propriamente dita e do fazer tradutório, em toda a sua complexidade, levando em consideração questões relevantes, tais como: as línguas e culturas de partida e de chegada; as escolhas do tradutor; o público-alvo; o estilo adotado pelo tradutor; a recepção da tradução; a questão do sentido e da equivalência; a terminologia

\footnotetext{
34 The goals of pure research are to describe the phenomena of translating and translation(s) as they manifest themselves in the world of our experience, and to establish general principles by means of which these phenomena can be explained and predicted (HOLMES, 1988, p. 71).
} 
envolvida nesse processo, entre outros. Por outro lado, os Estudos de Tradução Aplicada dizem respeito ao treinamento e formação de tradutores; às ferramentas de auxílio ao tradutor (dicionários, obras terminográficas/lexicográficas, softwares); às críticas da tradução, ou seja, a avaliação e correção de traduções e, também, à política da tradução, do lugar que a tradução deve ocupar na sociedade e no ensino de línguas (MUNDAY, 2001, p. 12).

Nesse sentido, nosso trabalho se enquadra no segundo bloco, já que compilamos um dicionário terminológico multilíngue do setor feirístico para o auxílio de tradutores e intérpretes que trabalham com o domínio especializado em questão, nas quatro línguas de nosso estudo. No quadro de Holmes, portanto, o nosso dicionário está localizado em Translation Aids, em Estudos de Tradução Aplicada, como pode ser visualizado abaixo, em destaque:

Figura 3: Estudos de Tradução: Pura e Aplicada

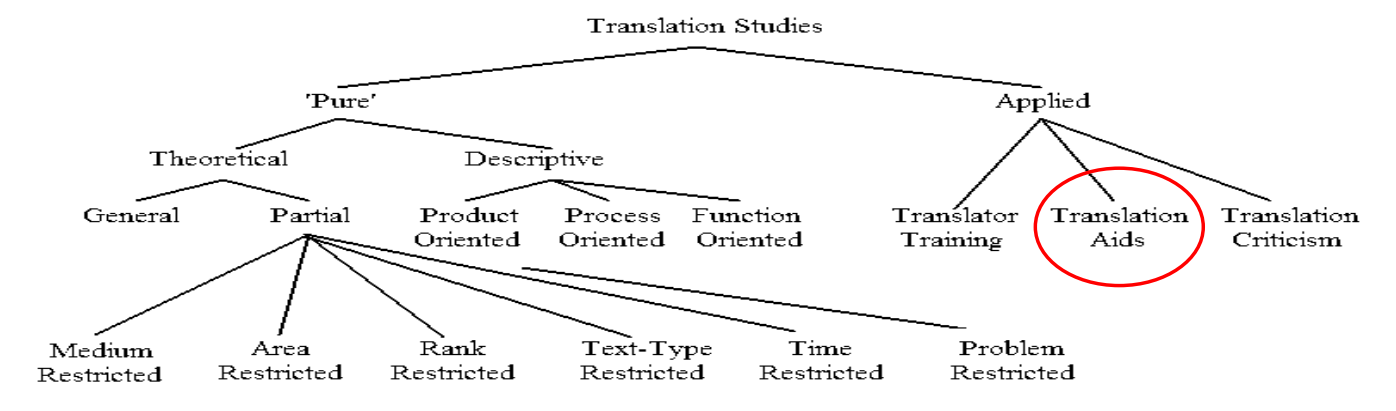

Fonte: Holmes' map of Translation Studies (MUNDAY, 2001, p. 10).

Nesse mapa proposto por Holmes, é possível visualizar a estruturação dos Estudos da Tradução e a inter-relação entre os Estudos de Tradução teóricos, descritivos e práticos, o que tem contribuído para diminuir o abismo entre a teoria e a prática da tradução (MUNDAY, 2001, p. 17). Como se sabe, dependendo da perspectiva teórica adotada pelo tradutor, ele produzirá (na prática) uma determinada tradução, o que significa dizer que, em tradução, teoria e prática caminham juntas.

Os Estudos da Tradução ainda são "uma jovem disciplina com um longo caminho à sua frente” (BASSNETT, 2003, p. 208). Nesse sentido, nós, pós-graduandos, pesquisadores, tradutores e professores de teoria e prática de tradução contribuiremos hoje e sempre para o desenvolvimento e o amadurecimento dessa jovem disciplina, debatendo e refletindo sobre o processo tradutório e o seu entorno, desmistificando conceitos tão arraigados como fidelidade e equivalência na tradução e desempenhando o nosso papel de disseminadores do conhecimento e elo de ligação entre os povos. Afinal, como meritoriamente descreve José Saramago, "os autores escrevem as suas respectivas literaturas nacionais, mas a literatura mundial é obra dos 
tradutores" (SARAMAGO, 2010). Também o conhecimento científico e técnico é difundido entre os países pela tradução. Neste âmbito, a relação entre a Terminologia e a Tradução (que será abordada no próximo item) aparece mais marcadamente, uma vez que a Terminologia tem seu objeto de estudo na base das comunicações técnicas, científicas e comerciais, tendo surgido com mais força nos Estudos da Tradução na década de 1980 com a virada empírica que trouxe a necessidade de mais estudos voltados à prática, devido aos avanços em tecnologia e ao processo de globalização.

A lexia "terminologia" é polissêmica, referindo-se tanto à disciplina científica quanto ao conjunto de termos específicos de um domínio especializado. As bases teóricometodológicas dos estudos terminológicos podem ser empregadas no ensino e aprendizagem de línguas, na tradução, na elaboração de obras de referência, na padronização das denominações em um campo especializado, e têm como objeto de estudo o termo, que designa um conceito próprio de uma área de especialidade ${ }^{35}$ e deve ser analisado a partir de seus aspectos linguísticos, cognitivos e sociais (Krieger e Finatto, 2004; Barros, 2004; Cabré, 1999; Alpízar-Castillo, 1995; Dubuc, 1985).

A Terminologia é, portanto, uma disciplina científica que estuda as linguagens de especialidade e tem como unidade padrão o termo, definido pela Norma Internacional ISO 1087 como "a designação verbal de um conceito geral em um domínio específico" "36 (ISO 1087, 2000, p. 6), isto é, a unidade lexical de um domínio especializado. Vale destacar que a Terminologia, com " $t$ " maiúsculo, é a "ciência que estuda a estrutura, a formação, o desenvolvimento, o uso e a gestão das terminologias de diferentes domínios"37 (ISO 1087, 2000, p. 10), ou seja, é identificada como disciplina científica. Com "t" minúsculo, por sua vez, significa o "conjunto de termos próprios de um domínio, de um grupo de pessoas ou de um indivíduo" 38 (BOUTINQUESNEL, 1985, p. 17) e representa o objeto de estudo da primeira acepção. Assim, na presente pesquisa, estudamos a terminologia com " $\mathrm{t}$ " minúsculo do domínio das feiras que constitui a matéria-prima para a elaboração do dicionário terminográfico multilíngue.

Em síntese, a Terminologia, refere-se às unidades lexicais com conteúdo específico dentro de um campo especializado; à disciplina científica que explica as relações entre

\footnotetext{
${ }^{35} \mathrm{Uma}$ área do conhecimento humano frequentemente associada a uma atividade sócio-profissional (L'HOMME, 2004, p. 22).

36 Désignation verbale d'un concept général dans un domaine spécifique (ISO 1087, 2000, p. 6).

${ }^{37}$ Science étudiant la structure, la formation, le développement, l'usage et la gestion des terminologies dans différents domaines (Ibid., p. 10).

${ }^{38}$ Ensemble des termes propes à un domaine, à un groupe de personnes ou à un individu (BOUTIN-QUESNEL, 1985, p. 17).
} 
conceitos e termos de uma área de especialidade e à metodologia utilizada na recolha e análise dos termos de um domínio específico (SAGER, 1990, p. 3).

Apesar do seu rápido desenvolvimento, a classificação da Terminologia como disciplina científica já foi alvo de debates. Os discípulos de Wüster e da Escola de Viena consideram a Terminologia uma ciência; Dubuc, por sua vez, a considera uma arte, uma prática; Sager, contudo, a rejeita como ciência ou disciplina e a considera como uma metodologia de coleta, análise e descrição de termos (ALVES, 1997, p. 99-100).

Em realidade, pode-se dizer que a Terminologia é um somatório de tudo isso: ela é uma disciplina, uma arte, uma ciência, um conjunto de práticas, um campo de estudos, tal é a sua abrangência, afinal, ela está presente em todo lugar. Não é à toa que ainda não se chegou a um consenso para defini-la ou descrevê-la, devido à sua amplitude e importância.

Na graduação em tradução da UNESP, a disciplina Terminologia não fazia parte, até o início dos anos 2000, da grade curricular. Ela aparecia, implicitamente, nas traduções técnicas e científicas realizadas pelos alunos, mas sem uma reflexão explícita sobre o domínio e seus $\operatorname{conceitos}^{39}$. Hoje, felizmente, uma vez que é essencial para a formação de um tradutor ao ampliar seus conhecimentos técnicos e científicos para a realização de seu trabalho, a disciplina está mais presente nos cursos brasileiros de graduação, mestrado e doutorado, colaborando também para a formação de futuros terminológos.

Bowker e Pearson, concordando com Sager, descrevem o trabalho dos terminológos da seguinte maneira:

quando começam a trabalhar em um glossário completamente novo, eles começam decidindo o domínio e a língua de trabalho para o glossário. A documentação recolhida durante o projeto de terminologia será constituída de diferentes tipos de textos que lidam com o domínio. A documentação será usada para selecionar termos e observar evidências de uso incomum ou típico. [...] À medida que os terminólogos trabalham através da documentação, eles vão começar a pensar sobre como os candidatos a termo individuais se relacionam entre si e já podem começar a esboçar a estrutura do subcampo ${ }^{40}$ (BOWKER; PEARSON, 2002, p. 141).

\footnotetext{
${ }^{39}$ Acabei de ter um insight sobre o meu primeiro contato com a Terminologia. Foi ainda na graduação, quando fizemos o levamento dos termos da área da construção (Le bâtiment) para a exposição de um seminário para a classe. Fizemos o levantamento dos materiais de construção como, por exemplo: brique, chaux, ciment, béton, pierre, gravier, sable, poutrellle; das instalações do canteiro de obras como, por exemplo: chantier, bétonnière, clôture, grue, treuil e dos profissionais da construção civil como, por exemplo: chef de chantier, conducteur d'engins, constructeur, charpentier métallique, couvreur. Entretanto, não me lembro se, na época, chamávamos essas unidades lexicais da área da construção civil de termos, uma vez que não estudávamos Terminologia na graduação. De qualquer forma, hoje sei que o seminário que apresentamos para a sala na graduação era sobre a terminologia da construção civil em francês.

${ }^{40}$ When professional terminologists start work on a completely new glossary, they start by deciding on the domain and working language for the glossary. The documentation collected during the terminology project will consist of different types of texts dealing with the domain. The documentation will be used to select terms and to note
} 
São justamente essas as atividades que realizamos ao compilar o glossário bilíngue no mestrado e, agora, ao compilar o dicionário multilíngue no doutorado: delimitamos o domínio a ser estudado; recolhemos os materiais especializados sobre esse domínio, ou seja, selecionamos os corpora de estudo; fizemos o levantamento das unidades terminológicas; analisamos e sistematizamos os candidatos a termo; delineamos o mapa conceitual da área para entender a relação dos termos entre si; fizemos o preenchimento das fichas terminológicas com informações detalhadas sobre os candidados a termo; elaboramos a macro e a microestrutura da obra; validamos a pertinência temática dos termos coletados com especialistas da área e, ao final, redigimos os verbetes para a finalização do dicionário.

De acordo com Camacho (2004, p. 53), na terminologia "não interessa tanto saber o que determinada forma linguística significa, mas saber, para um conceito claramente definido, qual é a forma linguística que o representa" ${ }^{41}$. Nesse sentido, é fundamental entender o funcionamento do domínio especializado estudado, delinear a estrutura conceitual desse domínio, entender as relações entre os conceitos, compreender o papel e lugar dos termos dentro desse sistema estruturado e as relações que os termos mantêm entre si e, a partir daí, buscar as formas linguísticas que correspondam a esses conceitos, constituindo, portanto, a terminologia de uma área de especialidade (CAMACHO, 2004, p. 53; BIDERMAN, 2001, p. 20). Assim, para a Terminologia é muito importante compreender a relação entre o conceito e a denominação que "corresponde à forma que os especialistas efetivamente utilizam quando se referem a um conceito da estrutura nocional"42 (CABRÉ, 1993, p. 92). Em outras palavras, em Terminologia, a relação entre conceito e denominação se dá exclusivamente dentro de uma área de especialidade, pois, ao se modificar o domínio especializado estudado, essa relação também se modificará. Conhecer essa relação é também fundamental para estabelecer equivalências entre duas ou mais línguas para um dado domínio do conhecimento, caso da presente pesquisa.

Portanto, considerando a importância dos mapas conceituais para a visualização dos termos da área feirística e a compreensão de suas relações hierárquicas e não-hierárquicas (essas relações serão abordadas mais adiante no subitem 2.5), elaboramos os sistemas organizacionais das feiras de negócios que poderão ser consultados no Capítulo 3 (em português) e no Apêndice

evidence of unusual or typical usage. [...] As the terminologists work their way through the documentation, they will start to think about how the individual term candidates relate to each other and may already start to sketch a rough outline of the structure of the subfield (BOWKER; PEARSON, 2002, p. 141).

${ }^{41}$ No interesa tanto saber qué significa determinada forma lingüística, sino saber para una noción claramente delimitada cuál es la forma lingüística que la representa (CAMACHO, 2004, p. 53).

${ }^{42}$ Que corresponde a la forma que utilizan efectivamente los especialistas cuando se refieren a un concepto de la estructura nocional (CABRÉ, 1993, p. 92). 
III (nas demais línguas).

No que diz respeito ao objeto de estudo da Terminologia, L'Homme (2004, p. 33) reforça que a particularidade do termo está no fato de veicular um sentido especializado. Alves (1999a, p. 213) traz a definição de termo proposta por Boutin-Quesnel et al., no Vocabulaire systématique de la terminologie (1985, p. 20): "unidade significante constituída por uma palavra (termo simples) ou diversas palavras (termo complexo) e que designa um conceito de forma unívoca no interior de uma área”. Para Bowker, os termos são as designações linguísticas atribuídas a conceitos (BOWKER, 2009, p. 286).

Maciel concorda com Bowker e declara que

os termos começam a existir quando se unem indissoluvelmente a conceitos determinados dentro de um conjunto conceitual estruturado em uma área de especialidade. Só então, no interior desse sistema, as unidades lexicais se constituem em unidades terminológicas e passam a constituir uma terminologia (MACIEL, 2001, p. 41).

Em outros termos, uma unidade lexical torna-se uma unidade terminológica quando ela se une a um conceito pertencente à estrutura conceitual de um domínio especializado, adquirindo status de termo. Assim, os termos de uma determinada área de especialidade referem-se a conceitos específicos e característicos desse campo. Nesse sentido, o conceito veiculado por uma unidade terminológica pode mudar de acordo com o domínio de especialidade onde ela se encontra. Assim, uma mesma denominação pode vincular conceitos completamente diferentes em domínios especializados distintos.

Em terminologia, como em todos os estudos sobre o léxico, o contexto é de fundamental importância para a compreensão do conceito atrelado ao termo. Considerando que as línguas de especialidade estão inseridas em um contexto sócio-cultural, é "no contexto e no discurso que o termo é investido de valor" (LOTTE, 1961, p. 8, apud BARROS, 2004, p. 50). Cabré compartilha dessa visão e afirma que "o caráter de termo é ativado em função de seu uso em um contexto e situação adequados" $" 43$ (CABRÉ, 1999, p. 132). Por essas razões, os termos do nosso dicionário são coletados e analisados em seus contextos de uso reais, dentro do discurso das feiras de negócios, em cada língua, uma vez que a sua condição de termo só é estabelecida em função da situação comunicativa em que é utilizado.

Azenha Junior (2010, p. 46) acrescenta que "os termos incluem deslocamentos de perspectiva que variam de cultura para cultura", uma vez que os textos de especialidade também são culturamente marcados e, consequentemente, os conceitos e a forma de designá-los variam

\footnotetext{
${ }^{43}$ El carácter de término se activa em función de su uso en um contexto y situación adecuados (CABRÉ, 1999, p. 132).
} 
de uma cultura para outra.

Do ponto de vista da estrutura, o termo pode constituir-se de um único lexema ou de uma sequência lexemática. De acordo com Barros (2004, p. 100), o termo pode ser simples, definido pela Norma Internacional ISO 1087 como “constituído de um só radical”44 (ISO 1087, 2000, p. 7), ou complexo, isto é, “formado por dois ou mais radicais" 45 (ISO 1087, 2000, p. 7). Os termos complexos são predominantes nas comunicações especializadas. Isso ocorre devido ao modelo de formação lexical encontrado nas línguas de especialidade. A partir de um termo base são acrescentados modificadores que especificam o seu conteúdo com o objetivo de nomear novas realidades (ALPÍZAR-CASTILLO, 1995, p. 94).

Do ponto de vista da categoria gramatical, prevalecem, nas línguas de especialidade, os substantivos, ou seja, as unidades terminológicas de categoria nominal com valor referencial e denominativo são os termos mais comumente encontrados na terminologia de uma área de especialidade (CABRÉ, 2010, p. 358). Do mesmo modo, como observamos no glossário compilado no mestrado e no dicionário elaborado no doutorado, dentre os termos essenciais da área feirística predominam os substantivos.

Outro aspecto que merece destaque é a dificuldade na identificação de uma unidade lexical como unidade terminológica. Para Maciel esse é o ponto crítico

para aqueles que trabalham no estabelecimento da nomenclatura de um dicionário técnico-científico. As fronteiras entre a língua comum e a linguagem usada na área de especialidade são muito tênues, já que tanto uma como outra se constituem basicamente dos mesmos elementos (MACIEL, 2001, p. 82).

De fato, essa é a grande preocupação dos terminológos ao elencarem os termos que compõem a nomenclatura de um dicionário terminológico de língua de especialidade ${ }^{46}$. É preciso selecionar bem os materiais que farão parte dos corpora de estudo utilizados para a recolha dos possíveis "candidatos a termo" e ainda consultar especialistas da área para a confirmação do status de termo de uma unidade lexical dentro de um domínio especializado.

Também o modo de organização de uma dada terminologia é tema de interesse para os terminológos, uma vez que, segundo Cabré (1998, p. 38), as regras que governam o funcionamento dos termos são as mesmas que governam o léxico em geral. Dessa maneira, podemos afirmar que o trabalho lexicográfico e terminográfico se entrecruza em vários pontos

\footnotetext{
${ }^{44}$ Découlant d'une seule racine (ISO 1087, 2000, p. 7).

${ }^{45}$ Découlant de deux racines ou plus (Id.).

${ }^{46}$ Língua de especialidade ou tecnoleto representa um subsistema linguístico que compreende o conjunto dos meios linguísticos próprios a um campo de experiência particular (disciplina, ciência, técnica, profissão, etc) (BOUTIN-QUESNEL et al., 1985, p. 20-21).
} 
(BEVILACQUA; FINATTO, 2006, p. 49), mesmo que, de um lado, a Lexicologia/Lexicografia leve em consideração as possibilidades de realização e de significação da unidade léxica em uma dada língua e, de outro, a Terminologia/Terminografia leve em consideração o conceito que a unidade terminológica possui no domínio específico no qual está sendo analisado.

No que se refere à classificação das obras lexicográficas e terminográficas, Barbosa afirma que

são bastante tênues as fronteiras entre um e outro tipo de texto lexicográfico ou terminográfico e que não há uma relação biunívoca entre conceitos e termos, ainda que sejam considerados numa área bem limitada, como, por exemplo, o da lexicografia, ou da terminologia e da terminografia. Esses elementos parecem confirmar que, não raras vezes, obras da mesma natureza e função são classificadas de maneira diversa, segundo critérios adotados por este ou aquele autor, fato que conduz à existência de numerosas denominações para o mesmo núcleo conceptual 'obra lexicográfica/obra terminográfica' (BARBOSA, 1996, p. 32).

Logo, podemos concluir que a classificação de uma obra de referência como terminográfica ou lexicográfica, como dicionário, glossário ou vocabulário depende muito mais do autor da obra em questão do que de uma nomenclatura pré-estabelecida e rígida. No nosso caso, a pesquisa culminou em um dicionário multilíngue de uma área de especialidade, a área feirística.

É importante mencionar outro tradicional ponto de diferenciação entre os pares Linguística/língua comum e Terminologia/língua de especialidade: o terminológo parte do conceito em busca da designação (abordagem onomasiológica), ao passo que o linguista parte da unidade lexical em busca de sua definição (abordagem semasiológica) (FINATTO, 2001, p. 309). De modo semelhante, Cabré afirma que a confecção de um dicionário de léxico geral

parte de uma lista de palavras que constitui o inventário das entradas de um dicionário. O lexicógrafo descreve-as semanticamente por meio da definição. O processo que se segue, portanto, é do tipo semasiológico, ou seja, da forma ao significado. O processo de trabalho na terminologia acontece em sentido inverso. O terminológo estabelece em primeiro lugar a lista de conceitos que faz parte de um sistema conceitual de uma atividade especializada. O terminológo atribui a cada conceito uma determinada denominação, que corresponde à forma utilizada pelos especialistas. Este processo que, em terminologia se passa do conceito à denominação, chama-se processo onomasiológico ${ }^{47}$ (CABRÉ, 1993,

\footnotetext{
${ }^{47}$ la confección de un diccionario de léxico general parte de una lista de palabras que constituye el inventario de las entradas de un diccionario. El lexicógrafo procede a a describirlas semánticamente por medio de la definición. El proceso que se digue, pues, es de tipo semasiológico: se pasa de la forma al significado. El proceso de trabajo en terminología se produce en sentido inverso. El terminólogo establece en primer lugar la lista de conceptos que forma parte del sistema conceptual de una actividad especializada. El terminólogo atribuye entonces a cada casilla conceptual una determinada denominación, que corresponde a la forma que utilizan efectivamente los especialistas. Este proceso, que en terminología pasa del concepto a la denominación, se denomina proceso onomasiológico (CABRÉ, 1993, p. 92).
} 


$$
\text { p. 92). }
$$

Todavia, acredita-se hoje que é possível ter as duas abordagens tanto na Lexicologia como na Terminologia, visto que "o terminológo parte do termo e procede a uma análise de seu conteúdo semântico (percurso semasiológico) e ao redigir as definições, parte do significado para chegar a um enunciado (percurso onomasiológico)” (BARROS, 2004, p. 67).

Considerada em toda a sua plurivocidade cabe à Terminologia, "como disciplina teórica, como sistema de termos e como conjunto de princípios para elaboração de dicionários, contribuir para que esses instrumentos de referência possam cumprir melhor sua missão" (MACIEL, 2001, p. 46). Esse é justamente o nosso objetivo com este trabalho, produzir um dicionário de qualidade que atenda às necessidades a que se propõe, ou seja, informar ao consulente as equivalências em inglês, francês e italiano para os termos em português pesquisados, as variantes (sinônimos) em cada língua, bem como os contextos de ocorrência, para facilitar a compreensão do uso desses termos em cada idioma e contribuir com o trabalho de tradutores, intérpretes e profissionais do setor.

Desse modo, para o êxito de uma pesquisa terminológica multilígue alguns fatores devem ser considerados, tais como: o entendimento da relação entre os conceitos e os termos no interior do domínio especializado; a relevância do contexto de ocorrência dos termos para a compreensão do sentido; o conhecimento da estrutura morfossintática e léxico-semântica dos termos e a aplicabilidade das bases teórico-metodológicas dos estudos terminológicos na tradução, como será abordado no item a seguir.

\subsection{A Relação entre Tradução e Terminologia}

A relação Tradução-Terminologia é uma via de mão dupla: os tradutores se beneficiam da Terminologia como meio para obter informações sobre determinado campo especializado e também como instrumental, pois utilizam fontes terminológicas de todos os tipos para auxiliálos durante o processo tradutório; os terminológos, por sua vez, se beneficiam da Tradução, pois ao realizar o seu trabalho de recolha de termos em várias línguas, eles se valem da tradução durante o processo de busca pelos equivalentes.

No presente trabalho, portanto, a relação Tradução-Terminologia aparece mais nitidamente na busca pelas equivalências. De um lado, as estabelecemos de fato, ou seja, traduzimos um termo numa língua por outro em outra língua; de outro, utilizamos uma abordagem teórica da Terminologia que nos auxilia nesse processo, como será abordado mais 
adiante no subitem 2.5. Inserimo-nos, portanto, no conjunto das pesquisas que objetivam auxiliar tradutores, intépretes, pesquisadores e estudantes de tradução por meio da elaboração de instrumentos de trabalho com elevado grau de precisão e confiabilidade.

Os Estudos da Tradução e a Terminologia são disciplinas autônomas, com objetos de estudo, pressupostos teóricos e metodológicos distintos. Ambas surgiram de necessidades práticas: "a Terminologia, do interesse dos cientistas e técnicos em fixar os conceitos e denominações de suas respectivas áreas; a Tradução, da necessidade de facilitar a compreensão em línguas distintas" (RAMOS, 2001, p. 164).

Para Aubert, a relação entre Tradução e Terminologia se caracteriza como positiva na direção da Terminologia à Tradução, já que a Terminologia e a Terminografia são vistas como ferramentas que auxiliam a atividade tradutória nos domínios técnico e científico; e negativa na direção da Tradução à Terminologia, pois tradução e tradutores são vistos como fontes de neologismos, expansão exagerada de sinonímias e decalques (AUBERT, 2001, p. 42 e 44).

Ramos apresenta uma outra visão, diferente de Aubert, ao afirmar que a relação entre Tradução e Terminologia apresenta um caráter unidirecional: a terminologia busca suas fontes em textos produzidos em situação real por especialistas, abstendo-se, portanto, da tradução que, por sua vez, se vale dos materiais terminográficos e dos recursos oferecidos pela Terminologia (RAMOS, 2001, p. 166).

Contudo, os estudos terminológicos/tradutológicos estão tão avançados e mais elaborados que, como dissemos anteriormente, essa relação hoje é uma via de mão dupla, isto é, uma alimentando a outra e não mais como os autores supracitados escreveram há 18 anos.

Apesar de seus pontos de convergência, a Tradução e a Terminologia são campos distintos de conhecimento e de atuação: a Tradução "constitui uma finalidade nela mesma ao produzir um texto em outra língua, enquanto que a Terminologia, ao elaborar obras de referência, oferece instrumentos pragmáticos para facilitar o trabalho de tradutores" (KRIEGER, 2001, p. 159), os principais usuários de recursos terminológicos, fornecendo-lhes as informações de que necessitam para a busca dos equivalentes ou escolha do termo mais adequado entre as várias opções disponíveis (CABRÉ, 2010, p. 358).

Cabré complementa que, a despeito de suas semelhanças, esses campos do conhecimento se concentram em dois objetos diferentes: enquanto a tradução lida com o processo tradutório e o que esse processo envolve, a terminologia preocupa-se com o conceito e a designação dos termos que constituem o conhecimento estruturado na mente dos especialistas (CABRÉ, 2010, p. 357). A autora menciona ainda que 
a Terminologia e Tradução são também explicitamente distintas pelos seus propósitos. A tradução está preocupada em expressar em uma língua uma estrutura semântico-pragmática originalmente produzida em outra língua. A terminologia visa recolher termos especializados para compilá-los e produzir recursos terminológicos (glossários, dicionários, vocabulários ou bancos de dados) destinados a serem acessíveis e úteis para especialistas em tradução, entre outros profissionais $^{48}$ (CABRÉ, 2010, p. 357).

Assim, a Tradução e a Terminologia, além de possuírem objetos distintos, também têm finalidades diferentes: a tradução objetiva comunicar em uma língua a mensagem que fora produzida em outra língua, levando em considerações aspectos semânticos, pragmáticos, culturais, funcionais e a terminologia, por sua vez, tem como objetivo a elaboração de obras terminográficas que auxiliam os tradutores nesse processo de tradução.

Vale destacar que para a elaboração de materiais terminográficos os termos são extraídos de textos originais, isto é, textos traduzidos não são utilizados como fontes para esse fim, salvo raras exceções. Assim, em nossa pesquisa, trabalhamos com textos especializados do setor feirístico, originalmente escritos em português, inglês, francês e italiano para a recolha dos termos. Contudo, é muito difícil determinar se um manual foi traduzido ou escrito originalmente numa língua. Em geral, equipes de tradutores de várias línguas trabalham traduzindo e adaptando um manual da língua mãe de um equipamento, de um produto, entre outros. Por isso, mesmo procurando, às vezes não dá para saber se é tradução ou não.

Não obstante as diferenças de objetos e propósitos, existe entre a tradução especializada e a Terminologia uma relação visível e inevitável, isto é, os caminhos da Tradução e da Terminologia se entrecruzam na tradução de textos especializados (RAMOS, 2001, p. 165). Isso pode ser observado em nosso trabalho quando traduzimos os manuais e guias do expositor ${ }^{49}$ no momento do estabelecimento das equivalências. Do mesmo modo, Bowker acrescenta que o conhecimento das teorias da Terminologia é importante para o trabalho dos tradutores, uma vez que lhes auxilia no desenvolvimento de tarefas essenciais, tais como:

determinar as relações entre conceitos, lidar com situações em que os conceitos são similares ao invés de idênticos, criar termos na língua de chegada para os novos conceitos e encontrar termos que correspondam ao mesmo conceito nas duas línguas, que às vezes envolve a seleção de

\footnotetext{
48 Terminology and translation are also explicitly distinguished by their purposes. Translation is concerned with expressing in a language a semantic-pragmatic structure originally produced in another language. Terminology aims at collecting specialized terms to compile them and produce terminological resources (glossaries, dictionaries, vocabularies or databases) intended to be readily accessible and useful to translation experts, among other professionals (CABRÉ, 2010, p. 357).

${ }^{49}$ Esses materiais são indispensáveis para a participação em qualquer feira, seja no Brasil ou no exterior, e devem ser necessariamente lidos e analisados por expositores de todo o mundo, previamente à assinatura do contrato de locação do estande.
} 
um termo dentre um número de expressões alternativas possíveis ${ }^{50}$ (BOWKER, 2009, p. 286-287), etc.

Essas são, portanto, as várias situações a que o tradutor está exposto durante a atividade tradutória e as diversas escolhas que ele precisa fazer o tempo todo para realizar com êxito o seu trabalho, e o conhecimento das teorias da Terminologa e das técnicas do fazer terminológico podem ajudá-lo nesse processo. As diferentes correntes teóricas da Terminologia serão abordadas em mais detalhes no próximo item.

A proximidade dessa relação entre a Tradução e a Terminologia pode ser mais facilmente observada quando o tradutor, ao se deparar com um conceito para o qual ainda não exista uma denominação em outra língua, atue como terminológo, desempenhando, portanto, duas funções: usuário e produtor de terminologia. Como usuário, consulta todos os tipos de fontes disponíveis (textos especializados, dicionários mono, bi e multilíngues, glossários, bancos de dados terminológicos, entre outros); como produtor, cria seus próprios glossários e, na ausência de fontes terminográficas em uma determinada área, acaba desempehando o papel de terminólogo, produzindo terminologia para resolver os problemas de tradução que surgem pelo caminho (CAMACHO, 2004, p. 26).

Nesse sentido, Cabré acrescenta que, para encontrar um equivalente,

o tradutor atua como um terminológo do ponto de vista da metodologia: uma vez que o problema situa-se na estrutura conceitual do campo, a lacuna terminológica é preenchida por meio da proposta de um termo novo, que é feita baseada na observação dos padrões de formação do termo no domínio da especialidade, e ponderada no que diz respeito a sua viabilidade de utilização. Nesse caso, o tradutor começa a ser minimamente ativo na terminologia e atua como um terminológo ad hoc ${ }^{51}$ (CABRÉ, 2010, p. 363).

Assim, o tradutor, na função de terminológo ad hoc, pode, diante de um problema terminológico, observar os critérios de formação dos termos no interior daquele domínio especializado para propor um termo novo. A língua de chegada é obviamente beneficiada pelo trabalho dos tradutores que, ao exercitarem a sua criatividade, criam terminologias adequadas para denominar conceitos e realidades a que são expostos (DELISLE; WOODSWORTH, 1998,

\footnotetext{
${ }^{50}$ For translators because they will need to apply it in order to carry out tasks such as determining relationships between concepts, dealing with instances where concepts are similar rather than identical, creating target language terms for new concepts and finding terms that correspond to the same concept in two languages, which sometimes involves selecting one term from among a number of possible alternative expressions (BOWKER, 2009, p. 286287).

${ }^{51}$ The translator acts as a terminologist from the methodological point of view: once the problem is located in the conceptual structure of the field, the terminological gap is filled by means of a new term proposal, which is done based on the observation of the patterns of term-formation in the field of specialty, and pondered regarding its viability of use. In this case, the translator starts to be minimally active in terminology and acts as ad hoc terminologist (CABRÉ, 2010, p. 363).
} 
p. 127 e 136). Entretanto, antes de criar um neologismo, é necessário que o tradutor se certifique de que realmente não haja uma denominação para aquele conceito na área de especialidade em questão na língua para a qual traduz, para evitar a "expansão descontrolada de sinonímia", mencionada por Aubert (2001, p. 44).

Pode-se dizer, portanto, que existem duas situações em que a relação TraduçãoTerminologia não é favorável ao trabalho dos tradutores: primeiramente, quando não há obras de referência publicadas na área de especialidade na qual o tradutor está trabalhando, ou quando as informações contidas nas obras terminográficas disponíveis são insuficientes ou inadequadas para as necessidades específicas da tradução; em segundo lugar, quando o tradutor depara-se com dificuldades para identificar um termo complexo, ou sintagma terminológico (que caracteriza grande parte de uma terminologia), e isso pode levá-lo a cometer erros na tradução.

Para solucionar essa questão, ao menos na área feirística, elaboramos um dicionário constituído principalmente por termos complexos e que trazem informações suficientes ao consulente e ao tradutor sobre os termos-entrada, seus equivalentes e variantes.

Em suma, a Terminologia não se confunde com a Tradução, a primeira centra-se na "busca das denominações naturais em cada língua que correspondam a um conceito especializado"52 (CAMACHO, 2004, p. 58) e a segunda, como afirma Randolph Quirk, "é uma das mais difíceis tarefas que o escritor pode empreender" (BASSNETT, 2003, p. 26).

Assim, respeitando as diferenças e os níveis de dificuldade que envolvem ambas as práticas, tradutória e terminológica, consideramos a Terminologia como uma grande aliada da Tradução. Afinal, como mencionamos anteriormente, a relação Tradução-Terminologia é uma relação em que ambas saem beneficiadas, pois desfrutam de enriquecimento e auxílio mútuos. Em nosso trabalho, a relação Tradução-Terminologia é percebida claramente ao traduzirmos os termos da área feirística de uma língua para outra, com base nos fundamentos teóricos da Terminologia e da proposta dos ganchos terminológicos de Dubuc, como veremos mais adiante no subitem 2.5 .

\subsection{As Correntes Teóricas da Terminologia}

Há várias correntes teóricas relacionadas à Terminologia, dentre as quais citamos: a Teoria Geral da Terminologia (TGT) de Eugen Wüster, a Socioterminologia de Gaudin e

\footnotetext{
52 [...] una búsqueda de las denominaciones naturales en cada lengua correspondientes a un concepto especializado (CAMACHO, 2004, p. 58).
} 
Boulanger, a Teoria Comunicativa da Terminologia (TCT) de Cabré, a Etnoterminologia de Barbosa, a Terminologia Sociocognitiva de Temmerman, a Terminologia Textual de Bourigault e Slodzian e a Terminologia Cultural de Diki-Kidiri.

As diferentes teorias surgiram em períodos distintos, com propósitos diversos, mas todas elas desempenharam um papel importante dentro dos Estudos Terminológicos e dos Estudos da Tradução. A TGT fundou as bases da Terminologia, seguida pela Socioterminologia que, ao verificar algumas deficiências da primeira teoria, propôs algumas mudanças de paradigma. Depois, veio a TCT que complementou as ideias propostas pela Socioterminologia, trazendo à luz a questão do estudo do termo em contexto. Outras teorias vieram com suas particularidades e propósitos para enriquecer ainda mais os Estudos Terminológicos. Claro está que, dependendo da teoria adotada, há uma maneira de analisar e estudar as terminologias com enfoque e objetivos específicos. Em relação à tradução, como mencionado por BOWKER (2009) anteriormente, conhecer as teorias da Terminologia é importante para os tradutores, já que são úteis para determinar as relações entre os conceitos. Logo, pretendemos apresentar as diferentes teorias, comparando-as, ao situar nosso trabalho de pesquisa dentro da TCT.

O marco inicial da Terminologia é atribuído ao engenheiro austríaco Eugen Wüster (1898-1977), representante da Escola de Viena, que em 1931 apresentou a sua tese de Doutorado intitulada A normalização internacional da terminologia técnica, com a qual lançou as bases da disciplina e da atividade terminológica. Teve início, portanto, na década de 30, a Teoria Geral da Terminologia (TGT), com o trabalho desse autor, e mais tarde com os trabalhos de D.S. Lotte, co-fundador da Escola Soviética, e "primeiro verdadeiro professor de Terminologia"53 (RONDEAU, 1984, p. 6).

Gaudin ressalta que existe uma diferença na apreensão linguística do fenômeno terminológico. Com efeito, “onde Wüster separa estritamente léxico e gramática para se interessar apenas pelos termos, o fundador da Escola Soviética reconhece a primazia do contexto e do discurso onde o termo recebe seu valor"54 (GAUDIN, 1993, p. 27), ou seja, Wüster considerava os termos independentemente do contexto e Lotte, ao contrário, admitia a importância do discurso para a expressão real do termo. O autor acrescenta ainda que

para que a terminologia seja precisa, basta que a monossemia do termo seja relativa. Trata-se aqui do reconhecimento de fato do caráter essencialmente polissêmico do léxico ainda que Wüster o admita somente na língua comum, desde que ela tenha por objetivo a variedade

\footnotetext{
${ }^{53}$ Le premier véritable professeur de terminologie (RONDEAU, 1984, p. 6).

${ }^{54}$ Là où Wüster sépare strictement lexique et grammaire pour ne s'intéresser qu'aux termes, le fondateur de l'école soviétique reconnaît le primat du contexte et du discours au sein duquel le terme reçoit sa valeur (GAUDIN, 1993, p. 27).
} 
na expressão ${ }^{55}$ (LOTTE, 1981, p. 67 apud GAUDIN, 1993, p. 27-28).

Nesse sentido, Lotte reforça que tanto o léxico da língua de especialidade quanto o léxico da língua comum é polissêmico e que, portanto, para atingir a precisão nas terminologias almejada por Wüster, era suficiente considerar a monossemia relativa do termo.

Terminólogos tradicionais, como Wüster, estavam interessados apenas em estabelecer o que os termos representavam, não se importando, portanto, em analisar os termos em uso (PEARSON, 1998, p. 11). Assim, o objetivo principal da Teoria Geral da Terminologia é a padronização: primeiro o conceito é fixado; depois, a designação é padronizada (BOWKER, 2009, p. 287), ou seja, o objetivo de Wüster era padronizar e fixar a relação entre termo e conceito. Os principais princípios consubstanciados nesta teoria incluem

os de onomasiologia (ou seja, começando com o conceito e trabalhando até o termo), a natureza clara de conceitos (ou seja, os conceitos têm limites precisos e um lugar fixo dentro de um sistema de conceitos), a univocidade (ou seja, a relação um-para-um entre conceito e termo), e a sincronia (ou seja, com foco no uso atual de conceitos e termos, ao invés de sua evolução) ${ }^{56}$ (BOWKER, 2009, p. 287).

Para Wüster, portanto, a relação entre conceito e termo que o denomina deve ser unívoca, objetivando alcançar uma uniformização conceitual e denominativa da terminologia utilizada por especialistas para assegurar a exatidão na comunicação dentro de um âmbito profissional.

Desse modo, na visão de Wüster, "não deveria haver nem denominação plurivalente (homônimos e polissemia), nem denominação múltipla de uma mesma noção (sinônimos)" "57 (KOCOUREK, 1982, p. 162). Nesse sentido, o papel da terminologia é, segundo Wüster, acabar com as ambivalências nas comunicações técnicas e científicas (RONDEAU, 1984, p. 6).

Em 1951, após a Segunda Guerra Mundial, foi criada a ISO (International Organization for Standardization) que estabeleceu um comitê técnico para a normalização terminológica e, em 1971, foi criada, em Viena, pela Unesco, a Infoterm (International Information Centre for Terminology), com o objetivo de coordenar as atividades terminológicas em todo o mundo e melhorar a comunicação entre especialistas.

\footnotetext{
${ }^{55}$ Pour que la terminologie soit précise, affirme-t-il, il suffit que la monossémie du terme soit relative. Il s'agit là d'une reconnaissance de fait du caractère essentiellement polysémique du lexique alors que Wuster ne l'admet dans la langue commune que pour autant qu'elle a pour objectif la variété dans l'expression (LOTTE, 1981, p. 67). ${ }^{56}$ The main principles embodied in this theory include those of onomasiology (i.e. beginning with the concept and working towards the term), the clear-cut nature of concepts (i.e. concepts have precise limits and a fixed place within a system of concepts), univocity (i.e. one-to-one relationship between concept and term), and synchrony (i.e. focusing on current use of concepts and terms rather than on their evolution). (BOWKER, 2009, p. 287).

${ }^{57} \mathrm{Il}$ ne devrait donc y avoir ni dénomination plurivalente (homonymes et polysèmes) ni dénomination multiples d'une même notion (synonymes) (KOCOUREK, 1982, p. 162).
} 
Rondeau, assim como Wüster, acredita que o trabalho do terminólogo começa pela definição e descrição do conceito para, então, decidir qual denominação é adequada, levando em conta que o valor de um termo se estabelece pelo lugar que ocupa na estrutura conceitual do domínio ao qual pertence e que o seu conceito deve ser descrito com base nas relações com outros conceitos do mesmo domínio (PEARSON, 1998, p. 12).

Em resumo, a Teoria Geral da Terminologia estabelecida por Eugen Wüster nos anos 1930 assume um caráter metodológico de natureza prescritiva e preconiza uma visão estática e normalizadora dos termos, com o intuito de assegurar a univocidade da comunicação profissional, fundamentada nos pressupostos da "monossemia terminológica, exclusividade designativa e monorreferencialidade" (KRIEGER, 2000, p. 12), anulando as dimensões comunicativa e pragmática inerentes às linguagens de especialidade, uma vez que os termos são vistos como independentes do contexto e do discurso, e renegando, portanto, a polissemia, a sinonímia e a homonímia. Nesse contexto, o conceito deve ser estabelecido de antemão e, só então, deve-se procurar a expressão linguística que mais adequadamente designe o conteúdo terminológico em questão.

Contrariamente à TGT, surge em meados dos anos noventa a Socioterminologia que se desenvolveu principalmente no âmbito dos falantes de língua francesa e é orientada por L. Guespin e J. C. Boulanger, em Quebec, e por Yves Gambier e François Gaudin da Universidade de Rouen, na França. Sua principal crítica à TGT é o fato de não levar em conta o uso social real da terminologia e os parâmetros sociais do discurso especializado ${ }^{58}$ (CAMACHO, 2004, p. 42).

Portanto, a Socioterminologia, em oposição à Teoria Geral da Terminologia, considera o termo em seu uso real, desvencilhando-se pois da visão tradicionalista de que um termo referese exclusivamente a um e somente um conceito dentro de um determinado campo.

A Socioterminologia, ao considerar o uso social real da língua, adota uma abordagem descritiva à terminologia, contrária à padronização prescritiva, introduz o estudo de sinonímia e polissemia e põe em dúvida a existência de conceitos e domínios claramente definidos (BOWKER, 2009, p. 287), ou seja, conceitos com limites precisos e um lugar fixo dentro de um sistema de conceitos.

No trabalho terminológico de cunho descritivo, "a variação e a mudança linguística são observadas e respeitadas [...], e a relação unívoca entre um termo e um conceito deixa de ser

\footnotetext{
${ }^{58}$ Socioterminología se desarrolla a mediados de los años noventa principalmente en el ámbito franco hablante y es orientada por L. Guespin y J.C Boulanger en Québec, y por Yves Gambier y François Gaudin de la Universidad de Rouen, en Francia. Su principal crítica a la TGT es el hecho de no tener en cuenta el uso social real de la terminología y los parámetros sociales del discurso especializado (CAMACHO, 2004, p. 42).
} 
um pressuposto necessário para garantir a eficácia da comunicação" (ALVES, 1999a, p. 214), já que o termo estabelece relações significativas com outros termos e pode estar sujeito à polissemia. Vale acrescentar que o fenômeno da homonímia também é bastante frequente entre as línguas de especialidade. Em nosso trabalho podemos citar, por exemplo, o termo "expositor" que refere-se tanto ao objeto utilizado no estande para expor um produto, quanto à pessoa que aluga um estande em uma feira para expor produtos ou oferecer serviços.

Em resumo, a Socioterminologia, estabelecida por François Gaudin e Boulanger em 1993, preconiza que os termos e as línguas de especialidade estão inseridos em um contexto sociocultural e que, portanto, é fundamental levar em consideração o uso dos termos. Essa teoria reconhece que há variação linguística nos discursos especializados e que as variantes lexicais e conceituais devem ser analisadas em contexto. Reconhece, desse modo, a dimensão social do discurso especializado e a inter-relação das unidades terminológicas com os contextos comunicativos em que ocorrem. Considerando que a dimensão sociocultural não é relevante para os objetivos do presente trabalho, não utilizamos essa corrente teórica da Terminologia.

No que diz respeito à Teoria Sociocognitiva da Terminologia, Temmerman afirma que

é um paradigma que envolve uma série de princípios que diferem do paradigma da teoria tradicional da terminologia. Para ser uma disciplina totalmente desenvolvida, a teoria da terminologia precisa mais do que princípios. Ela também precisa de ferramentas, ou seja, métodos e técnicas para a análise dos dados terminológicos que possam servir a um propósito duplo. Por um lado, esses métodos e técnicas permitem que os pesquisadores testem a validade dos princípios e, por outro lado, eles oferecem aos terminógrafos dados para a sua prática descritiva ${ }^{59}$ (TEMMERMAN, 2001, p. 83).

Essa teoria foi criada em oposição à teoria tradicional da terminologia e oferece ferramentas para a descrição e análise dos termos, baseadas na análise de informações textuais, ao contrário da TGT que, baseada apenas em princípios, concentrava-se na padronização terminológica, e não na descrição do significado real dos termos nos arquivos textuais em que são encontrados.

Temmerman afirma que a padronização é apenas um aspecto do que deveria ser a preocupação da Teoria Tradicional da Terminologia e que o erro foi eleger os princípios de padronização como a Teoria Geral da Terminologia. Desse modo, os fundamentos e

\footnotetext{
${ }^{59}$ Sociocognitive terminology theory is a paradigm involving a number of principles which differ from the paradigm of traditional terminology theory. In order to be a fully-fledged discipline terminology theory needs more than principles. It also needs tools, i.e. methods and techniques for the analysis of terminological data which can serve a double purpose. On one hand these methods and techniques allow the researchers to test the validity of the principles and on the other hand they provide the terminographer with data for his descriptive practice (TEMMERMAN, 2001, p. 83).
} 
metodologias da Teoria Tradicional da Terminologia devem ser acrescidos dos princípios da sua contraparte Sociocognitiva que desempenha um papel importante no desenvolvimento de novas ideias e considera que os termos são motivados (TEMMERMAN, 2001, p. 75-78), o que refuta a visão de Wüster de que o conceito precede a denominação.

Para Temmerman, a Teoria Tradicional da Terminologia

teoricamente estipula que um especialista pode descrever o conceito antes de dar qualquer atenção ao termo. O conceito é considerado de uma forma abstrata, sem reconhecer o papel que a linguagem desempenha na categorização e comunicação. Artificialmente, o fato de que o termo já existe para comunicar o conhecimento no domínio especializado em questão está convenientemente esquecido. Com o objetivo de chegar a uma comunicação inequívoca, o modelo artificial insiste em primeiro delinear claramente um conceito e depois nomeálo, a fim de obter mononímia e monossemia ${ }^{60}$ (TEMMERMAN, 2001, p. 79-80).

Nesse sentido, a autora afirma que o termo já existe na mente do especialista para comunicar o conhecimento no domínio especializado, ao contrário do que Wüster queria provar, ou seja, que os conceitos existiam independentemente da compreensão e linguagem humana.

Visto que as terminologias só podem ser estudadas em discurso, "é melhor aceitar que é o termo que é o ponto de partida na descrição terminológica [...] e o que é nomeado pelo mesmo termo em diferentes textos pode ter diferentes referentes" ${ }^{61}$ (TEMMERMAN, 2001, p. 80). Nesse sentido, o ponto de partida não é mais o conceito como era estabelecido pela TGT, mas o termo em si que, de acordo com a presente teoria, é "uma unidade de compreensão [...] que expressa um modelo sociocultural de apreensão das terminologias" (KRIEGER, 2001, p. 127), o que não é relevante para a nossa pesquisa, como mencionado anteriormente.

Assim, a Teoria Sociocognitiva da Terminologia, proposta por Rita Temmerman em 2000, sugere uma nova concepção de termo cujo significado é descrito com base na análise do texto no qual o termo está inserido, levando em consideração as dimensões linguística, pragmática, discursiva e comunicativa. Destaca que o termo já existe para comunicar o conhecimento no domínio especializado e nega a monorreferencialidade proposta por Wüster, já que o mesmo termo em diferentes textos pode ter diferentes referentes.

\footnotetext{
${ }^{60}$ TTT theoretically stipulates that a specialist can describe the concept before giving any attention to the term. The concept is considered to exist in an abstract way, without acknowledging the role language plays in categorisation and communication. Artificially, the fact that terms already exist to communicate about the knowledge in the specialised domain under consideration is conveniently overlooked. With the aim of arriving at unambiguous communication the artificial model insists on first clearly delineating a concept and then naming it in order to obtain mononymy and monosemy (TEMMERMAN, 2001, p. 79-80).

${ }^{61}$ it is better to accept that it is the term which is the starting point in terminological description and what is named by the same term in different texts can be shown to have different referents (Ibid., p. 80).
} 
Por outro lado, Barbosa afirma que a Etno-terminologia

busca a delimitação das estruturas morfo-semântico-conceptuais de sua unidade padrão, o vocábulo/termo, uma das características do universo do discurso etno-literário. Essas reflexões tomam como ponto de partida a questão da tênue fronteira existente entre o termo técnicocientífico e o vocábulo da língua geral e procuram mostrar que uma mesma unidade lexical pode assumir os valores e as funções, ou de termo ou de vocábulo, conforme o universo de discurso em que se inscrevem. Diferente é o estatuto das unidades lexicais dos discursos etno-literários, que subsumem as duas funções, nos mesmos universos de discurso e nos mesmos discursos-ocorrência (BARBOSA, 2007, p. 433).

Portanto, diferentemente de uma unidade lexical que assume o valor de termo ou vocábulo de acordo com a situação comunicativa em que ocorrem, as unidades lexicais estudadas pela Etno-terminologia assumem ao mesmo tempo o valor e função de termo $\underline{\mathrm{e}}$ vocábulo dentro do discurso etno-literário e são chamadas por Barbosa (2007, p. 442) de "unidades multifuncionais", pois é um vocábulo nos seus aspectos referenciais, pragmáticos e simbólicos [...], e é um termo, já que possui características de uma linguagem especializada (BARBOSA, 2007, p. 441). Elas resultam, portanto, do cruzamento de processos de metaterminologização e metavocabularização.

Vale esclarecer que a vocabularização é a transformação do termo em vocábulo; a terminologização é a transformação do vocábulo em termo, ou de um conceito em termo, e a metaterminologização é a transposição de um termo de uma área para outra, com a manutenção de alguns traços semânticos ou, ao contrário, com a perda dos traços semânticos que possuía no universo de partida (arroba: medida de peso e arroba: símbolo de endereço eletrônico) (BARBOSA, 2007, p. 437-438).

Portanto, a Etno-terminologia, sistematizada por Maria Aparecida Barbosa em 2006, considera que, no discurso etno-literário, as unidades lexicais desempenham ao mesmo tempo as duas funções, de vocábulo e termo e, por esse motivo, possuem um estatuto diferente. Nesse sentido, essa teoria não serve aos objetivos do presente trabalho, uma vez que os termos do setor feirístico serão sempre termos, em textos com densidades terminológicas diferentes, segundo Cabré.

A Terminologia Textual, por sua vez, é uma abordagem descritiva na qual as unidades lexicais são analisadas dentro do corpus. Assim, o texto é o ponto de partida para a elaboração da descrição lexical, ou seja, parte-se do texto em direção ao termo. De acordo com essa abordagem, as bases teóricas da terminologia devem estar ancoradas em uma linguagem textual, apoiadas pelas ferramentas da linguística de corpus (BOURIGAULT; SLODZIAN, 1999, p. 
29-32). Nossa pesquisa possui similiaridade com essa corrente teórica do ponto de vista metodológico, visto que o nosso ponto de partida também é o corpus (constituído de textos especializados) e utilizamos as ferramentas da linguística de corpus para a recolha dos termos. Contudo, não trabalhamos com a questão sociocultural que também é abordada por essa corrente teórica.

E ainda, a investigação terminológica proposta por Diki-Kidiri, que traz um enfoque cultural da terminologia, ou seja, considera a diversidade cultural no processo de elaboração de terminologias, para a promoção de línguas e culturas africanas que buscam referências no ocidente para suprir suas necessidades de modernização, uma vez que a representação da realidade se dá de forma diferente de uma cultura para outra, gerando conceitos específicos em cada cultura (DIKI-KIDIRI, 2009, p. 5).

Por fim, a Teoria Comunicativa da Terminologia (TCT), guiada pela catalã Maria Teresa Cabré, do Instituto Universitário de Linguística Aplicada (IULA), da Universidade Pompeu Fabra de Barcelona, considera que a Terminologia é interdisciplinar (integrando aspectos da Linguística, das Ciências Cognitivas e das Ciências Sociais) e transdisciplinar (atua em todas as disciplinas, pois não há representação e comunicação eficiente do conhecimento sem uma terminologia). Logo, é vista como uma teoria linguística não redutiva,

que inclui a competência e a atuação dos falantes contemplados na heterogeneidade cognitiva e comunicativa e deve propor uma teoria que, ao mesmo tempo, dê conta dos fenômenos da língua geral, descreva as especificidades cognitivas, linguísticas (gramaticais, pragmáticas, textuais e discursivas) e comunicativas das unidades terminológicas e explique como o falante-especialista adquire essas especificidades e utiliza essas unidades (CABRÉ, 1999, p. 119) ${ }^{62}$.

Desse modo, a Teoria Comunicativa da Terminologia (TCT) valoriza os aspectos comunicativos das linguagens especializadas, reconhece a existência de variação conceitual e denominativa nos domínios de especialidade e leva em consideração a dimensão textual e discursiva dos termos, objeto central da Terminologia, analisando-os sob uma perspectiva poliédrica, ou seja, em seus aspectos linguísticos, cognitivos e sociais (CABRÉ, 1999, p. 119; 123). Segundo essa teoria, os termos são "unidades lexicais ativadas singularmente por suas condições pragmáticas de adequação a um tipo de comunicação"63 (CABRÉ, 1999, p. 123), ou

\footnotetext{
${ }^{62}$ La terminología, vista desde una teoría lingüística no reductiva que incluya la competencia y la actuación de los hablantes contemplados en su heterogeneidad cognitiva y comunicativa, debe proponer una teoría que al mismo tiempo que dé cuenta de los fenómenos del lenguaje general, describa las especificidades cognitivas, lingüísticas (gramaticales, pragmáticas, textuales y discursivas) y comunicativas de las unidades terminológicas, y explique cómo el hablante-especialista adquiere estas especificidades y utiliza estas unidades (CABRÉ, 1999, p. 119).

${ }^{63}$ Unidades léxicas activadas singularmente por sus condiciones pragmáticas de adecuación a un tipo de comunicación (Ibid., p. 123).
} 
seja, uma unidade lexical adquire valor terminológico quando pelas características pragmáticas do discurso seu significado especializado é ativado (CABRÉ, 2005, p. 9). Em outras palavras, uma unidade lexical torna-se termo (assume valor de termo) de acordo com o uso em um contexto comunicacional específico (CABRÉ, 1999, p. 124). Podemos citar, como exemplo, "laranja", unidade do léxico geral que pode ativar a característica de termo relacionada a uma área de especialidade (o direito penal), tendo como significado o indivíduo que empresta seu nome - muitas vezes sem saber- para transações financeiras e comerciais criminosas, ocultando a identidade do verdadeiro responsável pelo crime. A pragmática é, portanto, “indispensável para explicar a ativação do valor terminológico das unidades lexicais"64 (CABRÉ, 2005, p. 9). Assim, a TCT tem como propósito descrever

[...] formal, semântica e funcionalmente as unidades que podem adquirir valor terminológico, dar conta de como são ativados e explicar suas relações com outros tipos de signos do mesmo sistema ou distinto, para expandir o conhecimento sobre a comunicação especializada e as unidades nela utilizadas (CABRÉ, 1999, p. 124) ${ }^{65}$.

Para tanto, os termos devem ser analisados em seu ambiente natural de ocorrência, ou seja, nos discursos especializados. O exame dos contextos e das situações comunicativas assume um papel fundamental na determinação das terminologias (KRIEGER, 2001, p. 73), bem como na produção terminográfica. São fatores determinantes do grau de especialização de um texto: quem o produz; para quem é produzido; em que domínio; o contexto e a terminologia. Um manual escrito para um leigo, por exemplo, contemplará os termos relacionados ao assunto em questão (ainda que para o especialista a interpretação desse manual seja diferente), não excluindo, desse modo, a possibilidade de um termo ser um termo em contextos diversos. Nesse sentido, Cabré explica que o conhecimento especializado, os textos especializados e as unidades terminológicas podem ocorrer em diferentes níveis de especialização e serem descritas em diferentes níveis de representação (CABRÉ, 1999, p. 126).

A TCT, portanto, é uma teoria terminológica descritiva de base linguística que privilegia os aspectos comunicativos e pragmáticos dos léxicos e das linguagens especializadas. O enfoque comunicativo que se estabelece com essa teoria enfatiza que um signo linguístico pode realizar-se no discurso como termo ou palavra dependendo da situação comunicativa, levandose em consideração diversos fatores: o tema, a perspectiva em que o tema está sendo tratado,

\footnotetext{
${ }^{64}$ La pragmática, además, es indispensable para explicar la activación del valor terminológico de las unidades léxicas (CABRÉ, 2005, p. 9).

${ }^{65}[\ldots]$ formal, semántica y funcionalmente las unidades que pueden adquirir valor terminológico, dar cuenta de cómo lo activan y explicar sus relaciones con otros tipos de signos del mismo o distinto sistema, para hacer progressar el conocimiento sobre la comunicación especializada y las unidades que se usan en ella (CABRÉ, 1999, p. 124).
} 
os interlocutores, o nível de especialização, o grau de formalidade, a situação, o propósito e o tipo de discurso (CABRÉ, 1999, p. 123).

$\mathrm{Na}$ presente pesquisa, adotamos os pressupostos teóricos da Teoria Comunicativa da Terminologia (CABRÉ, 1999), pois compreendemos os termos como unidades lexicais suscetíveis dos mesmos processos de variação e sinonímia que ocorrem no léxico geral e que também estão muito presentes na terminologia das feiras de negócios; corroboramos a importância do contexto e do discurso nos estudos terminológicos, já que em nosso dicionário analisamos os termos em seus contextos de ocorrência, ou seja, nos manuais e guias do expositor e elaboramos um material terminográfico dirigido a vários tipos de consulentes (estudantes, pesquisadores, profissionais envolvidos no setor feirístico, tradutores e intérpretes) que produzem diversos tipos de discurso, em variadas situações comunicativas. Ressalta-se aqui, portanto, o caráter comunicativo da Terminologia, que analisa o processo comunicativo do campo especializado e deve ser adequado às necessidades comunicativas dos profissionais e dos usuários em geral, bem como o papel pragmático dos termos dentro do discurso especializado, que se materializam na linguagem em funcionamento para comunicar um conhecimento técnico-científico, no caso do presente trabalho, o universo das feiras de negócios. A seguir, discorremos sobre as obras terminográficas, em especial os dicionários terminológicos multilíngues.

\subsection{As Obras Terminográficas: Os Dicionários Terminológicos Multilíngues}

O dicionário ocupa um lugar de destaque na sociedade: é o "depositário do acervo lexical de uma cultura" (BIDERMAN, 1998, p. 161); o lugar onde o trabalho de recolha de unidades lexicais ou terminólogicas se materializa (CABRÉ, 1993, p. 90).

Um dicionário multilíngue é uma obra lexicográfica ou terminográfica que apresenta a entrada na língua de partida (LP) e seus respectivos equivalentes em outras línguas (Língua de Chegada-LC). Pode apresentar, ou não, definições, contextos de ocorrência dos termos e fontes.

Existem disponíveis no mercado dicionários terminológicos multilíngues de: Agenciamento de Viagens e Turismo; Línguas Indígenas para Crianças; Ciências do Solo; Ciências da População; Astronomia; e dicionários multilíngues de: Termos Jurídicos; Regência Verbal; Economia, Gestão e Comércio; Cores; Língua Gestual; Termos Típicos da Internet, entre outros. A carência de obras terminográficas da área feirística disponíveis no mercado foi o que primeiro motivou a elaboração do glossário bilíngue no mestrado e, agora, a elaboração do dicionário multilíngue no doutorado. Essa realidade dá à pesquisa o caráter de obra inédita, 
que tem como objetivo principal auxiliar o trabalho de estudantes, pesquisadores, tradutores e intérpretes que produzem textos orais e escritos em português, inglês, francês e italiano sobre esse domínio especializado e também para facilitar o trabalho de profissionais do setor feirístico como, por exemplo, os gerentes de exportação que viajam o mundo todo em busca de novos negócios para suas empresas ou, até mesmo, de pequenos empresários e comerciantes que queiram se introduzir no mundo das feiras. Assim, o dicionário foi elaborado para auxiliá-los a identificar e compreender a terminologia do setor feirístico em língua portuguesa, inglesa, francesa e italiana.

No que diz respeito ao aparecimento dos primeiros dicionários multilíngues, sabe-se que na Renascença, com o florescimento da lexicografia ocidental,

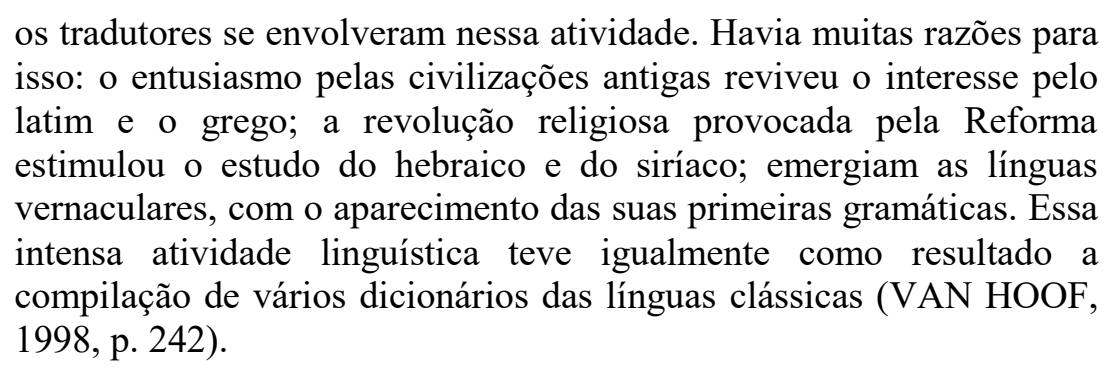

Portanto, o interesse pelas línguas antigas e o aparecimento das línguas vernáculas e de suas gramáticas, suscitaram a elaboração de vários dicionários. As principais obras publicadas na França, Itália e Inglaterra, nos séculos XVII, XVIII e XIX, foram as seguintes:

- Em 1638, a Académie Française começou a preparar o dicionário de que ficou incumbida, cuja primeira edição só seria concluída em 1694

- Na França, o Grand Vocabulaire Français foi publicado pelo livreiro Charles Joseph Panckoucke (1736-1798)

- Émile Littré produziu seu celebrado Dictionnaire de la Langue Française, em um período de dez anos (1863-1873)

- O Grand Dictionnaire Universel du XIXe Siècle (1866-1876) de Pierre Larousse era, ao mesmo tempo, uma enciclopédia alfabética e um dicionário que incluía neologismos e termos de gíria

- Na Inglaterra, havia muitos glossários de palavras difíceis, como a exemplar Glossographi (1656) de Thomas Blount

- Na Grã-Bretanha, Nathan Bailey compilou o impressionante Dictionarium Britannicum (1730), base do celebrado Dictionary of the English Language (1747-55) de Samuel Johnson (1709-84)

- Na Inglaterra, James Muray publicou o exemplar New English Dictionary on Historical Principles (1879), batizado The Oxford English Dictionary, em 1895

- Na Itália, a Accademia della Crusca publicou seu Vocabolario (1612), o primeiro dos grandes dicionários nacionais (VAN HOOF, 1998, p. 243-244).

As trocas entre os países em nível econômico, político, científico e cultural também estimularam a prática lexicográfica e, como resultado, vários dicionários dedicados às línguas 
nacionais foram publicados; a Renascença ficou, portanto, conhecida com a "idade de ouro" dos dicionários multilíngues. Os dicionários em que o latim não estava presente eram, contudo, uma novidade renascentista, como: o Vocabulary in French and English (1840) de William Caxton e o dicionário italiano-inglês $A$ World of Words (1598) de John Florio (VAN HOOF, 1998, p. 245-246).

No século XVIII, conhecido pelas suas enciclopédias, os dicionários multilíngues também progrediram: o francês ao lado do alemão, inglês, italiano, espanhol e holandês; terminologias foram criadas para os novos conceitos, devido à expansão tecnológica e científica da época. No século XIX, por sua vez, em virtude do estreitamento das relações internacionais em vários campos, os tradutores e os dicionários se tornaram fundamentais. No início do século $\mathrm{XX}$, quase todas as línguas importantes já possuíam seus próprios dicionários e, com o advento do ensino obrigatório, edições resumidas dos dicionários foram publicadas para utilização em sala de aula (VAN HOOF, 1998, p. 244-250).

De acordo com a norma ISO 1087 o dicionário terminológico é "um conjunto de verbetes terminológicos que contêm informações relativas a conceitos ou denominações de um ou vários domínios particulares"66 (ISO, 2000, p. 12). Van Hoof(1998, p. 249) define dicionário especializado como "aquele que se concentra em uma área específica do conhecimento". O autor afirma que o século XVIII foi uma época de explosão científica e tecnológica e os lexicógrafos não tardaram a trabalhar ativamente na criação de terminologia para os novos conceitos. Assim, os dicionários especializados refletem o rápido crescimento do vocabulário técnico e científico. Desse modo, Van Hoof menciona alguns exemplos de dicionários especializados, dentro os quais destacamos:

- As obras do gramático Herodianus e de Heródoto, o Médico: dois glossários médicos gregos, explicam os termos técnicos usados por Hipócrates e datam do primeiro século

- O Livro das estradas e dos reinos, de Bakri (século XI)

- Dicionário biográfico do Islam (século XIII), traduzido para o inglês, no século XIX, pelo orientalista William de Slane (1801-79)

- Liber continentis ou Livro abrangente, obra do físico Rhazes (865-925), em que enumerava órgãos e doenças em grego, siríaco, persa, hindi e árabe

- O médico Maimônides (1139-1204) escreveu um glossário com 405 nomes de plantas em árabe, grego, siríaco, persa, berbere e andaluz

- Glossário grego-latino-árabe de Stephanus de Antióquia, do século XII, intitulado Medicaminum omnium breviarium

- Grand dictionnaire historique (1674), do autor e tradutor francês Louis Moreri (164380)

\footnotetext{
${ }^{66}$ Ensemble d'articles terminologiques répertoriant des informations relatives à des concepts ou des désignations d'un ou plusieurs domaines particuliers (ISO, 2000, p. 12).
} 
- Livro sobre agricultura escrito por Miguel Agusti em 1617, que incluía um glossário de termos especializados em latim, espanhol, catalão, italiano, português e francês

- Na França, Diderot e seus colaboradores traduziram o Medical dictionary (1744-48) de Robert James

- Dictionnaire des sciences médicales (1812), de Charles-Louis Panckoucke (17801844)

- Illustrierte technische Wörterbücher de Alfred Schlomann e da Editora Oldenbourg, com a terminologia em alemão, inglês, francês, espanhol, italiano e russo, cobrindo a maioria dos campos tecnológicos e suas aplicações industriais

- Na Segunda Guerra Mundial, dicionários sobre combate, armamento, transporte e administração militar foram compilados

- Dictionary of television, radar and antenas (1955) em seis línguas, Dictionary of electronics and waveguides (1957), Dictionary of nuclear science and technology (1958), Dictionary of automation, computers, control and measuring (1961), de W. Clason

- A Bibliography of interlingual scientific and technical dictionaries (1951), de Edwin Holmstrom, relaciona 550 obras publicadas desde 1949

- International bibliography of specialized dictionaries de K. G. Saur, embora catalogasse somente as obras publicadas depois de 1970, era uma lista impressionante com 5700 títulos (VAN HOOF, 1998, p. 249-252).

O autor salienta que os tradutores desempenharão um importante papel na produção dos grandes dicionários do futuro, bem como na produção de outras formas de material terminográfico (VAN HOOF, 1998, p. 253). Vinte anos mais tarde, podemos comprovar essa afirmação do autor, uma vez que os tradutores, hoje, produzem seus próprios glossários, dicionários e banco de dados terminológicos, disponibilizando-os por meio impresso ou online e desempenhando um papel primordial na disseminação do conhecimento (especializado ou não) em nível mundial.

Em relação à sua organização interna, as obras terminográficas apresentam três componentes estruturais: a macroestrutura, a microestrutura e o sistema de remissivas. A macroestrutura ${ }^{67}$ diz respeito à organização geral da obra terminográfica; a microestrutura ${ }^{68}$ é a organização dos dados terminológicos dentro do verbete e o sistema de remissivas fornece as relações semântico-conceituais entre os termos apresentados na obra. Em outras palavras, a macroestrutura é o conjunto ordenado das entradas que constitui a nomenclatura da obra terminológica, que pode ser disposta em ordem alfabética ou temática; a microestrutura é o conjunto das informações contidas em cada verbete, que deve ser constante no interior da obra, e o sistema de remissivas explicita a rede de relações entre os verbetes (variação, sinonímia) para os termos pesquisados (Rey-Debove, 1971; Cabré, 1993; Barbosa, 1999). As informações

\footnotetext{
${ }^{67}$ Organização das entradas em um repertório (ISO 1087, 2000, p. 13).

${ }^{68}$ Organização dos dados em cada uma das entradas de um repertório (Id.).
} 
sobre a macroestrutura, a microestrutura e o sistema de remissivas de nosso dicionário podem ser consultadas no Capítulo 3, em Metodologia.

Do mesmo modo, para Biderman, um dicionário é constituído de entradas lexicais,

ou lemas [...] e a lista total desses lemas constitui a nomenclatura do dicionário, a sua macroestrutura. Quanto ao verbete, essa microestrutura tem como eixos básicos a definição da palavra em epígrafe e a ilustração contextual desse mesmo vocábulo, quer através de abonações por contextos realizados na língua escrita ou oral, quer através de exemplos. Quanto à ilustração contextual (e/o abonação) ela é essencial para explicar claramente o significado e/ou uso registrado na definição (BIDERMAN, 2001, p. 18).

Nesse trecho, Biderman descreve a importância de acrescentar, nos verbetes dos dicionários, os contextos e os exemplos de uso da palavra, o que auxilia o consulente a compreender o sentido descrito na definição. A autora destaca também a relevância de fazer remissões a outras unidades do léxico associadas a este lema, por meio de redes semânticolexicais (BIDERMAN, 2001, p. 18). No presente trabalho, apresentamos apenas as remissivas dos termos-entrada em português, visto que se trata de um dicionário unidirecional, do português para as outras línguas. Para um futuro trabalho, poderemos apresentar o sistema de remissivas nas outras línguas também.

No que diz respeito à disposição das entradas, elas podem ser alfabéticas (ordem pela forma) ou sistemáticas (ordem pelo conteúdo). No segundo caso, os termos são organizados em um sistema de conceitos e as definições baseiam-se nas relações que os conceitos descritos mantêm entre si (BARROS, 2004, p. 148). Entrando no âmbito bilíngue ou multilíngue, temos dois tipos de pesquisa terminológica: a pesquisa pontual, que tem como objetivo solucionar problemas isolados de designação e promover soluções mais rápidas, e a pesquisa temática, que tem como objetivo fazer o levantamento da terminologia de uma área de especialidade (AUBERT, 1996, p. 47). Sobre o número de línguas envolvidas, a pesquisa terminológica pode ser monolíngue, bilíngue ou plurilíngue (CABRÉ, 1993, p. 289). Logo, nossa pesquisa terminológica tem caráter temático e plurilíngue, uma vez que procedemos à busca de equivalentes em francês e em italiano para o conjunto de termos em português e em inglês (coletados no mestrado e complementados no doutorado) utilizados nas feiras de negócios, os quais estão dispostos no dicionário terminológico de maneira unidirecional, do português para as outras línguas, e em ordem alfabética.

É válido frisar que o dicionário terminológico constitui-se em "facilitador da comunicação no labirinto de terminologias dos campos especializados do mundo moderno" (MACIEL, 2001, p. 46). De fato, auxilia tanto os profissionais da área quanto estudantes, 
tradutores e intépretes a compreenderem melhor a terminologia de uma área e as relações entre os conceitos, o que torna mais fácil, não somente a comunicação oral, mas também a produção escrita acerca desse domínio especializado.

Entretanto, Vermeer, sob a perspectiva dos Estudos da Tradução, afirma que

do dicionário só se tira o que já se sabe: o dicionário serve para alguém relembrar o que esquecera. Mas cuidado com o dicionário, quando dele se quer retirar alguma informação nova. Geralmente não vem indicadas diferenciações estilísticas ou outras particularidades da situação (VERMEER, 1985, p. 28-29).

É notável observar o quão essa afirmação de Vermeer, proferida em 1985, nos parece muito atual, uma vez que existem muitas críticas frente ao déficit de informações elencadas na microestrutura de obras dessa natureza, como nos informa Holmes, Camacho e Bowker e Pearson, a seguir.

James Holmes afirma que "nossos dicionários bilíngues e gramáticas ainda são uma desgraça e um desespero"69 (HOLMES, 1988, p. 110). Camacho acrescenta que

os glossários e os dicionários não são sempre confiáveis, nem são exaustivos e raramente fornecem a solução definitiva que solucione os problemas terminológicos, seja porque o termo não aparece no glossário; seja porque ao não vir acompanhado de uma definição, o glossário pode oferecer vários termos equivalentes e o tradutor pode não determinar qual é o correto no contexto em que está traduzindo; seja porque o equivalente que lhe oferecem as fontes que consulta é inadequado, uma situação que ocorre com certa frequência nos dicionários bilíngues e, naturalmente, nos glossários ${ }^{70}$ (CAMACHO, 2004, p. 60).

Neste trecho, Camacho relaciona as principais dificuldades enfrentadas pelos tradutores durante uma consulta a dicionários terminológicos: termo não encontrado, ausência de definição, equivalente inadequado. Lamentavelmente, essas são situações muito comuns e que não só tornam o trabalho do tradutor mais árduo, como também podem, por exemplo, dificultar o trabalho de preparação e participação de uma empresa em uma feira.

Seguindo esse mesmo raciocínio, Bowker e Pearson evidenciam que uma das críticas mais comuns aos dicionários é o fato de apresentarem termos isolados, ao invés de termos em contexto, ou seja, não fornecem informações suficientes a respeito do uso dos termos

\footnotetext{
${ }^{69}$ Our bilingual dictionaries and grammars are still a disgrace and a despair (HOLMES, 1988, p. 110).

${ }^{70}$ Los glosarios y los diccionarios no siempre son de fiar ni son exhaustivos y rara vez facilitan la solución definitiva que resuelva sus problemas terminológicos, ya sea: porque no aparece el término en el glosario; porque al no ir acompañado de una definición, el glosario puede ofrecer varios términos equivalentes y el traductor no puede determinar cuál es el correcto en el contexto que está traduciendo; porque el equivalente que le ofrecen las fuentes que consulta resulta inadecuado, situación que suele presentarse con cierta frecuencia en los diccionarios bilingües y, naturalmente, en los glosarios (CAMACHO, 2004, p. 60).
} 
(BOWKER; PEARSON, 2002, p. 16). Pearson declara também que os dicionários especializados multilíngues

são ainda menos informativos do que dicionários especializados bilíngues e as páginas do dicionário são geralmente dispostas em colunas verticais com uma coluna diferente atribuída a cada idioma [...]. Apenas um número muito limitado de dicionários especializados multilíngues fornecem definições ${ }^{71}$ (PEARSON, 1998, p.72).

Como se sabe, em uma pesquisa terminológica bilíngue ou multilíngue, a definição desempenha um papel de destaque e sua elaboração é uma tarefa bastante complexa. No momento da redação de uma definição alguns cuidados devem ser tomados: ela deve ser elaborada de forma homogênea, com a mesma sintaxe e com o termo genérico na mesma classe gramatical e categoria de número. A norma ISO 1087, a define como "um enunciado que descreve um conceito e permite sua diferenciação de outros conceitos no interior de um sistema de conceitos"72. A referida norma apresenta dois tipos de definições: a definição por compreensão e a definição por extensão. A primeira diz respeito à definição que "descreve a compreensão de um conceito indicando o conceito superordenado (conceito mais genérico) bem como as características distintivas"73 e a segunda diz respeito à "descrição de um conceito enumerando todos os conceitos subordinados (conceitos mais específicos) correspondendo a um critério de subdivisão" ${ }^{\text {74 }}$. A definição é, portanto, essencial tanto para a compreensão do conceito veiculado pelo termo quanto para a identificação do termo equivalente apropriado (PEARSON, 1998, p. 71). Nesse sentido, Bowker e Pearson acrescentam que

todas as definições devem relacionar o termo sendo definido ao conceito/termo mais próximo no sistema de conceitos, ou seja, a estrutura hierárquica do domínio deve ser refletida na definição, tornando mais fácil entender o termo. Ao estruturar definições desse modo, um termo na parte inferior do sistema de conceitos herda automaticamente todas as características dos termos na parte superior da estrutura hierárquica aos quais estão relacionados ${ }^{75}$ (BOWKER; PEARSON, 2002, p. 142).

\footnotetext{
${ }^{71}$ Multilingual specialized dictionaries are even less informative than bilingual specialized dictionaries. The dictionary pages are generally laid out in vertical columns with a different column assigned to each language [...]. Only a very limited number of multilingual specialized dictionaries provide definitions (PEARSON, 1998, p.72).

${ }^{72} \mathrm{~A}$ statement which describes a concept and permits its differentiation from other concepts within the system of concepts (ISO 1087, 1990, p. 4).

${ }^{73}$ Décrit la compréhension d'un concept en indiquant le concept superordonné ainsi que les caractères distinctifs (ISO, 2000, p. 6).

${ }^{74}$ Description d'un concept en énumérant tous les concepts subordonnés correspondant à un critère de subdivision (Id.).

${ }^{75}$ All definitions must relate the term being defined upwards to the next nearest concept/term in the system of concepts. In other words, the hierarchical structure of the domain should be reflected in the definition, making it easier to understand the term. By structuring definitions in this way, a term at the bottom of the system of concepts automatically inherits all of the characteristics of the terms to which it is related further up the hierarchical structure (BOWKER; PEARSON, 2002, p. 142).
} 
Em outras palavras, faz-se referência ao conceito genérico mais próximo que já tenha sido definido e adiciona as características peculiares que abalizam o conceito a ser definido (ISO 1087, 1990, p. 4).

A definição terminológica, por conseguinte, "tem a função de descrever as características que delimitam um conceito e a função de particularizá-lo num determinado sistema conceitual ou domínio" (FINATTO, 2001, p. 309). Além disso, é preferível que se adapte aos propósitos do dicionário, satisfazendo as necessidades do público-alvo.

Para Sager (1990), a definição terminológica é "um breve enunciado que fornece uma clara compreensão do significado de um termo especializado apresentado em formato lexicográfico ou dicionário"76 (SAGER, 1990, p. 39) e possui três funções: verificar a existência de um dado termo; vincular o termo a um conceito e descrever o conceito dentro de um campo específico, admitindo que os conceitos podem ter outras definições em áreas do conhecimento distintas (SAGER, 1990, p. 45-51).

Alves (1996) apresenta os tipos de definições elencadas por Sager (1990, p. 42-44) que podem ser encontradas em trabalhos de cunho terminológico, a saber: definição analítica/por compreensão (termo genérico e características específicas): pneumonia - inflamação do tecido pulmonar $^{77}$; definição sinonímica: margarida - Bellis perennis ${ }^{78}$; definição por paráfrase: brancura: qualidade de branco $^{79}$; definição por síntese (descreve e identifica relações): metatarsalgia: dor na ponta do pé que muitas vezes se espalha para cima até a perna ${ }^{80}$; definição por implicação (o uso do termo em um contexto explicativo): diagnóstico - fazemos um diagnóstico quando identificamos certos sintomas como característicos de condições específicas $^{81}$; definição por denotação/ por extensão (relaciona exemplos): cachorro - cocker, poodle, pequinês, pastor-alemão e animais similares ${ }^{82}$; definição por demonstração (fotografias, ilustrações) (ALVES, 1996, p. 126).

Como vimos, existem diferentes tipos de definição, inclusive a ilustração, muito utilizada atualmente. A definição clássica que envolve a definição de uma palavra per genus et differentiam (gênero próximo e diferença específica) possibilita que os termos sejam explicados por meio da fórmula clássica

\footnotetext{
76 A brief statement that provides a clear understanding of the meaning of a specialized term presented in lexicographical or dictionary-like format (SAGER, 1990, p. 39).

${ }^{77}$ Pneumonia: inflammation of the lung tissue.

${ }^{78}$ Daisy: bellis perennis.

${ }^{79}$ Whiteness: state of being white.

${ }^{80}$ Metatarsalgia: painful neuralgic condition of the foot felt in the ball of the foot and often spreading thence up the leg.

${ }^{81}$ Diagnosis: we make a diagnosis when we identify certain symptoms as characteristics of specific conditions.

${ }^{82}$ Dog: dogs are spaniels, poodles, pekinese, alsatian and similar animals.
} 
$\mathrm{X}=\mathrm{Y}+$ característica(s) distintiva(s). $\mathrm{X}$ é a entrada, $\mathrm{Y}$ é o superordenado e a característica distintiva destina-se a distinguir $\mathrm{X}$ de outros membros da mesma classe. A seleção de um superordenado adequado é fundamental para a inteligibilidade da declaração definitória, em particular no caso de termos ${ }^{83}$ (PEARSON, 1998, p. 86).

Desse modo, para a definição dos termos em português, utilizamos a definição per genus et differentiam (e a fórmula clássica $\mathrm{X}=\mathrm{Y}+$ característica(s) distintiva), citada acima por Pearson, pois é mais clara, permite que o termo seja facilmente descrito e atende bem aos propósitos de nosso trabalho e elaboramos um verbete atrativo, de fácil consulta e que fornece não apenas a definição do termo-entrada, mas também informações importantes para a compreensão do termo em português e de seus equivalentes nas três línguas atendendo às necessidades do consulente. Incluimos, portanto, exemplos autênticos de uso dos termos e das variantes e as fontes de onde foram retirados, atestando a pertinência temática dentro do domínio das feiras de negócios, validando a escolha dos equivalentes e conferindo maior credibilidade à nossa obra terminográfica multilíngue.

A título de exemplificação, temos: $\mathrm{X}=\mathrm{Y}+$ característica distintiva, onde:

\begin{tabular}{|c|c|c|}
\hline $\begin{array}{c}\text { X= termo-entrada } \\
\text { "feira especializada" }\end{array}$ & $\begin{array}{c}\text { Y= superordenado } \\
\text { (feira: local para exibir } \\
\text { produtos e/ou serviços, } \\
\text { conhecer novas fontes de } \\
\text { comercialização e conquistar } \\
\text { novos mercados) }\end{array}$ & $\begin{array}{c}\text { característica distintiva } \\
\text { (segmento especializado } \\
\text { da indústria; público } \\
\text { profissional) }\end{array}$ \\
\hline
\end{tabular}

Portanto, como definição para o termo em questão, temos:

feira especializada: s.f. feira de um segmento especializado da indústria, destinada ao público profissional.

Para a confecção das definições nos valemos também de outros recursos, a saber: "aquele que"; "relativo a"; "conjunto de"; "local de"; "ação de", como pode ser observado nos exemplos a seguir:

- projetista de estande:- s.prep. responsável pela realização do projeto de estande baseado nas especificações fornecidas pelo cliente.

- setor feirístico:- neol. relativo ao âmbito das feiras de negócios.

- material promocional da empresa expositora:-s.prep. conjunto de elementos distribuídos no interior dos estandes aos visitantes durante a realização da feira (amostras, brindes, cartões de visitas, leaflets).

- exposição:-s.f. local de promoção, exposição de produtos e oferta de serviços de um ou

\footnotetext{
${ }^{83}$ Such terms are frequently explained using the classic formula: $\mathrm{X}=\mathrm{Y}+$ distinguishing characteristic(s). $\mathrm{X}$ is the entry, $\mathrm{Y}$ is the superordinate and the distinguishing characteristic is intended to distinguish $\mathrm{X}$ from other members of the same class. The selection of an appropriate superordinate is crucial to the intelligibility of the defining statement, particularly in the case of terms (PEARSON, 1998, p. 86).
} 
mais segmentos de indústria para o público em geral, visando negócios, sem venda direta aos visitantes.

- degustação de produtos dentro dos limites do estande:-fraseol. ação de provar um produto oferecido pelo expositor aos visitantes da feira dentro dos limites do estande.

As definições dos termos-entrada em português que compõem a nomenclatura de nosso dicionário foram formuladas a partir das informações coletadas durante a pesquisa de mestrado (cf. Apêndice V), complementadas e aprimoradas no doutorado (cf. Apêndice VI), dos conhecimentos adquiridos durante o curso de especialização em Negócios Internacionais e da experiência de trabalho em uma consultoria americana especializada em feiras. A seguir, trazemos algumas considerações a respeito da Terminologia Multilíngue e a Equivalência Terminológica, temas fundamentais para nossa pesquisa.

\subsection{A Terminologia Multilíngue e a Equivalência Terminológica}

No mestrado, trabalhamos com a terminologia bilíngue das feiras de negócios, buscando os equivalentes terminológicos em inglês para os termos em português coletados sobre o tema. $\mathrm{Na}$ pesquisa atual, trabalhamos com a terminologia multilíngue do setor feirístico, compilando os equivalentes terminológicos em francês e em italiano para os termos em português e em inglês da pesquisa anterior, bem como para os novos termos coletados no doutorado.

A questão da equivalência é um tema muito debatido nos Estudos da Tradução. Fala-se em equivalência linguística, estilística, semântica, formal, referencial, pragmática, dinâmica, funcional, entre outras. Assim, como ocorre nos Estudos da Tradução, a equivalência também é muito discutida dentro do domínio da Terminologia e se caracteriza pela "relação entre designações de línguas diferentes que representam o mesmo conceito" ${ }^{84}$ (ISO 1087, 2000, p. 9).

Em outras palavras, quando descrevemos, por exemplo, um objeto com o intuito de conhecer o equivalente em inglês para o objeto em português que temos em mente (uma cadeira), descrevemos as características desse objeto: it is made of wood or metal, it is used to seat, it has four legs, etc. Logo, a partir da descrição das características desse objeto em inglês, ou seja, da tradução dessas características, o nosso interlocutor nativo nos dirá o equivalente em inglês que estamos procurando: it is a chair! Nesse sentido, tradução e equivalência estão inter-relacionadas, pois nos valemos da tradução como parte do processo de conhecimento e busca dos equivalentes. O mesmo se dá em Terminologia, com a diferença de que utilizamos

\footnotetext{
${ }^{84}$ Relation entre désignations représentant le même concept dans des langues diferentes (ISO 1087, p. 9).
} 
uma metodologia específica sistematizada pela Terminologia multilíngue para o estabelecimento das equivalências, como será abordado mais adiante.

Para Cabré a equivalência terminológica é:

a chave da terminologia multilíngue. Os autores dos dicionários técnicos bilíngues ou multilíngues partem frequentemente do princípio de que as terminologias refletem estruturas objetivas da realidade. No entanto, a estruturação da realidade de uma língua de especialidade pode não coincidir em duas línguas distintas, especialmente em campos pouco estruturados como os das ciências humanas ou sociais ${ }^{85}$ (CABRÉ, 1993, p. 107).

Isso ocorre porque cada língua recorta o mundo de determinada maneira que lhe é única (hipótese de Sapir-Whorf). Por conseguinte, a análise semântico-conceitual dos termos pesquisados é de extrema importância, uma vez que, para determinar os equivalentes, é necessário fazer a comparação dos conceitos da língua de partida com os conceitos das línguas de chegada, levando em consideração o contexto em que os termos ocorrem.

Assim, é oportuno salientar que nas línguas de especialidade o significado de um termo é determinado em relação ao sistema conceitual a que pertence (ALVES, 1999a, p. 216). Por sistema de conceitos compreende-se um "conjunto de conceitos estruturado com base nas relações estabelecidas entre eles" ${ }^{\prime 86}$ (ISO 1087, 2000, p. 4). Boutin-Quesnel (1985, p. 19) acrescenta que, em um sistema de conceitos, "cada conceito é determinado por sua posição dentro do sistema" ${ }^{" 87}$, ou seja, dentro do domínio especializado estudado.

De acordo com a Norma ISO 1087 a relação entre dois conceitos pode ser uma relação genérica ou uma relação partitiva. Por relação partitiva, compreende-se uma "relação entre dois conceitos, na qual um dos conceitos constitui o todo e o outro conceito uma parte desse todo" 88 (ISO 1087, 2000, p. 5). Nesse tipo de relação, os conceitos podem ser integrantes (conceito superordenado $^{89}$ ) ou partitivos (conceito subordinado ${ }^{90}$ ). Por relação genérica, compreende-se uma "relação entre dois conceitos na qual a compreensão de um dos conceitos inclui a do outro

\footnotetext{
${ }^{85}$ La equivalencia terminológica es la clave de la terminología multilingüe. Los autores de diccionarios técnicos bilingües o multilingües parten a menudo del principio de que las terminologías reflejan estructuras objetivas de la realidad. Sin embargo, la estructuración de la realidad de una lengua de especialidad puede no coincidir en dos lenguas distintas, especialmente en campos poco estructurados como los de las ciencias humanas o sociales (CABRÉ, 1993, p. 107).

${ }^{86}$ Ensemble de concepts structuré selon les relations qui les unissent (ISO 1087, 2000, p. 4).

${ }^{87}$ Chaque notion est déterminée par sa position dans le système (BOUTIN-QUESNEL, 1985, p. 19).

${ }^{88}$ Relation entre deux concepts dans laquelle l'un des concepts constitue le tout et l'autre concept une partie de ce tout (ISO 1087, 2000, p. 5).

${ }^{89}$ Em um sistema do tipo hierárquico, o conceito superordenado é aquele que pode ser dividido em vários conceitos de nível inferior, chamados conceitos subordinados (BOUTIN-QUESNEL, 1985, p. 18).

${ }^{90}$ Em um sistema do tipo hierárquico, o conceito subordinado é aquele que resulta da divisão de um conceito superordenado (Ibid., p. 19).
} 
conceito e no mínimo mais um traço distintivo suplementar"91 (ISO 1087, 2000, p. 5). Do mesmo modo, uma noção específica é um conceito subordinado a um conceito genérico e uma noção genérica inclui as específicas e estabelece com elas relações de hierarquia (BARROS, 2004, p. 117). Em semântica, o conceito mais genérico corresponde ao hiperônimo e o mais específico ao hipônimo. Pensando no domínio das feiras, o termo "estande" é o mais genérico (hiperônimo) e o termo “estande ilha”, por exemplo, é o mais específico (hipônimo). A relação hiperonímia-hiponímia observada no conjunto de termos do setor feirístico será apresentada em detalhes no Capítulo 5.

As relações genéricas ou partitivas são relações hierárquicas de acordo com a Norma ISO 1087. As relações não-hierárquicas, entretanto, são as relações sequenciais, ou seja, relações de causa-efeito, produtor-produto ou etapas de um processo e as relações pragmáticas ou temáticas (BARROS, 2004, p. 115). Na presente pesquisa encontramos também termos em relação não-hierárquica do tipo sequencial que dizem respeito às etapas do processo de participação em uma feira: atividades de preparação (pré-feira), participação (durante a feira) e atividades de fechamento (pós-feira).

No que diz respeito à equivalência terminológica, nos baseamos em Dubuc (1985). Para o autor, "dois termos são equivalentes se possuírem uma identidade quase completa de sentido e de usos dentro de um mesmo domínio de aplicação"92; dois termos são correspondentes quando "o termo da língua A só recobre parcialmente o campo de significação do termo da língua B e vice-versa"93 (DUBUC, 1985, p. 69). Pode ocorrer, ainda, uma ausência de equivalência ou correspondência entre línguas diferentes, quando o termo da língua A não encontra nenhum termo na língua B, ou vice-versa. De modo semelhante, Kade (1968) categoriza as relações de equivalência

de acordo se há uma única expressão na língua fonte para uma única expressão na língua de chegada (equivalência um-para-um); mais de uma expressão na língua de chegada para uma única expressão na língua fonte (equivalência um-para-muitos); uma expressão na língua de chegada que recobre parte de um conceito designado por uma única expressão na língua fonte (equivalência um-para-parte-de-um) e nenhuma expressão na língua de chegada para uma expressão na língua fonte (equivalência nula) ${ }^{94}$ (KADE, 1968, apud KENNY, 2009, p. 97).

\footnotetext{
${ }^{91}$ Relation entre deux concepts dans laquelle la compréhension de l'un de concepts inclut celle de l'autre concept et au moins un caractère distinctif supplémentaire (ISO 1087, 2000, p. 5).

92 Deux termes sont dits équivalents s'ils affichent une identité à peu prés complète de sens et d'usage à l'intérieur d'un même domaine d'application (DUBUC, 1985, p. 69).

${ }^{93}$ Le terme de la langue A ne recouvre que partiellement le champ de signification du terme de la langue B ou vice versa (Id.).

${ }^{94}$ Kade (1968) categorizes equivalence relationships according to whether there is: a single expression in the TL for a single SL expression, i.e. one-to-one equivalence; more than one TL expression for a single SL expression, i.e. one-to-many equivalence; a TL expression that covers part of a concept designated by a single SL expression,
} 
Dessa maneira, por meio dessa categorização, podemos verificar algumas semelhanças entre as teorias de Kade (1968) e Dubuc (1985) no que diz respeito à questão da equivalência. Ainda sobre esse tema, Barbosa nos apresenta um esquema no qual considera as relações entre os conceitos e as denominações e afirma que:

não existe uma relação biunívoca entre os elementos do metassistema conceptual e os elementos dos diferentes sistemas semióticos dele dependentes. De fato, a um conceito (ou noção, ou, ainda, ao nível hiperprofundo, a um feixe noêmico) pode corresponder uma única denominação (expressão e conteúdo - semema - do signo), caso em que a relação é biunívoca; a um conceito podem corresponder duas ou mais denominações, numa relação de injeção; a dois ou mais conceitos pode corresponder uma denominação apenas, numa relação de sobrejeção; enfim, a um conceito pode não corresponder, em determinado estágio de língua, nenhuma denominação (designatio virtual ou latente), conforme ilustrado na figura abaixo (BARBOSA, 2010, p. 71):

Figura 4: conjunto conceptual e conjunto linguístico

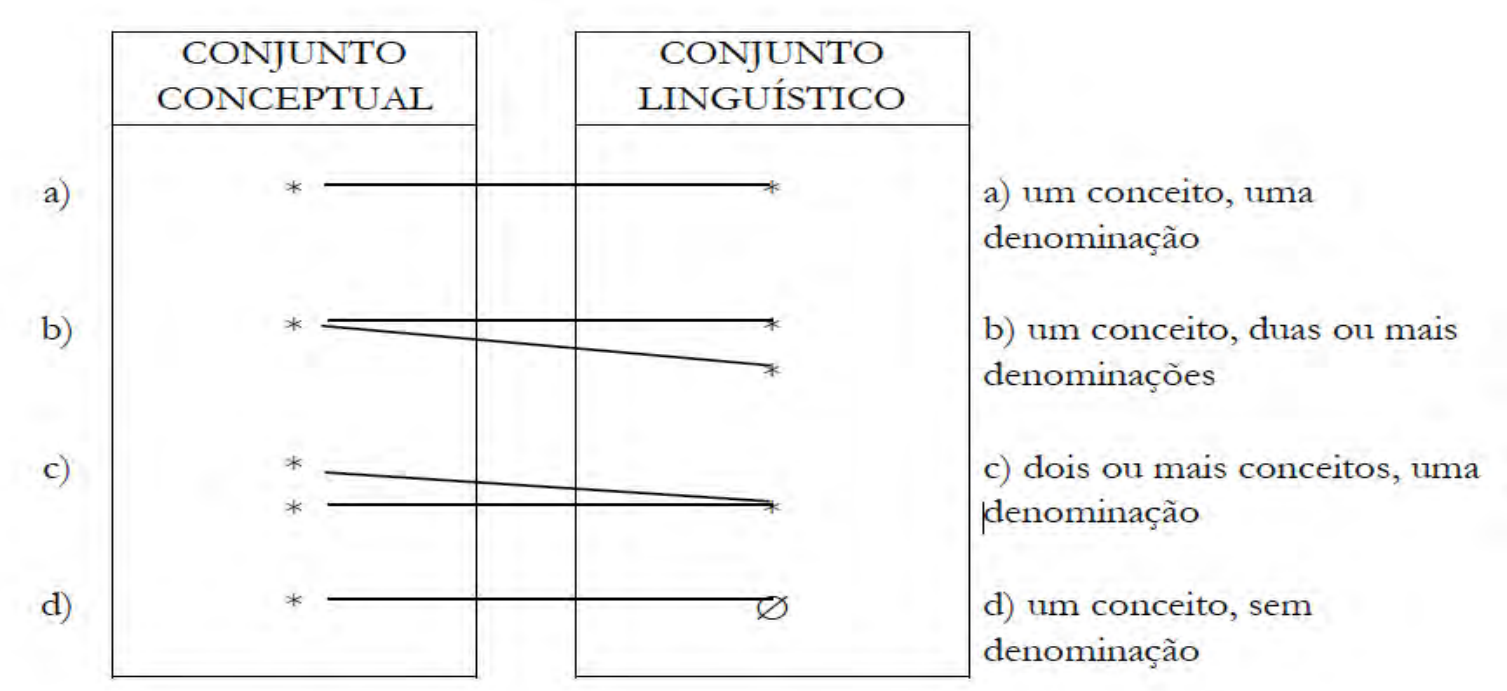

Fonte: Revista Italiano UERJ - Ano 1, v.1, $\mathrm{n}^{\mathrm{o}} 1,2^{\circ}$ semestre 2010

No universo das feiras de negócios, essas relações também aparecem entre as quatro línguas no estabelecimento das equivalências, considerando o português como língua fonte e as demais como línguas alvo: a) um conceito e uma designação apenas em cada língua: "pavilhão" (português), pavilion (inglês), pavillion (francês) e padiglione (italiano); b) um conceito e várias designações em uma das línguas alvo: estande de uma face (português) e stand de rangée, stand d'allée, stand à une face, stand entre deux voisins, stand mitoyen (francês); c)

i.e. one-to-part-of-one equivalence; or no TL expression for an SL expression, i.e. nil equivalence (KADE, 1968, apud KENNY, 2009, p. 97). 
uma designação da língua fonte e dois ou mais conceitos na língua fonte: o termo "expositor", que em português pode ser tanto o suporte utilizado para expor um produto dentro do estande (coisa: expositor ou display (português); display (inglês); display ou présentoir (francês); display (italiano)), como a empresa que aluga um estande e expõe seus produtos em uma feira (pessoa: expositor (português); exhibitor (inglês); exposant (francês); espositore (italiano)), ou seja, para cada um dos homônimos, designações diferentes nas línguas alvo. Logo, as relações entre conceitos e denominações são muitas e é exatamente aí que reside a beleza em estudar a terminologia de uma área de especialidade em determinada língua e buscar os equivalentes nas demais línguas.

Desse modo, percebe-se a complexidade da rede de relações que se estabelece entre as unidades da língua de partida e aquelas que devem ser propostas como equivalentes. A relação nunca é biunívoca, já na linguagem coloquial. Nas linguagens de especialidade, a rede de possíveis 'equivalentes' torna-se ainda mais complexa. Por vezes, não há nenhuma unidade lexical que possa ser proposta como equivalente e a solução tem de ser buscada numa paráfrase ou mesmo numa 'explicação' de tipo enciclopédico (BARBOSA, 1999, p. 43).

Neste trecho, Barbosa reitera que "a relação entre termos nunca é biunívoca", ou seja, para um conceito, uma única denominação e, às vezes, não existe um equivalente adequado para um termo em determinada língua e a saída, nesse caso, é recorrer ao uso da explicação do termo, ou paráfrase, a fim de se evitar o vazio de equivalência. Muitas vezes, as diferenças mais profundas estão relacionadas à própria organização conceitual da cultura e ao sistema de valores correspondente (BARBOSA, 1999, p. 44), os quais, como mencionamos anteriormente, mudam de uma língua para outra, de uma cultura para outra. Na presente pesquisa, discorreremos sobre esse tema no Capítulo 5, ao descrever os problemas de tradução encontrados na busca pelas equivalências.

Nesse sentido, Alpízar-Castillo complementa que:

a correspondência entre termos de idiomas diferentes situa-se em um diapasão de possibilidades que vai desde o total recobrimento do conteúdo do termo da língua $\mathrm{A}$ por um da língua $\mathrm{B}$, até a total falta de equivalências, passando por uma variada gama de recobrimentos parciais (ALPÍZAR-CASTILLO, 1995, p. 101) ${ }^{95}$.

Assim, podemos fazer um paralelo dessa teoria de equivalência proposta por AlpízarCastillo (1995) com a teoria de equivalência proposta por Dubuc (1985), uma vez que ambas

\footnotetext{
${ }^{95} \mathrm{La}$ correspondencia entre términos de idiomas diferentes se sitúa en un diapasón de probabilidades que va desde el total recubrimiento del contenido del término de la lengua A por uno de la lengua B, hasta la total falta de equivalencias, pasando por una variada gama de recubrimientos parciales (ALPÍZAR-CASTILLO, 1995, p. 101).
} 
preveem a existência de: termos equivalentes (Dubuc) x recobrimento total de conteúdo (Alpízar-Castillo); ausência de equivalência (Dubuc) x falta total de equivalência (AlpízarCastillo) e termos correspondentes (Dubuc) x recobrimento parcial (Alpízar-Castillo).

Felber acrescenta ainda que muitos conceitos comparados em diferentes línguas não se equiparam completamente e, por esse motivo, os vocabulários especializados deveriam indicar os diferentes graus de equivalências (FELBER, 1984, p. 131). Isso ocorre porque "o sistema de significação de uma língua é socialmente estabelecido" (RODRIGUES, 2000, p. 96), o que justifica a não coincidência completa de conceitos em línguas diferentes. Além disso, as relações de sentido nas línguas não são estáveis ou predizíveis, não sendo possível saber como cada pessoa lida com os significados e como os representa internamente (BORBA, 2011, p. 22).

Apesar das dificuldades apontadas, é possível estabelecer uma equivalência satisfatória entre termos de línguas distintas (os Estudos da Tradução e os Estudos Terminológicos comprovam isso), desde que se leve em consideração a situação discursiva em que a unidade terminológica está sendo utilizada, evitando, desse modo, "a velha indistinção entre sentido diferente e contexto diverso", mencionada por Borba (2011, p. 23).

$\mathrm{Na}$ visão de Werner Koller, nossa pesquisa se enquadra no que ele chama de equivalência denotativa, ou seja, "concentra-se na descrição de equivalentes em pares linguísticos específicos e está focada no nível do léxico” (KOLLER, 1979, p. 228, apud MOREIRA, 2014, p. 106). Ela se volta, portanto, à identificação de termos ou expressões que designam os mesmos objetos da realidade extralinguística, uma vez que buscamos os equivalentes em francês e italiano para os termos em português e em inglês que se referem à realidade das feiras de negócios.

Ao realizar um trabalho comparativo entre duas ou mais línguas, contrapõem-se automaticamente realidades linguísticas distintas, e disso resulta o grande desafio para o terminólogo, ou seja, encontrar o termo utilizado em cada comunidade linguística. Nesse sentido, Azenha Junior destaca que "a terminologia, longe de ser algo estático, é dinâmica e reconhece sua dificuldade em controlar a subjetividade no tratamento de seu objeto, a linguagem" (AZENHA JUNIOR, 1996, p. 141). Para tanto, utilizamos os ganchos terminológicos presentes nos corpora de estudo como um dos principais recursos para a busca dos equivalentes para os termos do setor feirístico. Os ganchos terminológicos, ferramenta de grande importância no momento de busca e análise de equivalência de termos em seus contextos, são definidos por Dubuc como "os descritores comuns aos contextos que 
acompanham os termos em uma ficha terminológica" 96 (DUBUC, 1985, p. 72). Por descritores, entendem-se os "elementos reveladores do conceito contidos no contexto", sendo os mais significativos aqueles que exprimam natureza, finalidade e modo. O número e a qualidade dos descritores presentes no contexto determinam o tipo de contexto, a saber: definitório, explicativo e associativo.

O contexto definitório oferece características semânticas precisas acerca do conceito do termo estudado. Dubuc apresenta o seguinte exemplo de contexto definitório:

Quadro 1: Contexto definitório e descritores

\begin{tabular}{|c|l|l|}
\hline Termo & \multicolumn{1}{|c|}{ Contexto } & \multicolumn{1}{|c|}{ Descritores } \\
\hline weaving & $\begin{array}{l}\text { "Weaving is a method of producing cloth by } \\
\text { interlacing two or more sets of yarns at right } \\
\text { angle to each other". }\end{array}$ & $\begin{array}{l}\text { method: nature } \\
\text { producing cloth: fin } \\
\text { interlacing two or more sets of } \\
\text { yarns: manière }\end{array}$ \\
\hline
\end{tabular}

Fonte: Dubuc, 1985, p. 62

Por meio deste contexto o terminológo tem uma ideia precisa do significado do termo "weaving", já que evidencia a natureza, a finalidade da operação bem como o modo como ela é realizada (DUBUC, 1985, p. 62).

O contexto explicativo oferece apenas uma ideia acerca da natureza ou um aspecto do termo estudado, mas não o define claramente. Dubuc apresenta o seguinte exemplo de contexto explicativo:

Quadro 2: Contexto explicativo e descritores

\begin{tabular}{|l|l|l|}
\hline Termo & \multicolumn{1}{|c|}{ Contexto } & \multicolumn{1}{c|}{ Descritores } \\
\hline shed & $\begin{array}{l}\text { "Each warp yarn must run straight from cloth } \\
\text { beam to warp beam without being crossed with } \\
\text { any other yarn; this is essential for raising and } \\
\text { lowering the different harnesses to form a shed". }\end{array}$ & $\begin{array}{l}\text { raising, lowering, harnesses: } \\
\text { manière }\end{array}$ \\
\hline
\end{tabular}

Fonte: Dubuc, 1985, p. 62

Como podemos observar no exemplo acima, os descritores explicam apenas a maneira como "shed" é formado, sem especificar a sua natureza ou finalidade. Para alguém que conheça o funcionamento de uma tecelagem, pode parecer claro que o termo "shed" se refere ao ângulo formado quando o fio de trama é separado em duas camadas, embora isso não esteja expresso claramente no contexto (DUBUC, 1985, p. 62).

\footnotetext{
${ }^{96}$ Les descripteurs communs aux contextes accompagnant les vedettes d'une fiche terminologique (DUBUC, 1985, p. 72).
} 
O contexto associativo, por sua vez, não fornece características semânticas, apenas permite ligar o termo estudado a determinado campo de aplicação por meio da associação com termos que o cercam. É o caso, por exemplo, de um termo que figure em uma enumeração ou que seja empregado com um valor puramente funcional. O contexto definitório citado acima, por exemplo, oferece para "yarn" um contexto associativo, já que informa que ele é utilizado no processo de tecelagem. Vale destacar que os contextos definitórios e explicativos são mais informativos, embora o contexto associativo também possa ser utilizado, na ausência dos dois primeiros (DUBUC, 1985, p. 63).

Mais importante do que a quantidade de descritores encontrados é a sua qualidade. Um descritor que apresente um aspecto essencial do termo, como dissemos anteriormente, a sua natureza, finalidade e modo, tem mais valor do que um descritor que forneça apenas características circunstanciais de tempo, lugar, modalidade, função, objeto ou matéria, forma, causa, efeito, composição, característica, domínio, oposição, etc (DUBUC, 1985, p. 68).

$\mathrm{Na}$ mesma linha de Dubuc estão Philippe Thoiron, Pierre Arnaud, Henri Béjoint e Claude Pierre Boisson com a noção de arqui-conceito e denominação ${ }^{97}$. Estes autores apontam para o fato de que um conjunto de características semânticas que constituem um termo são de natureza cognitiva e podem ser reproduzidas nas várias línguas em maior ou menor grau. Segundo os autores, “o arqui-conceito está em correspondência, nas diversas culturas, com diversos conceitos. O grau de semelhança entre os conceitos, aqui chamados de homólogos, não é prejudicado: pode ser forte ou fraco". ${ }^{98}$ Desse modo, a reunião dos traços conceituais de um termo constituiría seu arqui-conceito, como no exemplo que eles trazem em "règle à calcul", cujos elementos conceituais são: a sua função, o seu modo de manipulação, o seu tipo de usuário, o seu princípio teórico, etc. Os autores afirmam que "se operarmos no nível da linguagem (langage) a suposição da pertinência cognitiva é maior do que se operarmos no nível das línguas (des langues), já que podemos esperar alcançar mecanismos válidos translinguisticamente e, desse modo, diretamente relacionados às habilidades cognitivas universais da humanidade" 99 . A leitura do texto "Notion d'archi-concept et dénomination", dos autores supracitados, foi uma recomendação da supervisora do estágio na França.

\footnotetext{
97 Thoiron, P., Arnaud, P., Béjoint, H. \& Boisson, C. (1996).Notion d'« archi-concept » et dénomination. Meta, 41(4), 512-524.

98 “On reconnaîtra seulement que l'archi-concept est en correspondence, dans les diverses cultures, avec divers concepts. Le degré de similitude entre concepts, dits ici homologues, n'est pas préjugé: il peut être grand ou faible" (THOIRON et al, 1996, p. 516).

${ }^{99} \mathrm{Si}$ l'on opère au niveau "du langage", la présomption de pertinence cognitive est plus grande que si l'on opère au niveau "des langues", puisqu'on peut espérer atteindre des mecanismes valables translinguistiquement et, dans cette mesure, directement accrochés aux capacités cognitives universelles de l'humanité (Ibid., p. 522).
} 
De acordo com Dubuc, portanto, a identificação do conceito por meio de análise contextual aparece como método fundamental da pesquisa terminológica, uma vez que detecta elementos significativos (DUBUC, 1985, p. 20) e indispensáveis para a compreensão do conceito e, consequentemente, para a busca das equivalências.

A descrição dos contextos em que aparecem os termos é feita, portanto, por meio do preenchimento de fichas terminológicas, documento que contém todas as informações que permitem identificar o conteúdo nocional de um termo e legitimar o seu uso (DUBUC, 1985, p. 75). Bowker e Pearson (2002, p. 142) dialogam com Dubuc e afirmam que os terminólogos coletam informações sobre os termos selecionados e as armazenam em fichas terminológicas ${ }^{100}$. Um exemplo de ficha terminológica adotada para a pesquisa está disponível no Capítulo 3, em Metodologia, e também no Apêndice II.

Em resumo, por meio da análise contextual é possível identificar o conceito veiculado por uma unidade terminológica; reconhecer os sinônimos e registrar as formas derivadas ou expandidas de termos simples (DUBUC, 1985, p. 61). A análise do contexto em que o termo aparece é, portanto, "o guia para encontrar o seu significado"101 (ALPÍZAR-CASTILLO, 1995, p. 51).

Do mesmo modo, dar sentido a uma palavra é relacioná-la a um co-texto e um contexto específicos, visto que fora do texto e do discurso a palavra tem múltiplos sentidos que não estão consolidados (TOGNINI-BONELLI, 2001, p. 19; ZAVAGLIA, 2008, p. 35). Assim, uma unidade lexical é um termo quando possui um conceito próprio e particular do domínio das feiras de negócios, como é o caso do presente trabalho, dentro dos manuais do expositor, livros e revistas especializados sobre o assunto.

Nesse sentido, com base na teoria de significação contextual de Firth, Tognini-Bonelli reitera que

quando uma oração, uma frase, uma palavra ou um morfema é examinado, cada um é encontrado em um contexto - e o co-texto verbal é tão importante quanto o contexto cultural mais amplo. A suposição é que cada item linguístico ocorre em um contexto, e esse contexto é altamente relevante para a determinação do significado de um item, seja ele uma palavra ou uma frase (TOGNINI-BONELLI, 2001, p. 4) ${ }^{102}$.

\footnotetext{
100 Terminologists will start to collect information about the terms that have been selected. This information will be stored in what is known as a terminological record sheet (BOWKER; PEARSON, 2002, p. 142).

${ }^{101}$ Es la guía para encontrar su significado (ALPÍZAR-CASTILLO, 1995, p. 51).

102 When a clause, a phrase, a word or a morpheme is examined, each is found to occur in a context - and the verbal co-text is at least as important as the wider cultural context. The assumption is that every linguistic item occurs in a context, and that context is highly relevant for the determination of the meaning of the item, whether it be a word or a sentence (TOGNINI-BONELLI, 2001, p. 4).
} 
Portanto, a autora reforça a importância do contexto e também do co-texto (palavras à direta e à esquerda do termo pesquisado) ao se analisar e identificar o sentido de uma palavra ou o conceito de um termo. Os estudos que levam o contexto em consideração e que tentam investigar o uso, só são possíveis com o acesso a dados reais (BAKER, 1993, p. 237; MAGALHÃES, 2001, p. 97). Do mesmo modo, Catford reconhece que os fatores contextuais e co-textuais influenciam incessantemente a busca pelas equivalências (CATFORD, 1965, p. 30-31) e Jumpelt, em consonância com Dubuc e Catford, afirma que "a equivalência é vista como dependente do contexto e da situação"103 (JUMPELT, 1961, p. 51, apud OLOHAN, 2009, p. 247). Consequentemente, os termos de nosso dicionário são analisados e apresentados em seus contextos de uso reais, uma vez que concordamos que os contextos são essenciais para a compreensão do conceito veiculado pela unidade terminológica e para o trabalho de estabelecimento de equivalências entre termos de línguas diferentes. Portanto, a metodologia proposta pela Terminologia multilíngue em conjunto com a teoria dos ganchos terminológicos de Dubuc demonstraram-se eficazes para a análise dos termos e, principalmente, para a busca dos equivalentes nas quatro línguas para a elaboração do dicionário. A seguir, apresentamos um aspecto importante em nossa pesquisa que diz respeito às variantes terminológicas.

\subsection{A Variação Terminológica}

Desde a pesquisa realizada no mestrado, percebemos que a variação terminológica estava muito presente na terminologia das feiras de negócios em português e em inglês. E o mesmo apresentou-se agora, durante a pesquisa de doutorado, no francês e no italiano. Por isso, resolvemos abordar novamente essa questão tão relevante para a nossa pesquisa. Assim, em relação à variação terminológica, Camargo pontua que

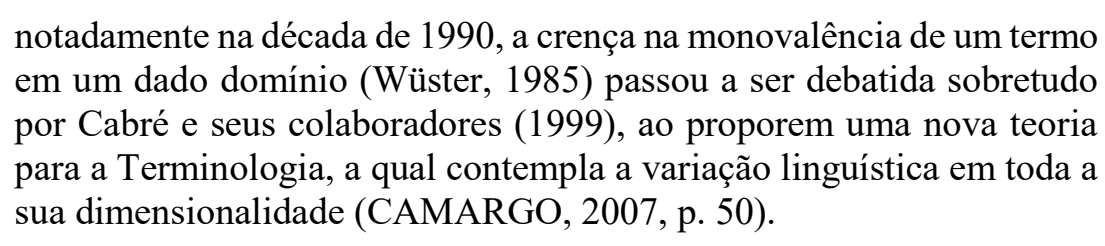

Como vimos na seção 2.3, Wüster, com o objetivo de alcançar uma padronização terminológica, considerava que a relação entre conceito e termo que o denomina deveria ser unívoca. Por outro lado, Cabré desconstrói essa concepção de termo, ao admitir a variação linguística como legítima dentro de uma área de especialidade. Afinal, todo processo de

${ }^{103}$ Equivalence is seen as dependent on context and situation (JUMPELT, 1961, p. 51, apud OLOHAN, 2009, p. 247). 
comunicação envolve intrinsecamente variação e esse princípio é universal também para as unidades terminológicas (CABRÉ, 1999, p. 85), já que no interior de um domínio especializado, nem sempre há um só conceito ou uma única denominação correspondente (KRIEGER, 2001, p. 102).

A Norma ISO 1087 (1990, p. 6) define variante como "cada uma das formas existentes para um termo" 104 e indica como principais tipos de variantes as ortográficas, morfológicas e sintáticas.

Vários autores têm trabalhado com a questão da variação terminológica, dentre os quais podemos citar Freixa (2002) que em sua tese de doutorado elaborou uma proposta de análise das causas da variação em terminologia e propôs uma tipologia das causas da variação denominativa nos textos especializados, a saber: causas prévias, dialetais, funcionais, discursivas, interlinguísticas e cognitivas (FREIXA, 2002, p. 125-156). A autora declara que ao se dedicar ao estudo dos termos sob uma perspectiva variacionista, a descrição da variação dos termos é apenas o primeiro passo para entender algo mais fundamental: "por que os termos variam, quais regularidades existem nessa variação, quais parâmetros regem este comportamento alternativo e aparentemente aleatório?"105 (FREIXA, 2013, p. 38). Assim, quando a autora descreveu o "o quê" e o "como" da variação terminológica foi com a intenção de entender o "porquê". Para Freixa, "somente com estudos empíricos que abordem as diferentes perspectivas poderemos interpretar com maior objetividade as verdadeiras causas da variação terminológica e explicar o comportamento linguístico dos falantes"106 (FREIXA, 2013, p. 44).

Na presente pesquisa, entretanto, nos baseamos na teoria da variação terminológica sistematizada por Enilde Faulstich $(1998,2001)^{107}$, uma vez que atende aos propósitos de nosso trabalho, e nos ajuda a identificar os diferentes tipos de variantes terminológicas que constituem a terminologia do setor feirístico nas quatro línguas. A autora classifica as variantes em três categorias: as variantes concorrentes, coocorrentes e competitivas. A categoria das variantes concorrentes dá origem a variantes formais, a das coocorrentes, a sinônimos e as competitivas, a empréstimos.

\footnotetext{
${ }^{104}$ Chacune des formes existantes pour un terme (ISO 1087, 1990, p. 6).

${ }^{105}$ ¿Por qué varían, los términos, ¿qué regularidades hay en esta variación, ¿qué parámetros rigen este comportamiento alternativo y aparentemente aleatorio (FREIXA, 2013, p. 38).

${ }^{106}$ Solo con estudios empíricos que, complementariamente, aborden las distintas perspectivas podremos interpretar con mayor objetividad las verdaderas causas de la variación terminológica y, con ello, añadiremos un grano de arena a la explicación del comportamiento lingüístico de los hablantes (Ibid., p. 44).

${ }^{107} \mathrm{O}$ trabalho da autora não deixa de dialogar com Coseriu (1969) e principalmente de ser influenciado pelas perspectivas de Boulanger (1991), Auger (1994) e notadamente Gaudin (1993) (para mais detalhes V. Faulstich 2001).
} 
A categoria das variantes concorrentes subdivide-se em dois grupos: as variantes linguísticas e as variantes de registro. Conforme a autora, as variantes terminológicas linguísticas "são aquelas cujo fenômeno propriamente linguístico determina o processo de variação”, podendo ser fonológicas, morfológicas, sintáticas, lexicais e gráficas (FAULSTICH, 2001, p. 23 e 28). Parafraseando a autora e retomando seus próprios exemplos, a variante fonológica ocorre quando a escrita surge de formas decalcadas da fala (portfólio e porta-fólio); a morfológica apresenta alternância de estrutura de ordem na constituição do termo (bactéria avirulenta e bactéria não-virulenta); a sintática ocorre quando há a substituição de uma parte do item lexical por outro com estrutura semelhante, formando uma mesma unidade terminológica (vetor de clonagem gênica e vetor de clonagem de genes); a variante lexical ocorre quando algum item da estrutura lexical da unidade terminológica complexa sofre apagamento ou movimento de posição (melhoramento genético de plantas e melhoramento de plantas); por fim, a variante gráfica se apresenta sob forma gráfica diversificada de acordo com as convenções da língua (pólen e polem).

As variantes terminológicas de registro são, por sua vez, "aquelas cuja variação decorre do ambiente de concorrência, no plano horizontal, no plano vertical e no plano temporal em que se realizam os usos linguísticos dos termos" e podem ser geográficas, de discurso e temporais (FAULSTICH, 2001, p. 28). A variante geográfica depende do uso regional, com formas diferentes de mesmo significado (mandioca, macaxeira e aipim); a de discurso decorre de contextos discursivos de diferentes níveis (popular, familiar, técnico, acadêmico, profissional), como ataque do coração e infarto (exemplo nosso); a temporal se configura como duas formas diferentes do ponto de vista diacrônico (arrátel e libra) (FAULSTICH, 2001, p. 2930).

A categoria das variantes coocorrentes é a que congrega variantes "que têm duas ou mais denominações para um mesmo referente" (FAULSTICH, 2001, p. 21) e são, a nosso ver, sinônimos. A autora cita Duquet-Picard (1982) e Oliveira (2001) para especificar os sinônimos terminológicos que seriam "hipônimos concorrenciais de mesmo nível”, ou seja, as variantes concorrentes geográficas, discursivas ou históricas não seriam consideradas sinônimas. Já a categoria das variantes competitivas agrupa os termos de línguas diferentes, dentre as quais os estrangeirismos e os empréstimos (stress e estresse).

Os empréstimos linguísticos são unidades lexicais que se originam de uma língua estrangeira e que no contexto da língua receptora dão origem a uma forma vernacular equivalente (FAULSTICH, 2001, p. 32-33).

O léxico do português tem-se beneficiado ao longo dos anos por meio de empréstimos 
de outros sistemas linguísticos (ALVES, 1995, p. 319): a partir do século XVIII, com unidades lexicais de origem francesa, resultado da influência da França sobre os costumes brasileiros, e com os italianismos que também contribuíram para o enriquecimento da língua portuguesa (ALVES et al., 2004, s.p.). Além disso, o uso de estrangeirismos (unidades lexicais oriundas de outros idiomas) também é percebido em todas as terminologias (ALVES et al., 2003, p. 43), inclusive no universo das feiras de negócios. Nesse sentido, Alves complementa que

na fase de implantação do conceito e de seu respectivo termo, empréstimos de outras línguas são introduzidos no português. Correspondem, portanto, a uma necessidade do desenvolvimento econômico e tecnológico. Todavia, tendem a ser, pouco a pouco, traduzidos ou substituídos por termos de caráter vernáculo pelos próprios usuários, os profissionais que trabalham com as línguas de especialidade. Nem sempre, é verdade, os termos criados em português são condizentes com as regras de formação da língua portuguesa (ALVES, 1995, p. 320).

Esse fato pôde ser observado também em nosso trabalho. Podemos citar como exemplo o termo stand, um estrangeirismo proveniente da língua inglesa que aparece em português, em francês e em italiano em sua forma original, stand, e que hoje tornou-se um decalque no português, dicionarizado como “estande". Nesse sentido, pode-se evidenciar no português uma tendência de vernaculização

dos estrangeirismos. São várias as formas pelas quais esse fenômeno se manifesta. Primeiramente, pode-se destacar as formações de termos híbridos em que um sintagma é composto por um radical vernáculo e um estrangeiro; os casos de termos em que sufixos vernáculos são associados a radicais estrangeiros e os casos dos decalques, em que o termo vernáculo criado é totalmente baseado na forma estrangeira (ALVES et al., 2004, s.p.).

Em outras palavras, uma unidade lexical, ao ser introduzida em um novo idioma, acaba perdendo alguns de seus traços originais, adquirindo outros da língua que a acolheu. Temos vários exemplos desse tipo na língua portuguesa como, por exemplo, deletar (delet), resetar (reset), plugar (plug), entre outros, e em nosso corpus, o termo "estande", mencionado acima. Além do aspecto formal, a unidade lexical proveniente de idioma estrangeiro pode sofrer também alterações em nível semântico, ao ser introduzida em uma nova comunidade linguística.

Segundo Alpízar-Castillo, "se o estrangeirismo é um elemento que aparece suficientemente documentado nas fontes, ele é um termo frequentemente usado pelos especialistas"108 (ALPÍZAR-CASTILLO, 1995, p. 119) e pode ser incluído e definido em uma

${ }^{108} \mathrm{Si}$ el extranjeirismo es un elemento que aparece suficientemente documentado en las fuentes, porque es término del que hacen frecuente uso los especialistas (ALPÍZAR-CASTILLO, 1995, p. 119). 
obra terminográfica. Por essa razão, incluimos em nosso dicionário os estrangeirismos encontrados no setor feirístico, uma vez que são utilizados pelos profissionais da área.

Segundo os estudiosos, os estrangeirismos mais comuns e frequentes são os provenientes da língua inglesa. Isso se deve ao fato de que o inglês "configura-se como o latim das relações internacionais contemporâneas" (AUBERT, 1996, p. 17), tornando-se, portanto, "a língua universal da ciência e da tecnologia" (BIDERMAN, 2001, p. 15). Isso explica o motivo pelo qual encontramos muitos termos utilizados em inglês no conjunto terminológico das feiras de negócios em português. Por essa razão, decidimos manter esses termos em inglês, em alguns verbetes do glossário elaborado durante o mestrado. Para a pesquisa de doutorado procedemos da mesma maneira, uma vez que também encontramos termos utilizados em inglês nos conjuntos de termos do setor feirístico em francês e em italiano. Porém, não é possível generalizar, uma vez que não conhecemos as relações entre línguas mais distantes culturalmente falando, como o mandarim e as línguas neolatinas e anglogermânicas, e também temos consciência de que cada domínio especializado tem uma história distinta, como a Moda ou a Gastronomia, com muitos estrangeirismos no português e em outras línguas provindos do francês, ou a Música Clássica, com estrangeirismos italianos.

Existe uma grande discussão em torno dos conceitos de variante e sinônimo em Terminologia. Sabe-se que a sinonímia é a relação entre designações diferentes que representam um mesmo conceito. Vale destacar que os termos que são intercambiáveis em todos os contextos de uma área são chamados sinônimos e aqueles que são intercambiáveis em apenas alguns contextos dessa área são chamados de quase-sinônimos. Na pesquisa de mestrado discorremos sobre esse assunto com mais detalhes, por isso optamos por mencionar en passant essa questão aqui, esclarecendo que na presente pesquisa de doutorado estamos trabalhando com o conceito de variantes proposto por Faulstich (2001).

Por outro lado, verificamos ao longo da pesquisa e, mais especificamente após os estágios no exterior, que a variação na terminologia das feiras é mais frequente no campo do conceito como, por exemplo, em “estande com mezanino", "estande de dois andares" e "estande com piso superior" do que no campo da forma (ortográfica, lexical, morfológica, sintática) como, por exemplo, em stand en coin e stand de coin ou stand ad angolo e stand d'angolo. Por conseguinte, cogitamos sobre a possibilidade da sinonímia cognitiva ser a origem da evidente variação terminológica encontrada neste trabalho, conforme sugeriu a supervisora do estágio na França que nos indicou a leitura do texto "Notion d'archi-concept et dénomination", mencionado anteriormente. 


\subsection{A Contribuição da Linguística de Corpus}

A Linguística de Corpus veio facilitar o trabalho de pesquisadores, professores, tradutores e terminológos no sentido de agilizar a leitura e análise de grandes quantidades de textos escritos, por meio de um computador. Hoje um tradutor consegue fazer um levantamento linguístico ou terminológico de uma área do conhecimento e elaborar o seu próprio glossário de maneira mais fácil e rápida, para auxiliá-lo no processo de tradução. Do mesmo modo, um terminológo consegue recolher e analisar os termos de uma área de especialidade para a elaboração de materiais teminográficos de forma muito mais ágil, produtiva e confiável.

Assim, Camargo chama a atenção para o fato de que

a mudança de uma perspectiva conceitual e semântica da linguagem para uma perspectiva situacional e de uso da linguagem levou a uma mudança nos métodos de investigação dos estudos linguísticos, passando a solicitar o acesso a dados reais para a observação sobre o uso da linguagem (CAMARGO, 2012, p. 31).

Essa mudança da metodologia de investigação linguística por meio do acesso a dados reais para a observação da língua em uso deve-se ao surgimento de uma abordagem empírica para o estudo da linguagem, baseada na observação de corpus, como veremos adiante.

Os significados das palavras passam, então, a ser identificados por meio da análise de seus usos no texto, ou seja, o foco de atenção passa do domínio exclusivo do léxico para o textoem-situação nas linguagens de especialidade (AZENHA JR, 2010, p. 49-50; PEARSON, 1998, p. 49-50).

No campo da Terminologia, a busca dos dados passou a ser feita dentro de um corpus. Por este, entende-se o "conjunto de dados linguísticos coletados para fins de análise" 109 (ISO 1087, 2000, p. 11), ou a coletânea de textos autênticos, em formato eletrônico, relativos ao domínio estudado, considerados representativos de uma língua, selecionados e organizados de acordo com critérios linguísticos específicos, utilizados como fonte de dados para a pesquisa linguística (BOUTIN-QUESNEL, 1985, p. 26; BERBER SARDINHA, 2004, p. 17; TAGNIN, 2004, p. 4; LAVIOSA, 2010, p. 80).

Bassnett (2003, p. 16) e Snell-Hornby (2005, p. 125) afirmam que na década de noventa floresceram novas linhas de investigação geradas pelo enorme interesse suscitado pela investigação com corpus, tal como foi preconizado por Mona Baker. Assim, a utilização do computador dá aos estudos de corpora maior precisão e praticidade. Dessa atividade, nasceu

\footnotetext{
${ }^{109}$ Ensemble de données linguistiques recueillies à des fins d'analyse (ISO 1087, 2000, p. 11).
} 
uma verdadeira disciplina científica, a Linguística de Corpus que, segundo Berber Sardinha (2004, p. 3), é uma área em pleno desenvolvimento que se "dedica à exploração da linguagem por meio de evidências empíricas, extraídas por computador”. Vale destacar que a Linguística de Corpus também se fortaleceu nos Estudos da Tradução na década de oitenta, com a virada empírica. Para o autor, a Linguística de Corpus ocupa-se da coleta e da investigação de corpora, para fins de pesquisa de uma língua ou variedade linguística e ressalta a importância do corpus como fonte de informação, uma vez que registra a linguagem utilizada em situações reais (BERBER SARDINHA, 2004, p. 3 e 32).

Nesse sentido, Sinclair declara que "devemos confiar no texto e estar abertos para o que ele pode nos trazer" ${ }^{110}$ (SINCLAIR, 2004, p. 23). Segundo ele, um corpus "é desenhado para o estudo da linguagem, os conteúdos devem ser escolhidos para apoiar este propósito e representar a língua de onde foram retirados"111 (SINCLAIR, 2005, s.p.). Sanchez, igualmente, afirma que a expressão corpus refere-se a um

conjunto de dados linguísticos [...], sistematizados segundo determinados critérios, suficientemente extensos em amplitude e profundidade, de maneira que sejam representativos da totalidade do uso linguístico ou de algum de seus âmbitos, dispostos de tal modo que possam ser processados por computador, com a finalidade de obter resultados úteis para a descrição e a análise (SANCHEZ, 1995, p. 8$9)^{112}$.

Como vimos, diversos autores se debruçaram sobre o assunto, concordando que um corpus diz respeito a um conjunto de textos, legíveis pelo computador, compilados de acordo com parâmetros específicos, cujo objetivo principal é a descrição e análise linguística, por meio da observação de dados reais. Nesse sentido, as pesquisas baseadas em corpus, consolidaramse como um reconhecido modelo para a investigação linguística, inclusive nos estudos terminológicos.

Por conseguinte, de acordo com Sager, a compilação em Terminologia está firmemente baseada em

corpora. O desejo de construir um sistema conceitual abstrato e organizado deu lugar à necessidade prática de abordar o que acontece na vida real. Os termos não são mais extraídos de listas prévias, mas são retirados de um corpus representativo de textos autênticos em formato

\footnotetext{
${ }^{110}$ We should trust the text, we should be open to what it may tell us (SINCLAIR, 2004, p. 23).

${ }^{111}$ Is made for the study of language, the contents of the corpus should be chosen to support the purpose, and represent the language from which they are chosen (SINCLAIR, 2005, s. p.).

112 [...] conjunto de datos lingüísticos (pertenecientes al uso oral o escrito de la lengua, o a ambos), sistematizados según determinados criterios, suficientemente extensos en amplitud y profundidad de manera que sean representativos del total del uso lingüístico o de alguno de sus ámbitos y dispuestos de tal modo que puedan ser procesados mediante ordenador con el fin de obtener resultados varios útiles para la descripción y el análisis (SÁNCHEZ, 1995, p. 8-9).
} 
eletrônico ${ }^{113}$ (SAGER, 1990, p. 130).

Assim, a coleta dos termos a partir de corpora especializados, escritos por especialistas, em condições reais de uso, contribuem para o enriquecimento dos estudos terminológicos, uma vez que as obras terminográficas são elaboradas com base em fatos e situações reais como, por exemplo, em nossa pesquisa, os guias e manuais do expositor, elaborados pelas organizadoras de feiras e fundamentais para o sucesso da participação de todos expositores em qualquer feira nacional ou internacional.

Para Baker, corpora é uma coletânea de textos legíveis por computador, e que podem ser analisados de diferentes maneiras. Em sua metodologia, Baker define três tipos distintos de corpora eletrônicos: corpora paralelos, corpora multilígues e corpora comparáveis. Segundo a autora, corpora paralelos, incluem textos na língua fonte (originais) e suas respectivas traduções; corpora multilíngues são textos em diferentes línguas e não incluem textos traduzidos; corpora comparáveis são textos originalmente escritos em uma língua e textos traduzidos para a mesma língua (BAKER, 1995, p. 230-244). Portanto, na classificação de Baker, nossa pesquisa se enquadra no segundo tipo, ou seja, corpora multilíngues do domínio das feiras de negócios.

Entretanto, para Tognini-Bonelli (2001, p. 7), corpora comparáveis são corpora escolhidos para serem amostras similares de suas respectivas línguas, excluindo-se textos traduzidos, o que significa, portanto, que o alinhamento não é possível, mas correspondências podem ser estabelecidas entre os corpora. Nesse sentido, nossa proposta de extração de termos a partir de corpora comparáveis corrobora a proposta de Tognini-Bonelli, uma vez que trabalhamos principalmente com corpora comparáveis constituídos de textos escritos originalmente em português, inglês, francês e italiano e não com textos traduzidos para essas línguas ${ }^{114}$.

De modo semelhante, para Tagnin, os corpora mais adequados para o trabalho terminológico

são os corpora comparáveis, ou seja, corpora com textos originais em ambas as línguas [...]. Isto se deve principalmente porque espera-se que eles retratem o uso autêntico da língua. Para serem comparáveis, os textos devem cobrir as mesmas áreas técnicas, os mesmos períodos de

\footnotetext{
${ }^{113}$ Terminology compilation is now firmly corpus-based. The desire to construct abstract and neat conceptual systems has given way here to the practical need of addressing what happens in real life. Terms are therefore no longer extracted from previous lists but are rather drawn from a representative corpus of authentic texts held in electronic form (SAGER, 1990, p. 130).

${ }^{114}$ Contudo, encontramos um único manual intitulado The Role of Exhibitions in the Marketing Mix publicado em inglês em 2014 e traduzido para o português, o francês e o italiano. Às vezes, recorremos a esses manuais para ver as traduções.
} 
tempo e pertencerem aos mesmos tipos textuais ${ }^{115}$ (TAGNIN, 2012, p. 171).

Assim, com a ajuda de corpora comparáveis relativos ao domínio das feiras de negócios, de mesmo tipo textual e que recobrem os mesmos períodos de tempo, é possível ter acesso ao termo como ele é realmente empregado em cada língua, dentro de um contexto, o que possibilita uma escolha mais adequada do termo equivalente, baseando-se em evidências reais de uso nas quatro línguas.

Vale lembrar que o trabalho terminológico exige corpora especializados, isto é, corpora de um domínio específico, os quais devem ser construídos pelo pesquisador, já que poucos estão disponíveis gratuitamente online (TAGNIN, 2012, p. 171). Para Laviosa, o corpus especializado deve ser representativo da linguagem utilizada dentro de um domínio especializado do conhecimento (LAVIOSA, 2010, p. 80).

Para construir um corpus de uma variedade específica, neste caso, do âmbito das feiras de negócios, deve-se ser o mais seletivo possível na escolha dos exemplares, para que os mesmos reflitam de fato a variedade escolhida. Nesse sentido, Berber Sardinha cita os quatro pré-requisitos para a formação de um corpus eletrônico: o corpus deve ser constituído de textos autênticos, em linguagem natural, escritos por falantes nativos, escolhidos com prudência e representativos de uma variedade linguística ou idioma (BERBER SARDINHA, 2004, p. 19). No que diz respeito à tipologia e considerando a pesquisa em questão, estamos trabalhando com corpora comparáveis, escritos, especializados e multilíngues (originalmente escritos em português, inglês, francês e italiano).

Biderman (2003, p. 181) afirma que "o fato do dicionário fundamentar-se em corpus autêntico da língua como ela é realmente utilizada pelos falantes confere a essa obra uma autoridade indiscutível”, e a Linguística de Corpus felizmente possibilita isso. Por essas razões, elaboramos o nosso dicionário a partir de corpora do domínio especializado das feiras de negócios, conforme será apresentado no Capítulo 3. De fato, tem-se mais objetividade na organização da macroestrutura e microestrutura de um dicionário baseado em corpus, evitandose, por exemplo, a criação individual de acepções (BORBA, 2011, p. 21).

É importante destacar que em terminologia e terminografia, o critério de representatividade é mais importante para o reconhecimento de um termo do que o critério estatístico numérico, uma vez que a palavra não é examinada pela frequênca com que ocorre

\footnotetext{
115 The most adequate corpora for bilingual terminological work are comparable corpora, that is, corpora with original texts in both languages, English and Portuguese in our case. This is mainly because they are expected to portray authentic language use. To be comparable, texts must cover the same technical areas, the same periods of time and belong to the same textual types (TAGNIN, 2012, p. 171).
} 
dentro do corpus, mas pelo seu valor na representação dos propósitos da área a que pertence (MACIEL, 2001, p. 375).

Portanto, o corpus deve ser representativo daquilo que pretende analisar e compete ao criador do corpus estabelecer os critérios que garantam essa representatividade, já que como bem colocou Leech, "a representatividade é um ato de fé"116 (LEECH, 1991, p. 27).

Como vimos, o critério da representatividade é prioritário para o trabalho terminológico. Contudo, a verificação da frequência dos itens lexicais também é válida para o dicionarista no momento de estabelecer o conjunto das entradas do dicionário ou sequenciar as acepções dentro dos verbetes (BORBA, 2011, p. 20). Desse modo, concordamos com Maciel (2001, p. 376) que “os métodos estatísticos e linguísticos não são excludentes, mas complementares e sua integração poderia reduzir ao máximo tanto a não identificação de candidatos a termos ${ }^{117}$, como o seu reconhecimento errôneo ou incompleto". No presente trabalho, utilizamos tanto o critério da representatividade como o critério da frequência para a seleção de termos-entrada e variantes do dicionário.

Como se sabe, a pesquisa terminológica tradicional feita na ponta do lápis e a olho nu tornou-se inviável, cedendo lugar à pesquisa terminológica realizada por meio de ferramentas computacionais (MACIEL, 2001, p. 373). Assim, levando em consideração o fato de que os documentos estão cada vez mais disponíveis em formato eletrônico, ferramentas estão sendo desenvolvidas para ajudar a processá-los para fins terminológicos (BOWKER, 2009, p. 288), como, por exemplo, os sistemas de extração de termo que combinam técnicas

como padrão de correspondência e processamento estatístico para chegar a uma lista de possíveis candidatos a termo. Outras ferramentas, como os concordanciadores, estão disponíveis para permitir que terminológos ou tradutores conduzam uma investigação mais aprofundada de um determinado termo ou candidato, examinando-o nos contextos em que aparece dentro do corpus $^{118}$ (BOWKER, 2009, p. 288).

Neste trecho, Bowker descreve as ferramentas utilizadas para a criação de listas de palavras e análise de candidatos a termos em contexto. Assim, para a análise dos corpora de estudo da presente pesquisa, o programa utilizado é o WordSmith Tools, versão 6.0 (SCOTT, 2012). Trata-se de um programa que reúne as principais ferramentas que o linguista de corpus

\footnotetext{
116 The representativeness (of a corpus) must be regarded largely as an act of faith (LEECH, 1991, p. 27).

117 Palavra-chave com possibilidade de ser um termo no domínio em estudo (TAGNIN; VIANA, 2010, p. 357).

${ }^{118}$ Term extraction systems combine techniques such as pattern-matching and statistical processing to come up with the list of possible term candidates. Still other tools, such as concordancers, are available to allow terminologists or translators to conduct a more in-depth investigation of a given term or candidate by examining it in the range of contexts in which it appears within the corpus (BOWKER, 2009, p. 288).
} 
precisa para identificar e comparar frequências e listar palavras no seu contexto original. É composto de três ferramentas principais, conforme apresentado em Godoy (2014, p. 65):

1. WordList: propicia a criação de listas de palavras: uma ordenada alfabeticamente e outra classificada por ordem de frequência de palavras

2. KeyWords: permite a seleção de uma lista de palavras (ou mais) por meio da comparação de sua frequência com uma lista de referências. O resultado do contraste é uma lista de palavras-chave ${ }^{119}$, ou palavras cujas frequências são estatisticamente diferentes nos corpora de estudo ${ }^{120}$ e no corpus de referência ${ }^{121}$

3. Concord: produz as ocorrências de um item específico (chamado palavra de busca), acompanhado do texto ao seu redor (cotexto) (BERBER SARDINHA, 2004, p. 91-105).

Essa ferramenta conta também com outros utilitários como collocates que apresentam os colocados da palavra de busca; clusters que relacionam os agrupamentos em que aparece a palavra de busca e aligner que alinha dois textos (TAGNIN; VIANA, 2010, p. 360).

Para a pesquisa, utilizamos as ferramentas WordList e KeyWords para a busca e coleta dos candidatos a termos e a ferramenta Concord para a análise e a busca dos contextos em que os termos ocorrem, para a confecção do dicionário terminológico multilíngue das feiras de negócios.

É importante destacar que o computador é capaz apenas de sugerir os candidatos a termos que, por sua vez, somente terão o seu valor de termo confirmado após serem devidamente analisados em seus contextos de uso pelo terminológo e avaliados pelo especialista da área. Por outro lado, a coleta manual, articulando conhecimentos linguísticos com conhecimentos da área especializada, pode produzir resultados muito satisfatórios (MACIEL, 2001, p. 374 e 382). Isso pôde ser observado no mestrado, enquanto compilávamos os termos para o glossário. Fizemos uma coleta manual dos termos (ainda não conhecíamos o WST) e depois, com a aquisição do software, fizemos a coleta dos termos por meio da Wordlist. Comparamos as duas listas de palavras e nos surpreendemos com a coleta que havíamos feito manualmente, que nos pareceu bastante completa, o que significa que as buscas feitas manualmente também podem ser eficazes.

Vale ressaltar que na abordagem corpus-driven (dirigida pelo corpus), o compromisso do linguista é com as evidências apresentadas pelo corpus, sem pressuposições teóricas; os terminógrafos, por sua vez, utilizam essa abordagem para descobrir novos fatos sobre a língua

\footnotetext{
119 Resultados da comparação entre o corpus de estudo e um corpus de referência. Essa comparação elimina palavras com frequência relativa similar nos dois corpora de modo que restem as palavras cuja frequência é estatisticamente significativa (TAGNIN; VIANA, 2010, p. 359).

${ }^{120}$ Corpora em que se baseia a pesquisa (Ibid., p. 358).

${ }^{121}$ Corpus que serve de termo de comparação para o corpus de estudo. Em geral, deve ter três a cinco vezes o tamanho do corpus de estudo (Id.).
} 
ou para identificar candidatos a termo em um corpus (TOGNINI-BONELLI, 2001, p. 84; PEARSON, 1998, p. 49-50), exatamente como procedemos na presente pesquisa. Assim, o linguista se aproxima do corpus com uma mente aberta,

na esperança de validar uma hipótese, mas esperando descobrir novos insights para refinar a hipótese. O corpus não é utilizado apenas como um repositório de exemplos para apoiar teorias pré-definidas. O linguista está igualmente interessado nas exceções às teorias que estão sendo validadas e as usa como meio de aperfeiçoar as declarações que ele está fazendo sobre a linguagem. A abordagem orientada pelo corpus está sendo cada vez mais adotada pelos pesquisadores como base para aperfeiçoar teorias linguísticas ${ }^{122}$ (PEARSON, 1998, p. 49).

Foi exatamente assim que nos posicionamos frente aos corpora de estudo, sem ideias pré-concebidas, com o intuito de elaborarmos uma hipótese a partir da observação dos corpora e análise dos dados, contribuindo, desse modo, para os Estudos da Tradução e os Estudos Terminológicos.

Borba também se posiciona de forma semelhante a Pearson ao afirmar que "com os corpora computadorizados foi possível atinar com fenômenos curiosos dentro das línguas, antes não percebidos" (BORBA, 2011, p. 22). E aqui reside o encanto de trabalhar com corpus e com as ferramentas de processamento de corpora, ou seja, a possibilidade de descobrir fatos novos, impensados, que enriquecem a pesquisa linguística, saindo do que é esperado e previsível.

Tagnin faz uma distinção entre a terminologia tradicional e a terminologia direcionada pelo corpus: na primeira, os corpora são usados para recuperar exemplos e construir definições; na segunda, pelo contrário, as entradas são extraídas a partir do corpus e exemplos, colocados, fraseologias e equivalentes são fornecidos (TAGNIN, 2012, p. 170). Em outras palavras, na metodologia baseada em corpus, a partir da suposição de que determinada unidade lexical poderia caracterizar um termo, buscam-se exemplos específicos desse termo, a título de comprovação. E, na metodologia dirigida pelo corpus, a busca por um termo revela outro ainda não registrado, o que pode expandir o número de verbetes de um dicionário, como pôde ser observado em nosso trabalho.

É oportuno salientar que "Munday refere-se à Linguística de Corpus como uma

\footnotetext{
122 The linguist approaches the corpus with an open mind, hoping to validate a hypothesis but expecting to discover new insights in order to refine the hypothesis. The corpus is not used just as a repository of examples to back predefined theories. The linguist is equally interested in the exceptions to the theories being validated and uses these as means of refining the statements which he/she is making about language. The corpus-driven approach is being increasingly adopted by researchers as basis of refining linguistic theories (PEARSON, 1998, p. 49).
} 
metodologia e não como uma disciplina" ${ }^{23}$ (SNELL-HORNBY, 2005, p. 158). Em nossa pesquisa, também utilizamos os fundamentos e preceitos da Linguística de Corpus como arcabouço metodológico, que se mostraram bastante eficazes para alcançarmos os objetivos propostos na pesquisa.

Para Borba, a metodologia oferecida pela Linguística de Corpus "veio não só agilizar o trabalho de organização de dicionários como também proporcionar mais segurança aos resultados" (BORBA, 2011, p. 18). Concordamos com o autor e, por isso, optamos por utilizar essa metodologia em nossa pesquisa para a elaboração do dicionário multilíngue de termos do setor feirístico, uma vez que nos possibilita analisar grandes quantidades de textos de uma só vez, de maneira rápida e segura, já que o trabalho manual, além de ser mais dispendioso em termos de tempo, poderia nos privar de descobertas que somente a abordagem corpus-driven pôde nos revelar.

\subsection{As Unidades Fraseológicas nas Feiras de Negócios}

Ao contrário dos termos simples que são formados por uma única palavra, os fraseologismos são constituídos pela combinação de duas ou mais palavras, as unidades fraseológicas, objeto de estudo da Fraseologia, definidas por Corpas Pastor (1996, p. 20) como "unidades léxicas formadas por mais de duas palavras gráficas em seu limite inferior, cujo limite superior situa-se no nível da oração composta" ${ }^{24}$. De acordo com a autora, as características linguísticas que distinguem as unidades fraseológicas de outros tipos de unidades léxicas são a frequência, a institucionalização, a estabilidade, a idiomaticidade, a variação e a gradação, conforme descrição a seguir:

1. A frequência, tanto de uso dessas combinatórias, quanto de coocorrência de seus elementos constitutivos

2. A institucionalização, sinônimo de convencionalização pela comunidade falante, graças à frequência de ocorrência e a sua fixidez formal e semântica

3. A estabilidade, no sentido de fixidez formal e de fixidez de conteúdo, aspectos estritamente relacionados, dado que a fixidez formal leva à mudança semântica

4. A idiomaticidade, propriedade semântica de certas unidades fraseológicas, em que o significado global não corresponde à somatória do sentido de cada um de seus elementos constituintes

5. A variação, uma característica presente em algumas UFs que possuem variantes, entendidas como formas alternativas parcialmente idênticas em sua estrutura e

\footnotetext{
${ }^{123}$ Munday refers to corpus linguistics as a methodology and not a discipline (SNELL-HORNBY, 2005, p. 158).

${ }^{124}$ Unidades léxicas formadas por más de dos palabras gráficas en su límite inferior, cuyo límite superior se sitúa en el nivel de la oración compuesta (CORPAS PASTOR, 1996, p. 20).
} 
componentes e que não apresentam diferenças de sentido

6. A gradação, que baseia-se nos critérios de grau de restrição colocacional, de fixidez sintático-estrutural e de opacidade semântica ou idiomaticidade (SABINO, 2011, p. 388).

Desse modo, são unidades fraseológicas, segundo a autora, as colocações, as locuções e os enunciados fraseológicos. Neste subitem, contudo, trataremos apenas das colocações, pois são mais frequentes no domínio das feiras de negócios.

A estudiosa define as colocações como "unidades fraseológicas formadas por duas unidades lexicais [...] que apresentam restrições de combinação estabelecidas pelo uso"125 (CORPAS PASTOR, 1996, p. 66). Para a teórica, as colocações são expressões semi-fixas com significado transparente que se pode traduzir a partir de seus componentes particulares, ao passo que as locuções, por exemplo, são expressões fixas com o significado idiomático, ou seja, de cujos componentes não se pode deduzir os significados individualmente.

O termo collocation (colocação) foi criado em 1951 pelo linguista britânico J. R. Firth, autor da frase "uma palavra é conhecida pela companhia que mantém" e são definidas como a ocorrência de duas ou mais palavras dentro de um curto espaço (uma da outra) em um texto em que não perdem o sentido literal que possuem separadamente e cuja combinação vem determinada pelo uso (SINCLAIR, 1991, p. 170; REY, 2003, p. 216; SILVA, 2006, p. 17). O espaço entre as palavras é definido pela distância de cerca de quatro palavras à direita ou à esquerda da palavra investigada, nomeada por Sinclair de node.

Hausmann (1985, apud DESMET, 2002, p. 39) faz uma distinção entre combinações fixas (formada pelas expressões idiomáticas) e não fixas (as colocações). O autor propõe uma terminologia para referir-se aos elementos que compõem uma colocação: o elemento base e o elemento colocado. A base refere-se ao elemento conhecido, ou seja, aquele que faz parte de nosso universo, e é geralmente um substantivo ou verbo; o colocado, por sua vez, refere-se ao elemento desconhecido de uma colocação; qualquer elemento que co-ocorra de forma significativa com uma palavra de busca (TAGNIN, 2010, p. 357-358).

Orenha (2012, p. 152) traz a distinção entre o elemento base e o elemento colocado de acordo com Heid et al. (1991): a base é um elemento independente e sua tradução não depende de seu uso na colocação; o colocado, por outro lado, funciona como um conceito modificador e sua tradução depende do uso na colocação.

\footnotetext{
${ }^{125}$ Unidades fraseológicas formadas por dos unidades léxicas [...] que presentan restricciones de combinación establecidas por el uso (CORPAS PASTOR, 1996, p. 66).
} 
Vale destacar as características que qualificam uma combinação como colocação, a saber: Recorrência - frequência superior a 1; Não-idiomaticidade - seu significado deve ser composicional; Coesão - é necessário que haja uma forte ligação entre seus elementos; Restrição contextual - deve haver uma probabilidade de que ocorra dentro de um contexto específico e Coocorrência arbitrária entre seus elementos - não há razão semântica que explique tal coocorrência (TAGNIN, 1998b, p. 41).

L'Homme e Bertrand (2000, p. 498) afirmam que as "colocações são combinações convencionais em uma dada comunidade linguística, enquanto que as colocações especializadas são combinações convencionais em um grupo de especialistas". Desse modo, a base das colocações da língua geral é uma unidade lexical pertencente à própria língua geral e, no caso das colocações especializadas, a base é uma unidade lexical com um conteúdo específico em um domínio de especialidade específico, ou seja, a base é um termo ou uma unidade terminológica. Na terminologia das feiras de negócios, por exemplo, as bases que compõem as colocações especializadas desse domínio são: "feira", "estande”, “expositor”, "pavilhão", "visitante" e "exposição", como será tratado no Capítulo 5.

Alves acrescenta que, diferentemente da língua geral,

em que predominam formações simples, constituídas por um único elemento, caracterizam-se as línguas de especialidade por apresentarem predominantemente formações sintagmáticas, em que dois ou mais elementos constituem uma unidade complexa e correspondem a um único conceito (ALVES, 1999b, p. 71).

Essa é realmente uma característica marcante das línguas de especialidade e, como dissemos anteriormente, também ocorre no setor feirístico, uma vez que as formações sintagmáticas são as mais frequentes no conjunto terminológico das feiras de negócios nas quatro línguas estudadas.

Em seu Manual de Fraseologia, Corpas Pastor nos apresenta uma tipologia das colocações, podendo ser constituídas de: substantivo (sujeto) + verbo; verbo + substantivo (objeto); adjetivo + substantivo; substantivo + preposição + substantivo; verbo + advérbio e adjetivo + advérbio.

De igual modo, Orenha (2009, p. 41), a partir da proposta de Hausmann (1985), nos apresenta a tipologia das colocações. Desse modo, temos: colocações nominais, adjetivas, adverbiais e verbais. A seguir, apresentamos um exemplo para cada tipo de colocação:

1 Colocações Nominais: Substantivo (base) + Preposição + Substantivo (colocado)

Exemplo: feira de negócios 
2 Colocações Adjetivas: Substantivo (base) + Adjetivo (colocado)

Exemplo: feira especializada

3 Colocações Adverbiais: Advérbio (colocado) + Substantivo (base)

Exemplo: pré-feira; pós-feira

4 Colocações Verbais: Verbo (colocado) + Substantivo (base)

Exemplo: desmontar estande

À luz da Terminologia, os exemplos citados acima seriam analisados de maneira distinta. Não se falaria em "colocações" e sim em "unidades terminológicas". Contudo, como vimos em Tagnin (1998), em Fraseologia, os exemplos supracitados são considerados colocações. Assim, em decoração de estande, por exemplo, temos uma colocação nominal em que "estande" é o elemento base e "decoração" o elemento colocado que coocorre com estande. Em Terminologia, entretanto, esse seria um caso de "termo complexo", ou seja, termo formado por dois ou mais radicais.

Bevilacqua (2005, p. 242), por sua vez, discorre sobre unidade fraseológica especializada, ou seja, "unidade resultante da combinação de duas unidades léxicas, uma das quais é o núcleo (colocador) e a outra o colocado; são semilexicalizadas e possuem determinados padrões morfossintáticos". Assim, "colocação", "termo complexo", ou "unidade fraseológica especializada" são denominações distintas utilizadas por diferentes abordagens teóricas para designar a mesma expressão linguística. Como citamos no Capítulo 2, em Terminologia, "termo simples" é aquele constituído de um radical e um "termo complexo" é aquele constituído de dois ou mais radicais.

Segundo Alves, essas formações, que recebem variadas denominações,

(unidades sintagmáticas, segundo Guilbert (1975, p. 249), termossintagmas, segundo Kocourek (1991, p.135), entre outras) resultam da lexicalização de segmentos frásicos. Constituem uma consequência do caráter onomasiológico da disciplina terminológica, em que o conceito usualmente precede a criação do termo correspondente. Desse modo, a explanação do conceito, expressa por segmentos frásicos, muitas vezes condiciona a lexicalização desses segmentos, que se tornam termos. Esses termos-sintagmas são em geral transparentes, facilmente interpretáveis por causa da junção de seus elementos integrantes (ALVES, 1999b, p. 72).

Neste trecho, Alves nos explica que nas línguas de especialidade o processo de formação de termos ocorre por meio da junção de elementos que especificam (e explicam) um determinado conceito, dando origem, portanto, a um novo termo. 
Em suma, as formações sintagmáticas constituem processo mais comum de formação de novas unidades nas línguas de especialidade, uma vez que um termo vai gerando outros termos por meio da adição de determinantes adjetivais, de determinantes introduzidos por preposição ou por outra forma de expansão (ALVES, 1999b, p. 69 e 74; ALVES et al., 2003, p. 38). Um estudo mais detalhado da constituição interna de termos-chave do setor feirístico em português, inglês, francês e italiano será apresentado no Capítulo 5.

Sabe-se que a delimitação dos termos sintagmáticos de uma área de especialidade é problemática. Nesse sentido, alguns critérios citados por Picoche (1977, p. 15-17) podem contribuir para resolver essa dificuldade, a saber:

- Critério da inseparabilidade: a possibilidade de inserção de elementos no interior de um sintagma invalida sua classificação como sintagma lexicalizado e pode indicar a geração de um novo termo

- Critério da comutação: baseia-se no fato de que uma unidade sintagmática lexicalizada integra uma rede de oposições com unidades simples, o qual nem sempre pode ser aplicado, já que esses sintagmas não apresentam, comumente, correspondências com formações simples

- Critério de caráter sintático: os sintagmas lexicalizados tendem a ser mais limitados do que os sintagmas livres, a uma média de dois ou três elementos por formação; a ausência de artigos também revela a coesão interna do sintagma

- Critério de caráter semântico: refere-se à imprevisibilidade do sintagma do ponto de vista de sua significação; ocorre nos casos em que um dos constituintes do sintagma tem um uso metafórico. Critério não muito aplicado, pois grande parte dos sintagmas em vias de lexicalização possui um significado transparente e explicativo

- Critério da frequência: de grande importância para a lexicalização de um sintagma, pois o uso sistemático de uma mesma formação sintagmática permite avaliar a inserção discursiva e a aceitabilidade desse elemento entre os usuários de uma língua de especialidade (ALVES, 1999b, p. 73-79).

Dentre os critérios mencionados acima adotamos, principalmente, o critério da frequência (e também da representatividade no interior do domínio) para a delimitação dos termos-sintagmas da área das feiras de negócios.

Tagnin enfatiza que o conhecimento das estruturas padronizadas de uma língua é de fundamental importância para se adquirir a fluência nessa língua e explica que a co-ocorrência de certas palavras não é baseada em regras linguísticas, mas sim em convenções (TAGNIN, 2001, p. 490-491). Assim, é muito importante que o tradutor identifique que determinada estrutura é convencional, para que ele possa buscar o equivalente adequado. No entanto, as fontes terminológicas tendem a registrar principalmente termos individuais, o que demonstra ser pouco produtivo para os tradutores, uma vez que "a língua é composta principalmente de 
um repertório de blocos pré-fabricados"126 (TAGNIN, 2012, p. 169 e 179), ou seja, unidades fraseológicas.

Nossa contribuição, nesse sentido, é que trabalhamos em nosso dicionário não apenas com termos simples (ou individuais, segundo Tagnin) mas, principalmente, com termos complexos (ou colocações, segundo Tagnin), que constituem o repertório terminológico das feiras de negócios, o que auxiliará o trabalho de tradutores e intérpretes que atuam nessa área de especialidade. No próximo Capítulo, apresentamos a metodologia utilizada em nossa pesquisa, a base de dados textual, a base de dados terminológica, o sistema organizacional das feiras em português e os modelos de macroestrutura, microestrutura e sistema de remissivas de nosso dicionário.

${ }^{126}$ Tend to focus primarily on single terms, which eventually prove to be of little use to translators and other text producers because language consists mostly of a repertoire of pre-fabricated chunks (TAGNIN, 2012, p. 169). 


\section{METODOLOGIA}

Para o levantamento dos termos em francês e em italiano, uma vez que os corpora em inglês e português foram constituídos e os termos levantados no mestrado (embora tenham sido revistos e complementados constantemente no doutorado), foram reunidos corpora a partir de: livros, artigos e revistas especializados; estudo de mercado das feiras; trabalhos acadêmicos; manuais de participação e orientação em feiras produzidos por órgãos públicos e privados e, principalmente, guias e manuais do expositor das principais feiras realizadas entre 2012 e 2019 no Brasil, Reino Unido, França e Itália, o que garante a representatividade do domínio estudado e recobre a terminologia essencial das feiras de negócios. A maior parte desses guias e manuais são disponibilizados online nos sites das feiras a cada vez que uma edição é realizada. As principais feiras analisadas são: Feiras em Paris (Paris Porte de Versailles e Paris Porte Villepinte), Montpellier, Nantes, Nice, Bordeaux, Marseille, Lyon; Feiras em Roma, Milão, Bolonha, Genova, Nápoles, Rimini, Expo Milano; Feiras em Londres (Olympia London, Excel London, Business Design Centre), Feiras em Birmingham (National Exhibition Centre (NEC)) e Feiras em São Paulo (Expo Center Norte, Pavilhão de Exposições do Anhembi e do Imigrantes). Os manuais dessas feiras são considerados documentos oficiais, pois fazem parte do contrato de locação de estande e devem, portanto, serem lidos e analisados pelos expositores antes de se inscreverem para participar de uma feira. Desse modo, as fontes têm um grau elevado de confiabilidade e correspondem, portanto, aos critérios e pré-requisitos de Berber Sardinha (2004) para a elaboração de um corpus. A maioria dos textos foram retirados da internet e salvos em formato *.txt.

Para a coleta dos corpora de estudo, inicialmente fizemos uma busca por manuais e guias do expositor no google.fr e google.it. Fizemos também uma busca por livros especializados sobre feiras e exposições no google books e encontramos alguns exemplares. Encontramos as revistas especializadas em sites de associações e instituições responsáveis pela organização de feiras nesses países como a AEFI e a UFI, citadas no Capítulo 1.

Os dados foram coletados por meio de software para processamento de corpora, neste caso, como já dissemos anteriormente, a ferramenta utilizada foi o Wordsmith Tools versão 6.0 (SCOTT, 2012). Utilizamos as ferramentas WordList e KeyWords para a busca e coleta dos termos e a ferramenta Concord para a análise e a busca dos contextos em que ocorrem os termos de nosso dicionário multilíngue de termos do setor feirístico.

Assim, confeccionamos quatro WordLists, uma em português, uma em inglês, uma em 
francês e uma em italiano e fizemos a comparação dessas listas de palavras com as listas de palavras dos corpora de referência nas quatro línguas, a saber: BNC (British National Corpus $^{127}$, para o inglês; Folha de São Paulo, para o português; frWaC, para o francês, e itWac ${ }^{128}$ para o italiano. Desse modo, obtivemos como resultado listas de KeyWords (termoschave) de nossa pesquisa, que foram comparadas entre si, a fim de identificarmos os equivalentes prima facie $^{129}$. Em seguida, fizemos a pesquisa de concordância desses termoschave no Concord para identificarmos a posição em que aparecem na frase, quais termos estão a eles coligados, à direita e à esquerda e, principalmente, para verificarmos se os equivalentes prima facie ocorrem no mesmo contexto, ou trata-se de falsos cognatos.

Além da ferramenta WordSmith tools utilizamos também como ferramentas de apoio, quando necessário, o BootCat para a compilação de textos para compor os nossos corpora de estudo e a ferramenta WebCorp Live para fazer a concordância dos termos-chave de nossa pesquisa e, assim, analisá-los em seus contextos de uso.

Em relação aos corpora de referência em francês e em italiano ${ }^{130}$, procedemos da seguinte maneira:

1- Acessamos o site WaCky ${ }^{131}$-The Web-As-Corpus Kool Ynitiative-, disponível em: $<$ http://wacky.sslmit.unibo.it> e selecionamos o item Download/Use. Em Free web interfaces, selecionamos o link: <http://nl.ijs.si/noske/wacs.cgi/first_form $>$. Em seguida, selecionamos o item WordList e a língua francesa, frWaC (French Web), elaboramos uma WordList de 1.328 .628 palavras e a salvamos em txt. Nesta WordList apareceram duas colunas, uma com os termos e outra com a frequência.

2- Em seguida, para rodar essa WordList no software WordSmith tools, foi preciso realizar uma grande limpeza nesta lista, já que, de acordo com o programa WordSmith tools, esta não era uma lista válida.

3- Contatamos duas vezes o criador do programa, o senhor Mike Scott, que, gentilmente, nos sugeriu fazer um trabalho de "detetive" nesta lista para remover os caracteres não reconhecidos pelo sistema. Assim o fizemos e, felizmente, deu certo. Foi um trabalho minucioso e que levou muitos dias, mas finalmente conseguimos uma WordList do corpus de referência em francês de 1.231.371 palavras (após essa limpeza o número de palavras foi reduzido) para, desse modo, criarmos as listas de KeyWords, comparando esta WordList do corpus de referência frWaC com a WordList de nosso corpus de estudo em francês.

\footnotetext{
${ }^{127}$ As listas de palavras dos corpora de referência BNC, com 512 mil palavras, e Folha de São Paulo, com 380 mil palavras, foram adquiridas durante as aulas da disciplina Linguística de Corpus no mestrado.

128 http://wacky.sslmit.unibo.it/doku.php?id=corpora.

129 Palavras que, à primeira vista, podem ser consideradas como equivalentes (TAGNIN, 2012, p. 175).

${ }^{130}$ Tomamos conhecimento dos corpora de referência frWac e itWac em uma apresentação sobre Linguística de Corpus apresentada pela professora Stella Tagnin na USP, durante a disciplina "Tópicos em Tradução" ministrada pelo professor João Azenha.

${ }^{131}$ A Universidade de Bologna criou vários corpora a partir de dados da Internet, aos quais chamou de WaCky. Atualmente conta com corpora em alemão (deWaC), francês ( $\mathrm{frWaC}$ ), inglês britânico (ukWaC) e italiano (itWaC) (TAGNIN, 2010, p. 370).
} 
A título de exemplificação, retiramos da WordList do corpus de referência em francês, o que não era relevante para a pesquisa, tal como descrito a seguir:

- htttp:// - não se trata de termo

- www - website não é termo

- @- e-mail não é termo

- $1 \tilde{O}, \mathrm{dO}, \mathrm{nO}, \mathrm{j} \tilde{\mathrm{O}}$ - estes caracteres apareciam no início das palavras; não houve problema em retirá-los, apesar de serem muitas as ocorrências

- $\quad \ddot{i}, \ddot{e}, \ddot{a}$ - retiramos o sinal de trema das vogais

- $\tilde{A} S=c ̧-$ alteramos as palavras em que apareciam ÃS e colocamos ç

- .com

- .fr

Utilizamos essa mesma metodologia para a confecção da WordList do corpus de referência em língua italiana, o itWaC (Italian Web), necessária para a criação da lista de KeyWords de nosso corpus de estudo em italiano. Após a limpeza, obtivemos uma WordList do corpus de referência em italiano de 1.236 .628 palavras.

Durante o estágio de pesquisa no exterior realizado na University of Surrey (Reino Unido) conhecemos uma nova ferramenta utilizada no tratamento de corpora, a Sketch Engine (KILGARRIFF; RYCHLÝ, 2003). Por meio dessa ferramenta foi possível detectar novos termos que não estavam presentes em nossas listas como, por exemplo, os termos em inglês (e seus equivalentes em francês e italiano): stand plan, complex stand, government stand, independent stand, open space stand, stand drawing, stand dressing, stand designer, stand builder, stand fittings, stand personnel, stand package, stand catering, stand features, stand booking. Os passos realizados para a utilização dessa metodologia estão descritos a seguir: primeiramente foi necessário agrupar todos os arquivos dos corpora de estudo para que fosse possível realizar o upload na ferramenta. Como resultado, a ferramenta nos trouxe as informações referentes a esses corpora como, por exemplo, os corpora de estudo em inglês, apresentado a seguir: 
Tabela 7: Informações sobre os corpora de estudo em inglês

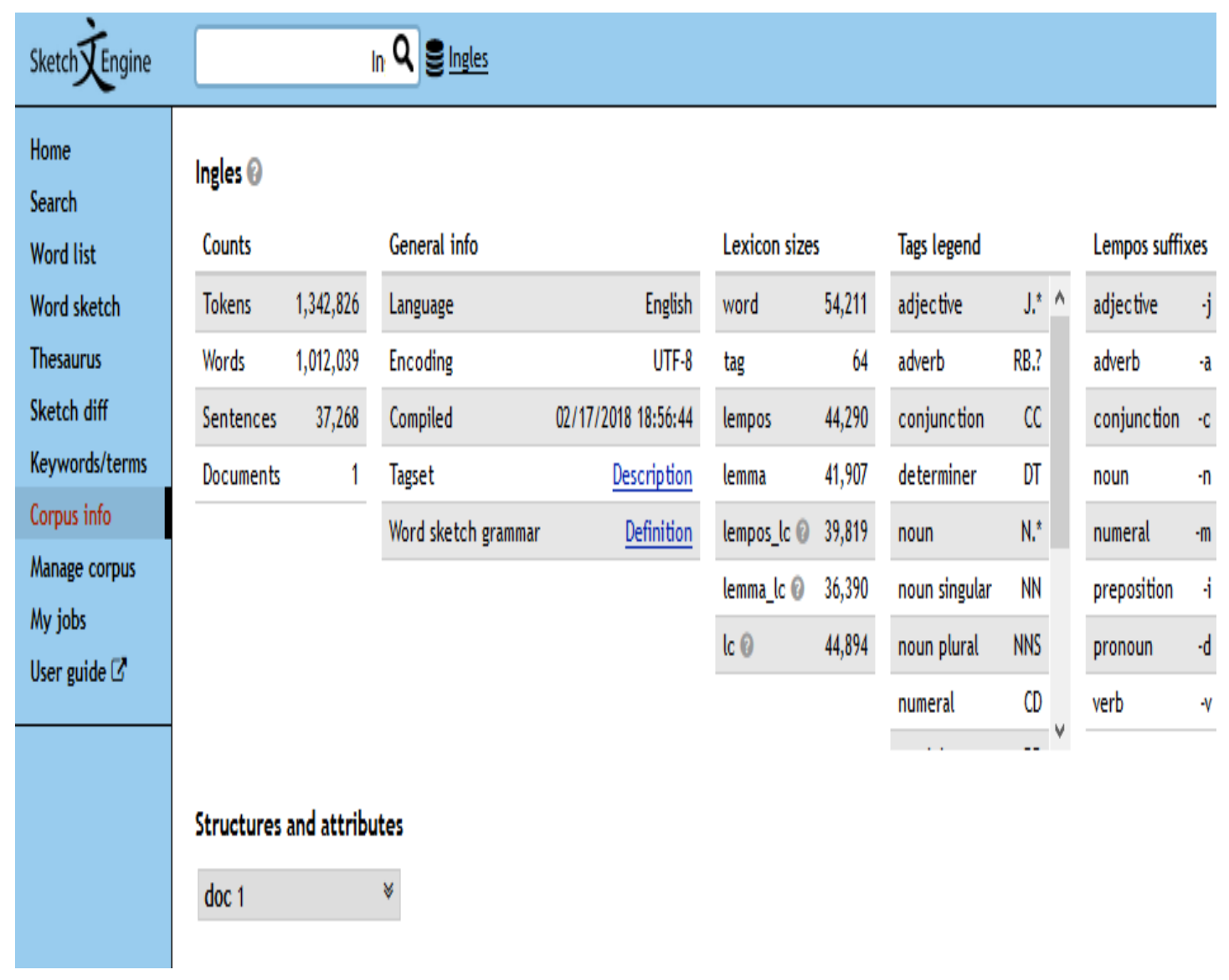

Posteriormente, utilizamos a ferramenta Word Sketch, que traz os colocados dos termos base do dicionário de forma reduzida em uma única tela, para olhar os colocados de alguns termos-chave do dicionário como, por exemplo, o termo stand e o resultado dessa busca pode ser observado nas tabelas abaixo: 
Tabela 8: Word Sketch - Colocados do termo stand I

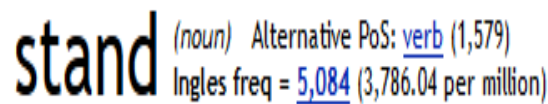

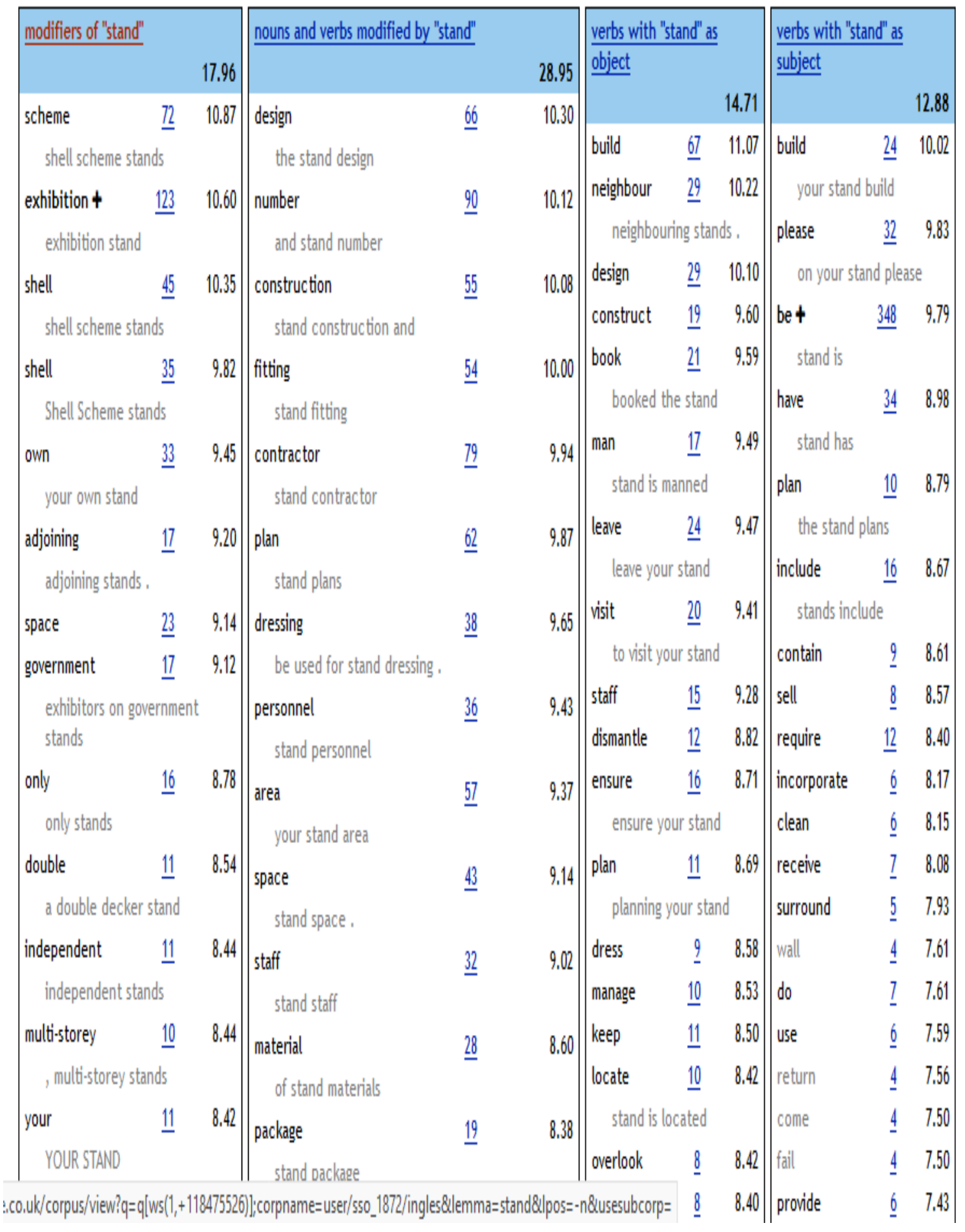


Tabela 9: Word Sketch - Colocados do termo stand II

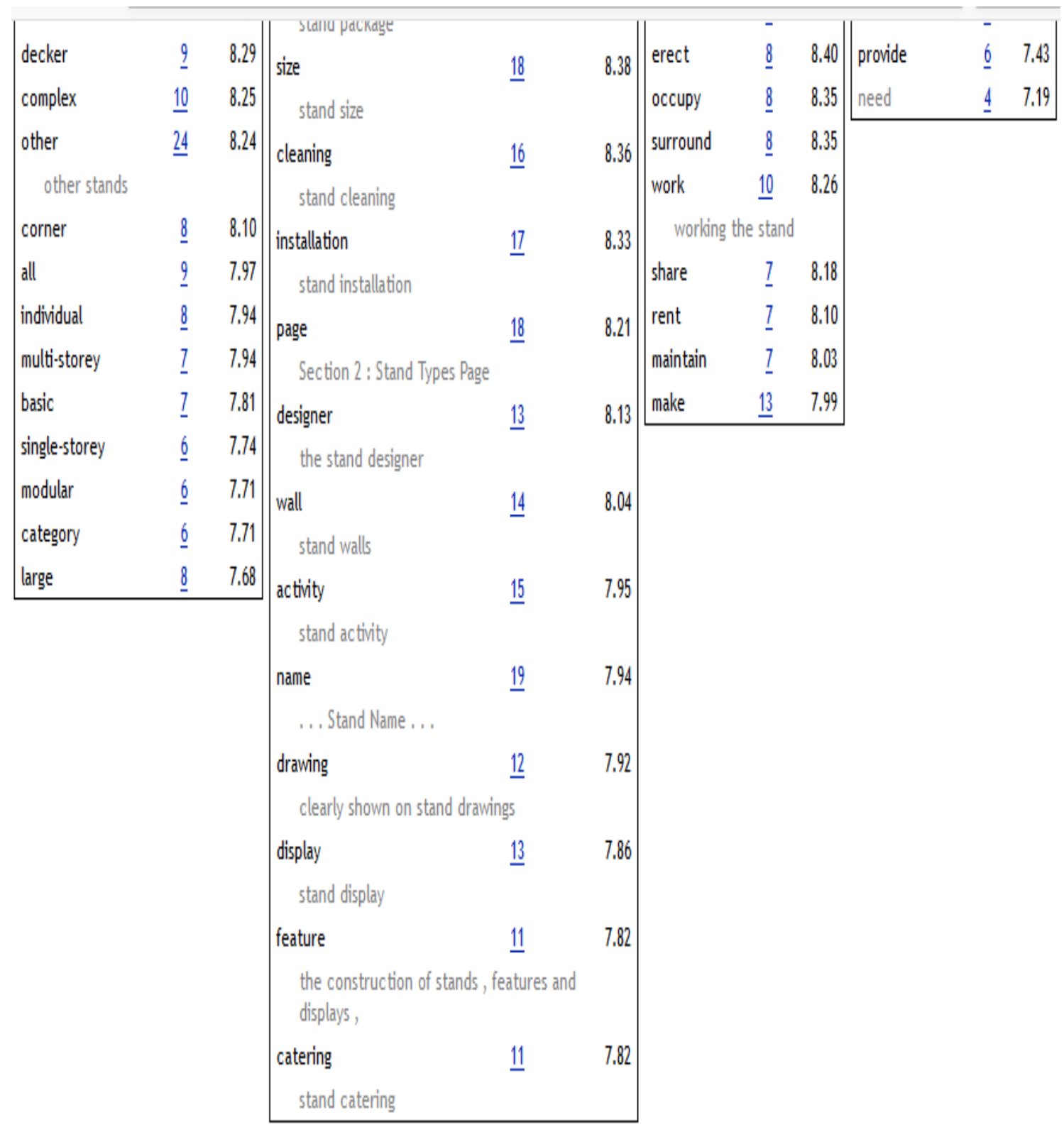

\section{prepositional phrases}

... on "stand" $\quad 59211.64$

... of "stand" $\quad 58411.49$

... to "stand" $\quad 255 \quad 5.02$ adjective predicates of "stand"

2.52

unattended $\quad \underline{12} \quad 11.20$

stand unattended 
Tabela 10: Word Sketch - Colocados do termo stand III

\begin{tabular}{|c|c|c|c|c|c|}
\hline \multicolumn{3}{|c|}{ prepositional phrases } & \multicolumn{3}{|c|}{ adjective predicates of "stand" } \\
\hline$\ldots$ on "stand" & $\underline{592}$ & 11.64 & & & 2.52 \\
\hline$\ldots$ of "stand" & $\overline{584}$ & 11.49 & unattended & $\underline{12}$ & 11.20 \\
\hline$\ldots$ to "stand" & $\underline{255}$ & 5.02 & \multicolumn{3}{|c|}{ stand unattended } \\
\hline$\ldots$ for "stand" & $\underline{165}$ & 3.25 & ready & $\underline{12}$ & 11.15 \\
\hline ... from "stand" & $\underline{109}$ & 2.14 & \multicolumn{3}{|c|}{ ensure that your stand is ready on arrival, } \\
\hline "stand" at ... & $\underline{83}$ & 1.63 & accessible & $\underline{8}$ & 10.65 \\
\hline$\ldots$ in "stand" & $\underline{51}$ & 1.00 & $4 \mathrm{~m}$ & $\underline{6}$ & 10.49 \\
\hline ... at "stand" & $\underline{46}$ & 0.90 & such & $\underline{12}$ & 9.86 \\
\hline "stand" during ... & $\underline{44}$ & 0.87 & \multicolumn{3}{|c|}{ design of the stand is such that it can } \\
\hline "stand" with ... & $\underline{44}$ & 0.87 & more & 4 & 9.57 \\
\hline "stand" in ... & $\underline{36}$ & 0.71 & complete & 4 & 9.53 \\
\hline ... within "stand" & $\underline{36}$ & 0.71 & available & $\underline{8}$ & 8.44 \\
\hline "stand" for ... & $\underline{35}$ & 0.69 & \multirow{3}{*}{\multicolumn{3}{|c|}{ "stand" is a ... }} \\
\hline "stand" on ... & $\underline{25}$ & 0.49 & & & \\
\hline "stand ${ }^{-}$to ... & $\underline{22}$ & 0.43 & \multirow{2}{*}{ workplace } & & 0.49 \\
\hline$\ldots$ with "stand" & $\underline{19}$ & 0.37 & & $\underline{8}$ & 12.95 \\
\hline "stand" by ... & $\underline{18}$ & 0.35 & \multirow{2}{*}{\multicolumn{3}{|c|}{ possessors of "stand" }} \\
\hline "stand" within ... & $\underline{14}$ & 0.28 & & & 0.73 \\
\hline "stand" from ... & $\underline{12}$ & 0.24 & \multirow{3}{*}{$\begin{array}{l}\text { exhibitor } \\
\text { the Exhibitor's stand } \\
\text { company }\end{array}$} & \multirow{3}{*}{$\begin{array}{l}\underline{25} \\
\underline{7}\end{array}$} & \multirow[t]{2}{*}{10.83} \\
\hline$\ldots$ into "stand" & $\underline{12}$ & 0.24 & & & \\
\hline$\ldots$ if "stand" & $\underline{12}$ & 0.24 & & & 10.10 \\
\hline ... above "stand" & $\underline{12}$ & 0.24 & & & \\
\hline$\ldots$ around "stand" & $\underline{10}$ & 0.20 & \multicolumn{3}{|c|}{ verbs with particle "up" and "stand" as object } \\
\hline ... behind "stand" & $\underline{10}$ & 0.20 & & & 0.22 \\
\hline$\ldots$ by "stand" & $\underline{9}$ & 0.18 & set & & 11.99 \\
\hline
\end{tabular}

Apresentamos, a seguir, as informações dos corpora de estudo em italiano bem como os colocados para o termo fiera como pode ser observado nas tabelas abaixo: 
Tabela 11: Informações sobre os corpora de estudo em italiano

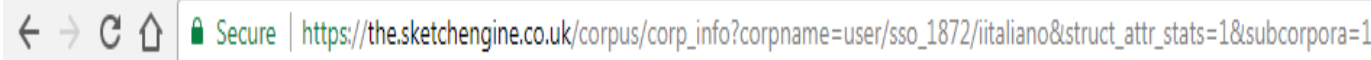

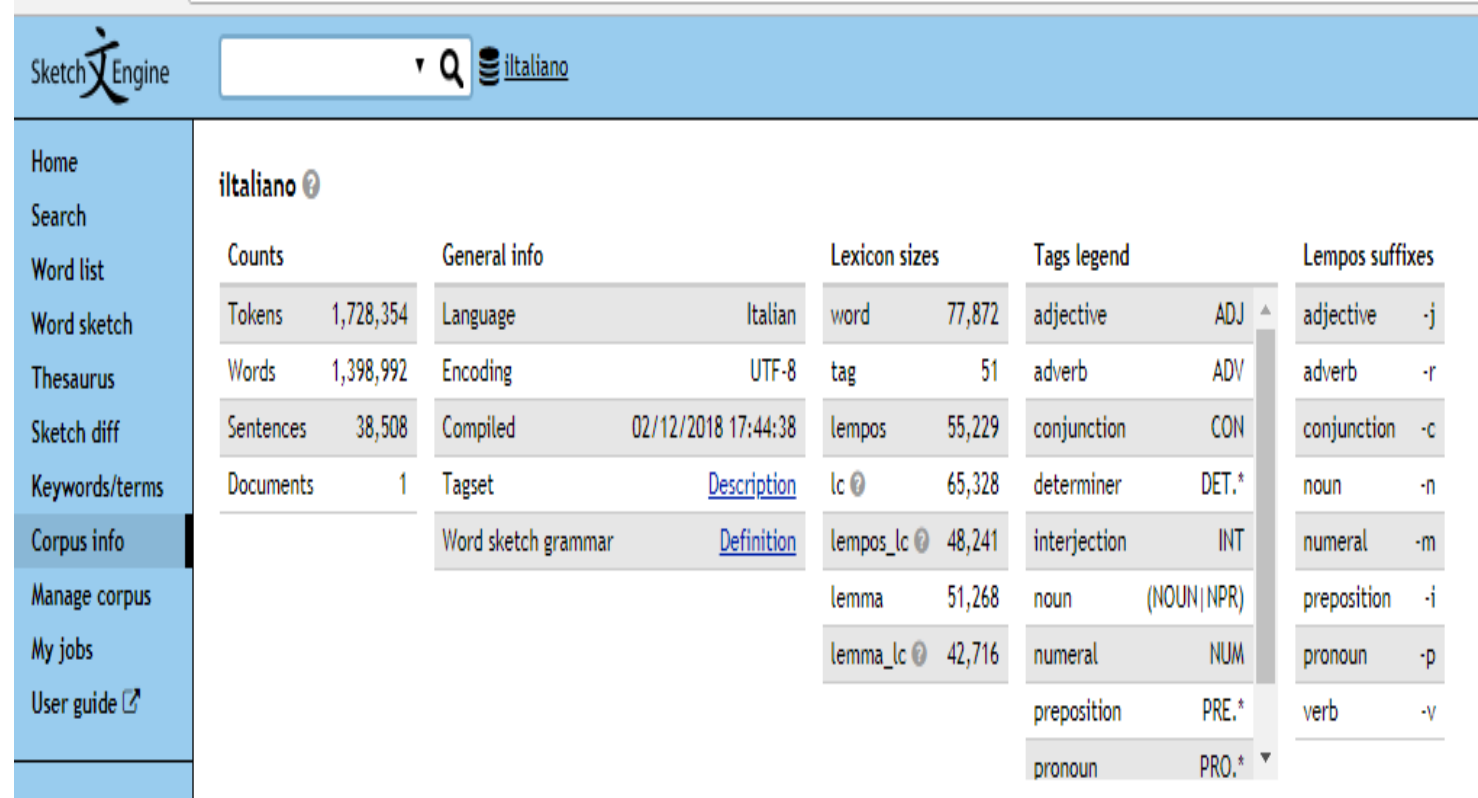

Structures and attributes

$\begin{array}{ll}\operatorname{doc} 1 & \forall \\ \text { archive_file } 112 \quad \forall\end{array}$ 
Tabela 12: Word Sketch - Colocados para o termo fiera

Secure $\mid$ https://the.sketchengine.co.uk/corpus/wsketch?corpname=user\%2Fsso_1872\%2Fiitaliano\&lreload=\&lemma=fiera\&lpos=-n\&/minfreq=auto\&lminscore=0.0

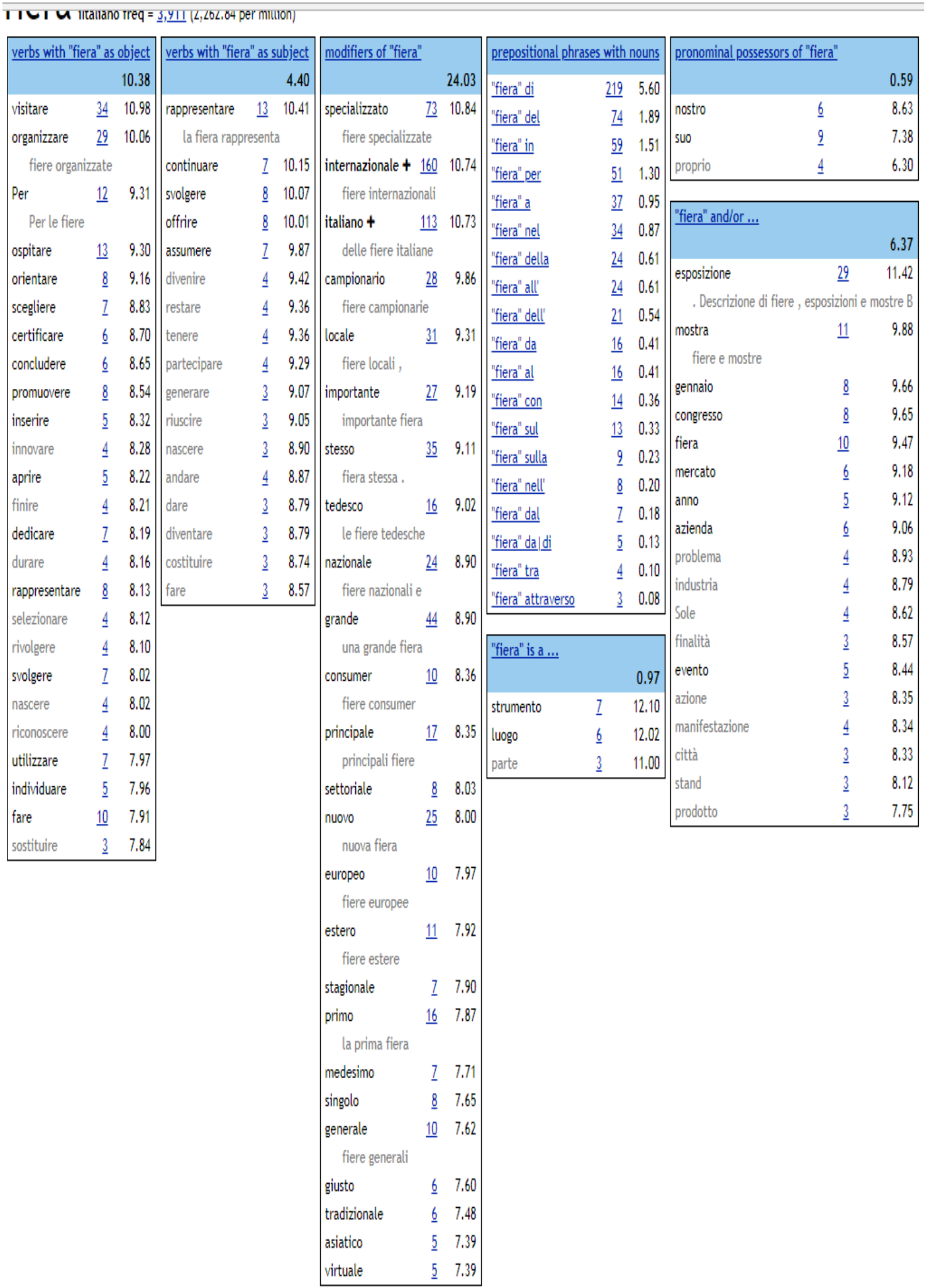


Do mesmo modo, apresentamos as informações dos corpora de estudo em francês e, ao invés de mostrarmos os colocados de um dos termos-chave do dicionário em francês, apresentamos, a seguir, uma outra função da ferramenta Sketch Engine que traz uma lista de termos formados por uma só palavra e uma lista de termos formados por duas ou mais palavras, como pode ser observado a seguir:

Tabela 13: Informações sobre os corpora de estudo em francês

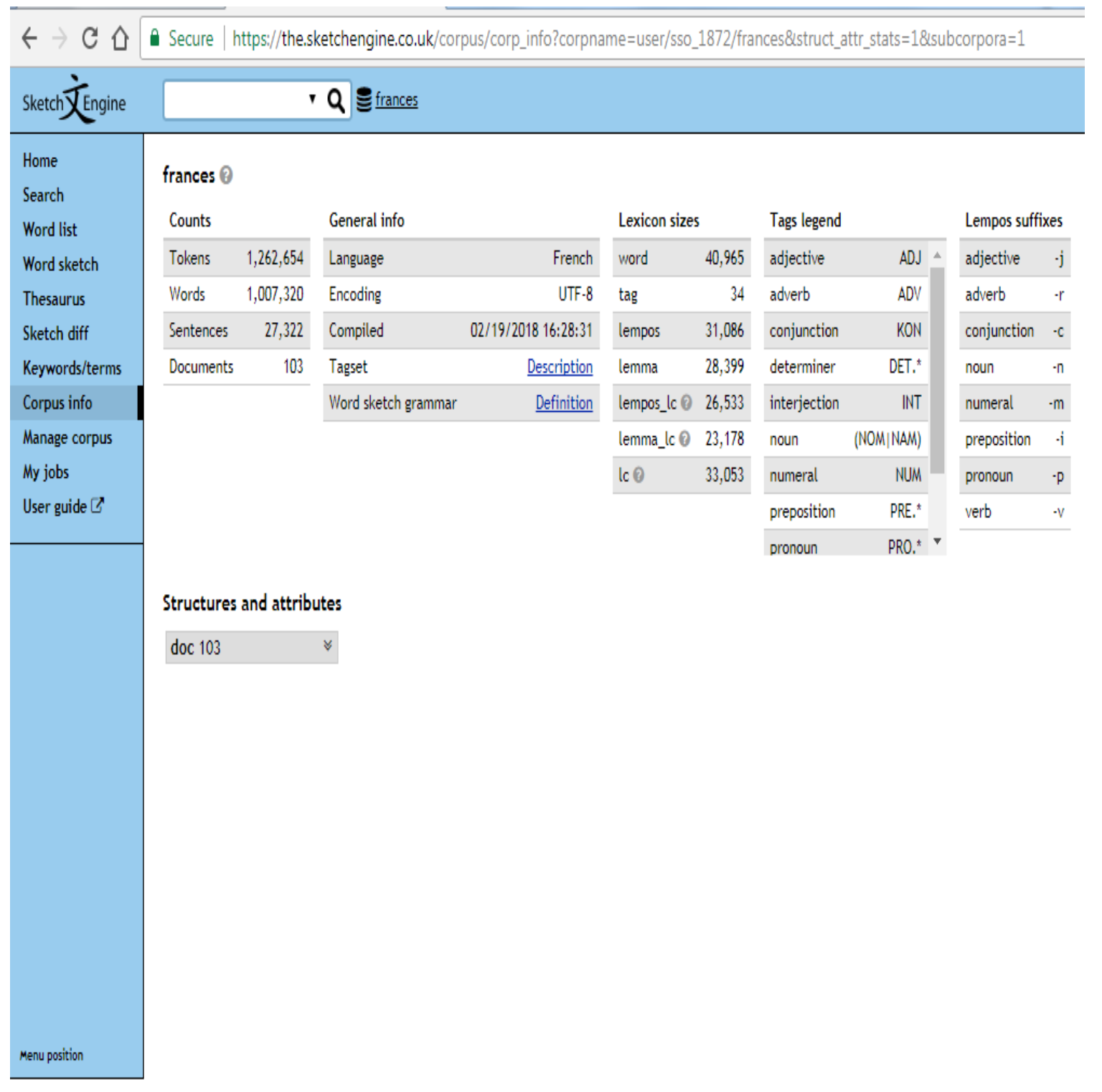


Tabela 14: Sketch Engine - lista de termos simples e complexos em francês I

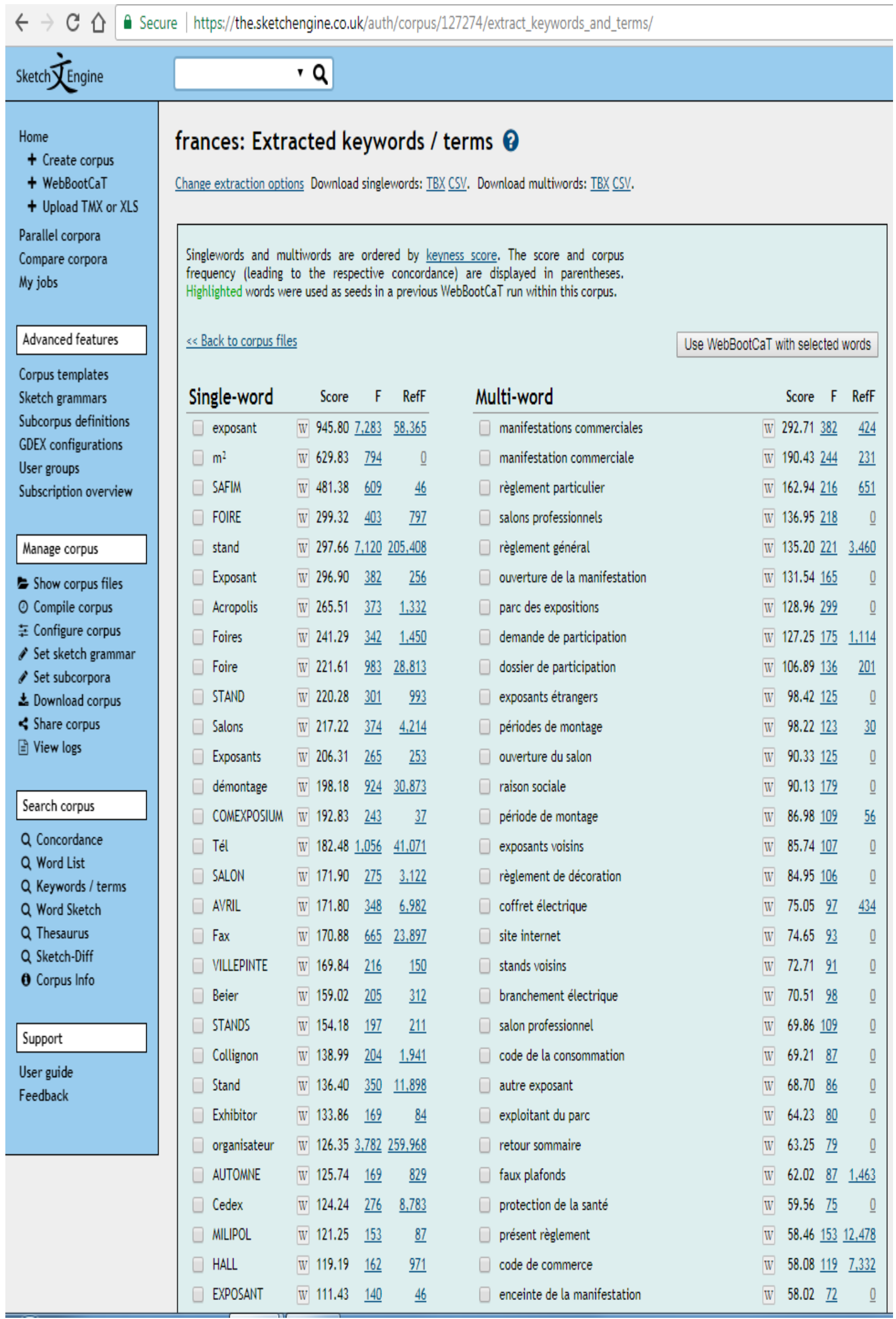


Tabela 15: Sketch Engine - lista de termos simples e complexos em francês II

\begin{tabular}{|c|c|c|c|c|c|c|c|c|}
\hline$=\cdot \cdots$ & $\ddot{4}$ & 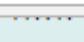 & $\approx$ & - & (n) & $\ddot{*}$ & $\cdots+$ & $\ldots$ \\
\hline$\square$ EXPOSANT & WV & 111.43 & $\underline{140}$ & $\underline{46}$ & $\square$ enceinte de la manifestation & W & $58.02 \underline{72}$ & $\underline{0}$ \\
\hline$\square$ badge & WV & 111.40 & $\underline{571}$ & $\underline{35,117}$ & $\square$ autres exposants & W & $55.08 \underline{71}$ & $\underline{0}$ \\
\hline$\square$ élingue & IV & 111.40 & $\underline{166}$ & $\underline{2,165}$ & $\square$ appareils de cuisson & W & $54.09 \underline{71}$ & $\underline{672}$ \\
\hline$\square$ Esplanade & WV & 104.42 & $\underline{200}$ & $\underline{6,026}$ & $\square$ état initial & W & $53.51 \underline{94}$ & $\underline{4,697}$ \\
\hline$\square$ MAl & IV & 103.15 & $\underline{268}$ & $\underline{12,217}$ & $\square$ surface nette & W & $53.37 \quad \underline{67}$ & $\underline{0}$ \\
\hline$\square$ Moquette & IV & 102.45 & $\underline{136}$ & $\underline{699}$ & $\square$ prestations techniques & $\mathbb{W}$ & $52.89 \underline{71}$ & $\underline{945}$ \\
\hline$\square$ ignifugation & WV & 98.97 & $\underline{127}$ & $\underline{302}$ & $\square$ visiteurs étrangers & W & $52.75 \underline{83}$ & $\underline{0}$ \\
\hline$\square$ cloison & IV & 98.47 & $\underline{568}$ & $\underline{40,957}$ & $\square$ cloison de séparation & $\mathbb{W}$ & $52.69 \quad 67$ & $\underline{301}$ \\
\hline$\square$ EXPOSANTS & WV & 95.03 & $\underline{120}$ & $\underline{121}$ & $\square$ admission temporaire & W & $51.91 \quad \underline{69}$ & $\underline{0}$ \\
\hline$\square$ INTERMAT & WV & 94.59 & $\underline{119}$ & $\underline{79}$ & $\square$ visiteurs français & $\mathbb{W}$ & $51.73 \quad \underline{67}$ & $\underline{0}$ \\
\hline$\square$ COMMANDE & WV & 92.92 & $\underline{140}$ & $\underline{2,335}$ & $\square$ commande de stand & W & $51.69 \quad \underline{64}$ & $\underline{0}$ \\
\hline$\square$ ASSURANCES & W & 91.95 & $\underline{127}$ & $\underline{1,199}$ & $\square$ secteur des foires & $\mathbb{W}$ & $50.00 \quad \underline{62}$ & $\underline{0}$ \\
\hline$\square \hat{\imath}$ & WV & 87.02 & $\underline{119}$ & $\underline{1,082}$ & $\square$ règlement général des manifestations & W & $49.31 \quad \underline{61}$ & $\underline{0}$ \\
\hline$\square$ Chanot & WV & 85.74 & $\underline{117}$ & $\underline{1,057}$ & $\square$ directeur de stand & W & $48.52 \quad \underline{60}$ & 1 \\
\hline$\square$ EUREXPO & W & 85.12 & $\underline{107}$ & $\underline{83}$ & $\square$ aménagement de stand & $\mathbb{W}$ & $48.42 \quad \underline{60}$ & $\underline{23}$ \\
\hline$\square$ EXPOSITIONS & W & 84.66 & $\underline{109}$ & $\underline{360}$ & $\square$ communication évènementielle & W & $48.01 \underline{61}$ & $\underline{313}$ \\
\hline$\square$ Organisateur & W & 83.35 & $\underline{124}$ & $\underline{2,177}$ & $\square$ cloisons de séparation & W & $47.80 \quad \underline{60}$ & $\underline{181}$ \\
\hline$\square$ foire & WV & 82.57 & $\underline{1,047}$ & $\underline{103,632}$ & $\square$ règlement général des manifestations commerciales & W & $47.73 \quad \underline{59}$ & $\underline{0}$ \\
\hline$\square$ Démontage & WV & 82.17 & $\underline{107}$ & $\underline{498}$ & $\square$ opérations de montage & W & $47.06 \quad \underline{60}$ & $\underline{0}$ \\
\hline$\square$ NOVEMBRE & WV & 80.34 & $\underline{155}$ & $\underline{6,186}$ & $\square$ réservation de stand & $\mathbb{W}$ & $46.89 \quad \underline{58}$ & $\underline{19}$ \\
\hline$\square$ SOLUTRANS & WV & 78.94 & $\underline{99}$ & $\underline{67}$ & $\square$ aménagement des stands & W & $46.79 \quad \underline{58}$ & $\underline{35}$ \\
\hline$\square$ Salon & WV & 77.57 & $\underline{1,158}$ & $\underline{124,019}$ & $\square$ durée de la manifestation & W & $46.10 \quad \underline{57}$ & $\underline{0}$ \\
\hline$\square$ SOMMAIRE & W & 77.39 & $\underline{112}$ & $\underline{1,821}$ & $\square$ chaussures de sécurité & $\mathbb{W}$ & $45.94 \quad \underline{64}$ & $\underline{1,438}$ \\
\hline$\square$ VIPARIS & WV & 76.62 & $\underline{96}$ & $\underline{61}$ & $\square$ notice de sécurité & W & $45.64 \quad \underline{57}$ & 134 \\
\hline$\square$ branchement & IV & 73.50 & $\underline{387}$ & $\underline{36,438}$ & $\square$ nombre de visiteurs & W & $45.10 \underline{125}$ & $\underline{13,933}$ \\
\hline$\square$ any & W & 72.79 & $\underline{218}$ & $\underline{15,857}$ & $\square$ stands nus & W & $44.56 \quad \underline{55}$ & $\underline{0}$ \\
\hline$\square$ PARC & IV & 70.96 & $\underline{119}$ & $\underline{3,916}$ & $\square$ demande de réservation & W & $44.38 \quad \underline{61}$ & $\underline{1,275}$ \\
\hline$\square$ GUIDE & WV & 70.43 & $\underline{112}$ & $\underline{3,131}$ & $\square$ espace exposant & W & $43.77 \quad \underline{54}$ & $\underline{2}$ \\
\hline$\square$ FSCEF & WV & 68.89 & $\underline{86}$ & $\underline{37}$ & $\square$ lieu de la manifestation & W & $43.72 \underline{54}$ & $\underline{0}$ \\
\hline$\square$ Prof & IV & 68.82 & $\underline{203}$ & $\underline{15,459}$ & $\square$ prestations complémentaires & W & $43.69 \quad 64$ & $\underline{2,097}$ \\
\hline$\square$ Montage & W & 67.55 & $\underline{123}$ & $\underline{5,230}$ & $\square$ emplacement déterminé & W & $43.59 \quad \underline{54}$ & $\underline{49}$ \\
\hline$\square$ Villepinte & WV & 67.23 & $\underline{124}$ & $\underline{5,444}$ & $\square$ représentant fiscal & W & $42.95 \quad \underline{54}$ & $\underline{0}$ \\
\hline$\square$ inflammable & W & 65.53 & 178 & $\underline{13,352}$ & $\square$ surface du stand & W & $42.89 \quad \underline{53}$ & $\underline{0}$ \\
\hline$\square$ Sécurité & W & 65.13 & $\underline{529}$ & $\underline{62,357}$ & $\square$ installation des stands & W & $42.47 \quad \underline{53}$ & $\underline{143}$ \\
\hline$\square$ Expositions & W & 63.38 & $\underline{92}$ & $\underline{1,893}$ & $\square$ présentes conditions générales & W & $41.43 \quad \underline{75}$ & $\underline{0}$ \\
\hline$\square$ SIREN & WV & 62.41 & $\underline{88}$ & $\underline{1,520}$ & $\square$ allées de circulation & W & $41.02 \underline{51}$ & $\underline{112}$ \\
\hline$\square$ PARTICIPATION & WV & 61.95 & $\underline{85}$ & $\underline{1,177}$ & $\square$ retombées économiques & W & $40.82 \quad \underline{86}$ & $\underline{0}$ \\
\hline$\square$ Stands & WV & 61.42 & $\underline{84}$ & $\underline{1,138}$ & $\square$ entière responsabilité & Wv & $40.65 \quad \underline{82}$ & $\underline{0}$ \\
\hline$\square \mathrm{AU}$ & W & 60.71 & $\underline{594}$ & $\underline{77,433}$ & $\square$ société gestionnaire & W & $40.17 \quad \underline{52}$ & $\underline{578}$ \\
\hline$\square$ Porte & WV & 60.70 & $\underline{172}$ & $\underline{14,429}$ & $\square$ durée du salon & IV & $40.14 \quad \underline{52}$ & $\underline{592}$ \\
\hline$\square$ SÉCURITÉ & W & 60.11 & $\underline{90}$ & $\underline{2,318}$ & $\square$ biens des exposants & W & $39.81 \quad \underline{49}$ & $\underline{0}$ \\
\hline$\square \mathrm{HT}$ & IV & 58.18 & $\underline{382}$ & $\underline{48,261}$ & $\square$ réglementation des manifestations commerciales & IV & $39.81 \quad \underline{49}$ & $\underline{0}$ \\
\hline
\end{tabular}


Tabela 16: Sketch Engine - lista de termos simples e complexos em francês III

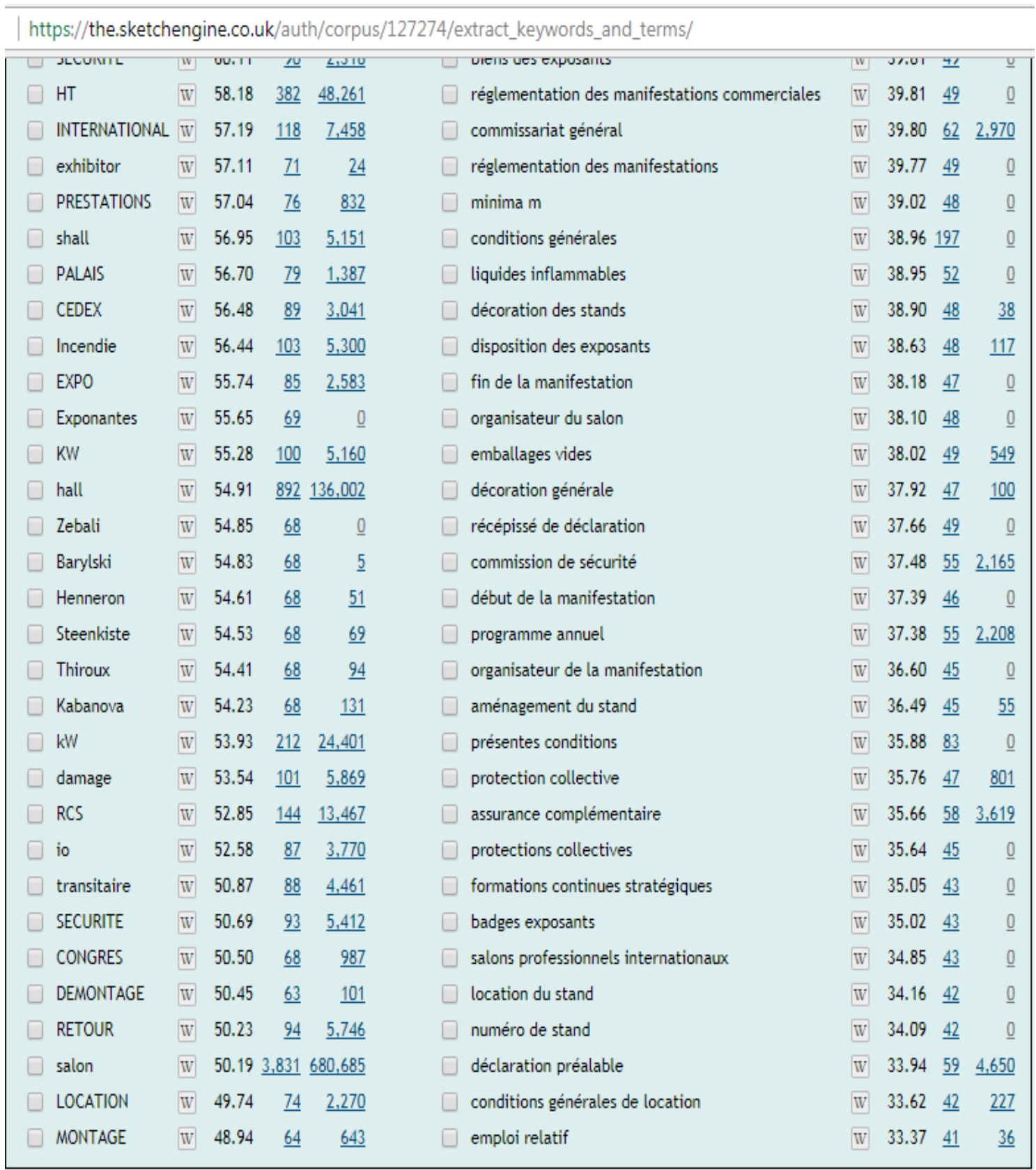

\section{Change extraction options}

\begin{tabular}{|c|c|c|}
\hline \multirow[t]{2}{*}{ Reference corpus } & French Web 2012 (frTenTen12) & \\
\hline & A list of compatible reference corpora. & \\
\hline \multirow[t]{2}{*}{ Corpus attribute } & lemma & \\
\hline & The corpus attribute to be used for keyword extraction. & \\
\hline \multirow[t]{2}{*}{ Simple maths param $\mathrm{N}$} & 1 & \\
\hline & $\begin{array}{l}\text { Increasing the value adds higher-frequency words to the } \\
\text { list of extracted keywords. More about simple maths. }\end{array}$ & \\
\hline Exclude stop words & ] & \\
\hline
\end{tabular}


Após uma atenta análise dessas listas, pudemos observar que os colocados que aparecem com o termo stand ou fiera já estavam presentes na macroestrura de nosso dicionário, o que confirma e valida os resultados obtidos anteriormente por meio da ferramenta WordSmith tools. O mesmo foi feito para os demais termos-chave do dicionário nas quatro línguas (feira, estande, expositor, pavilhão, exposição e visitante). O Sketch Engine traz ainda a ferramenta Concordance que também foi utilizada para a busca de contextos e dos ganchos terminológicos que indicam a equivalência entre os termos nas quatro línguas. Contudo, como pudemos observar, essa ferramenta possui algumas deficiências: ela traz apenas o termo de busca em destaque e seu contexto imediatamente ao redor; ela não traz os colocados destacados (em cores) e a quantidade de contexto que pode ser visualizada é limitada, cerca de 4 linhas para cima e 4 linhas para baixo. Assim, durante uma análise, tivemos que buscar o arquivo onde o termo estava originalmente para olhar o contexto como um todo, o que acaba sendo uma perda de termpo. Outra desvantagem é que a ferramenta somente permite que seja feito o upload de 1 milhão de palavras por vez. Assim, tivemos que trabalhar com cada língua separadamente, já que cada corpus de estudo possui mais de 1 milhão de palavras. Trabalhar com as quatros línguas simultaneamente seria o ideal, uma vez que existem certas situações que precisam ser checadas no momento em que elas ocorrem, caso contrário, elas podem acabar sendo perdidas ou esquecidas. Nesse sentido, a ferramenta Wordsmith Tools se mostrou mais produtiva, sendo a ferramenta Sketch Engine utilizada mais como um método de verificação e validação dos dados anteriormente coletados.

Vale mencionar que durante o estágio com a professora Silvia Bernardini na Universidade de Bolonha utilizamos também a ferramenta AntConc 3.4.3 (ANTHONY, 2014) para trabalharmos a questão das equivalências em inglês e em italiano, recorrendo a listas de palavras-chave, clusters e concordance. Para tanto, fizemos uma busca de corpora na WEB utilizando o BootCat (BARONI; BERNARDINI, 2004) para confrontar a terminologia fornecida por esses corpora novos por meio do AntConc e constatamos que as informações mais uma vez se repetiam, o que demonstrava que estávamos trabalhando na direção certa. Assim, foi possível realizar por meio do Concordance a análise das palavras que surgiam ao redor do termo de busca (análise contextual), identificando, desse modo, os ganchos terminológicos que trazem o conceito do termo estudado, o que caracteriza o método de análise baseado no corpus. O estudo das listas de palavras e das listas de palavras-chave também pôde ser realizado por intermédio dessa ferramenta caracterizando, portanto, a análise direcionada pelo corpus (cf. Tognini-Bonelli, 2001, p. 84-85). Assim, neste trabalho, utilizamos tanto a análise baseada no corpus como a análise direcionada pelo corpus, movendo de uma para outra 
ao longo da pesquisa, conforme a necessidade, o que é comum em um trabalho terminológico. Do mesmo modo como ocorreu com o Sketch Engine, pudemos constatar que os dados apresentados pelo AntConc eram muito parecidos com os dados coletados previamente por meio do WordSmith Tools. Entretanto, essa ferramenta também nos trouxe alguns termos novos como, por exemplo, venue manager, venue staff, venue services, additional stand, accessible stand, stand contractors, também considerados como possíveis candidatos a termo.

Uma vez coletados os termos, pertencentes à categoria gramatical dos substantivos, constituímos uma base de dados terminológica multilíngue. Esta base de dados terminológica é constituída de fichas terminológicas e foi criada, inicialmente, com o apoio da ferramenta computacional Microsoft Access $2010^{132}$ e, recentemente, com o apoio da ferramenta SDL MultiTerm $2017^{133}$, como será explicado mais adiante. Cada ficha terminológica ${ }^{134}$ é composta, de acordo com Aubert (1996, p. 73), dos campos descritos abaixo:

- Entrada: espaço para se colocar o termo em português

- Categoria gramatical do termo em português

- Definição do termo em português

- Outras designações: espaço para se registrar as variantes do termo em português

- Contextos: espaço para se registrar os contextos que atestam a validade do termo e de suas variantes em português

- Fontes: local reservado para se registrar as fontes das quais foram retirados os contextos do termo e de suas variantes em português

- Equivalentes: espaço para registrar os termos equivalentes em inglês, francês e italiano

- Outras designações: espaço para se registrar as variantes dos termos em inglês, francês e italiano

- Contextos: espaço para se registrar os contextos que atestam a validade dos equivalentes e de suas variantes em inglês, francês e italiano

- Fontes: local reservado para se registrar as fontes das quais foram retirados os contextos dos equivalentes e de suas variantes em inglês, francês e italiano.

Durante o estágio de pesquisa na Universidade de Bolonha, o professor Eros Zanchetta nos ajudou a converter um arquivo em WORD de 537 páginas, contendo as entradas em português, os equivalentes, os contextos e as fontes nas quatro línguas para o formato EXCEL. Para tanto, foi necessário padronizar as informações ao longo do arquivo para que os comandos do EXCEL fossem reconhecidos e a conversão realizada. Com o arquivo em formato EXCEL foi possível convertê-lo em um banco de dados terminológicos, por meio do software SDL

\footnotetext{
${ }^{132}$ Ferramenta da Microsoft Office utilizada para o armazenamento de dados (banco de dados).

133 O SDL MultiTerm é uma ferramenta de gerenciamento de terminologia, desenvolvida pela SDL Plc, para armazenar e gerenciar terminologia multilíngue. É um banco de dados terminológico utilizado na elaboração de glossários, dicionários, etc., que contém termos e informações relacionadas a termos, podendo armazenar um número ilimitado de entradas.

${ }^{134}$ Um exemplo de ficha terminológica nas quatro línguas pode ser consultado no Apêndice II.
} 
MultiTerm (SDL Plc, 2017). A professora Claudia Lecci nos mostrou as funções dessa ferramenta e nos ajudou na conversão do arquivo de EXCEL para o SDL MultiTerm, utilizado como base para a confecção do dicionário.

Posteriormente, fizemos a revisão de cada entrada do dicionário no MultiTerm e escolhemos 1 contexto para cada termo em português, 1 contexto para cada variante em português, 1 contexto para cada equivalente em cada uma das três línguas e 1 contexto para cada variante encontrada em inglês, francês e italiano. Decidimos colocar apenas um (1) contexto, pois somado ao fato de trabalharmos com quatro línguas, temos muitas variantes, e o verbete poderia ficar extenso em demasia. Para os termos que não apresentam variantes acrescentamos dois (ou mais) contextos. A versão final do dicionário em formato SDL MultiTerm (após a revisão dos termos e a escolha dos contextos em cada língua) está disponível no Apêndice IX.

Após a coleta dos termos representativos do setor das feiras e o preenchimento das fichas terminológicas, passamos à elaboração dos sistemas organizacionais das feiras em cada língua. Em seguida, procedemos à análise semântica dos termos, destacando os principais problemas encontrados na tradução, busca e estabelecimento das equivalências, como será apresentado no Capítulo 5.

Ao analisarmos os termos em seus contextos de uso, estabelecemos as equivalências de acordo com DUBUC (1985, 1992), como descrito no subitem 2.5. Desse modo, identificamos, por meio dos ganchos terminológicos, a equivalência, a correspondência e a ausência de equivalência e/ou correspondência entre os termos. Nesse sentido, utilizamos a Linguística de Corpus como instrumental para a coleta e sistematização dos termos e análise dos contextos.

A seguir, apresentamos o sistema organizacional das feiras em português, (os sistemas organizacionais nas outras línguas podem ser consultados no Apêndice III): 
Figura 5: Sistema organizacional das feiras em português

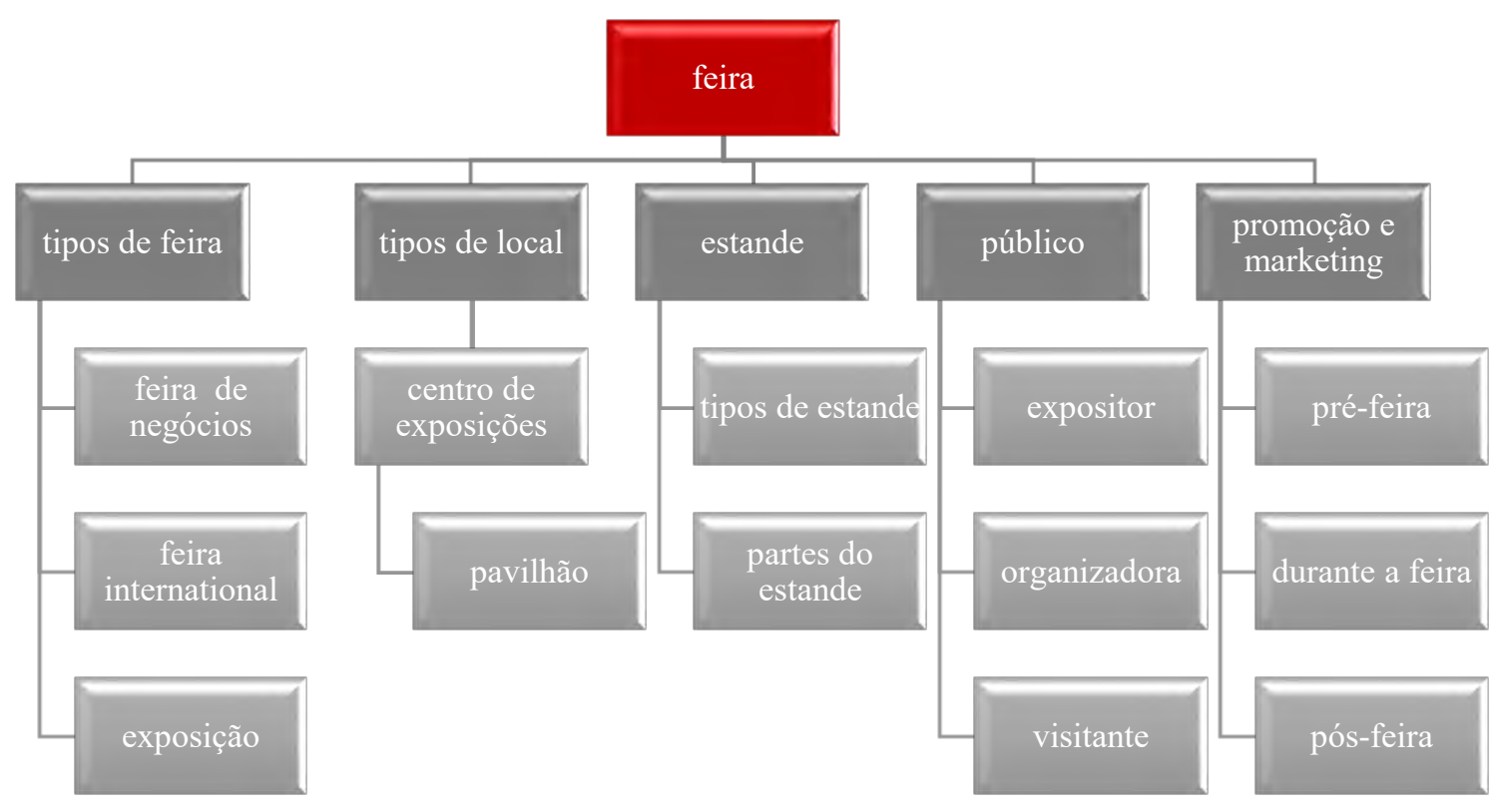

Fonte: Adaptado de (GODOY, 2014, p. 88)

Uma feira é um conhecimento especializado e tem uma dimensão pragmática organizacional que se sobrepõe. Assim, ao analisarmos como uma feira é organizada, podemos identificar a sua terminologia. O presente sistema organizacional das feiras de negócios foi elaborado com base nas decisões que o expositor deve tomar e nas ações que ele deve empreender ao participar de uma feira. Esse processo de preparação pode iniciar até 12 meses antes da data da feira, já que algumas organizadoras já abrem as inscrições para a próxima edição de uma feira, imediatamente após o término da edição atual. Assim, o expositor precisa decidir qual é o tipo de feira de que deseja participar, ou seja, feira geral, feira especializada, feira nacional, feira internacional, feira virtual [...]; o expositor precisa decidir também sobre o seu espaço de exposição, ou seja, como será o seu estande: estande básico, estande construído, estande coletivo, estande ilha, estande de esquina [...]; o tipo de público que a feira escolhida atrai também é muito importante: público geral, público especializado (atacadistas, agentes, fornecedores, distribuidores, compradores, etc) ou ambos; as ações de promoção e marketing também devem ser consideradas e dizem respeito às atividades que o expositor deve realizar no período pré-feira, ou seja, a pesquisa de mercado, o planejamento da feira, o preenchimento da ficha de inscrição, a leitura atenta do manual do expositor, a assinatura do contrato de participação na feira, o planejamento do estande, o treinamento da equipe [...]; no período durante a feira, o expositor deverá estar preparado e ter em mãos os materiais promocionais 
necessários, tais como: banners, displays, cartões de visita, amostras, brindes, gráficos, mostruários, catálogos de produtos, lista de preços [...] e, no período pós-feira, estão as atividades mais relevantes para o sucesso de sua participação em uma feira, a saber: o acompanhamento pós-feira, as visitas comerciais, o fechamento de contratos, os pedidos de compra, as condições de pagamento e de entrega, etc. O tipo de local onde será realizada a feira, ou seja, no pavilhão de um centro de exposições ou em um centro de convenções, por exemplo, está mais relacionado ao trabalho da organizadora da feira do que propriamente ao expositor, mas devido a sua relevância nesse processo de preparação e organização para uma feira, decidimos acrescentar esse item no nosso sistema organizacional das feiras de negócios.

Ao estabelecermos os sistemas organizacionais do domínio das feiras de negócios nas quatro línguas, verificamos que a relação hiperonímia/hiponímia está muito presente em nossa pesquisa e será abordada mais detalhamente no Capítulo 5 quando apresentamos as variantes terminológicas encontradas ao longo da pesquisa.

Uma vez coletados os termos, feita a organização dos mesmos em sistemas organizacionais e encontradas as equivalências, por meio da metodologia de análise dos ganchos terminológicos, procedemos à elaboração da macroestrutura e da microestrutura de nosso dicionário, cujos verbetes são constituídos da definição do termo em português, seguida dos contextos de uso, das fontes e dos equivalentes nas demais línguas. Assim, a macroestrutura adotada é a de um dicionário multilíngue português-inglês-francês-italiano, contendo lista de abreviaturas, sistemas organizacionais das feiras nas quatro línguas-alvo de nossa pesquisa e a lista de entradas disposta em ordem alfabética. A microestrutura do verbete preferencial contém a entrada em português e seus equivalentes em inglês, francês e italiano, conforme o modelo de verbete proposto por Babini (2001, p. 45-48), já utilizado em nossa pesquisa de mestrado (GODOY, 2014, p. 90-92) e adaptado de acordo com os objetivos da pesquisa atual:

Quadro 3: Modelo de microestrutura de verbete preferencial

\begin{tabular}{|c|l|}
\hline 1. Entrada & Termo em língua portuguesa \\
\hline $2 . \quad$ Categoria gramatical & $\begin{array}{l}\text { Categoria gramatical referente ao termo em } \\
\text { português }\end{array}$ \\
\hline 3. Definição & Definição do termo em língua portuguesa \\
\hline $4 . \quad$ Outras designações (variantes) & $\begin{array}{l}\text { Variante(s) do termo estudado em língua } \\
\text { portuguesa }\end{array}$ \\
\hline $5 . \quad$ Contexto1 & Texto em que ocorre o termo em português \\
\hline 6. Fonte 1 & A fonte do contexto do termo em português \\
\hline $7 . \quad$ Contexto 2 & $\begin{array}{l}\text { Texto em que ocorre a(s) variante(s) em } \\
\text { português }\end{array}$ \\
\hline
\end{tabular}




\begin{tabular}{|c|l|}
\hline 8. Fonte 2 & $\begin{array}{l}\text { A fonte do contexto da(s) variante(s) em } \\
\text { português }\end{array}$ \\
\hline 9. SN & (scope notes) notas \\
\hline 10. Equivalentes & $\begin{array}{l}\text { Equivalentes em inglês, francês e italiano } \\
\text { para o termo em português }\end{array}$ \\
\hline 11. Outras designações (variantes) & $\begin{array}{l}\text { Variantes dos termos em língua inglesa, } \\
\text { francesa e italiana }\end{array}$ \\
\hline 12. Contexto 1 & $\begin{array}{l}\text { Textos em que ocorrem os equivalentes em } \\
\text { inglês, francês e italiano }\end{array}$ \\
\hline 13. Fonte 1 & $\begin{array}{l}\text { As fontes dos contextos dos equivalentes em } \\
\text { inglês, francês e italiano }\end{array}$ \\
\hline 14. Contexto 2 & $\begin{array}{l}\text { Textos em que ocorrem as variantes em } \\
\text { inglês, francês e italiano }\end{array}$ \\
\hline 15. Fonte 2 & $\begin{array}{l}\text { As fontes dos contextos das variantes em } \\
\text { inglês, francês e italiano }\end{array}$ \\
\hline 16. SN & (scope notes) notas \\
\hline
\end{tabular}

Quadro 4: Modelo de microestrutura de verbete remissivo

\begin{tabular}{|l|l|}
\hline 1. Entrada & Termo + categoria gramatical + Ver (V.) \\
\hline 2. Contexto & Texto em que ocorre o termo \\
\hline 3. Fonte do Contexto & Fonte do contexto em que ocorre o termo \\
\hline 4. SN & (scope notes) notas \\
\hline
\end{tabular}

Portanto, a microestrutura dos verbetes dos termos preferenciais (não remissivos) é composta do termo-entrada em português, definição, categoria gramatical, outras designações em português (variantes), contextos de uso em português, fontes dos contextos em português e notas; equivalente em inglês, outras designações em inglês (variantes), contextos de uso em inglês, fontes dos contextos em inglês e notas; equivalente em francês, outras designações em francês (variantes), contextos de uso em francês, fontes dos contextos em francês e notas; equivalente em italiano, outras designações em italiano (variantes), contextos de uso em italiano, fontes dos contextos em italiano e notas.

O termo-entrada é escrito em negrito e com letra minúscula; a categoria gramatical é escrita em caracteres normais, sem negrito e de forma abreviada (ex: s.f.=substantivo feminino). Mais adiante, incluímos um exemplo (pág. 131).

A microestrutura do verbete remissivo apresenta-se com menor quantidade de informações, sendo composta de uma entrada, que se inicia com letra minúscula e em negrito, a categoria gramatical, a remissiva "V." (Ver) - que orienta o consulente sobre a entrada à qual 
deve dirigir-se para encontrar a informação de que precisa -, o contexto de uso, a fonte do contexto e notas. A remissiva é utilizada para ligar outras designações ao termo principal.

No campo OUTDES (outras designações) do verbete preferencial o consulente encontrará as variantes (em português, em inglês, em francês e em italiano) para o termo pesquisado. Entretanto, considerando que o nosso dicionário é unidirecional, partindo do português para as demais línguas, apenas termos do português são entradas de verbetes remissivos. Um exemplo de verbete preferencial e remissivo poderá ser visualizado no subitem 4.2 mais adiante.

No que diz respeito à validação dos termos de nosso dicionário, além de minha própria experiência na área (trabalhei três anos em uma consultoria americana com sede em São Paulo especializada em comércio exterior e, principalmente, em feiras de negócios internacionais; sou Especialista em Negócios Internacionais pela Universidade Presbiteriana Mackenzie, onde realizei um estudo aprofundado sobre a importância da participação de empresas brasileiras em feiras no exterior e pesquisadora dessa terminologia desde 2012 quando iniciei o mestrado), profissionais especializados em feiras de negócios no Brasil e no exterior também foram consultados.

Conforme descrito no relatório científico de estágio de pesquisa no exterior, realizamos um extenso trabalho de pesquisa de campo. Foram realizadas, no total, 63 entrevistas com as organizadoras de feiras, sendo 18 no Reino Unido, 24 na França e 21 na ltália. A metodologia utilizada durante as entrevistas nos três países está descrita a seguir: listas com os termos-chave do dicionário foram preparadas e apresentadas às organizadoras de feiras que sublinharam ou circularam os termos que estavam corretos e que eram realmente utilizados no pré, durante e pós-feira; riscaram os termos que elas desconheciam, que não eram utilizados por elas na prática, ou que estavam incorretos; sugeriram equivalentes mais apropriados (ao sentido descrito nas listas), bem como termos novos, que não estavam nas listas, o que foi uma grande contribuição para a pesquisa.

As entrevistas foram posteriormente reescritas em formato EXCEL com o objetivo de facilitar as análises, uma vez que nos permite ter uma visão mais geral e completa de cada termo utilizado por cada organizador entrevistado. Vale destacar que as entrevistas não são idênticas. A cada entrevista realizada, informações das entrevistas anteriores eram acrescentadas. Assim, preparamos listas diferentes: uma versão completa (com todos os termos da macroestrutura) e uma versão reduzida (com os termos que tínhamos mais dúvidas), já que alguns organizadores não queriam (ou não podiam) responder a uma lista longa. Desse modo, tivemos a ideia de reduzir a lista de termos para duas páginas apenas, com o propósito de conseguir a colaboração 
do maior número possível de organizadores. Assim, após realizadas as entrevistas, a macroestrutura do dicionário se modificou: termos foram subtraídos, outros acrescentados e a maioria validados nas três línguas (inglês, francês e italiano). Essas entrevistas foram fundamentais para conferir ao trabalho confiabilidade, o que geralmente se espera de uma pesquisa multilíngue terminológica rigorosa.

As informações coletadas durante as entrevistas foram analisadas cuidadosamente e a escolha dos equivalentes foi baseada tanto nas informações retiradas dos corpora de estudo como nas informações recolhidas durante as entrevistas com as organizadoras. Desse modo, combinamos duas perspectivas de análise neste trabalho: a perspectiva baseada nos corpora de estudo e a perspectiva baseada nos usuários (especialistas da área), o que traz uma visão mais abrangente da terminologia utilizada nesse domínio. Essa metodologia sócio-corpus-linguística nos traz ainda input para analisar a consistência do corpus para o estudo de uma língua de especialidade: A terminologia presente nos corpora de estudo, nos manuais do expositor, é realmente a terminologia utilizada pelos especialistas na prática? Essa reflexão poderá ser desenvolvida em um trabalho futuro e poderá trazer contribuições para os Estudos da Tradução e Terminológicos.

O objetivo deste trabalho é, portanto, apresentar os termos que são realmente utilizados pelas organizadoras de feiras. Esta é a razão pelo qual fizemos uma ampla pesquisa de campo e visitamos várias feiras na Inglaterra, França e Itália. A seguir, trazemos um quadro-resumo da metodologia utilizada na pesquisa:

Quadro 5: quadro-resumo da metodologia utilizada na pesquisa

\begin{tabular}{|l|l|}
\hline Tipologia de termos & Termos simples, complexos e fraseologismos \\
\hline $\begin{array}{l}\text { Termo versus léxico } \\
\text { geral }\end{array}$ & $\begin{array}{l}\text { O termo representa um conceito dentro da área de feiras de negócios } \\
\text { como, por exemplo, "estande"; "amostra", por sua vez, uma unidade } \\
\text { do léxico geral frequentemente utilizada no setor feirístico }\end{array}$ \\
\hline $\begin{array}{l}\text { Critério de seleção } \\
\text { de termos }\end{array}$ & $\begin{array}{l}\text { Frequência, representatividade e números de textos nos quais } \\
\text { aparecem }\end{array}$ \\
\hline $\begin{array}{l}\text { Método de coleta de } \\
\text { termos }\end{array}$ & $\begin{array}{l}\text { Listas de palavras-chave elaboradas por meio das ferramentas } \\
\text { WordSmith Tools, Sketch Engine e } \text { AntConc }\end{array}$ \\
\hline $\begin{array}{l}\text { Consistência } \\
\text { terminológica }\end{array}$ & $\begin{array}{l}\text { Recomendação de termos mais comumente utilizados na prática pelas } \\
\text { organizadoras de feiras no interior de cada língua com o objetivo de } \\
\text { diminuir a inconsistência terminológica na área }\end{array}$ \\
\hline Mapa conceitual & Elaboração dos sistemas organizacionais das feiras \\
\hline $\begin{array}{l}\text { Fichas } \\
\text { terminológicas }\end{array}$ & $\begin{array}{l}\text { Elaboração de fichas com o auxílio das ferramentas Access, Word, } \\
\text { Excel e SDL MultiTerm }\end{array}$ \\
\hline $\begin{array}{l}\text { Apresentação do } \\
\text { dicionário }\end{array}$ & $\begin{array}{l}\text { Verbete contendo o termo-entrada em português, categoria gramatical, } \\
\text { definição, variantes, contextos e fontes e os equivalentes nas três } \\
\text { línguas seguidos de variantes, contextos e fontes }\end{array}$ \\
\hline O tipo de corpus & Preferencialmente guias e manuais do expositor coletados via WEB \\
\hline
\end{tabular}




\begin{tabular}{|l|l|}
\hline $\begin{array}{l}\text { Critério para } \\
\text { estabelecimento de } \\
\text { equivalências }\end{array}$ & Metodologia dos ganchos terminológicos de Dubuc \\
\hline $\begin{array}{l}\text { Critério para } \\
\text { validação dos termos }\end{array}$ & $\begin{array}{l}\text { Entrevistas com especialistas da área, organizadoras de feiras no Brasil } \\
\text { e no exterior }\end{array}$ \\
\hline
\end{tabular}

Fonte: elaborada pela autora

A seguir, apresentamos informações sobre o dicionário, os grupos temáticos, a lista de abreviaturas e a lista de verbetes. 


\section{SOBRE O DICIONÁRIO}

Apresentamos, neste Capítulo, o Dicionário Multilíngue (português-inglês-francêsitaliano) de Termos do Setor Feirístico. Após a realização dos estágios de pesquisa no exterior, os termos preferenciais (a princípio $211 \mathrm{em}$ cada língua) e as variantes (a princípio $40 \mathrm{em}$ português, $64 \mathrm{em}$ inglês, $93 \mathrm{em}$ francês e $90 \mathrm{em}$ italiano) foram modificados. O dicionário apresenta hoje 311 termos em cada língua (dos quais 161 são termos preferenciais, 79 são termos remissivos e 71 são termos pertencentes aos grupos temáticos) perfazendo um total de 1244 termos. Em relação às variantes, encontramos 206 variantes em português, 307 variantes em inglês, 289 variantes em francês e 335 variantes em italiano, perfazendo um total de 1137 variantes. Desse modo, trabalhamos para este dicionário com um total de 2381 termos. As variantes em inglês, francês e italiano são contabilizadas como remissivas, mas, por se tratar de uma obra unidirecional, do português para as demais línguas, somente as variantes do português são entradas de verbetes remissivos.

Conforme mencionado no Capítulo 3, a proposta do dicionário é apresentar como entrada o termo mais comumente utilizado em português e seus equivalentes mais habitualmente utilizados em inglês, em francês e em italiano, ou seja, os termos que as organizadoras de feiras utilizam na prática, listando os demais como variantes. Este trabalho poderá facilitar o processo de preparação, participação e pós-feira de empresas brasileiras, inglesas, francesas e italianas, considerando o significante comércio bilateral entre esses países como foi apresentado no Capítulo 1. Assim, um dos objetivos do dicionário é auxiliar aqueles que já participam (ou pretendem participar) de feiras de negócios, a saber: organizadoras, promotoras, montadoras, expositores, staff, intérpretes, tradutores, visitantes, entre outros; contribuir para a melhoria da comunicação na área e a otimização do tempo de preparação para uma feira, tornando essa atividade mais acessível para todos os tipos de público, especialistas e não-especialistas. Como se sabe, uma falha na comunicação pode trazer muitos prejuízos. Desse modo, propomos descomplicar o trabalho dos indivíduos envolvidos nessa ou em áreas afins para que possam usufruir de uma experiência mais lucrativa e bem-sucedida nesse universo de infinitas oportunidades de negócios.

Considerando as críticas dos autores Holmes, Camacho, Bowker e Pearson em relação à microestrutura de obras terminográficas (cf. Capítulo 2, págs. 73-74), pretendemos contribuir com a pesquisa terminológica e também com o trabalho dos tradutores e intérpretes, produzindo um dicionário terminológico multilíngue de qualidade, com exemplos de ocorrência dos termos 
e definições dos termos-entrada em português. Além disso, as páginas do nosso dicionário não são dispostas em colunas verticais com uma coluna para cada língua, como mencionado por Pearson. Elaboramos uma forma de apresentação funcional e de fácil leitura para otimizar a pesquisa do usuário.

Nesse sentido, como mencionamos no Capítulo 3, nas páginas 121-123, a macroestrutura do dicionário é constituída de lista de abreviaturas, sistemas organizacionais das feiras nas quatro línguas e lista de entradas disposta em ordem alfabética. A microestrutura, por sua vez, apresenta o termo em português, seguido de informações gramaticais, definição, variantes, contextos de uso e fontes e dos respectivos equivalentes em inglês, francês e italiano, variantes, exemplos autênticos de uso e fontes de onde foram retirados.

O tipo de definição utilizado para o termo em português é a definição aristotélica (gênero/espécie), a qual permite que o termo seja descrito de forma mais clara e atende, portanto, aos objetivos da presente pesquisa. Assim, ao definirmos o termo "estande ponta de ilha", por exemplo, a definição traz o conceito contido no termo "estande", ou seja, "espaço no interior do pavilhão de um centro de exposições utilizado pelo expositor para a exposição de produtos e oferta de serviços durante uma feira de negócios", e acrescentará a(s) característica(s) específica(s) que o difere de outros tipos de estandes, ou seja, "o fato de possuir três lados abertos e dar acesso a três corredores do pavilhão simultaneamente". Nesse exemplo, o termo "estande" é o hiperônimo e o termo "estande ponta de ilha" é o seu hipônimo. Ambos os termos em português (hiperônimo e hipônimo) têm um verbete próprio dentro da macroestrutura de nosso dicionário. Discorreremos sobre essas relações semânticas em mais detalhes no Capítulo 5.

Como dissemos no Capítulo 2, na página 85 , a identificação do conceito por meio da análise contextual aparece como método fundamental da pesquisa terminológica. E é exatamente assim que procedemos na presente pesquisa, isto é, identificamos o conceito de um termo por meio da análise do contexto onde este termo é encontrado e fizemos o levantamento dos ganchos terminológicos que nos permitem identificar o conceito vinculado por esse termo e, a partir daí, buscamos os equivalentes nas outras línguas (cf. será exemplificado no Capítulo $5)$.

Em relação à organização do dicionário, além dos termos pertencentes ao setor feirístico, apresentamos também termos provenientes de áreas correlatas (comércio exterior, marketing, vendas, etc.), termos do léxico geral e fraseologismos.

O termo "amostra", por exemplo, é um termo que aparece em várias áreas do conhecimento. Contudo, foi incluído no dicionário, assim como os termos "brinde", "vitrine" e 
“display”, pois são termos muito frequentes e relevantes no setor feirístico, uma vez que não existe um único estande sem amostras ou sem brindes, já que todos os expositores distribuem "amostras" de seus produtos aos visitantes durante uma feira, entregam-lhes algum tipo de "brinde" (caneta, sacola, marcador de página, etc.) e utilizam "vitrines" e "displays" para colocar os produtos em evidência no interior do estande. A pesquisa, portanto, além de um objetivo teórico possui também um objetivo prático, ou seja, do ponto de vista teórico, apresenta a descrição dos termos do setor feirístico e sua terminologia e, do ponto de vista prático, inclui de maneira simples termos que são relevantes para os usuários do dicionário, embora não pertençam a essa área, como é o caso dos termos mencionados acima e de vários outros (praça de alimentação, posto médico, bilheteria, estacionamento, etc.). Estes termos fazem parte da planta do pavilhão e foram acrescentados na macroestrura do dicionário, bem como termos da área de marketing (pesquisa de marketing, mix de marketing, estratégia de marketing, etc.) e da área de vendas (catálogo de produtos, condições de entrega, condições de pagamento, frete, lista de preços, etc.) e apresentam uma configuração um pouco diferente. Assim, são apresentados no verbete apenas a entrada em português e os equivalentes nas três línguas, sem definição ou contextos de uso, exatamente para fazer a diferenciação dos termos pertencentes à área feirística. Os termos provenientes do léxico geral e de outras áreas e que também são utilizados frequentemente no setor feirístico foram agrupados em grupos temáticos como pode ser observado a seguir:

\section{GRUPO 1: Profissionais de feiras de negócios}

agente

atacadista

comprador

concorrente

distribuidor

fabricante

fornecedor

imprensa

intérprete

patrocinador

recepcionista

representante de vendas

tomadores de decisão

tradutor

\section{GRUPO 2: Público visitante da feira}

cliente

cliente atual

cliente novo 
cliente potencial

consumidor

consumidor final

GRUPO 3: Materiais promocionais utilizados no estande

banner

cartão de visita

cartaz

folheto

mostruário

GRUPO 4: Identificação e acesso à feira

crachá

credencial

ingresso

GRUPO 5: Componentes do estande

depósito

equipamentos de áudio-visual

locação de linha telefônica

locação de mobiliário

piso elevado

ponto de água

rampa de acesso

sala de reuniões

serviço de buffet

serviço de telecomunicações

totem

treliça

vitrine

GRUPO 6: Planta do pavilhão

bilheteria

coluna

estacionamento

hall de entrada

portão de entrada

posto médico

praça de alimentação

saída de emergência

GRUPO 7: Termos relacionados à area de marketing

congresso

estratégia de marketing

mala direta

mix de marketing

pesquisa de mercado

plano de marketing

press kit

press release 
seminário

GRUPO 8 : Termos relacionados à area de vendas

catálogo de produtos

condições de entrega

condições de pagamento

data de entrega

frete

lista de preços

pedido de compra

promoção de vendas

transporte

venda direta

\section{GRUPO 9: Outros termos relevantes}

ficha de inscrição

fluxo de visitantes

patrocínio

registro de contatos

O produto da presente pesquisa é, portanto, um dicionário terminológico de uma área de especialidade, as feiras de negócios, cujo objetivo é apresentar os termos essenciais do setor feirístico em quatro línguas. Essa obra terminográfica tem como público-alvo, estudantes de comércio exterior e relações internacionais, profissionais do setor feirístico e, principalmente, tradutores e intérpretes que traduzem e produzem textos nas línguas de nosso estudo. A seguir, apresentamos a lista de abreviaturas e a lista de verbetes de nosso dicionário multilíngue de termos do setor feirístico.

\subsection{Lista de Abreviaturas}

Ao redigirmos a microestrutura de nosso dicionário, nos utilizamos de algumas abreviaturas, listadas a seguir:

- cat. gram.: categoria gramatical

- $\quad$ s.: substantivo

- f.: feminino

- m.: masculino

- s.f.: substantivo feminino

- s.m.: substantivo masculino

- s. prep.: sintagma preposicional

- fraseol.: fraseologismo

- neol.: neologismo

- V.: Ver

- ant.: antônimo 
- OUTDES: outras designações (variantes)

- SN: scope notes

- Def.: definição

4.2 Lista de Verbetes

A lista completa em ordem alfabética dos verbetes preferenciais e remissivos, elaborados com o auxílio da ferramenta SDL MultiTerm, e que compõem a macroestrutura de nosso Dicionário Multilíngue de Termos do Setor Feirístico, na direção unidirecional do português para o inglês, o francês e o italiano, pode ser consultada no Apêndice VIII do presente trabalho. A seguir, apresentamos 10 exemplos de verbetes (preferenciais e remissivos) de nosso dicionário:

\section{estande $_{\text {s.m }}$ espaço de exposição equipado para exibir produtos e oferecer}

serviços em feiras. $O$ estande é como a vitrine do produto ou serviço a ser divulgado e negociado, estrutura em que se materializa a participação de empresas numa feira e, como tal, não devem ser poupados esforços na sua elaboração. É a imagem que tem por objetivo chamar a atenção do público-alvo (MOFE).

stand (booth) $\mathrm{n}$. The trade fair stand is the companies calling card, and as such, should be of a standard that is in keeping with the products exhibited and the significance of the company both in size and design and appearance. A presentation of the exhibits which takes into account the needs of the visitor must be a priority. The trade fair stand should be attractive to the eye and pleasant to the ear, and can also appeal to the visitor's emotions (SPTF). A booth is more like a billboard than a datasheet. Attendees won't stand in your booth to read its signage, and in any case it is the job of booth staff to communicate key messages and product features. The booth should be an environment for selling (TSWP). SN: stand is the European term for booth.

stand (stand d'exposition; kiosque) n.m. Stand: construction provisoire édifiée par les participants à une foire, à un salon ou à une exposition pour y accueillir des visiteurs et présenter des produits (AE). Le stand d'exposition: C'est un stand composé de différents modules évolutifs qui peuvent être assemblés et aménagés en fonction des besoins de l'exposant. Ces modules (cloisons, mobiliers etc.) sont généralement proposés par l'installateur général du salon mais également par certains concepteurs de stands (GPFGPS). L'exposant ne doit pas laisser son kiosque sans surveillance (MEE). SN : Le standiste est un professionnel qui conçoit et fabrique des stands d'exposition. Il est donc réalisateur, créateur et maître d'oeuvre.

stand (posteggio; stand fieristico) s.m. Per stand si intende lo spazio assegnato all'espositore per la presentazione dei propri prodotti o servizi (RMF). L'Espositore si impegna a esporre nel proprio posteggio, per tutta la durata della manifestazione, i prodotti di propria produzione appartenenti al repertorio merceologico di cui all'allegato $D$ del presente Regolamento Generale (MEWDP). Il vostro sito internet ne sarà l'elemento fondamentale. Se aumentano $i$ visitatori del vostro sito, aumentano anche le possibilità di 
trasformarne la quota che vi interessa in visitatori del vostro stand fieristico (PSUEDPSF).

estande aberto s. m. V. estande ilha. [...] numa feira de máquinas, apenas para público profissional, onde o expositor esteja fazendo o lançamento de um novo equipamento, com demonstração do seu funcionamento, certamente o melhor local não é aquele imediatamente após a entrada principal da feira. Uma posição mais para o meio é mais conveniente, neste caso. Já, se estiver fazendo alguma promoção e distribuindo brindes, numa feira de bens de consumo, um estande aberto, logo na entrada do pavilhão, pode funcionar melhor (MFES).

\section{estande coletivo s.m estande compartilhado entre duas ou mais} empresas expositoras com produtos similares ou afins. A CBL (Câmara Brasileira do Livro) permitirá estandes coletivos para associações. A área total reservada para estas entidades será considerada quando da definição da planto do evento e a escolha das áreas, cabendo à CBL e à organizadora a determinação do melhor local (MEBIL).

collective stand (joint stand; shared stand) $\mathrm{n}$. The advantage of the project

is the fact that in this case the contact area between companies participating with a collective stand and eventual client companies is wider. When a client arrives to the stand attracted by a certain company, the client could also become interested in the supply of the other firms (TTFL). Government agencies, associations or other institutions, such as the Chambers of Industry and Commerce, have teams of professionals experienced in trade fairs and exhibitions who organize joint participation for individual federal states or branches of industry or joint stands with many exhibitors under one roof. This form of participation is a useful way of gaining experience of trade fairs at minimum cost in terms of time and Money (SPTFTE). Sub-letting or shared stands: the exhibitor may only sub-let or share its stand with the prior written consent of the organiser, but will have to pay a fee if the co-exhibitor wishes to have a full catalogue entry. Company name only is free of charge (TCSI).

stand collectif (stand en commun) n.m. Plus économique et plus facile à organiser, ce stand est partagé entre plusieurs exposants. Il faut cependant rester prudent sur ce type de stand car l'entreprise n'est pas seule. En fonction des autres exposants, la visibilité de l'entreprise peut être diminuée. Si l'attention est monopolisée par un exposant, les autres participants ne tireront pas profit du stand collectif (PSPECROSCEE). Article 7: La cession de tout ou partie de stand ou d'emplacement est interdite. Toutefois, avec l'accord de l'Organisateur, plusieurs fabricants ressortissant d'une profession analogue pourront occuper un même stand en commun, sous réserve que chacun d'eux ait au préalable acquitté les droits de constitution de dossier (FboGE).

stand collettivo (stand condiviso) s.m. La partecipazione alla manifestazione fieristica con stand collettivo organizzato dalla Camera di Commercio è subordinata all'adesione e alla presenza di almeno dodici espositori della provincia di Avellino (PFCCA). Anche in occasione dell'edizione 
2017 GISI rinnova il patrocinio e il supporto a OMC e, per rispondere alle numerose richieste pervenute dagli associati, organizzerà uno stand condiviso. Si tratta di una soluzione molto apprezzata da coloro che desiderano partecipare a questo importante evento espositivo contenendo $i$ costi e avvalendosi del riconosciuto supporto "chiavi in mano" offerto da GISI (GAEVP).

\section{estande com mezanino s. prep. estande com área térrea igual ou} superior a $70 \mathrm{~m}^{2}$ e piso superior de cerca de $50 \%$ da área térrea. No projeto do estande com mezanino ou $2^{\circ}$ piso, deverá constar a memória de cálculo estrutural do segundo piso. A estrutura do mezanino ou $2^{\circ}$ piso deverá ser montada de acordo com as normas da Associação Brasileira de Normas Técnicas -ABNT (FM).

double decker stand (two-storey stand; 2 storey stand; double-storey

stand; double-deck stand; stand with two floors; multi-storey stand; mezzanine) $n$. The method statement for a double decker stand should include: Construction sequences, noting the starting point; Methods to ensure stability, including the use of temporary components; The detailed construction scheme that identifies the lifting, alignment and connection requirements; The preferred system to prevent falls from height, the safe means of access and any special platforms or equipment; The provision of suitable plant and equipment with which to construct the structure safely (ECRPMUEV). We have made arrangements for basic stand cleaning to be carried out at no charge to you in the evening before the show opens each day. This does not apply to the upper deck of a twostorey stand, if you require cleaning of the 2nd storey you need to order this direct with ExCeL London cleaning (SWCEEM). In the interests of the Exhibition as a whole we reserve the right to determine the position of any 2 storey structure within a stand. The area occupied by the structure must not be greater than 50\% of the total stand space. All 2 storey stands are classified as complex stands and charges will be made for structural approval (MTIESR). Please Note: Double-storey stands or stands higher than $4 m$ are not permitted unless explicit permission has been granted by the Informa Event Organiser (EGHEC). This guidance identifies the main elements of safe construction of a double-deck stand. It supports the requirements for complex structures set out in the Stand Plans section (ECRPMUEV). Stands with two floors are not permitted without the authorization from the show's Directors. It is necessary to first contact the Commercial Department that will inform the cost for contracting the complementary area (BEGM). The floor of the upper level of a multi-storey stand must be capable of withstanding a weight loading of $5 \mathrm{kn} / \mathrm{sqm}$ (ECRGEUV). In order to assemble the mezzanine it is necessary to: respect the rules of the setback informed by the promoter, present the structural calculations, the A.R.T. and to specify the maximum capacity in $\mathrm{Kg} / \mathrm{sqm}$ and quantity of people from the beginning of the stairs (first floor) (BEGM).

stand à étage (stand à l'étage; stand en surélévation; stand sur deux étages) n.m. Chaque stand ne peut avoir qu'un sel niveau en surélévation. Tous les stands à étage doivent faire l'objet d'un contrôle de solidité par une 
personne ou un organisme agrée. En aucun cas le niveau en surélévation ne peut être couvert (GEFIM). Ce dossier comportera: un plan du stand avec les dimensions et les accès; une notice descriptive précisant les matériaux utilisés pour la construction et la décoration du stand; Une note de calcul élaborée par un bureau d'étude pour les stands à l'étage (GEEAO). Les stands en surélévation devront être accessible aux personnes en situation de handicap si l'effectif, à l'étage, est $>50$ personnes ou si l'activité à l'étage n'est pas proposée au RdC: ascenseur ou monteescalier. Dans le cas contraire, un escalier devra être conforme aux règles d'accessibilité (GEFV). A cette fin un modèle orienté conseil est préférable. Pour la consultance il est important d'avoir des zones où se retirer au calme. Au même moment, la présentation de produits et de marques doit être possible. Une option est de concevoir le stand sur deux étages (CUf).

stand a due piani (stand con soppalcho; stand bipiano; stand con un piano sopraelevato) s.m. La realizzazione di stand a due piani è possibile a condizione che l'ampiezza non superi i $100 \mathrm{mq}$ e si rispettino le altezze massime previste per ogni scaglione come indicate al punto 1, 2, 3 e 4 del presente articolo. La Direzione Tecnica di Rimini Fiera, a suo insindacabile giudizio, si riserva la facoltà di approvare progetti di stand a 2 piani con dimensioni superiori ai limiti sopra indicati solo nel caso in cui la azienda abbia ottemperato agli obblighi di sicurezza come da Decreto interministeriale Salute Lavoro del 22 luglio 2014 (RGMS). La realizzazione di stand con soppalchi che, comunque, non potranno superare l'altezza massima di 5,50 m, è sottoposta all'approvazione dell'Organizzatore che ne valuterà la fattibilità sulla base della posizione dello stand all'interno del padiglione. I soppalchi (con altezza massima $5,50 \mathrm{~m}$ ) potranno essere realizzati dalle aziende che abbiano una superficie espositiva superiore ai $64 \mathrm{~m} 2$ e, compatibilmente con le caratteristiche tecniche dell'area assegnata, nella misura massima del $60 \%$ della superficie delimitata in pianta (MECB). In particolare la realizzazione dello stand bipiano è consentita nelle aree a 4 lati liberi (isole), e nelle aree a 3 lati liberi (penisole), per quest'ultimo caso con l'obbligo di mantenere lo stesso numero di lati liberi dell'area sottostante e di rifinire decorosamente le strutture o pareti che si affacciano su stand contigui. L'altezza standard per il bipiano è fissata a m. 5,50 (RTMFP). Fermo restando che gli Organizzatori hanno la facoltà di non autorizzare la costruzione di simili stand, le norme per il rilascio dell'eventuale autorizzazione sono, comunque, le seguenti: nessuna struttura (anche se portante) di uno stand con un piano sopraelevato può appoggiarsi a muri, colonne, ecc., del padiglione; gli stand potranno essere innalzati solo per il 50\% della loro superficie a terra, fino all'altezza massima di metri 4,50 calcolati al bordo superiore del passamano del piano rialzato fatte salve specifiche deroghe o restrizioni imposte dalle autorità competenti [...] (MEDGT).

\section{estande com piso superior: s.prep. V. estande com mezanino.}

Sugerimos que por medida de segurança a estrutura de montagem do estande seja reforçada, especialmente na parte superior (elementos acima de 4,50m até o limite máximo de $5,50 \mathrm{~m}$ ou 
de 7,00m para estande com piso superior), tendo em vista que no pavilhão do Riocentro ocorre com periodicidade ventilação cruzada intensa (MEEF).

\section{estande construído s.m. estande personalizado em termos de}

montagem e material. Estande Construído: totalmente elaborado sem utilizar o sistema modular. Geralmente possuem paredes em marcenaria, pintadas ou revestidas com materiais semelhantes ao corvin. Podem ter peças construídas em serralheria, madeira ou estruturas de Box truss. Suas portas são do tipo blindex ou convencionais de madeira (NBTE).

custom-built stand n.You will be expected to produce a professionally presented custom-built stand with a high level of finish and safety compliance and one that is in line with the high-quality, professional nature of the event. Whilst this will be a significant investment in the short term, it will pay dividends by allowing you to stand out within the show and gain much more exposure (EMRS).

stand sur mesure (stand personnalisé) n.m. Le stand sur mesure c'est un espace de communication sur-mesure, réalisé par un concepteur de stand, architecte des espaces éphémères. C'est un espace de communication unique, qui valorise les produits et services d'une entreprise et tient compte de sa communication, de sa stratégie de marque. Le stand sur-mesure répondra aux besoins spécifiques du client. Il conviendra pour des surfaces supérieures à $18 \mathrm{~m}^{2}$ pouvant aller jusqu'à $1000 \mathrm{~m}^{2}$ et plus (GPFGPS). Si vous avez choisi un emplacement $n u$, vous avez la possibilité, selon votre budget: soit d'opter pour un stand personnalisé en vous adressant à un décorateur, qui vous proposera différents projets de stands dits «traditionnels», c'est à dire en menuiserie, tapisserie, signalétique et autres éléments reprenant votre charte graphique de communication [...] (GEOPS).

stand personalizzato (stand su misura) s.m. Stand personalizzato -

utilizzato soprattutto da grandi aziende e leader di settore che vogliono consolidare e comunicare il proprio marchio e la corporate identity. L'obiettivo è catturare l'attenzione del visitatore, trasmettendo il messaggio dell'azienda in maniera (FSCP). Lo stand su misura: $\grave{E}$ progettato e realizzato appositamente per una singola azienda ed anche per una sola fiera con materiali e strutture anche non standard. È il più costoso e il più complesso da gestire, ma assicura i migliori risultati di immagine e la migliore rispondenza funzionale alle finalità dell'espositore (PF).

estande contíguo s.m. V. estande vizinho. As paredes deverão obedecer à tabela de recuos a partir das paredes divisórias dos estandes contíguos, ou seja, nas divisas com os vizinhos. Na divisa do estande com as ruas, as paredes para fechamento poderão ser construídas numa área de no máximo $50 \%$ da metragem linear de cada lado da fachada do estande (MEACF). 
estande de dois andares s. prep. V. estande com mezanino. Estande de 2 (dois) andares: permitido para áreas térreas iguais ou superiores a $70 \mathrm{~m}^{2}$. A construção deverá ter no máximo $50 \%$ da área total do estande e deve obedecer às regras de recuo e altura máxima. Apresentar ART's do cálculo estrutural do mezanino. É obrigatório indicar a capacidade de pessoas/ peso na escada de acesso ao $2^{\circ}$ pavimento do estande (MEFut).

\section{estande de esquina ${ }_{\text {s. prep. }}$ estande com duas faces abertas para dois}

corredores. Os estandes de esquina ficarão abertos para duas ruas, tendo somente duas paredes, uma de fundo e uma lateral, dividindo o estande vizinho (MEH).

corner stand (2 open sides stand) n. A corner stand has more sides accessible to the public, but the same overall area, and is therefore more effective than a stand situated in a row. Since a corner stand can be seen from two aisles, higher numbers of visitors can be expected (SPTFTE). Each stand will have a minimum of a solid back wall. Depending upon the position of your stand on the floorplan, it will also have 3, 2 or 1 open side(s). Open sides must remain open and unblocked by a full height run of solid graphic display (CSNEM).

stand d'angle (stand en coin; stand de coin; stand avec 1 angle) n.m. Notons aussi que la plupart des visiteurs sont droitiers et que leur sens de visite spontané commence par les allées de droite. Enfin, un stand d'angle, ouvert sur deux allées, vous donnera un linéaire plus important et une plus large visibilité (FSPMEG). Un stand en coin se situe à la fin d'une rangée. Il permet un accès par deux cotés, du couloir le long de la rangée et de celui perpendiculaire à celle-ci. Un stand en coin a plus de cotés accessibles au public, mais une aire similaire, et est donc plus efficace. Comme un stand en coin peut être vu de deux couloirs, un nombre accru de visiteurs peut être attendu (CUf). Les différents types de stands pour un salon sont influencés par l'attribution de l'espace et l'accès aux couloirs. Il y a 4 types de stands de base: stand de rangée; stand de coin; stand de tête; stand en îlot (CUf). Emplacement réserve: cocher la configuration du stand: stand sans angle; stand avec 1 angle; stand avec 2 angles; stand avec 4 angles (FIMDRPC).

stand ad angolo (stand d'angolo; stand angolare; stand con 2 fronti espositivi) s.m. I costi che verranno fatturati agli espositori sono: la tassa d'ammissione; la superficie espositiva per metro quadrato; la quota assicurativa per danni verso terzi; l'eventuale sovrapprezzo per stand ad angolo; l'eventuale sovrapprezzo per la vendita diretta (PF). Uno stand d'angolo si trova all'estremità di una fila. É accessibile da due lati, dalla corsia lungo la fila e da quella perpendicolare rispetto a quest'ultima. Uno stand d'angolo dispone di un numero superiore di lati aperti al pubblico, ma ha la stessa superficie complessiva di uno stand di fila, pertanto risulta più funzionale. Grazie alla sua posizione, lo stand è visibile da più corsie, di conseguenza ci si aspetta un maggiore afflusso di visitatori (URFMM). Gli stand angolari danno una sensazione di apertura e quindi catturano i visitatori facilmente. Hanno una grande affluenza anche gli stand con una buona apertura verso $i$ corridoi, oppure posizionati vicino ai punti ristoro (COES). TARIFFE: Art. 17 - 
Le aree espositive sono tenute in condizioni di visibilità ed accessibilità. Il canone di partecipazione relativo alle aree interne ai Padiglioni, per area nuda e per tutta la durata della fiera, è cosi differenziato: $\epsilon$ 192,00/mq - stand con 1 fronte espositivo; $€$ 209,00/mq - stand con 2 fronti espositivi [...] (RGMS). SN: stand a catena con accesso da due lati opposti e confini laterali condivisi.

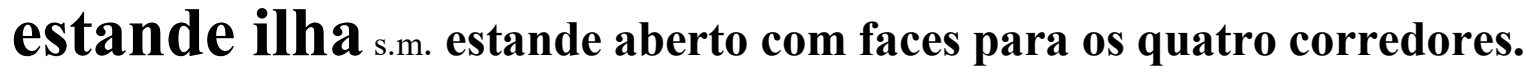

Entende-se por ilha os estandes que fazem divisa com as 4 vias de circulação. As paredes dos estandes ilha não deverão obedecer à tabela de recuo, somente altura máxima. Os estandes não poderão impedir a visualização interna do estande e das laterais que estejam voltadas para as vias de circulação (MEFeip).

island stand (block stand; island site) $\mathrm{n}$. The block stand or island stand, the most expensive type of stand, is accessible for visitors from all sides and attracts a great deal of attention due to the fact that it is completely isolated from all other stands (SPTFTE). Island sites: All island sites will have fascia to the perimeters with ceiling supports and vertical uprights within the stand where deemed necessary by Freeman UK. No walling is provided (GINBNWS).

stand en îlot (stand îlot) n.m. Le stand en îlot est entouré de couloirs.

Puisqu'il est accessible aux visiteurs de tous les cotés, il attire une grande partie de l'attention, en raison de sa totale indépendance des autres stands. Ce type de stand est le plus cher. Il requiert un design plus élaboré, qui se reflète dans des coûts plus élevés pour l'assemblage et l'aménagement du stand (Cuf). Le stand îlot: ouvert sur 4 côtés, 4 allées (GPFGPS).

stand ad isola (stand isola; stand a isola; stand con 4 fronti espositivi) s.m.

Nel caso di occupazioni di stand ad isola (4 lati aperti) ed a penisola (3 lati aperti), gli allestimenti dovranno limitare l'utilizzo di pareti perimetrali (RGMS). Lo stand isola è circondato da corsie lungo tutto il perimetro. Essendo accessibile da ogni lato e indipendente dagli altri stand, attira molto l'attenzione dei visitatori. Questo tipo di stand è il più costoso; richiede infatti un progetto più complesso che impone costi di montaggio e allestimento più elevati (URFMM). Potremo pertanto avere stand a isola o a penisola, rispettivamente con quattro o tre lati liberi (MFFM). Art.17- Le aree espositive sono tenute in condizioni di visibilità ed accessibilità. Il canone di partecipazione relativo alle aree interne ai Padiglioni, per area nuda e per tutta la durata della fiera, è così differenziato: $€$ 192,00/mq - stand con 1 fronte espositivo, $€$ 209,00/mq - stand con 2 fronti espositivi; $€ 218,00 / m q$-stand con 3 fronti espositivi; $€ 224,00 / m q$ - stand con 4 fronti espositivi (RGMS).

É importante destacar que este é apenas um modelo de layout para o dicionário, o qual poderá sofrer alterações dependendo do formato da publicação. A seguir, apresentamos o Capítulo 5 com as análises realizadas ao longo da pesquisa. 


\section{ANÁLISE DE DADOS}

A identificação dos traços conceituais e semânticos de um termo em um contexto é possível graças aos ganchos terminológicos, ferramenta de grande importância no momento de busca e análise da equivalência entre termos em seus contextos de uso. O contexto fornece informações sobre os traços semânticos de um conceito ou sobre o uso de um termo.

Para a presente pesquisa terminológica multilíngue elaboramos a definição do termo em português e estabelecemos as equivalências em inglês, francês e italiano, a partir da análise dos ganchos terminológicos presentes nos contextos de uso nas quatro línguas de estudo, para a elaboração do dicionário multilíngue de termos do setor feirístico.

A seguir, apresentamos alguns termos que compõem a macroestrutura de nosso dicionário terminológico das feiras de negócios nas quatro línguas. Estes termos foram coletados de corpora especializados e, portanto, são apresentados em seus contextos reais. Os ganchos terminológicos, que trazem a equivalência conceitual entre eles, aparecem destacados na terceira coluna, nas cores azul (descritores de natureza), rosa (descritores de finalidade) e laranja (descritores de modo), como pode ser observado nos quadros abaixo:

Quadro 6: Termo "estande" e seus equivalentes

\begin{tabular}{|l|l|}
\hline Termo & \multicolumn{1}{c|}{ Contexto + descritores } \\
\hline estande & $\begin{array}{l}\text { O estande é como a vitrine do produto ou serviço a ser divulgado e negociado, } \\
\text { estrutura em que se materializa a participação de empresas numa feira e, como tal, } \\
\text { não devem ser poupados esforços na sua elaboração. É a imagem que tem por } \\
\text { objetivo chamar a atenção do público-alvo. }\end{array}$ \\
\hline stand & $\begin{array}{l}\text { The trade fair stand is the companies calling card, and as such, should be of a } \\
\text { standard that is in keeping with the products exhibited and the significance of the } \\
\text { company both in size and design and appearance. A presentation of the exhibits } \\
\text { which takes into account the needs of the visitor must be a priority. The trade fair } \\
\text { stand should be attractive to the eye and pleasant to the ear, and can also appeal to } \\
\text { the visitor's emotions. }\end{array}$ \\
\hline stand & $\begin{array}{l}\text { Stand: construction provisoire édifiée par les participants à une foire, à un salon ou } \\
\text { à une exposition pour y accueillir des visiteurs et présenter des produits. }\end{array}$ \\
\hline stand & $\begin{array}{l}\text { Per stand si intende lo spazio assegnato all'espositore per la presentazione dei } \\
\text { propri prodotti o servizi. }\end{array}$ \\
\hline
\end{tabular}

Quadro 7: Termo "área livre" e seus equivalentes

\begin{tabular}{|l|l|}
\hline \multicolumn{1}{|c|}{ Termo } & \multicolumn{1}{c|}{ Contexto + descritores } \\
\hline área & $\begin{array}{l}\text { Área livre: Considera-se área livre o espaço contratado sem quaisquer elementos } \\
\text { divre }\end{array}$ \\
& $\begin{array}{l}\text { Pavilhão, cabendo ao mesmo todo trabalho de montagem e acabamento do espaço } \\
\text { locado. Caberá também ao Expositor o acabamento nas paredes de fundo, laterais e } \\
\text { vista superior entre estandes vizinhos. }\end{array}$ \\
\hline
\end{tabular}




\begin{tabular}{|l|l|}
\hline $\begin{array}{l}\text { space } \\
\text { only } \\
\text { stand }\end{array}$ & $\begin{array}{l}\text { Space only stands are to be built and completed by the exhibitor and their } \\
\text { contractors. No stand fitting, walling, carpet or electrical mains and fittings are } \\
\text { included. You are only hiring the space. }\end{array}$ \\
\hline stand nu & $\begin{array}{l}\text { Le stand nu: Il représente la surface louée. C'est l'espace qui vous est réservé, et } \\
\text { délimité sur le salon. Il est livré avec ou sans moquette, selon les besoins } \\
\text { d'aménagement. On peut y trouver des contraintes comme un poteau du hall ou } \\
\text { R.I.A (Robinet d'Incendie Armé). }\end{array}$ \\
\hline $\begin{array}{l}\text { area } \\
\text { nuda }\end{array}$ & $\begin{array}{l}\text { Per plateatico si intende esclusivamente l'area nuda, sprovvista di pareti, moquette, } \\
\text { impianto di illuminazione ed arredi vari. }\end{array}$ \\
\hline
\end{tabular}

Quadro 8: Termo "estande coletivo" e seus equivalentes

\begin{tabular}{|l|l|}
\hline \multicolumn{1}{|c|}{ Termo } & \multicolumn{1}{c|}{ Contexto + descritores } \\
\hline $\begin{array}{l}\text { estande } \\
\text { coletivo }\end{array}$ & $\begin{array}{l}\text { O espaço compartilhado superará em número de participantes e tamanho a edição } \\
\text { de 2014. Naquele ano, foram 11 empresas presentes, num estande coletivo de } \\
280 \mathrm{~m}^{2} \text {. Em 2015, os 20 estarão numa área de 440m². Outras cinco marcas } \\
\text { participarão em estandes individuais, são elas: La Femme, Pampili, Pé com Pé, } \\
\text { Kidy e Klin. }\end{array}$ \\
\hline $\begin{array}{l}\text { collective } \\
\text { stand }\end{array}$ & $\begin{array}{l}\text { The advantage of the project is the fact that in this case the contact area between } \\
\text { companies participating with a collective stand and eventual client companies is } \\
\text { wider. When a client arrives to the stand attracted by a certain company, the client } \\
\text { could also become interested in the supply of the other firms. }\end{array}$ \\
\hline $\begin{array}{l}\text { stand } \\
\text { collectif }\end{array}$ & $\begin{array}{l}\text { Le stand collectif: C'est un espace dédié à un collectif d'entreprises ou de marques } \\
\text { (Fédération professionnelle, chambre de commerce..). Il regroupe des stands sous } \\
\text { une même bannière (de pavillons nationaux ou régionaux par exemple) qui sont } \\
\text { généralement pré-équipés ou packagés. }\end{array}$ \\
\hline $\begin{array}{l}\text { stand } \\
\text { collettivo }\end{array}$ & $\begin{array}{l}\text { La partecipazione alla manifestazione fieristica con stand collettivo organizzato } \\
\text { dalla Camera di Commercio è subordinata all'adesione e alla presenza di almeno } \\
\text { dodici espositori della provincia di Avellino. }\end{array}$ \\
\hline
\end{tabular}

Quadro 9: Termo "estande com mezanino" e seus equivalentes

\begin{tabular}{|l|l|}
\hline \multicolumn{1}{|c|}{ Termo } & \multicolumn{1}{c|}{ Contexto + descritores } \\
\hline $\begin{array}{l}\text { estande } \\
\text { com } \\
\text { mezanino }\end{array}$ & $\begin{array}{l}\text { No projeto do estande com mezanino ou } 2^{\circ} \text { piso, deverá constar a memória de } \\
\text { cálculo estrutural do segundo piso. A estrutura do mezanino ou } 2^{\circ} \text { piso deverá ser } \\
\text { montada de acordo com as normas da Associação Brasileira de Normas Técnicas - } \\
\text { ABNT. }\end{array}$ \\
\hline $\begin{array}{l}\text { two- } \\
\text { storey } \\
\text { stand }\end{array}$ & $\begin{array}{l}\text { We have made arrangements for basic stand cleaning to be carried out at no charge } \\
\text { to you in the evening before the show opens each day. This does not apply to the } \\
\text { upper deck of a two-storey stand, if you require cleaning of the 2nd storey you } \\
\text { need to order this direct with ExCeL London cleaning. }\end{array}$ \\
\hline $\begin{array}{l}\text { stand à } \\
\text { étage }\end{array}$ & $\begin{array}{l}\text { Chaque stand ne peut avoir qu'un sel niveau en surélévation. Tous les stands à } \\
\text { étage doivent faire l'objet d'un contrôle de solidité par une personne ou un } \\
\text { organisme agrée. En aucun cas le niveau en surélévation ne peut être couvert. }\end{array}$ \\
\hline $\begin{array}{l}\text { stand a } \\
\text { due piani }\end{array}$ & $\begin{array}{l}\text { Il parapetto che protegge il secondo livello dello stand a due piani deve essere } \\
\text { alto almeno 1,1 m. }\end{array}$ \\
\hline
\end{tabular}

Quadro 10: Termo "estande com piso superior"

\begin{tabular}{|l|l|}
\hline \multicolumn{1}{|c|}{ Termo } & \multicolumn{1}{|c|}{ Contexto + descritores } \\
\hline estande & Será permitida montagem de estande com piso superior $\left(1^{\circ}\right.$ andar $)$ para \\
com piso & empresas expositoras com áreas térreas iguais ou superiores a $150 \mathrm{~m}^{2}$, após \\
superior & análise e aprovação da Inovar e dos Promotores. \\
V. estande & \\
com & \\
mezanino & \\
\hline
\end{tabular}


Quadro 11: Termo "estande construído" e seus equivalentes

\begin{tabular}{|l|l|}
\hline \multicolumn{1}{|c|}{ Termo } & \multicolumn{1}{c|}{ Contexto + descritores } \\
\hline $\begin{array}{l}\text { estande } \\
\text { construído }\end{array}$ & $\begin{array}{l}\text { Estande construído: totalmente elaborado sem utilizar o sistema modular. } \\
\text { Geralmente possuem paredes em marcenaria, pintadas ou revestidas com } \\
\text { materiais semelhantes ao corvin. Podem ter peças construídas em serralheria, } \\
\text { madeira ou estruturas de Box truss. Suas portas são do tipo blindex ou } \\
\text { convencionais de madeira. }\end{array}$ \\
\hline $\begin{array}{l}\text { custom-built } \\
\text { stand }\end{array}$ & $\begin{array}{l}\text { You will be expected to produce a professionally presented custom-built } \\
\text { stand with a high level of finish and safety compliance and one that is in line } \\
\text { with the high-quality, professional nature of the event. Whilst this will be a } \\
\text { significant investment in the short term, it will pay dividends by allowing you } \\
\text { to stand out within the show and gain much more exposure. }\end{array}$ \\
\hline $\begin{array}{l}\text { stand sur } \\
\text { mesure }\end{array}$ & $\begin{array}{l}\text { Le stand sur mesure c'est un espace de communication sur-mesure, réalisé } \\
\text { par un concepteur de stand, architecte des espaces éphémères. C'est un espace } \\
\text { de communication unique, qui valorise les produits et services d'une } \\
\text { entreprise et tient compte de sa communication, de sa stratégie de marque. Le } \\
\text { stand sur-mesure répondra aux besoins spécifiques du client. Il conviendra } \\
\text { pour des surfaces supérieures à 18 m² pouvant aller jusqu'à 1000 m² et plus. }\end{array}$ \\
\hline $\begin{array}{l}\text { stand } \\
\text { personalizzato }\end{array}$ & $\begin{array}{l}\text { Stand personalizzato - utilizzato soprattutto da grandi aziende e leader di } \\
\text { settore che vogliono consolidare e comunicare il proprio marchio e la } \\
\text { corporate identity. L'obiettivo è catturare l'attenzione del visitatore, } \\
\text { trasmettendo il messaggio dell'azienda in maniera. }\end{array}$ \\
\hline
\end{tabular}

Quadro 12: Termo "estande contíguo"

\begin{tabular}{|l|l|}
\hline \multicolumn{1}{|c|}{ Termo } & \multicolumn{1}{c|}{ Contexto + descritores } \\
\hline estande & As paredes deverão obedecer à tabela de recuos a partir das paredes divisórias \\
contíguo: & dos estandes contíguos, ou seja, nas divisas com os vizinhos. Na divisa do \\
V. estande & estande com as ruas, as paredes para fechamento poderão ser construídas numa \\
vizinho & área de no máximo 50\% da metragem linear de cada lado da fachada do estande. \\
\hline
\end{tabular}

Quadro 13: Termo "estande de dois andares"

\begin{tabular}{|c|c|}
\hline Termo & Contexto + descritores \\
\hline $\begin{array}{l}\text { estande de } \\
\text { dois } \\
\text { andares: V. } \\
\text { estande } \\
\text { com } \\
\text { mezanino }\end{array}$ & $\begin{array}{l}\text { Estande de } 2 \text { (dois) andares: permitido para áreas térreas iguais ou superiores } \\
\text { a } 70 \mathrm{~m}^{2} \text {. A construção deverá ter no máximo } 50 \% \text { da área total do estande e deve } \\
\text { obedecer às regras de recuo e altura máxima. Apresentar ART’s do cálculo } \\
\text { estrutural do mezanino. É obrigatório indicar a capacidade de pessoas/peso na } \\
\text { escada de acesso ao } 2^{\circ} \text { pavimento do estande. }\end{array}$ \\
\hline
\end{tabular}

Quadro 14: Termo "estande de esquina" e seus equivalentes

\begin{tabular}{|l|l|}
\hline \multicolumn{1}{|c|}{ Termo } & \multicolumn{1}{c|}{ Contexto + descritores } \\
\hline $\begin{array}{l}\text { estande de } \\
\text { esquina }\end{array}$ & $\begin{array}{l}\text { Os estandes de esquina ficarão abertos para duas ruas, tendo somente duas } \\
\text { paredes, uma de fundo e uma lateral, dividindo o estande vizinho. }\end{array}$ \\
\hline $\begin{array}{l}\text { corner } \\
\text { stand }\end{array}$ & $\begin{array}{l}\text { A corner stand has more sides accessible to the public, but the same overall } \\
\text { area, and is therefore more effective than a stand situated in a row. Since a corner } \\
\text { stand can be seen from two aisles, higher numbers of visitors can be expected. }\end{array}$ \\
\hline $\begin{array}{l}\text { stand } \\
\text { d'angle }\end{array}$ & $\begin{array}{l}\text { Notons aussi que la plupart des visiteurs sont droitiers et que leur sens de visite } \\
\text { spontané commence par les allées de droite. Enfin, un stand d'angle, ouvert sur } \\
\text { deux allées, vous donnera un linéaire plus important et une plus large visibilité. }\end{array}$ \\
\hline $\begin{array}{l}\text { stand ad } \\
\text { angolo }\end{array}$ & $\begin{array}{l}\text { Al momento dell'iscrizione è possibile richiedere che il proprio stand sia aperto } \\
\text { su due o più lati, in modo da avere garantita una maggiore visibilità. Ogni angolo } \\
\text { comporta un costo aggiuntivo di 150 } € \text {. Il numero degli stand ad angolo è } \\
\text { limitato e la conferma dell'effettiva disponibilità sarà comunicata dagli } \\
\text { organizzatori entro il 28 febbraio 2014. L'assegnazione avverrà in base }\end{array}$ \\
\hline
\end{tabular}




\begin{tabular}{|l|l|}
\hline & $\begin{array}{l}\text { all'ordine temporale di perfezionamento dell'iscrizione, tramite il pagamento } \\
\text { della quota di partecipazione. Le realtà che non dovessero avere assegnato lo } \\
\text { stand ad angolo verranno rimborsate della somma versata relativa. }\end{array}$ \\
\hline
\end{tabular}

Quadro 15: Termo "estande ilha" e seus equivalentes

\begin{tabular}{|l|l|}
\hline \multicolumn{1}{|c|}{ Termo } & \multicolumn{1}{c|}{ Contexto + descritores } \\
\hline estande ilha & $\begin{array}{l}\text { Entende-se por ilha os estandes que fazem divisa com as 4 vias de circulação. } \\
\text { As paredes dos estandes ilha não deverão obedecer à tabela de recuo, somente } \\
\text { altura máxima. Os estandes não poderão impedir a visualização interna do } \\
\text { estande e das laterais que estejam voltadas para as vias de circulação. }\end{array}$ \\
\hline island stand & $\begin{array}{l}\text { The block stand or island stand, the most expensive type of stand, is accessible } \\
\text { for visitors from all sides and attracts a great deal of attention due to the fact that } \\
\text { it is completely isolated from all other stands. }\end{array}$ \\
\hline $\begin{array}{l}\text { stand en } \\
\text { ilot }\end{array}$ & $\begin{array}{l}\text { Le stand en îlot est entouré de couloirs. Puisqu'il est accessible aux visiteurs de } \\
\text { tous les cotés, il attire une grande partie de l'attention, en raison de sa totale } \\
\text { indépendance des autres stands. Ce type de stand est le plus cher. Il requiert un } \\
\text { design plus élaboré, qui se reflète dans des coûts plus élevés pour l'assemblage } \\
\text { et l'aménagement du stand. }\end{array}$ \\
\hline $\begin{array}{l}\text { stand ad } \\
\text { isola }\end{array}$ & $\begin{array}{l}\text { Nel caso di occupazioni di stand ad isola (4 lati aperti) ed a penisola (3 lati } \\
\text { aperti), gli allestimenti dovranno limitare l'utilizzo di pareti perimetrali. }\end{array}$ \\
\hline
\end{tabular}

Pelo exposto, verificamos que os ganchos terminológicos contribuem de fato para a verificação da equivalência de sentido e de uso entre os termos e foram essenciais para a busca dos equivalentes em língua inglesa, francesa e italiana para os termos em português supracitados. A análise dos ganchos terminológicos nas quatro línguas também pode ser visualizada no Apêndice IV do presente trabalho.

Portanto, a verificação dos termos em seu uso real, nesse caso, nos guias e manuais do expositor, e a análise dos contextos em que esses termos ocorrem são de extrema importância para o desenvolvimento de uma pesquisa terminológica multilíngue, uma vez que a análise dos descritores nos trazem a noção de equivalência e/ou correspondência semântico-conceitual entre os termos nas diferentes línguas.

Neste Capítulo, além dos exemplos de termos equivalentes analisados acima, apresentamos também alguns exemplos de termos correspondentes, termos homônimos, estrangeirismos, fraseologismos, falsos cognatos e colocações (nominais e adjetivas) encontrados na terminologia do setor feirístico nas quatro línguas. Além disso, trazemos também a estrutura morfossintática e léxico-semântica dos termos, algumas especificidades encontradas, a descrição da tipologia de feiras versus tipologia de público, o conjunto de variantes terminológicas das feiras de negócios e suas relações de hiperonímia, hiponímia e sinonímia, assim como a questão da inconsistência terminológica observada nesse domínio, o estudo da constituição interna dessa terminologia e reflexões acerca dos estágios no exterior, como pode ser verificado a seguir: 


\section{Termos correspondentes}

No português, utilizamos o termo "aluguel de estande". No inglês, existe a distinção entre o aluguel de estande para participar de uma feira pela primeira vez (rental) e o aluguel de estande como parte do marketing mix, utilizado de forma regular (lease). Assim, do ponto de vista da língua inglesa, os termos rental e lease são correspondentes do termo "aluguel" em português, pois possuem sentidos e usos diferentes em inglês (cf. GODOY, 2014, p. 343). No italiano, encontramos o termo locazione dello spazio espositivo e, no francês, location du stand.

Assim temos:

\begin{tabular}{llll} 
português & inglês & francês & italiano \\
\hline aluguel de estande & stand rental & location du stand & locazione dello spazio espositivo \\
\hline \multicolumn{3}{c}{ stand lease } \\
\hline
\end{tabular}

O mesmo ocorre com o termo em português "cliente" que corresponde aos termos customer e client em inglês, com diferenças de uso e consequentemente de sentido, como podemos observar a seguir:

- Customer: aquele que compra um produto ou serviço;

- Client: pessoa, empresa ou organização que utiliza os serviços profissionais de outra.

O termo em português não faz esta distinção, como ocorre no inglês. Desse modo, do ponto de vista da língua inglesa, customer e client são correspondentes do termo "cliente" em português, pois possuem sentido e uso diferentes em inglês (cf. GODOY, 2014, p. 340). No italiano, encontramos o termo cliente e no francês, o termo client. Assim temos:

\begin{tabular}{|c|c|c|c|}
\hline Partindo do português: & Partindo do inglês: & Em italiano: & Em francês: \\
\hline cliente $\Rightarrow$ customer/client & $\begin{array}{l}\text { customer } \Rightarrow \text { cliente } \\
\text { client } \quad \Rightarrow \text { cliente }\end{array}$ & cliente & client \\
\hline
\end{tabular}

\section{Termos homônimos}

Conforme apresentamos no mestrado em Godoy (2014, p. 331), o termo “expositor” em português é um homônimo, já que possui o mesmo significante e dois sentidos distintos:

1. aquele que expõe em uma feira (pessoa);

2. suporte utilizado para expor os produtos em uma feira (coisa).

Assim, no primeiro sentido, temos o termo exhibitor em inglês e no segundo sentido, temos o termo display em inglês. No francês, encontramos o termo exposant (pessoa) e 
présentoir (coisa) e, no italiano, encontramos o termo espositore (pessoa) e display espositivo (coisa), (cf. descrito na página 81 ).

\section{Estrangeirismos}

Como mencionamos no subitem 2.6, observamos uma forte tendência ao uso de estrangeirismos na terminologia do setor feirístico. Por esse motivo, apresentamos nos quadros abaixo alguns exemplos encontrados em português, em francês e em italiano:

Quadro 16: Estrangeirismos encontrados em português

\begin{tabular}{|l|l|l|}
\hline stand & sponsor & prospects \\
\hline merchandising & mailing & marketing \\
\hline follow up & networking & press release \\
\hline press kit & souvenir & display \\
\hline totem & banner & poster \\
\hline
\end{tabular}

Quadro 17: Estrangeirismos encontrados em francês

\begin{tabular}{|l|l|l|}
\hline stand & sponsor & prospects \\
\hline display & totem & banner \\
\hline poster & & \\
\hline
\end{tabular}

quadro 18: estrangeirismos encontrados em italiano

\begin{tabular}{|l|l|l|}
\hline stand & sponsor & prospects \\
\hline follow up & colonne* & hostess \\
\hline decision maker & dépliant* & receptionist \\
\hline display & totem & banner \\
\hline poster & moquette* & \\
\hline
\end{tabular}

*Estrangeirismos do francês

\section{Fraseologismos}

A seguir, apresentamos um fraseologismo muito recorrente no domínio das feiras de negócios:

Quadro 19: Exemplo de fraseologismo

\begin{tabular}{|l|l|}
\hline PORTUGUÊS & antes, durante e após (a feira) \\
INGLÊS & before, during and after (the fair) \\
FRANCÊS & avant, pendant ou après (la foire) \\
\hline ITALIANO & prima, durante e dopo (la fiera) \\
\hline
\end{tabular}


No glossário elaborado no mestrado, apresentamos os termos em separado: "o préfeira", "o durante a feira" e "o pós-feira". Entretanto, no dicionário elaborado no doutorado, decidimos incluir na nomenclatura um verbete com o fraseologismo "antes, durante e após a feira" que se repete nas quatro línguas estudadas de maneira sistemática.

\section{Falso cognato}

Durante a busca pelo equivalente em francês para o termo "expositor" encontramos um exemplo de falso cognato. Procuramos pelo termo expositeur, seguindo a lógica da língua francesa, como pode ser observado no quadro abaixo, e não o encontramos, até que nos deparamos com o termo realmente utilizado em língua francesa, o termo exposant, como pode ser visualizado a seguir:

Quadro 20: Exemplo de falso cognato

\begin{tabular}{|l|l|l|l|}
\hline PORTUGUÊS & INGLÊS & FRANCÊS & ITALIANO \\
\hline distribuidor & distributor & distributeur & distributore \\
\hline visitante & visitor & visiteur & visitatore \\
\hline Expositor & exhibitor & expositeur & espositore \\
\hline & & "exposant" & \\
\hline & & & \\
\hline
\end{tabular}

Colocações Nominais e Adjetivas

Conforme apresentamos no subitem 2.8, as colocações nominais são constituídas por: substantivo+preposição+substantivo e as colocações adjetivas são constituídas por: substantivo+adjetivo (HAUSMANN, 1985; CORPAS PASTOR, 1996). A seguir, apresentamos alguns exemplos de colocações nominais e adjetivas encontradas em nossa pesquisa nas quatro línguas, como pode ser observado no quadro abaixo: 
Quadro 21: Colocações nominais e adjetivas

\section{PORTUGUÊS:}

INGLÊS:

FRANCÊS:

ITALIANO:

\section{estande com piso superior}

estande ponta de ilha stand with two floors

shell scheme stand

stand construit avec des matériaux écologiques

stand modulable prêt à exposer

stand chiavi in mano

stand con due fronti espositivi

Retomaremos essa questão da constituição interna da terminologia das feiras de negócios mais adiante (cf. págs. 163-168).

Estrutura morfossintática e léxico-semântica dos termos nas quatro línguas

Apresentamos no quadro a seguir, alguns exemplos de termos simples, constituídos de um só radical (ISO 1087, 2000, p. 7), e termos complexos, constituídos de dois ou mais radicais (ISO 187, 2000, p. 7), encontrados na terminologia das feiras de negócios em português, inglês, francês e italiano:

Quadro 22: Estrutura morfossintática e léxico-semântica dos termos

\begin{tabular}{|l|l|}
\hline \multicolumn{1}{|c|}{ TERMOS SIMPLES } & \multicolumn{1}{|c|}{ TERMOS COMPLEXOS } \\
\hline feira; fair, foire, fiera & $\begin{array}{l}\text { feira nacional; national trade show; foire } \\
\text { nationale; fiera nazionale }\end{array}$ \\
\hline expositor; exhibitor; exposant; espositore & $\begin{array}{l}\text { feira internacional; international trade show; } \\
\text { salon international; fiera internazionale }\end{array}$ \\
\hline pavilhão; pavilion; pavillion; padiglione & $\begin{array}{l}\text { estande ilha; island stand; stand en îlot; stand ad } \\
\text { isola }\end{array}$ \\
\hline estande; stand; stand; stand & $\begin{array}{l}\text { estande básico; shell scheme stand; stand pré- } \\
\text { équipé; stand preallestito }\end{array}$ \\
\hline exposição; exhibition; salon; esposizione & $\begin{array}{l}\text { visitante potencial; potential visitor; visiteur } \\
\text { potentiel; potenziale visitatore }\end{array}$ \\
\hline
\end{tabular}

Especificidades encontradas na terminologia das feiras

Ao longo da pesquisa observamos algumas peculiaridades, principalmente no que diz respeito à língua francesa. Assim, para o termo "feira especializada" encontramos:

- specialised trade show (ing.) 
- fiera specializzata (it.)

- salon specialisé (fr.)

Como pode ser observado, não encontramos em nossos corpora em francês o termo foire specialisé. Portanto, o termo "feira" não será sempre traduzido por foire, já que isso depende do contexto, da frequência e do uso na língua. Da mesma maneira, para o termo "feira de consumo", encontramos:

- consumer show (ing.)

- fiera per (il) consumatore (it.)

- salon grand public ou salon de consommation (fr.)

Ou seja, o equivalente em francês para o termo pesquisado é salon grand public ou salon de consommation (e não foire grand public). Essas questões serão retomadas mais adiante, quando discorreremos sobre os problemas de tradução encontrados na busca pelas equivalências.

Tipo de feira versus tipo de público

Neste subitem, apresentamos alguns tipos de feira (com exposição de produtos ou venda de produtos; de um segmento especializado da indústria ou mais de um segmento da indústria) e o tipo de público (público geral ou público especializado), como pode ser observado no quadro abaixo:

Quadro 23: Tipo de feira versus tipo de público

\begin{tabular}{|c|c|c|c|c|c|c|}
\hline & $\begin{array}{l}\text { público } \\
\text { geral } \\
\text { (B2C) }\end{array}$ & $\begin{array}{c}\text { público } \\
\text { especializado } \\
\text { (B2B) }\end{array}$ & $\begin{array}{l}\text { exposição } \\
\text { de } \\
\text { produtos }\end{array}$ & $\begin{array}{l}\text { venda } \\
\text { de } \\
\text { produtos }\end{array}$ & $\begin{array}{l}\text { segmento } \\
\text { especializado } \\
\text { de indústria }\end{array}$ & $\begin{array}{l}\text { mais de um } \\
\text { segmento de } \\
\text { indústria }\end{array}$ \\
\hline \multicolumn{7}{|l|}{ feira geral } \\
\hline \multicolumn{7}{|l|}{ feira especializada } \\
\hline \multicolumn{7}{|l|}{ exposição } \\
\hline \multicolumn{7}{|l|}{ trade fair ${ }^{1}$} \\
\hline \multicolumn{7}{|l|}{ trade show ${ }^{2}$} \\
\hline \multicolumn{7}{|l|}{ exhibition } \\
\hline \multicolumn{7}{|l|}{ foire } \\
\hline \multicolumn{7}{|l|}{ salon $^{3}$} \\
\hline \multicolumn{7}{|l|}{ salon professionel ${ }^{4}$} \\
\hline \multicolumn{7}{|l|}{ salon grand public } \\
\hline \multicolumn{7}{|l|}{ fiera } \\
\hline \multicolumn{7}{|l|}{ esposizione } \\
\hline \multicolumn{7}{|l|}{ fiera generale } \\
\hline fiera specializzata & & & & & & \\
\hline
\end{tabular}

Fonte: Adaptado de (GODOY 2014, p. 305)

1. Na Europa e na Ásia temos o termo trade fair para feiras de negócios;

2. Nos EUA e Inglaterra temos o termo trade show para feiras de negócios; 
3. Salon: reúne profissionais do mesmo setor de atividade que buscam encontrar pessoas interessadas em seus produtos e serviços: fornecedores, clientes, parceiros, concorrentes, etc;

4. Salon professionnel: aberto somente aos representantes de um único setor de atividade e seu acesso é regulamentado.

Assim, conforme os dados apresentados acima, uma feira especializada é direcionada ao público profissional, pressupõe exposição de produtos e tem como foco um segmento da indústria, assim como trade show, salon professionel e fiera specializzata. Em contrapartida, uma exposição é direcionada ao grande público, pressupõe exposição de produtos e tem como foco mais de um segmento da indústria, assim como exhibition e esposizione. Por outro lado, feira geral e salon grand public pressupõem a venda de produtos.

Conjunto de variantes das feiras de negócios e suas relações de hiperonímia, hiponímia e sinonímia

Fizemos uma busca em livros de Semântica (Gottlob Frege, A. J. Greimas, Robert Martin, D. A Cruse, F. R. Palmer, Stephen Ulmann) e foi em Lyons (1977) que encontramos mais informações sobre a hiponímia. Em seu livro Semantics 1, Lyons nos ensina que a hiponímia é uma relação paradigmática de sentido entre um lexema mais específico, ou subordinado, e um lexema mais geral, ou superordenado. Segundo o autor, o termo hiperonímia vem do grego (cf. Mulder \& Hervey, 1972) e foi cunhado a partir de antonímia e sinonímia e, por ser muito semelhante à hiponímia, ele optou por usar o termo "superordenado" para se referir ao hiperônimo (LYONS, 1977, p. 291).

Lyons afirma que "o hipônimo representa o sentido de algum modificador adjetival combinado com o sentido do lexema superordenado"135 (LYONS, 1977, p. 293), ou seja, "o sentido de um hipônimo pode ser percebido como o resultado do sentido do seu hiperônimo acrescido de um modificador adjetival"136 (LYONS, 1977, p. 293). Do mesmo modo, o autor menciona que os "co-hipônimos de um mesmo hiperônimo diferem em sentido e que a natureza deste contraste pode ser explicada em termos da diferença acrescida ao termo superordenado pelo modificador sintagmático"137 (LYONS, 1977, p. 294) .

Partindo do constructo teórico de Lyons (1977) a relação hiperonímia-hiponímia é,

\footnotetext{
135 a hyponym encapsulates the sense of some adjectival modifier and combines it with the sense of the superordinate lexeme (LYONS, 1977, p. 293).

136 the sense of a hyponym can be regarded as the product of the sense of a superordinate noun and of some actual or potential adjectival modifier (Id.).

137 co-hyponyms of the same superordinate will contrast in sense and the nature of the contrast can be explicated in terms of a difference in the encapsulated syntagmatic modification of the superordinate (Ibid., p. 294).
} 
portanto, uma relação hierárquica de inclusão semântica entre:

1. termo geral: superordenado ou hiperônimo e

2. termo específico: subordinado ou hipônimo

Assim, o segundo, além de conservar as características semânticas do primeiro, possui os seus próprios traços distintivos como, por exemplo, em:

Figura 6: relação hiperonímia-hiponímia-co-hiponímia

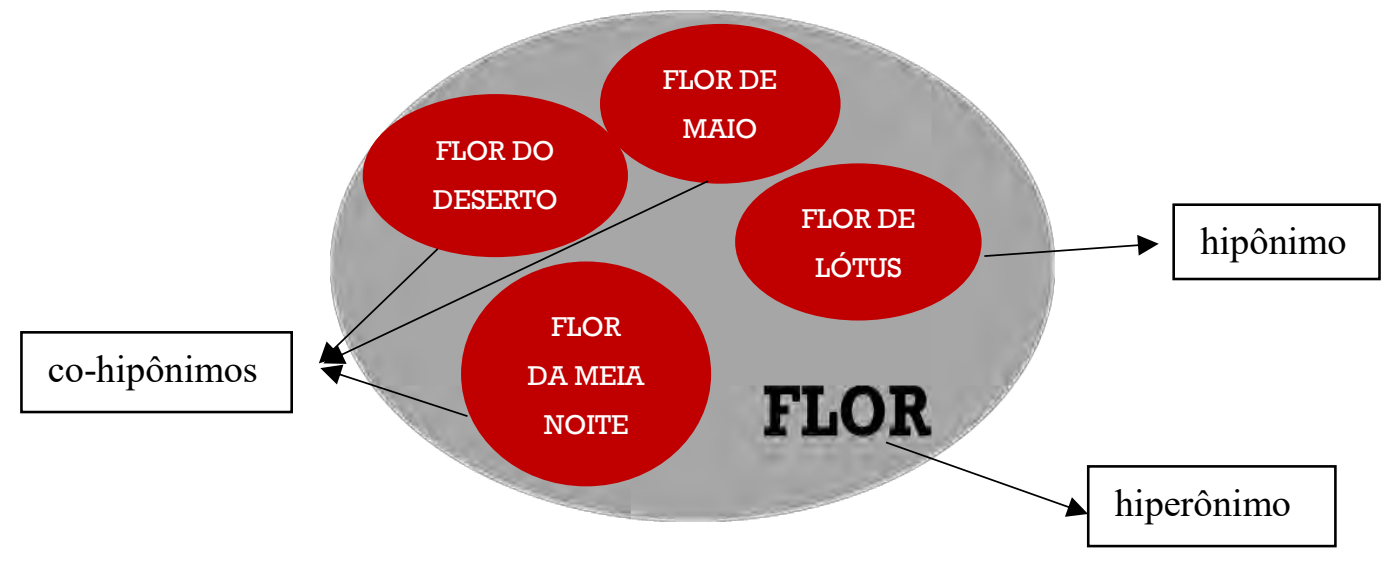

Fonte: elaborado pela autora

Do mesmo modo, no domínio das feiras de negócios essa relação semântica também está presente, principalmente ao considerarmos o fato dessa ser uma área com poucos termos de base (hiperônimos), mais especificamente seis, a saber: "estande”, “expositor", "feira", "exposição", "visitante” e "pavilhão". A própria terminologia nos levou a estudar essa relação, visto que nesse domínio de apenas 6 termos base, os novos termos são criados a partir da especificação do termo de base e estão, portanto, em relação de hiperonímia-hiponímia. Assim, o processo de criação de novos termos nessa área decorre da especificação do hiperônimo, ou seja, do acréscimo de um adjetivo ou de um substantivo preposicionado ao termo de base, como pode ser observado em: "estande + personalizado", "estande + ilha", "estande + de esquina", “estande + com mezanino", etc. (cf. figura 6 adiante). Estes termos, portanto, são hipônimos de "estande" e estão em relação de co-hiponímia entre si. Um estudo mais detalhado da constituição interna dos termos dessa área será apresentado mais adiante.

Assim, o termo "estande ilha", por exemplo, traz o conceito contido no termo "estande" e acrescenta a(s) característica(s) específica(s) que o difere de outros tipos de estandes, a saber:

1. estande: "espaço no interior do pavilhão de um centro de exposições utilizado pelo expositor para a exposição de produtos e oferta de serviços durante uma feira de negócios"

2. estande + ilha: "estande que possui os quatro lados abertos, pode ser visto de qualquer ângulo e dá acesso aos quatros corredores do pavilhão simultaneamente" 
3. estande + de esquina: "estande com somente duas paredes, uma de fundo e uma lateral com o estande vizinho, e duas faces abertas para dois corredores".

Portanto, do ponto de vista semântico, o conceito mais genérico corresponde ao hiperônimo "estande" e o mais específico, ao seu hipônimo "estande ilha", tendo como variante coocorrente (sinônimo) o termo "estande de meio de quadra" e como co-hipônimo o termo "estande de esquina". Assim, como ocorre com os diferentes tipos de estande que são criados a partir da especificação do termo "estande", o mesmo se dá com o termo "feira" e seus hipônimos, o termo "expositor" e seus hipônimos, o termo "pavilhão" e seus hipônimos e assim por diante.

O processo de criação de novos termos por especificação é comum em Terminologia. Kageura (2002) afirma que é "um princípio básico ver a formação de termos como a especificação de conceitos dentro de uma classe conceitual, representada pelo núcleo, por meio de modificações representadas pelos determinantes"138.

Do mesmo modo, Alves $(1999,2003)$ afirma que formações sintagmáticas são o processo mais comum de criação de novos termos em linguagens especializadas, uma vez que dá origem a outros termos pelo acréscimo de determinantes adjetivais, determinantes introduzidos por preposição ou outra forma de expansão, conforme citado no Capítulo 2.

Cogitamos sobre as possíveis razões pelas quais temos poucos termos base nesse domínio e um processo de criação de novos termos por especificação, como descrito a seguir: a inexistência de um órgão de regulamentação dessa terminologia (cada organizadora de feira utiliza sua própria terminologia); o fato de ser um domínio internacional amplo, formado por diferentes comunidades, o que indica que seria mais fácil especificar termos já existentes do que criar termos novos (com o objetivo de preservar a inteligibilidade) e ainda o fato desse domínio não ser visto com relevância pelas áreas que poderiam estudá-lo sob diferentes perspectivas (social, antropológica, econômica, etc.), apesar de sua origem longínqua e importância econômica. Como resultado, encontramos uma vasta variação terminológica nessa área de especialidade.

Portanto, na terminologia do setor feirístico, o surgimento de novos termos não advém da criação de termos novos ou do empréstimo de termos de outras línguas (ainda que possa ser encontrado nessa terminologia termos oriundos de outras áreas, como mencionamos no Capítulo 4, por se tratar de uma área híbrida), mas sim, de um processo de tipificação que resulta

${ }^{138}[\ldots]$ it is a basic tenet to see term formation as the specification of concepts within a conceptual class, as
represented by the nucleus, by means of modifications represented by the determinants (KAGEURA, p. 59, 2002). . 
em diferentes tipos de feiras, de estandes, de expositores, de visitantes, etc. Desse modo, podemos ver uma relação entre a hiperonímia-hiponímia e o específico processo de criação de novos termos por especificação neste domínio.

A seguir, apresentamos por meio de figuras a relação hiperonímia-hiponímia-sinonímia entre os diferentes tipos de estande nas quatro línguas. Em vermelho, temos o hiperônimo "estande"; em cinza escuro, seus hipônimos e, em cinza claro, suas variantes (sinônimos). Como podemos observar, a partir do termo base "estande", foram encontrados 18 termos em relação de co-hiponímia, a saber: estande básico; estande coletivo; estande com mezanino; estande complexo; estande construído; estande de alimentação, estande de esquina; estande de uma face; estande de área livre; estande fechado; estande ilha; estande individual; estande institucional; estande misto; estande ponta de ilha; estande sustentável; estande virtual e estande vizinho, como podemos observar na Figura 7 a seguir: 
Figura 7: Variantes do termo "estande" em português

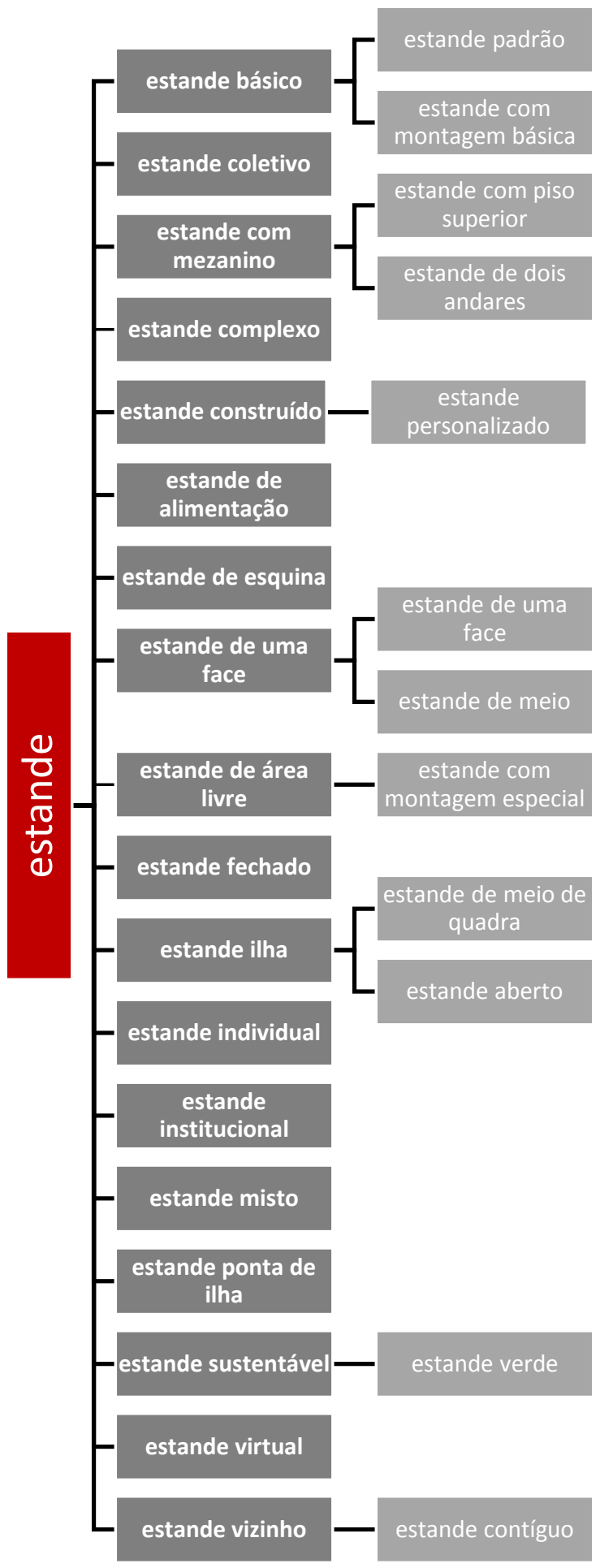

O mesmo pode ser observado em inglês, em francês e em italiano, conforme as figuras 8,9 e 10 a seguir: 
Figura 8: Variantes do termo stand em inglês

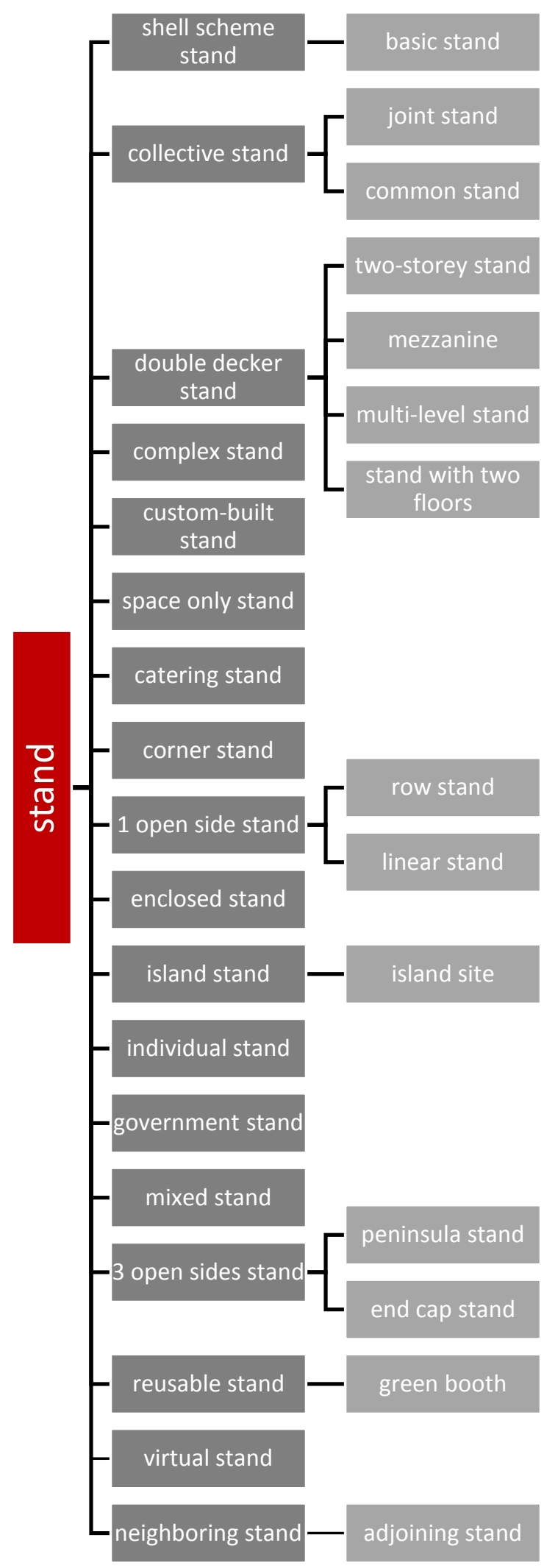


Figura 9: Variantes do termo stand em francês

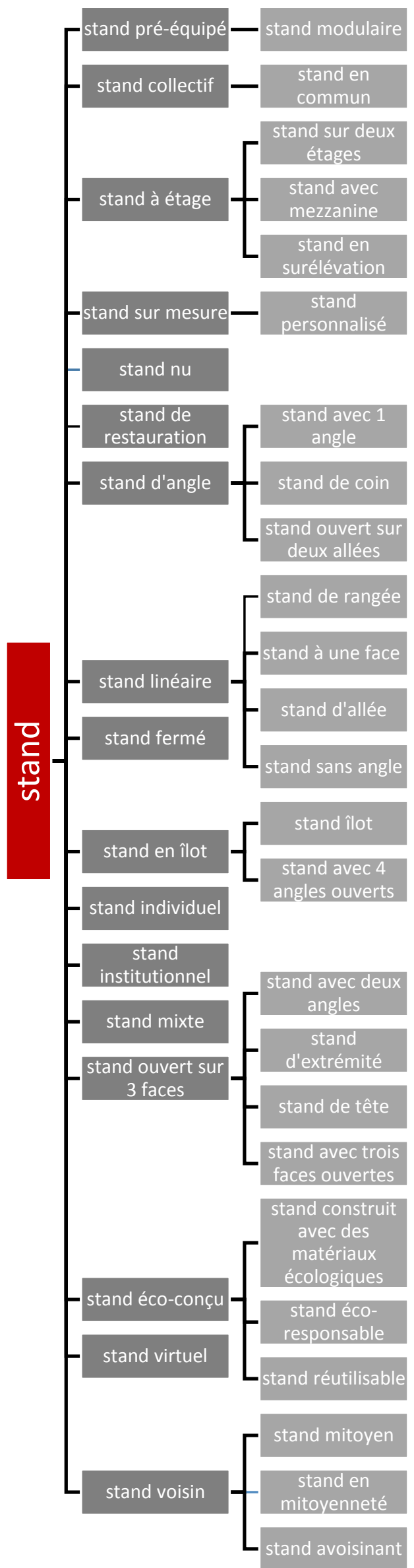


Figura 10: Variantes do termo stand em italiano

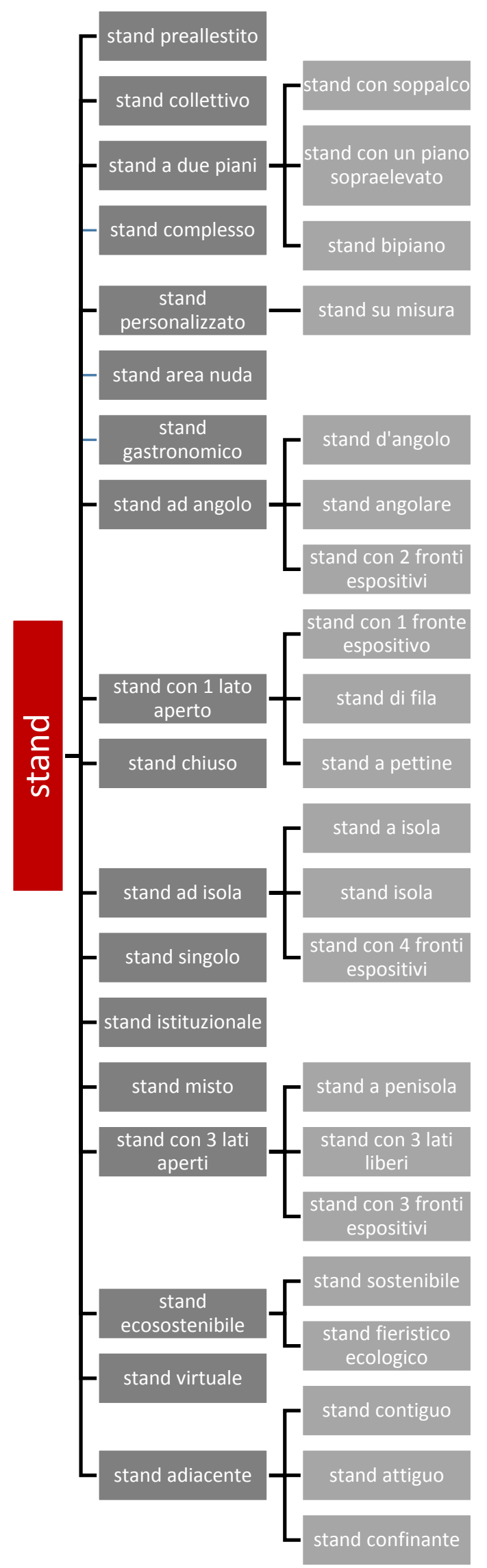


De igual modo, destacamos três hipônimos de "estande", escolhidos devido a sua chavicidade dentro do domínio estudado, e suas variantes em português, inglês, francês e italiano, demonstrando a evidente relação de hiperonímia-hiponímia-sinonímia entre eles, como pode ser observado abaixo:

Quadro 24: Termo "estande com mezanino"

\begin{tabular}{|l|l|}
\hline hiperônimo & estande \\
\hline hipônimo em português & estande com mezanino \\
\hline sinônimos (variantes) & $\begin{array}{l}\text { estande com piso superior; estande de dois andares; } \\
\text { mezanino }\end{array}$ \\
\hline hiperônimo & stand \\
\hline hipônimo em inglês & double-decker stand \\
\hline sinônimos (variantes) & $\begin{array}{l}\text { two-storey stand; double-deck stand; mezzanine; multi- } \\
\text { level stand; } \text { multi-storey stand; twin decked stand; stand } \\
\text { with two floors }\end{array}$ \\
\hline hiperônimo & stand \\
\hline hipônimo em francês & stand à étage \\
\hline sinônimos (variantes) & $\begin{array}{l}\text { stand à l'étage; stand en surélévation; stand sur deux } \\
\text { étages; stand avec mezzanine; stand avec étages }\end{array}$ \\
\hline & stand \\
\hline hiperônimo & stand a due piani \\
\hline hipônimo em italiano & $\begin{array}{l}\text { stand con soppalcho; stand com un piano sopraelevato; } \\
\text { stand bipiano; stand pluripiano; stand multipiano }\end{array}$ \\
\hline sinônimos (variantes) &
\end{tabular}

Quadro 25: Termo "estande de uma face"

\begin{tabular}{|l|l|}
\hline hiperônimo & estande \\
\hline hipônimo em português & estande de uma face \\
\hline sinônimos (variantes) & $\begin{array}{l}\text { estande com uma frente; estande em linha; estande } \\
\text { meio de ilha }\end{array}$ \\
\hline & \\
\hline hiperônimo & stand \\
\hline hipônimo em inglês & one open side stand \\
\hline sinônimos (variantes) & row stand; linear stand \\
\hline & stand \\
\hline hiperônimo & stand linéaire \\
\hline hipônimo em francês & $\begin{array}{l}\text { stand de rangée; stand d'allée; stand à une face; stand } \\
\text { sans angle }\end{array}$ \\
\hline sinônimos (variantes) & stand \\
\hline & stand con 1 lato aperto \\
\hline hiperônimo & $\begin{array}{l}\text { stand in linea; stand con 1 fronte espositivo; stand di } \\
\text { fila; stand a pettine }\end{array}$ \\
\hline hipônimo em italiano \\
\hline sinônimos (variantes)
\end{tabular}

Quadro 26: Termo "estande ilha"

\begin{tabular}{|l|l|}
\hline hiperônimo & estande \\
\hline hipônimo em português & estande ilha \\
\hline sinônimos (variantes) & estande de meio de quadra; estande em ilha; estande \\
\hline
\end{tabular}




\begin{tabular}{|l|l|}
\hline & em formato de ilha; ilha \\
\hline hiperônimo & stand \\
\hline hipônimo em inglês & island stand \\
\hline sinônimos (variantes) & island site; open space stand; island booth \\
\hline & \\
\hline hiperônimo & stand \\
\hline hipônimo em francês & stand en îlot \\
\hline sinônimos (variantes) & $\begin{array}{l}\text { stand îlot; } \text { stand bénéficiant d'angles; stand avec 4 } \\
\text { angles ouverts }\end{array}$ \\
\hline & \\
\hline hiperônimo & stand \\
\hline hipônimo em italiano & stand ad isola \\
\hline sinônimos (variantes) & $\begin{array}{l}\text { stand isola; stand a isola; stand con 4 fronti espositivi; } \\
\text { isole }\end{array}$ \\
\hline
\end{tabular}

Pelo exposto nos quadros 24 a 26 e nas figuras 7 a 10, podemos observar que, na terminologia das feiras de negócios nas quatro línguas, a relação semântica de hiperonímiahiponímia está embasada no processo de criação de novos termos por meio da especificação do termo de base, ou seja, pelo acréscimo de uma característica específica que o difere do termo geral, como será apresentado mais adiante. Como vimos, as variantes encontradas são coocorrentes (sinônimas) e concorrentes (sintáticas). Lembrando que a categoria das variantes coocorrentes que congrega variantes "que têm duas ou mais denominações para um mesmo referente" (FAULSTICH, 2001, p. 21), ou seja, sinônimos, é a mais recorrente nessa área. Vale mencionar que não há variantes competitivas neste estudo, pois nos exemplos apresentados o termo stand não está em competição com outro termo da língua. Devido à sua importância e abrangência, apresentamos outros exemplos de sinônimos encontrados no repertório terminológico das feiras de negócios, a saber:

Quadro 27: Variantes coocorrentes (sinônimos)

\begin{tabular}{|l|l|}
\hline & VARIANTES COOCORRENTES \\
\hline feira de negócios & feira comercial (port.) \\
\hline corredores do pavilhão & vias de circulação do pavilhão (port.) \\
\hline consumer show & consumer fair; B2C show (ing.) \\
\hline trade show & trade fair; B2B show (ing.) \\
\hline manuel de l'exposant & guide de l'exposant (fr.) \\
\hline
\end{tabular}




\begin{tabular}{|l|l|}
\hline montage du stand & assemblage du stand (fr.) \\
\hline smontaggio dello stand & disallestimento dello stand; sgombero dello stand (it.) \\
\hline fiera & manifestazione fieristica; manifestazione; rassegna (it.) \\
\hline
\end{tabular}

A seguir, apresentamos nossas reflexões acerca de uma característica fundamental observada nesse domínio: a variação

A insconsistência terminológica no domínio das feiras de negócios: variação

Como vimos, além da relação de hiperonímia-hiponímia-sinonímia, existe no setor feirístico uma outra característica muito relevante, a variação. A variação terminológica no domínio das feiras de negócios é vastíssima e as causas para tanto estão sendo estudadas. À medida que a área se desenvolve, novos hipônimos são criados (pela adição de especificadores aos termos de base, como foi citado anteriormente e será retomado em detalhes no próximo subitem), o que dá lugar à variação em termos de sinônimos. Como pôde ser observado durante os estágios de pesquisa no exterior, mais especificamente durante as visitas às feiras, diferentes organizadoras de feiras dentro da Itália, por exemplo, utilizam diferentes termos para designar as mesmas noções, conforme descrito a seguir:

- FIERA MILANO (norte da Itália): utilizam o termo noleggio dello stand para "aluguel de estande" em português;

- VERONA FIERE (norte da Itália): utilizam o termo locazione dello spazio espositivo para "aluguel de estande" em português;

- RIMINI FIERA (centro-sul da Itália): utilizam o termo affitto dello stand para designar o mesmo conceito;

- VEBOFIERA (sul da Itália): utilizam o termo locazione dell'area espositiva para designar o mesmo conceito;

- BOLOGNA FIERE (centro-norte da Itália): $\underline{1}^{\text {a }}$ entrevista - utilizam os termos locazione dello spazio espositivo; locazione dell'area espositiva e locazione dello stand como sinônimos de "aluguel de estande" em português; $2^{\mathrm{a}}$ entrevista - informaram o termo affitto dello spazio espositivo para designar o mesmo conceito.

Do mesmo modo, o Manual do expositor da FOIRE D'AUTOMNE de 2012, por exemplo, utilizou o termo halls d'exposition para designar "o local dentro do centro de exposições onde ocorre a feira", como pode ser visualizado em: "Pour pénétrer à l'intérieur des halls d'exposition, toute personne doit être munie d'un badge d'accès [...]". Em contrapartida, o Manual do expositor da FOIRE D'AUTOMNE de 2015, ou seja, três anos mais tarde, utilizou 
o termo pavillon d'expositions para designar o mesmo conceito, como descrito a seguir: "Pour pénétrer à l'intérieur du pavillon d'expositions, toute personne doit être munie d'un badge d'accès $[. .$.$] ". Estamos falando aqui de uma mesma feira, de uma mesma organizadora e de um$ mesmo manual do expositor.

Igualmente, em uma entrevista com a organizadora do Salon du Chocolat, em Paris, ela afirmou que: “[...] não há uma padronização dessa terminologia na França; cada organizadora utiliza a sua própria terminologia; as empresas que organizam as feiras não conversam entre si; é um setor muito fechado".

Esse cenário, portanto, gera um alto índice de variação nessa terminologia. Como consequência, observamos uma inconsistência terminológica em nível intralingual, no interior de uma mesma feira (e mesma organizadora) e no interior de diferentes feiras, com organizadoras distintas, dentro do mesmo país. O que dizer das feiras que acontecem em diferentes países e em idiomas diferentes? Como podemos contribuir para amenizar esse problema? Informando aos consulentes os termos mais comumente utilizados pelas organizadoras de feiras em cada país, apontando os demais como variantes.

A seguir, listamos mais alguns exemplos de variação terminológica encontrada nos corpora de estudo nas quatro línguas:

1. Fiera di roma: motore dello sviluppo territoriale: apresenta três variantes para quartiere fieristico: quartiere, quartieri espositivi, centro fieristico; duas variantes para "eventos paralelos": eventi collaterale e eventi paralleli

2. Manual de participação em feiras internacionais: utiliza "co-expositor" e "co-exibidor" no mesmo contexto

3. Vente en foires et en salons spécialisés: utiliza duas variantes para demande de participation: bulletin d'admission e dossier d'admission

4. Guide technique de l'exposant Paris Nord Villepinte 2016: utiliza as variantes carte d'invitation e carton d'invitation. Em 2015, apresenta o termo cloisons de séparation entre les stands e, em 2016, cloisons de séparation entre les stands mitoyens

5. Aprés l'exposition: traz display (estrangeirismo) e présentoir como sinônimos

6. Regolamento generale di manifestazione Sigep: o manual de 2016 utiliza o termo stand con 3 fronti espositivi e o manual de 2018 utiliza o termo stand a penisola para denominar o "estande com 3 lados abertos"; utiliza ainda as variantes catalogo ufficiale di manifestazione e catalogo della manifestazione para o termo "catálogo oficial da feira" em português

7. Progetto Fiera: Fiera Bolzano: utiliza as variantes stand di barriera e stand parzialmente chiuso; utiliza também as variantes catalogo ufficiale della fiera, catalogo della fiera e catalogo ufficiale para se referir ao "catálogo oficial da feira"

8. Guide exposant Milipol Paris 2015: utiliza os termos stand construit avec des materiaux écologiques e stand réutilisé para o mesmo conceito

9. Realizzare uno stand fieristico ecologico: apresenta as variantes stand fieristico ecologico e stand ecosostenibile

10. Fertility 2017 exhibitor manual: utiliza as variantes overseas exhibitors e exhibitors from overseas 
11. Euro Fair Statistics 2010: main exhibitor e direct exhibitor

12. Legge quadro sul settore fieristico, 11 gennaio 2001: apresenta os termos manifestazioni fieristiche e rassegna como sinônimos. Como pode ser observado, até mesmo no interior de uma lei italiana sobre feiras, não há uma padronização da terminologia

13. Le professioni del settore fieristico: Il caso di Fiera Milano: fiera per il consumatore e fiere dirette al consumatore

14. General Information NEC Birmingham 2015 National Wedding Show: goods removal form e official goods removal form

15. Guide de l'exposant Foire de Marseille: utiliza quatro variantes no mesmo manual: guide technique de l'exposant, guide de l'exposant, guide technique e guide technique du salon

16. Regolamento tecnico SIGEP 2018: materiali esposti, prodotti esposti, materiali ed $i$ campioni esposti

17. Mipimuk 2016 exhibitor manual: utiliza stand contractor ou simplesmente contractor

18. eguide 2011 UK Common Regulative Policy for Major UK Exhibition Venue: stand construction e stand building. É um texto sobre normas reguladoras de feiras e utiliza variantes, não há uma padronização

19. Foire Européenne 2014 Guide Technique de l'exposant: utiliza cloisons de séparation e cloisons mitoyennes no mesmo documento. A lei Règlement général des manifestations commerciales utiliza o termo panneaux de cloisonnement para denominar as "paredes divisórias entre os estandes". Entretanto, as organizadoras de feiras utilizam outras denominações em seus manuais, a saber: cloison de séparation entre les stands; cloisons de séparation; cloisons de séparation entre les stands mitoyens; cloisons mitoyennes; cloison de mitoyenneté; cloisons de mitoyenneté avec le stand voisin; cloisons; paroi

20. Guide exposant Foire de Paris 2015 repertoire: ora utiliza pavillons d'exposition, ora utiliza somente pavillons

21. La fiera di successo una guida per gli espositori: post-fiera e dopo-fiera

22. La fiera internazionale: un mezzo per accellerare l'ingresso nel mercato: programa di follow-up; continuità; verifica

23. Guide pratique pour faciliter et guider vos projets de stand - Fédération Française des Métiers de l'Exposition et de l'Événement: règlementation des salons e règlement $d u$ salon

24. Official London Book Fair Contractors Manual 2017: utiliza exhibitor's responsibility; BCSC 2016 Manchester Exhibitor Manual: utiliza exhibitors responsabilities (exemplos de variantes ortográficas em inglês, com e sem ('s))

25. Manual digital do Expositor Feira APAS 2016: "responsável pelo estande" e "responsável do estande"

26. Manuale come in fiera: responsabile di stand e responsabili dello stand

27. Avant l'exposition: les grandes allées e les allées les plus fréquentées de la manifestation

28. EXPOMED nuovo polo fieristico: corridoio centrale della fiera (com descritor) e corridoio centrale (sem descritor)

29. Documento unico di valutazione dei rischi: quartiere fieristico di Bologna ARTEFIERA 2015: utiliza corsie trasversali; Documento unico di valutazione dei rischi: Quartiere Fieristico di Carrara TIRRENO CT \& BALNEAREA 2017: utiliza corsie longitudinali. São documentos muito parecidos e, ainda assim, os centros de exposição de Bolonha e Carrara utilizam termos diferentes para designar as "ruas transversais" dentro do pavilhão

30. Introduction to how trade shows work: trade show attendee e show attendee. 
À título de exemplificação, apenas para o termo "estande" (e seus hipônimos) foram encontradas: 14 variantes em português; 22 variantes em inglês; 47 variantes em francês e 52 variantes em italiano, perfazendo um total de 135 variantes.

Esses números corroboram o que foi observado nas pesquisas de campo nos três países: a terminologia das feiras de negócios em francês e em italiano apresenta uma maior variação terminológica, e consequentemente, uma menor padronização, em comparação à terminologia em inglês e em português que, embora presente, ocorre em menor escala. Podemos inferir desse fato que a terminologia em português tenha se baseado na terminologia em inglês, sendo essa provavelmente a primeira a ser sistematizada na área, por se tratar de uma atividade internacional (e o inglês, ser considerado a língua global).

Como vimos no Capítulo 1, a Terminologia, com " $t$ " maiúsculo, é a "ciência que estuda a estrutura, a formação, o desenvolvimento, o uso e a gestão das terminologias de diferentes domínios" (ISO 1087, 2000, p. 10). Entretanto, testemunhamos que a terminologia das feiras de negócios não possui um órgão regulador que crie e supervisione essa terminologia, especialmente em francês e italiano, onde há uma extensa variação terminológica nesse domínio. O mesmo ocorre em inglês e em português, mas em grau um pouco menor, o que sugere que exista uma certa padronização dos termos e uma menor variação nessas duas línguas.

Desse fato, surgiu a necessidade da elaboração do Dicionário Multilígue de Termos do Setor Feirístico que busca, portanto, ser fonte de recomendação de termos mais comumente utilizados nos quatro idiomas e ferramenta monolíngue de auxílio à uniformização da terminologia no interior de cada língua.

Ao analisarmos, por exemplo, em português, o hiperônimo "estande", seu hipônimo “estande com mezanino" e suas variantes (sinônimos) "estande com piso superior", "estande com dois pisos", "estande com pavimento superior" e "estande de/com dois andares"; em inglês, o hiperônimo stand, seu hipônimo double decker stand e suas variantes (sinônimos) twostorey stand, double-storey stand e twin decked stand; em francês, o hiperônimo stand, seu hipônimo stand à étage e suas variantes (sinônimos) stand sur deux étages, stands avec étages, stand avec mezzanine e stand en surélévation; em italiano, o hiperônimo stand, seu hipônimo stand a due piani e suas variantes (sinônimos) stand con soppalco, stand con un piano sopraelevato e stand bipiano, concordamos com Duquet-Picard (1982) e Oliveira (2001) que os sinônimos terminológicos (variantes) são "hipônimos concorrenciais de mesmo nível". Tanto isso é verdade que neste domínio diferentes denominações são utilizadas por diferentes organizadoras de feiras dentro de um mesmo país para designar as mesmas noções. Até mesmo no interior de uma mesma organizadora, encontramos diferentes denominações para um mesmo 
conceito, como foi mencionado anteriormente. Tudo isso nos revela algo importante sobre essa terminologia: existe uma co-ocorrência entre as variantes neste domínio.

Assim, a análise do comportamento dos termos, de sua constituição, de sua formação, bem como a confirmação de especialistas, nos fez inferir que em uma área pouco estudada e pouco sistematizada linguística e terminologicamente, na qual não haja uma padronização e, principalmente, uma supervisão de sua terminologia, as variantes (sinônimos) possuem o mesmo prestígio e importância de seu hipônimo, estão em um mesmo nível e co-ocorrem nos mesmos contextos. Logo, podemos afirmar que a relação hiperonímia-hiponímia está presente também na variação, já que as variantes, assim como seu hipônimo, estão em relação com o hiperônimo do qual derivam. Em outras palavras, stand à étage e suas variantes são hipônimos de stand, como pode ser observado nas figuras 11 e 12 a seguir:

Figura 11: relação hiperonímia-hiponímia-sinonímia em 3 níveis

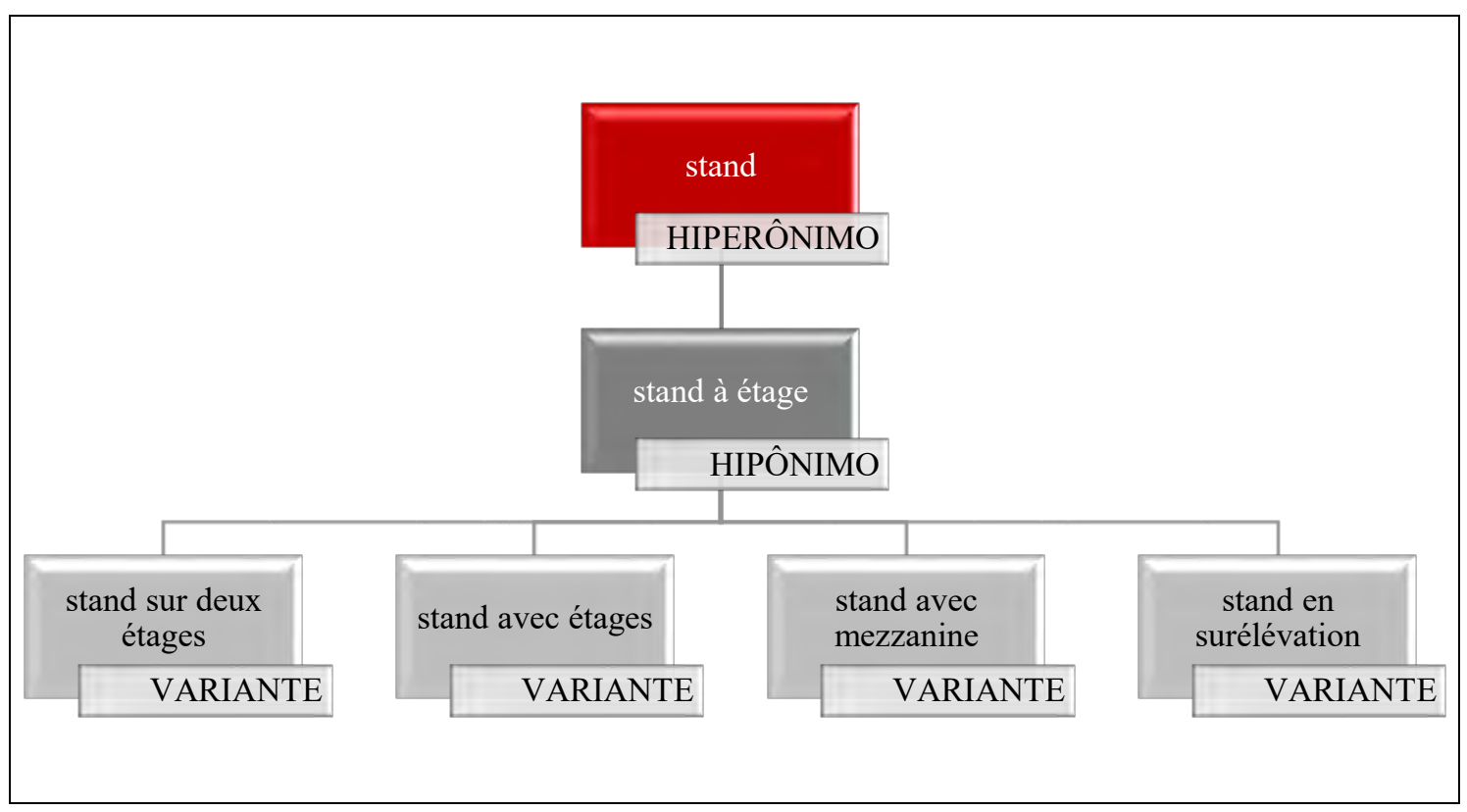

Fonte: elaborado pela autora

$\mathrm{Na}$ terminologia das feiras de negócios, entretanto, o hipônimo e suas variantes coocorrem e estão no mesmo nível: 
Figura 12: relação hiperonímia-hiponímia-sinonímia em 2 níveis

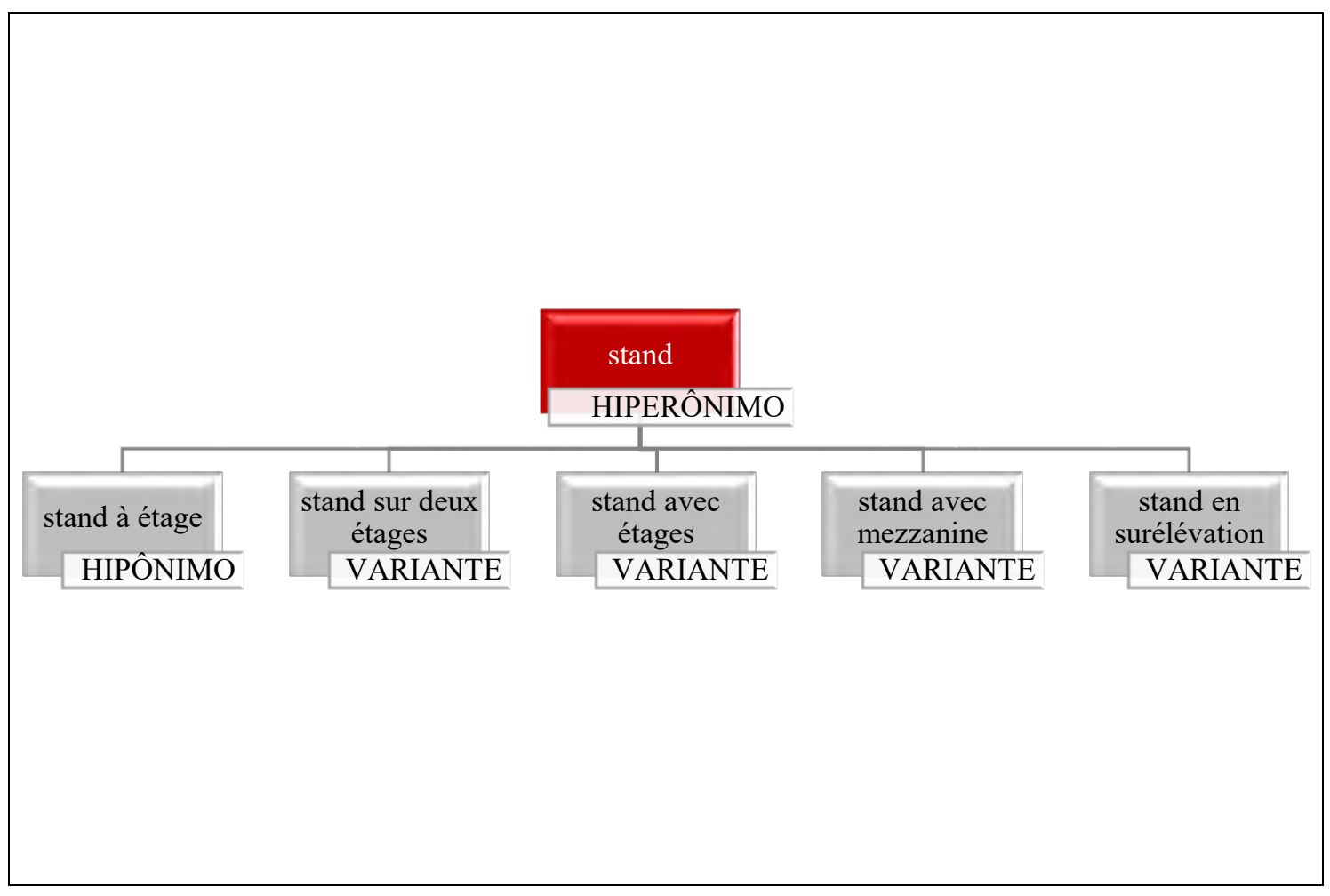

Fonte: elaborado pela autora

Como pôde ser observado nas figuras 11 e 12, essa maneira de criar novos termos acrescentando um especificador ao hiperônimo contribui para a expressiva variação encontrada na área, uma vez que as variantes, em sua grande maioria, obedecem o mesmo padrão constitutivo, ou seja, são formadas por meio da especificação do hiperônimo do qual derivam e estão, pelo uso, no mesmo nível de seu hipônimo e são, portanto, hipônimos bilaterais ou simétricos (cf. Lyons, 1977, p. 292). Em outras palavras, a variante stand avec mezzanine está em relação com seu hiperônimo stand, foi formada a partir dele, por meio da adição de especificadores (avec (preposição) + mezzanine (substantivo)) e está em relação de sinonímia com o seu hipônimo stand à étage. Esta relação é permeada pelo uso indiferenciado na área dos termos (hipônimo e suas variantes), ou seja, de maneira intercambiável, o que os coloca no mesmo nível. Do mesmo modo, entre estande com mezanino (hipônimo) e estande de dois andares (sinônimo) também existe uma relação de hiponímia bilateral ou simétrica, cristalizada pelo uso na área, que os colocam no mesmo nível. Assim, as variantes não estão mais em um terceiro nível, como esperado, mas sim, no mesmo nível de seu hipônimo devido ao uso na área, conforme observado nas pesquisas de campo e confirmado nas entrevistas com os especialistas. Desse modo, tanto as variantes como seu hipônimo estão em relação direta com o hiperônimo do qual se originaram, reafirmando, assim, que a hiperonímia, nessa área, está presente também 
na variação. E o uso indiferenciado, de forma permutável, tanto do hipônimo como das variantes, corrobora a relação entre hiperonímia e hiponímia na variação terminológica, o que configura a contribuição deste trabalho para os Estudos da Tradução e Terminológicos, uma vez que essa relação poderá ser vislumbrada em outras áreas do conhecimento pouco estudadas, como é o caso das feiras de negócios, sendo, portanto, passível de generalização e utilização em Terminologia. Apresentamos, a seguir, um estudo sobre a constituição interna dessa terminologia, o que corrobora a questão da hiperonímia nessa área.

Entendendo a terminologia das feiras de negócios: da constituição interna das unidades fraseológicas à organização da microestrutura do dicionário

Durante o desenvolvimento deste trabalho, observamos que o setor feirístico é bastante produtivo em termos complexos. Para lidar com essa questão, principalmente em relação à microestrutura do dicionário, resolvemos nos debruçar mais detidamente sobre seu entendimento considerando suas relações de equivalência (DUBUC, 1985, 1992). Para tanto, começamos a tratar esses termos como "unidades fraseológicas", ou seja, "combinações estáveis formadas pelo menos por duas palavras gráficas" (CORPAS PASTOR; FLORENTINA, 2004), conforme mencionamos no subitem 2.8, e a olhar com mais atenção para esse inventário com base na Linguística de Corpus, um dos estudos que faz a fraseologia avançar de modo interdisciplinar (CORPAS PASTOR, 2017). O estudo do termo "estande", de seus equivalentes nas outras três línguas e das unidades fraseológicas formadas a partir deles nos ajudou a entender um pouco melhor a constituição interna da área e de sua terminologia para aperfeiçoar a organização da microestrutura do dicionário.

Como dissemos anteriormente, a terminologia das feiras de negócios é constituída essencialmente de unidades fraseológicas formadas por um termo base e um especificador. Apresentamos, a seguir, o termo "estande" e alguns de seus colocados nas 4 línguas. Esse estudo foi realizado durante o estágio de pesquisa no exterior por meio da ferramenta Sketch Engine (KILGARRIFF; RYCHLÝ 2003), mais especificamente da ferramenta Word Sketch que traz os colocados do termo base de forma resumida em uma única tela.

$\mathrm{O}$ conhecimento da estrutura interna da terminologia relacionada às feiras de negócios nos trouxe um maior entendimento da própria área, mostrando as tendências linguísticas das línguas envolvidas, suas preferências singulares e suas semelhanças. Dentre as estruturas mais frequentes, podemos citar o acréscimo de um adjetivo a um substantivo, de uma preposição e de um substantivo a um substantivo, de um substantivo derivado de verbo e de uma preposição 
a um substantivo. A seguir, apresentamos a formação das unidades fraseológicas relacionadas a "estande" (pt) e stand (ing., fr., it.), com as estruturas preferenciais nas quatro línguas, o que reforça a questão da hiperonímia nesta área:

\section{PORTUGUÊS}

substantivo ${ }^{139}+$ adjetivo: estande coletivo

substantivo + preposição + substantivo: estande com mezanino

substantivo + preposição + numeral + substantivo: estande de dois andares $(\mathrm{v})^{140}$

substantivo + preposição + substantivo + adjetivo: estande com piso superior (v)

substantivo derivado de verbo + preposição(+artigo) + substantivo: desmontagem do estande

outros substantivos + preposição(+artigo)+ substantivo: número do estande

outros substantivos + adjetivo + preposição(+artigo) + substantivo: comunicação visual do estande

Quadro 28: Constituição interna das unidades fraseológicas em português

\section{INGLÊS}

adjetivo + substantivo: shared stand (v)

substantivo + substantivo: island stand

substantivo + preposição + numeral + substantivo: stand with two floors (v)

adjetivo + substantivo + substantivo: custom-built exhibition stand

substantivo + substantivo derivado de verbo: stand building

substantivo + outros substantivos: stand graphics

Quadro 29: Constituição interna das unidades fraseológicas em inglês

\section{FRANCÊS}

substantivo + adjetivo: stand personnalisé (v)

substantivo + preposição + substantivo: stand en surélévation (v)

substantivo + adjetivo + preposição + (artigo/numeral) + substantivo: stand ouvert sur deux allées

(v)

substantivo + preposição + numeral + substantivo: stand sur deux étages (v)

substantivo + preposição + numeral + substantivo + adjetivo: stand avec deux angles ouverts (v)

substantivo derivado de verbo + preposição(+artigo) + substantivo: location du stand

substantivo + adjetivo + preposição $+($ artigo/numeral $)+$ substantivo: support audio-visuel sur le stand

outros substantivos + preposição(+artigo) + substantivo: moquette du stand

outros substantivos + adjetivo + preposição + substantivo: mètre carré de stand

Quadro 30: Constituição interna das unidades fraseológicas em francês

ITALIANO

substantivo + adjetivo: stand preallestito

substantivo + preposição + substantivo: stand con soppalcho (v)

substantivo + preposição + numeral + substantivo + adjetivo: stand con 4 latti aperti (v)

substantivo + substantivo + adjetivo: stand area nuda

substantivo + preposição + substantivo + adjetivo: stand in area libera (v)

substantivo + preposição + numeral + substantivo: stand a due piani

substantivo + adjetivo + preposição + substantivo: stand progettato ad hoc (v)

substantivo derivado de verbo + preposição(+artigo) + substantivo: smontaggio dello stand

substantivo derivado de verbo + preposição(+artigo) + substantivo + adjetivo: locazione della area espositiva

outros substantivos + preposição(+artigo) + substantivo: grafica dello stand

${ }^{139}$ substantivo $=\mathrm{TB}=$ termo de base (hiperônimo)

${ }^{140} \mathrm{v}=$ variante. 
outros substantivos + adjetivo + preposição(+artigo) + substantivo: metro quadrato dello stand

Quadro 31: Constituição interna das unidades fraseológicas em italiano

Como podemos observar, a constituição interna das variantes (v) também parte da especificação do termo de base (hiperônimo) como, por exemplo, em: stand + personnalisé, descrito no quadro 30. Do mesmo modo, existem padrões que se repetem nas quatro línguas, como aqueles que têm especificadores derivados de verbos. Tais substantivos derivados de verbos referem-se a ações, como pode ser visualizado a seguir:

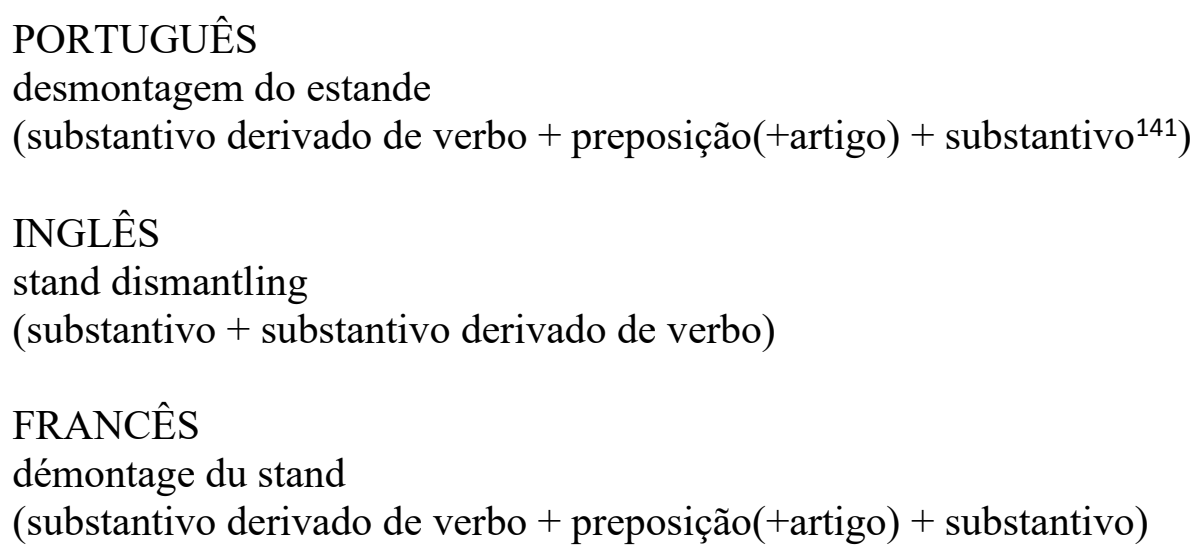

\section{ITALIANO}

disallestimento dello stand

(substantivo derivado de verbo + preposição(+artigo) + substantivo)

A própria descrição de tais termos em dicionários, embora circular, evidencia seu caráter acional: desmontagem - ato ou efeito de desmontar; dismantling - do verbo dismantle: take (a machine or structure) to pieces; démontage - action de démonter; disallestimento - ação contrária ao verbo allestire: preparare, mettere a punto, approntare. A ocorrência desse tipo de padrão nas quatro línguas corresponde, a nosso ver, ao aspecto dinâmico da área cujo inventário de unidades fraseológicas eventivas (cf. BEVILACQUA, 2004) designa em grande parte ações a serem empreendidas pelos sujeitos envolvidos (organizadores, promotores, expositores, visitantes, tradutores, intérpretes, staff, etc.). Demos especial atenção a esta construção que se repete nos quatro idiomas e permite entender a área como um domínio dinâmico e acional.

Os verbos que acompanham os termos base do setor feirístico nos quatro idiomas, e que com eles constituem fraseologismos, são em sua maioria igualmente dinâmicos, ou sejam, comunicam uma ação. Destacam-se, por exemplo, para o termo "estande", os verbos do português montar, desmontar, projetar, visitar, decorar, limpar; para stand, em inglês, build, design, book, visit, dismantle, plan, dress, rent; em francês, com stand, monter, démonter,

\footnotetext{
${ }^{141}$ substantivo $=\mathrm{TB}($ termo de base $)$
} 
visiter, louer, décorer, nettoyer; para stand, os verbos em italiano allestire, disallestire, vigilare, visitare, progettare, pulire. Contudo, vale mencionar que para esse dicionário trabalhamos preferencialmente com substantivos.

Outros tipos de unidades fraseológicas também permitem entrever o caráter dinâmico da área, como as que reapresentamos a seguir (cf. citado na página 143), muito recorrentes nas quatro línguas:

\begin{tabular}{|l|l|}
\hline PORTUGUES & antes, durante e após (a feira) \\
INGLÊS & before, during and after (the fair) \\
FRANCÊS & avant, pendant ou après (la foire) \\
ITALIANO & prima, durante e dopo (la fiera) \\
\hline
\end{tabular}

Os advérbios e preposições que formam essas quatro unidades designam temporalmente ações acompanhando verbos dinâmicos, como por exemplo "prospectar novos clientes para fechar negócios antes, durante e após a feira"; "connect with buyers before, during and after the show" (fair); "personnes et sociétés à contacter avant, pendant ou après la manifestation" (foire); "comunicare con i potenziali clienti prima, durante e dopo la fiera". Em francês, encontramos também o fraseologismo "période de montage, ouverture et démontage", frequente nos manuais do expositor e utilizado na prática pelas organizadoras de feiras na França, bem como "fase di allestimento e disallestimento" em italiano e "build up and breakdown times" em inglês.

O conhecimento da organização interna da terminologia do setor feirístico nos proporcionou um maior entendimento da própria área e, por conseguinte, uma reflexão acerca da constituição dos verbetes do dicionário. Como grande parte das unidades fraseológicas em estudo é formada por um termo base e um especificador (inclusive no que diz respeito à constituição das variantes), a microestrutura do dicionário poderá também espelhar essa estrutura, colocando o termo base como entrada do verbete, seguida de sua definição e seus equivalentes e as unidades fraseológicas correspondentes como subentradas, com seus equivalentes, como apresentado a seguir:

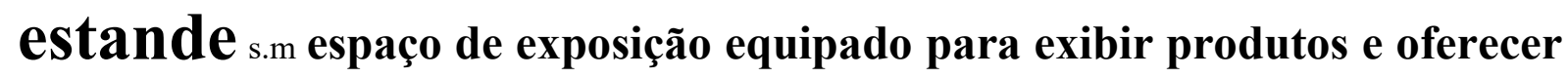
serviços em feiras. O estande é como a vitrine do produto ou serviço a ser divulgado e negociado, estrutura em que se materializa a participação de empresas numa feira e, como tal, não devem ser poupados esforços na sua elaboração. É a imagem que tem por objetivo chamar a atenção do público-alvo (MOFE). 
stand (ing.) n., stand (fr.) n.m., stand (it.) s.m.

estande ilha port. estande aberto com faces para os quatros corredores. Entende-se por ilha os estandes que fazem divisa com as 4 vias de circulação. As paredes dos estandes ilha não deverão obedecer à tabela de recuo, somente altura máxima. Os estandes não poderão impedir a visualização interna do estande e das laterais que estejam voltadas para as vias de circulação (MEFeip).

island stand ing. (block stand) The block stand or island stand, the most expensive type of stand, is accessible for visitors from all sides and attracts a great deal of attention due to the fact that it is completely isolated from all other stands (SPTFTE).

stand en îlot fr. (stand îlot) Le stand en îlot est entouré de couloirs. Puisqu'il est accessible aux visiteurs de tous les cotés, il attire une grande partie de l'attention, en raison de sa totale indépendance des autres stands. Ce type de stand est le plus cher. Il requiert un design plus élaboré, qui se reflète dans des coûts plus élevés pour l'assemblage et l'aménagement du stand (CUf). Le stand îlot: ouvert sur 4 côtés, 4 allées (GPFGPS).

stand ad isola it. (stand isola; stand a isola; stand con 4 fronti espositivi) Nel caso di occupazioni di stand ad isola (4 lati aperti) ed a penisola (3 lati aperti), gli allestimenti dovranno limitare l'utilizzo di pareti perimetrali (RGMS). Lo stand isola è circondato da corsie lungo tutto il perimetro. Essendo accessibile da ogni lato e indipendente dagli altri stand, attira molto l'attenzione dei visitatori. Questo tipo di stand è il più costoso; richiede infatti un progetto più complesso che impone costi di montaggio e allestimento più elevati (URFMM). Potremo pertanto avere stand a isola o a penisola, rispettivamente con quattro o tre lati liberi (MFFM). Art. 17 - Le aree espositive sono tenute in condizioni di visibilità ed accessibilità. Il canone di partecipazione relativo alle aree interne ai Padiglioni, per area nuda e per tutta la durata della fiera, è così differenziato: [...] stand con 3 fronti espositivi; $\epsilon$ 224,00/mq - stand con 4 fronti espositivi (RGMS).

Como já dissemos, a criação de novas unidades fraseológicas nesse domínio, constituído de poucos termos base, dá-se por especificação. A natureza desse perfil terminológico da área ainda está em investigação, mas talvez tenha relação histórica, uma vez que a origem das feiras para a humanidade é insondável e remota, mas seus elementos de base, que a própria história nos ajuda a entrever, diferentemente de outras áreas, como a economia, na qual abundam neologismos ${ }^{142}$, são poucos: o local de exposição (estande), o pavilhão, o expositor, o visitante, o produto e o organizador.

142 O projeto TermNeo (Observatório de Neologismos Científicos e Técnicos do Português Brasileiro Contemporâneo), sob a coordenação da Profa. Dra. Ieda Maria Alves, tem se dedicado, desde 1993, a coletar e analisar a neologia do português contemporâneo do Brasil com base em um corpus jornalístico constituído por jornais (Folha de S. Paulo e O Globo) e revistas de divulgação (IstoÉ e Veja). 
De todo modo, a relação entre o termo base e seus especificadores espelhada no verbete poderá auxiliar o consulente, seja ele tradutor, intérprete, aprendiz ou professor, leigo ou especialista, a entender a própria constituição interna da área das feiras de negócios (indispensável para o trabalho de busca das equivalências) e a comunicar-se de forma mais produtiva e eficaz nesse domínio. A seguir, apresentamos algumas reflexões acerca dos problemas de tradução encontrados na busca pelas equivalências.

\section{Problemas de tradução encontrados na busca pelas equivalências}

Em relação aos problemas de tradução encontrados na busca pelas equivalências, podemos citar, por exemplo, o termo "feira especializada" e seu equivalente em francês, conforme mencionado no início desse capítulo. Encontramos para esse termo o equivalente em inglês specialised trade show, o equivalente em italiano, fiera specializzata e o equivalente em francês, salon specialisé. Não encontramos em nossos corpora de estudo em francês o termo foire specialisé, como era esperado, o que nos fez refletir que o termo "feira" nem sempre será traduzido por foire, já que isso depende do contexto, da frequência e do uso na língua. O mesmo ocorreu com o termo "feira de consumo". No inglês, encontramos o termo consumer show, no italiano, fiera per consumatore e no francês, salon grand public. Essa questão foi observada claramente durante os estágios no exterior. Não existe um consenso sobre a utilização do termo foire e salon entre as organizadoras de feiras na França. A maioria utiliza o termo salon. A única feira que visitei que se chamava foire foi a Foire de Paris, uma feira muito tradicional na França. Além disso, elas também se referem à feira por manifestation commerciale ou, simplesmente, manifestation. Na Itália, aconteceu algo parecido. Muitas organizadoras de feiras se referiam à "feira" como salone, manifestazione commerciale ou manifestazione. O termo fiera também era utilizado em italiano (com menos frequência), mas não existe uma diferenciação clara e objetiva entre fiera e salone, eles são utilizados de maneira intercambiável. De igual modo, na Inglaterra, as organizadoras de feiras utilizam o termo trade show, ou simplesmente show para se referirem às feiras de negócios. Não utilizam jamais o termo trade fair ou fair e afirmam que se trata de um termo europeu (como se a Inglaterra não estivesse localizada na Europa...). Tanto o termo trade show (ou, simplesmente, show), como o termo exhibition são utilizados. O primeiro pressupõe público especializado e foco em um segmento da indústria; o segundo, público geral, e foco em mais de um segmento da indústria, ambos sendo realizados para a exposição de produtos. 
O termo "estande misto" (port.), por outro lado, é uma combinação do estande básico (padrão) e do estande personalizado. É construído com base de materiais padronizados e acabamentos diversos, personalizados. Entretanto, esse termo não existe em inglês, visto que eles possuem apenas dois tipos de montagens de estandes: shell scheme e space only. Neste caso, um "estande misto" em inglês seria o correspondente ao space only stand, em que o expositor cria o seu próprio estande. No francês, as organizadoras desconhecem o termo stand mixte, bem como na Itália, onde o termo stand misto também não é conhecido. No entanto, encontramos o termo stand modulare que contempla as mesmas características do "estande misto" (combinação de elementos padrão (como no stand preallestito) que permitem, entretanto, uma maior personalização (como no stand su misura)). Para que o consulente tenha uma ideia do que seria o "estande misto" nas outras línguas, tivemos a ideia de utilizar a remissiva V. (shell scheme stand + custom-built stand), no inglês; V. (stand pré-équipé + stand sur mesure) em francês, e V. (stand preallestito + stand su misura) em italiano, explicando na definição em português que se trata de um estande de montagem mista, elaborado com materiais padronizados e acabamentos variados e personalizados.

Em relação ao termo "estande semi-aberto", em português, as organizadoras de feiras na Inglaterra não reconhecem o termo partially open stand, assim como as organizadoras na Itália desconhecem o termo stand parzialmente chiuso. O mesmo se deu na França com o termo stand semi-ouvert que também não é utilizado pelas organizadoras que classificam os estandes em: stand nu ou stand pré-équipé. Entretanto, considerando que encontramos o termo "estande semi-aberto" e seus equivalentes nos corpora de estudo, nas três línguas, resolvemos mantê-los na nomenclatura do dicionário.

Vale mencionar também um caso particular. Todo estande com dois andares ou estande com altura superior a 4 metros é considerado complexo. Assim, explicamos isso na definição em português e utilizamos a remissiva V. "estande com mezanino" e V. "estande construído", no português, uma vez que não encotramos o termo "estande complexo". No inglês, por outro lado, encontramos o termo complex stand e no italiano o termo stand complesso. Do mesmo modo como procedemos no português, acrescentamos as remissivas V. stand sur mesure e V. stand à étage, no francês.

Ao buscar pelos equivalentes do termo "estande individual" (port.), nos deparamos com uma questão na qual não havíamos pensado. No português, "estande individual" é aquele utilizado por apenas uma empresa expositora, ao contrário de um "estande coletivo" no qual diversas empresas compartilham o espaço de exposição. Contudo, na França, quando mostramos o termo stand individuel para a organizadora e explicamos o sentido, ela nos 
respondeu: esse é o stand en îlot, aquele que não tem vizinhos em nenhum dos lados. Essa é, portanto, uma outra perspectiva, uma outra forma de olhar para um mesmo termo. Possui também a característica de exclusividade, mas sob um outro prisma, o que é pertinente mencionar aqui.

Ao procurarmos o equivalente em inglês para o termo "área de exposição" e analisarmos os descritores, encontramos o termo exhibition hall. Como se sabe, hall em inglês é o equivalente de "pavilhão". Assim, percebemos que "área de exposição" e "pavilhão" são equivalentes em português, pois o "pavilhão" é uma área utilizada para a exposição de produtos no interior de estandes. Verificamos ainda que, no inglês, não é utilizado o termo pavilion, somente o termo hall.

Em relação ao termo "contrato de locação de estande", observamos que na França e Itália eles não falam em "contrato" mas em demande de participation e domanda di partecipazione que é um documento no qual o expositor expõe o seu interesse em participar da feira, escolhe o tipo e o tamanho do estande que deseja contratar e assina. Esse documento, após o aceite da organizadora, já funciona como um "contrato de locação de estande". No inglês, o termo utilizado é exhibition space contract.

Ao pesquisarmos junto às organizadoras de feiras na Inglaterra o equivalente em inglês para o termo "estande aberto", elas nos informaram o termo island stand e não open stand. $\mathrm{Na}$ Beauty Show, entretanto, eles nos disseram que esse seria o equivalente ao space only stand, ou seja, aquele que só possui um traço no chão, sem nenhum tipo de montagem. Na França, eles nos disseram que existe o termo stand ouvert sur " $X$ " faces. É necessário informar o número de lados abertos, mas que o termo stand ouvert sozinho não era utilizado. Na Itália, nos informaram que o equivalente seria stand isola, ou seja, estande com 4 lados abertos. Assim, resolvemos colocar o termo "estande aberto" como remissiva do termo "estande ilha", considerando também o fato de "estande aberto" não ser muito frequente em português.

Em relação ao termo "remoção do estande", ao explicarmos o sentido para as organizadoras na França e Itália, elas nos informaram os termos smontaggio dello stand e démontage du stand, respectivamente. Não fazem a distinção entre desmontar o estande primeiro e depois removê-lo. No inglês, encontramos o termo stand removal que tem o mesmo sentido de stand dismantling. Assim, colocamos o termo "remoção do estande" como remissiva do termo "desmontagem do estande".

O termo stand fittings também nos trouxe algumas dificuldades. Seria o equivalente de "decoração do estande", "instalações do estande" ou "mobiliário do estande"? Por meio da análise dos ganchos terminológicos nas 4 línguas percebemos que se trata de itens que são fixos 
no estande após sua montagem como, por exemplo, prateleiras, balcões, etc. Trata-se de uma variante de stand furniture em inglês. Desse modo, o equivalente em português, para stand fittings, é "mobiliário do estande". Por outro lado, o termo stand installations tem a ver com as “instalações do estande" (conexões hidráulicas, de eletricidade e de gás no interior do estande), e o termo stand dressing é mais voltado para a "decoração do estande".

O termo aménagement $d u$ stand também nos trouxe algumas reflexões. A tradução literal de aménagement para o inglês é layout. Contudo, não encontramos layout du stand em francês. Ao analisarmos o termo aménagement em contexto, juntamente com seus descritores, verificamos que se trata da "decoração do estande" e não do layout. Assim, confirmamos com os especialistas na França que o termo utilizado em francês para "layout do estande" é disposition du stand.

Outros termos que precisamos nos debruçar mais detalhadamente foram os termos arredamento e allestimento em italiano. Tivemos a impressão de que o termo allestimento dello stand seria o equivalente de "instalações do estande" (elétrica, hidráulica, etc.), em português. Porém, após uma análise atenta dos contextos e dos ganchos terminológicos, verificamos que se tratava de um sinônimo de montaggio dello stand (montagem do estande). O termo arredamento dello stand, por sua vez, é relativo à colocação de mesas, cadeiras e móveis no estande e tem como equivalente em inglês, o termo stand furniture ou stand fittings. Portanto, também não tem a ver com "instalações do estande" em português. A organizadora da feira em Bolonha, afirmou ainda que arredamento dello stand é diferente de decorazione dello stand que tem a ver com a colocação de elementos gráficos no estande.

Em relação ao termo aisle number, encontramos o equivalente numéro des allées em francês. Contudo, não encontramos o termo "número do corredor" em português e numero delle corsie em italiano. O mesmo se deu para os termos hall number, numéro du pavillon e numero del padiglione. O equivalente "número do pavilhão" em português não foi encontrado, apenas a sua menção: pavilhão 1, pavilhão 2, pavilhão 3, etc. Contudo, após novas consultas, descobrimos o termo "cor do pavilhão" e várias menções a pavilhão vermelho, verde, azul, etc. Então, decidimos utilizar o termo "cor do pavilhão" como entrada no português.

Do mesmo modo, encontramos os termos exhibitor's technical manual e guide technique de l'exposant, mas os equivalentes "manual técnico do expositor" e manuale tecnico dell'espositore não foram encontrados. Nesse sentido, os termos em inglês e em francês foram acrescentados como variantes no verbete "manual do expositor" em suas respectivas línguas.

Em relação ao termo "paredes divisórias entre os estandes" encontramos no inglês: dividing walls, separation walls, sharing walls e partitioning walls. Contudo, encontramos 
também os termos stand walls, shell walls e wall panels que, embora não tragam a ideia de divisão entre os estandes, também são utilizadas nesse contexto. Portanto, foram acrescentados ao verbete em inglês como variantes.

Para o termo "planta técnica da feira", encontramos em inglês o termo "technical floor plan". Contudo, não encontramos os equivalentes em francês e em italiano: plan technique du salon e pianta tecnica della fiera. Desse modo, utilizamos a remissiva V. guide technique du salon (em francês) e V. regolamento tecnico di manifestazione (em italiano), onde o consulente poderá encontrar as informações relacionadas a esses termos.

Para o termo "aluguel de estande", encontramos os termos stand rental (ing.); location du stand (fr.) e locazione dell'area espositiva. Como se pode perceber, em italiano o que é locado não é o estande propriamente dito e sim a área onde será montado o estande. O mesmo se dá com o termo "reserva de estande", que no italiano é prenotazione dello spazio espositivo, ao contrário do inglês (stand booking) e do francês (demande de réservation de stand).

No português, encontramos o termo "centro de atendimento ao expositor" e a sigla (CAEX) que é uma secretaria montada no pavilhão, desde o início da montagem até a desmontagem da feira, para atender aos expositores. O equivalente em inglês é organiser's office; em francês, commissariat général du salon e em italiano, segreteria organizzativa, os quais não apresentam siglas. Vale destacar que o escritório responsável serviço de assistência técnica ao expositor é outro e tem como equivalentes: service desk (ing.); accueil exposant (fr.) e servizio assistenza tecnica espositori (SATE) em italiano, o qual apresenta uma sigla também.

Em relação ao termo "convite da feira", a maioria dos organizadores sugeriram show invitation, guest ticket ou guest pass. Entretanto, encontramos o termo free invitation ticket e não encontramos o termo show invitation nos corpora de estudo, bem como pass ospite e invito clientela, em italiano, apesar de algumas organizadoras na Itália terem sugerido esses termos. Para o italiano, encontramos o equivalente biglietto invito.

Vale mencionar aqui que uma organizadora na França nos informou que em uma feira B2B os visitantes utilizam um visitor badge (ing.), badge visiteur (fr.) ou badge visitatore (it.) e, em uma feira B2C, os visitantes utilizam um visitor ticket (ing.), ticket (fr.) ou biglietto di ingresso (it.) para ter acesso à feira.

Um ponto a mencionar aqui também é a utilização do termo "estande" escrito em inglês (stand) em manuais do expositor em português, como pode ser observado no Manual do expositor Fenacam 2014: “A decoração interna dos stands é de livre escolha do EXPOSITOR, desde que observadas algumas limitações [...]”. Temos em torno de 875 ocorrências desse tipo nos manuais em português. 
Em relação ao termo "entrega do estande" que significa a entrega do estande aos expositores para a colocação do material de exposição e da decoração, uma organizadora na Inglaterra, na feira Beauty Show, sugeriu os termos stand sign off ou stand hand over. Encontramos o termo sign off mas sem o descritor (stand). Existem muitos outros casos desse tipo na terminologia, em que o termo aparece sem o descritor, como em heating \& ventilation, ao invés de hall heating \& ventilation; zone de livraison ao invés de zone de livraison du hall; zone di carico/scarico ao invés de zone di carico/scarico del padiglione.

Merece ainda destaque os termos que foram sugeridos pelas organizadoras na Inglaterra, França e Itália e que não foram encontrados nos corpora de estudo como, por exemplo: ufficio comitato organizzativo; consociata; pass ospite; corsie di emergenza; tessera visitatore; stand in area collettiva; stand con due livelli; stand in batteria; stand in linea; stand riciclabile; stand riusabile; eco-stand (it.); pier des expositions; publicité du salon; stand annexes; stand ouvert sur 4 allées; stand ouvert sur tous les côtés; le off du salon; à côté de la manifestation; évènement du salon; salon ouvert au public et aux professionnels; salon ouvert a tous; espace de livraison (fr.); show invitation; split stand; two tiers stand; aisle stand; open sided stand; green stand; recyclable stand; hybrid show; goods in/goods out form; drop off - pick up form, fringe events; conference streams; satellite events (ing.), entre outros. Nesse caso, como não encontramos contextos de uso, em nossos corpora de estudo, para exemplificá-los, eles não foram incluídos no dicionário. E ainda os termos que foram encontrados nos corpora de estudo, mas que os organizadores desconhecem, tais como: stand unificato, stand di testa, stand di barriera (it.); stand péninsule (fr.); mixed show, traditional fair; virtual show (ing.). Nesse caso, resolvemos mantê-los nos respectivos verbetes no campo das variantes, uma vez que estão presentes nos manuais coletados.

Em relação ao termo "liberação do estande", um organizador na Inglaterra me explicou que se tratava de stand approval que é a liberação do estande, por parte da organizadora, para a montagem. É diferente de stand sign off que consiste em entregar o estande para o expositor para a colocação de materiais e produtos, após ser testado e considerado seguro e adequado ao objetivo a que se propõe.

É importante mencionar também o termo display. Trata-se de um exemplo de estrangeirismo do inglês, utilizado em português, em francês e em italiano. No português, utilizamos também o termo "expositor", homônimo de "expositor" (pessoa). No francês, além de display, eles utilizam também o termo, em francês, présentoir. No italiano, observamos algo curioso: eles utilizam o termo em inglês (display) e, ao invés de criar um termo em italiano (como é o caso do francês), eles acrescentaram um adjetivo em italiano (espositivo) ao termo 
em inglês (display), dando origem ao termo display espositivo, que é uma variante de display em italiano. A seguir, apresentamos algumas reflexões acerca dos estágios no exterior.

\section{Estágios no exterior: reflexões}

De setembro de 2017 a maio de 2018 realizamos três estágios de pesquisa no exterior em três universidades distintas: University of Surrey (Guildford/UK), Université Sorbonne Nouvelle Paris 3 (Paris/França) e Università di Bologna (Forlì/Itália), com o apoio financeiro da FAPESP (Processo BEPE/FAPESP/2016/20172-9). A realização dos estágios foi fundamental para a discussão de hipóteses teóricas levantadas previamente durante a pesquisa (a questão da hiperonímia e da variação, da variação e do processo de criação), trouxe sugestões para reflexões (a relação entre a variação e o processo de criação de novos termos por meio de especificação e o problema da inconsistência interna nessa área) e o entendimento da relação de base desse domínio específico: a relação entre hiperonímia e hiponímia na variação terminológica, conforme discorremos anteriormente.

Além de contribuir para a reflexão e aprofundamento de importantes questões teóricas acerca do tema pesquisado e o enriquecimento substancial da terminologia por meio das pequisas de campo (entrevistas com especialistas em feiras) nos três países, os estágios no exterior serviram para reforçar a importância e impacto deste trabalho para os profissionais do setor, para professores e pesquisadores em Terminologia, para intérpretes, tradutores e estudantes envolvidos e que trabalham na área ou em áreas afins.

Para os profissionais do setor, a disponibilidade de um dicionário multilíngue das feiras de negócios é, sem dúvida, proveitosa. O que esses profissionais realmente precisam saber? Eles precisam conhecer, por exemplo, qual termo é o melhor, mais utilizado. E nós podemos fazer essa recomendação, visto que um termo com diferentes variantes pode tornar-se um problema para os participantes de uma feira, além de constituir empecilho para a boa comunicação, até mesmo dentro de uma mesma língua. Desse modo, podemos auxiliar a comunicação na área por meio da recomendação dos termos mais comumente utilizados. Nesse sentido, a pesquisa pode ser um input para uma maior padronização da terminologia das feiras de negócios em português, inglês, francês e italiano (como apontamos no Capítulo 3). É oportuno mencionar aqui que quando visitamos uma feira de franchising no Brasil, encontramos o presidente da associação de feiras daquele setor que expressou um genuíno interesse na pesquisa e nos pediu para avisá-los quando o dicionário estivesse disponível no mercado. 
Para a comunidade científica (e contribuição teórica para a Terminologia) é pertinente conhecer como certas características que observamos nos termos (considerável variação dentro de um mesmo termo; o processo de criação de novos termos por especificação e a ausência de padronização) corresponde à maneira como as pessoas se comunicam nessa área, ou seja, o que aprendemos sobre as especificidades da terminologia usada nesse setor poderia nos ajudar a descrever o processo que dá origem a esse tipo específico de terminologia. Por que isso acontece dessa forma considerando como é a comunidade discursiva das feiras de negócios? Como se sabe, por exemplo, em uma comunidade discursiva muito fragmentada a terminologia não é padronizada e vice-versa.

Para os estudantes e professores de Terminologia, poderíamos esclarecer que em uma comunidade discursiva mais aberta e menos padronizada haverá muita variação e o processo de criação de novos termos será analítico, baseado em especificação. Entretanto, em um campo altamente regulamentado, haverá pouca ou nenhuma variação no interior de um mesmo termo e o processo de criação de novos termos será sintético, com novos termos sendo criados.

Além da reflexão de importantes questões teóricas (a verificação do processo de criação de novos termos por especificação, bem como a observação da relação hiperonímia-hiponímia na variação) e da aplicabilidade deste trabalho para os diferentes tipos de público (profissionais do setor, professores, estudantes e pesquisadores em Terminologia, intérpretes e tradutores), o conhecimento da ferramenta Sketch Engine, a conversão do dicionário para um banco de dados terminológico (SDL MultiTerm), o aprendizado de metodologias para trabalhar a questão das equivalências, a reflexão sobre o potencial do dicionário para facilitar a comunicação não apenas entre as diferentes línguas, mas também no interior de cada língua são contribuições valiosas dos estágios de pesquisa no exterior para o desenvolvimento e conclusão desta tese. A seguir, trazemos as considerações finais da pesquisa. 


\section{CONSIDERAÇÕES FINAIS}

As feiras de negócios são um importante mecanismo de penetração de produtos brasileiros no mercado externo e de produtos estrangeiros no mercado interno. Trata-se de uma área de irrefutável importância do ponto de vista econômico e, do ponto de vista prático, é um setor amplamente organizado com inúmeros sujeitos envolvidos no planejamento, organização, promoção, montagem e desmontagem de feiras e estandes, ao lado de milhares de expositores e visitantes interagindo mutuamente e realizando negócios.

Visitamos diversos pavilhões e centros de exposições no Brasil e no exterior e constatamos o quão dinâmica e bem sucedida pode tornar-se a participação de uma empresa em uma feira de negócios, revelando-se uma oportunidade ímpar para as empresas que almejam penetrar em novos mercados, encontrar parceiros comerciais, testar a aceitabilidade de seus produtos e serviços, aumentar suas receitas, entre outros benefícios.

Todavia, para que uma empresa alcance tais objetivos, faz-se necessário um rigoroso trabalho de preparação e planejamento: a decisão sobre qual feira participar, a análise dos custos envolvidos, do mercado e do público-alvo, a familiarização com a língua e, obviamente, com a terminologia. Logo, o conhecimento da terminologia das feiras de negócios em quatro idiomas otimiza a participação das empresas brasileiras em feiras no exterior, do mesmo modo que aprimora (e descomplica) a execução de todas as etapas envolvidas neste processo: o pré-feira, a feira propriamente dita e o pós-feira.

Apesar de muito antiga (as primeiras feiras surgiram na Idade Média), bem estruturada e altamente lucrativa (as feiras de negócios movimentam bilhões de reais, geram centenas de empregos diretos e indiretos e atraem milhares de pessoas ao redor do mundo), esta ainda é uma área pouco estudada, talvez pelo fato de não ser vista com relevância pelas áreas que poderiam investigá-la sob diferentes perspectivas. Do ponto de vista linguístico-terminológico é constituída de poucos termos de base, ou hiperônimos. Durante os vários anos de pesquisa e estudo desta área (o interesse começou em uma Especialização, teve continuidade no Mestrado, estendendo-se ao Doutorado), observamos que a terminologia da área feirística é constituída de seis termos de base: "estande", "feira", "expositor", "exposição", "pavilhão" e "visitante". A partir destes termos base, outros termos foram sendo criados, pela especificação do hiperônimo. Assim, observamos no setor feirístico, uma relação entre a hiperonímia-hiponímia e o específico processo de criação de novos termos por especificação. Uma possível explicação para esse fato poderia ser de natureza histórica, uma vez que as variáveis deste setor são sempre 
as mesmas e participam da base dos novos conceitos. Isso acontece, talvez, pela praticidade (é mais fácil acrescentar um especificador a um termo já existente do que criar um termo novo), ou para manter a inteligibilidade e garantir a boa comunicação na área, especialmente por se tratar de uma atividade internacional que envolve diferentes tipos de público (organizadores, expositores, visitantes, prestadores de serviços, etc.) com diferentes backgrounds. Soma-se a isso o fato desta ser uma área hibrida que empresta muitos termos de outras áreas do conhecimento como, por exemplo, do marketing, vendas, comércio exterior, etc. Assim, além do objetivo teórico (e de uma metodologia sócio-corpus-linguística baseada no corpus e em entrevistas com especialistas), a pesquisa possui também um objetivo prático, buscando informar aos consulentes os termos que, embora pertençam a outros domínios, são também utilizados na área feirística.

Quando iniciamos este trabalho não tínhamos uma questão teórica previamente estabelecida. Entretanto, sabíamos que ela surgiria a partir da análise dos dados. Assim, o estudo da terminologia das feiras de negócios em quatro línguas nos fez perceber uma característica muito evidente desta área: a variação. A realização dos estágios de pesquisas no exterior e as entrevistas realizadas com as organizadoras de feiras na Inglaterra, França e Itália trouxeram importantes contribuições nesse sentido e nos ajudaram a entrever uma inconsistência terminológica neste domínio, uma vez que cada organizadora utiliza uma terminologia própria para designar conceitos básicos da área, no interior de uma mesma língua, o que acarreta uma grande variação em termos de sinônimos. Esse cenário nos fez perceber que as diferentes variantes (sinônimos) encontradas possuem o mesmo status, a mesma importância de seus hipônimos, uma vez que são utilizadas de maneira intercambiável, nos mesmos contextos, o que nos levou a concluir que no setor feirístico a relação hiperonímia-hiponímia está presente também na variação. É possível que essa característica possa ser encontrada em outras áreas com as mesmas características, igualmente ainda pouco estudadas, sendo passível de generalização.

O conhecimento da estrutura interna da terminologia das feiras de negócios, constituída principalmente por unidades fraseológicas, nos trouxe um maior entendimento da própria área, mostrando as tendências linguísticas das línguas envolvidas, suas preferências singulares e suas semelhanças. A frequente utilização de substantivos deverbais nos fez ainda perceber o caráter dinâmico e acional da área, revelando as ações que devem ser empreendidas pelos sujeitos envolvidos em uma feira. Todas essas questões devem ser consideradas no momento da busca de equivalentes que é, sem dúvida, uma tarefa de grande complexidade, especialmente no que diz respeito aos Estudos da Tradução e Terminológicos que fundamentam a pesquisa. 
Para tanto, elaboramos quatro corpora de estudo, constituídos principalmente de manuais do expositor elaborados pelas organizadoras de feiras, bem como manuais de orientação para participação em feiras produzidos por órgãos públicos e privados; utilizamos as ferramentas da Linguística de corpus para a coleta de candidatos a termos, o preenchimento das fichas terminológicas e a análise dos termos em seus contextos de uso, identificando os ganchos terminológicos que denotam a equivalência de sentido entre os termos nas quatro línguas. Neste sentido, a metodologia de Dubuc mostrou-se satisfatória.

Assim, podemos assegurar que o setor feirístico é um domínio de especialidade que apresenta significativa variação no interior de um mesmo termo; seu processo de criação de novos termos é analítico, baseado na especificação de termos de base e sua terminologia ainda não é padronizada. A falta de supervisão dessa terminologia explica a expressiva variação terminológica encontrada, principalmente na França e Itália, sendo menos expressiva no Brasil, provavelmente pelo fato da terminologia em português ser baseada na terminologia em inglês, por se tratar de uma área de cunho internacional e o inglês ser considerado a língua de negócios.

Conforme apresentado no Capítulo 4, o dicionário apresenta 311 termos preferenciais em cada língua, 206 variantes em português, 307 variantes em inglês, 289 variantes em francês e 335 variantes em italiano, perfazendo um total de 2381 termos, dos quais 1244 são preferenciais e 1137 são variantes. É importante salientar que o total de variantes encontradas praticamente iguala-se ao total de termos estudados em cada língua, o que comprova e reforça o que temos dito ao longo deste trabalho em relação à expressiva presença de variação neste domínio. Ademais, consideramos que o resultado deste trabalho supera as expectativas de um dicionário cuja proposta inicial era analisar os termos fundamentais do setor feirístico.

Em resumo, respondendo às questões levantadas na Introdução, verificamos que a terminologia da área feirística nas quatro línguas é constituída essencialmente de seis termos base que acrescidos de sintagmas especificadores dão origem a termos complexos (unidades fraseológicas). Por essa razão, verificamos que a melhor maneira de estruturá-la, unidirecionalmente do português para as outras línguas em um dicionário multilíngue, seria espelhando a evidente relação de hiperonímia-hiponímia-sinonímia na microestrutura, informando ao consulente o termo geral em português, os equivalentes nas três línguas e as unidades fraseológicas formadas a partir dele, bem como suas variantes (sinônimos). Acreditamos que esse espelhamento da organização da terminologia na microestrutura possa ser generalizável para outras áreas do conhecimento.

A metodologia dos ganchos terminológicos de Dubuc nos permitiu entrever as relações de equivalência entre os termos nos quatro idiomas, com exceção de alguns exemplos de 
correspondência encontrados em inglês, conforme descrito no Capítulo 5. E as pesquisas de campo e as entrevistas com os especialistas (durante os estágios no exterior) trouxeram contribuições substanciais e credibilidade à pesquisa, corroborando a metodologia sóciocorpus-linguística utilizada nesta tese.

Em relação aos problemas de tradução encontrados na busca pelas equivalências e descritos no Capítulo 5, verificamos que o termo "feira", por exemplo, nem sempre é traduzido por foire em francês, já que isso depende do contexto, da frequência e do uso na língua. Além disso, na França, as organizadoras de feiras também utilizam manifestation commerciale ou, simplesmente, manifestation para se referirem ao termo "feira". O mesmo acontece na Itália, uma vez que muitas organizadoras se referem à "feira" como salone, manifestazione commerciale ou manifestazione. O termo fiera também é utilizado em italiano (com menos frequência), mas não existe uma diferenciação clara e objetiva entre fiera e salone, os quais são utilizados de maneira permutável. De igual modo, na Inglaterra, as organizadoras de feiras utilizam o termo trade show, ou simplesmente show, para se referirem às feiras de negócios. Não utilizam o termo trade fair ou fair que são, segundo elas, utilizados apenas na Europa.

Igualmente relevante é observar o modo como cada língua designa as relações semânticas em um mesmo paradigma como, por exemplo, em tipos de estande. Nos quatro idiomas estudados, eles são agrupados de acordo com o tipo de montagem (estande de área livre, estande básico ou estande construído; estande aberto ou estande fechado); com o número de lados abertos para os corredores do pavilhão (estande de esquina; estande de uma face; estande ilha; estande ponta de ilha) e com o número de andares (estande (térreo) e estande com mezanino ou estande de dois andares). De igual modo, as feiras são agrupadas de acordo com o tipo de público-alvo (público geral ou público especializado), com o setor de negócios (foco em um ou mais de um segmento da indústria) e com a atividade realizada durante a feira (exposição ou venda de produtos). Assim, percebemos uma certa homogeneização no modo como as quatro línguas organizam e agrupam os termos.

Em relação à questão da variação, observamos que o específico processo de criação de novos termos por especificação utilizado neste domínio contribui sobremaneira para a variação terminológica em termos de sinônimos, especialmente em francês e em italiano, o que acarreta uma expressiva inconsistência interna nessa área. Consequentemente, a utilização intercambiada das variantes (sinônimos), muitas vezes formadas a partir do hiperônimo acrescido de um especificador, as colocam no mesmo nível de seus hipônimos, visto que coocorrem nos mesmos contextos, o que nos traz o entendimento da relação de base deste domínio: a relação entre hiperonímia e hiponímia na variação terminológica. 
O Dicionário Multilígue de Termos do Setor Feirístico, portanto, busca ser: fonte de recomendação de termos mais comumente utilizados nos quatro idiomas; ferramenta monolíngue de auxílio à uniformização da terminologia no interior de cada língua, o que caracteriza uma importante contribuição para a área e para os Estudos Terminológicos e Tradutológicos; instrumento de consulta que, além de preencher uma lacuna no conhecimento (uma vez que não existe um dicionário das feiras de negócios em quatro línguas disponível no mercado), facilitará a comunicação em nível interlingual (apresentando os equivalentes nas diferentes línguas) e em nível intralingual (apontando os termos mais frequentemente utilizados) contribuindo, assim, para o uso consistente da terminologia no interior de cada idioma. Neste sentido, o dicionário poderá ser utilizado tanto como uma ferramenta quadrilíngue como uma ferramenta monolíngue, uma vez que cada parte do dicionário poderá ser extraível (o que aumentará drasticamente o número de usuários do dicionário). A contribuição principal deste trabalho é, portanto, ser uma ferramenta de auxílio e consulta para expositores (experientes e/ou leigos), tradutores e intérpretes. Como consequência, esperamos que mais empresas (nacionais e internacionais) possam participar de feiras de negócios no Brasil e no exterior, gerando receitas e impactando positivamente a balança comercial de seus países de origem.

Ademais, gostaríamos de registrar que criamos o termo "setor feirístico" em português, visto que ainda não se encontra dicionarizado e nos sites de busca disponíveis aparecem apenas os nossos trabalhos publicados. Trata-se de um neologismo tradutório cunhado a partir do italiano "settore fieristico". Este termo foi utilizado no título do glossário bilíngue desenvolvido no mestrado (GODOY, 2014) e, agora, no título do dicionário multilíngue elaborado no doutorado. Isso corrobora o fato dessa área ser ainda pouco explorada, constituída de uma terminologia ainda não padronizada e de um modelo de criação de termos que contribui para o problema da variação e da inconsistência na área, tanto no português, como nas demais línguas estudadas. Esperamos que este trabalho possa servir de estímulo para a reflexão sobre essas questões e que possa também trazer mais visibilidade para outras áreas de especialidade que possuam um perfil semelhante ao das feiras de negócios.

Por fim, gostaríamos de destacar que a descoberta da relação de hiperonímia-hiponímia na variação, o uso de uma combinação metodológica sócio-corpus-linguística, baseada nos corpora de estudo e em entrevistas com usuários dessa terminologia (o que nos trouxe uma visão mais completa e abrangente da terminologia utilizada nesta área) e o espelhamento da organização da terminologia na microestrutura do dicionário são contribuições desta tese para os Estudos da Tradução e para os Estudos Terminológicos, uma vez que essa relação poderá 
ser vislumbrada em outras áreas igualmente pouco estudadas e a metodologia replicada, do mesmo modo que esta estruturação de verbetes (que reflete a constituição interna da área e de sua terminologia) possui um grande potencial de generalização para outras áreas do conhecimento e utilização em Terminologia.

Consideramos que ainda há muito para ser descoberto em relação a este domínio de especialidade. Ao longo desta tese, sugerimos reflexões para trabalhos futuros que seguramente serão desenvolvidos em nível de Pós-Doutorado como, por exemplo, o desenvolvimento do sistema de remissivas nas outras línguas e a investigação da consistência dos corpora para o estudo dessa língua de especialidade (a terminologia encontrada nos manuais do expositor é realmente a terminologia utilizada pelos especialistas na prática?), o que também poderá trazer contribuições para os Estudos da Tradução e Terminológicos. 


\section{REFERÊNCIAS BIBLIOGRÁFICAS}

AEFI. Road to Expo 2015a. Disponível em: $<$ http://www.aefi.it/Aefi/media/misc/roadtoexpo/brochure-ita.pdf $>$. Acesso em: 03 out. 2015.

AEFI. I Numeri del Settore Fieristico Italiano 2015b. Disponível em: $<$ http://www.aefi.it/Aefi/media/misc/made-in-italy/sfi_2015.pdf $>$. Acesso em: 03 out. 2015.

ALPÍZAR-CASTILlO, Rodolfo. Como Hacer um Dicionário Científico-Técnico? Buenos Aires: Editorial Memphis, 1997.

. Como Hacer um Dicionário Científico-Técnico? La Habana: Félix Varela, 1995.

ALVES, Ieda Maria. Polissemia e Homonímia: a Perspectiva Terminológica. In: HORA, Dermeval da; CHRISTIANO, Elizabeth (Orgs.). Estudos Linguísticos: realidade brasileira. João Pessoa: Ideia, 1999a.

A delimitação da unidade lexical nas línguas de especialidade. In: BASÍLIO, Margarida (Org.). A delimitação de Unidades Lexicais. Rio de Janeiro: Grypho, 1999b.

. Questões Epistemológicas e Metodológicas em Terminologia. In: Anais do $1^{o}$. Encontro Nacional do GT de Lexicologia, Lexicografia e Terminologia da ANPOLL. Faculdade de Letras/UFRJ, 22-24 de abril de 1997.

. Definição terminológica: da teoria à prática. TradTerm, 3, 1996, p. 125-136.

Empréstimos nas línguas de especialidade: algumas considerações. In: Ciência da Informação. Terminologia: a disciplina da nova era. Brasília, Volume 24, n. 3, p. 319-321, setembro/dezembro 1995.

ALVES, Ieda Maria; SILVA, Manoel Messias Alves; ARAUJO, Mariângela de. O léxico nas línguas especializadas. In: HENRIQUES, Claudio Cezar (Org.). Linguagem, conhecimento e aplicação: estudos de língua e linguística. Rio de Janeiro: Editora Europa, 2003, p. 37-47.

ALVES, Ieda Maria; MARONEZE, Bruno Oliveira; ZANON, Maria Cecília; ARAUJO, Mariângela de; BACCIN, Paola Giustina. Estrangeirismos no português brasileiro: do mito à realidade. In: Revista Estudos Linguísticos do GEL (São Paulo), Campinas, Volume 33, 2004.

ANTHONY, Laurence. (2014). AntConc (Version 3.4.3) [Computer Software]. Tokyo, Japan: Waseda University. Available from $<$ http://www.laurenceanthony.net/software $>$.

Associazione esposizioni e fiere italiane (AEFI). Disponível em: $<$ http://www.aefi.it/Aefi/site/it/associazione/chi-siamo>. Acesso em: 23 out. 2015.

AUBERT, Francis. Henrik. Introdução à Metodologia da Pesquisa Terminológica Bilíngue. São Paulo: Humanitas Publicações-FFLCH/USP, 1996 (Cadernos de Terminologia, 2).

. Tradução Técnico-científica e Terminologia: um ensaio exploratório de uma via de mão dupla. TradTerm, p. 41-52, 2001.

AZENHA JUNIOR, João. Tradução técnica, condicionantes culturais e os limites da 
responsabilidade do tradutor. Cadernos de Tradução, v. 1, n. 1, p. 137-149, 1996.

. Transferência cultural em tradução: contextualização, desdobramentos, desafios. TradTerm, 16, p. 37-66, 2010.

BABINI, Maurizio. Proposition d'um nouveau modele de dictionnaire terminologique onomasiologique. São José do Rio Preto: Beatriz, 2001.

BAKER, Mona. Corpora in Translation Studies: an overview and some suggestion for future research. Target. Volume 7, Number 2, p. 223-243, 1995.

Corpus linguistics and translation studies: implications and applications. In: BAKER, M.; FRANCIS, G.; TOGNINI-BONELLI, E. (Eds.). Text and technology: in honour of John Sinclair. Amsterdam/Philadelphia: John Benjamins, p. 233-250, 1993.

BAKER, Mona; SALDANHA, Gabriela. Routledge Encyclopedia of Translation Studies. London and New York: Routledge, 2009, $2^{\mathrm{a}}$ ed.

BARBOSA, Maria Aparecida. Revista Italiano UERJ - Ano 1, v.1, nº 1, $2^{\circ}$ semestre 2010. 44, 2009.

Terminologia aplicada: percursos interdisciplinares. Polifonia (UFMT), v. IV, p. 29-

Etno-Terminologia e Terminologia Aplicada: objeto de estudo, campo de atuação. In: ISQUERDO, Aparecida Negri; Alves, Ieda Maria. As Ciências do Léxico: lexicologia, lexicografia, terminologia. Campo Grande: Editora UFMS, 2007.

Dicionário, vocabulário, glossário: concepções. In: Alves, I. M. (Org.) A constituição da normalização terminológica no Brasil. São Paulo: Citrat: FFLCH (USP), p. 23-45, 1996.

Para uma Etno-Terminologia: Recortes Epistemológicos. In: Ciência e Cultura: temas e tendências. Vol. 58, n. 2, São Paulo, abril/junho de 2006, p. 48-51.

Sistema Conceptual e Sistema Terminológico. In: Revista TradTerm, v. 7, p. 71-94, São Paulo, 2001.

. Estrutura, funções e processos de produção de dicionários terminológicos multilíngues. In: Revista do GELNE - Grupo de Estudos Linguísticos do Nordeste - Ano 1, No. 2, Fortaleza: UFC/GELNE, 1999.

BARBOSA, Maria Aparecida; LAFACE, Antonieta; BARROS, Lídia Almeida. Grupo de Trabalho: Questões Epistemológicas e Metodológicas em Lexicologia, Lexicografia e Terminologia. In: Anais do XLV Seminário do GEL, São José do Rio Preto, p. 177-185, 1998.

BARBOSA, Maria Magdalena Vila. Evolución Histórica do Concepto de Equivalencia en Tradutoloxía. Cadernos de Tradução, n. 29, p.11-29, Florianópolis, 2012/1.

BARONI, Marco; BERNARDINI, Silvia. 2004. BootCaT: Bootstrapping corpora and terms from the web. Proceedings of LREC 2004.

BARROS, Lidia Almeida. Curso Básico de Terminologia. São Paulo: Editora da Universidade de São Paulo, 2004.

. Conhecimentos de terminologia geral para a prática tradutória. São José do Rio Preto: 
Editora Novagraf, 2007.

BASSNETT, Susan. Estudos da Tradução: Fundamentos de uma Disciplina. Lisboa: Fundação Calouste Gulbenkian, 2003. Tradução de Vivina de Campos Figueiredo.

BOGAARDS, Paul. Uses and users of dictionaries. In: STERKENBURG, Piet van. A practical Guide to Lexicography. Amsterdam/Philadelphia: John Benjamins Publishing Company, 2003, Vol. 6.

BERBER SARDINHA, Tony. Linguística de Corpus. São Paulo: Editora Manole, 2004.

. A língua portuguesa no computador. Campinas, SP: Mercado de Letras; São Paulo:

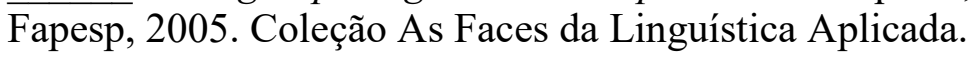

BEVILACQUA, Cleci Regina. Unidades fraseológicas especializadas: estado da questão em relação a sua definição, denominação e critérios de seleção. In: TradTerm, 11, 2005, p. 237 253.

. Unidades Fraseológicas Especializadas Eventivas: descripción y reglas de formación en el ámbito de la energía solar. Tesis doctoral. Orientadora: Maria Teresa Cabré. Barcelona: Instituto Universitario de Lingüística Aplicada, Universidad Pompeu Fabra, 2004.

BEVILACQUA, Cleci. Regina; FINATTO, Maria José Bocorny. Lexicografia e Terminografia: alguns contrapontos fundamentais. Alfa, São Paulo, v. 50, n.2, p. 43-54, 2006.

BIDERMAN, Maria Teresa Camargo. Um dicionário para o Português do Brasil. In: SEABRA, Maria Cândida Trindade Costa (org.). O Léxico em estudo. Belo Horizonte: Faculdade de Letras da UFMG, 2006. p. $173-184$.

Corpora informatizados e dicionários. In: DIAS-DA-SILVA, B.C. (org). Todas as trilhas: perfilando pesquisas e projetos. Araraquara: Laboratório Editorial/FCL/UNESP; São Paulo: Cultura Acadêmica, p. 179-193, 2003.

.As Ciências do Léxico. In: OLIVEIRA, Ana Maria Pinto Pires de; ISQUERDO, Aparecida Negri (Orgs.). As Ciências do Léxico: lexicologia, lexicografia, terminologia. 2.ed. Campo Grande: Ed. UFMS, 2001.

Dicionário didático de português. 2a . Ed. São Paulo: Ática, 1998.

BONELLI-TOGNINI, Elena. Corpus Linguistics at Work. Amsterdam/Philadelphia: John Benjamins, 2001.

BOONE, Louis E.; KURTZ, David L. Marketing Contemporâneo. Tradução de Aline Neves Leite de Almeida et al. 8 ed. Rio de Janeiro: Editora LTC, 1998.

BORBA, Francisco da Silva; VILLAR, Mauro de Salles. O trabalho do dicionarista. In: XATARA, Claudia; BEVILACQUA, Cleci Regina; HUMBLÉ, Philippe René Marie (Orgs.). Dicionários na teoria e na prática: como e para quem são feitos. São Paulo: Parábola Editorial, 2011.

BOURIGAUlT, Didier; SLODZIAN, Monique. 1999. Pour une terminologie textuelle. 
Disponível

em:

$<$ http://www.termisti.org/rifal/PDF/tn19/tn19_Bourigaut\%20et $\% 20$ Slodzian.pdf $>$. Acesso em: 10 nov 2016.

BOUTIN-QUESNEL, Rachel. et al. Vocabulaire systématique de la terminologie. Québec: Publications du Québec, 1985. (Cahiers de l'Office de la langue française).

BOWKER, Lynne. Terminology. In: BAKER, Mona; SALDANHA, Gabriela. Routledge Encyclopedia of Translation Studies. London and New York: Routledge, 2009, $2^{\mathrm{a}}$ ed.

BOWKER, Lynne; PEARSON, Jennifer. Working with specialized language: a practical guide to using corpora. London: Routledge, 2002.

BRAZIL EXPORT MAGAZINE. A importância das feiras no aumento das exportações. Disponível em: $<$ http://www.brazilexportmagazine.com.br/revista/rev388/files/importancia_p.pdf $>$. Acesso em: 09 jan. 2015.

CABRÉ, Maria Teresa. Terminology and translation. In: GAMBIER, Yves; DOORSLAER, Luc van. Handbook of Translation Studies. Philadelfia: John Benjamins Publishing Company, Vol 1, 2010.

. La Terminologia, una disciplina en evolución: pasado, presente y algunos elementos de futuro. Debate Terminológico 1. París: RITERM (Red Iberoamericana de Terminología). ISSN 1813-1867, 2005.

Una nueva teoría de la Terminología: de la denominación a la comunicación. In: $L a$ terminología: representación y comunication. Elementos para una teoría de base comunicativa y otros artículos. Barcelona: IULA, p.109-127, 1999.

. La terminologia hoy: replanteamiento o diversificación. Organon, Porto Alegre, v. 12, n. 26, p. 33-41, 1998.

- La terminologia: teoria, metodologia, aplicaciones. Barcelona: Editorial Antártida/Empúries, 1993.

CAMACHO, Emma Rodríguez. Terminología y Traducción. Gestión de la terminología en la traducción de textos especializados. Cali: Universidad del Valle, p.127-153, 2004.

CAMARGO, Diva Cardoso de. Tradução e Tipologia Textual. Tradução e Comunicação. 16, p. 46-52, 2007.

CAMARGO, Diva Cardoso de; ROCHA, Celso Fernando; PAIVA, Paula Tavares Pinto. Pesquisas em Estudos da Tradução e Corpora Eletronicos no Brasil. São Paulo: Editora UNESP, 2012.

CATFORD, John Cunnison. A Linguistic Theory of Translation. London: Oxford University Press, 1965.

Confederação Nacional da Indústria (CNI). Disponível em: $<$ http://www.portaldaindustria.com.br/cni/imprensa/2015/06/1,64669/comercio-internacional- 
deve-ser-o-propulsor-do-crescimento-economico-diz-robson-braga-de-andrade-aempresarios-franceses.html>. Acesso em: 16 jun. 2015

Centro Brasileiro Britânico (CBB). Disponível em: <http://www.cbb.org.br/wps/portal/CBB>. Acesso em 28 out. 2015.

Chambre de commerce et d'industrie Paris Île-de-France. Disponível em: <http://www.cciparis-idf.fr/>. Acesso em 28 out. 2015.

CORPAS PASTOR, Gloria.: Manual de fraseología española, Madrid: Gredos, 1996.

CORPAS PASTOR, Gloria; FLORENTINA, M.M.M. Letras de Hoje. Porto Alegre, v. 39, n.1, p. 9-43, março de 2004.

CORTINAS LOPEZ, José Manoel. Comércio Exterior Competitivo. São Paulo: Aduaneiras, 2010.

DELISLE, Jean; Judith WOODSWORTH. Os tradutores na história. São Paulo: Ática, 1995. Tradução de Sérgio Bath (1998).

DESMET, Isabel. Teoria e prática da fraseologia de especialidade: aplicações. In: Filol. Linguíst. Port., n. 5, p. 27-56, 2002.

DIKI-KIDIRI, Marcel. Un enfoque cultural de la terminologia. In: Debate Terminológico, No. 5, Ago. 2009.

Direction Général des Entreprises. Disponível em: <https://www.entreprises.gouv.fr/>. Acesso em: 20 out. 2015.

Doing business in Brazil: Brazil trade and export guide: Disponível em $<$ https://www.gov.uk/government/publications/exporting-to-brazil/exporting-to-brazil>. Acesso em: 10 fev. 2014.

DUBUC, Robert. Manuel pratique de terminologie. $2^{\mathrm{a} e d .}$ Québec: Linguatech, 1985. . Manuel pratique de terminologie. Montreal : Linguatec, 1992.

DUQUET-PICARD, Diane. La synonymie en langues de spécialité: étude du problème en terminologie. Québec : GIRSTERM, Université Laval, 1986.

. La définition en terminologie : aspect didactique. In Rondeau, G. (dir.). Travaux de Terminologie, v. 2. Québec : GISTERM, Université Laval, 1982, p.77-92.

FAULSTICH, Enilde. Aspectos de terminologia geral e terminologia variacionista. TradTerm, v. 7, São Paulo, 2001.

. Entre a sincronia e a diacronia: variação terminológica no código e na língua. In: Simpósio Ibero-Americano de Terminologia. Paris: Riterm, p. 7-12, 1998.

FELBER, Helmut. Manuel de terminologie. [pour le Programme general d'information et 
1'UNISIST et pour le Centre international d'information pour la terminologie]. Paris: UNESCO/INFOTERM, 1984.

FINATTO, Maria José Bocorny. A definição terminológica do dicionário TERMISUL: expressão linguística de relações conceituais complexas. In: KRIEGER, Maria da Graça; MACIEL, Anna Maria Becker. Temas de Terminologia. Porto Alegre/São Paulo: Ed. Universidade/ UFRGS/Humanitas/USP, 2001, p. 306-316.

FIRTH, John Rupert. 1968. Linguistic Analysis as a Study of Meaning. In: E R. Pa1mer (ed.) 1968. Selected Papers of J. R. Firth 1952-59. Londres y Harlow: Longmans. 12-26.

FREIXA, Judit. Otra vez sobre las causas de la variación denominativa. Debate Terminológico. No. 9, Feb. 2013; pp. 38-46.

. La variació terminològica: anàlisi de la variació denominativa en textos de diferent grau d'especialització de l'àrea de medi ambient, Sèrie Tesis 3, Barcelona, Universitat Pompeu Fabra, 2002.

frWaC (French Web). Disponível em: $<$ http://nl.ijs.si/noske/wacs.cgi/wordlist_form?corpname=frwac $>$. Acesso em: 01/06/2015.

GAUDIN, François. Pour une Socioterminologie: des problemes semantiques aux pratiques institutionnelles. Publications de l'université de Rouen $\mathrm{N}^{\circ} 182,1993$.

GODOY, Ariane Dutra Fante; ZAVAGLIA, Adriana. A terminologia multilíngue das feiras de negócios: das unidades fraseológicas à organização da microestrutura de um dicionário especializado. Guavira Letras, v. 14, n. 27, p. 114-124, 2018.

GODOY, Ariane Dutra Fante. A busca de equivalentes para a elaboração de um dicionário terminológico multilíngue das feiras de negócios. Debate Terminológico 16, p. 28-38, 2016.

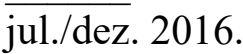

Colocações Especializadas do Setor Feirístico. Revista GTLex, v.2, n.1, p. 93-114, - Glossário Bilíngue dos Termos Fundamentais do Setor Feirístico: Busca de Equivalências em Inglês. Dissertação de mestrado apresentada ao programa de pós-graduação em Estudos Linguísticos da Unesp, campus de São José do Rio Preto, 2014.

GODOY, Ariane Dutra Fante; BABINI, Maurizio. Proposta de Glossário dos Termos Fundamentais das Feiras de Negócios. As Ciências do Léxico: lexicologia, lexicografia, terminologia, volume VII, Campo Grande: Ed. UFMS, 2014.

Os Termos Fundamentais das Feiras de Negócios: Busca de Equivalentes em Língua Inglesa. Revista Estudos Linguísticos, v. 43, n. 01, 2014.

A Terminologia das feiras de negócios: análise das variantes linguísticas. Acta Semiótica et Lingvistica. v. 18, n. 1, 2013.

Glossário Bilíngue dos Termos Fundamentais do Setor Feirístico: Busca de 
Equivalências em Inglês. III Simpósio Nacional de Letras e Linguística e II Simpósio Internacional de Letras e Linguística: linguagem, cultura, identidade e ensino, 3, 2013, Catalão. Anais.... Catalão: UFG, 2013, p. 174-186. Disponível em $<$ http://www.letras.catalao.ufg.br/uploads/508/original_ANAIS_SINALEL_-_Parte_1.pdf $>$. Acesso em: 20 dez. 2013.

GODOY, Ariane Dutra Fante. Um estudo exploratório sobre a importância da participação das indústrias paulistas de alimentos em promoções na Flórida para a abertura do mercado norte-americano. Monografia apresentada ao programa de pós-graduação lato sensu da Universidade Presbiteriana Mackenzie, São Paulo, 2006.

HEID, Ulrich.; MARTIN, Willy; POSCH, Ilse. An overview of approaches towards the description of collocations. In: Feasibility of standards for collocational description of lexical items. In: Eurotra 7 - Report, Stuttgart/Amsterdam, 1991.

HOLMES, JAMES S. The name and the nature of translation studies. In: Lawrence Venuti, (ed.). The Translation Studies Reader. London: Routledge, 2000, p. 419-428.

. The Name and nature of Translation Studies. In: Translated! Papers on Literary Translation and Translation Studies. Amsterdam \& Atlanta: Rodopi, 1988, p. 67-80.

ISQUERDO, Aparecida Negri; ALVES, Ieda Maria. As Ciências do Léxico: Lexicologia, Lexicografia, Terminologia. Vol. 3. Campo Grande: Editora UFMS, 2007.

KAGEURA, KYO. The dynamics of terminology: a descriptive theory of term formation and terminological growth. Amsterdam: John Benjamins Publishing, 2002.

KENNY, Dorothy. Equivalence. In: BAKER, Mona; SALDANHA, Gabriela. Routledge Encyclopedia of Translation Studies. London and New York: Routledge, 2009, $2^{\mathrm{a}}$ ed..

KILGARRIFF, Adam.; RYCHLÝ, Pavel. Sketch Engine. United Kingdom: 2003.

KOCOUREK Rostislav, 1982. La langue française de la techique et de la science. Brandstetter Verlag, Wiesbaden, 259p.

. (1991). La langue française de la technique et de la Science. 2è éd. Wiesbaden: Oscar

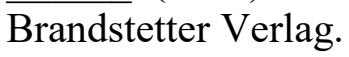

KOLLER, Werner. Einführung in die Übersetzungswissenschaft, Wiebelsheim, Quelle \& Meyer, 1979/2004. In: MOREIRA, Marcelo Victor de Souza. Estudos Funcionais da Tradução: rupturas e continuidades. Dissertação de mestrado. São Paulo: FFLCH, 2014.

KOTABE, Masaaki, HELSEN, Kristiaan. Administração de Marketing Global. Tradução de Ailton Bomfim Brandão. São Paulo: Editora Atlas, 2000.

KOTLER, Philip. Administração de Marketing. Tradução de Mônica Rosemberg, Claudia Freire e Brasil Ramos Fernandes. São Paulo: Editora Pearson, 12 ed., 2006. 
. Administração de Marketing: análise, planejamento, implementação e controle. Tradução de Ailton Bomfim Brandão. 5 ed. São Paulo: Atlas, 1998.

KRIEGER, Maria da Graça; FINATTO, Maria José Bocorny. Introdução à Terminologia: teoria e prática. São Paulo: Contexto, 2004.

KRIEGER, Maria da Graça; MACIEL, Anna Maria Becker. Temas de Terminologia. Porto Alegre/São Paulo: Ed. Universidade/ UFRGS/ Humanitas/USP, 2001.

KRIEGER, Maria da Graça. Relações entre Terminologia e Tradução. In: KRIEGER, Maria da Graça; MACIEL, Anna Maria Becker. Temas de Terminologia. Porto Alegre/São Paulo: Ed. Universidade/ UFRGS/Humanitas/USP, 2001, p.155-163.

. O termo: questionamentos e configurações. In: KRIEGER, Maria da Graça; MACIEL, Anna Maria Becker. Temas de Terminologia. Porto Alegre/São Paulo: Ed. Universidade/ UFRGS/Humanitas/USP, 2001, p.62-81.

Terminologia revisitada. In: D.E.L.T.A. Vol. 16, N. ${ }^{\circ}$ 2, 2000, p. 209-228.

LAVIOSA, Sara. Corpora. In: GAMBIER, Yves; DOORSLAER, Luc van. Handbook of Translation Studies. Amsterdam/ Philadelphia: John Benjamins, 2010. Vol. 1, p. 80-86.

LEECH, Geoffrey. The State of the Art in Corpus Linguistics. In: AIJMER, K.; ALTENBERG, B (eds.). English Corpus Linguistics. London: Longman, 1991, p. 8-29.

L'HOMME, Marie-Claude. La terminologie: principes et techniques. Canadá: Paramètres, 2004.

L'HOMME, Marie-Claude.; BERTRAND, Claudine. Specialized lexical combinations: should they be described as collocations or in terms of selectional restrictions? In: Proceedings. Ninth EURALEX International Congress, Germany, p. 497-506, 2000.

LOTTE, D. S. Principes d'établissement d'une terminologie scientifique et technique, [1961]. Versão francesa publicada em RONDEAU, G. \& FELBER, H. (org.) Textes choisis de terminologie, Québec: GIRSTERM, 1981, p. 3-53.

LYONS, John, Semantics. UK: Cambridge University Press, 1977.

MACIEL, Anna Maria Becker. Terminologia, linguagem de especialidade e dicionários. In: KRIEGER, Maria da Graça; MACIEL, Anna Maria Becker. Temas de Terminologia. Porto Alegre/São Paulo: Ed. Universidade/ UFRGS/Humanitas/USP, 2001, p. 39-46.

. Da análise e reconhecimento de candidatos a termo de um dicionário jurídico. In: KRIEGER, Maria da Graça; MACIEL, Anna Maria Becker. Temas de Terminologia. Porto Alegre/São Paulo: Ed. Universidade/ UFRGS/Humanitas/USP, 2001, p. 82-89.

. Processamento semi-automatizado da linguagem jurídica: problemas na seleção de termos. In: KRIEGER, Maria da Graça; MACIEL, Anna Maria Becker. Temas de Terminologia. Porto Alegre/São Paulo: Ed. Universidade/ UFRGS/Humanitas/USP, 2001, p. 372-382. 
MAGALHÃES, Célia Maria. Pesquisas textuais/discursivas em tradução: o uso de corpora. In: PAGANO, A (Org.). Metodologias de pesquisa em tradução. Belo Horizonte: FALE-UFMG, p. 93-103, 2001.

MÉDIAMÉTRIE. Salons et Foires en France: un puissant outil de développement pour les entreprises, 2015. Disponível em: <http://www.unimev.fr/files/unimev.fr/public/2015-0612_etude_salons_foires_outils_def.pdf $>$. Acesso em: 02 out. 2015.

Ministério do Desenvolvimento, Indústria e Comércio Exterior (MDIC). Disponível em: $<$ http://www.mdic.gov.br/sitio/interna/noticia.php?area=5\&noticia=13383>. Acesso em: 24 out. 2014.

MDIC. Brasil realiza encontros bilaterais durante reunião de comércio do G20. 2014. Disponível em: <http://www.mdic.gov.br/sitio/interna/noticia.php?area=1\&noticia=13307>. Acesso em: 02 out. 2015.

MDIC. Cresce o Comércio Bilateral entre Brasil e Itália. 2014. Disponível em: $<$ http://www.exportnews.com.br/2014/07/cresce-o-comercio-bilateral-entre-brasil-e-italia/>. Acesso em: 02 out. 2015.

MRE. Estudos e Documentos de Comércio Exterior: Série Como Exportar. Brasília, 2009. Disponível em: $<$ http://www.aprendendoaexportar.gov.br/uniaoeuropeia/paginas/perfisMercadoUE/PDF/com oexportarreinounido2009.pdf>. Acesso em: 28 out. 2015.

MRE. Reino Unido: Comércio Exterior. Abril de 2015. Disponível em: $<$ http://www.investexportbrasil.gov.br/sites/default/files/publicacoes/indicadoresEconomicos/ INDReinoUnido.pdf>. Acesso em: 28 out. 2015.

MRE. União Europeia: Intercâmbio Comercial com o Brasil. Junho de 2015. Disponível em: $<$ http://www.investexportbrasil.gov.br/sites/default/files/publicacoes/indicadoresEconomicos/ ICBrasilUniaoEuropeia.pdf>. Acesso em: 28 out. 2015.

MULDER, Jan; HERVEY, Sándor. Theory of the Linguistic Sign. Haia: Mouton, 1972.

MUNDAY, Jeremy. Introducing Translation Studies: Theories and Applications. London \& New York, 2001.

Translation Studies. In: GAMBIER, Yves; DOORSLAER, Luc Van. Handbook of translation studies, v. 1. Amsterdam/Philadelphia: John Benjamins Publishing Company, 2010.

NICKELS, William G, WOOD, Marian B. Marketing: relacionamentos, qualidade, valor. Tradução de Luiz Roberto M. Gonçalves. Rio de Janeiro: Editora LTC, 1999.

OLIVEIRA, Maria Francisca Amorim. (2001). O tratamento da sinonímia no dicionário escolar. Dissertação de mestrado. Brasília, UnB, LIV.

OLOHAN, Maeve. Scientific and technical translation. In: BAKER, Mona; SALDANHA, Gabriela. Routledge Encyclopedia of Translation Studies. London and New York: Routledge, $2009,2^{\mathrm{a}}$ ed.. 
ORENHA, Adriane. Unidades fraseológicas especializadas: colocações e colocações estendidas em contratos sociais e estatutos sociais traduzidos no modo juramentado e nãojuramentado. 2009. 282 f. Tese (Doutorado em Estudos Linguísticos) - IBILCE, Universidade Estadual Paulista, São José do Rio Preto, 2009.

Semelhanças e diferenças entre colocações e colocações especializadas. In: ORTIZALVAREZ, M. L. (Org.). Tendências atuais na pesquisa descritiva e aplicada em fraseologia e paremiologia. 1 ed. Campinas: Editora Pontes, 2012, v. 2, p. 147-163.

ORGANISATION INTERNATIONALE DE NORMALISATION. Terminologie Vocabulaire. Genebra, ISO, 1990 (Norme Internationale ISO 1087:1990). Genève: ISO 1990.

ORGANISATION INTERNATIONALE DE NORMALISATION. Travaux terminologiques Vocabulaire Partie 1. Théorie et application. Genebra: ISO 1087: 2000. Genève: ISO 2000.

PAVEL, Silvia; NOLET, Diane. Manual de Terminologia. 2001. Tradução de Enilde Faulstich. Disponível em: <https://linguisticadocumentaria.files.wordpress.com/2011/03/pavelterminologia.pdf >. Acesso em: 01 dez. 2015.

PEARSON, Jennifer. Terms in context: studies in corpus linguistics. Amsterdam/Philadelphia: John Benjamins, 1998.

PICOCHE, J. Précis de lexicologie française. Paris: Fernand Nathan, 1977.

PIPKIN, Alex. Marketing internacional. São Paulo: Aduaneiras, 2000.

RAMOS, Patrícia Chittoni. Interface Tradução Terminologia. In: KRIEGER, Maria da Graça; MACIEL, Anna Maria Becker. Temas de Terminologia. Porto Alegre/São Paulo: Ed. Universidade/ UFRGS/Humanitas/USP, 2001, p.164-170.

Revista Largo Consumo n.1/2015. Disponível em: $<$ http://www.largoconsumo.info/012015/ARTMercatoFieristicoFiereEstereInternazionalizzazi oneExportAgroalimentareFoodWineMadeInItalyPmiAefiIceComunicazione72-0115.pdf.> Acesso em : 02 out. 2015.

REY-DEBOVE, Josette. Étude linguistique et sémiotique des dictionnaires français contemporains. The Hague/Paris: Mouton, 1971.

REY Isabel González. La phraséologie du français. Cahiers de praxématique, 41, 2003, p. 191214. Disponível em: < https://praxematique.revues.org/2690 >. Acesso em 07 dez. 2015.

RODRIGUES, Cristina Carneiro. Tradução: a questão da equivalência. In: Alfa, São Paulo, 44 (n.esp.), p. 89-98, 2000.

RÓNAI, Paulo. A Tradução Vivida. Rio de Janeiro: Nova Fronteira, 1981 [1975].

RONDEAU, Guy. 1984. Introduction à la terminologie. Quebec: Gaetan Morin. 
RUIZ GURILLO, Leonor: Aspectos de fraseología teórica española. Valencia: Universitat de Valencia, 1997.

SABINO, Marilei Amadeu. O campo árido dos fraseologismos. In: Signótica. Goiânia, v. 23, n. 2, p. 385-401, jul./dez. 2011.

SAGER, Juan C. A Practical Course in Terminology Processing. Amsterdam/ Philadelphia: John Benjamins Publishing Company, 1990.

Salons et Foires en France : un puissant outil de développement pour les entreprises. Disponível em: $\quad<$ http://www.unimev.fr/files/unimev.fr/public/2015-0612_etude_salons_foires_outils_def.pdf>.Acesso em: 02 out. 2015.

SANCHEZ, Aquilino. Definición e historia de los corpus. In: SANCHEZ, A et al (Org.) CUMBRE - corpus linguistico de espanol contemporaneo. Madrid: SGEL, 1995.

SARAMAGO, José. As palavras de Saramago: catálogo de reflexões pessoais, literárias e políticas / Fernando Gómez Aguilera (sel. e org.). São Paulo: Companhia das Letras, 2010.

SAUSSURE, Ferdinand de. Cours de linguistique générale, éd. Critique de Tullio de Mauro. Paris : Payot, 520p, 1985.

SCOTT, Mike. WordSmith Tools: version 6.0. Oxford: Oxford University Press, 2012.

SDL Plc. SDL MultiTerm. United Kingdom: 2017

SEABRA, Maria Cândida Trindade Costa de; WELKER, Herbert Andreas. Questões teóricas genéricas. In: XATARA, Claudia; BEVILACQUA, Cleci Regina; HUMBLÉ, Philippe René Marie (Orgs.). Dicionários na teoria e na prática: como e para quem são feitos. São Paulo: Parábola Editorial, 2011.

SERVIÇO BRASILEIRO DE APOIO ÀS MICRO E PEQUENAS EMPRESAS (SEBRAE). Disponível em: <http://www.sebrae.com.br>. Acesso em: 10 fev. 2015.

SILVA, Moisés Batista da. Uma palavra só não basta: um estudo teórico sobre as unidades fraseológicas. Revista de Letras, n. 28, vol. 1/2, jan/dez. 2006, p. 11-20. Disponível em: $<$ http://www.revistadeletras.ufc.br/r128Art02.pdf $>$. Acesso em 07 dez. 2015.

SINCLAIR, John. 2005. Corpus and Text - Basic Principles. In: Developing Linguistic Corpora: a Guide to Good Practice, ed. M. Wynne. Oxford: Oxbow Books. Disponível em: $<$ http://www.ahds.ac.uk/creating/guides/linguistic-corpora/chapter1.htm>. Acesso em: 11 mar. 2015.

. Trust the text: language, corpus and discourse. London: Routledge, 2004.

163

Corpus, Concordance, Collocation. Oxford: Oxford University Press, 1991, p. 109-

Beginning the study of lexis. In: BAZELL, C. E.; CATFORD, J. C.; HALLIDAY, M. A. K. \& ROBINS R.H (eds.). London: Longman, 1966. In Memory of FIRTH, J. R. (pp. 410430). 
SISKIND, Barry. O poder do marketing de exposições: guia completo para ser bem-sucedido em exposições, feiras de negócios e convenções. São Paulo: Editora Senac São Paulo, 2009. Tradução de Lenita Rimoli Esteves.

SNELL-HORNBY, Mary. The Turns of Translation Studies. John Benjamins, 2005.

TAGNIN, Stella Esther Ortweiller; VIANA, Vander (orgs.). Corpora no ensino de línguas estrangeiras. São Paulo: Hub Editorial, 2010.

TAGNIN, Stella Esther Ortweiller. (2002). "Os Corpora: instrumentos de auto-ajuda para o tradutor". In: Cadernos de Tradução $I X$. Florianópolis: UFSC. Disponível em: $<$ http://www.cadernos.ufsc.br/online/9/stella.htm - notas>. Acesso em 01 mar. 2014.

2005.

. O jeito que a gente diz: expressões convencionais e idiomáticas. São Paulo: Disal,

Certo está, só que não é assim que a gente diz... In: CARMAGNANI, Anna Maria G.; GRIGOLETTO, Marisa. Inglês como língua estrangeira: identidade, práticas e textualidade = English as a foreign language: identity, practices and textuality. São Paulo: Humanitas/FFLCH/USP, 2001.

Corpus-driven terminology in Brazil. In: POUPET, Armelle Le Bars; XATARA, Claudia. Cahiers de lexicologie: dynamique de la recherche en lexicologie, lexicographie et terminologie au Brésil. Paris: Classiques Garnier, 2012-2, n 101.

. Da prática à Teoria - Para Variar. In: Anais do I Congresso Ibero-Americano de Tradução e Interpretação: Tradução, Interpretação e Cultura na Era da Globalização. São Paulo, 11-14 maio, 1998a.

- Convencionalidade e produção de texto: um dicionário de colocações verbais inglês/português; português/inglês. São Paulo, 1998b, Tese (Livre-docência), FFLCH/USP.

Collecting data for a bilingual dictionary of verbal collocations: from scraps of paper to corpora research. In: LEWANDOWSKA-TOMASZCZYK, B; MELIA, P. J. (eds.). PALC'99: Practical Applications in Language Corpora. Papers from the International Conference at the University of Lodz,15-18 April 1999. Frankfurt am Main: Peter Lang GmbH, 1999, p. 399-407.

TEMMERMAN, Rita. Sociocognitive terminology theory. In: CABRÉ, M. T; FELIU, J. Terminología y cognición, 2001, p. 75-92.

TOGNINI-BONELLI, Elena. Corpus Linguistics at Work: Studies in Corpus Linguistics 6. Amsterdam/Philadelphia: John Benjamins, 2001.

THOIRON, P., ARNAUD, P., BÉJOINT, H. \& BOISSON, C. (1996).Notion d' «archi-concept» et dénomination. Meta, 41(4), 512-524.

UFI. Global Exhibition Industry Statistics March 2014. Disponível em: $<$ http://www.ufi.org/Medias/pdf/thetradefairsector/surveys/2014_exhibiton_industry_statistics .pdf $>$. Acesso em: 20 out. 2015. 
UK Trade \& Investment. Disponível em: < https://www.gov.uk/government/organisations/uktrade-investment>. Acesso em: 22 out. 2015.

UK Trade \& Investment. Brazil - Gateway to South America. Disponível em: $<$ http://www.bettshow.com/files/i2i7930_ukti_country_series_brazil_v2.pdf $>$. Acesso em: 22 out. 2015.

UK Trade \& Investment. Doing business in Brazil: Brazil trade and export guide. 2014. Disponível em: <https://www.gov.uk/government/publications/exporting-to-brazil/exportingto-brazil\#uk-and-brazil-trade>. Acesso em: 22 out. 2015.

UK Trade \& Investment. Doing business in Brazil? We can help. 2012. Disponível em: $<$ http://www.biopartner.co.uk/documents/BrazilBusinessGuide2012.pdf > . Acesso em: 28 out. 2015.

Union Française des Métiers de l'Evénement. Disponível em: <http://www.unimev.fr/>. Acesso em: 22 out. 2015.

VAN HOOF, Henri. Os Tradutores e os Dicionários. In: DELISLE, Jean; WOODSWORTH, Judith. Os Tradutores na História. São Paulo, Editora Ática, Tradução Sérgio Bath, 1998.

VERMEER, Hans. Esboço de uma teoria da tradução. Porto: Edições ASA, 1985.

ZAVAGLIA, Adriana. Lexicografia bilíngüe e corpora paralelos: procedimentos e critérios experimentais. Cadernos de Tradução, Florianópolis, v. 2, n. 18, p. 19-39, set. 2008. Disponível em: <https://periodicos.ufsc.br/index.php/traducao/article/view/6868>. Acesso em: $09 \mathrm{dez}$. 2015 .

\section{REFERÊNCIAS CORPORA DE ESTUDO EM PORTUGUÊS}

A história da maior feira mundial de tecnologia da informação. Disponível em: $<$ http://www.dw.de/a-hist\%C3\%B3ria-da-maior-feira-mundial-de-tecnologia-dainforma $\% \mathrm{C} 3 \% \mathrm{~A} 7 \% \mathrm{C} 3 \% \mathrm{~A} 3 \mathrm{o} / \mathrm{a}-466311>$. Acesso em: 10 out. 2013.

A importância da participação das empresas em feiras e exposições internacionais. Disponível em <http://www.abinee.org.br/abinee/dri/dri5.htm>. Acesso em: 31 out. 2012.

Agrishow manual do expositor 2012. Disponível em: $<$ http://www.abimaq.org.br/download/agrishow/Balanco_Agrishow.pdf $>$. Acesso em: 10 mai. 2015.

ALMEIDA, Joana; OLIVEIRA, Joana. Feiras Temáticas. 2006. Universidade do Minho. Disponível em: <http://foreigners.textovirtual.com/edit-value/feiras-tematiças.pdf $>$. Acesso em: 26 fev. 2012.

Associação brasileira da indústria elétrica e eletrônica (ABINEE). Disponível em: $<$ http://www.abinee.org.br>. Acesso em: 10 jul. 2011.

Barraca na Feira Livre - Seja Autônomo! Disponível em: $<$ http://trabalhoeinvestimento.blogspot.com.br/2013/09/barraca-na-feira-livre-sejaautonomo.html>. Acesso em: 01 mar. 2014. 
Calendário Brasileiro de Exposições e Feiras. Disponível em: $<$ http://www.brasilglobalnet.gov.br/arquivos/Publicacoes/CalendarioFeiras2012_P.pdf $>$. Acesso em: 20 ago. 2012.

Cartilha Comércio Exterior - 2. ed. - Vitória: SEBRAE/ES, 2006. Disponível em: $<$ http://201.2.114.147/bds/bds.nsf/2390285A6B21C64B832573A90068AD73/\$File/cartilhaco mercioexterioralta.pdf $>$. Acesso em: 22 mai. 2012.

CATEORA, Philip R., GILLY, Mary C., GRAHAM, John L. Marketing Internacional. AMGH Editora Ltda, 2013.

CENSI, Juliana Fonseca e. A participação em feiras de negócios como importante estratégia organizacional. 2004. Trabalho de Conclusão de Curso. Universidade de São Paulo. 2004. Disponível em:

$<$ http://www.rpbahia.com.br/biblioteca/academicos/paper/monografias/feiras_de_negocios.pdf $>$. Acesso em: 22 jun. 2012.

Check list feiras como fazer. In: RISPOLI, Reginaldo. Eventos como fazer. Brasília: Ed. Brasília, 2007.

Comércio exterior ABC. In: WERNECK, Paulo. Comércio Exterior: Política Aduaneira e Fiscal. Rio de Janeiro: [s. n.], 2008.

Como estar presente em uma feira de negócios. Disponível em: $<$ https://pt.scribd.com/document/130053093/Manual-Eventos>. Acesso em: 23 jun. 2012.

Como o Evento Eletrônico pode ser útil à organização de Feiras. Disponível em: $<$ http://www.mzo.com.br/pub/noticia/noticia_det.php?id_noticia=23>. Acesso em: 13 nov. 2018.

Como Participar em Feiras nos Mercados. Disponível em: $<$ http://www.portugalglobal.pt/PT/Internacionalizar/GuiadoExportador/Paginas/7ComoPartici paremFeirasnosMercados.aspx>. Acesso em: 25 jul. 2011.

Contrato aluguel de estande. Disponível em: <http://www.ieee.org.br/tdlamerica2010/Contrato-Aluguel_Estande.doc>. Acesso em: 14 fev. 2012.

Contrato de Locação de Estande com Montagem Básica. Disponível em: $<$ http://pegasus.f.mrp.usp.br/projeto/encontro/imagens/contrato.pdf $>$. Acesso em: 14 fev. 2012.

Contrato Intersolar South America 2017. Disponível em: $<$ https://www.intersolar.net.br/fileadmin/Intersolar-South-

America/2_Exhibitor_Material_2017/ISSA_Exhibitor-Application-Form-2017_PT.pdf $>$. Acesso em: 14 fev. 2017.

Contrato locação estande modelo. Disponível em: $<$ http://www.coweb.com.br/arquivo/arquivo9.doc>. Acesso em: 14 fev. 2012.

DAEMON, Dalton; GUERREIRO, Bruno. Marketing internacional: um enfoque latinoamericano. São Paulo: Editora Saraiva, 1979.

Dicas comportamentais para a equipe do stande SEBRAE. Disponível em: $<\mathrm{http}: / /$ www.abinee.org.br/abinee/dri/dri5.htm>. Acesso em: 14 nov. 2012.

Dicas de Como Participar de Feiras. Vitória: SEBRAE, 2004. Disponível em: $<$ http://vix.sebraees.com.br/arquivos/biblioteca/Diças\%20de\%20como\%20participar\%20de\% 20feiras.pdf $>$. Acesso em: 09 jan. 2012.

Dicas

de

feiras.

Disponível

em: 
$<$ http://www.marketingemsaude.com.br/home/download/DicasFeiras1.pdf $>$. Acesso em: 14 nov. 2012.

Eficácia na organização de eventos: feiras e exposições. Disponível em: $<$ http://repositorio.uniceub.br/bitstream/123456789/1450/2/20419432.pdf $>$. Acesso em: 14 out. 2013.

Dicas para Exposição. Disponível em: $<$ http://www.mercopar.com.br/expositores.asp?area=1\&idRegistro=55>. Acesso em 14 out. 2013.

Dicionário online de português. Disponível em: <http://www.dicio.com.br/mostruario/>. Acesso em: 05 mar. 2013.

Displays pantográficos. Disponível em: <http://www.portabanners.com.br/displayspantograficos.html>. Acesso em: 11 nov. 2013.

Elaboração de Programas Detalhados para Exposições e Feiras. Disponível em: $<$ http://www.google.com.br/url?sa $=\mathrm{t} \& \mathrm{rct}=\mathrm{j} \& \mathrm{q}=\&$ esrc $=$ s\&source $=$ web \&cd $=4 \& v e d=0 \mathrm{CDsQFj}$ AD\&url $=\mathrm{http} \% 3 \mathrm{~A} \% 2 \mathrm{~F} \% 2 \mathrm{Fportal}$. iefp.pt $\% 2 \mathrm{Fxeobd} \% 2$ Fattachfileu.jsp\%3Flook_parentBoui $\%$ 3D8613319\%26att_display\%3Dn\%26att_download\%3Dy\&ei=DDCBUsL3Aof1kQfK5YGA Dg\&usg=AFQjCNGJ5MfunTGcCeUxa7cPGe4bXNMzfg\&bvm=bv.56146854,d.eW0>.

Acesso em: 11 nov. 2013.

Embratur abre inscrições para participação em feiras. Disponível em: $<$ http://www.brasil.gov.br/turismo/2014/03/embratur-abre-inscricoes-para-participacao-emfeiras>. Acesso em: 10 abr. 2014.

Empresários de Birigui se preparam para a Francal 2015. Disponível em: $<$ http://www.francal.com.br/site/noticia_detalhe.asp?noticia_id=31267\&idioma_id=1\&sessao $=1 \#$. WXJNKIFv_IU >. Acesso em: 10 mai. 2017.

Entenda os tipos de estande - Stand básico. Disponível em: $<$ http://www.stand8.com.br/tiposstand.html?start=1>. Acesso em: 31 jan. 2013.

Entenda os tipos de stand - Stand Padrão. Disponível em: $<\mathrm{http}$ ://www.stand8.com.br/index.php?option=com_content\&view=article\&id=74\&Itemid=7 $1 \&$ limitstart=2 >. Acesso em: 11 mai. 2017.

Estande coletivo do rio grande do sul couromoda 2015. Disponível em: $<$ https://docplayer.com.br/18249131-Manual-do-expositor-estande-coletivo-do-rio-grande-dosul-sao-paulo-pret-a-porter-2015-11-a-14-de-janeiro-de-2015.html>. Acesso em: 03 ago. 2013.

Estandes de Birigui têm boa visitação na Francal. Disponível em: $<$ http://www.apiceshoes.com.br/texto.asp?C\%F3digo=220>. Acesso em: 03 ago. 2013.

Estandes nas feiras: abertos ou fechados? Disponível em: $<$ http://www.exclusivo.com.br/Noticias/58565/Estandes-nas-feiras:-abertos-ou fechados?.eol>. Acesso em: 30 jan. 2013. 
Eventos Internacionais Sebrae. Disponível em: $<$ http://www.biblioteca.sebrae.com.br/bds/bds.nsf/C3F4B07E011187D08325789B005227A3/ \$File/1196-SEBRAEMG-

S\%C3\%A9rie\%20Coopera\%C3\%A7\%C3\%A3o\%20Internacional\%20-

\%20Eventos\%20Internacionais.pdf>. Acesso em: 02 mai. 2012.

EXPO-ABRH tem lançamentos e brincadeiras para atrair público. Disponível em: $<$ http://maisrh.wordpress.com/2010/08/19/expo-abrh-tem-lancamentos-e-brincadeiras-paraatrair-publico/>. Acesso em: 30 jan. 2013.

Exponor - O Recinto. Disponível em: <http://www.exponor.com.br/exponor-portugal/>. Acesso em: 14 out. 2013.

Exportação Passo a Passo / Ministério das Relações Exteriores. Brasília: MRE, 2004. Disponível em: <http://www.schualm.com.br/artigos/Exportação.pdf>. Acesso em: 10 jan. 2012.

Exportação Passo a Passo/ Ministério das Relações Exteriores. Brasília: MRE, 2011. Disponível em: $<$ http://www.brasilglobalnet.gov.br/ARQUIVOS/Publicacoes/Manuais/PUBExportPassoPass o2012.pdf $>$. Acesso em: 14 nov. 2012.

Exposições, Feiras e Bons Negócios. Disponível em: $<$ http://www.marketingemsaude.com.br/home/download/DicasFeiras1.pdf $>$. Acesso em: 14 nov. 2012.

Expositores. Disponível em: <http://ehcbr.com.br/expositores.php>. Acesso em: 18 nov. 2013.

Feicon 2017 manual do expositor. Disponível em: $<$ http://arquivos.reedalcantara.com.br/feicon-2017-manual-do-expositor.pdf $>$. Acesso em: 12 fev. 2017.

$\begin{array}{llllll}\text { Feira } & 1 & a & 99 & \text { Brasil. }\end{array}$ $<$ http://www.portalradar.com.br/telas/noticias/detalhes.aspx?id=9348>. Acesso em: 06 jun. 2013.

Feira da mecânica manual do expositor 2016. Disponível em: $<$ http://www.mecanica.com.br/es/Exponer/Ya-Soy-Expositor/Manual--Normas-delExpositor/>. Acesso em: 10 mai. 2017.

Feira do Empreendedor 2014 Minas Gerais. Disponível em: $<$ http://feiradoempreendedormg.com.br/wp-content/uploads/2014/01/Manual-do-ExpositorFeira-do-Empreendedor-2014-Minas-Gerais.pdf > . Acesso em: 10 mai. 2017.

Feira do Empreendedor 2017 Sebrae-SP. Disponível em: $<$ https://www.inova.unicamp.br/noticia/feira-do-empreendedor-2017-sebrae-sp-abreinscricoes-para-expositores/>. Acesso em: $15 \mathrm{dez} 2018$.

Feira do livro de Frankfurt 2013 - Orientações Gerais. Disponível em: $<\mathrm{http}$ ://www.abeu.org.br/Apresentacao-ABEU-Frankfurt-2013-Novo.pdf $>$. Acesso em: 23 jun. 2013.

Feiras e eventos Sebrae 2014. Disponível em: <http://www.sebraemercados.com.br/wpcontent/uploads/2015/10/2014_04_10_BO_Jan_Tur_FeirasEventos_Validacao.pdf $>$. Acesso em: 20 jan. 2015. 
Feira Internacional dos Cerrados 2019: notícias. Disponível em: $<$ http://www.agrobrasilia.com.br/noticias/1505-coopa-df-participa-do-eixao-agro.html>. Acesso em: $20 \mathrm{dez} 2018$.

Feira internacional Expodireto 2017. Disponível em: $<$ https://www.expodireto.cotrijal.com.br/wp-content/uploads/2018/02/Expodireto-Manual-doExpositor-2018.pdf >. Acesso em: 11 set. 2017.

Feiras Internacionais - Roteiro para expositores. Disponível em: <http://www.sebraesc.com.br/ideais/default.asp?vcdtexto $=375 \& \% 5 \mathrm{E} \% 5 \mathrm{E}=>$. Acesso em: 14 out. 2013.

Feiras Livres. Disponível em: <http://www.cidadedesaopaulo.com/sp/br/o-quevisitar/atrativos/pontos-turisticos/2836-feiras-livres>. Acesso em: 01 mar. 2014.

Feira Mista - Gazeta Mercantil. Disponível em: $<$ http://www.jornalcana.com.br/noticia/Jornal-Cana/10469+Feira-mista $>$. Acesso em: 03 ago. 2013.

Feira profissional . Disponível em: <http://pt.wikipedia.org/wiki/Feira_profissional $>$. Acesso em: 20 ago. 2012.

Feiras são vitrines dos pequenos negócios. Disponível em: $<$ http://www.sebrae.com.br/uf/riogrande-do-norte/areas-de-atuação/ampliação-do-mercado/feiras-e-eventos $>$. Acesso em: 20 ago. 2012.

Feiras Temáticas. Disponível em: <http://foreigners.textovirtual.com/edit-value/feirastematicas.pdf> . Acesso em: 10 mar 2012.

Feiras virtuais de negócios. Disponível em: <http://www.arkadin.com/br/sobrevoce/necessidades/feiras-virtuais>. Acesso em: 23 jun. 2013.

FURINI, Elias; SPONCHIADO, Renato; SENGER, Carine Maria; PANNO, Fernando; SENGER, Igor. Participação em Feiras Comerciais como Ação Promocional dos Expositores. IV Seminário Internacional de Pesquisa em Comunicação Estratégicas e Identidades Midiáticas. UFSM. Disponível em: $<$ http://www.ufsm.br/sipecom/anais/artigos/acaopromocional/SENGER,\%20PANNO,\%20SE NGER,\%20SPONCHIADO\%20e\%20FURINI.pdf>. Acesso em: 20 ago. 2012.

GIACAGLIA, Maria Cecília. Organização de eventos: teoria e prática. São Paulo: Cengage Learning, 2003.

GODOY, Dutra Fante Ariane. Glossário Bilíngue dos Termos Fundamentais do Setor Feirístico: Busca de Equivalências em Inglês. Dissertação de mestrado apresentada ao programa de pós-graduação em Estudos Linguísticos da Unesp, campus de São José do Rio Preto, 2014.

Grupo Feira \& Cia. Disponível em: <http://www.feiraecia.com.br>. Acesso em: 10 jul. 2012.

Guia de acesso a feiras Sebrae Bahia 2016. Disponível em: $<$ https://m.sebrae.com.br/Sebrae/Portal\%20Sebrae/UFs/BA/Anexos/GUIA\%20ACESSO\%20 A\%20FEIRAS\%20SEBRAE\%20BAHIA-2016.pdf>. Acesso em: 02 mar. 2016. 
Guia de Boas Práticas de Comunicação em Feiras e Eventos - Práticas e Procedimentos. Disponível em: $<\mathrm{http}: / / \mathrm{www} . a b r a c o m . o r g . b r / g u i a f e i r a s e c o n g r e s s o s . p d f>$. Acesso em: 02 jun. 2012.

Guia de marketing para expositores Fispal food service. Disponível em: $<$ https://www.fispalcafe.com.br/content/dam/Informa/fispalfoodservice/pt/2016/pdfs/bra17ffs -is-guia-mkt.pdf>. Acesso em: 02 abr. 2016.

Guia de participação FIT 2018. Disponível em: <https://www.fit016.com.br/wpcontent/themes/anutec/download/Guia_Participacao_NOV18.pdf $>$. Acesso em: 7 nov. 2018.

Guia dicas MKT 2017 Feira hospitalar. Disponível em: $<$ https://www.hospitalar.com/images/download/Guia_de_Dicas_do_Marketing_2019_PT_v3_ AF.pdf $>$. Acesso em: 05 set. 2017.

Guia do Expositor2017 Fi Food Ingredients South America. Disponível em: $<$ https://www.fievents.com.br/images/download/348_Fi\%20_Guia_do_Expositor2017_v4.pdf >. Acesso em: 05 set. 2017.

Guia feiras e congressos. Disponível em: $<$ http://www1.abracom.org.br/cms/opencms/abracom/pt/uploads/pdf/Boas_Praticas_Feiras_e _Eventos.pdf >. Acesso em: 02 fev. 2014.

Inteligência de mercado em feiras Sebrae. Disponível em: $<$ https://m.sebrae.com.br/Sebrae/Portal\%20Sebrae/UFs/BA/Anexos/Intelig\%C3\%AAncia\%2 0em\%20Feiras\%20-\%20Beauty\%20Fair\%202016.pdf>. Acesso em: 10 jul. 2017.

KOTABE, Masaaki, HELSEN, Kristiaan. Administração de Marketing Global. Tradução de Ailton Bomfim Brandão. São Paulo: Editora Atlas, 2000.

KOTLER, Philip. Administração de Marketing. São Paulo: Prentice Hall, 2000, 10 ed., 2000. Disponível em: <http://www.sintracoopsc.com.br/wp-content/uploads/2009/03/PDFMarketing-Kotler-2000.pdf>. Acesso em: 13 abr. 2013.

KOVACS, Erica Piros; OLIVEIRA, Brigitte Renata Bezerra de; ALBUQUERQUE, Steven Paul Smrekar. Participação em Feiras: Uma Pesquisa Exploratória sobre Expositores Brasileiros e Estrangeiros em Eventos Internacionais. Disponível em: $<$ http://www.ead.fea.usp.br/semead/11semead/resultado/trabalhosPDF/379.pdf $>$. Acesso em: 12 mar. 2012.

Lei do turismo $n^{o}$ 11.771, de 17 de setembro de 2008. Disponível em: $<$ http://www.planalto.gov.br/ccivil_03/_ato2007-2010/2008/lei/111771.htm>. Acesso em: 10 out. 2013.

Mais de 12 mil pessoas visitaram a Brazil Automation 2012. Disponível em: $<\mathrm{http}$ ://www.manutencaoesuprimentos.com.br/conteudo/7430-mais-de-12-mil-pessoasvisitaram-brazil-automation-2012/>. Acesso em: 10 out. 2013.

Manual ABF Franchising Expo 2011. Disponível em: $<$ https://manualexpositor.btsinforma.com.br/entrar?ReturnUrl=\%2F\&tipo=Expositor $>$. Acesso em: 12 fev. 2013 
Manual Básico de Exportação Fiesp. Disponível em: $<$ http://www.fiesp.com.br/publicacoes/pdf/relacoes/manual_exportação.pdf $>$. Acesso em 26 fev. 2012.

Manual de Feiras e Exposições SEBRAE. Disponível em: $<$ http://201.2.114.147/bds/bds.nsf/2CEC7501C11CC400832573E0005C945F/\$File/NT00037 4AE.pdf>. Acesso em: 30 abr. 2012.

Manual de Orientação Feiras no Exterior. Disponível em: <http://www.softex.br/dn/_psisw/Documentos/manual_feiras_exterior.pdf>. Acesso em: 26 fev. 2012.

Manual de Participação em Feiras Internacionais. Disponível em: $<\mathrm{http}$ ://www.fbcvb.org.br/hotsite/inscrição/manual_de_apoio.asp>. Acesso em: 01 mar. 2012.

Manual digital Expositor feira APAS 2016. Disponível em: <http://www.apasshow.com.br/wpcontent/uploads/2018/01/MANUAL\%20APAS\%20SHOW\%202018\%20FINAL\%2017_01.p df $>$. Acesso em: 23 jul. 2016.

Manual do Expositor Abradilan Conexão Farma 2017. Disponível em: $<$ http://www.abradilanconexaofarma.com.br/assets/planta/manual_expositor_abradilan.pdf $>$. Acesso em: 09 mai. 2017.

Manual do expositor Abrin feira brasileira de brinquedos 2012. Disponível em: $<$ https://slidex.tips/download/manual-especifico-nele-voce-encontra-as-normas-queregulamentam-e-orientam-a-ope-8>. Acesso em: 05 abr. 2015.

Manual do expositor ABTCP 2016. Disponível em: <https://docplayer.com.br/6765202Promocao-e-organizacao-abtcp.html>. Acesso em: 06 mai. 2017.

Manual do expositor APAS SHOW 2018. Disponível em: <http://www.apasshow.com.br/wpcontent/uploads/2018/01/MANUAL\%20APAS\%20SHOW\%202018\%20FINAL\%2017_01.p df $>$. Acesso em: 06 out. 2018.

Manual do expositor Autonor 2017. Disponível em: <http://www.autonor.com.br/site/wpcontent/uploads/2018/07/estudos-manual-do-expositor-autonor-13-06-2017.pdf > . Acesso em: $15 \operatorname{dez} 2018$.

Manual do expositor Beauty fair 2017. Disponível em: $<$ http://beautyfashionfair-es.com/wpcontent/uploads/2017/04/MANUAL-EXPOSITOR-BFF-2017.pdf>. Acesso em: 02 jul. 2017.

Manual do expositor Beauty fest 2016. Disponível em: $<\mathrm{http}$ //www.beautyfest.com.br/documentos/manual_expositor.pdf $>$. Acesso em: 02 nov. 2017.

Manual do expositor XXXV CBP 2017. Disponível em: <http://www.cbpabp.org.br/hotsite/wpcontent/uploads/2017/06/XXXV-CBP-Manual-do-Expositor.pdf >. Acesso em: 15 nov. 2018.

Manual do Expositor CIAB FEBRABAN 2017. Disponível em: <http://www.ciab.org.br/>. Acesso em: 02 mar. 2018. 
Manual do expositor EQUIPOTEL REGIONAL 2018. Disponível em: $<\mathrm{http}$ ://arquivos.reedalcantara.com.br/normasespecificaspt-2018equipotelregional.pdf $>$. Acesso em: 17 set 2018.

Manual do Expositor EXPONOR 2017. Disponível em: <http://www.exponormg.com.br/wpcontent/uploads/2017/04/MANUAL-DO-EXPOSITOR-2017.pdf>. Acesso em: 03 set. 2017.

Manual do expositor Bienal Internacional do livro de São Paulo 2016. Disponível em: $<$ http://arquivos.reedalcantara.com.br/manualexpositor2016.pdf>. Acesso em: 10 mai. 2017.

Manual do Expositor CIOSP 2012. Disponível em: $<$ http://www.ciosp.com.br/assets/pdf/manual-do-expositor.pdf $>$. Acesso em: 07 mar. 2012.

Manual do Expositor CIOSP 2013. Disponível em $<$ http://www.ciosp.com.br/anexos/manual_formularios_expositor.pdf $>$. Acesso em: 14 out. 2012.

Manual do expositor CIOSP 2018. Disponível em: $<$ http://36.ciosp.com.br/assets/pdf/manualexpositor-portugues.pdf >. Acesso em: 04 out. 2018.

Manual do expositor Cipa Fiera Milano 2018 em SP. Disponível em: $<\mathrm{http}$ //www.fireshow.com.br/18/manuais/manual_regulamento_do_expositor_2018_fisp_fire show_pt.pdf $>$. Acesso em: 13 nov. 2018.

Manual do expositor Constrosul 2015 feira internacional da construção. Disponível em: $<$ http://www.feiraconstrusul.com.br/conteudo/wp-content/uploads/2014/03/ME-09-10-17.pdf >. Acesso em: 08 set. 2016.

Manual do expositor Equipotel Regional 2018. Disponível em: $<$ http://arquivos.reedalcantara.com.br/normasespecificaspt-2018equipotelregional.pdf $>$.

Acesso em: 11 dez. 2018.

Manual do expositor Exposuper 2018. Disponível em: $<$ http://www.exposuper.com.br/app/webroot/publicFiles/files/pdfs/MANUAL\%20DO\%20EX POSITOR\%20-\%20EXPOSUPER\%202018\%20ATUAL\%202.pdf>. Acesso em: 01 out 2018.

Manual do expositor ExpoVinis 2017. Disponível em: $<$ https://kipdf.com/manual-do-expositorpromoao-e-organizaao_5aaba6b61723dd343eec626f.html>. Acesso em: 10 set. 2018.

Manual do expositor Feira do Empreendedor. Disponível em: $<$ https://intranet.mt.sebrae.com.br/geoconnector/uploads/manual-de-orientacao.pdf $>$. Acesso em: 08 out. 2018.

MANUAL do expositor FEIRA bem casados 2016. Disponível em: $<$ https://slidex.tips/download/manual-do-expositor-feira-bem-casados-2016>. Acesso em: 01 out. 2016.

Manual do expositor FICONS 2016. Disponível em: $<$ http://www.ficons.com.br/2016/static/manual\%20do\%20expositor.pdf $>$. Acesso em: $20 \mathrm{dez}$. 2018. 
Manual do expositor XXXVII Congresso Brasileiro de Oftalmologia. Disponível em: $<$ http://www.google.com.br/url?sa $=\mathrm{t} \& \mathrm{rct}=\mathrm{j} \& \mathrm{q}=\&$ esrc $=$ s\&source=web\&cd=20\&ved=0CGAQ FjAJOAo\&url=http $\% 3 \mathrm{~A} \% 2 \mathrm{~F} \% 2 \mathrm{Fwww}$.congressocbo.com.br $\% 2 \mathrm{Fcbo} 2013 \% 2 \mathrm{Farquivos} \% 2 \mathrm{Fe}$ xposicao-comercial\%2Fmanual-doexpositor.pdf\&ei=qWRVUv_xOpDS9ATxn4HACA\&usg=AFQjCNG7ZkZDjT8EGh_i5eG_ p5skI0RFLA\&bvm=bv.53760139,d.eWU>. Acesso em: 09 out. 2013.

Manual do Expositor ExpoFood 2012. Disponível em: $<$ http://www.superrio.com.br/ManualExpositor2013.pdf>. Acesso em: 10 mai. 2013.

Manual do Expositor Feiplar Composites \& Feipur 2012. Disponível em: $<$ http://www.feiplar.com.br/images/manual/manual_feiplar.pdf $>$. Acesso em: 24 set. 2012.

Manual do Expositor Feira ArtRio 2013. Disponível em:

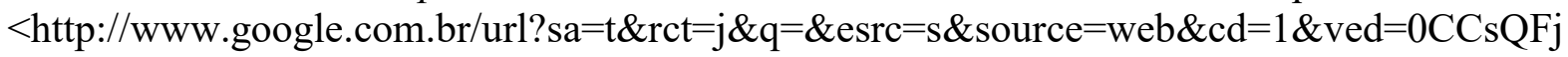
AA\&url=http $\% 3 \mathrm{~A} \% 2 \mathrm{~F} \% 2 \mathrm{Fwww}$.artrio.art.br\%2Fvendor\%2Fapplication $\% 2 \mathrm{FArtRio}-\mathrm{App}-$ 2013.pdf\&ei=4adWUs7yGtLh4APYsYDACQ\&usg=AFQjCNF0NHnflgB-

OwsNRzKcmamBTE827g\&bvm=bv.53760139,d.dmg>. Acesso em: 10 out. 2013.

Manual do Expositor Feira do Empreendedor 2012. Disponível em: $<$ http://feiradoempreendedor-rs.com.br/wp-content/uploads/2012/05/BS-0003-12AE-ManualExpositor.pdf $>$. Acesso em: 14 nov. 2012.

Manual do expositor Femult 2017. Disponível em: <http://acime.com.br/femult2017/wpcontent/uploads/2017/07/Manual-do-Expositor-FEMULT-2017.pdf>. Acesso em: 29 set. 2019.

Manual do expositor Femur 2016. Disponível em: $<$ http://www.femur.com.br/upload/file/manual_do_expositor_femur2018.pdf $>$. Acesso em: 13 abr. 2016.

Manual do expositor Fenac - Centro de Eventos e Negócios. Disponível em: $<$ http://www.fenac.com.br/>. Acesso em: 08 jun. 2018.

Manual do expositor Fenacam 2014. Disponível em: $<$ http://www.fenacam.com.br/assets/downloads/manual_do_expositor_2018.pdf $>$. Acesso em: 05 dez. 2014.

Manual do expositor Francal 2011. Disponível em: $<$ http://www.francal.com.br/FormularioWeb/Formularios/Download/MAN_francal2011.pdf $>$. Acesso em: 10 mai. 2017.

Manual do expositor Fipan 2017. Disponível em: <http://fipan.com.br/wpcontent/uploads/2017/02/MANUAL-EXPOSITOR-FIPAN-2017.pdf>. Acesso em: 10 ago. 2017.

Manual do expositor FORMOBILE 2018. Disponível em: $<$ https://www.formobile.com.br//content/dam/Informa/form\%c3\%b3bile/manual-expositor2018/ManualdoExpositorFormobile2018-oficial2.pdf>. Acesso em: 19 set. 2018. 
Manual do Expositor ISA Expo Campinas 2016. Disponível em: $<$ http://expositor.gmembers.com.br/login/>. Acesso em: 03 abr. 2017.

Manual do expositor $M \hat{A O} 2018.2$ Disponível em: $<$ http://www.mao2017.com.br/temas/mao2017/arquivos/Manual\%20do\%20expositor\%2037o \%20CBCM.pdf >. Acesso em: 08 dez. 2018.

MANUAL do expositor MERCOAGRO 2016. Disponível em: $<$ http://www.mercoagro.com.br/anexos/1109/37791/manual-expositor-mercoagro2018_versao-06-pdf $>$. Acesso em: 10 dez. 2016.

Manual do expositor Mercopar 2015. Disponível em: <https://www.mercopar.com.br/wpcontent/uploads/2015/01/Manual-Expositor_Mercopar2015pdf.pdf>. Acesso em: 02 nov 2018.

Manual do expositor Salão duas rodas 2015. Disponível em: $<\mathrm{http}$ //www.salaoduasrodas.com.br/Expor/Ja-Sou-Expositor/ManualNormas/>. Acesso em: 07 nov. 2016.

Manual do expositor PACKFAIR 2017. Disponível em: $<$ http://www.packfair.com.br/imagem/MANUAL\%20DO\%20EXPOSIOR\%20PACKFAIR\% 202017.pdf $>$. Acesso em: 13 jul. 2017.

Manual do Expositor BRAZIL PROMOTION 2015. Disponível em: $<$ http://www.easyeventos.com.br/easyweb/ManualEletronico/ManualEletronico/Login/CLT_ Login.aspx >. Acesso em: 07 set. 2016.

Manual do Expositor ABAV Expo Internacional de Turismo 2016. Disponível em: $<\mathrm{http}$ //www.abavexpo.com.br/manual/Manual_do_Expositor_Abav_Expo_2018.pdf $>$.

Acesso em: 04 mar. 2017.

Manual do expositor 24 Salão paranaense. Disponível em: $<\mathrm{http}$ ://salaoparanaense.com.br/sysfiles/manual-do-expositor-24-salao-paranaense.pdf $>$. Acesso em: 07 nov. 2018.

Manual do expositor salão paraense de turismo 2017. Disponível em: $<$ http://salaoparanaense.com.br/sysfiles/manual-do-expositor-24-salao-paranaense.pdf $>$. Acesso em: 11 jul. 2017.

Manual do expositor SBCCV 2011. Disponível em: $<$ http://www.sbccv.org.br/imagebank/regulamento_expositor_2011.pdf $>$. Acesso em: $20 \mathrm{dez}$ 2018.

Manual do expositor SOCESP XXXVII 2016. Disponível em: $<$ http://www.socesp2016.com.br/arquivos/feira-de-exposicao/MANUAL-DO-EXPOSITORSOCESP-XXXVII.pdf >. Acesso em: 03 ago. 2016.

Manual do Expositor XIX CONAD 2014. Disponível em: $<$ https://www.conad.adm.br/upload/manualExpositor.pdf >. Acesso em: 20 jan. 2016. 
Manual do expositor Fitness Brasil 2018. Disponível em: $<$ https://www.fitnessbrasil.com.br/wp-content/uploads/Anexo-IV-Manual-Especifico-deProcedimentos-e-Normas-de-Montagem-do-Expositor-Evento-FBSP-2018_V1.pdf $>$. Acesso em: 02 dez 2018.

Manual do expositor Feiarte 2015. Disponível em: <http://ivrozilla.com/doc/787581/manualdo-expositor-feiarte-2015-\%E2\%80\%93-edi\%C3\%A7\%C3\%A3o-curitiba-12-05>. Acesso em: 18 jan. 2016.

Manual do expositor Fiemabrasil 2018. Disponível em: $<$ https://fiema.com.br/downloads/manual_do_expositor_fiema_brasil_2018.pdf $>$. Acesso em: 02 dez. 2018.

Manual do Expositor FISA 2012. Disponível em: $<$ http://www.fievents.com.br/download/Call\%20for\%20papers2012/Manual\%20Fisa\%202012\%20\%20Portugues.pdf $>$. Acesso em: 27 out. 2012.

Manual do Expositor Fispal 2011. Disponível em: $<$ http://www.btsinforma.com.br/main.asp?cod_nucleo=10\&cod_evento=19\&cod_menutop $=1$ 13\&cod_menu=349\&cod_idioma=1\#>. Acesso em: 30 abr. 2012.

Manual do Expositor FIT - Feira Internacional do Setor Infanto-Juvenil 2012. Disponível em: $<$ http://www.fit016.com.br/MANUAL_2012nov12.pdf>. Acesso em: 24 set. 2012.

Manual do expositor Futurecom 2016. Disponível em: $<$ https:/futureshare.com.br/Futurecom_2016/Operacional/manual-do-expositor-e-montadorfuturecom-2016-official-pt1.pdf>. Acesso em: 11 mai. 2017.

Manual do Expositor Hortitec 2017. Disponível em: <http:/hortitec.com.br/site/wpcontent/uploads/2017/03/Manual-Expositor-Hortitec-2017.pdf>. Acesso em: 11 mai. 2017.

Manual do Expositor Look Hair - Profissional Norte 2013. Disponível em: $<$ http://www.google.com.br/url? sa $=$ t\&rct $=\mathrm{j} \& \mathrm{q}=\&$ esrc $=$ s\& source=web\&cd=58\&ved=0CFMQ FjAHODI\&url=http $\% 3 \mathrm{~A} \% 2 \mathrm{~F} \% 2 \mathrm{Fwww}$.lookhair.com.br\%2Fwpcontent $\% 2$ Fuploads $\% 2$ F2012\%2F10\%2FManual-do-Expositor-2013Revisado.pdf\&ei=x_hbUr61OaTAigL154CoBA\&usg=AFQjCNHzY5GJ8ZU8LtOdtJvqEV75miDzA\&bvm=bv.53899372,d.cGE>.Acesso em: 14 out. 2013.

Manual do Expositor RBD 2012. Disponível em: $<$ http://www.google.com.br/url?sa=t\&rct=j\&q=\&esrc=s\&source=web\&cd=1\&ved=0CDgQFj AA\&url=http $\% 3 \mathrm{~A} \% 2 \mathrm{~F} \% 2 \mathrm{Fwww}$.dermat $12 . \mathrm{com} . \mathrm{br} \% 2 \mathrm{Fexpositor} \% 2 \mathrm{Fmanual}$ sbd.pdf\&ei=IA ZIU7eaCITV0QGs84GYAQ\&usg=AFQjCNHBKHoV3rr0t6GbRBaUYuTO0ZvmGw\&sig2= 2T3DrQi5zPihc-I1ScHxwA\&bvm=bv.64542518,d.dmQ> . Acesso em: 10 abr. 2014.

Manual do expositor salão SABORES 2016. Disponível em: $<\mathrm{http}: / /$ feirasabores.com.br/wpcontent/uploads/2017/08/Manual-Expositor-Sabores2017.pdf>. Acesso em: 22 out. 2016.

Manual geral do expositor BTS 2012. Disponível em: $<$ https://manualexpositor.btsinforma.com.br/entrar?ReturnUrl=\%2F $>$. Acesso em: 05 mar. 2014.

MARTINS, Plinio Filho. Edusp: Um Projeto Editorial. São Paulo: Ateliê Editorial, 2001. 
MELIM, José Maria. Como participar de uma feira ou exposição. Joinville: Fundação Empreender. Disponível em: $\quad<$ http://www.nucleusinternational.net/Nuc_Portugues/P10_Download/P04_Special_Activities/P0401_Trade_Fair/P81_Feiras_Melim.pdf $>$. Acesso em: 22 set. 2012.

Mercado vertical $x$ mercado horizontal. Disponível em: $<\mathrm{http}$ ://empresasefinancas.hsw.uol.com.br/exposicoes-profissionais3.htm>. Acesso em: 11 mar. 2013.

NEVES, Maria Cristina Baeta; RAMAL, Silvina. Pequenos Negócios em Comércio e Serviços. Rio de Janeiro: SENAC Nacional, 2005. 160p.

Noções básicas: 02 - tipos de estandes. Disponível em: <http://www.falandodefeiras.info/ 2009/05/nocoes-basica-02-tipos-de-estandes.html>. Acesso em: 30 jan. 2013.

Obtendo Sucesso em Feiras Internacionais. Disponível em: $<$ http://www.abinee.org.br/abinee/dri/dri5.htm>. Acesso em : 25 jul. 2011.

O desafio das feiras de negócios. Disponível em: <http://www.connectonmkt.com.br/noticia.php?id=9>. Acesso em: 06 jun. 2013.

O estande que é a cara da sua empresa. Disponível em: $<$ http://www.diarioweb.com.br/sua_casa/corpo_noticia.asp?idCategoria=102\&idNoticia=122 26>.Acesso em: 18 nov. 2013.

O mercado brasileiro de feiras 2007. Disponível em: $<$ http://www.biblioteca.sebrae.com.br/bds/BDS.nsf/B181DA87B44053BE832573E0005BEE 1E/\$File/NT000374AA.pdf>. Acesso em: 02 mai. 2012.

O Mercado brasileiro de feiras 2008. Disponível em: $<$ http://www.biblioteca.sebrae.com.br/bds/BDS.nsf/DC9AE867A394C2D3832574F800652F2 D/\$File/NT0003A3CE.pdf $>$. Acesso em: 02 mai. 2012.

Orientações Básicas para participação em feiras internacionais. Disponível em: $<$ http://wiki.apexbrasil.com.br/@api/deki/files/1354/=OrientacoesBasiçasParticipaçãoFeirasIn ternacionais.pdf>. Acesso em: 26 fev. 2012.

Os bastidores de uma feira livre. Disponível em: $<$ http://www.google.com.br/url? sa =t\&rct=j\&q=\&esrc=s\&source=web\&cd=34\&ved=0CDkQ FjADOB4\&url=http\%3A\%2F\%2Fpuc-riodigital.com.puc-rio.br\%2Fmedia\%2F13\%2520$\% 2520$ os\%2520bastidores\%2520de\%2520uma\%2520feira\%2520livre.pdf\&ei=fokTU6nwG M75kQfQhoCgDA\&usg=AFQjCNGUKfvfK0LcDnByWc37E5d82knSHA\&bvm=bv. 622864 60,d.eW0>. Acesso em: 01 mar. 2014.

Paralela Gift - Feira de negócios. Disponível em: $<$ http://www.paralelagift.com.br/paginas/default.aspx>. Acesso em: 23 jun. 2013.

Participação em feiras nos EUA. Disponível em: <http://miami.itamaraty.gov.br/ptbr/feiras_e_eventos.xml\#Feiras\%20EUA>. Acesso em: 11 ago. 2018. 
Petink Soluções Inovadoras para PDV. Disponível em: <http:/www.petink.com.br/display-dechao-petink>. Acesso em: 28 mai. 2013.

Planejamento eficaz de feira comercial. Disponível em: $<$ http://brasil.smetoolkit.org/brasil/pt_br/content/pt_br/50/Planejamento-eficaz-de-feiracomercial>. Acesso em: 14 out. 2013.

Plast-ISO Plásticos de Engenharia \& Acrílico. Disponível em: <http://www.plastiso.com.br/>. Acesso em: 23 jun. 2013.

Projeto feira livre. Disponível em: $<$ http://www.emater.pr.gov.br/arquivos/File/Biblioteca_Virtual/Premio_Extensao_Rural/1_Pr emio_ER/ProjetoFeiraLivre.pdf >. Acesso em: 11 mai. 2017.

Projeto Organics Brasil destaca importância da feira e comemora sucesso do Fórum. Disponível em: $<\mathrm{http}: / /$ biobrazilfair.com.br/noticias_detalhe.asp?noticia_id=31191>. Acesso em: 11 mai. 2017.

Qual a diferença entre stand básico, misto $e$ construído? Disponível em: $<$ https://alumipac.com.br/diferencas-entre-stand-basico-misto-e-construido/>. Acesso em: 11 mai. 2017.

Regulamento geral $7^{\circ}$. SALIMP. Disponível em: $<$ http://www.rpsfeiras.com.br/feiras/imperatriz09/Regulamento\%20Geral.pdf >. Acesso em: 15 fev. 2016.

Regulamento Geral da Feira 1 a 99 Brasil $-25^{a}$ edição. Disponível em $<$ http://www.feira199brasil.com.br/upload/arquivos/regulamento.pdf $>$. Acesso em: 14 fev. 2012.

Relatório de Inteligência em Feiras - SEBRAE 2011. Disponível em: $<$ http://www.biblioteca.sebrae.com.br/bds/bds.nsf/CCCB3CAE80DF83CC8325795A0041740 5/\$File/NT00047266.pdf>. Acesso em: 02 mai. 2012.

Revista Feira\&Cia. São Paulo: Sansei Editora Ltda, ano 8, n. 65,2006. . São Paulo: Sansei Editora Ltda, ano 9, n.68, 2006. . São Paulo: Sansei Editora Ltda, ano 9, n.70, 2006. . São Paulo: Sansei Editora Ltda, ano 9, n.72, 2006. . São Paulo: Sansei Editora Ltda, ano10, n.74/75, 2007. . São Paulo: Sansei Editora Ltda, ano 10, n.77, 2007. . São Paulo: Sansei Editora Ltda, ano 11, n.85, 2009. . São Paulo: Sansei Editora Ltda, ano 11, n.88, 2009. 
. São Paulo: Sansei Editora Ltda, ano 13, n.94, 2010.

. São Paulo: Sansei Editora Ltda, ano 14, n.100, 2011.

São Paulo: Sansei Editora Ltda, ano 14, n.102, 2011.

. São Paulo: Sansei Editora Ltda, ano 15, n.105, 2012.

RISPOLI, Reginaldo. Feiras e Exposições. In: Eventos Como Fazer. Brasília: Editora Redgraf, 2007.

RODRIGUES, Rui Miguel da Silva. O contributo das Feiras Internacionais na Performance Exportadora das Empresas: a Percepção dos Empresários. 2010. Dissertação (Mestrado em Economia e Gestão Internacional) - Faculdade de Economia da Universidade do Porto, 2010. Disponível em: $\quad<$ http://www. $\quad$ http://repositorioaberto.up.pt/bitstream/10216/26924/2/RUI\%20RODRIGUES\%20\%20EGI.pdf>. Acesso em: 03 mar. 2012.

Termos e Condições Gerais de Participação em Feiras - Apex. Disponível em: $<$ http://www.apexbrasil.com.br/uploads/Termos\%20e\%20Condi\%C3\%A7\%C3\%B5es\%20Ge rais $\% 20-\% 20$ Participa $\% \mathrm{C} 3 \% \mathrm{~A} 7 \% \mathrm{C} 3 \% \mathrm{~A} 3 \mathrm{o} \% 20 \mathrm{em} \% 20 \mathrm{Feiras} \% 20-\% 20 \mathrm{v} 7$.pdf $>$. Acesso em: 10 jul. 2013.

Serviço brasileiro de apoio às micro e pequenas empresas (SEBRAE). Disponível em: $<$ www.sebrae.com.br >. Acesso em: 10 jul. 2011.

Seja um expositor - Feiplastic 2015. Disponível em: $<$ http://www.feiplastic.com.br/Expor/Seja-um-Expositor/>. Acesso em: 10 abr. 2014.

Sobre a Tubotech. Disponível em: <http://tubotech.com.br/16/>. Acesso em: 01 out. 2018.

SISKIND BARRY. Manual do expositor bem-sucedido. São Paulo: Nobel, 1992.

VILELA, Lamounier Erthal. Feiras Setoriais em Arranjos Produtivos Locais como Lócus de Inovação e Empreendedorismo - O caso da FEVEST de Nova Friburgo - RJ. Revista Administração em Diálogo, São Paulo, Vol.12, n.2, p. 121-150, Mai./Jun./Jul./Ago.2010.

Vinexpo, a maior feira internacional de vinhos, mostra resultados. Disponível em: $<$ http://www.academiadovinho.com.br/_ablog.php?art=75>. Acesso em: 08 fev. 2014.

ZINATELLI, Jennifer et al. Feiras de Negócios: O papel das Relações Públicas na Participação de Expositores. Trabalho apresentado no XVII Congresso de Ciências da Comunicação na Região Sudeste, Ouro Preto, 2012. Disponível em: $<$ http://www.intercom.org.br/papers/regionais/sudeste2012/resumos/R33-1049-1.pdf>.

Acesso em: 16 ago. 2012.

\section{REFERÊNCIAS CORPORA DE ESTUDO EM INGLÊS}

ABF Exhibitors General Manual 2012. Disponível em: $<$ http://www.portaldofranchising.com.br/Arquivos/ABF_Expo/2012/2012_Exhibitor_General _Manual_ABF_Expo.pdf $>$. Acesso em: 05 jun. 2012. 
ABF Exhibitors General Manual 2011. Disponível em: $<$ http://www.btsinforma.com.br/main.asp?cod_nucleo=10\&cod_evento $=19 \&$ cod_menutop $=1$ $13 \&$ cod_menu $=349 \&$ cod_idioma $=1>$. Acesso em: 10 jun. 2012

About Brunei Consumer Fair. Disponível em: $<$ http://www.bruneiconsumerfair.com/>. Acesso em: 10 out. 2013.

A Guide to Effective Exhibiting 2017. Disponível em: $<$ https://apex.co.uk/wpcontent/uploads/2017/02/Effective-Exhibiting-in-2017.pdf > . Acesso em: 06 set. 2018.

At-Show Marketing Activities. Disponível em: $<\mathrm{http}$ ://www.tsteacher.com/resources/tradeshow_teacher_article_atshow_marketing_activities _that_draw_prospects_to_your_booth.php >. Acesso em: 28 mai 2013.

All about different types of trade show displays. Disponível em: $<$ http://www.slideshare.net/impacttradedisplays/all-about-different-types-of-trade-showdisplays-8592495>. Acesso em: 28 mai. 2013.

APPLEGATE, Edd; JOHNSEN, Art. Cases in Advertising and Marketing Management: Real situations for tomorrow's managers. United Kingdom: Rownan \& Littlefield Publishers, 2007.

Architectural systems intelligently combined with custom-building. Disponível em: $<\mathrm{http}: /$ messerli3d.com/en/trade-fair-stands/mixed-stand-construction/>. Acesso em: 23 jun. 2013.

Asia's leading biennial trade fair for technical textiles and nonwovens announces dates for 2014. Disponível em: <http://www.asiatoday.com/pressrelease/asias-leading-biennial-tradefair-technical-textiles-and-nonwovens-announces-dates-2014>. Acesso em 10 out. 2013.

Automechanika Birmingham 2016 brochure A5. Disponível em: $<$ https://www.smmt.co.uk/wpcontent/uploads/sites/2/Automechanika-Birmingham-2016-brochure-A5.pdf $>$. Acesso em: 06 set. 2018.

Automechanika

Frankfurt.

Disponível

em:

$<$ https://automechanika.messefrankfurt.com/frankfurt/en.html >. Acesso em: 03 out. 2018.

Automechanika 2014 UK Pavilion Group. Disponível em: < https://www.smmt.co.uk/wpcontent/uploads/sites/2/Automechanika-ME-2014-brochure_new.pdf $>$. Acesso em 11 mai. 2016.

Basics for Organizing Trade Fairs - A Guide for Developing Countries. Disponível em: $<\mathrm{http}$ ://www.intracen.org/search-

results.aspx? searchtext=basics\%20for\%20organizing\%20trade\%20fairs $>$. Acesso em: 06 fev. 2013.

BCS 2018 Exhibitor manual. Disponível $<$ http://www.bcs.com/documents/conference/BCS\%20EXHIBITOR\%20MANUAL\%202018 \%20FINAL.pdf >. Acesso em: 09 dez 2018.

BCSC 2016 Manchester Exhibitor Manual. Disponível em: $<$ https://propertymanagersassociation.com/download.php?f=BCSC-2016-RetailerAdvert.pdf>. Acesso em 04 abr. 2017. 
Beauty UK Exhibitor Pack 2016. Disponível em: $<$ http://www.beautyukshow.com/files/4\%20SHOWS\%20Exhibitor\%20Pack\%202016653.pdf >. Acesso em: 15 mai. 2017.

Beauty UK show 2018 exhibitor manual. Disponível em: $<$ http://www.beautyukshow.com/files/4\%20SHOWS\%20Exhibitor\%20Pack\%2020181742.pdf $>$. Acesso em: 24 out. 2018.

Best Practices to Boost Your Trade Show Results. Disponível em: $<$ http://www.tsteacher.com/resources/tradeshow_teacher_article_best_practices.php $>$. Acesso em: 17 jun. 2016.

BIBA 2017 Terms and conditions. Disponível em: <https://www.biba2017.co.uk/wpcontent/uploads/2016/12/BIBA2017_TCs.pdf >. Acesso em: 17 mai. 2017.

Booth construction regulations. Disponível em: $<$ http://www.google.com.br/url? sa=t\&rct=j\&q=\&esrc=s\&source=web\&cd=5\&ved=0CGQQF jAE\&url=http $\% 3 \mathrm{~A} \% 2 \mathrm{~F} \% 2 \mathrm{Fdownload} .101$ com.com $\% 2 \mathrm{Fgig} \% 2 \mathrm{FEvents} \% 2 \mathrm{Fdownload} \% 2 \mathrm{~F} 20$ $13 \% 2 F B o o t h \_C o n t r u c t i o n \_$Regulations.pdf\&ei=ED-TUu-

SHMLAkQfb2YC4Ag\&usg=AFQjCNERHHgd42FD6xG6TManfh-

VAm32Uw\&sig2=W3_HDjNuYOf-rflMWjaH4Q\&bvm=bv.56988011,d.eW0>.

Acesso em:15 mar. 2013.

Booth Rental Agreement. Disponível em: <https://www.agreementsetc.com/booth-rental/>. Acesso em: 10 out. 2013.

Branch trade fairs and conferences as well as media patronages. Disponível em:

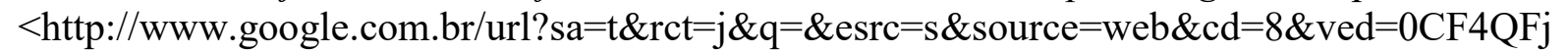
AH\&url=http $\% 3 \mathrm{~A} \% 2 \mathrm{~F} \% 2 \mathrm{Fwww}$. abrys.pl\%2Fuploads\%2Fmedia\%2FCommunal_Review_01 .pdf\&ei=1TFMU5zMDYu40QGc7IFw\&usg=AFQjCNHsEAbC7ughD0KgeFI5gee8s2Y0ḠQ \&bvm=bv.64542518,d.dmQ >. Acesso em: 14 abr. 2014.

British Craft Trade Fair 2016 newcomers guide. Disponível em: $<$ http://www.bctf.co.uk/forms/BCTF_2016_NEWCOMERS_GUIDE.pdf>. Acesso em: 17 mai. 2017.

BROWNE, T. The social Trade Show: Leveraging Social Media and Virtual Events to Connect with Your Customers. U.S: Pearson Education, 2012.

BSG 2017 exhibition services. Disponível em: <http://www.bsg2017.org.uk/media/1184/08bsg-2017-exhibition-services.pdf>. Acesso em: 17 mai. 2017.

BTS Exhibitor's General Manual 2012. Disponível em: $<$ http://cs.btsmedia.biz/pdf/2012_BTSInforma_Exhibitors_General_Manual_07-052012.pdf>. Acesso em: 05 jun. 2012.

Canton Fair 2013. <Disponível em: http://feiracantonfair.com.br/>. Acesso em: 14 out. 2013.

Canton Fair is the largest biannual China trade fairs held in Guangzhou. Disponível em: $<$ http://www.chinatours.org/index.php/canton-fair-is-the-largest-biannual-china-trade-fairsheld-in-guangzhou/>. Acesso em: 23 jun. 2013. 
Coach \& Bus UK 2017. Disponível em: <http://www.coachandbusuk.co.uk/show-news/coachbus-uk-2017-nearly-200-exhibitors-now-board/>. Acesso em: 03 out. 2018.

Computer insight UK 2016 exhibitors manual. Disponível em: $<$ https://eventbooking.stfc.ac.uk/uploads/ciuk2016exhibitorsmanual.pdf > . Acesso em: 08 fev. 2017.

Construction and Dismantling Time. Disponível em: <http://www.aqua-fisch.de/afen/exhibitors/construction-and-dismantling-time.php>. Acesso em: 18 nov. 2013.

Convergence Summit North 2015 Exhibitor Manual. Disponível em: <http://www.channellive.co.uk/wp-content/uploads/sites/4/2015/01/CSN15-Exhibitor-Manual-Final.pdf $>$. Acesso em: 22 jun. 2017.

CRE 2017 exhibitor manual. Disponível em: $<$ http://creonline.co.uk/wpcontent/uploads/2017/05/CRE-exhibitor-manual.pdf > . Acesso em: 22 jun. 2017.

Displays2go. Disponível em: <http:/www.displays2go.com/P-19082/Portable-DisplayCabinet-for-Exhibitions-With-Included-Carrying-Case >. Acesso em: 03 ago. 2013.

Difference between trade show stand and trade show exhibit. Disponível em: $<$ https://www.efourdesign.com/trade-show-tips-and-articles/european-exhibitingterminology/>. Acesso em: 02 abr. 2013.

Do trade shows pay off. Disponível em: $<$ https://pdfs.semanticscholar.org/a391/a56273ad2b5df188fa65acf1543618d69245.pdf>. Acesso em: 13 out. 2014.

DOs and DON'Ts for Effective Trade Show Booths. Disponível em: $<$ http://alexisexhibits.com/blog/bid/60096/DOs-and-DON-Ts-for-Effective-Trade-ShowBooths>. Acesso em 13 out. 2013.

DONELSON, Dave. Trade Shows - The Dynamic Manager's Handbook on How to Maximize your Expo Investment. USA: Donelson SDA, Inc., 2011.

EAU17 London Exhibitor Manual. Disponível em: <http://eau17.uroweb.org/wpcontent/uploads/Exhibitor-Manual-EAU17-London.pdf >. Acesso em: 22 jun. 2017.

Educational Forum and Trade Show 2013. Disponível em: $<$ http://www.prontario.org/index.php/ci_id/8125.htm>. Acesso em: 14 out. 2013.

eGuide 2011- Common Regulative Policy for Major UK Exhibition Venues. Disponível em: $<$ http://www.aeo.org.uk/files/eguide.pdf $>$. Acesso em: 10 jan. 2012.

eGuide 2012 - Common Regulative Guidance for Events in UK Venues. Disponível em: $<$ http://www.aev.org.uk/files/july_2012.pdf>. Acesso em: 16 aug. 2012.

ESPID 2016 exhibitors technical manual. Disponível em: $<$ http://espid2016.kenes.com/Documents/ESPID_2016_Exhibitors_Technical_Manual.pdf $>$. Acesso em: 23 jun. 2017. 
Esri uk annual conference 2016 sponsorship \& exhibitor information package. Disponível em: $<$ http://www.esriuk.com/ /media/esri-uk/ac2016/EUKAC2016-Exhibitor-Information-PackFINAL.pdf $>$. Acesso em: 22 jun. 2017.

Essential guide to exhibiting overseas. Disponível em: $<$ https://www.aeo.org.uk/_media/FaceTimeGuide/FaceTime_International_GuideFV.pdf $>$. Acesso em: 23 jun. 2017.

Euro Bus Expo 2018. Disponível em: <https://www.eurobusxpo.com/visitor-registrationopens-for-europes-biggest-bus-and-coach-show/ >. Acesso em: 16 dez 2018.

Euro Fair $2010 . \quad$ Statistics 2 Disponível $<$ http://www.auma.de/pages/d/16_Download/download/FKM/EuroFairStatisti cs2010.pdf>. Acesso em: 18 jan. 2012.

Exhibiting Guide updated 2017. Disponível em: <http://www.offshoreeurope.co.uk/RXUK/RXUK_Offshore-Europe/2017/Documents/Exhibiting\%20Guideupdated.pdf $>$. Acesso em: $1 \overline{0}$ mai. 2017.

Exhibition 2.0. Disponível em: <http://www.exhibitionworld.co.uk/2018/09/05/exhibition-20/>. Acesso em: 13 nov. 2018.

Exhibition Guide: A handbook for exhibitors and contractors 2015. Disponível em: $<$ http://www.ebdgroup.com/downloads/bioeurope/beu16/Exhibitors_and_Contractors_HS_M anual.pdf $>$. Acesso em: 10 mai. 2017.

Exhibition Manual for organisers and exhibitors. Disponível em: $<$ file://surrey.ac.uk/personal/HS101/m09893/downloads/44\%20(1).pdf >. Acesso em: 15 mai. 2017.

Exhibition Stand How to. Disponível em: <http://www.edmonds.co.uk/exhibition-standhowto.html>. Acesso em: 13 out. 2013.

Exhibition Stand, how to make it work for you. Disponível em: $<$ http://www.edmonds.co.uk/exhibition-stand-howto.html>. Acesso em: 19 ago. 2013.

Exhibitions Work - The case for a powerful, cost-effective marketing medium. Disponível em: $<\mathrm{http}$ //www.ufi.org/Medias/pdf/thetradefairsector/exhibition_promotion/ufi_exhibtions_work .pdf>. Acesso em: 09 jan. 2012.

Exhibiton industry 2011.2 Dtatistics em: $<$ http://www.ufi.org/Medias/pdf/thetradefairsector/2011_exhibiton_industry_statistics.pdf $>$. Acesso em: 09 jan. 2012.

Exhibitor area Bed Show 2019. Disponível em: <https://www.bedshow.co.uk/exhibitor-area/>. Acesso em: 05 out 2018.

Exhibitor credentials information 2014. Disponível em: $<\mathrm{http}: / / \mathrm{www}$.google.com.br/url?sa=t\&rct=j\&q=\&esrc=s\&source=web\&cd=10\&ved=0CG8Q FjAJ\&url=http $\% 3 \mathrm{~A} \% 2 \mathrm{~F} \% 2 \mathrm{Fwww}$.louisvilleboatshow.com $\% 2 \mathrm{Fassets} \% 2 \mathrm{Fcabinets} \% 2 \mathrm{FCabin}$ et 113\%2FExhibitor\%2520Credentials\%2520Information.pdf\&ei=WXKCUv79LrXIsASjwoH 
4Bw\&v6u=https $\% 3 \mathrm{~A} \% 2 \mathrm{~F} \% 2 \mathrm{Fs}-\mathrm{v} 6 \exp 1-$ v4.metric.gstatic.com\%2Fgen_204\%3Fip\%3D189.68.74.58\%26ts\%3D1384280666266652\% 26auth\%3D6zgsnh4qo7lxxppwuipge56c37c4efnd\%26rndm\%3D0.9881574393766261\&v6s= $2 \& v 6 \mathrm{t}=65952 \& u s g=A F Q j C N G A 1$ NPKhIjQUcIyf2d8mUEWlvs73A\&sig2=cx0XK07VEq3U 6DPQ3eyzfw\&bvm=bv.56343320,d.cWc $>$.Acesso em: 12 nov. 2013.

Exhibitor credential order form. Disponível $<\mathrm{http}: / / \mathrm{www}$.google.com.br/url?sa=t\&rct=j\&q=\&esrc=s\&source=web\&cd=7\&ved=0CFoQFj AG\&url=http $\% 3 \mathrm{~A} \% 2 \mathrm{~F} \% 2 \mathrm{Fwww}$. kansasstatefair.com $\% 2$ Fuploaded $\% 2$ Fvendors $\% 2$ FTicket Order.pdf\&ei=WXKCUv79LrXIsASjwoH4Bw\&usg=AFQjCNHFK1aOatcp6NwTsnxO3ZjL 7BvaIQ\&sig2=06bMYLjC3Qmv4tVSAWdAtQ\&bvm=bv.56343320,d.cWc $>$.Acesso em: 12 nov. 2013.

Exhibitor FAQs Pure Olympia London 2019. Disponível em: $<$ https://www.purelondon.com/exhibitor-faqs>. Acesso em: 05 nov. 2018.

Exhibitor guide Hair UK 2015. Disponível em: <http://www.hairukshow.com/files/HairUK2015-Exhibitor-Guide.pdf $>$. Acesso em: 15 dez 2018.

Exhibitor manual Channel Live 2017. Disponível em: <http://www.channel-live.co.uk/wpcontent/uploads/sites/14/2017/06/Exhibitor-Manual-2017-LIVE.pdf>. Acesso em: 13 nov. 2018 .

Exhibitor Rules and Regulations. Disponível em: $<$ http://www.acep.org/uploadedFiles/ACEP/MeetingSites/SA08/Exhibit/Exhibitor\%20Rules \%20and\%20Regulations.pdf $>$. Acesso em: 07 mar. 2013.

Exhibitor Services Manual MLG Finals 2015. Disponível em: $<$ https://ordering.ges.com/053600379/download/585977 >. Acesso em: 11 set. 2016.

Exhibitor Application and Contract for Exhibit Space. Disponível em: $<$ http://www.exhibitoronline.com/live/EXHIBITORLive2016SpaceApplication.pdf $>$. Acesso em: 30 ago. 2012.

Exhibitor Success Guide Tips and Strategies to Plan, Promote, and Sell More. Disponível em: $<$ http://www.nasda.org/File.aspx?id=336>. Acesso em: 22 jun. 2017.

Exhibitor Terms \& Conditions Fleet World Fleet Show 2017. Disponível em: $<$ http://thefleetshow.co.uk/exhibitor-terms-conditions/>. Acesso em: 05 out 2018.

2013 Expogef Rio Exhibitor manual. Disponível em: $<$ http://www.google.com.br/url?sa $=\mathrm{t} \& \mathrm{rct}=\mathrm{j} \& \mathrm{q}=\&$ esrc $=$ s\&source=web\&cd=1\&ved $=0 \mathrm{CCsQFj}$ AA\&url=http $\% 3 \mathrm{~A} \% 2 \mathrm{~F} \% 2 \mathrm{Fsys} 2$. sbgf.org.br\%2Fcongresso $\% 2 \mathrm{Farquivos} \% 2 \mathrm{FExhibitor}$ Manu al_English_Version.pdf\&ei=90ZdUofzGrGziQf2vYCABQ\&usg=AFQjCNEZNw4nCf8NeJw iZB0e-d-T1KxJQw\&bvm=bv.53899372,d.aGc>. Acesso em: 14 out. 2013.

Feiplar Composites \& Feipur 2014. Disponível em: $<$ http://www.feiplar.com.br/seja_mega.html>. Acesso em: 08 fev. 2014.

Fertility 2017 exhibitor manual. Disponível em: <http://fertilityconference.org/wpcontent/uploads/2016/09/Fertility-2017-Exhibitor-manual.pdf $>$. Acesso em: 23 jul. 2017. 
2014 Home \& Garden Show Floorplan. Disponível em: $<$ http://www.fresnoshows.com/floorplan/>. Acesso em: 19 nov. 2013.

Full $A-Z \quad$ organiser. Disponível em: $<$ https://www.exhibitioncentreliverpool.com/media/1630507/final-exhibition-organiser-az.pdf >. Acesso em: 02 jul. 2015.

Futurecom exhibitor manual 2013. Disponível em: $<$ http://www.google.com.br/url? sa $=\mathrm{t} \& \mathrm{rct}=\mathrm{j} \& \mathrm{q}=\&$ esrc $=$ s\&source=web\&cd=1\&ved=0CDAQF jAA\&url=http $\% 3 \mathrm{~A} \% 2 \mathrm{~F} \% 2 \mathrm{Fwww}$.futureshare.com.br\%2FFuturecom_Ano15\%2FManual_do expositor\%2FExhibitors_Manual_ano15_Futurecom.pdf\&ei=wuVHU5OYNrPF0AHkqIG4 $\overline{\mathrm{D} w \& u s g=A F Q j C N G H q Z A x N q D 8}$ 8x $0 x L T T$ 81LcC7sE7FqQ\&sig2=WP1GNCPKJrkK3do7yZV 6fw\&bvm=bv.64542518,d.dmQ>. Acesso em: 10 abr. 2014.

Gambia's Biennial Trade Fair Commences. Disponível em: $<$ http://gambianewsonline.blogspot.com.br/2011/12/gambias-biennial-trade-faircommences.html>. Acesso em: 10 out. 2013.

General information and regulations - NEC Birmingham. Disponível em: $<$ http://www.wexhibition.co.uk/images/Ops_Forms/General_Information_and_Regulations.p df $>$. Acesso em: 22 jun. 2017.

General Information NEC Birmingham 2015 National Wedding Show. Disponível em: $<$ http://www.nationalweddingshow.co.uk/wp-content/uploads/2014/11/Section-2-GeneralInformation-Olympia-2015-Stand-Specification-Breakdown-Procedures.docx $>$. Acesso em: 22 jun. 2017.

General Terms of Participation in International Exhibitions. Disponível em: $<$ http://belagro.minskexpo.com/en/belagro_uslov>. Acesso em: 19 nov. 2013.

2013 Georgia National Fair. Disponível em: < http://www.georgianationalfair.com/fair-map/>. Acesso em: 15 out. 2013.

Germany's biggest fair-trade exhibition expands its product portfolio. Disponível em: $<$ http://www.google.com.br/url?sa $=$ t\&rct $=\mathrm{j} \& \mathrm{q}=\&$ esrc $=$ s\&source=web\&cd=10\&ved $=0 \mathrm{CHIQF}$ jAJ\&url=http $\% 3 \mathrm{~A} \% 2 \mathrm{~F} \% 2 \mathrm{Fwww}$.westfalenhallen.de $\% 2 \mathrm{Fmessen} \% 2 \mathrm{Ffair} \% 2 \mathrm{Fen} \% 2 \mathrm{~F} 1858$.pdf \&ei $=\mathrm{mH}-$

CUtfKJ4m0sASC44DYBw\&usg=AFQjCNGzdGgcWCE2xZhYBRwqdej4rN7ovA\&bvm=bv. 56343320,d.cWc>. Acesso em: 12 nov. 2013.

Great Exposure. Great Selling Opportunities. Great Results. Disponível em: $<$ http://www.npe.org/show-floor-plan>. Acesso em: 14 abr. 2014.

Green Trade Show Displays FAQ. Disponível em: <http://boothster.com/green-displays-faq/>. Acesso em: 11 out. 2013.

Guidelines for participation in international trade fairs - exhibitions. Disponível em: $<$ https://www.tdap.gov.pk/pdf/Guidelines_for_Exhibition.pdf $>$. Acesso em: 14 ago. 2015.

Historical Development of Fairs \& Exhibitions. Disponível em: $<$ http://www.ufi.org/Public/Default.aspx?Clef_SITESMAPS=152>. Acesso em: 06 jun. 2012.

How to be a successful trade show exhibitor. Disponível em: $<$ http://divcom.com.hk/dl/how_to_be_a_successful_trade_show_exhibitor.pdf $>$. Acesso em: 22 jun. 2017. 
How to exhibit: experience the power of live events and making them work for you. Disponível em: <http://www.facetime.org.uk/files/how_to_exhibit.pdf>. Acesso em: 23 jun. 2017.

How to exhibit. Disponível em: <http://www.eco.co.uk/p/how-to-exhibit/84>. Acesso em: 21 ago. 2012.

How to exhibit: Maximising the power of exhibitions. UFI - the Global Association of the Exhibition Industry. Disponível em: $<$ http://www.ufi.org/Medias/pdf/thetradefairsector/exhibition_promotion/ufi_how_to_exhibit. pdf $>$. Acesso em: 22 mai. 2012.

How to Get the Most out of Exhibitions and Trade Shows - Tools for effective small business marketing. Disponível em: < $\quad$ http://www.clarity-incommunication.com/getattachment/15a6bffd-0321-41d0-b1ee-cf5f853f8f7e/How-to-get-theMost-out-of-Exhibitions-and-Trade-S.aspx>. Acesso em: 29 ago. 2012.

IDX Trade Show Rules and regulations 2017. Disponível em: $<$ http://secure.fia.org/idx/downloads/IDX_Trade_Show_Rules_2017.pdf $>$. Acesso em: 22 jun. 2017.

INDX Kidswear Show 2019. Disponível em: <https://www.cranmorepark.co.uk/indx-kidswearshow>. Acesso em: 02 dez. 2018.

Industry UK virtual exhibition: exhibitor FAQ. Disponível em: $<$ https://industryuk.online/exhibitor/exhibitor-faq/>. Acesso em: 16 out. 2017.

Influence of Trade Fairs on a Host City Brand. Disponível em: $<\mathrm{http}: / / \mathrm{www}$.google.com.br/url? $\mathrm{sa}=\mathrm{t} \& \mathrm{rct}=\mathrm{j} \& \mathrm{q}=\& \mathrm{esrc}=\mathrm{s} \&$ source=web\&cd=32\&ved=0CDEQ FjABOB4\&url=http\%3A\%2F\%2Fwww.mruni.eu\%2Flt\%2Fmokslo_darbai\%2Fvpa\%2Farchy vas\%2Fdwn.php\%3Fid\%3D340114\&ei=_5-LUp-

xBOjksATyuICYCw\&usg=AFQjCNHFS3ab99FQ597sSYCTq8teW7rTDg\&bvm=bv.566433 36,d.eW0>. Acesso em: 19 nov. 2013.

InnoTrans 2018 Conditions of Participation. Disponível em: $<$ https://www.innotrans.de/media/inno/inno_dl_en/inno_applicationforms/InnoTrans_2018_C onditions_of_Participation-2.pdf $>$. Acesso em: 15 abr. 2018.

InnoTrans exhibitor manual 2014.2 Disponível $<$ http://www.google.com.br/url?sa=t\&rct=j\&q=\&esrc=s\&source=web\&cd=1\&ved=0CD8QFj AA\&url=http $\% 3 \mathrm{~A} \% 2 \mathrm{~F} \% 2 \mathrm{Fwww}$. innotrans.de $\% 2 \mathrm{Fmedia} \% 2 \mathrm{Fen} \% 2 \mathrm{Finno} \% 2 \mathrm{Finno}$ media $\% 2$ Finno_pdf\%2Fanmeldeunterlagen\%2Fteilnahmebedingungen.pdf\&ei=ZkGTUvvGLYYXukQf h14CQAg\&usg=AFQjCNF2b0WKsfIsPu5-

ARJZ6Um4I727IQ\&sig2=3cBhkKz2rkcM7yLJ_UHRtw\&bvm=bv.56988011,d.eW0>.

Acesso em: 15 set. 2013.

International Trade Fair Plastics and Rubber Exibitor Manual 2014. Disponível em: $<$ http://www.interplastica.de/cipp/md_ww2/lib/pub/object/downloadfile,oid,27231/lang,2/tick et,g_u_e_s_t/src,ip_check_in_2014/ /INTERPLASTICA_2014_Check_in_WEB_Version.pdf >. Acesso em: 05 mai 2013.

International market trade fair - Management and performance of international trade fair exhibitors.

Disponível em: 
$<$ https://www.researchgate.net/profile/Philip_Rosson/publication/242344614_Management_a nd_Performance_of_International_Trade_Fair_Exhibitors_Government_Stands_vs_Independ

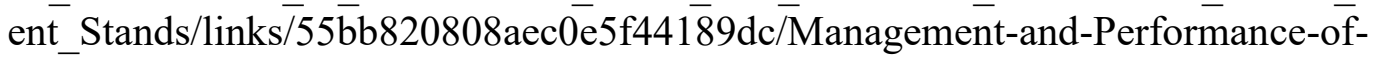
International-Trade-Fair-Exhibitors-Government-Stands-vs-Independent-Stands.pdf $>$. Acesso em: 15 abr. 2016.

International CES Exhibitor Services Manual 2013. Disponível em: $<$ https://www.ces.tech/Exhibitors/Show-Planning/Exhibitor-Manuals.aspx>. Acesso em: 09 jul. 2015.

International Convention Centre Rules and Regulations. Disponível em: $<$ http://www.theicc.co.uk/media/1451/international-convention-centre-rules-and-regs-april16-2.pdf>. Acesso em: 05 nov. 2016.

Introduction to How Trade Shows Work. Disponível em: $<$ http://money.howstuffworks.com/trade-show.htm>. Acesso em: 17 jan. 2013.

IP Protect Expo 2012 Exhibitors Manual. Disponível em: <http://www.ip-protectexpo.com/IPProtect-Expo-2012-Exhibitor-Manual.pdf>. Acesso em: 26 out. 2012.

Just V 2016 exhibitor manual. Disponível em: $<$ https://www.justvshow.co.uk/london >. Acesso em: 19 set. 2017.

KEEGAN, Warren J.; GREEN, Mark C. Principals of Global Marketing. São Paulo: Editora Saraiva, 1999.

London Art Fair Exhibitor Manual 2017. Disponível em : <http://www.londonartfair.co.uk/wpcontent/uploads/2016/10/LAF-Manual_A.pdf>. Acesso em: 17 mai. 2017.

London Design Fair Exhibitor Manual 2017. Disponível em: $<$ https://www.londondesignfair.co.uk/sites/default/files/images/2017/London $\% 20$ Design $\% 20$ Fair\%20-Exhibitor\%20Manual\%20-v2.pdf >. Acesso em: 09 fev. 2018.

Love Business Exhibitor Manual Leisure 2016. Disponível em: $<$ http://www.lovebusinessexpo.co.uk/download/clientfiles/files/Love\%20Business\%20Exhibi tor\%20Manual\%20Leisure.pdf>. Acesso em: 17 mai. 2017.

MADOYAN, Annie. Les Mots-clés Du Commerce International. France: Breal Edition, 1998.

Making the Most of Your Exhibition - A Structured Approach. Disponível em: $<\mathrm{http}: / / \mathrm{www} .2 \mathrm{seastrade} . \mathrm{eu} / \mathrm{images} /$ uploads/Making_the_Most_of_Exhibitions_-

_Advice_notes.pdf $>$. Acesso em: 14 nov. 2012.

Making trade fairs and exhibitions as effective platform for export marketing. Disponível em: $<$ http://shodhganga.inflibnet.ac.in/bitstream/10603/132543/11/11_chapter\%205.pdf $>$.

Acesso em: 22 jun. 2017.

Maximize Your Trade Show Investment With E-Mail. Disponível em: $<$ http://www.clickz.com/clickz/column/2138906/maximize-your-trade-show-investment-withemail>. Acesso em: 14 abr. 2014. 
Measuring and evaluating results. Disponível em: $<\mathrm{http}$ ://www.creativetraining.com/train/docs/MeasuringResults.pdf $>$. Acesso em: 06 set. 2018.

Med-Tech Innovation Expo 2017 Stand Regulations. Disponível em: <http:/www.medtechexpo.com/files/stand_regulations_mtiexpo2017.pdf >. Acesso em: 10 mai. 2017.

Miami Beach Convention Center Event Guide 2010. Eventos Internacionais. - $2^{\circ}$ ed., rev. e atualizada. Belo Horizonte: SEBRAE/MG, 2005. Disponível em: $<$ http://www.miamibeachconvention.com/uploadedFiles/12_MBCC-EventGuide2010Apr.pdf>. Acesso em: 02 mai. 2012.

MILLER, Steve. How to Get the Most out of Trade Shows. 3rd ed. USA: NTC Business Book, 1999.

Stop wasting your time at Trade Shows and start making money - a handbook for exhibit staffers. USA: Hikelly Productions, Inc., 2006.

Mipimuk 2016 manual. Disponivel em: $<$ https://www.mipimuk.co.uk/RM/RM_MipimUK/2016/documents/mipimuk-2016-exhibitormanual.pdf? $v=636029748261736295>$. Acesso em: 15 mai. 2017.

MUSGROVE, Linda. The Complete Idiot's Guide to Trade Shows. USA: Penguin Group, 2009.

National funeral exhibition trade stand exhibitor manual 2017. Disponível em: $<$ http://www.nationalfuneralexhibition.co.uk/wp-content/uploads/2017/05/Trade-StandManual-2017.pdf>. Acesso em: 22 jun. 2017.

National Painting and Decorating Show 2018. Disponível em: $<$ http://www.paintshow.co.uk/>. Acesso em: 01 out. 2018.

National wedding show rules and regulations 2013. Disponível em: $<$ http://www.nationalweddingshow.co.uk/wp-content/uploads/2014/11/Section-6-NWSRules-Regulations.doc>. Acesso em: 14 mai. 2014.

National Wedding Show Spring 2017 exhibitor manual. Disponível em: $<$ https://nationalweddingshow.co.uk/\# > . Acesso em: 11 nov. 2018.

New York Trade Shows Booth Rental. Disponível em: <http://www.exhibitsusa.com/new-yorkcity-nyc-trade-shows-displays-exhibit-booth-rentals>. Acesso em: 10 out. 2013.

North East EXPO Spring 2017 Exhibitor guide and information pack. Disponível em: $<$ http://northeastexpo.co.uk/wp-content/uploads/2016/11/NE-EXPO-2017-Spring-InfoGuide.pdf >. Acesso em: 22 jun. 2017.

NZSIF exhibitor manual 2013. Disponível em: $<\mathrm{http}: /$ www.google.com.br/url? $\mathrm{sa}=\mathrm{t} \& \mathrm{rct}=\mathrm{j} \& \mathrm{q}=\&$ esrc $=\mathrm{s} \&$ source=web\&cd=5\&ved $=0 \mathrm{CEkQFj}$ AE\&url=http $\% 3 \mathrm{~A} \% 2 \mathrm{~F} \% 2 \mathrm{Fwww}$.gosnow.co.nz $\% 2 \mathrm{Fwp}-$

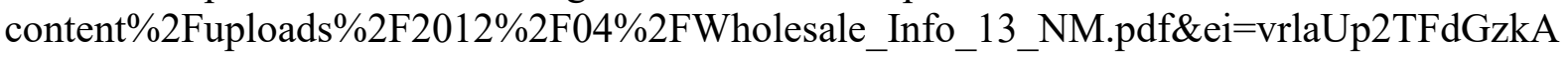
e354DIBA\&usg=AFQjCNF_yYgNk1xAc802XrjNHFCFgxmIw\&bvm=bv.53899372,d.eW0>. Acesso em: 13 out. 2013. 
Official London Book Fair Contractors Manual 2017. Disponível em: $<$ https://www.londonbookfair.co.uk/RXUK/RXUK_LondonBookFair/LBF\%202016/Docume nt/Official\%20LBF\%20Contractors\%20Manual\%202017.pdf?v=636202600084064041>. Acesso em: 17 mai. 2017.

ONKVISIT, Sak; SHAW, John. J. International Marketing: Strategy and Theory. New York: Routledge, 2009.

OTGAAR, Alexander H. J; BERG, Leo Van Den; BERGER, Christian.; FENG, Rachel Xiang. Industrial Tourism: Opportunities for City and Enterprise. Netherlands: Ashgate Publishing Company, 2010.

Participation in a trade fair. Disponível em: <http://www.carboncomposites.eu/en/performance-spectrum/participation-a-trade-fair>. Acesso em: 11 out. 2013.

PATS 2017 Exhibitor Manual. Disponível em: <https://www.patshow.co.uk/exhibitors >. Acesso em: 13 jun. 2018.

PDAC exhibitor manual 2014. Disponível em: <http://www.pdac.ca/convention/exhibitpresentation-opportunities/exhibitor-manual-trade-show-investors-exchange/section-7shipping-customs $>$. Acesso em: 14 abr. 2014.

Powerful Post Show Follow Up Processes. Disponível em: $<$ http://www.tsteacher.com/resources/tradeshow_teacher_article_powerful_post_show_follow _up_processes.php >. Acesso em: 22 jun. 2017.

PPMA Show 2017 Exhibitor Manual. Disponível em: $<$ http://www.ppmashow.co.uk/_media/Onsite-Services/PPMA-E-Manual-2017.pdf > . Acesso em: 22 jun. 2017.

Personalized Stand Design - Mixed Solutions. Disponível em: $<$ http://www.arounder.eu/3adesigneu/persmixed/mixed.html >. Acesso em: 11 mai. 2017.

Product 'totems' for Belgian dealers and tradeshows. Disponível em: $<$ http://www.banksys.com/index/en_US/0000/5745383/Product\%E2\%80\%98totems\%E2\%89 -for-Belgian-dealers-and-tradeshows-.htm>. Acesso em: 06 jun. 2013.

7 Reasons To Attend Trade Fairs. Disponível em: $<$ http://www.key4communications.com/en/key4/tendencias/7-reasons-to-attend-tradefairs_226.html >. Acesso em: 12 nov. 2013.

RCI Show 2016 Exhibitor manual. Disponível em: <http://www.rcishow.co.uk/wpcontent/uploads/2015/10/RCI-2016-Exhibitor-Manual2.pdf > . Acesso em: 10 mai. 2017.

Riverwalk market fair - The art of a summer saturday. Disponível em: $<$ http://riverwalkmarketfair.org/>. Acesso em: 04 mar. 2014.

RONEY, Michael; UTVICH, Michael; STEVE, Marcus. The guerilla guide to high-tech trade shows. United States: Random House, 1996.

QRCode_Tradeshow_Marketing_Guide.

Disponível em: $<$ http://tradeshowguyblog.com/downloads/QRCode_Tradeshow_Marketing_Guide.pdf $>$.Aces so em: 07 jul. 2015. 
Rules and regulations handbook for organisers and exhibitors. Disponível em: $<\mathrm{http}: / /$ www.businessdesigncentre.co.uk/sections/pdf/44/Rules-and-Regulations Handbook.pdf >. Acesso em: 17 mai. 2017.

SAENZ, Daniel Rodriguez. How to Successfully Participate in International Trade Show. Miami, 2007.

Safety \& Health Expo ExCel London 2019. Disponível em: <https://www.safety-healthexpo.co.uk/exhibit/exhibitor-faq >. Acesso em: 13 nov. 2018.

Scottish hair and beauty exhibitor manual 2017. Disponível em: $<$ http://www.scottishbeautyshow.com/files/SH\&B\%20Exhibitor\%20Pack\%202017-602.pdf >. Acesso em: 22 jun. 2017.

Security \& policing exhibitor manual 2014. Disponível em: $<$ http://ftp.icm.edu.pl/packages/Hacked\%20Team/Amministrazione/06\%20-

$\% 20$ FIERE/1\%20-\%20Fiere/2014/4.\%20HOSDB\%20-

\%20Farnborough\%20(March\%2011\%20-\%2013)/Exhibitor\%20Manual\%20V5.pdf>. Acesso em: 01 out 2018 .

SERINGHAUS, F. H. Rolf; ROSSON, Philip J. (1998) Management and performance of international trade fair exhibitors: government stands vs independent stands, International Marketing Review, Vol. 15 Iss: 5, pp.398 - 412. Disponível em: $<$ http://www.emarketing.net.cn/upload/file/2009/03/18/221237387403913.pdf>. Acesso em: 30 abr. 2012.

SITF exhibitors to part with minimum of 4500 euros. Disponível em: $<$ http://www.times.co.sz/index.php?news=15645>. Acesso em 01: fev. 2014.

Selecting $a$ Targeted Promotional Item. Disponível em: $<$ http://www.tsteacher.com/resources/tradeshow_teacher_article_selecting_a_targeted_promo tional_item.php>. Acesso em: 02 set. 2015.

SOA 2016 exhibition and sponsorship manual. Disponível em: $<$ https://soa.ics.ac.uk/files/5014/7696/9047/Exhibition_Manual_2016.pdf>. Acesso em: 23 jun. 2017.

Sponsors. Disponível em: <http://invitra.co.uk/sponsors/>. Acesso em: 18 nov. 2013.

Spring graduate fair 2017 exhibitor manual. Disponível em: $<$ https://www.springgradfair.co.uk/media/1717/spring17-exhibitor-manual_final.pdf $>$. Acesso em: 17 mai. 2017.

Stand Builder Guideline. Disponível em: $<$ http://www.google.com.br/url?sa=t\&rct=j\&q=\&esrc=s\&source=web\&cd=13\&ved=0CDoQ FjACOAo\&url=http $\% 3 \mathrm{~A} \% 2 \mathrm{~F} \% 2 \mathrm{Fwww} \cdot$ breadandbutter.com $\% 2 \mathrm{Fdownloads} \% 2 \mathrm{FStand}$ builde r_guideline_W14.pdf\&ei=ZImCUqObDtDJsQS9-

YD4DA\&usg=AFQjCNHZqPFWqtnezk7grKPg5yV8wHcEeg\&bvm=bv.56343320,d.cWc\&c $\mathrm{ad}=\mathrm{rja}>$. Acesso em: 12 nov. 2013. 
Stand Cleaning Expopharm. Disponível em: $<$ http://www.google.com.br/url?sa=t\&rct=j\&q=\&esrc=s\&source=web\&cd=30\&ved=0CG4Q FjAJOBQ\&url=http $\% 3 \mathrm{~A} \% 2 \mathrm{~F} \% 2 \mathrm{Fwww}$.expopharm.de $\% 2 \mathrm{Fwp}-$ content $\% 2$ Fuploads\%2F2013\%2F05\%2FB_76_2.pdf\&ei=jH2CUu3yNOTIsATSvoDYDA\&u $\mathrm{sg}=\mathrm{AFQjCNF} 1 \mathrm{~K} 036 \mathrm{JGHccLDJdThDu} 9 \mathrm{UwoD}$ jjtA\&bvm=bv.56343320,d.cWc>. Acesso em: 12 nov. 2013.

Stand construction. Disponível em: <http://www.remadays.com/index.php/en/forexhibitors/stand-construction>. Acesso em: 18 nov. 2013.

Stand Project and Quote. Disponivel em: <http://www.euroshoptradefair.com/cipp/md_euroshop/custom/pub/show,lang,2/oid,8038/xa_nr,2356384/ /WebProdDatasheet/prod_datasheet>. Acesso em: 15 out. 2013.

Star Wars Celebration Europe Exhibitor Manual 2016. Disponível em: $<$ https://www.starwarscelebration.com/RNA/RNA_StarWarsCelebration_V2/2016/docs/StarWars-Exhibitor-Manual-Shell-Scheme.pdf? $\mathrm{v}=636026334287923837>$. Acesso em: 10 mai. 2017.

Step by step guide to trade show planning. Disponível em: $<$ https://www.rims.org/annualconference/Exhibition/newsletter/Documents/TradeshowTimlel ine.pdf $>$. Acesso em: 22 jun. 2017.

Subsea Expo 2016 Exhibitor Manual. Disponível em: <http://www.subseaexpo.com/wpcontent/uploads/2013/10/Exhibitor-Manual-2016-v3.pdf >. Acesso em: 17 mai. 2017.

Successful Exhibit Marketing. Disponível em: $<$ http://www.ufi.org/Medias/pdf/thetradefairsector/howtoexhibit.pdf $>$. Acesso em: 09 jan. 2012.

Successful Participation in Trade Fairs: Tips for Exhibitors. Disponível em: $<$ http://www.auma.de/_pages/e/12_Download/download/TradeFairPreparation/Successful_pa rticipation.pdf>. Acesso em: 20 abr. 2012.

SuisseEMEX B2B trade show. Disponível em: $<$ http://www.suisse-emex.ch/english/>. Acesso em: 12 nov. 2013.

Summit North 2016 Exhibitor Manual. Disponível em: <http://www.channel-live.co.uk/wpcontent/uploads/sites/4/2013/05/Summit-North-2016-Exhibitor-Manual.pdf >. Acesso em: 22 jun. 2017.

Sumter County Fair 2012. Disponível em: <http://www.sumterfair.com/Docs/BOOTHRENTAL-2012.pdf>. Acesso em: 15 mar. 2013.

TAI 2018 exhibitor manual. Disponível $<$ http://www.cih.org/resources/PDF/Event\%20pdfs/TAI\%202018\%20Exhibitor\%20Manual\% 20FINAL.pdf > . Acesso em: 09 dez 2018.

Tampere Trade fairs Ltd. Disponível em: $<$ http://www.google.com.br/url?sa=t\&rct=j\&q=\&esrc=s\&source=web\&cd=19\&ved=0CHMQ 
FjAIOAo\&url=http\%3A\%2F\%2Fwww.exigo-

finland.com\%2Fnews\%2Falihankinta_on_the_road_press_release21092010.pdf\&ei $=81 \mathrm{tHU} 4$ XKBueU0gHzuYH4Dw\&usg=AFQjCNHnniocwL 7ri4APdm2Yd5vRcbub4Q\&sig2=oVr9Vj Lxh_-HbNWZeBMTWQ\&bvm=bv.64542518,d.dmQ>. Acesso em: 10 abr. 2014.

Terms \& Conditions Seawork International 2017. Disponível em: $<$ http://www.mercatormedia.com/our-business/terms-and-conditions/seawork-t-and-cs-2013>. Acesso em: 10 mai. 2017.

The 50 secrets of trade show success. Disponível em: $<$ https://books.google.com.br/books/about/The_50_Secrets_of_Trade_Show_Success.html?id $=\mathrm{kxt} 8 \mathrm{rgEACAAJ} \&$ redir_esc $=\mathrm{y}>$. Acesso em: 11 out. 2017.

The $A, \quad B, \quad C^{\prime} s$ of Exhibiting Effectively. Disponível em: $<$ http://www.tsteacher.com/resources/tradeshow_teacher_article_the_abcs_of_exhibiting_effe ctively.php>. Acesso em: 01 mai. 2014.

The Beacon Exhibition exhibitor manual 2016. Disponível em: $<$ http://www.beaconpurchasing.co.uk/docs/default-source/default-document-library/exhibitormanual.pdf?sfvrsn=10>. Acesso em: 04 out. 2018.

The Chocolate show London 2016 exhibitor manual. Disponível em: $<$ http://www.salonduchocolat.co.uk/guide/en/guide.pdf >. Acesso em: 17 mai. 2017.

The Effectiveness of Trade Shows and Exhibitions as Organizational Marketing Tool. Disponível em: $<$ http://ijbssnet.com/journals/Vol_3_No_22_Special_Issue_November_2012/19.pdf $>$. Acesso em: 06 set. 2018.

The green guide to exhibiting. Disponível em: $<\mathrm{http}: /$ www.marketingdonut.co.uk/exhibitionsand-events/exhibiting/the-green-guide-to-exhibiting>. Acesso em: 22 jun. 2017.

The legal aspects of trade show intelligence. Disponível em: $<$ http://www.rhesq.com/CI/The\%20Legal\%20Aspects\%20of\%20Trade\%20Show\%20Intellig ence.pdf $>$. Acesso em: 22 jun. 2017.

The purpose and value of trade shows. Disponível em: $<$ http://www.creativetraining.com/train/docs/Purpose.pdf >. Acesso em: 22 jun. 2017.

The Role of Exhibitions in the Marketing Mix. Disponível em: $<\mathrm{http}$ //www.ufi.org/medias/pdf/ufiactivities/education/ufi_education.pdf $>$. Acesso em: 29 jan. 2013.

The Role of the Interpreter in International Trade Fairs. Disponível em: $<$ http://www.tesionline.com/intl/thesis.jsp?idt=22403>. Acesso em: 23 jun. 2013.

The skills show exhibitor manual 2016. Disponível em: $<$ https://www.worldskillsuk.org/media/3081/the-skills-show-exhibitor-manual-2016-v8.pdf $>$. Acesso em: 22 jun. 2017.

The Trade Show for Kids' First Years. Disponível em: $<$ http://www.kindundjugend.com/en/kindundjugend/fuer_besucher/eintrittskarten_katalog/ind ex.php>. Acesso em: 10 out. 2013. 
The value of trade shows. Disponível em: <http://www.semaphoredisplay.co.uk/wpcontent/uploads/2016/06/Exhibition-White-Paper.pdf >. Acesso em: 03 out. 2018.

The world map of exhibition venues and future trends. Disponível em: $<$ http://www.ufi.org/Public/Default.aspx?Clef_SITESMAPS=142\&Clef_SITESMAPS=144>. Acesso em: 26 nov. 2012.

Tips for Trade Show Success. Disponível em: <http://www.adlerdisplay.com/resources/Tipsfor-TradeShow-Success.pdf>. Acesso em: 22 mai. 2012.

Top Ten List of Rental Display Advantages. Disponível em: $<\mathrm{http}: / / \mathrm{www} . t s t e a c h e r . c o m / r e s o u r c e s /$ tradeshow_teacher_article_top_ten_list_of_rental_displ ay_advantages.php>. Acesso em: 29 ago. 2012.

Top Types of Displays. Disponível em: $<\mathrm{http}$ ://www.tsteacher.com/resources/tradeshow_teacher_article_top_types_of_displays.php $>$. Acesso em: 29 ago. 2012.

Trade fair and exhibitions. Disponível em: $<$ http://www.exporthelp.org/modules/8_export_plan/promotion/trade_fairs.html $>$. Acesso em: 17 jan. 2013.

Trade Fair Stand Package. Disponível em: $<$ http://www.google.com.br/url?sa=t\&rct=j\&q=\&esrc=s\&source=web\&cd=1\&ved=0CCsQFj AA\&url=http $\% 3 \mathrm{~A} \% 2 \mathrm{~F} \% 2 \mathrm{Fwww}$.internetworldmesse.de\%2Feng\%2Fcontent\%2Fdownload\%2F888\%2F9963\%2Ffile\%2FIW13_Application StandPackage.pdf\&ei=q1uKUuXZMcaqkAfJ7IHoCQ\&usg=AFQjCNGUcSuHaJpSyJ2zwgJtYCwUk8A_Q\&bvm=bv.56643336,d.eW0>. Acesso em: 18 nov. 2013.

Trade Show Booths Are Like Real Estate: Location, Location, Location. Disponível em: $<$ http://www.smarttradeshows.com/articles/booth_location.htm>. Acesso em: 11 out. 2013.

Trade Show Budgeting. Disponível em: $<$ http://www.tradeshowinstitute.com/downloads/Trade\%20Show\%20Budgeting.pdf $>$. Acesso em: 22 mai. 2012.

Trade Show Executive Magazine, June 2012 Issue. Disponível em: $<$ http://www.tradeshowexecutive.com/RecentIssues.asp >. Acesso em: 15 jun. 2012.

Trade Show Executive Magazine, July 2012 Issue. Disponível em: $<$ http://www.tradeshowexecutive.com/RecentIssues.asp >. Acesso em: 20 jul. 2012.

Trade Show Executive Magazine, August 2012 Issue. Disponível em: $<$ http://www.tradeshowexecutive.com/RecentIssues.asp >. Acesso em: 12 aug. 2012.

Trade show focus. Disponível em: <http://www.tradeshowfocus.com/tag/floor-displays/>. Acesso em: 23 jun. 2013.

Trade Shows in USA. Disponível em: <http://www.expodatabase.com/trade-showsamerica/usa/>. Acesso em: 18 nov. 2013.

Trade Show Marketing Best Practices. Disponível em: <http://www.ggcomm.com/TradeShow_WhitePaper.pdf>. Acesso em: 22 mai. 2012. 
Trade Show Marketing Manual - How to Make the Most of and Get the Most out of Tradeshow exhibiting. Disponível em: <http://www.wcfexpo.com/pdf/tsmm2.pdf>. Acesso em: 22 mai. 2012.

Trade Show Teacher's Tips and Tricks "From the Trade Show Trenches". Disponível em: $<\mathrm{http}: / /$ www.tsteacher.com/resources/tradeshow_teacher_article_tips_and_tricks_from_the_tr ade_show_trenches.php>. Acesso em: 17 jan. 2013.

Trade Union Congress 2012. Disponível em: <http://www.tuc.org.uk/the_tuc/tuc-21061f0.cfm>. Acesso em: 15 mar. 2013.

Trends of Beauty Vienna cosmetics trade fair. Disponível em: $<$ http://trendsofbeautyenglish.wordpress.com/2013/07/24/73/\#more-73>. Acesso em: 12 nov. 2013.

UFI exhibtions work. Disponível em: $<$ https://eeaa.com.au/wpcontent/uploads/2016/12/eeaa_booklet_exhibitions_work_WEB.pdf $>$. Acesso em: 22 out. 2016.

UFI member exhibitions and venue activity. Disponível em: $<$ http://www.ufi.org/medias/pdf/membersarea/studies_reports/2008_ufi_member_exhibitions _and_venue_activity.pdf $>$. Acesso em: 09 jan. 2012.

UFI metrics booklet - how to measure exhibition success. Disponível em: $<$ https://www.exhibitin-europe.com/wp-content/uploads/How-to-Measure-Exhibition-Success-by-UFI.pdf $>$.

Acesso em: 01 fev. 2014.

UK games expo 2017 exhibitor guide. Disponível em: $<$ https://www.ukgamesexpo.co.uk/2017exhibitorspack.pdf >. Acesso em: 22 jun. 2017.

Union Displays. Disponível em: $<$ http://www.uniondisplays.com.br/loja/feiras-eexposicoes/display-pop-up-magnetico>. Acesso em: 28 mai. 2013.

V1 WCNA 2016 exhibitor technical manual. Disponível em: $<$ http://www.wcna2016.com/Documents/V1\%20WCNA\%202016\%20EXHIBITOR\%20TEC HNICAL\%20MANUAL.pdf >. Acesso em: 23 jun. 2017.

Varsity records excellent performance at trade fair. Disponível em: $<$ http://www.uonbi.ac.ke/node/4359 >. Acesso em: 23 nov. 2013.

Wedding Fair ExCel Spring 2016 Exhibitor Manual with forms. Disponível em: $<$ http://theweddingfairs.com/wp-content/uploads/2016/02/Wedding-Fair-ExCel-Spring-2016Exhibitor-Manual-with-forms.pdf>. Acesso em: 17 mai. 2018.

Welcome to the $W$ Exhibition. Disponível em: $<$ https://www.wexhibition.co.uk/>. Acesso em: 03 out. 2018.

What are the Different Types of Trade Show Displays? Disponível em: $<$ http://www.wisegeek.com/what-are-the-different-types-of-trade-show-displays.htm>.

Acesso em: 18 ago. 2013.

What Is a Trade Fair? Disponível em: <http://www.wisegeek.com/what-is-a-trade-fair.htm>. Acesso em: 14 abr. 2014.

Wisley Plant Society Show Exhibitor Guide 2017. Disponível em: <https://ebps.org.uk/wpcontent/uploads/2017/06/Plant-Society-Show-Exhibitor-Guide-2017.pdf >. Acesso em: 22 jun. 2017. 
Watch Out For End Cap Booth Spaces At Your Next Trade Show. Disponível em: $<$ http://alexisexhibits.com/blog/bid/36224/Watch-Out-For-End-Cap-Booth-Spaces-At-YourNext-Trade-Show>. Acesso em: 12 out. 2013.

Will a Trade Show Truss System Work For You? Disponível em: $<$ http://makingsense.hubpages.com/hub/Why-Trade-Show-Truss-Systems-Are-So-Popular $>$. Acesso em: 06 jun. 2013.

Working the trade show - Guide to Managing Media and Public Relations. Disponível em: $<$ https://www.tldp.org/LDP/Linux-Media-Guide/html/trade_show.html >. Acesso em: 06 jun. 2013.

Your success at a Trade Fair. Disponível em: <http://www.dega-expoteam.de/en/messebaustandbau/messen-erfolgreich-planen.html>. Acesso em: 14 abr. 2014.

ZOETEMAN, Kees. Sustainable Development Drivers. Disponível em: $<$ http://books.google.com.br/books?id=WfWdp_ny0YC\&pg=PA66\&lpg=PA66\&dq=Fair + trade + is + an + organized + social + movement + that + aims + to + help + producers + in + developing + countries + to + make + better+trading + conditio $\mathrm{ns}+$ and + promote + sustainability\&source $=$ bl\&ots $=$ ubWZWLi2oZ\&sig $=-$

SgnZLS7AxpuKzHbzczFQBOyrNk\&hl=pt-

BR\&sa $=$ X\&ei $=116$ PU76FFof54QTsp4HQAw\&ved $=0$ CFcQ6AEwBQ\#v=onepage $\& q=$ Fair\%2 0trade $\% 20$ is $\% 20$ an $\% 20$ organized $\% 20$ social $\% 20$ movement $\% 20$ that $\% 20$ aims $\% 20$ to $\% 20$ help $\% 20$ producers $\% 20$ in $\% 20$ developing $\% 20$ countries $\% 20$ to $\% 20$ make $\% 20$ better $\% 20$ trading $\% 20$ conditions \%20and\%20promote\%20sustainability\&f=false>. Acesso em: 07 fev. 2014.

\section{REFERÊNCIAS CORPORA DE ESTUDO EM FRANCÊS}

10 Conseils pour réussir votre exposition. Disponível em: $<$ http://www.clipdisplay.be/sites/default/files/10conseilsBD.pdf $>$. Acesso em: 04 nov. 2015.

2015 Foire Internationale de Marseille: documents à retourner et prestations complémentaires. Disponível em: $<$ http://www.foiredemarseille.com/files/2015/Livret\%20bdc\%202015\%20BD.pdf $>$. Acesso em: 30 out. 2015.

Guide de l'exposant 19EMES ASSISES ORL 2017. Disponível em: <http://www.assisesorl.fr/wp-content/uploads/2016/05/GUIDE-EXPOSANT-19EMES-Assises-ORL.pdf >. Acesso em: 10 mai. 2017.

2015 EMP Manuel de l'exposant. Disponível em: $<$ http://www2.gnb.ca/content/dam/gnb/Departments/en/conference/2015_EMP_EXHIBITOR _MANUAL-F.pdf >. Acesso em: 30 out. 2015.

2016 Répertoire des sites de Salons, biennales, foires, festivals, symposium, marchés et ateliers portes ouvertes. Disponível em: <http://www.active-art.net/documents/Repertoire-des-salons2016.pdf >. Acesso em: 05 ago. 2017.

Agenda - Le Tour de France des foires. Disponível em: $<$ http://www.pleinevie.fr/article/agenda-le-tour-de-france-des-foires-12438>. Acesso em: 05 ago. 2017. 
Après l'exposition. Disponível em: <http://aei.pitt.edu/35986/7/A2120-06.pdf > . Acesso em: 02 nov. 2015.

Arrêté du 12 juin 2006 relatif au régime de déclaration préalable des manifestations commerciales. Disponível em : $\quad<$ http://www.concurrences.com/en/review/issues/no-32006/alerts/Declaration-prealable-des >. Acesso em: 04 set. 2018.

Assurance l'exportation. Disponível em: $<$ http://www.fh2mre.ma/ar/images/stories/pdfs/Commerce_Exterieur/assurance_export.pdf $>$. Acesso em: 06 nov. 2015.

Avant 1 'exposition. Disponível em: <http://aei.pitt.edu/35986/5/A2120-04.pdf > . Acesso em: 02 nov. 2015.

Bilan foires et salons 2006. Disponível em: $<$ http://www.ojs.asso.fr/medias/fichiers/Bilan_foires_et_salons_2006.pdf > . Acesso em: 15 abr. 2017.

Brochure organiser son salon Eurosatory 2018. Disponível em: $<$ http://www.eurosatory.com/wp-content/uploads/EUROSATORY-2018_Brochure-organiserson-salon-2018-02.2018.pdf >. Acesso em: $01 \mathrm{dez} 2018$.

Cahier des charges a l'usage des organisateurs de manifestations. Disponível em: $<$ https://alpexpo.com/wp-content/uploads/2018/06/2018-CDC-ORGANISATEURS-SPLALPEXPO-EDITION-JANVIER-2018..pdf > . Acesso em: 20 abr. 2017.

CFIA 2016 dossier technique Parc Expo Rennes. Disponível em: <http://cfiaexpo.com/wpcontent/uploads/2016/07/CFIA-2016-Bilan-FR.pdf>. Acesso em: 28 ago. 2017.

Code de commerce - Article L762-2. Disponível em: $<$ https://www.legifrance.gouv.fr/affichCodeArticle.do;jsessionid=84DD6E844FD407F833D4 2179C9409E15.tplgfr34s_2?cidTexte=LEGITEXT000005634379\&idArticle=LEGIARTI000 $020627628 \&$ dateTexte $=20180904 \&$ categorieLien $=$ id\#LEGIARTI000020627628 $>$. Acesso em: 15 abr. 2017.

Comexposium recherche un.e Responsable Logistique\&Sécurité H/F. Disponível em: $<$ https://www.unimev.fr/travailler-dans-levenement/offre-emplois/comexposium-rechercheun-e-responsable-logistiquesecurite-h-f/ > . Acesso em: $20 \mathrm{dez} 2018$.

Comment la culture manga a envahi Paris. Disponível em: $<$ http://www.cnewsmatin.fr/culture/2012-09-13/comment-la-culture-manga-envahi-paris115650>. Acesso em: 15 abr. 2017.

Comment financier sa participation individuelle sur des foires et salons specialisées à l' étranger.

Disponível

em:

$<$ http://www.cc.lu/uploads/media/Aides_entreprises_luxembourgeoises_ODL_Joachim.pdf $>$. Acesso em: 10 fev. 2016.

Comment optimiser ma participation à un salon? Disponível em: $<$ http://www.animationeconomique.be/wp-content/uploads/2010/02/Salon-professionnelIgretec-10fev2010.pdf >. Acesso em: 04 nov. 2015.

Comment organiser sa participation à une foire grand public. Disponível em: 
$<$ http://www.dgae.gov.pf/wp-content/uploads/pdf/organisationfoire.pdf $>$. Acesso em: 02 jul. 2015.

Comment réaliser une bonne communication évènementielle?

Disponível em: <http://ekladata.com/s-zDFZfs 7J-fKtLsZQNoLlOfmgk.pdf>. Acesso em: 04 nov. 2015.

Conditions générales de location de surface et d'aménagement de stand. Salon Equip Auto. Disponível em: $\quad<$ http://services.equipauto.com/plateformeressources/personnalisation/1000121/ressources/pdf/cgls.pdf $>$. Acesso em: 30 out. 2015.

Conditions Générales de Location de Surface et d'Amenagement de Stand. Solutrans Lyon $2015 . \quad$ Disponível em: $<$ http://services.solutrans.fr/plateformeressources/personnalisation/1000126/ressources/pdf/cgls.pdf $>$. Acesso em: 30 out. 2015.

Conditions Générales de Location de Surfaces d'exposition «19 Mars 2014 ». Disponível em: $<$ http://www.ba06.com/wp-content/uploads/2013/10/CONDITIONS-GENERALES-DELOCATION-DE-SURFACES-2014.pdf >. Acesso em: 10 fev. 2016.

Conditions Générales de location de surfaces d'exposition et d'aménagement de stand. Règlements. Disponível em: $\quad<\mathrm{http}: / /$ services.sialparis.com/plateformeressources/personnalisation/1000003/ressources/pdf/cond_gl_loc_surf_expo_amenagement_st and.pdf >. Acesso em: 10 fev. 2016.

Conditions Générales de Vente sur salons, foires et autres évènements assimilés. Disponível em:

$<$ https://www.epson.fr/files/ckeditor/c/o/n/d/Conditions_G_n_rales_de_Vente_sur_salon_foir e_et_v_nement_assimil_.pdf $>$. Acesso em: 06 nov. 2015.

Contrat de participation exposants-sponsors. Disponível em: $<$ https://www.tunnel-conferencelyon.com/media/fichier/contrat-exposants-sponsors-conftunnel-lyon.pdf $>$.

Acesso em: 18 set. 2018.

Contrat de participation Foire Montpellier 2015. Disponível em: $<$ https://www.entreprendremontpellier.com/sites/default/files/contrat-foire.pdf $>$. Acesso em: 30 out. 2015.

Contrat de participation Salon du Littoral 2018. Disponível em: <https://www.littoralexpo.com/wp-content/uploads/2017/12/DA-SALON-LITTORAL_Mise-en-page-1.pdf $>$.

Acesso em: 08 nov. 2018.

Cours UFI. Disponível em: $<$ https://www.google.com.br/search?q=Le+R\%C3\%B4le+des+Foires+et + Salons + dans + le $+M$ arketing + Mix \&ie $=$ utf- $8 \& o e=u t f-8 \& g w s \_r d=c r \& e i=y R r C V o-C E Y P E w A S b m K S o B A>$. Acesso em: 10 fev. 2016.

Décret $n^{\circ} 69-948$ du 10 octobre 1969 relatif aux manifestations commerciales. Disponível em: $<$ https://www.legifrance.gouv.fr/affichTexte.do?cidTexte=LEGITEXT000006061694\&dateTe xte $=20060630>$. Acesso em: 10 fev. 2016. 
Décret n 2011-613 du 30 mai 2011 relatif aux fêtes et foires mentionnées par l'article L. 3322$9 d u$ code de la santé publique. Disponível em: $<$ https://www.legifrance.gouv.fr/affichTexte.do?cidTexte=JORFTEXT000024099446\&categ orieLien=id >. Acesso em: 02 abr. 2016.

Décret $n^{\circ} 2006-85$ du 27 janvier 2006 relatif au régime de déclaration préalable des manifestations commerciales. Disponível em: $<$ https://www.legifrance.gouv.fr/affichTexte.do?cidTexte=JORFTEXT000000455034>. Acesso em: 07 out. 2015.

Décrets, arrêtés, circulaires $2006 . \quad$ Disponível em: $<$ https://www.legifrance.gouv.fr/affichTexte.do?cidTexte=LEGITEXT000006053966\&dateTe $\mathrm{xte}=20090120>$. Acesso em: 30 mai 2016 .

Display de sol Moët \& Chandon. Disponível em: <https://www.fag-plv-carton.fr/display-desol/presentoir-moet-et-chandon.html>. Acesso em: 30 mai 2016.

Dossier de presse Foire Internationale de Nantes 2014. Disponível em : $<$ http://www.foiredenantes.fr/system/puzzle/block/type/file_attachments/826/attachments/orig inal_dp-foire-de-nantes-2014-light.pdf >. Acesso em: 05 maio 2016.

Dossier exposant Foire de Nice 2015. Disponível em: <http://docplayer.fr/5063720-Dossierexposant-foire-internationale-de-nice-7au-15mars2015-informations-pratiques-catalogue-desprestations-documents-obligatoires-a-nous-renvoyer.html>. Acesso em: 06 nov. 2015.

Dossier guide de l'exposant 2015 Foire Auxerre. Disponível em: <http://www.centrefranceevenements.com/download/743/dossier-exposant-foire-auxerre-2015-pdf.pdf $>$. Acesso em: 06 nov. 2015.

Dossier Participation Art Paris Art fair 2014-2016. Disponível em: $<$ http://www.artparis.com/fr/exhibitor/login >. Acesso em: 04 nov. 2017.

Dossier pratique de l'exposant SIVAL 2019. Disponível em: <http://exposant.sivalangers.com/media/dossier_pratique_technique_sival_2018_031371000_1417_04122017.pdf >. Acesso em: 20 dez. 2018.

Dossier presse: Salon International de l'Agriculture 2018. Disponível em: $<$ http://www.agencebio.org/sites/default/files/upload/agencebio-dossierdepressesia2018.pdf $>$. Acesso em: 28 set. 2018.

Enregistrement d'un parc d'exposition par son exploitant. Disponível em: $<$ http://www.unimev.fr/system/files/ressources/private/files/unimev_enregistrement_parc_par _son_exploitant.pdf $>$. Acesso em: Acesso em 28 set. 2018.

EQUIPMAG - Paris Porte de Versailles. Conditions générales de location de surface et d'aménagement de stand. Disponível em: <http://services.equipmag.com/plateformeressources/personnalisation/1000044/ressources/pdf/cgl.pdf >. Acesso em: 07 out. 2015.

Étude sur les Formations initiales et formations continues stratégiques pour les entreprises Foires, Salons et Congrès 2014. Disponível em: 
$<$ http://www.fafiec.fr/images/contenu/menuhaut/observatoire/etudes/2013/metiers_FSC/201407-02_OPIIEC_LIV2_Etude_FSC_Marche_Acteurs_Emplois.pdf $>$. Acesso em: $0 \overline{7}$ out. 2015.

Étude sur les retombées economiques des foires et salons. Disponível em: $<$ http://www.ojs.asso.fr/medias/fichiers/Etude_sur_les_retombees_economiques_des_foires_e t_salons.pdf $>$. Acesso em: 07 out. 2015.

Eurosatory 2014. Conditions Generales de Vente. Disponível em: $<$ http://www.eurosatory.com/Portals/0/Documents/PDF/Conditions-Generales-de-Vente.pdf $>$. Acesso em: 15 set. 2015.

Eurosatory 2018 Manuel de l'exposant. Disponível em: <http://www.eurosatory.com/wpcontent/uploads/Eurosatory-2018_Manuel-de-lexposant_Fascicule-2_FR_14_03_2018.pdf >

Acesso em: 01 jan. 2019.

FenCan WinDoor Prospectus des exposants 2017. Disponível em: $<$ http://www.fenestrationcanada.ca/sites/default/files//FenCan\%20WinDoor\%20-

$\% 20$ Exhibitor $\% 20$ Prospectus $\% 202017 \% 20-\% 20$ French\%20Apr\%204.pdf $>$. Acesso em: 10 abr. 2018.

FIAC demande de stand media 2017. Disponível em: $<$ https://www.fiac.com/REF/REF_Fiac/documents/medias/FIAC_DEMANDE\%20DE\%20ST AND\%20MEDIA\%202017_.pdf?

Foire d'Anger 2014 guide de l'exposant. Disponível em: <http://www.foireangers.com/media/dos_prat_foire_2008_041072100_1131_14032008.pdf>. Acesso em: 15 set. 2015.

Foire d'Art Contemporain 2016.2 Disponível em: $<$ http://www.slickartfair.com/pdf2016/PARTICIPATION_GALERIES_SLICK_2016_BD.pd f >. Acesso em: 02 jul. 2016.

Foire de Beré guide exposants 2015. Disponível em: $<$ http://www.foiredebere.fr/media/files/espace-exposants/pdf/guide-exposants-2015.pdf $>$. Acesso em: 15 set. 2015.

Foire de Bordeaux 2015 Guide Exposants. Disponível em: $<$ http://www.foiredebordeaux.com/Media/foire-de-bordeaux/files/guide-de-l-exposant-foire2015/\%28language\%29/fre-FR>. Acesso em: 15 set. 2015.

Foire de l'Isle-sur-la-Sorgue Antiques Art and You 2017. Disponível em: $<$ https://www.evous.fr/Foire-Isle-sur-la-Sorgue-Antiques-Art-and-You-dates-horaires-infosprogramme-1189943.html >. Acesso em: 15 abr. 2017.

Foire de Paris. Conditions générales de ventes edition 2015. Disponível em: $<\mathrm{http}$ ://services.foiredeparis.fr/plateformeressources/personnalisation/1000130/ressources/pdf/cgls.pdf >. Acesso em: 02 jul. 2015.

Foire de Paris 2015 - NOTICE DE SECURITÉ EXPOSANT. Disponível em: $<\mathrm{http}: / /$ services.foiredeparis.fr/plateforme-

ressources/personnalisation/1000130/ressources/pdf/notice_securite.pdf $>$. Acesso em: 04 set. 
2019.

Foire de Paris 2014 - conditions d'accès montage, ouverture, démontage. Disponível em: $<$ http://services.foiredeparis.fr/plateforme-

ressources/personnalisation/1000096/ressources/pdf/acces.pdf>. Acesso em: 04 set. 2018.

Foire écobiologique Humus 2016. Disponível em: <http://foire-ecobiologique-humuschateldon.fr/>. Acesso em: 29 mai 2016.

Foire et salons petit manuel de l'exposant gagnant. Disponível em: $<$ http://www.aerograf.be/librairie-virtuelle/Pub_petit_manuel.pdf $>$. Acesso em: 30 out. 2015.

Foire Européenne 2014 Guide Technique de l'exposant. 2014. Disponível em: $<$ http://www.foireurop.com/archives/2014/B2B/wpcontent/themes/fe2014_B2B/document/Guide_Technique_FE14.pdf $>$. Acesso em: 15 set. 2015 .

Foire Internationale de Marseille 2015 dossier de presse. Disponível em: $<\mathrm{http}: / / \mathrm{www}$.imageconseil.fr/sites/default/files/espace-client/dp_foire_de_marseille_2015_complet_0.pdf $>$. Acesso em: 28 ago. 2018.

Foire Internationale de Marseille 2015 demande de participation. Disponível em: $<$ http://foiredemarseille.com/files/2015/demandeparticipation.pdf >. Acesso em: 30 out. 2015.

Foire Internationale Saint-Étienne 2018 dossier d'admission exposants. Disponível em: $<$ http://www.foiredesaintetienne.com/sites/parcexpo2013/IMG/pdf/dossier_admission_2018_ 6mo.pdf >. Acesso em: 03 jan. 2019.

Foire Virtuelle de Nantes - la lère Foire 3D de France. Disponível em: <http://www.gazettesalons.fr/_decouvertes-gazette/foire-virtuelle-de-nantes-la-1ere-foire-3d-de-france>. Acesso em: 30 out. 2015 .

French Riviera Classic motor show. Conditions Générales de Location de Surface et d'aménagement de Stand. Disponível em: $<$ http://www.fr-cms.com/docs/conditions-generalesventes.pdf $>$. Acesso em: 30 out. 2015.

Gourmet Food \& Wine Selection 2015. Conditions Générales de Location de Surface et d'aménagement de stand. Disponível em: <http://services.salon-gourmetselection.com/plateforme-ressources/personnalisation/1000124/ressources/pdf/cgls.pdf $>$.

Acesso em: 06 nov. 2015.

Guide de l'exposant Belgian Roof Day 2017. Disponível em: $<$ http://belgianroofday.be/Portals/39/Documents/Guide\%20de\%201\%27exposant\%20Belgian \%20Roof\%20Day\%202017.pdf?ver=2017-09-11-155332-107>. Acesso em: 20 dez 2018.

Guide de l'exposant: bien préparer son salon-Chambre de Commerce et d'Industrie de Seineet-Marne.

Disponível em: $<$ http://www.seineetmarne.cci.fr/sites/default/files/ressources/votre_CCI/Publications/guidede-lexposant.pdf >. Acesso em: 06 nov. 2015. 
Guide de l'exposant E- commerce Paris 2012. Disponível em: $<$ http://services.ecommerceparis.com/plateformeressources/personnalisation/1000054/ressources/pdf/guide-exposant-fr.pdf $>$. Acesso em: 20 set. 2018.

Guide de l'exposant Eurocoat 2016. Disponível em: <http://www.eurocoatexpo.com/IMG/pdf/eurocoat_2016_-_guide_de_1_exposant_-_exhibitor_s_guide.pdf $>$. Acesso em: 20 set. 2018.

Guide de l'exposant Foire de Marseille 2012. Disponível em: $<$ http://www.foiredemarseille.com/files/media/pdf/guide_BDC_exposants_2012.pdf $>$. Acesso em: 30 out. 2015.

Guide de l'exposant Foire de Marseille 2015. Disponível em: $<$ http://foiredemarseille.com/files/2015/guide\%20expo\%201-2-3.pdf $>$. Acesso em: 30 out. 2015 .

Guide de l'exposant Foire Internationale de Marseille 2016. Disponível em: $<$ http://foiredemarseille.com/wp-content/uploads/2016/08/Guide-exposant-OK-AG.pdf $>$. Acesso em: 10 mai. 2017.

Guide de l'exposant - foires, salons, expositions. Disponível em: $<$ http://aei.pitt.edu/35986/2/A2120-01.pdf > . Acesso em: 02 nov. 2015.

Guide de l'exposant: optimisez votre participation à un salon professionnel. Disponível em: $<\mathrm{http}$ //www.sepem-industries.com/rouen/pdf/guide_exposant.pdf >. Acesso em: 30 out. 2015.

Guide de l'exposant Salon de la Haute-Façon Paris 2014. Disponível em: http://www.salonmadeinfrance.com/wp-content/uploads/2014/04/Guide-TechniqueMIF2014.pdf >. Acesso em: 13 abr. 2017.

Guide de l'exposant Salon $d u$ Mobilier Nantes 2014. Disponível em: $<$ http://www.salondumobilier.com/system/puzzle/block/type/file_attachments/753/attachment s/original_mobiliernantes2014-guide.pdf >. Acesso em: 13 abr. 2017.

Guide de l'exposant Salon Habitat Immobilier Décoration 2018. Disponível em: $<$ https://www.habitatangers.com/media/dossier_pratique_habitat_2016_018589900_1450_12072016.pdf>. Acesso em: 03 jan 2019.

Guide de l'exposant Silmo Paris 2016. Disponível em: $<\mathrm{http}$ ://services.silmoparis.com/plateformeressources/personnalisation/1000182/ressources/pdf/GT-SILMO-2016-FR-V1.pdf>. Acesso em: 03 jan 2019.

Guide des Prestations du Parc Foire de Lyon 2013. Disponível em:

$<$ http://www.eurexpo.com/commandestechniques/v2/salons/97_foire_13/docs/fr/guide_exposants.pdf $>$. Acesso em: 30 out. 2015.

Guide du Salon International, Optimisez Votre Participation. Disponível em: $<$ http://gndatabase.free.fr/EI/salon_international.pdf>. Acesso em: 30 out. 2015. 
Guide exposant E-commerce Paris 2012. Disponível em: $<\mathrm{http}$ ://services.ecommerceparis.com/plateformeressources/personnalisation/1000054/ressources/pdf/guide-exposant-fr.pdf $>$. Acesso em: 30 out. 2015.

Guide exposant Eurexpo Lyon 2013. Disponível em: $<$ http://services.solutrans.fr/plateformeressources/personnalisation/1000055/ressources/pdf/guide-exposant.pdf $>$. Acesso em: 30 out. 2015.

Guide Exposant Foire d'Automne 2012. Disponível em: $<\mathrm{http}: / /$ services.foiredautomne.fr/plateformeressources/personnalisation/1000049/ressources/pdf/Guide_Exposant.pdf $>$. Acesso em: 30 out. 2015.

Guide exposant Foire d'Autonne 2015. Disponível em: $<\mathrm{http}: / /$ services.foiredautomne.fr/plateformeressources/personnalisation/1000153/ressources/pdf/guide-exposant.pdf $>$. Acesso em: 30 out. 2015.

Guide exposant Foire de Paris 2012. Disponível em: <http://www.comexposiumadmin.com/plateforme-

ressources/personnalisation/1000046/ressources/pdf/guide_exposant.pdf $>$. Acesso em: 30 out. 2015.

Guide exposant Foire de Paris 2013. Disponível em: $<$ http://services.foiredeparis.fr/plateformeressources/personnalisation/1000071/ressources/pdf/guide-exposant.pdf $>$. Acesso em: 02 nov. 2015.

Guide exposant Foire de Paris 2015. Repertoire. Disponível em: $<\mathrm{http}$ ://services.foiredeparis.fr/plateformeressources/personnalisation/1000130/ressources/pdf/guide-exposant.pdf $>$. Acesso em: 30 out. 2015.

Guide exposant Foire Internationale de Marseille 2014. Disponível em: $<$ http://www.foiredemarseille.com/files/2014/Guide\%20exposantsInfos\%20Pratiques.pdf $>$. Acesso em: 30 out. 2015.

Guide exposant France Vet 2019. Disponível em: <https://france.vetshow.com/-exhibitormanual/guide-de-lexposant >. Acesso em: 07 jan. 2019.

Guide exposant Intermat Paris 2015. Disponível em: $<\mathrm{http}: / /$ services.intermatconstruction.com/plateformeressources/personnalisation/1000080/ressources/pdf/guide_exposant.pdf $>$. Acesso em: 30 out. 2015.

Guide exposant Le Mans Salon CE 2015. Disponível em: $<\mathrm{http}$ ://services.salonsce.com/plateformeressources/personnalisation/1000120/ressources/pdf/region/guide-exposant_contact_le-mans2015-semestre1.pdf >. Acesso em: 30 out. 2015. 
Guide exposant Milipol Paris 2015. Disponível em: <http://services.milipol.com/plateformeressources/personnalisation/1000129/ressources/pdf/guide-exposant.pdf $>$. Acesso em: 06 nov. 2015.

Guide Marketing Édition 2018.2 Disponível em : $<\mathrm{http}$ ://salonnationalhabitation.com/docs/librariesprovider37/PDFs/guide-marketing2018.pdf>. Acesso em: 13 abr. 2017.

Guide pratique des aides publiques pour le développement international des entreprises 2013. Disponível em: <http://docplayer.fr/4898075-Guide-pratique-des-aides-publiques-pour-ledeveloppement-international-des-entreprises.html >. Acesso em: 06 nov. 2015.

Guide pratique faciliter et guider vos projets de stand - Fédération Française des Métiers de l'Exposition et de l'Événement. Disponível em: <http://www.ffm2e.info/wpcontent/uploads/2014/06/ffm2e-guide-pratique-du-stand.pdf >. Acesso em: 06 nov. 2015.

Guide pratique organiser une manifestation eco-responsable. Disponível em: $<$ http://www.oise.fr/uploads/media/Brochure_Organiser_une_manifestation_ecoresponsable.pdf $>$. Acesso em: 06 nov. 2015.

Guide technique de l'exposant Foires de Champagne 2017. Disponível em: $<$ http://foiresdechampagne.com/wp-content/uploads/2017/01/GUIDE-TECHNIQUE-DELEXPOSANT-FOIRES-2017.pdf > . Acesso em: $20 \mathrm{dez} 2018$.

Guide technique de l'exposant Paris Nord Villepinte 2015. Disponível em: $<$ http://www.maison-

objet.com/exposants/MaisonObjet_Sept_2015/guides_techniques/50/_PDF/guide_FRA.pdf >. Acesso em: 14 abr. 2017.

Guide Technique de l'exposant Paris Nord Villepinte 2016. Disponível em: $<$ https://exhibitors.maison-objet.com/system/documents/attachments/1/fr/originaltechnical_guides.pdf?1448032428. Acesso em: 14 abr. 2017.

Guide Technique Exposant MSE Lyon 2018. Disponível em: <http://mesures-solutionsexpo.fr/images/protocole/Guide_Technique_Exposant_MSE2018.pdf $>$. Acesso em: 18 set. 2018.

Information sur la Logistique 2015. Disponível em: $<$ http://www.salonmaternitepaterniteenfants.com/uploads/documents/27/files/51/lang/1/files/ Manuel_exposant_QB_2017_2_SUM_160926.pdf>. Acesso em: 18 set. 2018.

La foire virtuelle, une bonne raison de rester chez soi. Disponível em: $<$ http://deco.journaldesfemmes.com/magazine/la-foire-virtuelle-une-bonne-raison-de-resterchez-soi-0412.shtml >. Acesso em: 18 set. 2018.

La participation à un salon professionnel, enjeux et conditions de réussite d'un outil stratégique de la communication externe pour une entreprise en B-to-B. Disponível em: $<$ http://dumas.ccsd.cnrs.fr/dumas-00846280/document >. Acesso em: 06 nov. 2015.

L'art et la manière d'organiser une foire dans les règles. Disponível em: 
$<$ http://lejournaldeleco.fr/942-catherine-merlot-1-art-et-la-maniere-d-organiser-une-foire-dansles-regles/ >. Acesso em: 15 abr. 2017.

Lausanne art fair magazine 2018. Disponível em: $<$ http://www.lausanneartfair.com/images/pdf/LAUSANNE-ART-FAIR-MAG-2018.pdf $>$. Acesso em: 04 set. 2018.

Les festivals gastronomiques dans toute la France. Disponível em: <http://blog.sehhotels.com/fr/top-des-festivals-et-foires-de-gastronomie-en-france/>. Acesso em: 15 abr. 2017.

Le magazine des services et des systèmes pour les foires N. 72 Juillet 2015. Disponível em: $<$ http://www.syma.ch/fileadmin/images_ch/Files/REPORT/Report_72/SYMA_Report_72_Kir chberg_FR_Web.pdf >. Acesso em: Acesso em: 15 abr. 2017.

Le marché des foires et salons à l'horizon 2015. Disponível em: $<$ http://www.scop.coop/FDCOM/liblocal/docs/Documentation/305-Foires_et_salons.PDF $>$. Acesso em: 06 nov. 2015.

Le poids des salons et des congrès. Disponível em: $<$ https://www.google.com.br/search?q=Le+poids + des + salons + et + des + congr $\% \mathrm{C} 3 \% \mathrm{~A} 8 \mathrm{~s}+\& \mathrm{ie}=$ utf- $8 \&$ oe $=$ utf- $8 \&$ client $=$ firefox-b-ab\&gws_rd $=$ cr\&ei $=6$ LaxWI3xOomzwATpjbpA $>$. Acesso em: 06 nov. 2015.

Le Rôle des Foires et Salons dans le Marketing Mix. Disponível em: $<$ https://slideplayer.fr/slide/1294032/>. Acesso em: 12 mar. 2015.

Le salon de la moto Paris 2015. Disponível em: http://lesalondelamoto.com/doc/exposants/SDM2015_DossierInscription_Reglement.pdf $>$. Acesso em: 13 jun. 2016.

Le Salon Solutrans 2015 est maintenu. Disponível em: <http://www.decisionatelier.com/LeSalon-Solutrans-2015-est-maintenu,7501>. Acesso em: 13 jun. 2016.

Le tourisme d'affaires: un enjeu pour la destination France. Disponível em: <http://www.adtherault.fr/content/media/document.php?id_document=1648\&id_format $=1>$. Acesso em: 06 nov. 2015.

Les acteurs des foires et salons en quête d'un nouveau souffle. Disponível em: $<$ http://www.offremedia.com/media/deliacms/media/1294/129465-3041f3.pdf > . Acesso em: 06 nov. 2015.

Les dix commandements $d u$ parfait exposant. Disponível em: $<$ https://business.lesechos.fr/entrepreneurs/marketing-vente/dossiers/114838/114839-les-dixcommandements-du-parfait-exposant-33155.php >. Acesso em: 20 dez 2018.

Les manifestations commerciales: - utilité et intérêt des manifestations commerciales. Disponível em: <http://aei.pitt.edu/35986/4/A2120-03.pdf>. Acesso em: 30 out. 2015.

Les Salons et la Presse Professionnelle. Disponível em: <http://www.christophebenaroya.fr/page30.php>. Acesso em: 06 nov. 2015. 
Les salons professionnels internationaux en France: un passeport pour l'export. Disponível em: $\quad<$ http://www.entreprises.cci-paris-idf.fr/c/document_library/get_file?uuid $=602 \mathrm{~d} 7 \mathrm{~b} 5 \mathrm{c}$ 54a0-44b2-b415-c2fb4b61177f\&groupId=10139>. Acesso em: 06 nov. 2015.

Manifestations organisées dans un parc des expositions enregistré FSCEF - mise à jour Février 2011. Disponível em: $<$ http://www.unimev.fr/system/files/ressources/private/files/unimev_manifestations_organisee s_dans_un_parc.pdf $>$.Acesso em: 13 jul. 2013.

Manuel de l'exposant EMP 2015. Disponível em: $<$ http://www2.gnb.ca/content/dam/gnb/Departments/en/conference/2015_EMP_EXHIBITOR _MANUAL-F.pdf >. Acesso em: 30 out. 2015.

Manuel de l'exposant Salon des Partenaires 2019. Disponível em: $<$ http://www.salonadmq.ca/fr/wp-content/uploads/2018/11/Manuel_exposant-ADMQ2019.pdf > . Acesso em: $16 \mathrm{dez} 2018$.

Manuel de l'exposant Salon industriel du Bas-Saint-Laurent 2018. Disponível em: $<$ https://salonsindustriels.com/wp-content/uploads/SIB_manuel_exposant.pdf >. Acesso em: 03 jan. 2019.

Manuel de l' exposant Salon des sports 2014. Disponível em: $<\mathrm{http}: / /$ montpellier.lesalondessportsdenature.fr/>. Acesso em 11 mar. 2015.

Manuel de l'exposant Salon des technologies environnementales 2014. Disponível em: $<$ http://www.salon-teq.org/UCtrl/scripts/kcfinder/upload/files/Plan $\% 20 \mathrm{de} \% 20$ partenariat $\% 20$ \%20Salon\%20des\%20teq\%202018.pdf $>$. Acesso em: 20 ago. 2015.

Manuel de l'exposant Salon du jeu 2018. Disponível em: <http://salondujeuetdujouet.com/wpcontent/uploads/2018/07/Manuel-de-lexposant.pdf >. Acesso em: 30 out. 2015.

Manuel exposant Technigrow Lyon 2014. Disponível em: $<$ http://www.technigrowfrance.fr/medias/manuel-exposant-technigrow-FR.pdf $>$. Acesso em: 17 jul. 2015.

Manuel technique Vinexpo Bordeaux 2017. Disponível em: $<$ https://vinexpo.site.calypsoevent.net/Data/ElFinder/s2/BX2017/Manuel\%20Technique/FINAL/VinexpoBordeaux2017_ R\%C3\%A9glementation_FR.pdf >. Acesso em: 17 ago. 2018.

Manuel utilisateur Foire Internationale de Bordeaux 2015. Disponível em: $<$ http://www.foiredebordeaux.com/content/download/30517/961926/version/4/file/Manuel\%2 Outilisateur.pdf $>$. Acesso em: 15 set. 2015.

Marchés et Foires de Haute Savoie. Disponível em: <http://www.hautesavoie.cci.fr/visionneuse?media=5516_3I96792E.pdf\&pageEnCours=documents $>$. Acesso em: 13 fev. 2017.

Marchés incontournables. Disponível em: <http://france.fr/fr/infosredac/marchesincontournables >.Acesso em: 15 nov. 2016.

Milipol Paris 2017 outils de communication. Disponível em: 
$<$ https://www.milipol.com/Media/Milipol-Paris-Medias/Fichiers/Brochure-outils-de-comm >. Acesso em: 20 jul. 2018.

Mode d'emploi de la Nouvelle Reglementation Relative au Regime de Declaration Prealable des Manifestations Commerciales. Disponível $<$ https://www.google.com.br/search?q=MODE+D\%E2\%80\%99EMPLOI+DE+LA+NOUVE LLE+REGLEMENTATION+RELATIVE+AU+REGIME+DE+DECLARATION+PREALAB LE+DES+MANIFESTATIONS+COMMERCIALES\&ie $=$ utf-8\&oe=utf8\&gws_rd=cr\&ei $=$ gRXCVrvILISlwATYzK7wBg >. Acesso em: 15 dez. 2015.

Mode d'emploi relatif la réglementation des manifestations commerciales - FSCEF Février 2011.

$<$ http://www.unimev.fr/system/files/ressources/private/files/unimev_declaration_calendrier_m anifestations.pdf $>$. Acesso em: 06 nov. 2015.

Notre visite au Mondial de l'Automobile. Disponível em: <https://reporterre.net/Notre-visiteau-Mondial-de-1-Automobile >. Acesso em: 15 abr. 2017.

Panorama $d u$ droit des foires et salons Juin 2008. Disponível em: $<$ http://www.expocert.fr/OpenDocument.aspx?open=y\&docid=35 >. Acesso em: 30 out. 2015.

Panorama du Droit des Metiers de l'Evenement (Foires, Salons, Evenements et Congres) Juin 2014. Disponível em: <http://www.carler-france.com/attachment/518415/ >. Acesso em: 06 nov. 2015.

Pendant l'exposition. Disponível em: <http://aei.pitt.edu/35986/6/A2120-05.pdf>. Acesso em: 02 nov. 2015.

Plan de prevention - montage et demontage d'une exposition Palais de Congres Viparis 2016. Disponível em: <http://docplayer.fr/29812576-Version-page-1-27-plan-de-prevention-viparismontage-et-demontage-d-une-exposition-niveaux-congres-de-1-adf-2016-11-20.html $>$. Acesso em: 10 mai. 2017.

Présentation du media salon - CCI Paris-Île-de-France. Disponível em: < http://www.cci-parisidf.fr/sites/default/files/etudes/wysiwyg/IMAGES/Tourisme/tourisme-media-salon.pdf $>$. Acesso em: 02 nov. 2015.

Présentoirs de sols. Disponível em : <http://www.aliageplv.fr/solutions-plvmultimateriaux/presentoirs-de-sol/ > . Acesso em: 30 mai 2016.

Programme Foires et Salons 2012-2013 de la CCIDEFA et Ses Partenaires. Disponível em: $<$ http://www.cgpme-paris-idf.fr/datas/files/international/calendrier_ccfa.pdf $>$. Acesso em: 02 nov. 2015.

Prospective sur les évolutions des marchés, des métiers et des emplois des Salons, Foires, Congrès et Evénements de France. Disponível em: $<$ http://www.fafiec.fr/images/contenu/menuhaut/observatoire/etudes/2010/Etude4-Salons3.pdf $>$. Acesso em: 06 nov. 2015.

Reglement général de foires et salons en France Août 2000. Disponível em: < http://www.salonimmo-jura.fr/uploads/pdf/reglement-foires-salons.pdf $>$. Acesso em: 10 fev. 2015. 
Règlement Général des Foires et Salons en France. Disponível em: <http://www.mountainplanet.com/upload/elfinder/pdf/reglement-general-fr.pdf>. Acesso em: 30 out. 2015.

Règlement Général des Manifestations Commerciales. Disponível em: $<$ https://www.unimev.fr/wp-content/uploads/ressources/unimev_rgmc_2015version_francaise.pdf $>$. Acesso em: 06 nov. 2015.

Règlement général des salons de Reed MIDEM. Disponível em: <http://www.mapicchina.com/RM/RM_RetailRealEstateShanghai/2015/documents/reedmidem-reglementgeneral-salons.pdf?v=635842251579579871>. Acesso em: 06 nov. 2015.

Règlement général régissant la participation aux foires et expositions à l'étranger 2014 Disponível em: <http://www.mincommerce.gov.dz/fichiers13/reglfoir-etran2014.pdf > Acesso em: 30 out. 2015 .

Règlement Interieur des Foires et Salons Avril 2012. Disponível em: $<$ http://www.exponantes.com/system/page_attachments/428/attachments/original_reglementdes-foires-et-salons-exponantes.pdf $>$. Acesso em: 30 out. 2015.

Règlement Interieur Foire Internationale Clermont Cournon 2014. Disponível em: $<\mathrm{http}: / / \mathrm{www}$.foire-de-clermont.com/sites/default/files/RI_FICC_2015.pdf $>$. Acesso em: 30 out 2015.

Réglement type des marchés de France. Disponível em: <http://www.drome.cci.fr/sinformersur/territoire/developper-son-territoire/?no_cache=1\&tx_drblob_pi1[downloadUid] $=449>$.

Acesso em: 06 nov. 2015.

Règlement général SPACE 2015. Parc des expositions de Rennes. Disponível em: $<$ http://www.space.fr/wpFichiers/1/1/Ressources/file/Exposer/Dossier-inscription-SPACE2015/Reglement-general_SPACE-2015.pdf >. Acesso em: 30 out. 2015.

Réservation de stand FRUIT LOGISTICA 2019. Disponível em: $<$ https://www.fruitlogistica.de/media/fl/fl_dl_all/Fr_Reservation_de_stand.pdf $>$. Acesso em: 27 set. 2018.

Rétroactu 17 mars 1904: La première Foire de Paris ouvre ses portes! Disponível em: $<$ http://www.pleinevie.fr/video/retroactu-17-mars-1904-la-premiere-foire-de-paris-ouvre-sesportes-14202 >. Acesso em: 27 set. 2018.

ler Salon Beauty Forum en France. Disponível em: <http://www.beautyforum.fr/blog_salon_beauty_forum.aspx >. Acesso em: 15 abr. 2017.

Salon $d u$ Livre de Paris 2019: Foire aux questions. Disponível em: $<$ https://www.livreparis.com/infos-pratiques/foire-aux-questions/>. Acesso em: 20 dez 2018.

Salons et Foires en France 5 atouts pour developper votre entreprise. Disponível em: $<$ http://www.cci-paris-idf.fr/sites/default/files/etudes/pdf/documents/etudes-salons-foiresdepliant-1506.pdf >. Acesso em: 07 out. 2015.

Salons et Foires en France un puissant outils de developpement pour les entreprises exposantes en France et en Ile-de-France. Disponível em: 
$<$ http://www.ojs.asso.fr/medias/fichiers/Salons_et_Foires_en_France_un_puissant_outils_de_ developpement_pour_les_entreprises_exposantes_en_France_et_en_İle_de_France.pdf ${ }_{-}^{-}$. Acesso em: 07 out. 2015 .

Salon expoprotection 2018 notice de sécurité exposant. Disponível em: $<$ https://www.expoprotection.com/REF/REF_ExpoProtection/EP\%202018_Notice\%20SECU RITE_FR.pdf?v=636640647887627198 >. Acesso em: 18 set. 2018.

Salon FTM 2018 notice de sécurité exposant. Disponível em: $<$ https://www.iftm.fr/REF/REF_IFTM/iftmmap/documents/Espacedeco/IFTMFR/IFTM2018 noticesecurite_FR3.pdf?v=636640439874551259 >. Acesso em: $01 \mathrm{dez} .2018$.

Salon virtuel Veille Documentation Guide des exposants. Disponível em: $<$ https://cnd.hcp.ma/docexpo2016/attachment/705570/ >. Acesso em: 28 set. 2018.

Tour de France des Foires 2017. Disponível em: <http://www.evous.fr/Tour-de-France-desFoires-calendrier-adresse-horaires-1186173.html >. Acesso em: 27 set. 2018.

Trouver des fournisseurs lors de foires commerciales et d'expositions. Disponível em: $<$ http://www.recherche-fournisseurs.com/index.php/trouver-un-fournisseur-deproduits/trouver-des-fournisseurs-lors-de-foires-commerciales-et-d-expositions $>$. Acesso em: 15 abr. 2017.

Unimev 2013. Règlement général des manifestations commerciales. Disponível em: $<$ http://www.unimev.fr/files/unimev.fr/public/ressources/files/unimev_rgmc_version_francais e.pdf >. Acesso em: 30 out. 2015.

Unimev 2015. Règlement général des manifestations commerciales. Disponível em: $<$ http://www.unimev.fr/files/unimev.fr/public/ressources/files/unimev_rgmc_2015version_francaise.pdf $>$. Acesso em: 30 out. 2015.

Unimev 2014 bilan chiffres 2013. Disponível em: $<$ http://www.unimev.fr/files/unimev.fr/public/ressources/files/unimev_2014_bilan_chiffres_2 013_0.pdf $>$. Acesso em: 15 set. 2015.

Unimev 2015 bilan 2014.20 Diffres emível $<$ http://www.unimev.fr/files/unimev.fr/public/ressources/files/unimev_2015-06-bilan-chiffres2014.pdf >. Acesso em: 07 out. 2015.

Unimev bilan chiffres 2012. Disponível $<$ http://www.unimev.fr/files/unimev.fr/public/ressources/files/unimev_bilan_chiffre_2012.pdf >. Acesso em: 07 out. 2015.

Unimev bilan chiffre premier semestre 2013. Disponível em: $<$ http://www.unimev.fr/files/unimev.fr/public/unimev_bilan_chiffre_premier_semestre_2013. pdf $>$. Acesso em: 07 out. 2015.

Unimev bilan chiffres 2011. Disponível em: $<\mathrm{http}: / /$ www.ojs.asso.fr/medias/fichiers/Bilan_dactivite_2011_de_la_filiere_et_perspectives_ 
20121.pdf >. Acesso em: 07 out. 2015.

Unimev memo chiffres 2013-2014. Disponível em: $<$ http://www.unimev.fr/files/unimev.fr/public/unimev_memo_chiffres_2013_2014.pdf $>$.

Acesso em: 07 out. 2015.

Vente en foires et en salons spécialisés. Disponível em: <http://www.solutionscreatives.com/telechargement/Fiches_foiresalons_ma.pdf >. Acesso em: 06 nov. 2015.

\section{REFERÊNCIAS CORPORA DE ESTUDO EM ITALIANO}

AEFI 2014. Potenzialità e Valori del Sistema Fieristico Italiano. Disponível em: $<\mathrm{http}: / /$ www.geoprogress.eu/wp-

content/uploads/2016/06/AEFI_GENERALE_2909.pdf>.Acesso em: 05 fev. 2015.

AEFI Calendario 2008 e statistiche 2006 delle manifestazioni fieristiche italiane riconosciute internazionali. Disponível em: < http://www.aefi.it/Aefi/media/misc/aefi_2008.pdf > . Acesso em: 05 fev. 2015.

AEFI Innovare le fiere per vincere la crisi. Disponível em: $<$ http://www.aefi.it/Aefi/media/misc/Innovare-le-fiere-per-vincere-la-crisi.pdf > . Acesso em: 05 fev. 2015.

AEFI Le Manifestazioni Fieristiche e la Nuova Direttiva Servizi 2011. Disponível em: $<$ http://docplayer.it/2298473-Le-manifestazioni-fieristiche-e-la-nuova-direttiva-servizi.html >. Acesso em: 13 jul. 2015.

AEFI Road to Expo 2015. Disponível em: $<$ http://www.aefi.it/Aefi/media/misc/roadtoexpo/brochure-ita.pdf >. Acesso em: 02 mai. 2016.

AEFI Il sole 24 ore 2006.20 Disponível em: $<$ http://www.aefi.it/Aefi/media/misc/aefiFiere18.pdf $>$. Acesso em: 13 jul. 2015.

AEFI Il sole 24 ore 2009. Disponível em: $<$ http://www.aefi.it/Aefi/media/misc/Aefi04_italiano.pdf >. Acesso em: 13 jul. 2015.

AEFI Il sole 24 ore Dicembre 2008. Disponível em: $<$ http://www.aefi.it/Aefi/media/misc/Aefi03_it_Ok.pdf >. Acesso em: 13 jul. 2015.

AEFI Il sole 24 ore Settembre 2008. Disponível em: $<$ http://www.aefi.it/Aefi/media/misc/Aefi02_it_ok.pdf >. Acesso em: 13 jul. 2015.

Alma Seges in fiera a Berlino con uno stand sostenibile. Disponível em: $<$ http://www.italiafruit.net/DettaglioNews.aspx?idNews=37630\&Titolo=alma-seges-in-fieraa-berlino-con-uno-stand-sostenibile >. Acesso em: 25 jun. 2017.

Arte Fiera 2015 Accesso al Quartiere. Disponível em: $<$ http://www.artefiera.it/media/artefiera/documents/2015/regolamenti_e_modulistica/AF2015 \%20accesso\%20al\%20Quartiere.pdf >. Acesso em: 25 ju. 2017. 
Arte Fiera 2015 Regolamento tecnico. Disponível em: $<$ http://www.artefiera.it/media/artefiera/documents/2015/regolamenti_e_modulistica/AF2015 _regolamentotecnico_ita.pdf >. Acesso em: 11 ago. 2018.

Avviso di indagine di mercato. Disponível em: $<\mathrm{http}$ ://www.promosmilano.it/ImagePub.aspx?id=953642 > . Acesso em: 27 set 2018 .

A-Z informazione utile per gli espositori Expo Ferroviaria 2014 Torino. Disponível em: $<$ http://docplayer.it/5578555-01-03-aprile-2014-lingotto-fiere-torino-italia-a-Z-informazioniutili-per-gli-espositori.html >. Acesso em: 27 set 2018.

Bologna Fiere 2015 Domanda di Partecipazione. Disponível em: <http://www.sieexpo.it/wpcontent/uploads/sites/14/2014/12/SIE_2015_Domanda_Partecipazione.pdf >.Acesso em: 27 set 2018 .

Business in fiera: come si pianifica e si partecipa con profitto ad una fiera. Disponível em: $<$ https://www.accademiafieramilano.it/static/upl/Br/Brochurecomepartecipareadunafiera.pdf $>$. Acesso em: 27 set 2018.

Calendario 2012 delle manifestazioni fieristiche internazionale in Italia. Disponível em: $<$ http://www.aefi.it/Aefi/media/misc/calendario-fiere-2012.pdf >. Acesso em: 17 mar. 2015.

Calendario Fieristico Italiano 2002. Disponível em: $<$ http://www.isfcert.it/isf/allegati/CALENDARIO_FIERISTICO.pdf >. Acesso em: 17 mar. 2015.

Catalogo Circuito Si Sposa 2015. Disponível em: <https://circuitosisposa.it/wpcontent/uploads/2015/03/WEB_CATALOGO-2015-161.pdf >. Acesso em: 20 jul. 2016.

Circolare Applicativa dell'accordo per l'internazionalizzazione del Sistema Fieristico Italiano 2005.

Disponível

em:

$<$ http://www.sviluppoeconomico.gov.it/images/stories/recuperi/Impresa_internazionalizzazion e/circolare-2005-fiere.pdf >. Acesso em: 17 mar. 2015.

Come esporre con successo in fiera secondo Asal. Revista Prisma 2004. Disponível em: $<$ http://www.expofairs.com/prisma/080/pagina_071.pdf >. Acesso em: 08 mai. 2015.

Come organizzare un evento fieristico di sucesso. Disponível em: $<$ http://www.altolazionotizie.it/economia/come-organizzare-un-evento-fieristico-disuccesso_48563.php >. Acesso em: 03 set. 2016.

Comune di Pordenone: Regolamento per la disciplina delle fiere. Disponível em: $<$ http://www.comune.pordenone.it/it/comune/atti/regolamenti/commercio/fiere.pdf/view $>$.

Acesso em: 22 abr. 2017.

Comunicati stampa. Disponível em: <http:/www.ucima.it/uc-it/press-area/comunicatistampa/le-macchine-italiane-per-il-confezionamento-e-limballaggio-protagoniste-assolute-alpack-expo-international-di-chicago/ >. Acesso em: 27 set. 2018.

Comunicati stampa AUTOSERVICETEC 2018. Disponível em: $<$ http://www.autoservicetec.it/comunic_stampa.html >. Acesso em: 03 out 2018. 
Condizioni generali di partecipazione BTC 2010. Disponível em: $<$ http://www.riminifiera.it/pagine/magazine\%20mostra.asp?Codart=1408\&Codice $=70>$. Acesso em: 17 mai. 2017.

Criteri di Riconoscimento della Qualifica Internazionale e Nazionale. Disponível em: $<$ http://www.aefi.it/Aefi/media/misc/CRITERI\%20DI\%20RICONOSCIMENTO\%20DELLA \%20QUALIFICA\%20INTERNAZIONALE\%20E\%20NAZIONALE.pdf>. Acesso em: 23 abr. 2017.

Condizioni Generali di Partecipazione SAIE 2016. Disponível em: $<\mathrm{http}$ //www.condominioitaliaexpo.com/Modulistica/condizionigenerali_privacy.pdf $>$. Acesso em: 23 abr. 2017.

Criteri espositivi a misura di cliente. Disponível em: $<$ http://www.porteefinestrenews.it/2013/02/18/criteri-espositivi-a-misura-di-cliente/>. Acesso em: 24 abr. 2017.

Dal locale al globale fare rete per rilanciare l'export attraverso le fiere. Disponível em: $<$ http://www.aefi.it/Aefi/media/misc/convegno14-09-2011-Campagnoli.pdf $>$. Acesso em: 08 mai. 2015.

Dati statistici feiristici. Disponível em: $<\mathrm{http}$ //www.isfcert.it/isf/allegati/ALLEGATO_SUB_A_PROTOCOLLO.pdf $>$. Acesso em: 08 mai. 2015.

Determinazione dei Sistemi Idonei ed Oggettivi di Rilevazione e Certificazione dei Dati Attinenti agli Espositori ed ai Visitatori delle Manifestazioni Fieristiche. Disponível em: $<$ http://www.aefi.it/Aefi/media/misc/DETERMINAZIONE.pdf $>$. Acesso em: 08 ago. 2015.

Disposizioni Generali Arte Fiera 2015. Disponível em: $<$ http://www.artefiera.it/media/artefiera/documents/2015/regolamenti_e_modulistica/disposizi oni\%20generali\%20AF2015.pdf > . Acesso em: 08 mai. 2015.

Documento delle Regioni sull'osservatorio per il Sistema Fieristico Italiano. Disponível em: $<\mathrm{http}: / /$ www.isfcert.it/isf/allegati/2309010osservatorio_fieristico.pdf >. Acesso em: 04 set. 2018.

Documento per gli espositori Altrocioccolato 2018 Umbria. Disponível em : $<$ http://www.altrocioccolato.it/website/wp-content/uploads/2018/08/ESPOSITORI-2018-

ALTROCIOCCOLATO-ok.pdf >. Acesso em: 04. set. 2018.

Documento per gli espositori Fiera Fa' la cosa giusta 2014. Disponível em: $<$ http://www.terre.it/flash/00_DOCUMENTI_pdf/FLCG/Documento_per_gli_espositori.pdf $>$. Acesso em: 25 set. 2018.

Documento unico di valutazione dei rischi: Fiera del Levante 2017. Disponível em: $<$ https://www.agrilevante.eu/it/pdf/2017-DUVRI.pdf >. Acesso em: 03 jan. 2019

Documento unico di valutazione dei rischi: quartiere fieristico di Bologna ARTEFIERA 2015.

Disponível

em:

$<$ http://www.artefiera.it/media/artefiera/moduli\%202015/9_DUVRI_artefiera_ita.pdf $>$.

Acesso em: 25 abr. 2017. 
Documento unico di valutazione dei rischi: Quartiere Fieristico di Carrara TIRRENO CT \& BALNEAREA 2017. Disponível em: <http://www.tirrenoct.it/img/informativepdf/DUVRI2017TirrenoCteBalnearia.pdf >. Acesso em: 25 abr. 2017.

Domanda di partecipazione Accadueo 2018. Disponível em: $<$ http://www.accadueo.com/media/h2o/2018/documenti/DDP_Accadueo2018_ITA_compilabi le.pdf $>$. Acesso em: 12 dez. 2018.

Domanda di partecipazione EICMA 2018. Disponível em: $<$ https://www.eicma.it/resources/Risorse/eicma-domanda-di-partecipazione.pdf $>$. Acesso em 12 dez. 2018

Domanda fierar Disponível em: $<$ http://www.comunedibelmontecalabro.cs.it/pdf_nuovo/ufficio $\% 20$ commercio/domanda_fier a.pdf $>$. Acesso em: 04 set.2018.

$75 a$ esposizione internazionale del ciclo e motociclo 2017. Disponível em: $<$ https://www.eicma.it/resources/documents/EICMA-Domanda-ITA-2017-.pdf $>$. Acesso em: $15 \mathrm{dez} 2018$.

72esima edizione Fiera del Levante. Disponível em: $<$ http://vintage.apuliafilmcommission.it/press/comunicati-stampa/72esima-edizione-fiera-dellevante.html >. Acesso em: 27 mai. 2017.

EXPOMED nuovo polo fieristico. Disponível em: $<$ http://www.sito.regione.campania.it/burc/pdf08/burc41or_08/del252_08/del252_08Allegato _ExpoMedultimo.pdf >. Acesso em: 27 mai. 2017.

Fabbrica da esposizione. Via Sarfatti 25 - Il quotidiano della Bocconi. Disponível em: $<$ http://www.cermes.unibocconi.it/wps/wcm/connect/92999967-d80d-47a8-826c48175759334d/Fabbrica+da+esposizione.pdf?MOD=AJPERES >. Acesso em: 27 mai. 2017.

Farete Exhibiton 2015 Bologna. Disponível em: <http://www.qwince.com/it/qwince-conneuralya-farete-2015/ >. Acesso em: 24 abr. 2017.

Feira di Bologna Regolamento Tecnico di Manifestazione 2012. Disponível em: $<\mathrm{https}$ ://www.eima.it/it/pdf/2018-EIMA-REGOLAMENTO-TECNICO.pdf $>$. Acesso em: 30 nov. 2012.

Fiera del Lavoro: una occasione da cogliere. Disponível em: $<$ https://www.lds.org/bc/content/shared/content/italian/pdf/languagematerials/37142_jsFair_ita.pdf?lang=ita >. Acesso em: 24 abr. 2017.

Fiera di Milano. Il gateway dell'economia. Disponível em: $<$ http://www.mi.camcom.it/c/document_library/get_file?uuid=c73fddcd-60bb-4cf3-8d9b0ea2f1d6e82e >. Acesso em: 24 abr. 2017.

Fiera di Pordenone. Disponível em: <http://www.happybusinesstoyou.it/newsdettaglio.php?id=1 >. Acesso em: 03 mar. 2016.

$41^{a}$ FIERA DITF 2017. Disponível em: <http://www.promecmodena.it/it/programmi-einiziative/bacheca/collettiva-alla-41-fiera-ditf-saba-saba-tanzania/at_download/file>. Acesso em: 03 jan. 2019. 
Fiera Internazionale del Tartufo report. Disponível em: $<$ http://www.fondazionecrc.it/images/documenti-centrostudi/quaderni-online/2013-quadernoonline-fieradeltartufo.pdf >. Acesso em: 25 fev. 2017.

Fiera Milano Relazione sulla gestione al 31 dicembre 2014. Disponível em: $<$ http://www.fieramilano.it/sites/default/files/Relazione_sulla_gestione_al_31_dicembre_2014 .pdf >. Acesso em: 25 fev. 2017.

Fiera di Roma motore dello sviluppo territoriale.

Disponível em: $<$ https://www.google.com.br/search?q=Fiera+di+Roma:+motore+dello+sviluppo+territoriale Rapporto+di+RicercaATS + Erfap + Lazio $+\%$ E2\%80\%93+Analisi + e+Ricerche+TerritorialiArtS $\mathrm{rl}+$ Roma\&ie $=$ utf- $8 \&$ oe $=$ utf- $8 \&$ client $=$ firefox-b-

ab\&gws_rd=cr\&ei $=\mathrm{iwWyWN} 3 \mathrm{yM} 4 \mathrm{mZwgTPhLPICA \# q=Fiera}+\mathrm{di}+\mathrm{Roma}:+$ motore + dello + svi luppo+territoriale\&* >. Acesso em: 25 fev. 2017.

Fiera Roma regolamento quartiere. Disponível em: <http://www.fieraroma.it/pdf/FDRRegolamentoquartiere_ITA.pdf >. Acesso em: 19 ago. 2017.

Fiere di nuova generazione tra le priorità c'è il marketing territoriale. Disponível em: $<$ https://www.manageritalia.it/content/download/Informazione/Giornale/Marzo_2008/10_15.p df $>$. Acesso em: 19 ago. 2017.

Fiere Doc e Con Marchio di Qualita'Anche In Italia Arriva la Certificazione dei Dati Statistici. Disponível em: $<$ http://www.isfcert.it/isf/allegati/COMUNICATO_STAMPA_AEFI-CFI-CFTUNIONCAMERE.pdf > . Acesso em: 19 ago. 2017.

Fiere e mostre. Disponível em: <http://www.impresaoggi.com/it/articoli/Artspec31.pdf $>$. Acesso em: 11 set. 2017.

Fiere Estere 2015. Largo Consumo. Disponível em: <http://www.expoconsulting.eu/site/wpcontent/uploads/2015/02/MercatoFieristicoFiereEstereInternazionalizzazioneExportAgroalim entareFoodWineMadeInItalyPmiAefiIceComunicazione72-0115.pdf $>$. Acesso em: 11 set. 2017.

Fiere internazionale come renderle efficace. Disponível em: $<$ http://www.imprese.intesasanpaolo.com/portalImpn0/pdf/Pmi_09_23_07.pdf $>$. Acesso em: 11 set. 2017.

Fiere la porta sul mercato: persone idee e prodotti si incontrano qui. Disponível em: $<$ http://www.fierabolzano.it/doc/marketingfolder_push_ita.pdf > . Acesso em: 11 set. 2017.

Fiera Milano: Relazione Finanziaria Annuale 2015. Disponível em: $<$ http://www.fieramilano.it/sites/default/files/Relazione_sulla_gestione_al_31_dicembre_201 4.pdf >. Acesso em: $20 \mathrm{dez} 2018$.

FMZ Internazionalizzarsi 2007. Disponível em: $<$ http://www.sportelloimpresa.it/repository/pubblicazioni/FMZ_Internazionalizzarsi.pdf $>$. Acesso em: 11 set. 2017.

Golositalia Fiera di Brescia 2014. Disponível em: <http://www.golositalia.it/press/rassegna- 
stampa/pubblicita-della-fiera-enogastronomica-sulla-rivista-mensile-terra-nuova-972>. Acesso em: 22 abr. 2016.

Grande adesione di espositori e visitatori all'mcT Petrolchimico. Disponível em: $<$ http://www.gisi.it/documents/notiziario/2016/09_Novembre.pdf >. Acesso em: 15 dez 2018.

Guida ai servizi Expocasa 2017. Disponível em: $<$ http://www.expocasa.it/public/upload_file/GUIDA\%20AI\%20SERVIZI_Expocasa_2017.pd f $>$. Acesso em 17 jan. 2019.

Guida ai servizi per gli espositori. Salone Internazionale del Libro di Torino 2017. Disponível em: $<$ http://www.salonelibro.it/it/documenti/cat_view/39-espositori.html $>$. Acesso em: $22 \mathrm{abr}$. 2017 .

Guida espositore Fiera Milano 2015. Disponível em: $<$ https://www.salonefranchisingmilano.com/images/banners/062_guida_espositore_16it.pdf $>$. Acesso em: 22 abr. 2016.

Guida EXPO 2015.2 Disponível em: $<$ https://www.esteri.it/mae/it/politica_estera/economia/l-esposizione-universale-dimilano.html>. Acesso em: 07 nov. 2015

Guida pratica espositore Salone Internazionale dell'ospitalità professionale 2013. Disponível em :

$<$ http:/host.fieramilano.it/sites/default/files/GUIDA_PRATICA_ESPOSITORE_rev._Giugno _2013_.pdf >. Acesso em: 25 abr. 2017.

I numeri del settore fieristico 2015 AEFI. Disponível em: $<$ http://www.aefi.it/Aefi/media/misc/made-in-italy/sfi_2015.pdf >. Acesso em: 04 set. 2018.

I più bei mercati storici italiani. Disponível em: $<$ http://viaggi.corriere.it/viaggi/weekend/i-piubei-mercati-storici-italiani-dove-fare-spesa-feste-f851 af14-8699-11e4-bef5-

43c0549a5a23/?refresh_ce-cp>. Acesso em: 24 abr. 2017.

Il Marketing per Generare Valore nel Sistema Evento. Disponível em: <http://www.marketingtrends-congress.com/archives/2005/Materiali/Paper/It/Cherubini_Iasevoli.pdf >. Acesso em: 22 abr. 2016.

Il ruolo delle fiere nel marketing mix UFI. Disponível em: <http://www.ufi.org/archive/ufionline-course/online_course_2010_IT.pdf >. Acesso em: 25 jul. 2017.

Il ruolo di AEFI nel mondo fieristico. Disponível em: $<$ http://www.aefi.it/Aefi/media/misc/dossierged18.pdf>. Acesso em: 10 ago. 2018.

Innovare e Promuovere il Sistema di Imprese con le Fiere 2002. Disponível em: $<$ http://www.aefi.it/Aefi/media/misc/Censis040304164925.pdf>. Acesso em: 04 set. 2018.

ISF Instituto di certificazione dati statistici fierestici. Disponível em: $<$ http://www.isfcert.it/isf/allegati/sole178x247.pdf>. Acesso em: 25 jul. 2017.

ITMA 2015: Regolamento generale $e$ indice dei prodotti. Disponível em: $<$ http://www.itma.com/docs/default-source/downloads/general- 
regulations/itma_2015_gr_iop_italian.pdf?sfvrsn=2 >. Acesso em: 22 abr. 2017.

Klimahouse 2019 Fiera Bolzano. em:

$<$ http://www.fierabolzano.it/klimahouse/vademecum.htm >. Acesso em: 08 dez. 2018.

L'ente Fiera come Impresa Turistica tra Diritto Pubblico e Diritto Privato. Disponível em: $<$ https://www.google.com.br/search?q=L\%E2\%80\%99ENTE+FIERA+COME+IMPRESA+T URISTICA+TRA+DIRITTO+PUBBLICO+E+DIRITTO+PRIVATO\&ie $=$ utf- $8 \&$ oe $=u t f-$

$8 \&$ client $=$ firefox-b-ab\&gws_rd $=$ cr\&ei $=$ OA2yWPDnDYaXwQS_7rWYBA $>$. Acesso em: 25 jul. 2017.

L'impatto delle Trasformazioni della Distribuzione sulle Fiere. Disponível em: $<$ http://www.aefi.it/Aefi/media/misc/tradelab.pdf >. Acesso em: 22 abr. 2017.

La fiera di sucesso: una guida per gli espositori. Disponível em: $<$ http://www.fierabolzano.it/doc/messeleitfaden_ita.pdf >. Acesso em: 22 abr. 2017.

La Fiera Internazionale: un mezzo per accellerare l'ingresso nel mercato. Disponível em: $<$ http://www.formazione-

maveco.it/SITO\%20WEB/SITO\%20WEB_formazione/Articoli\%20selezionati/marketing/LA \%20FIERA\%20INTERNAZIONALE.pdf $>$. Acesso em: 13 mar. 2017.

Lavorare in Fiere, Manifestazioni Culturali e Sportive. Disponível em: $<$ http://www.riminimpiego.it/data/lavoroindiretta/documenti/LINK_3.3.pdf $>$. Acesso em: 22 mai. 2016.

Le fiere come strumento di politica industriale per la promozione dell'export. Disponível em: $<\mathrm{http}: / / \mathrm{www}$. ispionline.it/it/documents/export_promotion_fiere.pdf $>$. Acesso em: 22 mai. 2016.

Le fiere come strumento di comunicazione e promozione 2010 presentazione Gruppo Azienda. Disponível em: $<$ http://dinamico1.unibg.it/turismo/material/Laboratorio_Fiere_2010_PresentazioneGruppoAz ienda\%20.pdf > . Acesso em: 03 fev. 2016.

Le fiere nel mix di comunicazione: come prepararle e come valutare i risultati. Disponível em: $<$ https://www.studiomaggiolo.it/files/fiere.pdf >. Acesso em: 04 set. 2018.

Le Professioni del Settore Fieristico: Il caso di Fiera Milano. Disponível em: $<$ https://www.fondazionefieramilano.it/static/upl/qu/quaderno7.pdf>. Acesso em: 03 fev. 2016.

Legge quadro sul settore fieristico 11 gennaio 2001. Disponível em: $<$ http://www.camera.it/parlam/leggi/010071.htm>. Acesso em: 08 jul. 2015.

L'evoluzione del sistema fieristico italiano: sfide e strategie per $i$ principali operatori. Disponível em: $\quad<$ http://dspace.unive.it/bitstream/handle/10579/2865/9865031164164.pdf? sequence=2 > . Acesso em: 08 jul. 2015.

Linee Guida Expo 2015.2 Disponível em: $<$ https://nullaostalavoro.dlci.interno.it/Ministero/LINEE_GUIDA_EXPO2015_it.pdf>. Acesso em: 10 out. 2016.

MADEexpo Worldwide 2015 domanda di partecipazione. Disponível em: 
$<$ http://www.madeexpo.it/esporre/Informazioni-tecniche.html>. Acesso em: 23 fev. 2016.

Manifestazioni fieristiche L.R. 1102 - schema di regolamento. Disponível em: $<$ https://cdn1.regione.veneto.it/alfstreaming-servlet/streamer/resourceId/1 eed369f-5fe6-40df92cc-fce2c965669e/REGOLAMENTO\%20MANIFESTAZIONI\%20FIERISTICHE.pdf>. Acesso em: 08 jul. 2015.

Manuale come in fiera: Fiera Milano. Disponível em: $<$ https://www.accademiafieramilano.it/static/upl/manuale/manualecomeinfieraweb.pdf $>$. Acesso em: 05 ago. 2015.

Manuale espositore Cosmopack Bologna 2014. Disponível em: $<$ https://www.google.com.br/search?q=Manuale_espositore.Cosmopack+Bologna $+2014 \& \mathrm{ie}=$ utf-8\&oe=utf-8\&client=firefox-b-ab\&gws_rd=cr\&ei=JxKyWJCEBIKSwgSIva-YBw>. Acesso em: 25 fev. 2017.

Manuale Espositore disposizioni generali e tecnique Fiera di Genova 2015. Disponível em: $<$ http://www.primaveraonline.it/images/PRIMAVERA_2016/Espositori/Primavera2016_Disposizioni_Generali_e_Te cniche.pdf >. Acesso em: 05 ago. 2015.

Manuale Espositore Fiera Primavera 2015. Disponível em: $<$ https://www.primaveraonline.it/la-fiera/>. Acesso em: 07 ago. 2016.

Manuale dell'Espositore Fiera di Genova 2013. Disponível em: <http://www.abcdonline.it/wp-content/uploads/2013/09/Manuale-dellEspositore-ABCD-2013-Informazioni.pdf >. Acesso em: 15 mar. 2017.

Manuale dell'Espositore Fiera di Genova 2014. Disponível em: <http://www.abcdonline.it/wp-content/uploads/2014/07/Manuale-dellEspositore-ABCD-2014-Informazioni-eModulistica.pdf > . Acesso em: 15 mar. 2017.

Manuale Espositore Cosmoprof Bologna 2015. Disponível em: $<$ http://www.cosmoprof.it/wpcontent/uploads/2013/02/wip2015.cosmoprof.it/MANUALE-ESPOSITORE.pdf > . Acesso em: 15 mar. 2017.

Manuale dell'espositore Cosmoprof Bologna 2016. Disponível em: $<$ http://www.cosmoprof.it/wp-content/uploads/2013/02/www.cosmoprof.it/MANUALEESPOSITORE-ITA-CPB16.pdf >. Acesso em: 15 mar. 2017.

Manuale Espositore Cosmofarma Bologna 2015. Disponível em: $<\mathrm{http}: / / \mathrm{www} \cdot \operatorname{cosmofarma.com/wp-}$ content/uploads/2014/02/www.cosmofarma.com/MANUALE-ESPOSITORE.pdf>. Acesso em: 06 out. 2016.

Manuale La Dolce Vita 2010. Disponível em: $<$ http://www.forimpz.it/uploaded/MANUALE\%20DV.pdf >. Acesso em: 18 set. 2018.

Mercato fieristico. Largo Consumo 2012. Disponível em: $<$ http://www.largoconsumo.info/092012/PL-0912-007.pdf >. Acesso em: 06 out. 2016. 
Mercato Fieristico Estero. Largo Consumo. Disponível em: $<$ http://www.largoconsumo.info/012014/ARTMercatoFieristicoEsteroExportInternazionalizza zione72-0114.pdf >. Acesso em: 22 abr. 2017.

Milano: presentazione della Fiera della Bomboniera, Regalo e Casa. Disponível em: $<$ https://www.sposimagazine.it/48065/news/milano-presentazione-della-fiera-dellabomboniera-regalo-e-casa/ >. Acesso em: 03 jan. 2019.

Motor Show Bologna 2016: Regolamento tecnico di manifestazione. Disponível em: $<$ http://www.motorshow.it/wpcontent/uploads/2016/10/regolamento_tecnico_manifest_MS20 16_low.pdf >. Acesso em: 04 set. 2018.

Ordina espositori fieristici. Disponível em: <https://www.helloprint.it/displaypopup>. Acesso em: 06 out. 2016.

Più successo: aumentare l'export diretto presentandosi con successo alle fiere. Disponível em: $<$ https://www.postfinance.ch/binp/postfinance/public/dam.1nfxSoZn0OTLpX9B589k-

Hyhw8L4p5D4Bdg_6NcAxLI.spool/content/dam/izv/doc/messeauftritt_it.pdf > . Acesso em: 06 out. 2016.

Pmi, meno fiere e più marketing. Jornal Italia Oggi. Disponível em: $<$ http://www.comarkspa.it/documents/1940305/3997104/pmi+meno+fiere+ma+marketing.pdf /3fa99578-a34e-4092-8812-eb6fbe38e4d7?version=1.0 >. Acesso em: 10 fev. 2017.

Politiche e instrumenti per l'internazionalizazzione delle imprese. Disponível em: $<$ http://www.sviluppoeconomico.gov.it/images/stories/documenti/pubblicazione-mincomesfondi.pdf>. Acesso em: 10 fev. 2017.

Posizionamento internazionale delle manifestazioni fieristiche italiane e analisi per settore. Elaborazione AEFI 2012. Disponível em: <http://www.aefi.it/Aefi/media/misc/euro-fairstatistics/elaborazione-aefi-2012.pdf>. Acesso em: 20 fev. 2015.

Potenzialità e Valori del Sistema Fieristico Italiano AEFI 2014. Disponível em: $<$ http://www.geoprogress.eu/wp-content/uploads/2016/06/AEFI_GENERALE_2909.pdf>. Acesso em: 20 fev. 2015.

Prenotazione spazio espositivo: Expo franchising Napoli 2017. Disponível em: $<$ http://www.expofranchisingnapoli.it/pdf/modulo-espositori.pdf $>$. Acesso em: 03 jan 2019.

Profilo Espositore per Incontri con Buyer Esteri. Disponível em: $<$ http://www.oliocapitale.it/2017b/modulo_buy_olio_2017.pdf >. Acesso em: 22 abr. 2017.

Progetto fiera: Fiera Bolzano. Disponível em: <http://www.fierabolzano.it/progettofiera.doc $>$. Acesso em: 20 fev. 2015.

Programma fieristico Camera di Commercio di Avelino. Disponível em: $<$ http://www.av.camcom.gov.it/index.phtml?Id_VMenu=1001>. Acesso em: 10 mai. 2017. 
Programmi Promozionali Grosseto Fiere 2016. Disponível em: $<$ http://www.grossetofiere.it/pdf/PROGRAMMI\%20PROMOZIONALI\%20Grosseto\%20Fier e\%202016.pdf >. Acesso em: 10 mai. 2017.

Pulire The Smart Show Verona 2015. Disponível em: <http:/www.pulire-it.com/2015/it/14pagine-web/guida-espositore/107-procedure-operative.html>. Acesso em: $20 \mathrm{dez} 2018$.

Quaderno espositori 2019 Bergamo Sposi. Disponível em: $<$ http://www.fierabergamosposi.it/wp-content/downloads/quaderno-espositori-2019.pdf $>$. Acesso em 17 jan. 2019.

Quaderno espositori Fiera di Bergamo 2012. Disponível em: $<$ http://www.bergamofiera.it/wpcontent/uploads/2012/02/quaderno_espositori_29_marzo_web.pdf $>$. Acesso em: 10 mai. 2017.

Questionario rilevazione panorama fieristico. Disponível em: $<\mathrm{http}$ :/www.apindustria.vi.it/index.php?option=com_docman\&view=download\&category_sl ug=categorie \&alias=2502-questionario-fiere\&Itemid=300668 > . Acesso em: 10 mai. 2017.

Rapporto di Sostenibilità 2014 Expo Milano 2015. Disponível em: $<$ http://www.accredia.it/UploadDocs/5475_EXPO_Report_Sustainability_ITA_rev2015.pdf $>$. Acesso em: 18 set. 2018.

Rapporto fiere. Il sole 24 ore Gennaio 2009. Disponível em: $<$ http://www.aefi.it/Aefi//media/misc/Rapporto_fiere.pdf >. Acesso em: 09 nov. 2015.

Regolamento architettonico Sial 2016. Disponível em: $<\mathrm{http}: / /$ services.sialparis.com/plateformeressources/personnalisation/1000150/ressources/pdf/regolamento-architettonico-sial-paris2016.pdf >. Acesso em 11 mar. 2018.

Regolamento generale delle manifestazioni. Disponível em: $<$ http://www.alteregofiere.com/public/img/documenti/SOGNIBISOGNIPIACERI/regolament ofiere.doc > . Acesso em: 18 set. 2018.

Regolamento Generale di Manifestazione SIGEP 2016. Disponível em: $<$ http://my.sigep.it/upload_janus/modulistica/SIG/regolamentoita.pdf > .Acesso em: 09 nov. 2015.

Regolamento Generale Fiera Milano Meat-Tech 2018. Disponível em: $<$ http://www.ipackima.com/sites/default/files/MEAT-TECH\%20Regolamento\%20ITA.pdf $>$.Acesso em: 03 jan. 2019.

Regolamento Mercati $e$ Fiere 2013. Disponível em: $<$ http://egov.hseweb.it/mattinata/zf/index.php/atti-generali/index/dettaglio-atto/atto/40 >. Acesso em: 16 jun. 2015.

Regolamento operativo della fiera. Disponível em: $<$ https://www.applitech.ch/de/images/PDF/Dienstleistungen/Ital/MeLu_Messebetriebsordnung_IT.pdf $>$. Acesso em: 3 jan. 2019. 
Regolamento per la Sicurezza sul Lavoro Fiera Di Vicenza 2013. Disponível em: $<$ https://www.hit-show.com/images/DOS_10-

03_REGOLAMENTO_SICUREZZA_SUL_LAVORO_REV3.pdf > . Acesso em: 16 jun. 2015.

Regolamento del mercato e delle fiere. Disponível em: <http://www.comune.baiso.re.it/wpcontent/uploads/2013/06/Regolamento-del-mercato-e-delle-fiere.pdf $>$. Acesso em: 16 jun. 2015.

Realizzare uno stand fieristico ecologico. Disponível em: $<$ http://ecoaziendeblognetwork.it/tag/stand-fieristico-ecologico/>. Acesso em: 25 jul. 2017.

Regolamento di manifestazione festival dell'edilizia leggera 2018. Disponível em: $<$ http://fel.edilizialeggera.it/wp-content/uploads/2018/02/REGOLAMENTO-DIMANIFESTAZIONE-FEL-2018.pdf > . Acesso em: 05 out. 2018.

Regolamento di Partecipazione Sapore in scena. Disponível em: $<$ http://www.saporinscena.it/files/files/Regolamento_Partecipazione_SIS.pdf >. Acesso em: 21 abr. 2017.

Regolamento di Partecipazione "SOLO BIO". Disponível em: $<$ http://www.fierasolobio.it/expopoint_solobioTest/files/media/files/Regolamento\%20di\%20P artecipazione\%20BIO.pdf >. Acesso em: 14 mar. 2017.

Regolamento espositori Altrocioccolato 2016 Umbria. Disponível em : $<$ http://www.altrocioccolato.it/website/wp-content/uploads/2016/08/AC-REGOLAMENTOESPOSITORI-2016-copia.pdf>. Acesso em: 25 abr. 2017.

Regolamento espositore Murabilia Murainfiore 2018. Disponível em: $<$ https://espositori2018.murabilia.com/repository/regolamento2018.pdf >. Acesso em: $01 \mathrm{dez}$. 2018.

Regolamento generale $A F$ - L'Artigiano in Fiera 2015. Disponível em: $<$ http://www.pi.camcom.it/uploads/Regolamento\%20Generale\%20AF.pdf >. Acesso em: 22 abr. 2017.

Regolamento generale fiera didacta italia. Disponível em: <http://fieradidacta.indire.it/wpcontent/uploads/2017/03/Regolamento-generale-didacta-italia-1.pdf $>$. Acesso em: 20 set 2018.

Regolamento generale Pulire The Smart Show 2017. Disponível em: <http://pulireit.com/images/docsPDF/PV17_REGOLAMENTO.pdf>. Acesso em: 15 dez 2018.

Regolamento generale Vinitaly 2017. Disponível em: $<$ http://www.vinitaly.com/globalassets/pdf/regolamento/regolamento-vinitaly.pdf $>$. Acesso em: 22 abr. 2017.

Regolamento tecnico ARIES 2018. Disponível em: <http://www.triestespresso.it/wpcontent/uploads/2018/06/REGOLAMENTOXTECNICOXTEEX2018.pdf>. Acesso em 17 jan. 2019.

Regolamento tecnico di manifestazione Fiera Bolzano. Disponível em: $<$ http://www.fierabolzano.it/site/mod_moduli_files/REGOLAMENTO_TECNICO.pdf $>$.Aces so em: 25 abr. 2017.

Regolamento Tecnico di Quartiere Fiera Roma 2013. Disponível em: $<\mathrm{http} / / / w w w . f i e r a r o m a . i t / p d f / F D R-R e g o l a m e n t o q u a r t i e r e \_I T A . p d f>$.Acesso em: 25 jul. 2017. 
Regolamento Tecnico di Manifestazione Fiera di Parma 2014. Disponível em: $<\mathrm{http}: / /$ www.salonedelcamper.it/wp-

content/uploads/2014/06/RegolamentoTecnicoManifestazioneNuovo.pdf > . Acesso em: 25 jul. 2017.

Regolamento Tecnico Fiera di Bologna 2016. Disponível em: $<$ http://marca.bolognafiere.it/media//marca/documents/2016/espositori/Regolamento\%20tecni co\%202016.pdf >. Acesso em: 03 jun. 2017.

Regolamento Tecnico Fiera Milano. Disponível

$<$ http://www.fieramilano.it/sites/default/files/8\%20-

$\% 20$ City_Technical\%20\%20Regulationes\%20Vers\%201\%200\%20-\%202018.pdf $>$. Acesso em 17 jan. 2019.

Regolamento tecnico Fiera di Vicenza 2015. Disponível em: $<$ http://www.mebelettroforniture.it/images/fiera_fornitori/modulistica/regolamento.pdf >. Acesso em: 25 abr. 2017.

Regolamento tecnico ITMA 2015 Fiera Milano Rho. Disponível em: $<$ http:/www.itma.com/docs/default-source/downloads/technical-regulations/itma-2015technical-regulations-italian.pdf?sfvrsn=12 >. Acesso em: 22 abr. 2017.

Regolamento tecnico 2019.2 Disponível em: $<$ https://my.sigep.it/upload_janus/modulistica/SIG/regolamentoita.pdf >. Acesso em 10 jan. 2019.

Revista Prisma 2008. Una Aefi più forte per rappresentare il sistema fieristico italiano. Disponível em: $<$ http://www.expofairs.com/prisma/091/pagina_047.pdf $>$. Acesso em: 25 jul. 2017.

Salone dell'arte e del restauro di Firenze 2018 regolamento generale. Disponível em: $<$ http://www.salonerestaurofirenze.com/restauro/2018/wpcontent/uploads/sites/11/2017/09/srf18_03_Regolamento-e-assicurazione_ita_eng_12.07.171.pdf >. Acesso em: 14 set. 2018

Salone Internazionale del libro Torino 2013. Disponível em: $<$ http://www.salonelibro.it/it/documenti/doc_download/783-modulo-iscrizione-espositori2017-compilabile.html > . Acesso em: 10 jul. 2014.

Sardegna impresa: il ruolo delle fiere 2014-03-10. Disponível em: $<\mathrm{http}: / / \mathrm{www}$. sardegnaimpresa.eu/it/servizi/internazionalizzazione/il-significato-diinternazionalizzarsi/il-percorso-di-8 >. Acesso em: 10 jul. 2015.

Scheda C - Fornitura di Energia Elettrica A\&T Torino 2015. Disponível em: $<$ http://www.affidabilita.eu/pdfeventi/SCHEDA_C_EnergiaElettrica2015.pdf >. Acesso em: 22 abr. 2017.

Schema di contratto per allestimento Fiera Ambiente 2016. Disponível em: $<\mathrm{http}: / / w w w . c e n t r o e s t e r o . o r g / r e p o s i t o r y / 10 \_12 \_2015 \_9$ 35_gara-allestimentiambienteallegato-7.pdf >. Acesso em: 22 abr. 2017. 
Smart Building Expo 2017 opportunità promozionali. Disponível em: $<$ https://smartbuildingexpo.it/wp-content/uploads/2017/06/opportunita-promozionali.pdf >. Acesso em: 18 set. 2018.

Storie e significati delle pratiche espositive 2015. Disponível em $<$ http://www.ricerchedisconfine.info/VI-1/sconfineVI-1.pdf > . Acesso em: 10 jul. 2016.

Strategie e strumenti per pianificare, gestire e massimizzare la partecipazione delle pmi ad eventi fieristici. Disponível em: $<$ http://www.federlazio.it/download/Vademecum\%20Passepartout\%20Fiere.pdf $>$. Acesso em: 25 abr. 2017.

Una Aefi più forte per rappresentare il sistema fieristico italiano Revista Prisma 2008. Disponível em: <http://www.expofairs.com/prisma/091/pagina_047.pdf >. Acesso em: 25 abr. 2017.

Unioncamere puglia: capitolato speciale per realizzazione di allestimento spazi espositivi. Disponível em: <http://www.unioncamerepuglia.it/Bandi/PROCEDURA-NEGOZIATASOTTO-SOGLIA-COMUNITARIA-PER-L-AFFIDAMENTO-DEI-SERVIZI-DIIDEAZIONE-PROGETTAZIONE-E-REALIZZAZIONE-DELL-ALLESTIMENTO-DEGLISPAZI-ESPOSITIVI-E-DEI-SERVIZI-CONNESSI-DESTINATI-AD-OSPITARE-LAREGIONE-PUGLIA-UNIONCAMERE-PUGLIA-IN-OCCASIONE-D/2/ >. Acesso em: 22 out. 2016.

Valorizzazione del sistema fieristico nazionale attraverso incentivi alla certificazione di qualità. Disponível em: <http://www.kr.camcom.gov.it/uploaded/2013/News/Brochure_info.pdf >. Acesso em: 19 set. 2015.

VERGANI, Tea. Lavorare in stand nelle fiere. Disponível em: $<$ https://books.google.com.br/books?id=3P-fIm8XN8C\&pg=PA17\&dq=fiere + in + Italia\&hl=pt-BR\&sa=X\&ei=ywP6VI6VGYTsQSCo4HQAg\&ved=0CD4Q6AEwAw\# $\mathrm{v}=$ onepage $\& \mathrm{q}=$ fiere $\% 20 \mathrm{in} \% 20$ Italia\&f $=$ false $\quad>$. Acesso em: 19 set. 2015.

Vicenza hit show diventa sempre più internazionale. Disponível em: $<$ http://www.tviweb.it/vicenza-hit-show-diventa-sempre-piu-internazionale/>. Acesso em: 22 out. 2016. 


\section{APÊNDICE I - QUESTIONÁRIO}

A finalidade do presente questionário é exclusivamente acadêmica. O conteúdo deste questionário será utilizado no trabalho de conclusão do curso de Pós-Graduação em Negócios Internacionais, pela Universidade Presbiteriana Mackenzie. Gostaria de esclarecer que não há necessidade de informar o nome de sua empresa, caso a empresa assim o preferir, e que a empresa receberá, caso tenha interesse, o resultado final da pesquisa. Fique à vontade em não responder à alguma pergunta ou item de alguma pergunta. O objetivo deste estudo é conhecer como a participação das indústrias de alimentos paulistas em promoção comercial na Flórida auxilia no processo de abertura do mercado norteamericano (cf. GODOY, 2006, p. 119-126).

1) Indique, dos itens abaixo, o grau de importância para sua empresa na escolha do mercado norteamericano. Assinale com um X.

Legenda:

MI: Muito importante

I: Importante

PI: Pouco Importante

SI: Sem Importância

$\mathrm{T}$ : Total (para contagem posterior)

\begin{tabular}{|c|c|c|c|c|c|}
\hline Características do mercado norte-americano & MI & I & PI & SI & $\mathrm{T}$ \\
\hline Tamanho do mercado & & & & & \\
\hline Poder aquisitivo da população & & & & & \\
\hline Logística facilitada & & & & & \\
\hline Gosto Latino (mais de 40 milhões de residentes de origem latina EUA) & & & & & \\
\hline Status & & & & & \\
\hline Vantagem competitiva & & & & & \\
\hline $\begin{array}{l}\text { Lei do Bioterrorismo - Necessidade de um Agent-in-charge junto ao } \\
\text { FDA }\end{array}$ & & & & & \\
\hline Presença local & & & & & \\
\hline
\end{tabular}

2) Quais os modos mais utilizados por sua empresa para a penetração neste mercado? Fique à vontade para escolher mais de uma alternativa, assinalando com um X.

a) Feiras ( )

b) Missões Comerciais ( )

c) Rodadas de Negócios ( )

d) Representantes ( )

e) Consultorias ( )

f) Visitas ( )

g) Participação em Showrooms de exposição permanente de produtos (como o São Paulo Business Center na Miami Free Zone) ( )

3) Além da Feira Fispal em Miami, a vossa empresa participou de outras feiras nos EUA? Assinale as alternativas abaixo:

a) All Things Organic em Chicago ( )

b) Feira de Alimentos Gourmet na Califórnia ( ) 
c) Feira de Alimentos e Bebidas das Américas na Flórida ( )

d) Fancy Food em Nova Iorque ( )

e) All Candy Expo em Chicago ( )

f) Outros:

4) Indique em ordem de importância as entidades que prestaram auxílio para que vossa empresa pudesse participar de um evento promocional nos EUA. Assinale com um X.

Legenda:

MI: Muito importante

I: Importante

PI: Pouco Importante

SI: Sem Importância

$\mathrm{T}$ : Total (para contagem posterior)

\begin{tabular}{|l|l|l|l|l|l|l|}
\hline Entidades de apoio ao exportador & MI & I & PI & SI & & T \\
\hline ITAL & & & & & & \\
\hline APEX & & & & & & \\
\hline AMCHAM & & & & & & \\
\hline ABIA & & & & & & \\
\hline FISPAL & & & & & \\
\hline FIESP & & & & & & \\
\hline CIESP & & & & & & \\
\hline SECRETARIAS do estado de São Paulo & & & & & & \\
\hline MRE
\end{tabular}

5) O que gerou para a vossa empresa a exposição de seus produtos na Feira Fispal em Miami? Pode-se escolher mais de um item, assinalando com um X.

a) Apenas contatos ( )

b) Relacionamento com fornecedores ( )

c) Relacionamento com futuros clientes ( )

d) Curiosidade apenas ( )

e) Contatos que transformaram-se em clientes ( )

f) Contatos que estão sendo trabalhados ( )

g) Contatos que se perderam ( )

h) Nada ( )

6) Para entrar no mercado norte-americano a vossa empresa necessitou adequar-se ou adequar seus produtos de acordo com as legislações norte-americanas no que diz respeito a: (mais de alternativa pode ser indicada):

a) Contratação de um Agente ( )

a) Adequação do produto quanto ao rótulo ( )

b) Adequação do produto quanto ao conteúdo ( )

c) Adequação do produto quanto à embalagem ( )

d) Análise laboratorial de outros órgãos como o USDA, BATF, além do FDA ( )

e) Registro da marca nos EUA ( )

f) Abertura de empresa nos EUA ( ) 
7) Em termos de trabalho pós-feira, o que vossa empresa tem realizado:

a) Mantém contato com os clientes abertos durante a feira ( )

b) Envio de novidades e informações sobre os produtos ( )

c) Envio de amostras ( )

d) Envio de informações sobre a empresa e suas atividades ( )

e) Visitas comerciais ( )

f) Envio de convites para que os potenciais clientes possam visitar e conhecer a vossa empresa ( )

g) Não tem o costume de fazer follow-up ( )

8) Em relação às vendas realizadas após a feira, responda os itens abaixo em ordem de importância no que tange a facilidades. Assinale com um X.

Legenda:

FT: Facilidade Total

MF: Muita Facilidade

PF: Pouca Facilidade

NF: Nenhuma Facilidade

\begin{tabular}{|l|l|l|l|l|l|l|}
\hline Facilidades encontradas no mercado norte-americano & FT & MF & PF & NF & & T \\
\hline Transporte & & & & & & \\
\hline Armazenagem & & & & & & \\
\hline Financiamento & & & & & & \\
\hline Distribuição no destino & & & & & \\
\hline Relacionamento com Brokers & & & & & \\
\hline Penetração dos produtos nas grandes redes & & & & & & \\
\hline Penetração dos produtos no mercado da saudade & & & & & & \\
\hline Aceitação do produto pela população americana & & & & & & \\
\hline Aceitação do produto pela população hispânica & & & \\
\hline
\end{tabular}

9) Qual a média de clientes abertos por vossa empresa com a participação em uma feira nos EUA, como a Feira Fispal? Assinale com um X.
a) 1 a $3($ )
b) 3 a 5 ( )
c) 5 a 7 ( )
d) mais de 7( )
e) Nenhum ( )

10) Qual a sua opinião sobre a feira? Assinale com um $X$.

Legenda:

E: Excelente

O: Ótima

B: Boa

R: Ruim

P: Péssima 


\begin{tabular}{|c|c|c|c|c|c|c|}
\hline \multirow{2}{*}{\begin{tabular}{|l|} 
Tamanho da feira \\
\end{tabular}} & \begin{tabular}{l|l}
$\mathrm{E}$ & $\mathrm{O}$
\end{tabular} & $\mathrm{B}$ & $\mathrm{R}$ & MR & $\mathrm{P}$ & $\mathrm{T}$ \\
\hline & & & & & & \\
\hline \multicolumn{6}{|l|}{ Localização da feira } & \\
\hline \multicolumn{6}{|l|}{ Tamanho do estande } & \\
\hline \multicolumn{6}{|l|}{ Número de visitantes } & \\
\hline \multicolumn{6}{|l|}{ Quantidade de negócios realizados } & \\
\hline \multicolumn{6}{|l|}{ Perfil do público } & \\
\hline \multicolumn{6}{|l|}{\begin{tabular}{|llllll}
$\begin{array}{l}\text { Atividades apresentadas durante a feira (gourmet show, } \\
\text { degustações etc..) }\end{array}$ & & & \\
\end{tabular}} & \\
\hline \multicolumn{6}{|l|}{ Resultados obtidos com a participação } & \\
\hline \multicolumn{6}{|l|}{ Ideia de participar em um próximo evento } & \\
\hline \multicolumn{6}{|l|}{ Organização do evento } & \\
\hline Expectativas foram superadas, em que nível? & & & & & & \\
\hline
\end{tabular}

11) Como você avalia o resultado obtido por sua empresa com a participação em feiras nos EUA no que diz respeito ao faturamento da empresa? Assinale com um X.

a) Houve alteração ( )

b) Permaneceu inalterado ( )

c) Aumentou ( )

d) Diminui ( )

e) Aumentou pouco (menos que 5\%) ( )

f) Aumentou razoavelmente (em torno de 20\%) ( )

g) Aumentou consideravelmente (acima de 50\%) ( )

h) Aumentou muito (superior a 70\%) ( )

12) Indique, em ordem de importância, o tipo de clientes que a vossa empresa pretende atingir nos EUA ao participar de um evento promocional. Assinale com um X.

Legenda:

MI: Muito importante

I: Importante

PI: Pouco Importante

SI: Sem Importância

$\mathrm{T}$ : Total (para contagem posterior)

\begin{tabular}{|l|l|l|l|l|l|l|}
\hline Mercados disponíveis nos EUA & MI & I & PI & SI & & T \\
\hline Retail & & & & & & \\
\hline Food-service & & & & & & \\
\hline Pequenas redes & & & & & & \\
\hline Redes de médio porte & & & & & & \\
\hline Grandes redes & & & & & & \\
\hline Navios & & & & & & \\
\hline Hotéis & & & & \\
\hline
\end{tabular}




\begin{tabular}{|l|l|l|l|l|l|l|}
\hline Mercados disponíveis nos EUA & MI & I & PI & SI & & T \\
\hline Retail & & & & & & \\
\hline Food-service & & & & & & \\
\hline Aéreo & & & & & & \\
\hline Mercado da Saudade & & & & & & \\
\hline Lojas de conveniência & & & & & & \\
\hline Mini-mercados (grocery) & & & & & \\
\hline Outros & & & & & \\
\hline
\end{tabular}

13) O que V. Sa. achou da participação de vossa empresa em feiras nos EUA? O que resultou em relação a cada um dos itens abaixo? Assinale com um X.

Legenda:

E: Excelente

O: Ótimo

B: Bom

R: Ruim

MR: Muito Ruim

P: Péssimo

\begin{tabular}{|l|l|l|l|l|l|l|l|}
\hline & E & O & B & R & MR & P & T \\
\hline Concretização de exportação & & & & & & & \\
\hline Aumento da base de clientes & & & & & & & \\
\hline Aumento do lucro & & & & & & \\
\hline Aumento do market share & & & & & & \\
\hline Aumento do conhecimento da marca no exterior & & & & & & & \\
\hline Aumento do reconhecimento no mercado interno & & & & & & \\
\hline Diminuição dos riscos & & & & & & & \\
\hline Presença local em um mercado como os EUA & & & & \\
\hline
\end{tabular}

14) Assinale com um $X$ como você classifica a vossa empresa no que tange a:

Número de funcionários:

a) entre 1 e 10 ( )

b) entre 10 e $30($ )

c) mais de $50($ )

d) mais $100($ )

Faturamento Anual:

a) até 100 mil dólares ( )

b) entre 100 mil e 300 mil dólares ( )

c) entre 300 mil e 500 mil dólares ( )

d) mais de 500 mil dólares ( ) 
Market Share Nacional (Participação de sua empresa no mercado interno):

a) entre 0 a $10 \%$ ( )

b) entre 10 a $20 \%$ ( )

c) entre 20 e $50 \%$ ( )

d) mais de $50 \%($ )

Market Share Internacional (Participação de sua empresa no mercado externo, em especial nos EUA):

a) entre 0 a $10 \%$ ( )

b) 1 entre 0 a $20 \%$ ( )

c) entre 20 e $50 \%$ ( )

d) mais de $50 \%$ ( )

Por gentileza, fique à vontade para informar ou não os dados da vossa empresa:

\begin{tabular}{|l|l|}
\hline Razão Social: & \\
\hline Nome Fantasia: & \\
\hline Endereço: & \\
\hline Telefone: & \\
\hline Website: & \\
\hline Contato/email: & \\
\hline
\end{tabular}

Espaço reservado para críticas, reclamações, sugestões ou elogios decorrentes da participação de vossa empresa em evento promocional nos EUA.

Caso tenha interesse em receber o resultado final da pesquisa por gentileza entre em contato com:

Ariane Godoy

E-mail: adfgodoy@hotmail.com ou oxfordbrazil@hotmail.com

Agradeço, mais uma vez, vossa boa vontade em responder a estas questões que muito ajudarão a conhecer os resultados obtidos pelas indústrias de alimentos paulistas ao participarem de um evento promocional nos EUA como, por exemplo, a Feira Fispal em Miami.

Atenciosamente,

Ariane Dutra Fante Godoy

Curso de Pós-Graduação em Negócios Internacionais da Universidade Presbiteriana Mackenzie 


\section{APÊNDICE II - EXEMPLO DE FICHA TERMINOLÓGICA NAS QUATRO LÍNGUAS}

Quadro 32: Ficha terminológica nas quatro línguas

\begin{tabular}{|c|c|}
\hline Entrada em português & estande \\
\hline Categoria gramatical & s.m \\
\hline Definição & $\begin{array}{l}\text { espaço utilizado pelo expositor para a exposição de } \\
\text { seus produtos em uma feira. }\end{array}$ \\
\hline OUTDES (variantes) & espaço de exposição \\
\hline Contexto 1 & $\begin{array}{l}\text { Entre as informações que podem ser mensuradas } \\
\text { estão: a quantidade de visitas ao estande pelo } \\
\text { número de visitantes da feira; a quantidade de visitas } \\
\text { ao estande pelo número de clientes potenciais, } \\
\text { clientes atuais e curiosos; o número total de vendas } \\
\text { diretas realizadas e a quantidade de oportunidades de } \\
\text { negócios criadas a partir do evento. }\end{array}$ \\
\hline Fonte 1 & (FNPRPPE) \\
\hline Contexto 2 & $\begin{array}{l}\text { É comum que, em feiras setoriais, os organizadores } \\
\text { executem uma farta divulgação entre o público-alvo; } \\
\text { contudo, nunca é demais fazer contatos diretos } \\
\text { através do relacionamento empresarial ou } \\
\text { institucional já existente, o que pode garantir uma } \\
\text { maior visitação ao estande durante a realização da } \\
\text { feira. }\end{array}$ \\
\hline Fonte 2 & (OBPFI) \\
\hline \multicolumn{2}{|l|}{$\mathrm{SN}$} \\
\hline Equivalente em inglês & stand \\
\hline OUTDES (variantes) & booth \\
\hline Contexto 1 & $\begin{array}{l}\text { Letting your customers know you will be there is a } \\
\text { vital element to your success and is often } \\
\text { overlooked. Examine all your communications with } \\
\text { potential and existing clients. There may be more } \\
\text { opportunities than you think to alert people to the } \\
\text { fact you will have a stand at the event. }\end{array}$ \\
\hline Fonte 1 & (HTE) \\
\hline Contexto 2 & $\begin{array}{l}\text { A corner stand has more sides accessible to the } \\
\text { public, but the same overall area, and is therefore } \\
\text { more effective than a stand situated in a row. }\end{array}$ \\
\hline Fonte 2 & (SPTFTE) \\
\hline SN & booth is the American term for stand \\
\hline Equivalente em francês & stand \\
\hline OUTDES (Variantes) & kiosque \\
\hline Contexto 1 & $\begin{array}{l}\text { Les exposants ne sont pas autorisés à sous louer et } \\
\text { partager leur stand. Ils ne pourront en aucun cas } \\
\text { disposer des surfaces autour de leur stand. }\end{array}$ \\
\hline Fonte 1 & (GEFMa2) \\
\hline Contexto 2 & $\begin{array}{l}\text { Aucun logo ou enseigne ne doit dépasser la hauteur } \\
\text { de la structure du stand. Aucun logo, visuel ou nom } \\
\text { d'entreprise ne peut être élingué ou suspendu au- } \\
\text { dessus du stand. }\end{array}$ \\
\hline Fonte 2 & (GTEPNV2) \\
\hline
\end{tabular}




\begin{tabular}{|l|l|}
\hline SN & $\begin{array}{l}\text { Le standiste est un professionnel qui conçoit et } \\
\text { fabrique des stands d'exposition. Il est donc } \\
\text { réalisateur, créateur et maître d'oeuvre. }\end{array}$ \\
\hline Equivalente em italiano & stand \\
\hline OUTDES (Variantes) & posteggio \\
\hline Contexto 1 & $\begin{array}{l}\text { Presa visione della normativa prevista nelle Norme } \\
\text { di Partecipazione integralmente accettate e } \\
\text { sottoscritte, si dichiara, sotto la propria } \\
\text { responsabilità, quanto segue: l'allestimento dello } \\
\text { stand assegnato è conforme alle normative previste } \\
\text { nel Manuale dell'Espositore [...]. }\end{array}$ \\
\hline Fonte 1 & (MEFP) \\
\hline Contexto 2 & $\begin{array}{l}\text { La moquette per lo stand è inclusa nel costo dello } \\
\text { stand preallestito. Se avete prenotato un'area nuda } \\
\text { potete richiedere la fornitura di moquette per lo stand } \\
\text { al costo di } € 6,50 \text { al mq. }\end{array}$ \\
\hline Fonte 2 & (MEFG2) \\
\hline SN & \\
\hline
\end{tabular}

Fonte: Elaborado pela autora 


\section{APÊNDICE III - SISTEMAS ORGANIZACIONAIS DAS FEIRAS}

Figura 13: Sistema organizacional das feiras em inglês

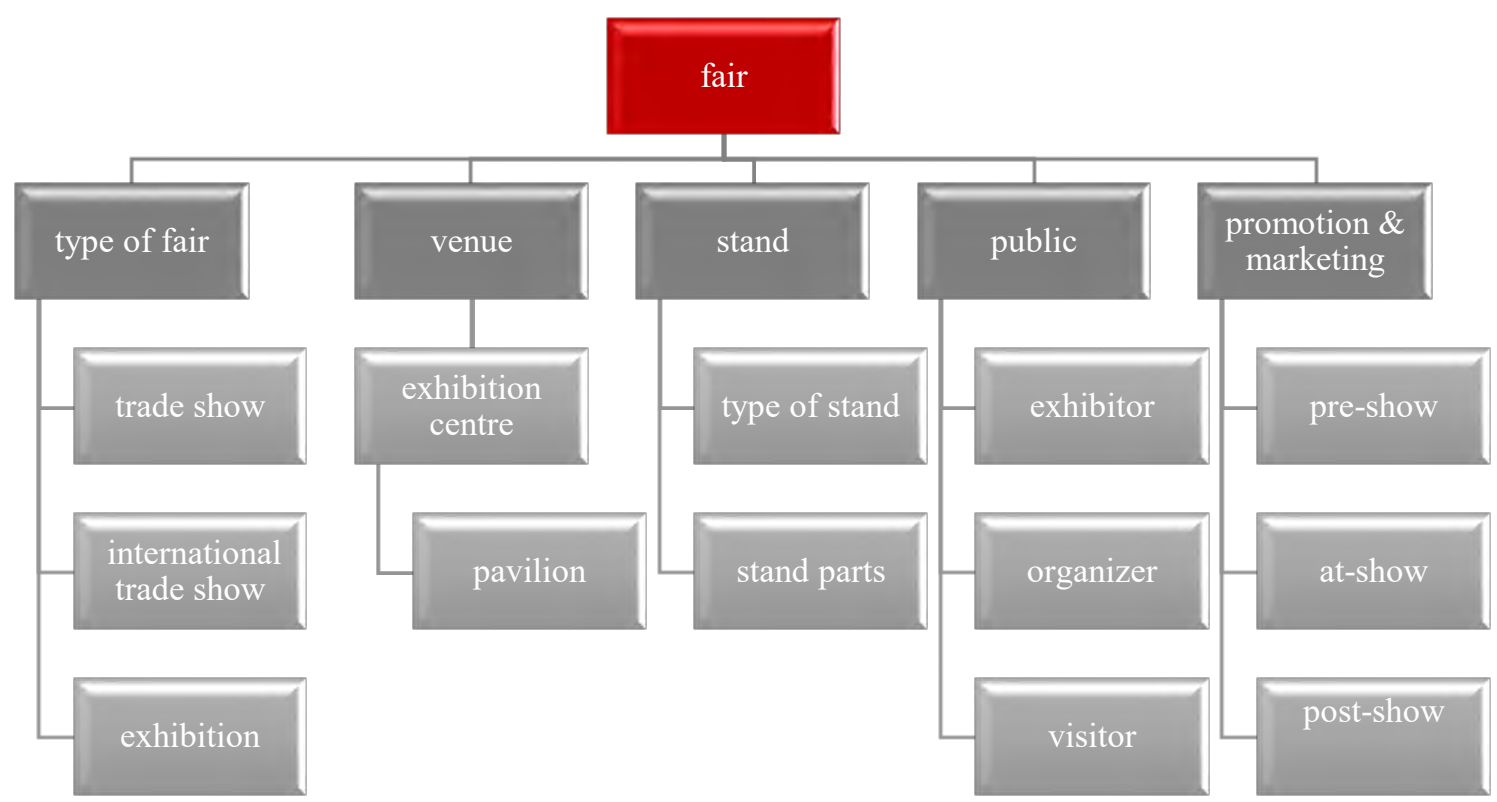

Fonte: Adaptado de (GODOY, 2014, p. 90)

Figura 14: Sistema organizacional das feiras em francês

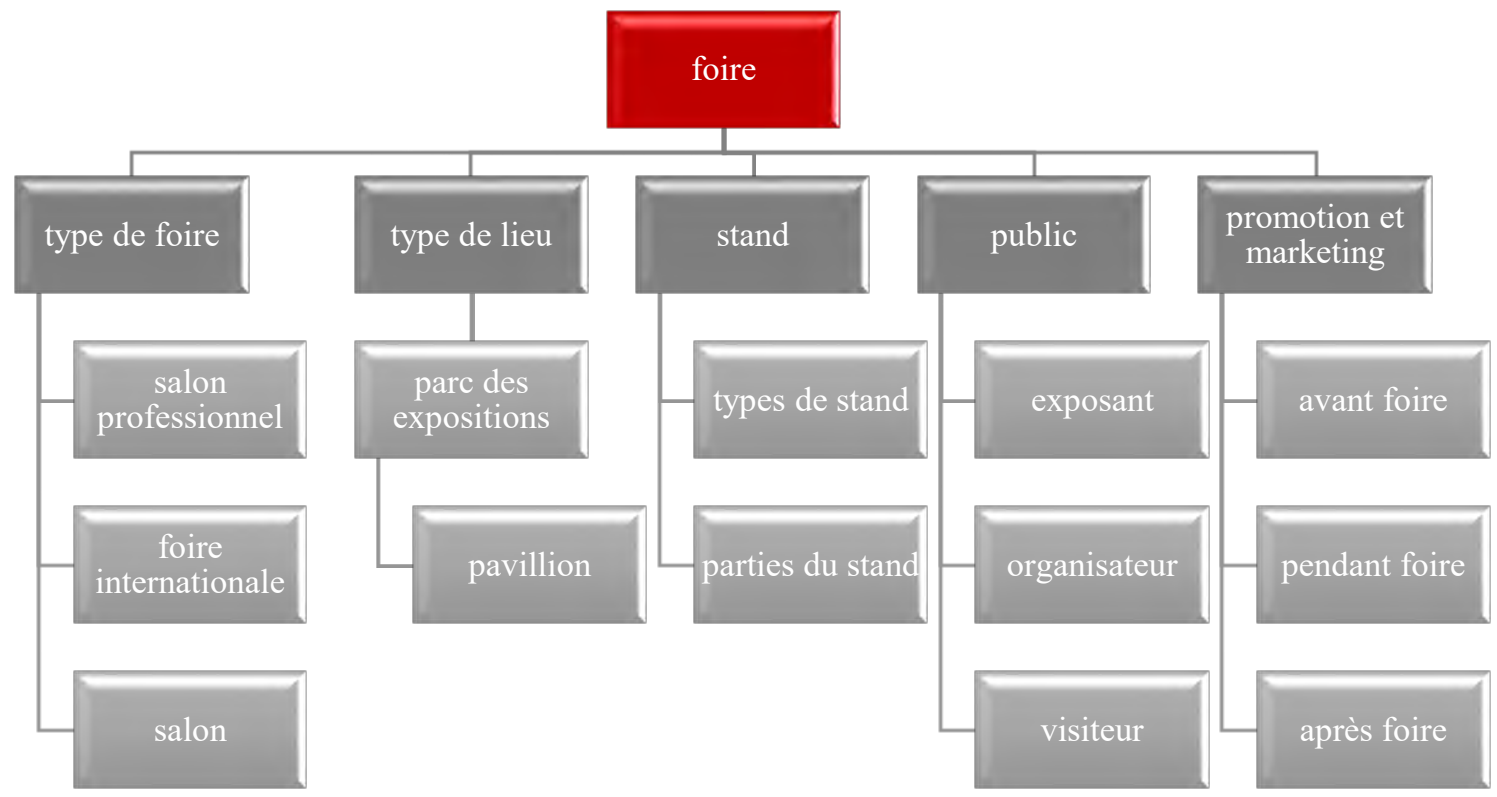

Fonte: Elaborado pela autora 
Figura 15: Sistema organizacional das feiras em italiano

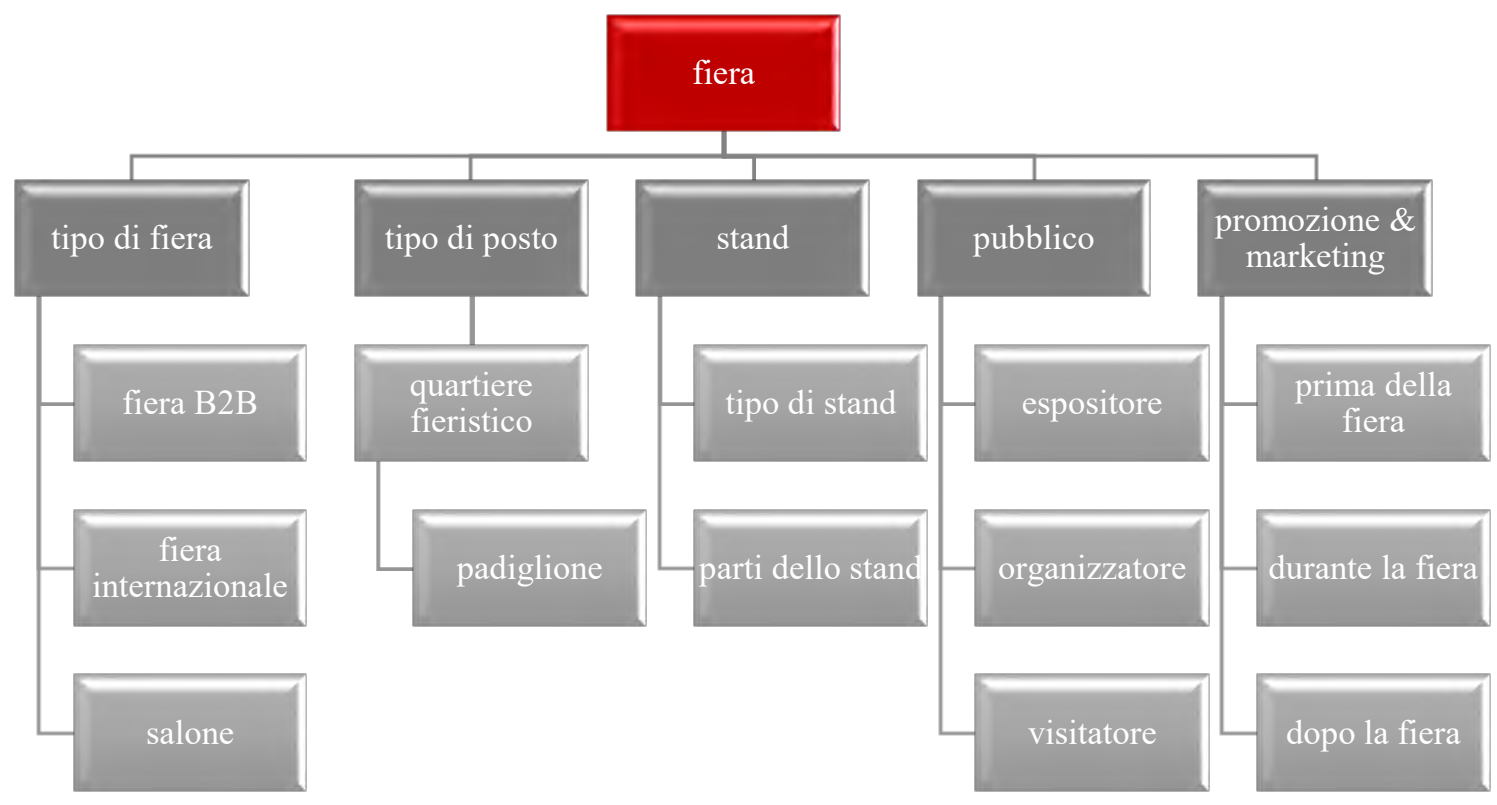

Fonte: Elaborado pela autora 


\section{APÊNDICE IV - GANCHOS TERMINOLÓGICOS NAS QUATRO LÍNGUAS}

Apresentamos, a seguir, a análise dos ganchos terminológicos nas quatro línguas de 10 (dez) termos do dicionário, complementando as análises apresentadas no Capítulo 5.

Obs. 1: Os ganchos grifados em azul são de natureza;

Obs. 2: Os ganchos grifados em rosa são de finalidade;

Obs. 3: Os ganchos grifados em laranja são de modo;

Obs. 4: Os termos grifados em vermelho foram excluídos;

Obs. 5: Os ganchos das remissivas estão em seus respectivos termos-entrada;

Obs. 6: Os contextos destacados em amarelo foram coletados durante o estágio no exterior na Universidade de Surrey com o auxilio da ferramenta Sketch Engine;

Obs. 7: Os contextos na cor turquesa foram coletados após os estágios no exterior, por meio da ferramenta WordSmith Tools, bem como os demais contextos (que não estão grifados em cores) e que foram coletados antes dos estágios no exterior.

Obs.8: Os contextos destacados em cinza foram os últimos contextos coletados.

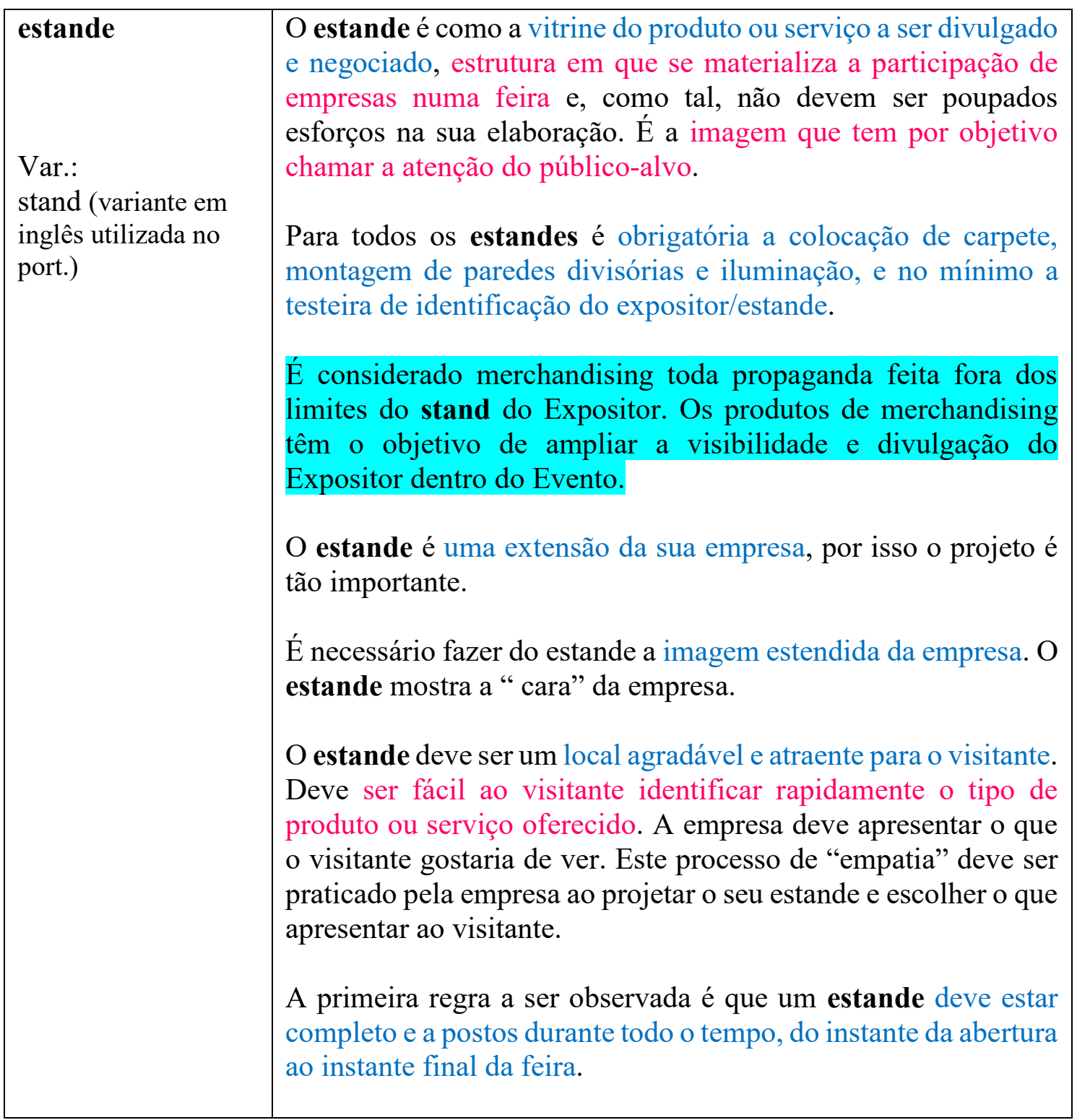




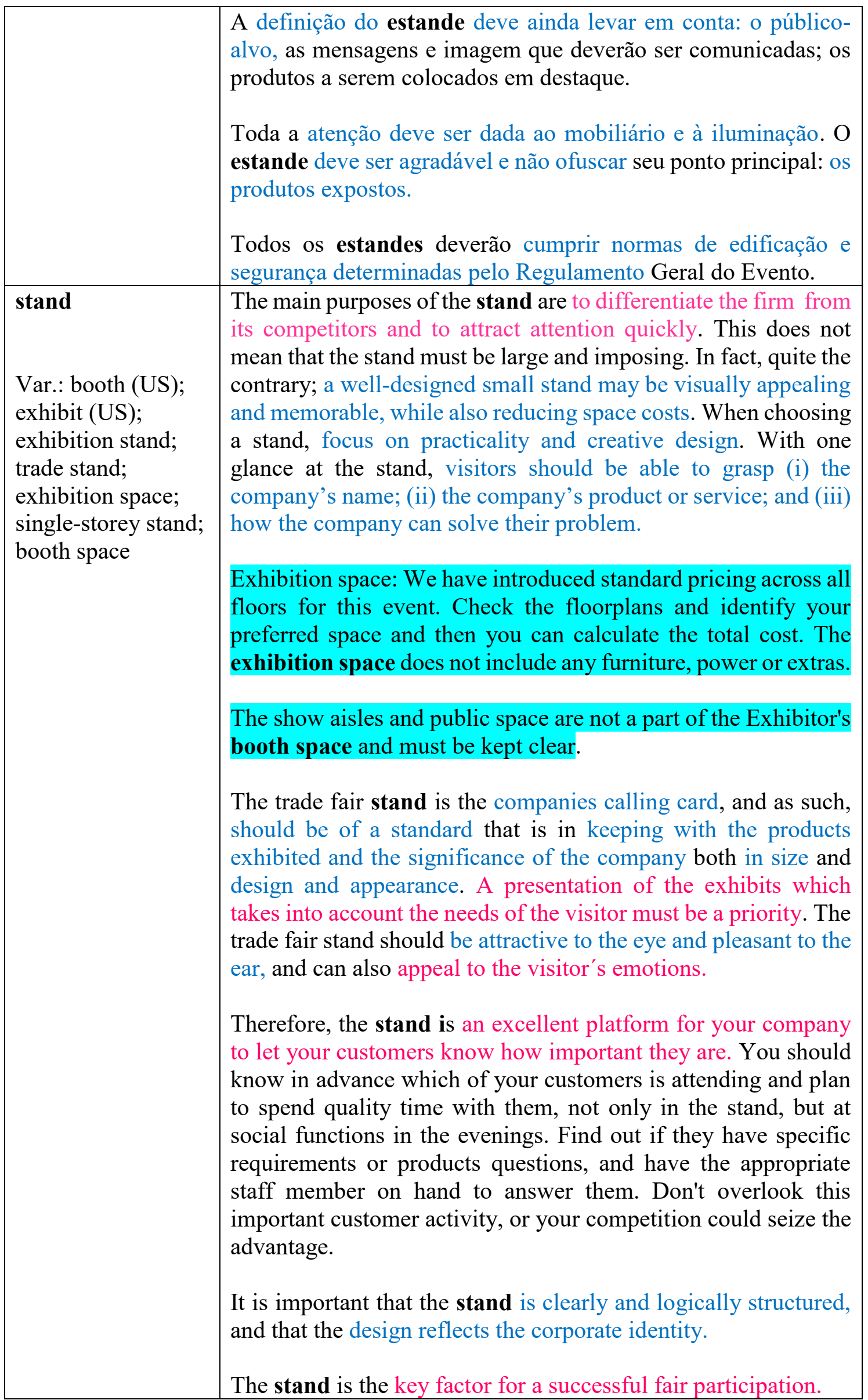




\begin{tabular}{|c|c|}
\hline & $\begin{array}{l}\text { Please ensure your stand is easily accessible to all visitors. } \\
\text { Disabled persons must be provided with the same service that is } \\
\text { provided to others and it is unlawful to not make a reasonable } \\
\text { adjustment for a disabled person. } \\
\text { Your stand is an open shop without windows or doors. Please } \\
\text { take a few moments to consider how you can secure your } \\
\text { products and belongings while on site. } \\
\text { A trade fair stand should be information driven. It must also have } \\
\text { the right combination of lighting, open space and graphic } \\
\text { presentation to help visitors focus and separate themselves from } \\
\text { the noise level of the trade fair. A stand that uses new, } \\
\text { lightweight materials, which reduce shipping and set-up time as } \\
\text { well as crate, labour and storage costs, offers many advantages. } \\
\text { During the open days please ensure your stand is manned } \\
\text { throughout the day and all exhibits remain on display during the } \\
\text { open hours. In order that no discourtesy is shown to last minute } \\
\text { visitors, there must be no dismantling of any displays or exhibits } \\
\text { before } 1600 \text { hours on Wednesday } 5 \text { October } 2016 \text {. } \\
\text { The overall height of stand fitting for single-storey stands is } 4 \mathrm{~m} \\
\text { from the floor level. }\end{array}$ \\
\hline $\begin{array}{l}\text { stand } \\
\text { Var.: stand } \\
\text { d'exposition; } \\
\text { kiosque; } \\
\text { espace d'exposition } \\
\text { stand exposant (0) }\end{array}$ & $\begin{array}{l}\text { Stand: construction provisoire édifiée par les participants à une } \\
\text { foire, à un salon ou à une exposition pour y accueillir des } \\
\text { visiteurs et présenter des produits. } \\
\text { On entend par 'stand"' l'espace occupé pour la présentation de } \\
\text { produits ou services ou l'espace utilisé pour réunir des clients ou } \\
\text { confrères. } \\
\text { Durant le salon, le stand représente la vitrine de l'entreprise. Il } \\
\text { doit donc remplir certaines fonctions: être une vitrine élogieuse } \\
\text { des produits et services de l'entreprise, favoriser l'accueil et } \\
\text { l'information rapide des visiteurs, permettre aux responsables } \\
\text { commerciaux de s'isoler avec leurs clients potentiels. } \\
\text { Présence sur l'espace d'exposition - L'exposant, ou son } \\
\text { représentant, est tenu d'être présent sur son espace dès le début } \\
\text { du démontage et jusqu'à évacuation complète. }\end{array}$ \\
\hline stand & $\begin{array}{l}\text { Per stand si intende lo spazio assegnato all'espositore per la } \\
\text { presentazione dei propri prodotti o servizi. }\end{array}$ \\
\hline $\begin{array}{l}\text { Var.: stand } \\
\text { espositivo; } \\
\text { stand fieristico; } \\
\text { posteggio; } \\
\text { stand aziendale; } \\
\text { spazio espositivo; }\end{array}$ & $\begin{array}{l}\text { Lo stand è la parte più visibile, più importante e spesso più } \\
\text { costosa della presenza ad una fiera e costituisce la presentazione } \\
\text { dell'azienda. Lo stand è però, un mezzo e non lo scopo della } \\
\text { partecipazione. Nelle scelte non ci si deve passivamente affidare } \\
\text { all'estro di un creativo, ma occorre chiedere un progetto che aiuti }\end{array}$ \\
\hline
\end{tabular}




\begin{tabular}{|c|c|}
\hline $\begin{array}{l}\text { posteggio } \\
\text { espositivo }\end{array}$ & $\begin{array}{l}\text { a realizzare gli obiettivi di partecipazione. Quindi anche lo stand } \\
\text { deriva dalle scelte sul tipo di presentazione. } \\
\text { L'Espositore si impegna a esporre nel proprio posteggio, per } \\
\text { tutta la durata della manifestazione, i prodotti di propria } \\
\text { produzione appartenenti al repertorio merceologico di cui } \\
\text { all'allegato D del presente Regolamento Generale. } \\
\text { Le varie tipologie di stand fieristici sono definite in base alla } \\
\text { tipologia dello spazio assegnato e all'accesso alle corsie. } \\
\text { Attività negli stand espositivi: Gli Espositori dovranno astenersi } \\
\text { in qualunque momento dall'uso delle aree comuni al di fuori del } \\
\text { proprio stand per l'esposizione di materiale promozionale. } \\
\text { BolognaFiere S.p.A. avrà il diritto di rimuovere tale materiale } \\
\text { dalle aree comuni e/o di addebitare il pagamento dello spazio } \\
\text { aggiuntivo utilizzato. } \\
\text { La mancata ricezione della corretta documentazione e senza } \\
\text { l'approvazione del progetto di allestimento da parte di Fiera } \\
\text { Milano, non permetterà all'Espositore (o all'allestitore) di } \\
\text { allestire il proprio spazio espositivo. } \\
\text { Per la manifestazione è ammessa la costruzione di stand a due } \\
\text { piani, la progettazione di stand a soppalco deve attenersi a quanto } \\
\text { stabilito dal Regolamento Tecnico. L'inosservanza di dette } \\
\text { procedure determinerà la mancata autorizzazione ad accedere al } \\
\text { quartiere fieristico e ad allestire lo spazio espositivo. } \\
\text { Regolamento Generale dell'Evento allegato alla domanda di } \\
\text { partecipazione - quanto segue: [...] le norme in materia di } \\
\text { sicurezza per l'attività di progettazione, installazione e } \\
\text { manutenzione delle strutture di allestimento espositive e relativi } \\
\text { impianti; le modalità di allestimento, di custodia, manutenzione } \\
\text { e sgombero dei posteggi espositivi presenti nel Quartiere } \\
\text { fieristico [...]. }\end{array}$ \\
\hline
\end{tabular}

\section{expositor}

Var.:

expositor

(homônimo)
O expositor somente poderá apresentar no estande produtos de sua marca. É proibida a distribuição ou divulgação de produtos de outras empresas não participantes dentro do estande, assim como a exposição de produtos que apresentem qualquer irregularidade (falsificação, contrabando ou pirateados).

O expositor normalmente é um fabricante ou distribuidor de produtos e serviços específicos/complementares a estas indústrias. Já o comprador típico é um industrial ou usuário final, ou outro distribuidor.

Ao contrário do expositor, que tem como principal objetivo a venda, seja no curto ou médio prazos, o visitante busca acima de 


\begin{tabular}{|c|c|}
\hline & 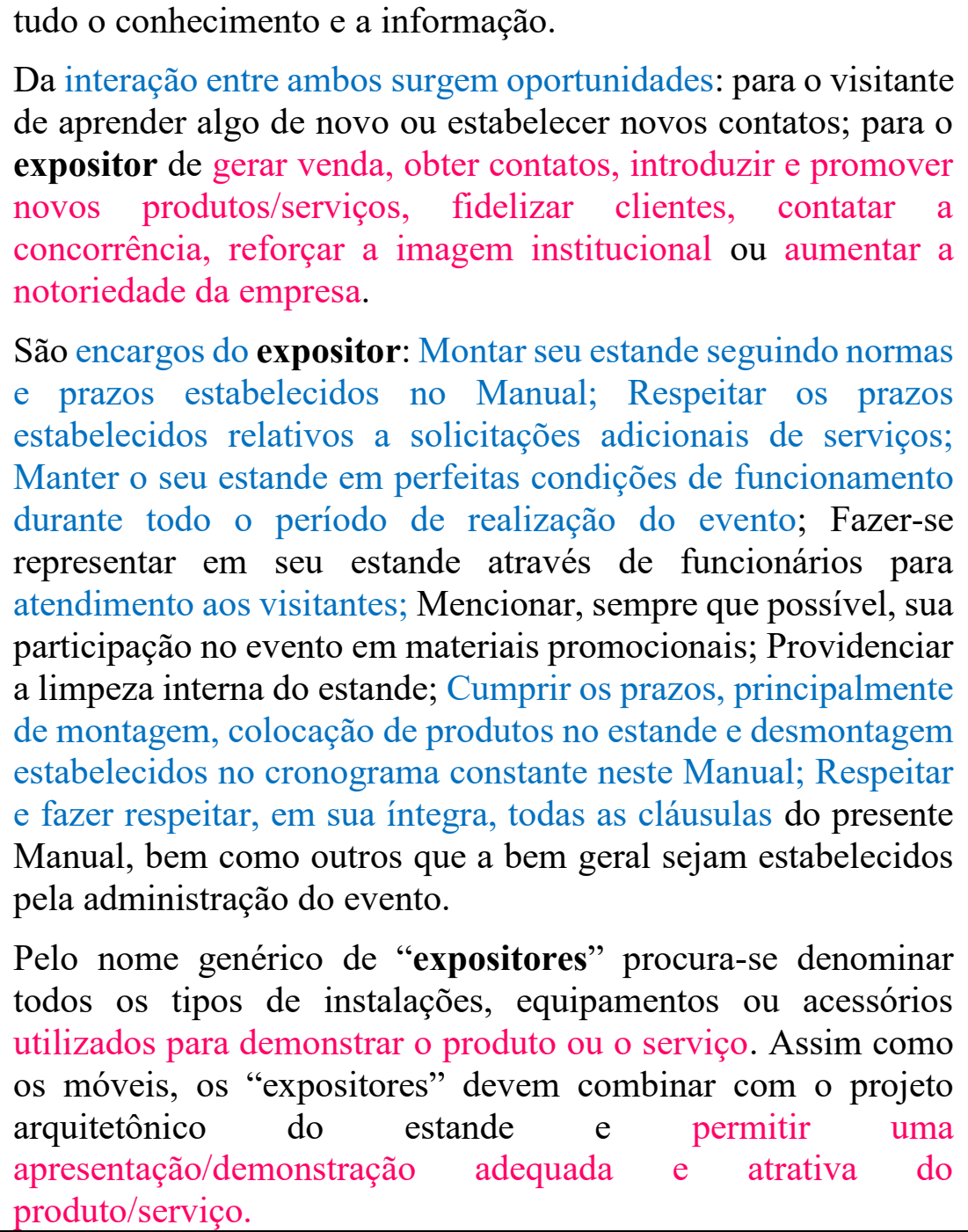 \\
\hline $\begin{array}{l}\text { exhibitor } \\
\text { Var.: stand holder }\end{array}$ & $\begin{array}{l}\text { [...] "the Exhibitor" means any company, partnership, firm or } \\
\text { individual for whom space has been allocated or provided } \\
\text { pursuant to a contract with the Organisers for the purpose of } \\
\text { exhibiting at the Exhibition and includes all employees, servants, } \\
\text { sub-contractors and agents of the Exhibitor [...]. } \\
\text { Exhibitors are permitted to display their own branding, pop ups } \\
\text { and collateral within the footprint of their stand. } \\
\text { The organisers do not accept responsibility for any loss or } \\
\text { damage from any cause whatever, in respect of any property } \\
\text { brought to the exhibition premises by exhibitors or stand } \\
\text { holders or their servants, agents, sub- contractors, or any other } \\
\text { property brought to the premises whether it is their property or } \\
\text { not . } \\
\text { As stand holders you reserve the right to permit visitors taking } \\
\text { pictures within your stand area or of your exhibits and products. } \\
\text { Each exhibitor is responsible for obtaining all necessary licenses } \\
\text { and permits to use live music, photographs or other copyrighted } \\
\text { material in exhibitor's booth or display. } \\
\text { After having registered to a fair, the exhibitor should ask the }\end{array}$ \\
\hline
\end{tabular}




\begin{tabular}{|c|c|}
\hline & $\begin{array}{l}\text { organizer for information materials about the event, like the hall } \\
\text { plans and the exhibitors' manual. The next step is the } \\
\text { development of a precise timetable regarding the preparative } \\
\text { actions. } \\
\text { Exhibitors are responsible for the safety and appropriateness of } \\
\text { all merchandise and promotional and other material displayed } \\
\text { and sales activity taking place within their stand. } \\
\text { Exhibiors should ensure that their stand \& work areas are tidy } \\
\text { and well maintained during the Show, and that all pathways } \\
\text { around the stand are kept clear at all times, in accordance with } \\
\text { Health \& Safety regulations. } \\
\text { Exhibitors are responsible for their own stand design and } \\
\text { construction. } \\
\text { Exhibitors are not permitted to hand out leaflets etc. at the } \\
\text { entrance to the event, in the gangways or any other part of the } \\
\text { exhibition hall unless written consent from the organisers is } \\
\text { obtained. } \\
\text { Exhibitors are responsible for their stand and are strongly } \\
\text { advised to take out insurance to cover any loss or damage to the } \\
\text { stand you are hiring and to cover public liability. } \\
\text { All exhibitors are expected to be present at their stands. } \\
\text { All Exhibitors are required to be registered and will receive a } \\
\text { badge displaying the exhibiting company's name. }\end{array}$ \\
\hline $\begin{array}{l}\text { exposant } \\
\text { Var.: locataire de } \\
\text { stand }\end{array}$ & $\begin{array}{l}\text { Exposants: personne physique ou morale qui contracte } \\
\text { directement avec l'organisateur d'une manifestation } \\
\text { commerciale et présente sur son stand ses propres produits ou } \\
\text { services par l'intermédiaire de son propre personnel. } \\
\text { Exposants: entité qui présente des produits ou des services } \\
\text { acceptés par l'organisateur par l'intermédiaire de personnel } \\
\text { présent sur la manifestation, y compris les exposants principaux } \\
\text { et les co-exposants. } \\
\text { L'exposant, ou son représentant dûment accrédité, est tenu } \\
\text { d'être présent sur son stand dès le début du démontage et jusqu'à } \\
\text { évacuation complete du stand. } \\
\text { Les exposants et locataires de stands doivent respectivement } \\
\text { appliquer et respecter les différentes règles de sécurité présentées } \\
\text { dans ce présent document, en plus des législations applicables. }\end{array}$ \\
\hline $\begin{array}{l}\text { espositore } \\
\text { Var.: partecipante }\end{array}$ & $\begin{array}{l}\text { Per "Espositori" si intendono coloro che partecipano alla } \\
\text { Manifestazione quali utilizzatori di aree espositive. } \\
\text { L'Espositore si impegna a esporre nel proprio posteggio, per } \\
\text { tutta la durata della manifestazione, i prodotti di propria } \\
\text { produzione appartenenti al repertorio merceologico di cui } \\
\text { all'allegato D del presente Regolamento Generale. } \\
\text { I partecipanti devono allestire e tenere i loro stand in modo da }\end{array}$ \\
\hline
\end{tabular}


non nuocere all'estetica e alla visibilità degli stand vicini e da non arrecare danno agli altri partecipanti. L'allestimento dovrà essere contenuto entro la superficie assegnata, individuabile mediante righe a vernice oppure a gesso. Poiché le aree non sono dotate di pareti divisorie, è fatto obbligo ad ogni azienda, a proprio carico, di realizzare allestimenti che prevedano tali separazioni dagli espositori confinanti.

\begin{tabular}{|c|c|}
\hline feira & $\begin{array}{l}\text { A participação em feiras é uma excelente oportunidade para a } \\
\text { realização de negócios. Preparar-se adequadamente para expor } \\
\text { produtos ou serviços pode ser o primeiro passo para alcançar } \\
\text { bons resultados. } \\
\text { As feiras são oportunidades de mostrar produtos/serviços, } \\
\text { conhecer novas fontes de comercialização e conquista de novos } \\
\text { mercados. Contudo, para que a feira seja um sucesso é necessário } \\
\text { existir um planejamento antecipado, levando em consideração } \\
\text { todas as variáveis possíveis. } \\
\text { Giacaglia (2003, p.42) define feiras como: "Eventos } \\
\text { direcionados a segmentos específicos de mercado, com duração } \\
\text { média de uma semana e são organizados e comercializados por } \\
\text { empresas especializadas no ramo. Normalmente ocorrem em } \\
\text { pavilhões de exposições especialmente preparados para esta } \\
\text { finalidade". } \\
\text { Feira pressupõe venda, seja durante o evento ou pedidos feitos } \\
\text { na ocasião e que serão entregues depois. Atualmente as empresas } \\
\text { consideram aproximadamente 03 semanas o período pós-evento } \\
\text { no qual os produtos expostos ainda têm efeito sobre os } \\
\text { consumidores e este tempo pode se estender caso a transação seja } \\
\text { feita entre dois países diferentes. } \\
\text { As feiras representam tanto para expositores quanto para } \\
\text { visitantes uma excelente oportunidade, senão única, de conversar } \\
\text { com um grande número de clientes ou empresas fornecedoras em } \\
\text { um curto espaço de tempo. } \\
\text { Não é, portanto, apenas um lugar de promoção e vendas. É muito } \\
\text { mais do que isso. Uma feira serve, entre outras, para as seguintes } \\
\text { finalidades: descobrir novos mercados; conhecer a concorrência; } \\
\text { verificar se há condições de exportação; trocar experiências; } \\
\text { iniciar acordos de cooperação e alianças estratégicas; organizar } \\
\text { os canais de distribuição; avaliar a competitividade da empresa; } \\
\text { descobrir novos clientes; avaliar as políticas de preço, de } \\
\text { desconto e de formas de pagamento; fazer o lançamento de novos } \\
\text { produtos; apresentar inovações; informar sobre a utilidade e } \\
\text { formas de utilização dos produtos; fazer demonstrações } \\
\text { educativas; conseguir representantes; treinar o pessoal de } \\
\text { vendas; auxiliar no planejamento estratégico; vender produtos. }\end{array}$ \\
\hline
\end{tabular}




\begin{tabular}{|c|c|}
\hline $\begin{array}{l}\text { fair } \\
\text { Var.: show }\end{array}$ & $\begin{array}{l}\text { A fair is also an ideal opportunity to observe the market and its } \\
\text { competitors (product comparison, competence of the stand } \\
\text { personnel, design of the competitors' stands, etc...), and to gather } \\
\text { competitors' information materials (brochures, catalogues). } \\
\text { After the fair, this information should be analyzed. } \\
\text { The differentiating factor between market and fair can be related } \\
\text { to duration: markets were regular and frequent happenings, fairs } \\
\text { were commercial events organized on special occasions. } \\
\text { It is important for an organization to be aware of its goals and } \\
\text { some of the goals that organizations could use to exhibit in } \\
\text { shows are; launching new lines, finding distributors (...), re- } \\
\text { establishing links with company in the market, and collecting } \\
\text { feedback on a projected new range of products. } \\
\text { But which shows are the best shows? The first place to start is } \\
\text { with your industry's associations. These shows will typically be } \\
\text { targeted right to your market, and often are reasonable in cost. } \\
\text { You can also check with the trade publications you advertise in } \\
\text { (or perhaps should be advertising in). Another resource is, of } \\
\text { course, the Web. Go to TSNN.com, tscentral.com, or FITA.org } \\
\text { for directories of shows around the world in all types of } \\
\text { industries. No list is entirely complete, however, so make sure } \\
\text { you go to more than one directory. }\end{array}$ \\
\hline $\begin{array}{l}\text { foire } \\
\text { Var.: foire- } \\
\text { exposition; } \\
\text { manifestation } \\
\text { commerciale; } \\
\text { manifestation; } \\
\text { événement }\end{array}$ & $\begin{array}{l}\text { Les manifestations commerciales, usuellement dénommées } \\
\text { "foires ", dans lesquelles un ensemble de personnes physiques } \\
\text { ou morales expose d'une façon collective et temporaire des biens } \\
\text { ou offre des services qui peuvent faire l'objet d'une vente directe } \\
\text { avec enlèvement de la marchandise ou exécution du contrat de } \\
\text { services. } \\
\text { Une foire est une manifestation commerciale qui se distingue } \\
\text { d'un salon par le fait que les biens et services exposés ne se } \\
\text { réfèrent pas à une liste limitative déterminée par l'organisateur } \\
\text { et qu'elle s'adresse principalement à des visiteurs non } \\
\text { professionnels. } \\
\text { Les foires sont des manifestations ouvertes au public dans les } \\
\text { mêmes conditions que les salons mais sans limitation à une } \\
\text { catégorie professionnelle. Le terme foire est donc plus général } \\
\text { que celui de salon, qui est une manifestation spécialisée: salon } \\
\text { des Artistes décorateurs, salon des Indépendants, salon des } \\
\text { Artisans d'art. } \\
\text { La foire, ou foire-exposition, réunit l'ensemble des acteurs } \\
\text { socio-économiques d'une région, proposant au visiteur une } \\
\text { rencontre avec tous les représentants de la vie économique } \\
\text { industrielle, artisanale et sociale. }\end{array}$ \\
\hline
\end{tabular}




\begin{tabular}{|c|c|}
\hline & $\begin{array}{l}\text { Les foires sont des «manifestations commerciales comportant } \\
\text { des ventes de marchandises au public dans un parc d'exposition» } \\
\text { (article L.310-2 III } 6 \text { du Code de commerce). } \\
\text { Enfin, foire, salon ou exposition, chaque manifestation évolue } \\
\text { sans que sa dénomination change: certaines se spécialisent, } \\
\text { d'autres se généralisent. } \\
\text { Chaque manifestation commerciale est sans rapport avec les } \\
\text { sessions précédentes ou suivantes : c'est un événement unique } \\
\text { défini par un nom, un lieu, une date et une présentation de l'offre } \\
\text { proposée au public communément appelé «nomenclature ». Le } \\
\text { présent règlement est, le cas échéant, complété par le règlement } \\
\text { particulier propre à chaque manifestation ou par un "guide" ou } \\
\text { "manuel de l'exposant". }\end{array}$ \\
\hline $\begin{array}{l}\text { Var.: } \\
\text { manifestazione } \\
\text { fieristica; } \\
\text { manifestazione; } \\
\text { rassegna }\end{array}$ & $\begin{array}{l}\text { Le fiere sono il momento d'incontro tra l'offerta e la domanda di } \\
\text { beni o di servizi. Sono perciò uno strumento efficace del } \\
\text { mercato. Per questa ragione esse sono antiche come la storia } \\
\text { dei mercati, delle necessità e dei conseguenti rapporti } \\
\text { economici e sociali tra le comunità: comunità di famiglie, } \\
\text { di tribù, popoli e di nazioni. } \\
\text { In molti casi, la partecipazione ad una fiera diviene per l'azienda } \\
\text { un momento fondamentale nel corso dell'anno, scelto per } \\
\text { importanti annunci di prodotti o strategie e di conseguenza è tale } \\
\text { da rivestire un ruolo strategico nel programma di marketing e } \\
\text { comunicazione, coinvolgendo diverse funzioni interne e } \\
\text { consulenti esterni. } \\
\text { Le fiere costituiscono per la maggior parte delle piccole e medie } \\
\text { imprese il principale, se non l'unico, investimento in } \\
\text { comunicazione ed immagine. L'investimento in fiera costa } \\
\text { quattro o cinque volte in meno rispetto agli altri strumenti di } \\
\text { contatto, come la pubblicità, le promozioni o la visita di un } \\
\text { venditore specializzato, in più un contatto attuato in fiera si } \\
\text { traduce in affari in almeno il } 30 \% \text { dei casi. } \\
\text { La fiera è il mercato, la vetrina; per l'imprenditore esporre ad } \\
\text { una grande fiera vuol dire davvero: mi metto in mostra. La fiera } \\
\text { è il perenne atto di coraggio delle imprese, la loro continua sete } \\
\text { di successo, la sfida che tutti gli imprenditori avvertono. È in } \\
\text { fiera che, come al casinò, continuamente si scommette, qui le } \\
\text { imprese fanno mercato. La fiera è l'arena dove la piccola azienda } \\
\text { scende realmente in competizione, una grande palestra per } \\
\text { l'imprenditore. } \\
\text { La fiera è un grande strumento di comunicazione e di } \\
\text { promozione. Per aziende medio piccole è spesso il principale } \\
\text { mezzo di comunicazione aziendale. Quindi, si deve dedicare alla }\end{array}$ \\
\hline
\end{tabular}




\begin{tabular}{|c|c|}
\hline & $\begin{array}{l}\text { comunicazione ed alla promozione, la stessa attenzione che allo } \\
\text { stand. } \\
\text { Ai fini della presente legge si intendono per manifestazioni } \\
\text { fieristiche, le attività commerciali svolte in via ordinaria in } \\
\text { regime di diritto privato ed in ambito concorrenziale per la } \\
\text { presentazione e la promozione o la commercializzazione, } \\
\text { limitate nel tempo ed in idonei complessi espositivi, di beni e } \\
\text { servizi, destinate a visitatori generici e ad operatori professionali } \\
\text { del settore o dei settori economici coinvolti. Tra le } \\
\text { manifestazioni fieristiche si individuano le seguenti tipologie: } \\
\text { fiere generali, fiere specializzate, mostre-mercato. } \\
\text { La realizzazione di una manifestazione fieristica richiede tempi } \\
\text { piuttosto lunghi e procedimenti complessi (da sei mesi per le } \\
\text { fiere semestrali fino a tre quattro anni per altre) con variazioni a } \\
\text { seconda della tipologia ( settore merceologico, tipo prevalente di } \\
\text { pubblico coinvolto: consumer o business), della frequenza e del } \\
\text { carattere nazionale o internazionale dell'evento in questione. } \\
\text { Espositori, quanti partecipano alla rassegna per presentare, } \\
\text { promuovere o diffondere beni e servizi, siano essi produttori o } \\
\text { rivenditori o enti pubblici o associazioni operanti nei settori } \\
\text { economici oggetto delle attività fieristiche o i loro } \\
\text { rappresentanti. }\end{array}$ \\
\hline $\begin{array}{l}\text { centro de } \\
\text { exposições }\end{array}$ & $\begin{array}{l}\text { Tipo de Feira: Nacional; Perfil e classificação da feira: Setorial; } \\
\text { Freqüência: Anual; Próxima Edição: } 09 \text { a } 12 \text { de fevereiro de } \\
\text { 2007; Período de Realização: } 18 \text { a } 21 \text { de fevereiro de } 2006 \text {; } \\
\text { Horário: } 10 \text { às } 19 \text { horas; Local Feira: Centro de } \\
\text { Exposições Imigrantes - São Paulo, SP; Número de expositores: } \\
\text { 160; Perfil do Expositor: Indústrias de móveis e acessórios de } \\
\text { alta decoração no Brasil; Número de visitantes: 20.000; Perfil do } \\
\text { visitante: Lojistas convidados pelos expositores, designers de } \\
\text { interiores, arquitetos, atacadistas, representantes, compradores, } \\
\text { fabricantes, imprensa e estudantes. } \\
\text { A União Brasileira dos Promotores de Feiras - UBRAFE - é a } \\
\text { entidade privada que representa desde } 1986 \text { as empresas } \\
\text { envolvidas na organização, promoção, operação e montagem das } \\
\text { principais feiras de negócios do Brasil. Com mais de } 40 \\
\text { associados (entre promotoras, centros de exposições, empresas } \\
\text { transitárias, de infra-estrutura e montadoras de estandes), a } \\
\text { UBRAFE é hoje um selo de qualidade que identifica as melhores } \\
\text { feiras do País. }\end{array}$ \\
\hline $\begin{array}{l}\text { exhibition venue } \\
\text { Var.: venue; } \\
\text { exhibition centre }\end{array}$ & $\begin{array}{l}\text { The permanent showrooms are complemented by over } 6000 \\
\text { sq.m of integrated exhibition space located on four levels. With } \\
\text { exhibitions mainly targeted at business, design and niche } \\
\text { consumer shows, the Centre is today regarded as London's } \\
\text { premier exhibition venue. }\end{array}$ \\
\hline
\end{tabular}




\begin{tabular}{|c|c|}
\hline & $\begin{array}{l}\text { The NEC is the UK's best connected venue: It is the only } \\
\text { UK exhibition venue with an airport and railway station on site } \\
\text { near an intersection of the UK's primary motorways. Easy to get } \\
\text { to as } 75 \% \text { of the UK population are within a three hour drive } \\
\text { time. Easy parking with } 16,500 \text { car park spaces. } \\
\text { The Venue: The NEC is the largest and most established national } \\
\text { exhibition venue in the UK. Hall 9, the location of } \\
\text { Automechanika Birmingham, offers } 11,000 \text { sqm of space. } \\
\text { No exhibitor (or staff member working on behalf of exhibitors) } \\
\text { is allowed to distribute any promotional material at any point } \\
\text { within the exhibition centre other than on their allocated stand } \\
\text { space. }\end{array}$ \\
\hline $\begin{array}{l}\text { parc des } \\
\text { expositions } \\
\text { Var. : } \\
\text { palais des } \\
\text { expositions; } \\
\text { enceinte de la } \\
\text { manifestation; } \\
\text { centre d'exposition }\end{array}$ & $\begin{array}{l}\text { Le Parc des Expositions dispose d'une surface totale de } \\
38.000 \mathrm{~m}^{2} \text { d'exposition répartis sur } 6 \text { Halls. Il accueille ou } \\
\text { organise chaque année près de } 85 \text { événements : salons } \\
\text { professionnels et grands publics, congrès, conventions et } \\
\text { événements d'entreprise, spectacles et rassemblements sportifs. } \\
\text { Un parc d'exposition est un ensemble immobilier clos } \\
\text { indépendant, doté d'installations et d'équipements appropriés } \\
\text { ayant un caractère permanent et non soumis à l'autorisation } \\
\text { prévue à l'article L. 752-1, qui accueille, pendant tout ou partie } \\
\text { de l'année, des manifestations commerciales ou autres, à } \\
\text { caractère temporaire. Le parc d'exposition est enregistré auprès } \\
\text { de l'autorité administrative compétente. Le programme des } \\
\text { manifestations commerciales qu'il accueille fait chaque année } \\
\text { l'objet d'une déclaration préalable auprès de l'autorité } \\
\text { administrative compétente. } \\
\text { Le Palais des Expositions est équipé d'un poste central de } \\
\text { sécurité, fonctionnant pendant les heures d'ouverture des } \\
\text { manifestations. } \\
\text { Le montage commence, dans l'enceinte de la manifestation, } \\
\text { dix à quinze jours avant son ouverture au public. Le début du } \\
\text { montage est parfois retardé par la pose du plancher qui est } \\
\text { effectuée par les services de la manifestation ; l'exposant et le } \\
\text { constructeur doivent donc veiller à ce que ce travail préliminaire } \\
\text { soit exécuté en temps utile. }\end{array}$ \\
\hline & $\begin{array}{l}\text { Ayant son siège à Paris, l'UFI est l'organisation maîtresse pour } \\
\text { les société organisatrices de foires, les managers de centres } \\
\text { d'exposition et des secteurs liés aux foires et salons partout dans } \\
\text { le monde. }\end{array}$ \\
\hline quartiere fieristico & $\begin{array}{l}\text { Localizzato in una posizione strategica, grazie alla facilità e } \\
\text { all'efficienza dei collegamenti, vicinissimo all'aeroporto } \\
\text { internazionale, alla principale rete autostradale nazionale e al } \\
\text { nodo ferroviario più grande d'Europa, il quartiere fieristico di }\end{array}$ \\
\hline
\end{tabular}




\begin{tabular}{|c|c|}
\hline $\begin{array}{l}\text { Var.: } \\
\text { quartiere } \\
\text { espositivo; } \\
\text { quartiere; } \\
\text { centro fieristico; } \\
\text { complesso } \\
\text { fieristico; } \\
\text { polo fieristico; }\end{array}$ & 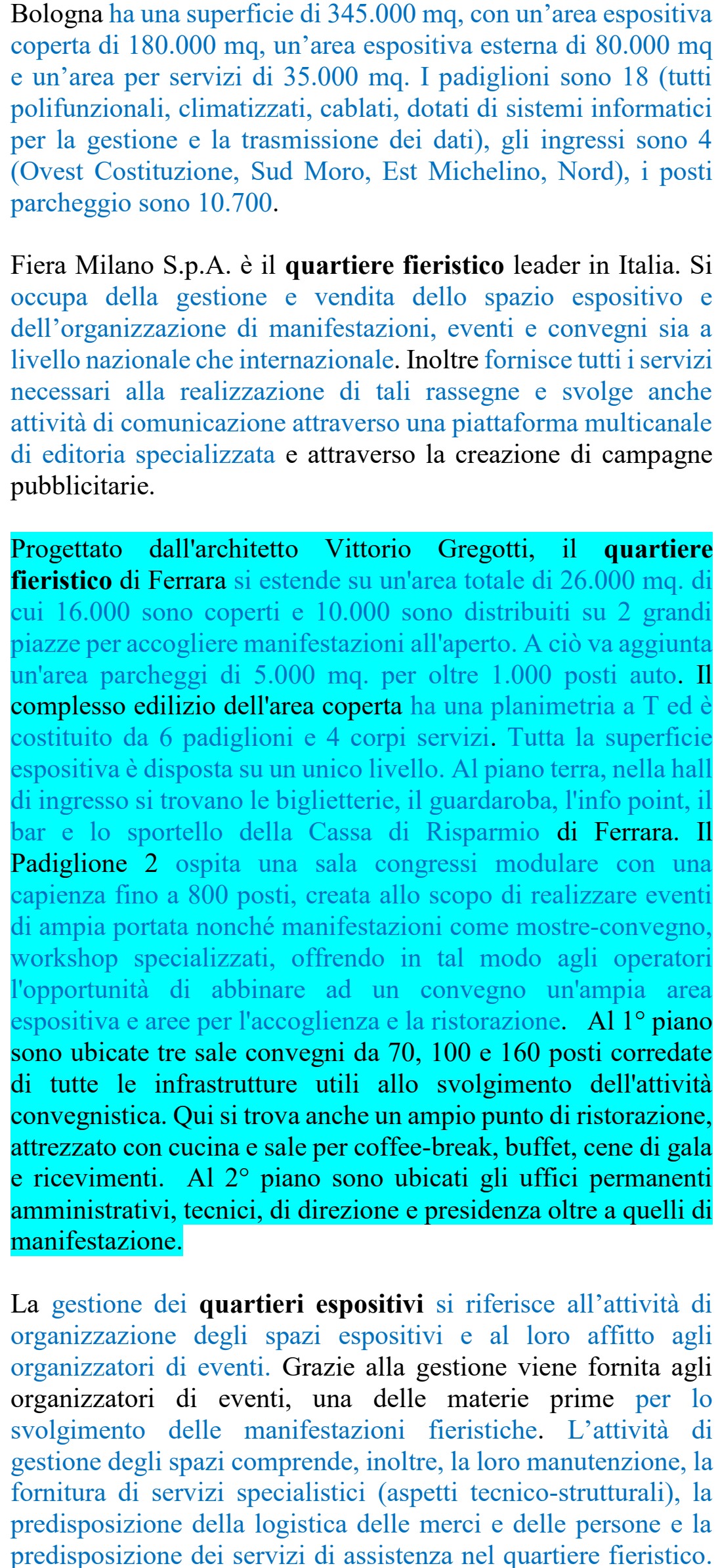 \\
\hline
\end{tabular}




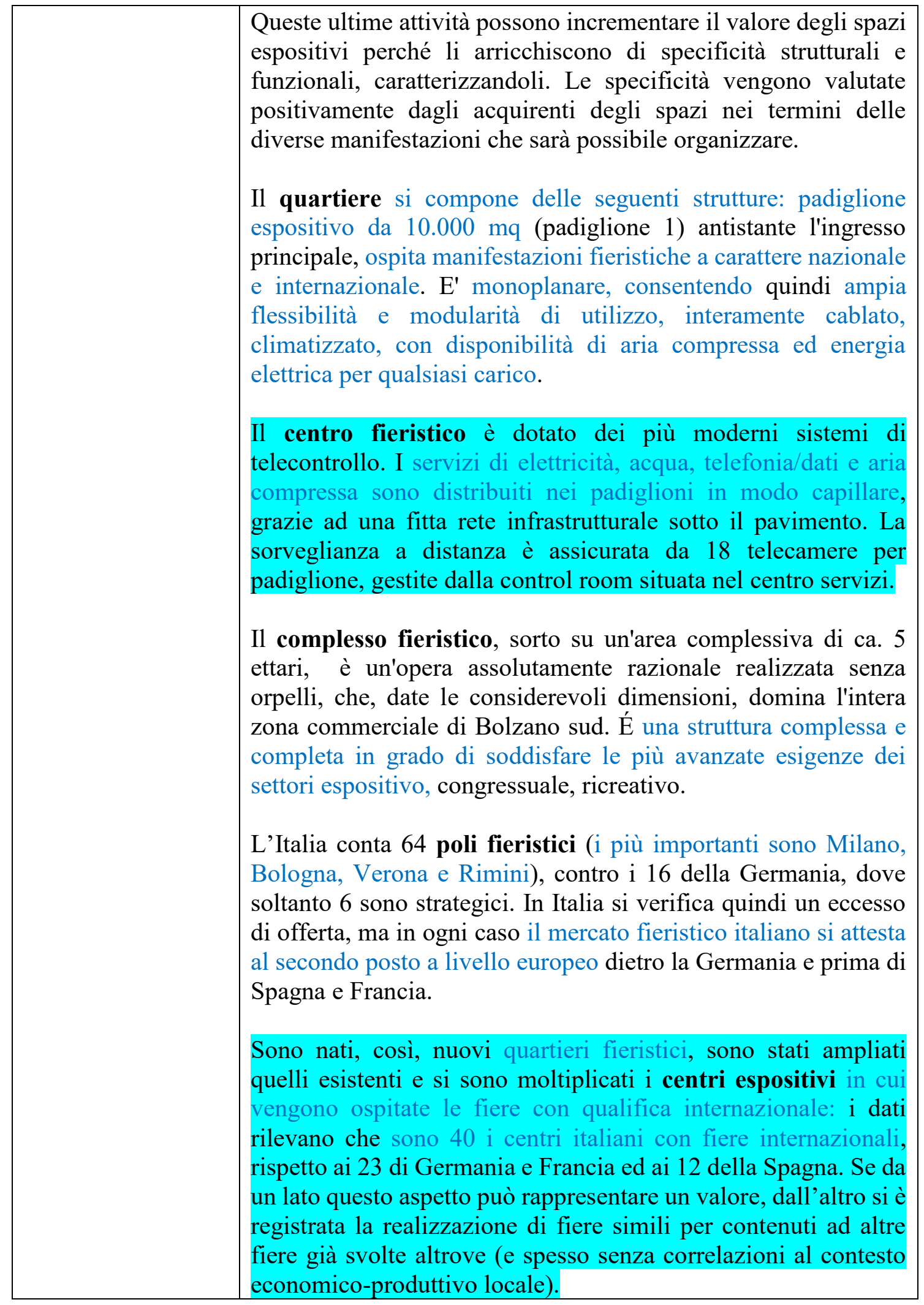

pavilhão

O Pavilhão do Expo Center Norte será dividido em áreas de exposição, praça de alimentação, área de conveniência, prestadores de serviços, locais reservados à administração, além de vias de circulação. A área de exposição estará aberta à visitação diariamente, das $10 \mathrm{~h}$ às $20 \mathrm{~h}$. O Expositor deverá 


\begin{tabular}{|c|c|}
\hline $\begin{array}{l}\text { Var.: } \\
\text { pavilhão de } \\
\text { exposições }\end{array}$ & $\begin{array}{l}\text { manter o seu estande em funcionamento durante todo o período } \\
\text { da feira, com pessoal habilitado para a sua operação. } \\
\text { É proibido apoiar, amarrar ou pendurar qualquer componente do } \\
\text { estande ou produtos expostos nas estruturas (eletro calhas, canos } \\
\text { de água, hidrantes e dutos de ar-condicionado), teto, paredes ou } \\
\text { colunas do pavilhão, bem como pintar ou furar esses elementos. } \\
\text { É terminantemente proibido o acesso de veículos de cargas e } \\
\text { descargas durante todo o período de funcionamento da FEIRA } \\
\text { no pavilhão de exposições. }\end{array}$ \\
\hline exhibition hall & $\begin{array}{l}\text { All stands, gangways and common areas within the exhibition } \\
\text { hall will be cleaned each day, prior to show open. }\end{array}$ \\
\hline $\begin{array}{l}\text { Var.: exhibition } \\
\text { area; hall; } \\
\text { exhibition arena }\end{array}$ & $\begin{array}{l}\text { The exhibition halls have to provide all necessary supply } \\
\text { sources for electricity, water, gas, and communication } \\
\text { connections, as well as clear and unambiguous signage system. } \\
\text { Infrastructures like restaurants, parking areas (separated between } \\
\text { exhibitors and visitors), toilets, and entrance areas are integral } \\
\text { parts of an exhibition ground. } \\
\text { The characteristics of the exhibition hall, such as the height of } \\
\text { the ceiling, the entrances and gangways, the neighbouring } \\
\text { stands, and the emergency exits must also be taken into } \\
\text { consideration when designing the stand. } \\
\text { The Organizers may change or replace the exhibition areas up } \\
\text { to the date of delivery of the event, in accordance with the rules } \\
\text { established by contract, to accommodate any unoccupied spaces } \\
\text { and provide a better overall environment for the event. } \\
\text { Exhibitors will have access to the exhibition areas from } 1 \text { pm to } \\
\text { 5pm on Wednesday } 10 \text { th February } 2016 \text { and from } 7 \text { am until } 8 \text { am } \\
\text { on Thursday } 11 \text { th February } 2016 \text {. } \\
\text { As part of the event we will ensure that all common areas are } \\
\text { cleaned throughout the day including toilets, conference rooms, } \\
\text { exhibition areas and walkways. } \\
\text { When choosing a stand to buy or rent, bear the following things } \\
\text { in mind. Before deciding how the company will mount its stand, } \\
\text { obtain a floor plan of the hall where the trade fair will be held. } \\
\text { Breakdown. N.B. Please note there will be NO access to the } \\
\text { Exhibition Arena outside the times as stated above. }\end{array}$ \\
\hline $\begin{array}{l}\text { Var. : } \\
\text { pavillon } \\
\text { d'expositions } \\
\text { zone d'exposition; }\end{array}$ & $\begin{array}{l}\text { Les exposants auront accès au hall d'exposition tous les jours } \\
\text { une heure avant l'heure officielle d'ouverture. Vendredi, } 1 \text { MAI, } \\
\text { jour de l'ouverture, les exposants auront accès au hall } \\
\text { d'exposition à partir de } 7 \mathrm{~h} 00 \text { pour se préparer à une inspection } \\
\text { des stands qui aura lieu à } 9 \mathrm{~h} 00 \text {. } \\
\text { Généralement les pavillons, le hall d'expositions et les } \\
\text { installations des parcs d'expositions répondent aux exigences de }\end{array}$ \\
\hline
\end{tabular}




\begin{tabular}{|c|c|}
\hline pavillon & $\begin{array}{l}\text { cet arrêté: accessibilité, sanitaires, parking etc. } \\
\text { Pour pénétrer à l'intérieur des halls d'exposition, toute personne } \\
\text { doit être munie d'un badge d'accès FOIRE D'AUTOMNE et } \\
\text { doit impérativement porter, en période de montage et de } \\
\text { démontage, l'équipement de sécurité avec notamment le port des } \\
\text { chaussures de sécurité. } \\
\text { Pour pénétrer à l'intérieur du pavillon d'expositions, toute } \\
\text { personne doit être munie d'un badge d'accès FOIRE } \\
\text { D'AUTOMNE et doit impérativement porter, en période de } \\
\text { montage et de démontage, l'équipement de sécurité avec } \\
\text { notamment le port des chaussures de sécurité. Dans le cas } \\
\text { contraire, l'accès au pavillon d'expositions sera refusé. } \\
\text { Durant les périodes de montage et de démontage, l'accès aux } \\
\text { pavillons d'exposition sera autorisé uniquement aux personnes } \\
\text { munies d'un badge Montage/Démontage. } \\
\text { La localisation du stand de l'exposant dans la zone d'exposition } \\
\text { peut aussi être vue comme une décision de distribution. Le bon } \\
\text { emplacement - fréquentation élevée de visiteurs - va influencer } \\
\text { le succès individuel de l'exposant. } \\
\text { Les pavillons de la Porte de Versailles sont numérotés de } 1 \text { à } 7 . \\
\text { Dans chaque pavillon, les allées sont désignées par une lettre. } \\
\text { Certains pavillons comportent plusieurs étages (exemple: le } \\
\text { pavillon } 7 \text { s'étend sur } 3 \text { étages. Il est numéroté comme suit: } \\
\text { pavillon } 7.1 \text { pour le niveau } 1 \text {, pavillon } 7.2 \text { pour le niveau } 2 \text {...). }\end{array}$ \\
\hline $\begin{array}{l}\text { padiglione } \\
\text { espositivo } \\
\text { Var.: padiglione } \\
\text { fieristico; } \\
\text { padiglione; } \\
\text { area espositiva; } \\
\text { zona espositiva }\end{array}$ & $\begin{array}{l}\text { Ogni padiglione espositivo è dotato di una zona d'ingresso, in } \\
\text { adiacenza ed alla quota del percorso pedonale sopraelevato. Da } \\
\text { tale zona, attraverso scale mobili, scale fisse ed ascensori per } \\
\text { disabili, si può scendere ed accedere all'area espositiva posta alla } \\
\text { quota inferiore a livello terreno. Al livello superiore, in } \\
\text { adiacenza alla hall d'ingresso sono previsti servizi per i visitatori } \\
\text { quale la "Master Hall" e le salette riunioni, nonché una } \\
\text { Reception. } \\
\text { I Padiglioni espositivi A e B costituiscono l'area espositiva } \\
\text { fieristica cui sono asserviti impianti di servizio posti in cunicoli } \\
\text { a terra, magazzini, locali manutenzione e tecnici, bar, servizi } \\
\text { igienici per il pubblico e per gli allestitori, locali per impianti } \\
\text { tecnici di suporto; Padiglione Espositivo C comprendente area } \\
\text { espositiva fieristica con annessi impianti di servizio posti nel } \\
\text { controsoffitto e/o su blindosbarra, locali tecnici, riscaldamento } \\
\text { con nuclei ventilconvettori aerei elettrici. Area espositiva } \\
\text { all'aperto pavimentata in asfalto, dotata di sottoservizi ed } \\
\text { impianti necessari per l'effettuazione di manifestazioni posti in } \\
\text { pozzetti a terra. } \\
\text { Padiglione espositivo che si compone di due livelli con una } \\
\text { superficie espositiva di } 1.700 \text { mq, oltre ai sevizi igienici ed alcuni } \\
\text { locali ad uso magazzino. }\end{array}$ \\
\hline
\end{tabular}


Il quartiere si compone delle seguenti strutture: padiglione espositivo da $10.000 \mathrm{mq}$ (padiglione 1) antistante l'ingresso principale, ospita manifestazioni fieristiche a carattere nazionale e internazionale. E' monoplanare, consentendo quindi ampia flessibilità e modularità di utilizzo, interamente cablato, climatizzato, con disponibilità di aria compressa ed energia elettrica per qualsiasi carico.

All'interno del padiglione fieristico possono operare solo i fotografi autorizzati da Rimini Fiera.

Ogni padiglione è dotato di tutti i servizi necessari all'organizzazione di una manifestazione (pronto soccorso, bar, ristoranti, servizi igienici, passi carrai...).

Anche la collocazione dello stand all'interno dell'area espositiva può essere considerata parte integrante della decisione in merito alla strategia di distribuzione. La giusta collocazione - elevato flusso di visitatori - inciderà sul successo individuale dell'espositore.

Inoltre BolognaFiere avrà facoltà di spostare, ridurre lo stand già assegnato, ovvero di trasferirlo in altra zona espositiva senza alcun diritto del partecipante ad indennizzi od a risarcimenti di sorta. Sarà comunque tenuto a darne comunicazione all'Espositore oltrechè con lettera raccomandata, spedita almeno 20 giorni prima dell'inizio del Salone, anche mediante telefax o altro idoneo mezzo.

\begin{tabular}{|l|l|}
\hline visitante da feira & $\begin{array}{l}\text { Os visitantes, por outro lado, não devem ser obrigados a usar } \\
\text { crachás, a não ser que os organizadores entendam que seja } \\
\text { indispensável. Para simplificar, basta que disponham de convites } \\
\text { ou ingressos, os quais devem ser recolhidos na entrada. O mais } \\
\text { importante é que deixem escritos e assinalados seus dados, no } \\
\text { verso do convite ou do ingresso. Esses dados são fundamentais } \\
\text { para se conhecer o perfil do visitante da feira, fato que poderá } \\
\text { contribuir para orientar os organizadores quanto a futuros planos } \\
\text { de mídia e ao planejamento. } \\
\text { Entre as informações que podem ser mensuradas e cruzadas, em } \\
\text { uma primeira análise, estão: a quantidade de visitas ao estande } \\
\text { pelo número de visitantes da feira e a quantidade de visitas ao } \\
\text { estande pelo número de clientes potenciais, clientes atuais e } \\
\text { curiosos. }\end{array}$ \\
\hline trade show visitor & $\begin{array}{l}80 \% \text { of trade show visitors are personally involved in buying } \\
\text { the products or services on show. And 29\% never see sales reps } \\
\text { other than at exhibitions! } \\
\text { In the final analysis, your company's exhibition success is } \\
\text { directly related to how well your stand personnel interact with } \\
\text { the show visitors - your current and future customers! }\end{array}$ \\
\hline $\begin{array}{l}\text { Var.: } \\
\text { show visitor; } \\
\text { trade show }\end{array}$
\end{tabular}




\begin{tabular}{|c|c|}
\hline $\begin{array}{l}\text { attendee; } \\
\text { trade fair visitor; } \\
\text { visitor; } \\
\text { show attendee; } \\
\text { attendee }\end{array}$ & $\begin{array}{l}\text { Trade show attendees are strolling down the aisle looking at } \\
\text { hundreds of booths, and unless you've pulled them to your booth } \\
\text { with a pre-show promotion, you have to very quickly make them } \\
\text { notice you and want to walk over to your booth. } \\
\text { The more attractively the exhibits are presented, the quicker the } \\
\text { attention of the visitor is caught. The most important thing is to } \\
\text { bring out quite clearly the benefits for the user. A presentation } \\
\text { must be seen through the eyes of the observer the trade fair } \\
\text { visitor; the exhibitor must put himself in their position. } \\
\text { The trade fair visitors are only partly included in the number of } \\
\text { tourists and overnight stays, as the visitor statistics for trade fairs } \\
\text { include local visitors too. } \\
\text { Visitors exclude the staff of exhibitors, services providers and } \\
\text { organizers. } \\
\text { First, as we mentioned above, engaging the show attendee is not } \\
\text { as simple as you might think. Assuming you don't have a magic } \\
\text { show, a live animal promo, or other crowd magnet, the burden } \\
\text { of getting people to stop at your booth is on your booth staff. The } \\
\text { first rule of engagement is: Don't ask a question that will allow } \\
\text { the attendee to simply give you a one word answer and keep on } \\
\text { walking. Ask them what product they are looking for at the show, } \\
\text { whether this show has been as helpful for them as another show, } \\
\text { if they are familiar with your company, etc. } \\
\text { The purpose of commercial exhibits is to further the education of } \\
\text { attendees through product and service displays and } \\
\text { demonstrations. Direct selling is not allowed; however, order } \\
\text { taking is permitted within the booth if business is conducted in a } \\
\text { manner consistent with the professional nature of the exhibits. }\end{array}$ \\
\hline $\begin{array}{l}\text { Var.: visiteur du } \\
\text { salon }\end{array}$ & $\begin{array}{l}\text { L'utilisation de ces emplacements permet, d'une part, d'attirer les } \\
\text { visiteurs de la manifestation vers le stand, d'autre part, de leur } \\
\text { rappeler l'existence du stand après qu'ils l'ont quitté et, donc, de } \\
\text { prolonger l'action du personnel de vente. } \\
\text { Nous vous rappelons que les ventes comportant livraison } \\
\text { immédiate et sur place à l'acheteur sont interdites (article } 4 \text { du } \\
\text { règlement général du salon). Notre salon étant exclusivement } \\
\text { réservé aux professionnels venant passer des commandes, nous } \\
\text { vous remercions de bien vouloir respecter et faire respecter cet } \\
\text { article aux visiteurs du salon. Un contrôle systématique du } \\
\text { justificatif professionnel est fait à l'entrée. } \\
\text { Capacité du stand à attirer les visiteurs (Part de visiteurs du } \\
\text { salon ayant visité le stand). }\end{array}$ \\
\hline $\begin{array}{l}\text { visitatore della } \\
\text { manifestazione }\end{array}$ & $\begin{array}{l}\text { Le società di servizio pubblico, le autorità, le associazioni e le } \\
\text { istituzioni presenti per offrire servizi agli espositori e/o ai } \\
\text { visitatori della manifestazione, potranno essere considerate } \\
\text { espositori solo nel caso in cui la loro offerta corrisponda alla } \\
\text { tematica della manifestazione all'interno dell'area espositiva. }\end{array}$ \\
\hline
\end{tabular}




\begin{tabular}{|l|l|}
\hline $\begin{array}{l}\text { Var.: visitatore } \\
\text { della fiera }\end{array}$ & $\begin{array}{l}\text { Tale validità permane in ogni caso, sia quando i visitatori della } \\
\text { fiera sono costituiti prevalentemente o esclusivamente da } \\
\text { operatori specializzati, sia quando sono rappresentati dal } \\
\text { pubblico generico dei potenziali acquirenti/consumatori. }\end{array}$ \\
visitatore del salone \\
$(0)$ & $\begin{array}{l}\text { In una fiera, lo scopo principale di quasi tutti gli espositori è } \\
\text { guadagnare più soldi e conquistare più clienti per la loro azienda. } \\
\text { Alla fine del prossimo ciclo di vendite potrete quindi capire } \\
\text { quanti visitatori della fiera sono effettivamente diventati clienti. }\end{array}$ \\
\hline
\end{tabular}

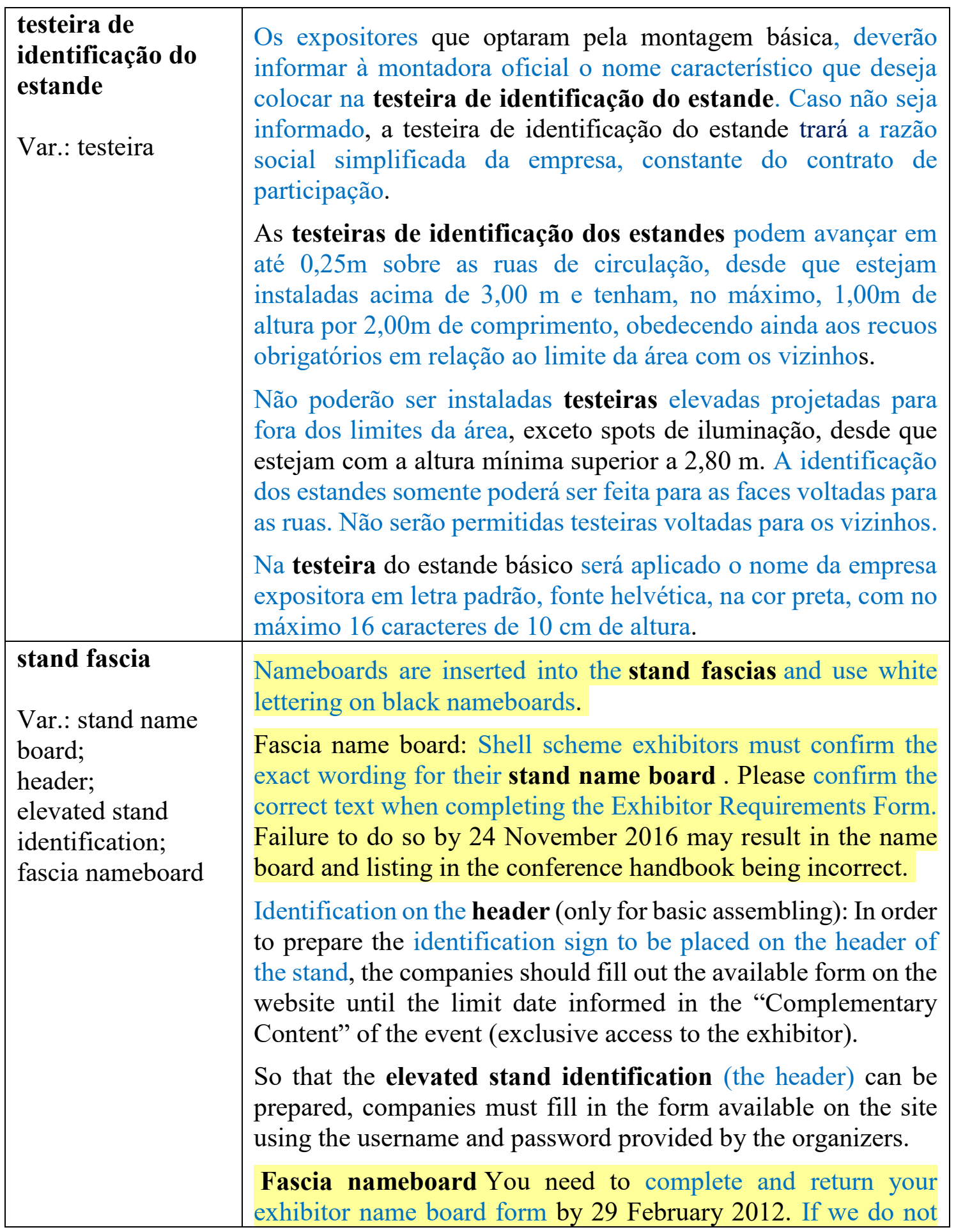




\begin{tabular}{|c|c|}
\hline & $\begin{array}{l}\text { receive the form, we will use the name on your booking form. } \\
\text { You can order additional name board features. Please see the } \\
\text { advertising brochure and the name board form for more details. }\end{array}$ \\
\hline enseigne du stand & $\begin{array}{l}\text { Tout document remis aux visiteurs sur son stand, tel que carte } \\
\text { commerciale, bon de commande, etc., devra comporter } \\
\text { l'enseigne du stand ou la raison sociale de l'Exposant figurant } \\
\text { sur la demande de participation. } \\
\text { L'enseigne doit se situer dans un espace compris entre } 3,00 \mathrm{~m} \text { et } \\
6,00 \mathrm{~m} \text { du sol. Les ponts lumière ne doivent pas dépasser la } \\
\text { hauteur de } 6,00 \mathrm{~m} \text { par rapport au sol du bâtiment. L'enseigne et } \\
\text { le pont lumière doivent être intégrés dans les limites du stand et } \\
\text { respecter un retrait de } 1,00 \mathrm{~m} \text { par rapport aux allées et aux } \\
\text { mitoyennetés. }\end{array}$ \\
\hline $\begin{array}{l}\text { fascione }(0) \\
\text { frontalino }(0) \\
\text { fascia frontale }(0)\end{array}$ & $\begin{array}{l}\text { Le insegne dello stand dovranno essere composte da lettere } \\
\text { adesive o similari; in nessun caso verranno accettate scritte a } \\
\text { mano. Le insegne dovranno comunque essere installate in modo } \\
\text { da non occultare o danneggiare gli stand confinanti. Gli } \\
\text { Organizzatori si riservano di intervenire, in caso contrario, a } \\
\text { spese dell'Espositore. Il retro delle pareti, se a vista, deve essere } \\
\text { rifinito e di colore bianco. } \\
\text { L'allestimento comprende: pareti, moquette, insegna con } \\
\text { ragione sociale a caratteri standard, } 1 \text { tavolo, } 3 \text { sedie, } 1 \\
\text { appendiabit, } 1 \text { cestino, } 1 \text { multipresa elettrica, illuminazione, } \\
\text { impianto elettrico. } \\
\text { È consentito: [...] esporre nel proprio stand le insegne con il } \\
\text { marchio della ditta di dimensioni max } 180 \text { x } 80 \text { cm, ad una } \\
\text { altezza di collocazione di oltre i } 2,50 \mathrm{~m} \text { posizionate sia } \\
\text { orizzontalmente che verticalmente. }\end{array}$ \\
\hline
\end{tabular}

\begin{tabular}{|l|l|}
\hline $\begin{array}{l}\text { montagem do } \\
\text { estande }\end{array}$ & $\begin{array}{l}\text { Montagem dos estandes - construção, instalação de máquinas e } \\
\text { equipamentos, e acabamento. } \\
\text { Var.: construção do } \\
\text { estande }\end{array}$ \\
$\begin{array}{l}\text { Muitas feiras têm montadora oficial, que nem sempre é a melhor } \\
\text { ou pratica os melhores preços. A escolha do material estrutural } \\
\text { pode elevar ou reduzir os custos com a montagem do estande. } \\
\text { É recomendável obter informações sobre esses fornecedores, } \\
\text { submeter-lhes o projeto do estande e negociar os orçamentos. } \\
\text { Para iniciar a montagem do estande, a Promotora exige do } \\
\text { expositor o pagamento imediato de qualquer pendência } \\
\text { financeira referente às parcelas do contrato e serviços } \\
\text { obrigatórios e/ou contratados. } \\
\text { A montagem do estande somente será autorizada se o projeto } \\
\text { estiver de acordo com as normas deste manual, podendo a } \\
\text { Promotora a qualquer tempo, interromper os trabalhos que não } \\
\text { estiverem obedecendo aos projetos previamente aprovados, até } \\
\text { que a irregularidade seja sanada. Caso contrário, será aplicada } \\
\text { notificação e multa. }\end{array}$ \\
\hline
\end{tabular}




\begin{tabular}{|c|c|}
\hline & $\begin{array}{l}\text { Efetuar a montagem do estande e colocação dos seus produtos } \\
\text { antes da abertura do evento e fora do horário de visitação pública. } \\
\text { Toda e qualquer execução de montagem de estande de } 01 \text { ou } 02 \\
\text { pisos (Mezanino) deve ser realizada estritamente dentro dos } \\
\text { limites da área locada, além da obrigatoriedade da apresentação } \\
\text { antecipada do Projeto, Laudo Técnico, A.R.T. - Anotação de } \\
\text { Responsabilidade Técnica do CREA-SP e o Termo de } \\
\text { Responsabilidade da Montadora disponível no manual de } \\
\text { participação da feira. } \\
\text { [...] pela montagem do estande de acordo com as regras, normas } \\
\text { e exigências contratuais estipuladas no Manual do Expositor e } \\
\text { também por todas aquelas expressas na legislação vigente. } \\
\text { A área de cada estande será demarcada pela PROMOTORA no } \\
\text { piso do PAVILHÃO. Para a montagem do estande, deverá ser } \\
\text { considerado o ÂNGULO INTERNO da marca no piso. } \\
\text { Todo expositor tem o direito de contratar qualquer que seja } \\
\text { empresa de montagem de projetos especiais, sendo que a mesma } \\
\text { cumpra com as obrigações deste manual. } \\
\text { A construção do estande será de inteira responsabilidade do } \\
\text { expositor, sendo vedada à construção de mezanino ou } 20 \text {. Piso. } \\
\text { Cabe ao expositor à montagem e instalação de seu estande } \\
\text { atendendo as exigências constantes neste manual e enviar à } \\
\text { Promotora o projeto, a planta baixa e imagem da elevação, com } \\
\text { cota de altura do mesmo até } 26 / 05 / 2017 \text { para o e-mail } \\
\text { montagemhortitec@rbbeventos.com.br. A altura máxima dos } \\
\text { estandes não poderá passar de } 4 \text { metros para os estandes internos } \\
\text { e } 6 \text { metros para os estandes externos. O expositor será } \\
\text { responsável, em caso de uso indevido, por perfurações e quebras } \\
\text { do material de montagem. }\end{array}$ \\
\hline $\begin{array}{l}\text { Var.: stand } \\
\text { building; } \\
\text { stand erection; } \\
\text { stand assembly }\end{array}$ & $\begin{array}{l}\text { All stand construction must be monitored during build-up by } \\
\text { the organiser's appointed structural engineer and floor } \\
\text { management team. Stands which appear to be complex, which } \\
\text { have not been submitted for approval, will be challenged and } \\
\text { construction may be stopped until satisfactory information has } \\
\text { been received. } \\
\text { No stand building or dismantling shall take place whilst the } \\
\text { public are in the venue. } \\
\text { However simple your stand erection is and the perceived risks } \\
\text { insignificant, we require something in writing from you that } \\
\text { shows that you have given due thought to the construction } \\
\text { process of your stand and the activities carried out on your stand } \\
\text { during the event and any possible risks involved - be they very } \\
\text { minimal or highly unlikely. } \\
\text { Stand assembly and disassembly: architecture, position, design } \\
\text { and technical facilities of the stand as well as the exhibits }\end{array}$ \\
\hline
\end{tabular}




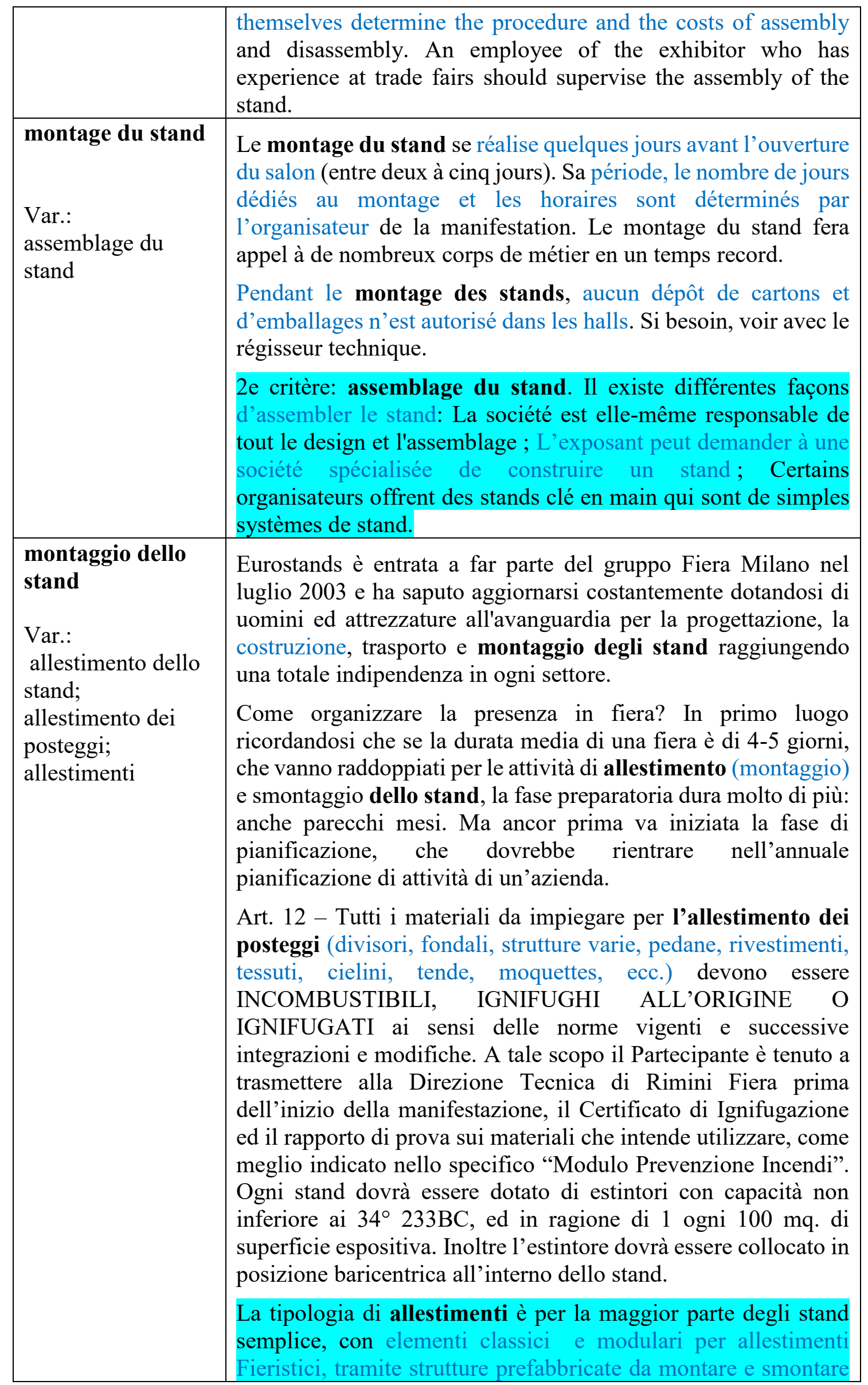




\begin{tabular}{|l|l|}
\hline il loco. Sui piazzali esterni sono posizionate tendostrutture e \\
gazebo messi a disposizione degli espositori e/o procurati dai \\
medesimi. I materiali utilizzati sono prevalentemente strutture \\
preallestite modulari metalliche, con tamponamenti o elementi \\
particolari di scenografia. Le chiusure in vetro devono essere \\
realizzate con lastre di vetro di sicurezza. I materiali combustibili \\
utilizzati per l'allestimento sono ignifughi all'origine o \\
successivamente trattati, e rispondono alle classi di reazione al \\
fuoco 1 e 2, a seconda del loro impiego. Gli Stand, nella \\
maggioranza dei casi, hanno una superficie variabile che è pari a \\
16 metri quadrati o multipli superiori sino a circa 300 mq. Nelle \\
giornate precedenti l'inizio della mostra è il singolo espositore \\
che allestisce il posteggio, direttamente o tramite allestitore di \\
propria fiducia, per quanto concerne le finiture e l'allestimento \\
interno per la valorizzazione della merce in esposizione. In tal \\
caso Fiera di Genova S.p.A. da l'informativa sulle tematiche di \\
sicurezza all'espositore il quale coordinerà i propri fornitori sotto \\
il profilo sicurezza ed igiene sul lavoro.
\end{tabular}

\section{manual do expositor}

Var.: guia do expositor; manual do expositor online; manual

manual digital do expositor (0)
O manual do expositor é o documento que irá lhe acompanhar durante todo o processo operacional da ABF FRANCHISING EXPO 2011. Você encontrará as principais informações sobre o evento, as normas, os direitos e deveres da promotora, bem como os de sua empresa e de seus contratados. As normas e os prazos estabelecidos neste documento devem ser cumpridos por sua empresa e por seus prestadores de serviços para garantir que sua exposição aconteça de forma tranquila e segura. A promotora se reserva o direito de estabelecer, a qualquer momento, novas normas que se façam necessárias para o bom andamento do evento. É de inteira responsabilidade da empresa expositora observar e cumprir as normas impostas neste manual.

O manual do expositor é peça obrigatória nas boas feiras. Trata de orientações da empresa organizadora para os expositores. Nele constam os formulários de requisição de tomadas de luz e força, de linha telefônica, de ligação de água e esgoto, de credenciais, de serviços de segurança e limpeza, etc. Há prazos muito rígidos para o preenchimento e entrega desses formulários. Os organizadores não assumem nenhum compromisso com solicitações feitas fora dos prazos estipulados.

O manual do expositor deve ser entregue no ato da contratação, juntamente com o regulamento da feira. E deve ser lido com muita atenção.

O manual do expositor geralmente é um documento impresso ou digital, elaborado pela empresa promotora do evento e que contém informações como datas importantes, dados técnicos a serem seguidos pela montadora, especificações para montagem e formulários a serem preenchidos pelo expositor, como por exemplo: credenciais, quantidade de energia elétrica a ser 


\begin{tabular}{|c|c|}
\hline & 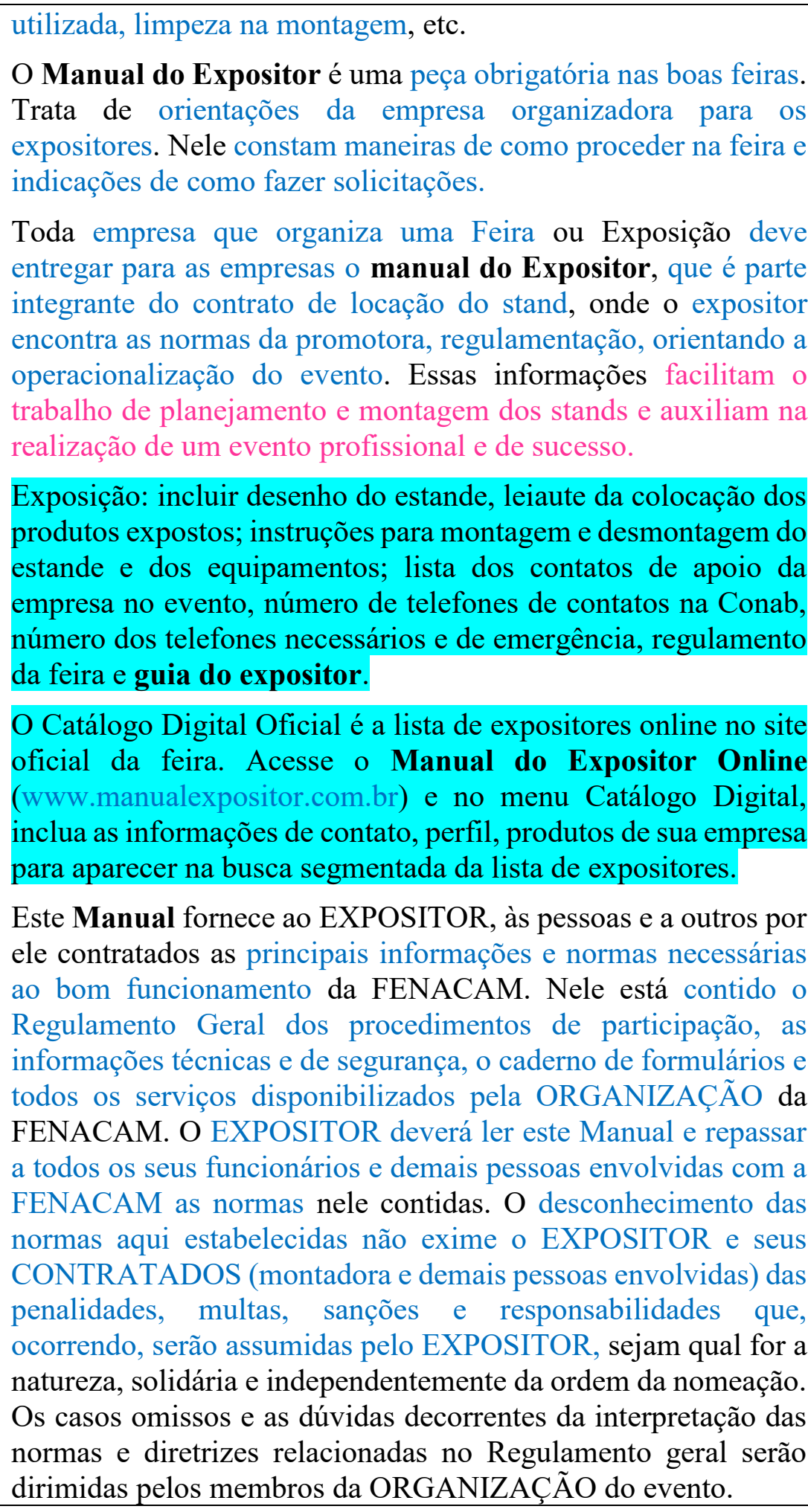 \\
\hline $\begin{array}{l}\text { Var.: exhibitors } \\
\text { manual; } \\
\text { exhibitor's manual; } \\
\text { exhibition manual; }\end{array}$ & $\begin{array}{l}\text { Our Exhibitor Manual has been designed to provide you with } \\
\text { all the relevant information you need to create your stand and } \\
\text { ensure the pre-show planning goes as smoothly as possible. } \\
\text { Your Exhibitor Manual: This manual has been produced to help } \\
\text { you prepare for a successful exhibition. It is important to ensure } \\
\text { that you have taken all the necessary actions in accordance with } \\
\text { the checklist by the stated deadlines in order to prevent possible }\end{array}$ \\
\hline
\end{tabular}




\begin{tabular}{|c|c|}
\hline $\begin{array}{l}\text { online exhibitor } \\
\text { manual; } \\
\text { exhibitors' } \\
\text { echnical } \\
\text { nanual }\end{array}$ & 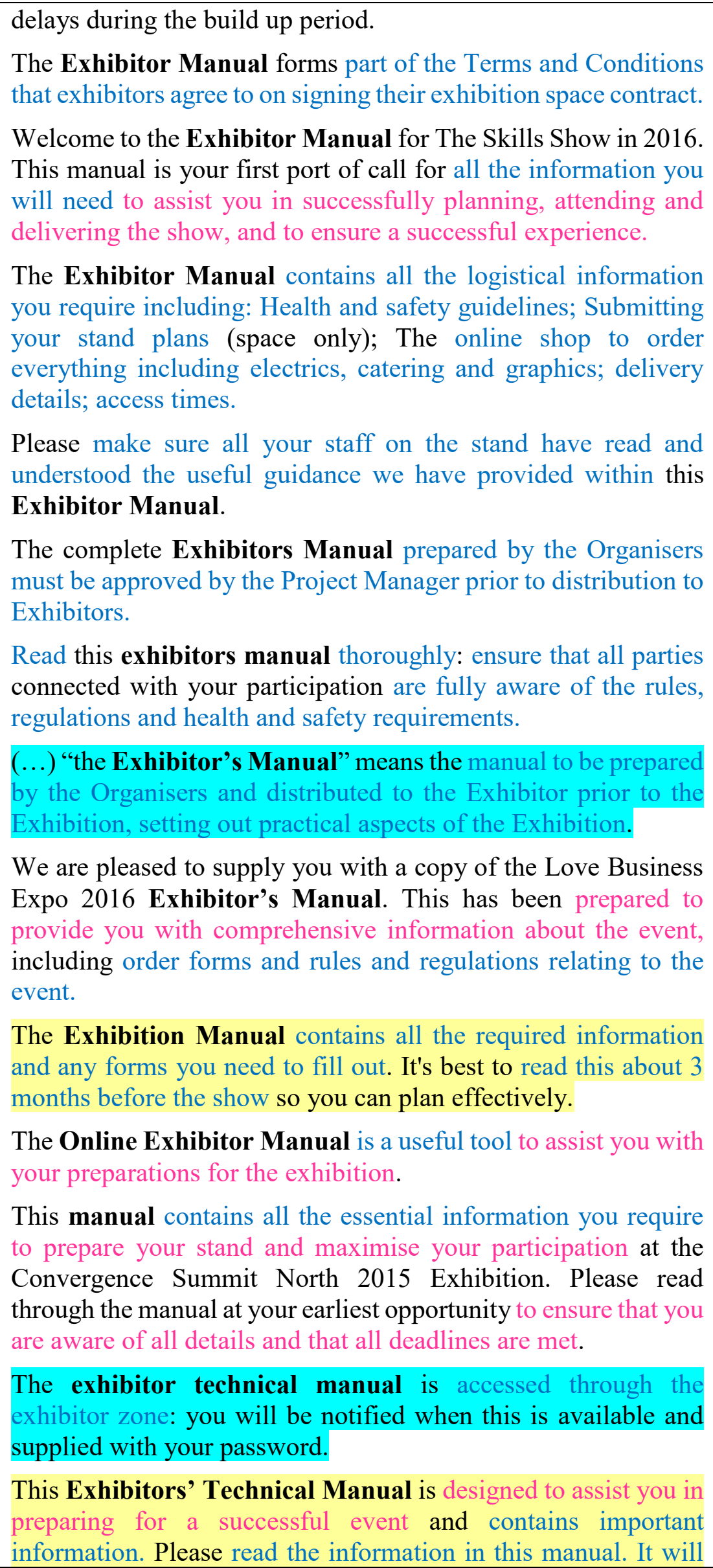 \\
\hline
\end{tabular}




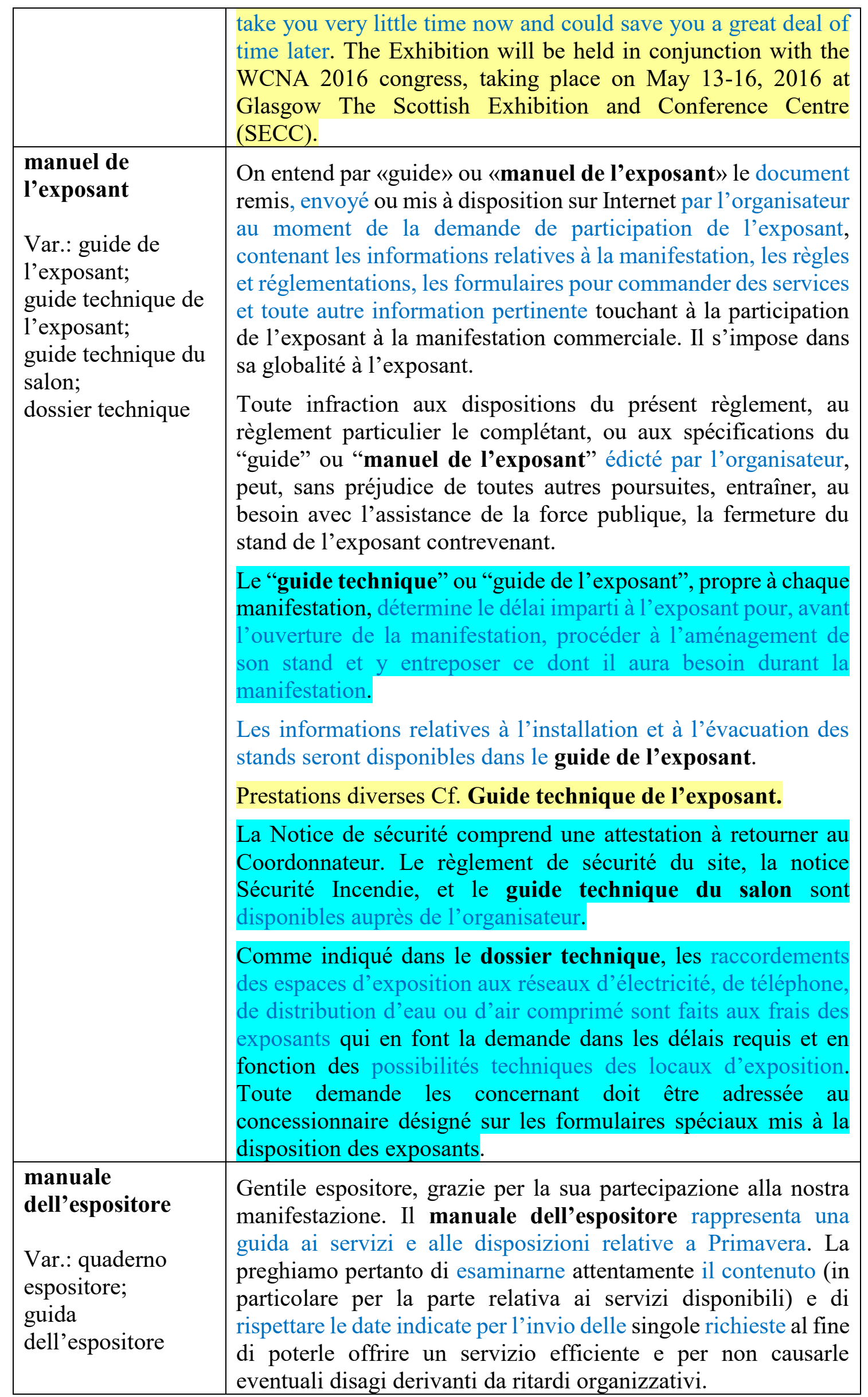


agenda

dell'espositore (0)
Quaderno Espositori: Questo fascicolo è stato elaborato per facilitare la conoscenza della realtà in cui si opera nell'accedere al polo espositivo di Bergamo. Contiene le regole di ingresso e le norme da osservare per ottemperare alle disposizioni di prevenzione incidenti e infortuni, la modulistica utile per chiedere servizi di supporto per la propria presenza in Fiera e alcune notizie e riferimenti per approfondire la conoscenza del quartiere espositivo.

Ai sensi della legislazione in vigore e conformemente alla guida degli espositori, gli stand muniti di pedane con un'altezza superiore ai $2 \mathrm{~cm}$ dovranno essere equipaggiati di apposito accesso per persone a mobilità ridotta, senza che lo stesso sconfini nelle corsie.

\section{corredores do pavilhão}

Var.: corredor; ruas de circulação; vias de circulação
Os corredores do pavilhão são de uso comum, não sendo neles permitido o aliciamento de visitantes ou distribuição de impressos quaisquer outros artigos, bem como não será permitida, neles ou sobre eles, a colocação ou fixação de faixas, painéis, motivos decorativos, tapetes, robôs, vitrines vivas ou qualquer material, objeto ou pessoa que caracterize propaganda e divulgação.

Os corredores do Expo Center Norte são de uso comum, não sendo neles permitido o aliciamento de visitantes ou distribuição de impressos ou brindes, apresentações artísticas, assim como não é permitido neles ou sobre eles a colocação de faixas, painéis, motivos decorativos, mesas, cadeiras, tapetes, etc.

Solicitamos enfaticamente aos Expositores e Montadores que determinem em seus projetos área demarcada para possíveis filas que se formem durante a degustação de produtos e/ou distribuição de brindes. Esta área deverá estar demarcada nas áreas limites dos estandes. Esta providência deverá ser tomada com o intuito de evitar ao máximo que se formem filas nos corredores atrapalhando assim a circulação dos visitantes. Caso isso ocorra o Organizador poderá solicitar a qualquer tempo a suspensão da ação.

$\mathrm{O}$ projeto arquitetônico determina as áreas individuais (espaço para estandes), os corredores para o tráfego de pessoas, as áreas comuns, as áreas reservadas, entre outras [...].

A montagem dos estandes deverá estar concluída no dia 11 de setembro de 2016, até as 18 horas, para colocação dos carpetes nas ruas de circulação.

As vias de circulação são de uso comum, não sendo permitida a distribuição de panfletos, impressos, brindes, revistas ou 


\begin{tabular}{|c|c|}
\hline & $\begin{array}{l}\text { qualquer outro material durante o horário de funcionamento, sob } \\
\text { pena de recolhimento do material pela Promotora. }\end{array}$ \\
\hline gangway & "Gangway" means any passage or walkway within the Centre. \\
\hline \multirow[t]{2}{*}{$\begin{array}{l}\text { Var.: aisle; } \\
\text { corridor }\end{array}$} & $\begin{array}{l}\text { Aisles, as escape routes, must remain, at all times, passable, } \\
\text { including during set-up and dismantling periods. All material } \\
\text { must be kept within the limits of the assembly area or the stand, } \\
\text { leaving aisles and other common areas completely free. The } \\
\text { cleaning services of ExCeL London will remove any object } \\
\text { deposited in these areas, with the exhibitor having no right to } \\
\text { claim for damages. }\end{array}$ \\
\hline & $\begin{array}{l}\text { All required exits, including entrance/exit and lobby areas of } \\
\text { each hall, the center exit pod and all corridors/aisles shall be } \\
\text { unlocked and kept free of exhibits, booths, tables, registration } \\
\text { desks and all other obstructions during show hours. }\end{array}$ \\
\hline \multirow{7}{*}{$\begin{array}{l}\text { allée } \\
\text { Var.: allées de } \\
\text { circulation; } \\
\text { allée de circulation } \\
\text { du public; } \\
\text { couloir de } \\
\text { circulation; } \\
\text { couloir }\end{array}$} & \\
\hline & $\begin{array}{l}\text { Les pavillons de la Porte de Versailles sont numérotés de } 1 \text { à } 7 \text {. } \\
\text { Dans chaque pavillon. les allées sont désignées par une lettre. }\end{array}$ \\
\hline & $\begin{array}{l}\text { N'oubliez pas que l'allée est aussi dans votre zone d'action. Ne } \\
\text { vous limitez pas à l'espace de votre stand, restez debout, } \\
\text { souriant, mobile. Donnez envie qu'on vous aborde. Et s'il vous } \\
\text { plaît, ne vous mettez jamais dos à l'allée, pour mieux vous } \\
\text { concentrer sur un travail urgent à faire sur votre ordinateur } \\
\text { portable. Vous feriez fuir à tout jamais les plus vaillants de vos } \\
\text { prospects! }\end{array}$ \\
\hline & $\begin{array}{l}\text { Toute construction ou élément de décor supérieur à } 3,00 \mathrm{~m} \text { et } \\
\text { dans la limite de } 5,00 \mathrm{~m} \text { par rapport au sol du bâtiment, érigé en } \\
\text { mitoyenneté, doit respecter un retrait de } 1,00 \mathrm{~m} \text { avec le stand } \\
\text { voisin et les allées de circulation. }\end{array}$ \\
\hline & $\begin{array}{l}\text { Si le stand est fermé par des portes, celles-ci doivent s'ouvrir } \\
\text { dans le sens de la sortie, sans système de condamnation et sans } \\
\text { débattre sur l'allée de circulation du public. }\end{array}$ \\
\hline & $\begin{array}{l}\text { Circulation dans le Parc des expositions : Respect du code de la } \\
\text { route; Vitesse limitée à } 20 \mathrm{~km} / \mathrm{h} \text {; Arrêt et stationnement interdits } \\
\text { sur les couloirs de circulation; La circulation est interdite dans } \\
\text { les halls à tous véhicules. }\end{array}$ \\
\hline & $\begin{array}{l}\text { Les différents types de stands pour un salon sont influencés par } \\
\text { l'attribution de l'espace et l'accès aux couloirs. }\end{array}$ \\
\hline $\begin{array}{l}\text { Var.: } \\
\text { corsie dei } \\
\text { padiglioni; } \\
\text { corsie di pas }\end{array}$ & $\begin{array}{l}\text { La Fiera di Genova S.p.A. provvede alla vigilanza in materia di } \\
\text { sicurezza, che potrà essere effettuata dai tecnici incaricati dalla } \\
\text { medesima, controllando che durante le fasi di allestimento, } \\
\text { mostra e disallestimento: Non si creino restringimenti delle } \\
\text { corsie; Non siano presenti possibili disturbi o fonti di } \\
\text { rallentamento del flusso delle persone lungo le corsie, quali }\end{array}$ \\
\hline
\end{tabular}




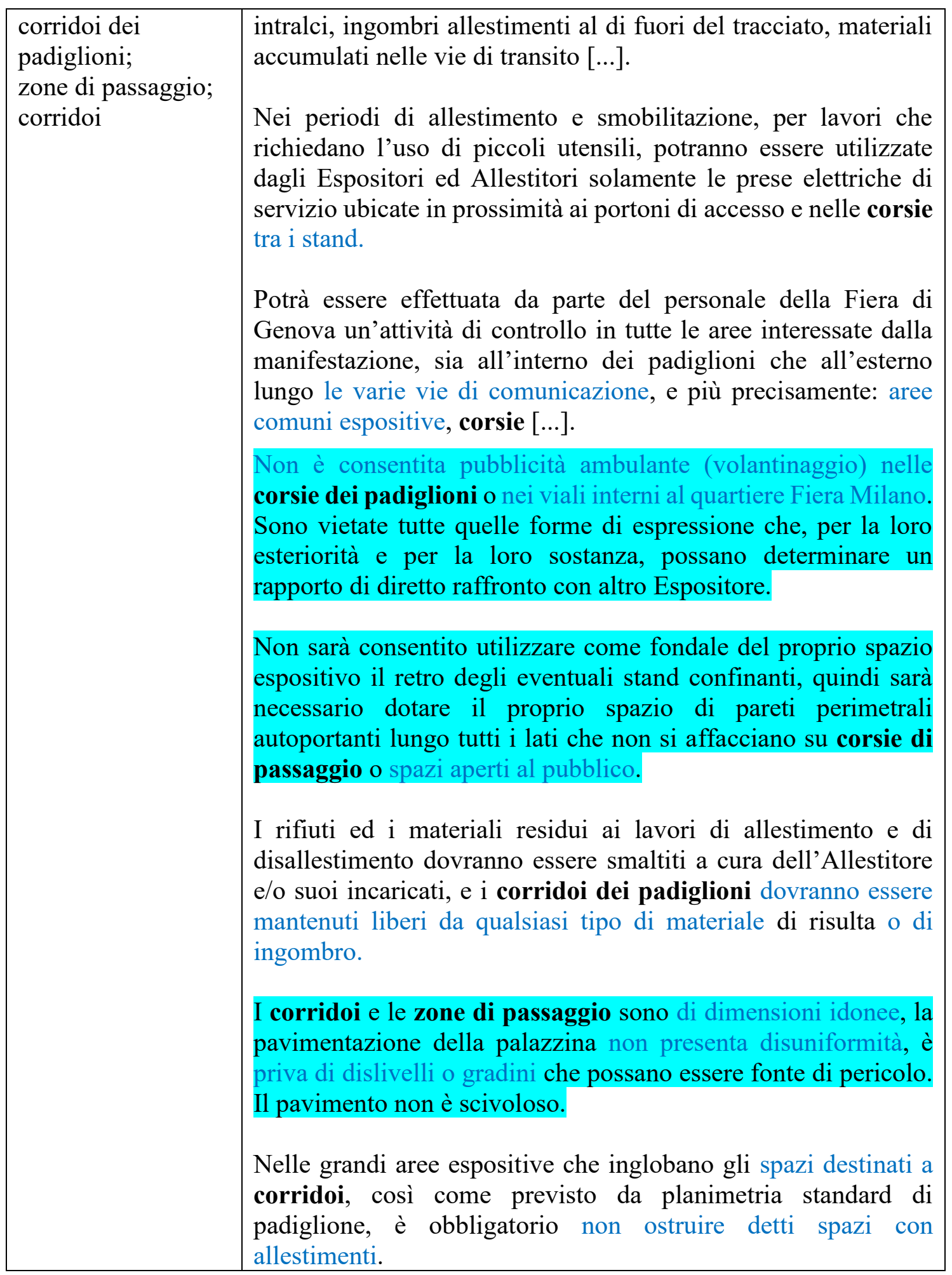

Nos Apêndices seguintes apresentamos as definições elaboradas antes e após a análise dos ganchos terminológicos nas quatro línguas. 


\section{APÊNDICE V - DEFINIÇÕES ELABORADAS ANTES DA ANÁliSE DOS GANCHOS TERMINOLÓGICOS}

Apresentamos, a seguir, a definição de 10 (dez) termos do dicionário, elaboradas antes da análise dos ganchos terminológicos:

1. estande: -s.m. espaço de exposição alugado pelo expositor para exibir produtos e serviços em uma feira.

2. expositor: - s.m. aquele que expõe seus produtos e/ou serviços em uma feira.

3. feira: -s.f. local de exposição, demonstração e comercialização de produtos e/ou serviços pelos expositores em estandes.

4. centro de exposições: -loc.adj. local de grandes dimensões que abriga pavilhões divididos em setores onde são realizadas as feiras.

5. pavilhão: -s.m. local que recebe feiras e exposições e possui amplas áreas de exposição.

6. visitante da feira: -loc.adj. aquele que vai a uma feira para aprender algo de novo, estabelecer novos contatos, buscar conhecimento e informação ou adquirir um produto ou serviço.

7. testeira de identificação do estande:-loc.adj. placa instalada no estande com a razão social da empresa expositora.

8. montagem do estande: -loc.adj. ação de construir o estande e colocar materiais e produtos que serão expostos durante a feira.

9. manual do expositor:-loc.adj. documento de leitura obrigatória, contendo as informações sobre a participação do expositor em uma feira, com regras, regulamentos e formulários para a contratação de serviços.

10. corredores do pavilhão: -loc.adj. áreas internas do pavilhão destinadas à circulação de visitantes e expositores durante a realização da feira.

Vale reforçar que, após os estágios de pesquisa no exterior, a lista de termos-entrada do dicionário em português foi reconfigurada (termos foram acrescentados, outros excluídos). A redação das definições, após a análise dos ganchos terminológicos (descrita no Apêndice IV), dos 10 (dez) termos apresentados acima pode ser conferida no Apêndice VI a seguir. 


\section{APÊNDICE VI - REVISÃo E APRIMORAMENTO DAS DEFINIÇÕES APÓS A ANÁLISE DOS GANCHOS TERMINOLÓGICOS}

As definições dos termos-entrada em português que compõem a macroestrutura do dicionário foram revisadas e aprimoradas após a análise dos ganchos terminológicos apresentada no Apêndice IV. A seguir, apresentamos a definição de 10 (dez) termos do dicionário elaboradas após a análise dos ganchos terminológicos:

1. estande: - s.m. espaço de exposição provisório e atrativo alugado pelo expositor para a participação em uma feira que tem por objetivo exibir produtos e/ou oferecer serviços e chamar a atenção do público-alvo, levando em consideração as necessidades dos visitantes, equipado com carpete, paredes divisórias, iluminação e testeira de identificação, completo e a postos durante toda a realização da feira, desde a sua abertura até o seu encerramento.

2. expositor: - s.m. 1. aquele que contrata junto à organizadora da feira um estande para a exposição de seus produtos e oferecimento de seus serviços, podendo ser um fabricante ou um distribuidor, tendo como objetivos principais a geração de vendas, no curto e médio prazos, a obtenção de novos contatos comerciais, a introdução e promoção de novos produtos e/ou serviços, a fidelização de clientes, o contato com a concorrência e a consolidação da imagem da empresa. 2. suporte utilizado para expor ou demonstrar um produto no interior do estande $-\mathrm{V}$. display.

3. feira: - s. f. local de exposição, difusão, demonstração e venda de produtos e/ou serviços por empresas expositoras, no interior de estandes montados em pavilhões localizados em centros de exposições, organizado e promovido por empresas especializadas no ramo.

4. centro de exposições: -loc.adj. local de grandes dimensões que abriga pavilhões onde empresas responsáveis pela organização (organizadora), promoção (promotora) e montagem (montadora de estandes) realizam feiras para a exposição e vendas de produtos de empresas expositoras pertencentes a um ou mais segmentos da indústria para o público geral ou especializado.

5. pavilhão: -s.m. espaço físico climatizado onde são realizadas as feiras, dividido em área de exposição, onde são montados os estandes, praça de alimentação, área de conveniência, prestadores de serviços, locais reservados à administração, pronto socorro, corredores de circulação e saídas de emergência, podendo ser redistribuído pela organização da feira para acomodar os espaços não ocupados, respeitando a dimensão da área locada pelos expositores, com a infraestrutura necessária para a realização de uma feira (redes de energia elétrica e hidráulica, gás, telefonia, internet, estacionamento, toilets, sinalização, etc.).

6. visitante da feira: -loc.adj. aquele que visita uma feira, mediante convite ou pagamento de ingresso, para percorrer os estandes das empresas expositoras, estabelecer novos contatos, buscar conhecimento e informações sobre produtos e processos, realizar parcerias e negócios, adquirir um produto e/ou serviço ou participar de eventos paralelos oferecidos na feira; cliente em potencial, profissional ou consumidor final (público geral).

7. testeira de identificação do estande: -loc.adj. placa instalada no estande vertical ou horizontalmente nas faces voltadas para as ruas contendo a razão social da empresa expositora e podendo avançar em até $0,25 \mathrm{~m}$ sobre as ruas de circulação, desde que instaladas acima de $3,00 \mathrm{~m}$ e tenham, no máximo, $1,00 \mathrm{~m}$ de altura por $2,00 \mathrm{~m}$ de comprimento, obedecendo aos recuos obrigatórios em relação ao limite da área com os 
vizinhos.

8. montagem do estande: -loc.adj. ação de construir o estande, instalar paredes divisórias, revestimentos de piso (madeira ou carpete), máquinas e equipamentos e realizar o acabamento, de responsabilidade do expositor, mediante autorização da organizadora a partir da apresentação antecipada do projeto, laudo técnico, A.R.T. (Anotação de Responsabilidade Técnica) do CREA e o termo de responsabilidade da montadora.

9. manual do expositor: -loc.adj. documento impresso ou digital, parte integrante do contrato de locação do estande, elaborado pela empresa organizadora da feira, entregue no ato da contratação, juntamente com o regulamento da feira, ao expositor, contendo datas, local, endereço e horários de funcionamento da feira, especificações técnicas e de segurança para montagem dos estandes, lista de fornecedores oficiais e formulários para a requisição de serviços (tomadas de luz e força, linha telefônica, ligação de água e esgoto, credenciais, serviços de segurança e limpeza, etc.), bem como os direitos e deveres da organizadora, dos expositores e de seus contratados, as normas da organizadora orientando a operacionalização da feira (orientações técnicas e operacionais relativas aos períodos de montagem, realização e desmontagem).

10. corredores do pavilhão: -loc.adj. áreas internas do pavilhão, de uso comum, identificadas por letras, algarismos ou ambos, destinadas à circulação de visitantes e expositores durante a realização da feira e que permite a visitação dos estandes, não podendo ser utilizada para o aliciamento de visitantes, distribuição de impressos ou brindes e apresentações artísticas ou para a colocação de faixas, painéis, motivos decorativos, mesas ou cadeiras, sob pena de advertência.

A redação final das definições, reformuladas após a defesa, dos 10 (dez) termos apresentados acima pode ser conferida no Apêndice VII a seguir. 


\section{APÊNDICE VII - REFORMULAÇÃO DAS DEFINIÇÕES APÓS A DEFESA DA TESE}

Após a defesa da tese, as definições dos termos-entrada em português foram reformuladas, conforme sugestão da banca: partes serão excluídas e acrescentadas em notas (entre colchetes), outras adicionadas (sublinhado) ou modificadas (itálico) para a futura publicação $^{143}$ do dicionário. Apresentamos, a seguir, a definição de 10 (dez) termos do dicionário reformuladas após a defesa:

1. estande: - s.m. espaço de exposição [provisório e atrativo alugado pelo expositor para a participação em uma feira que tem por objetivo] equipado para exibir produtos e/ou oferecer serviços em feiras. [e chamar a atenção do público-alvo, levando em consideração as necessidades dos visitantes, equipado com carpete, paredes divisórias, iluminação e testeira de identificação, completo e a postos durante toda a realização da feira, desde a sua abertura até o seu encerramento.]

2. expositor: - s.m. fabricante ou distribuidor [aquele] que contrata junto à organizadora [da feira] um estande para a exposição de produtos e/ou oferecimento de serviços em feiras. [podendo ser um fabricante ou um distribuidor, tendo como objetivos principais a geração de vendas, no curto e médio prazos, a obtenção de novos contatos comerciais, a introdução e promoção de novos produtos e/ou serviços, a fidelização de clientes, o contato com a concorrência e a consolidação da imagem da empresa.] 2. suporte utilizado no estande para expor ou demonstrar um produto. [no interior do estande] - V. display.

3. feira: - s. f. local de exposição, [difusão,] demonstração e venda de produtos e serviços por empresas expositoras [,no interior de] em estandes montados em pavilhões localizados em centros de exposições, organizado e promovido por empresas especializadas no ramo.

4. centro de exposições: - s.prep. local de grandes dimensões que abriga pavilhões onde empresas responsáveis pela organização (organizadora), promoção (promotora) e montagem (montadora de estandes) realizam feiras para a exposição e vendas de produtos de empresas expositoras [pertencentes a] de um ou mais segmentos da indústria para o público geral ou especializado.

5. pavilhão: - s.m. espaço físico climatizado onde são realizadas as feiras, dividido em área de exposição, [onde são montados os estandes,] praça de alimentação, área de conveniência, prestadores de serviços, locais reservados à administração, pronto socorro, corredores de circulação e saídas de emergência, [podendo ser redistribuído pela organização da feira para acomodar os espaços não ocupados, respeitando a dimensão da área locada pelos expositores,] com a infraestrutura necessária para [a realização de uma feira] o seu funcionamento (redes de energia elétrica e hidráulica, gás, telefonia, internet, estacionamento, sanitários, sinalização, etc.).

6. visitante da feira: - s.prep. aquele que visita uma feira, mediante convite ou pagamento de ingresso. [,para percorrer os estandes das empresas expositoras, estabelecer novos contatos, buscar conhecimento e informações sobre produtos e processos, realizar parcerias e negócios, adquirir um produto e/ou serviço ou participar de eventos paralelos oferecidos na feira.] V. visitante profissional; V. público geral.

7. testeira de identificação do estande:- s.prep. placa instalada no estande [vertical ou horizontalmente] nas faces voltadas para as ruas de circulação contendo a razão social

${ }^{143}$ Dependendo da editora e do formato da publicação - impresso ou eletrônico -, novos ajustes serão realizados. 
da empresa expositora. [e podendo avançar em até $0,25 \mathrm{~m}$ sobre as ruas de circulação, desde que instaladas acima de 3,00m e tenham, no máximo, 1,00m de altura por $2,00 \mathrm{~m}$ de comprimento, obedecendo aos recuos obrigatórios em relação ao limite da área com os estandes vizinhos.]

8. montagem do estande: -s.prep. ação de construir o estande (instalar paredes divisórias, revestimentos de piso [(madeira ou carpete)], máquinas e equipamentos e realizar o acabamento), de responsabilidade do expositor, mediante autorização da organizadora [a partir da] e apresentação antecipada do projeto, laudo técnico, A.R.T. (Anotação de Responsabilidade Técnica) do CREA e termo de responsabilidade da montadora.

9. manual do expositor: -s.prep. documento impresso ou digital, parte integrante do contrato de locação do estande, elaborado pela empresa organizadora da feira, entregue ao expositor no ato da contratação, [juntamente com o regulamento da feira, ao expositor,] contendo datas, local, endereço e horários de funcionamento da feira, especificações técnicas e de segurança para montagem dos estandes, lista de fornecedores oficiais, formulários para a requisição de serviços [(tomadas de luz e força, linha telefônica, ligação de água e esgoto, credenciais, serviços de segurança e limpeza, etc.), bem como os direitos e deveres da organizadora, dos expositores e de seus contratados,] e as normas de [da organizadora orientando a] operacionalização da feira [(orientações técnicas e operacionais] relativas aos períodos de montagem, realização e desmontagem.

10. corredores do pavilhão: - s.prep. [áreas internas do] ruas de circulação do pavilhão, de uso comum, identificadas por letras, algarismos ou ambos, destinadas [à circulação] ao tráfego de visitantes e expositores durante a realização da feira e que permite [a visitação dos] o acesso aos estandes. [,não podendo ser utilizada para o aliciamento de visitantes, distribuição de impressos ou brindes e apresentações artísticas ou para a colocação de faixas, painéis, motivos decorativos, mesas, cadeiras ou tapetes, sob pena de advertência.] 


\section{APÊNDICE VIII - APRESENTAÇÃO DO DICIONARIO NO FORMATO SDL MULTITERM}

Os verbetes do Dicionário Multilíngue de Termos do Setor Feirístico, elaborados por meio da ferramenta SDL MultiTerm, a lista de abreviaturas e as fontes de onde os contextos de uso do dicionário foram retirados nas quatro línguas, serão mantidos em acervo reservado na Biblioteca Digital de Teses e Dissertações da USP, de acordo com a Resolução CoPGr No 7569 , de 03 de outubro de 2018. 


\section{APÊNDICE IX - AMOSTRA DE 1 (UM) VERBETE EXTRAÍDO DA PRIMEIRA VERSÃO DO DICIONÁRIO ELABORADA NO MULTITERM}

A seguir, apresentamos uma amostra de 1 (um) verbete extraído da versão original e mais completa do dicionário elaborada por meio da ferramenta SDL MultiTerm que contém todos os contextos e informações coletadas sobre os termos nas quatro línguas. Essa primeira versão do dicionário foi elaborada a apartir de um arquivo em WORD de 537 páginas (iniciado no mestrado e complementado no doutorado) convertido, primeiramente, para o EXCEL pelo Professor Eros Zachetta da Universidade de Bolonha e, posteriormente, para o formato SDL MultiTerm pela Professora Claudia Lecci, da mesma Universidade (durante os estágios de pesquisa no exterior). Na sequência, apresentamos o mesmo verbete extraído da versão final do dicionário, elaborado após a revisão dos termos, a análise dos ganchos terminológicos e a escolha dos contextos em cada língua, de modo a elucidar o extenso e minucioso trabalho realizado para a confecção de cada verbete do dicionário, como pode ser observado a seguir: 
VERSÃO ORIGINAL

Página 1 de 6

Entry ld: 95

\section{ENTRADA EM PORTUGUÊS}

estande - s.m.

OUTDES PORTUGUÊS: espaço de exposição; stand

CONTEXTO PORTUGUÊS 1: O estande é como a vitrine do produto ou serviço a ser divulgado e negociado, estrutura em que se materializa a participação de empresas numa feira $e_{r}$ como tal, não devem ser poupados esforços na sua elaboração. É a imagem que tem por objetivo chamar a atenção do público-alvo.

CONTEXTO PORTUGUÊS 2: A parte mais delicada e crítica de qualquer feira ou exposição é vender bem os espaços. Por vender bem se deve entender: selecionar muito bem as empresas-alvo, comunicar-se com elas, visitá-las sempre que possível e tratar de fechar a venda dos espaços de exposição.

CONTEXTO PORTUGUÊS 3: Entre as informações que podem ser mensuradas estão: a quantidade de visitas ao estande pelo número de visitantes da feira; a quantidade de visitas ao estande pelo número de clientes potenciais, clientes atuais $\mathrm{e}$ curiosos; o número total de vendas diretas realizadas e a quantidade de oportunidades de negócios criadas a partir do evento.

CONTEXTO PORTUGUÊS 4: É comum que, em feiras setoriais, os organizadores executem uma farta divulgação entre o público-alvo; contudo, nunca é demais fazer contatos diretos através do relacionamento empresarial ou institucional já existente, o que pode garantir uma maior visitação ao estande durante a realização da feira.

CONTEXTO PORTUGUÊS 5: Enviamos mala direta e, por telefone, os gerentes ligam para clientes e não clientes, incentivando-os a visitar nosso estande, onde sempre lançamos produtos, mantemos um buffet bastante agradável, $\mathrm{e}$ fazemos sorteios. Conectividade é um dos principais elementos do marketing e ajuda as pessoas saberem com clareza quem é a empresa.

CONTEXTO PORTUGUÊS 6: O horário de chegada do pessoal do estande deverá anteceder 30 minutos à abertura do evento todos os dias. $O$ estande deve estar aberto e pronto para receber os visitantes desde o primeiro instante de funcionamento da feira. Fica terminantemente proibido o fechamento do estande antes do horário de encerramento do evento.

CONTEXTO PORTUGUÊS 7: Quanto ao estande - o local deve estar organizado de forma adequada à visita e troca de ideias mais profundas, não podendo nunca ficar ao abandono. Não deve ser território do vendedor, nem do comprador, mas sim um território neutro.

CONTEXTO PORTUGUÊS 8: O estande é uma extensão da sua empresa, por isso o projeto é tão importante.

CONTEXTO PORTUGUÊS 9: É necessário fazer do estande a imagem estendida da empresa. $O$ estande mostra a " cara" da empresa.

CONTEXTO PORTUGUÊS 10: O estande deve ser um local agradável e atraente para o visitante. Deve ser fácil ao visitante identificar rapidamente o tipo de produto ou serviço oferecido. A empresa deve apresentar o que o visitante gostaria de ver. Este processo de "empatia" deve ser praticado pela empresa ao projetar o seu estande e escolher o que apresentar ao visitante.

CONTEXTO PORTUGUÊS 11: A primeira regra a ser observada é que um estande deve estar completo e a postos durante todo o tempo, do instante da abertura ao instante final da feira.

CONTEXTO PORTUGUÊS 12: A definição do estande deve ainda levar em conta: o público-alvo, as mensagens e imagem que deverão ser comunicadas; os produtos a serem colocados em destaque.

CONTEXTO PORTUGUÊS 13: 
Toda a atenção deve ser dada ao mobiliário e à iluminação. 0 estande deve ser agradável e não ofuscar seu ponto principal: os produtos expostos.

CONTEXTO PORTUGUÊS 14: Para todos os estandes é obrigatória a colocação de carpete, montagem de paredes divisórias e iluminação, e no mínimo a testeira de identificação do expositor/estande.

CONTEXTO PORTUGUÊS 15: Todos os estandes deverão cumprir normas de edificação e segurança determinadas pelo Regulamento Geral do Evento.

FONTE CONTEXTO PORTUGUÊS 1: MOFE

FONTE CONTEXTO PORTUGUÊS 2: MFES

FONTE CONTEXTO PORTUGUÊS 3: FNPRPPE

FONTE CONTEXTO PORTUGUES 4: OBPF|

FONTE CONTEXTO PORTUGUESS 5: RFC1

FONTE CONTEXTO PORTUGUÊS 6: MEFIS

FONTE CONTEXTO PORTUGUÊS 7: OSFI

FONTE CONTEXTO PORTUGUES 8: GDMFH

FONTE CONTEXTO PORTUGUÊS 9: DCPFS

FONTE CONTEXTO PORTUGUÊS 10: CPFE

FONTE CONTEXTO PORTUGUÊS 11: EFBN

FONTE CONTEXTO PORTUGUES 12: MOFE

FONTE CONTEXTO PORTUGUES 13: MFES

FONTE CONTEXTO PORTUGUÊS 14: MEFIS

FONTE CONTEXTO PORTUGUÊS 15: MECI

\section{EQUIVALENTE EM INGLÊS}

stand

OUTDES INGLÊS: $\quad$ booth US; exhibit US; stall; exhibition stand; trade stand; exhibit space

CONTEXTO INGLÊS 1: Letting your customers know you will be there is a vital element to your success and is often overlooked. Examine all your communications with potential and existing clients. There may be more opportunities than you think to alert people to the fact you will have a stand at the event.

CONTEXTO INGLÊS 2: The trade fair stand is the companies calling card, and as such, should be of a standard that is in keeping with the products exhibited and the significance of the company both in size and design and appearance. A presentation of the exhibits which takes into account the needs of the visitor must be a priority. The trade fair stand should be attractive to the eye and pleasant to the ear, and can also appeal to the visitor's emotions.

CONTEXTO INGLÊS 3: The stand is the key factor for a successful fair participation. The concept and design of the stand is determined from the objectives of the fair participation, because the question is: "What should be reached through the stand?". The first important stand features are its size and its location on the exhibition floor. The characteristics of the exhibition hall, such as the height of the ceiling, the entrances and gangways, the neighbouring stands, and the emergency exits must also be taken into consideration when designing the stand.

CONTEXTO INGLÊS 4: Therefore, the stand is an excellent platform for your company to let your customers know how important they are. You should know in advance which of your customers is attending and plan to spend quality time with them, not only in the stand, but at social functions in the evenings. Find out if they have specific requirements or products questions, and have the appropriate staff member on hand to answer them. Don't overlook this important customer activity, or your competition could seize the advantage.

CONTEXTO INGLÊS 5: 
Página 3 de 6

It is important that the stand is clearly and logically structured, and that the design reflects the corporate identity.

CONTEXTO INGLÊS 6: The stand is the key factor for a successful fair participation.

CONTEXTO INGLÊS 7: Please ensure your stand is easily accessible to all visitors. Disabled persons must be provided with the same service that is provided to others and it is unlawful to not make a reasonable adjustment for a disabled person.

CONTEXTO INGLÊS 8: Your stand is an open shop without windows or doors. Please take a few moments to consider how you can secure your products and belongings while on site.

CONTEXTO INGLÊS 9: A trade fair stand should be information driven. It must also have the right combination of lighting, open space and graphic presentation to help visitors focus and separate themselves from the noise level of the trade fair. A stand that uses new, lightweight materials, which reduce shipping and set-up time as well as crate, labour and storage costs, offers many advantages.

CONTEXTO INGLEES 10: During the open days please ensure your stand is manned throughout the day and all exhibits remain on display during the open hours. In order that no discourtesy is shown to last minute visitors, there must be no dismantling of any displays or exhibits before 1600 hours on Wednesday 5 October 2016.

CONTEXTO INGLÊS 11: Companies whose booths are visually appealing and are larger in size usually receive greater recall by visitors.

CONTEXTO INGLÊS 12: A booth is more like a billboard than a datasheet. Attendees won't stand in your booth to read its signage, and in any case it is the job of booth staff to communicate key messages and product features. The booth should be an environment for selling.

CONTEXTO INGLÊS 13: It is the responsibility of the Exhibitor to ensure that anyone contracted to build their stand/exhibit is competent to do so.

CONTEXTO INGLÊS 14: Every exhibition stand is a miniature workplace and therefore needs a risk assessment.

CONTEXTO INGLES 15: The RHS requests that children under the age of 16 are not permitted to assist with the actual set-up, running or breakdown of trade stands.

FONTE CONTEXTO INGLÊS 1: UHEMPE

FONTE CONTEXTO INGLÊS 2: SPTFTE

FONTE CONTEXTO INGLÊS 3: HDFE

FONTE CONTEXTO INGLÊS 4: SEM

FONTE CONTEXTO INGLÊS 5: HDFE

FONTE CONTEXTO INGLÊS 6: HDFE

FONTE CONTEXTO INGLÊS 7: WFESEMF

FONTE CONTEXTO INGLÊS 8: TCSLEM

FONTE CONTEXTO INGLÊS 9: MTFEEPEM

FONTE CONTEXTO INGLÊS 10: GIR

FONTE CONTEXTO INGLEES 11: TSMM

FONTE CONTEXTO INGLEES 12: TSWTSMBP

FONTE CONTEXTO INGLÊS 13: SHBEM

FONTE CONTEXTO INGLÊS 14: SESM

FONTE CONTEXTO INGLÊS 15: WPSSEG

\section{EQUIVALENTE EM FRANCÊS}

\section{stand}

OUTDES FRANCÊS: stand d'exposition; kiosque

CONTEXTO FRANCÊS 1: Stand: construction provisoire édifiée par les participants à une foire, à un salon ou à une exposition pour $y$ accueillir des visiteurs et présenter des produits. 
CONTEXTO FRANCÊs 2: On entend par "stand" l'espace occupé pour la présentation de produits ou services ou l'espace utilisé pour réunir des clients ou confrères.

CONTEXTO FRANCÊS 3: Une démonstration sur place est un élément clé pour le succès d'un stand d'exposition. II faut préparer les démonstrations bien à l'avance et faire en sorte qu'elles soient informatives et rapidement menées.

CONTEXTO FRANCÊS 4: Durant le salon, le stand représente la vitrine de l'entreprise. II doit donc remplir certaines fonctions: être une vitrine élogieuse des produits et services de l'entreprise, favoriser l'accueil et l'information rapide des visiteurs, permettre aux responsables commerciaux de s'isoler avec leurs clients potentiels.

CONTEXTO FRANCÊS 5: Le stand d'exposition: C'est un stand composé de différents modules évolutifs qui peuvent être assemblés et aménagés en fonction des besoins de l'exposant. Ces modules (cloisons, mobiliers etc.) sont généralement proposés par l'installateur général du salon mais également par certains concepteurs de stands

CONTEXTO FRANCÊS 6: Le stand d'exposition: C'est un espace dédié sur les foires, salons, congrès, etc. qui est réservé aux échanges et à la vente de produits et de services. Le stand d'exposition est de plus en plus apparenté à un espace de communication. La surface du stand est définie traditionnellement par un module de base de $9 \mathrm{~m}^{2}$ ( $3 \mathrm{~m}$ de profondeur $\mathrm{x} 3 \mathrm{~m}$ de façade). Les surfaces supérieures fonctionnent par ajout de $3 \mathrm{~m}^{2}: 12 \mathrm{~m}^{2}, 15 \mathrm{~m}^{2}, 18 \mathrm{~m}^{2}, 24 \mathrm{~m}^{2}, 36$ $\mathrm{m}^{2}[\cdot-\cdot]$.

CONTEXTO FRANCÊs 7: L'exposant ne doit pas laisser son kiosque sans surveillance.

CONTEXTO FRANCÊS 8: Dans une manifestation commerciale, la publicité a pour rôle d'amener les prospects, à visiter le stand et à prendre contact avec l'exposant dans le but d'acheter ses produits.

CONTEXTO FRANCÊS 9: L'Exposant s'interdit expressément pendant toute la durée de la manifestation de se livrer à des actes de concurrence déloyale tels que les enquêtes en dehors de son stand et la distribution d'objets promotionnels en dehors de son stand, pouvant donner lieu à un détournement à son profit des visiteurs de la manifestation.

CONTEXTO FRANCÊS 10: Les exposants s'engagent à prendre toutes les précautions que comporte la nature des objets durant leur séjour dans l'enceinte du Salon et tout particulièrement à veiller à ce que les marchandises soient exposées dans les limites du stand attribué.

CONTEXTO FRANCÊS 11: Afin d'attirer à votre stand un nombre suffisant de visiteurs des secteurs cibles, il vous faut définir le public cible en déterminant les caractéristiques des visiteurs de l'année précédente et voir dans quelle mesure ils correspondent à ce que vous recherchez.

CONTEXTO FRANCÊS 12: Les exposants ne sont pas autorisés à sous louer et partager leur stand. Ils ne pourront en aucun cas disposer des surfaces autour de leur stand.

CONTEXTO FRANCÊS 13: Aucun logo ou enseigne ne doit dépasser la hauteur de la structure du stand. Aucun logo, visuel ou nom d'entreprise ne peut être élingué ou suspendu au-dessus du stand.

CONTEXTO FRANCÊS 14: EMP assure la sécurité pendant l'événement de trois jours, mais seulement pendant les heures d'ouverture de l'exposition. EMP décline toute responsabilité à l'égard des pertes ou dommages que pourrait subir le kiosque ou le matériel de l'exposant.

FONTE CONTEXTO FRANCÊS 1: AEX

FONTE CONTEXTO FRANCÊS 2: GEIP

FONTE CONTEXTO FRANCÊS 3: COPFGP

FONTE CONTEXTO FRANCÊS 4: PSPECROSCEE

FONTE CONTEXTO FRANCÊS 5: GPFGPS

FONTE CONTEXTO FRANCÊS 6: GPFGPS

FONTE CONTEXTO FRANCÊS 7: MEE

FONTE CONTEXTO FRANCÊS 8: AE 


\begin{abstract}
FONTE CONTEXTO FRANCÊS 9: CGLSASSL
FONTE CONTEXTO FRANCÊS 10: CPFM

FONTE CONTEXTO FRANCÊS 11: COPFGP

FONTE CONTEXTO FRANCÊS 12: GEFMa

FONTE CONTEXTO FRANCÊS 13: GTEPNV2

FONTE CONTEXTO FRANCÊS 14: MEE
\end{abstract}

\title{
EQUIVALENTE EM ITALIANO
}

stand

OUTDES ITALIANO: stand espositivo; stand fieristico; posteggio; stand aziendale

CONTEXTO ITALIANO 1: Per stand si intende lo spazio assegnato all'espositore per la presentazione dei propri prodotti o servizi.

CONTEXTO ITALIANO 2: Lo stand è la prima cosa a cui, dal punto di vista operativo, pensa un espositore. Sotto alcuni aspetti, lo stand 'è la fiera'. Per un'azienda espositrice è il cuore del suo investimento, il biglietto da visita, la vetrina, la sua base operativa, è il luogo in cui incontra clienti, partner, giornalisti e persone influenti nel settore.

CONTEXTO ITALIANO 3: II vostro sito internet ne sarà l'elemento fondamentale. Se aumentano i visitatori del vostro sito, aumentano anche le possibilità di trasformarne la quota che vi interessa in visitatori del vostro stand fieristico.

CONTEXTO ITALIANO 4: Nella realizzazione degli stand espositivi le aziende allestitrici dovranno considerare che essi sono effettuati in presenza di pubblico e come tale si dovranno studiare soluzioni che, nel rispetto delle normative vigenti, assicurino la sicurezza del pubblico e degli espositori.

CONTEXTO ITALIANO 5: È necessario ottenere dalla partecipazione ad una fiera il massimo dei contatti utili. Occorre informare il maggior numero di clienti per indurli a visitare lo stand aziendale (aspetto spesso sottovalutato o trascurato dalle aziende, che attribuiscono gli insuccessi alla scarsa efficacia delle manifestazioni).

CONTEXTO ITALIANO 6: Nel caso in cui si debbano inviare merci per il proprio stand, consigliamo di richiedere la consegna nei giorni di allestimento direttamente ad un incaricato della ditta espositrice presente presso lo stand.

CONTEXTO ITALIANO 7: Sarà cura degli Espositori spegnere le luci del proprio stand al termine di ogni giorno di manifestazione; qualora ciò non venisse effettuato, il personale addetto degli Organizzatori prowederà ad interrompere l'erogazione di energia elettrica dalle cassette di derivazione, per poi ripristinarla la mattina successiva, dietro richiesta dell'Espositore.

CONTEXTO ITALIANO 8: Presa visione della normativa prevista nelle Norme di Partecipazione, integralmente accettate e sottoscritte, si dichiara, sotto la propria responsabilità, quanto segue: l'allestimento dello stand assegnato è conforme alle normative previste nel Manuale dell'Espositore [...].

CONTEXTO ITALIANO 9: L'Espositore si impegna a esporre nel proprio posteggio, per tutta la durata della manifestazione, i prodotti di propria produzione appartenenti al repertorio merceologico di cui all'allegato $D$ del presente Regolamento Generale.

CONTEXTO ITALIANO 10: Le varie tipologie di stand fieristici sono definite in base alla tipologia dello spazio assegnato e all'accesso alle corsie.

CONTEXTO ITALIANO 11: La moquette per lo stand è inclusa nel costo dello stand preallestito. Se avete prenotato un'area nuda potete richiedere la fornitura di moquette per lo stand al costo di $€ 6,50$ al mq.

CONTEXTO ITALIANO 12: Durante l'orario di apertura dei padiglioni l'Espositore dovrà vigilare il proprio stand direttamente o attraverso proprio personale. Bolognafiere, pur prowvedendo per tutta la durata del Salone e per tutti i giorni previsti per l'allestimento e lo sgombero degli stand, ad un servizio generale di 
vigilanza diurna e notturna all'interno del Quartiere Fieristico negli orari di chiusura al pubblico ed agli espositori, è esonerato da ogni e qualsiasi responsabilità in ordine a furti $e / 0$ danni che dovessero verificarsi nei confronti dell'Espositore.

CONTEXTO ITALIANO 13: Una presenza in fiera non si esaurisce allo stand e nemmeno nel quartiere fieristico. Anzi, non si esaurisce nemmeno nell'orario canonico di apertura dei padiglioni. La partecipazione alla manifestazione può essere una gradita occasione per organizzare altri eventi a cura dell'espositore e rivolti a partner commerciali, clienti, stampa, vip.

CONTEXTO ITALIANO 14: Se volete che la vostra azienda e il vostro stand approfittino di questo «buzz», dovete confrontarvi con ciò che sta a cuore ai visitatori ed essere in grado di reagire tempestivamente. C'è qualcuno che vorrebbe venire a visitarvi ma ha difficoltà a trovare il vostro stand? Ovviamente ogni fiera ha la sua mappa, ma una reazione rapida vi garantirà un approccio molto più personale al vostro visitatore.

CONTEXTO ITALIANO 15: GL events Italia S.p.a. si riserva comunque la facoltà di modificare le modalità di partecipazione e l'ubicazione del posteggio assegnato, avendo facoltà insindacabile di sostituire il posteggio assegnato con altro di uguale o differente ubicazione o metratura.
FONTE CONTEXTO ITALIANO 1: RMF
FONTE CONTEXTO ITALIANO 2: MFFM
FONTE CONTEXTO ITALIANO 3: PSAEDPSF
FONTE CONTEXTO ITALIANO 4: RTMFP
FONTE CONTEXTO ITALIANO 5: FSCP
FONTE CONTEXTO ITALIANO 6: MEFG1
FONTE CONTEXTO ITALIANO 7: MEFG1
FONTE CONTEXTO ITALIANO 8: MEFP
FONTE CONTEXTO ITALIANO 9: MEWW
FONTE CONTEXTO ITALIANO 10: URFMM
FONTE CONTEXTO ITALIANO 11: MEFG2
FONTE CONTEXTO ITALIANO 12: MECprB
FONTE CONTEXTO ITALIANO 13: MFFM
FONTE CONTEXTO ITALIANO 14: PSAEDPSF
FONTE CONTEXTO ITALIANO 15: SILT
SN: - 
VERSÃO FINAL

Página 1 de 3

Entry ld: 568

ENTRADA EM PORTUGUÊS

estande - s.m.

OUTDES PORTUGUÊS: stand

CONTEXTO PORTUGUÊS 1: O estande é como a vitrine do produto ou serviço a ser divulgado e negociado, estrutura em que se materializa a participação de empresas

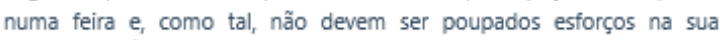
elaboração. É a imagem que tem por objetivo chamar a atenção do público-alvo.

CONTEXTO PORTUGUÊS 2: É considerado merchandising toda propaganda feita fora dos limites do stand do Expositor. Os produtos de merchandising têm o objetivo de ampliar a visibilidade e divulgação do Expositor dentro do Evento.

FONTE CONTEXTO PORTUGUÊS 1: MOFE

FONTE CONTEXTO PORTUGUÊS 2: MESS

SN: Def.: estande: - 5.m. espaço de exposição provisório e atrativo alugado pelo expositor para a participação em uma feira que tem por objetivo exibir produtos e/ou oferecer serviços e chamar a atenção do público-alvo, levando em consideração as necessidades dos visitantes, equipado com carpete, paredes divisórias, iluminação e testeira de identificação do estande, completo e a postos durante toda a realização da feira, desde a sua abertura até o seu encerramento.

\section{EQUIVALENTE EM INGLÊS}

stand

OUTDES INGLÊS: booth (US); exhibit (US); exhibition stand; trade stand; exhibition space; singlestorey stand; exhibit space (US)

CONTEXTO INGLÊS 1: The main purposes of the stand are to differentiate the firm from its competitors and to attract attention quickly. This does not mean that the stand must be large and imposing. In fact, quite the contrary; a well-designed small stand may be visually appealing and memorable, while also reducing space costs. When choosing a stand, focus on practicality and creative design. With one glance at the stand, visitors should be able to grasp (i) the company's name; (ii) the company's product or service; and (iii) how the company can solve their problem.

CONTEXTO INGLÊS 2: A booth is more like a billboard than a datasheet. Attendees won't stand in your booth to read its signage, and in any case it is the job of booth staff to communicate key messages and product features. The booth should be an environment for selling.

CONTEXTO INGLÊS 3: It is the responsibility of the Exhibitor to ensure that anyone contracted to build their stand/exhibit is competent to do so.

CONTEXTO INGLÊS 4: Every exhibition stand is a miniature workplace and therefore needs a risk assessment.

CONTEXTO INGLÊS 5: The RHS requests that children under the age of 16 are not permitted to assist with the actual set-up, running or breakdown of trade stands.

CONTEXTO INGLÊS 6: Exhibition space: We have introduced standard pricing across all floors for this event. Check the floorplans and identify your preferred space and then you can calculate the total cost. The exhibition space does not include any furniture, power or extras.

CONTEXTO INGLÊS 7: The overall height of stand fitting for single-storey stands is $4 \mathrm{~m}$ from the floor level.

CONTEXTO INGLÊS 8: 


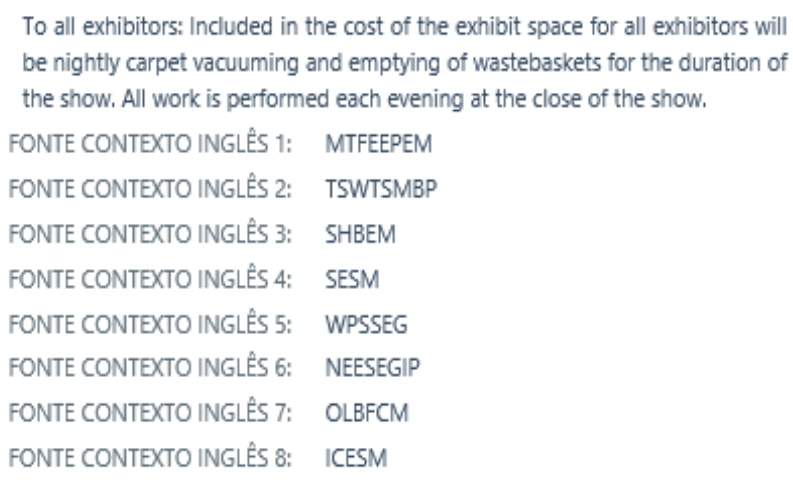

\section{EQUIVALENTE EM FRANCÊS}

stand

OUTDES FRANCÊS: stand d'exposition; kiosque; espace d'exposition

CONTEXTO FRANCÊS 1: Stand: construction provisoire édifiée par les participants à une foire, à un salon ou à une exposition pour $y$ accueillir des visiteurs et présenter des produits.

CONTEXTO FRANCÊS 2: Le stand d'exposition: C'est un espace dédié sur les foires, salons, congrès, etc. qui est réservé aux échanges et à la vente de produits et de services. Le stand d'exposition est de plus en plus apparenté à un espace de communication. La surface du stand est définie traditionnellement par un module de base de $9 \mathrm{~m}^{2}$ ( $3 \mathrm{~m}$ de profondeur $x 3 \mathrm{~m}$ de façade). Les surfaces supérieures fonctionnent par ajout de $3 \mathrm{~m}^{2}: 12 \mathrm{~m}^{2}, 15 \mathrm{~m}^{2}, 18 \mathrm{~m}^{2}, 24 \mathrm{~m}^{2}, 36$ $\mathrm{m}^{2} \ldots$

CONTEXTO FRANCÊS 3: L'exposant ne doit pas laisser son kiosque sans surveillance.

CONTEXTO FRANCÊS 4: Présence sur l'espace d'exposition - L'exposant, ou son représentant, est tenu d'être présent sur son espace dès le début du démontage et jusqu'à évacuation complète.

FONTE CONTEXTO FRANCÊS 1: AEX

FONTE CONTEXTO FRANCÊS 2: GPFGPS

FONTE CONTEXTO FRANCÊS 3: MEE

FONTE CONTEXTO FRANCÊS 4: URGMC2

\section{EQUIVALENTE EM ITALIANO}

stand

OUTDES ITALIANO; stand espositivo; stand fieristico; posteggio; spazio espositivo; posteggio espositivo

CONTEXTO ITALIANO 1: Per stand si intende lo spazio assegnato all'espositore per la presentazione dei propri prodotti o servizi.

CONTEXTO ITALIANO 2: Attività negli stand espositivi: Gli Espositori dovranno astenersi in qualunque momento dall'uso delle aree comuni al di fuori del proprio stand per l'esposizione di materiale promozionale. Bolognafiere S.p.A. avrà il diritto di rimuovere tale materiale dalle aree comuni e/o di addebitare il pagamento dello spazio aggiuntivo utilizzato.

CONTEXTO ITALIANO 3: Le varie tipologie di stand fieristici sono definite in base alla tipologia dello spazio assegnato e all'accesso alle corsie.

CONTEXTO ITALIANO 4: L'Espositore si impegna a esporre nel proprio posteggio, per tutta la durata della manifestazione, i prodotti di propria produzione appartenenti al 
Página 3 de 3

repertorio merceologico di cui all'allegato D del presente Regolamento

Generale.

CONTEXTO ITALIANO 5: La mancata ricezione della corretta documentazione e senza l'approvazione del progetto di allestimento da parte di Fiera Milano, non permetterà all'Espositore (o all'allestitore) di allestire il proprio spazio espositivo.

CONTEXTO ITALIANO 6: II presente Regolamento Tecnico stabilisce ad integrazione del Regolamento Generale dell'Evento allegato alla domanda di partecipazione - quanto segue: [...] le norme in materia di sicurezza per l'attività di progettazione, installazione e manutenzione delle strutture di allestimento espositive e relativi impianti; le modalità di allestimento, di custodia, manutenzione e sgombero dei posteggi espositivi presenti nel Quartiere fieristico [...].

FONTE CONTEXTO ITALIANO 1: RMF

FONTE CONTEXTO ITALIANO 2: RTFB

FONTE CONTEXTO ITALIANO 3: URFMM

FONTE CONTEXTO ITALIANO 4: MEWW

FONTE CONTEXTO ITALIANO 5: GPESIOP

FONTE CONTEXTO ITALIANO 6: FRRQ 
APÊNDICE X - APRESENTAÇÃO DE ALGUMAS FOTOS TIRADAS DURANTE AS PESQUISAS DE CAMPO REALIZADAS NA INGLATERRA, FRANÇA E ITÁLIA

As fotos anexadas a seguir ilustram alguns dos centros de exposições, pavilhões e diferentes tipos de estandes que visitamos durante os estágios de pesquisa no exterior:

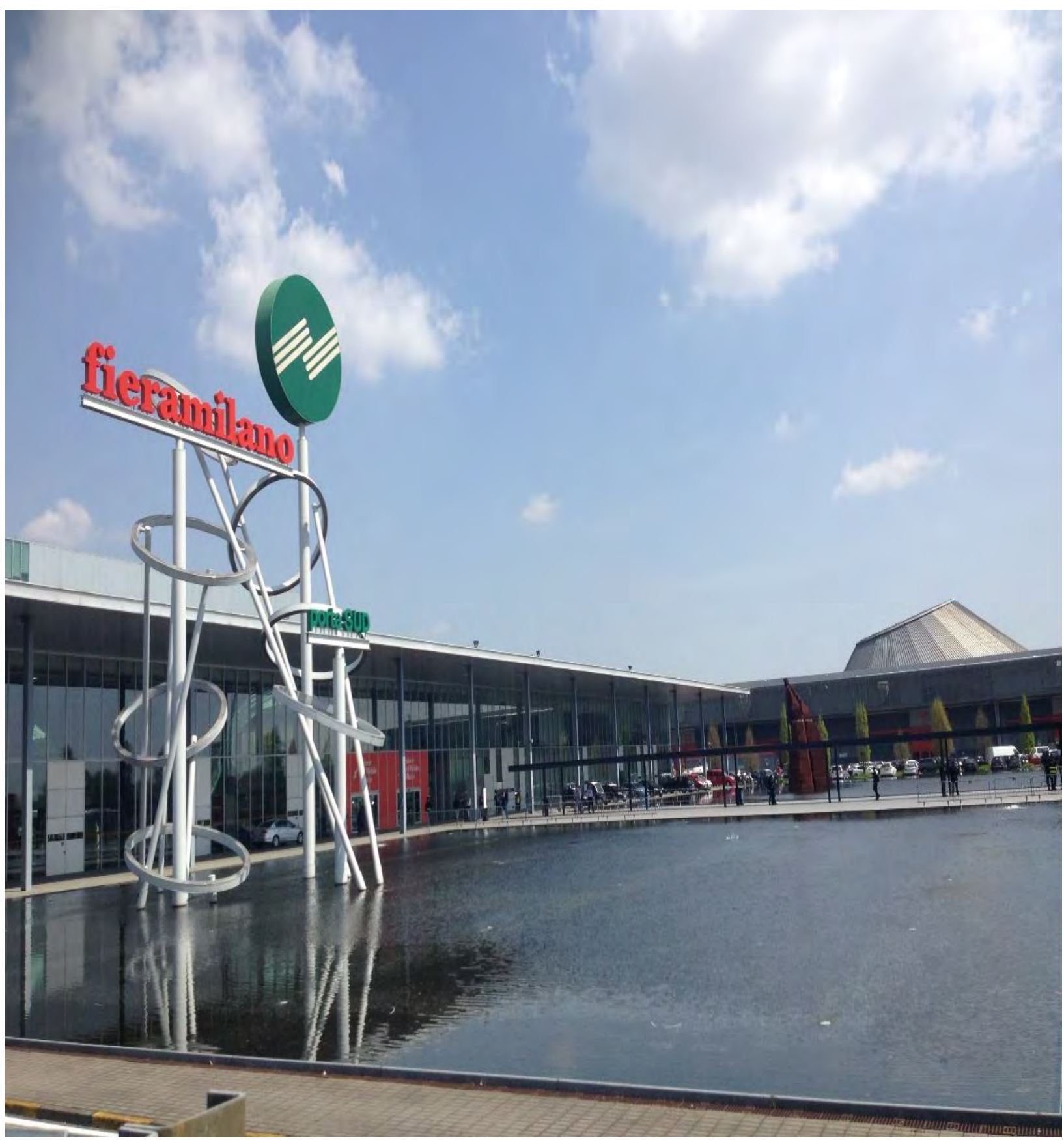

Centro de exposições Fiera Milano 


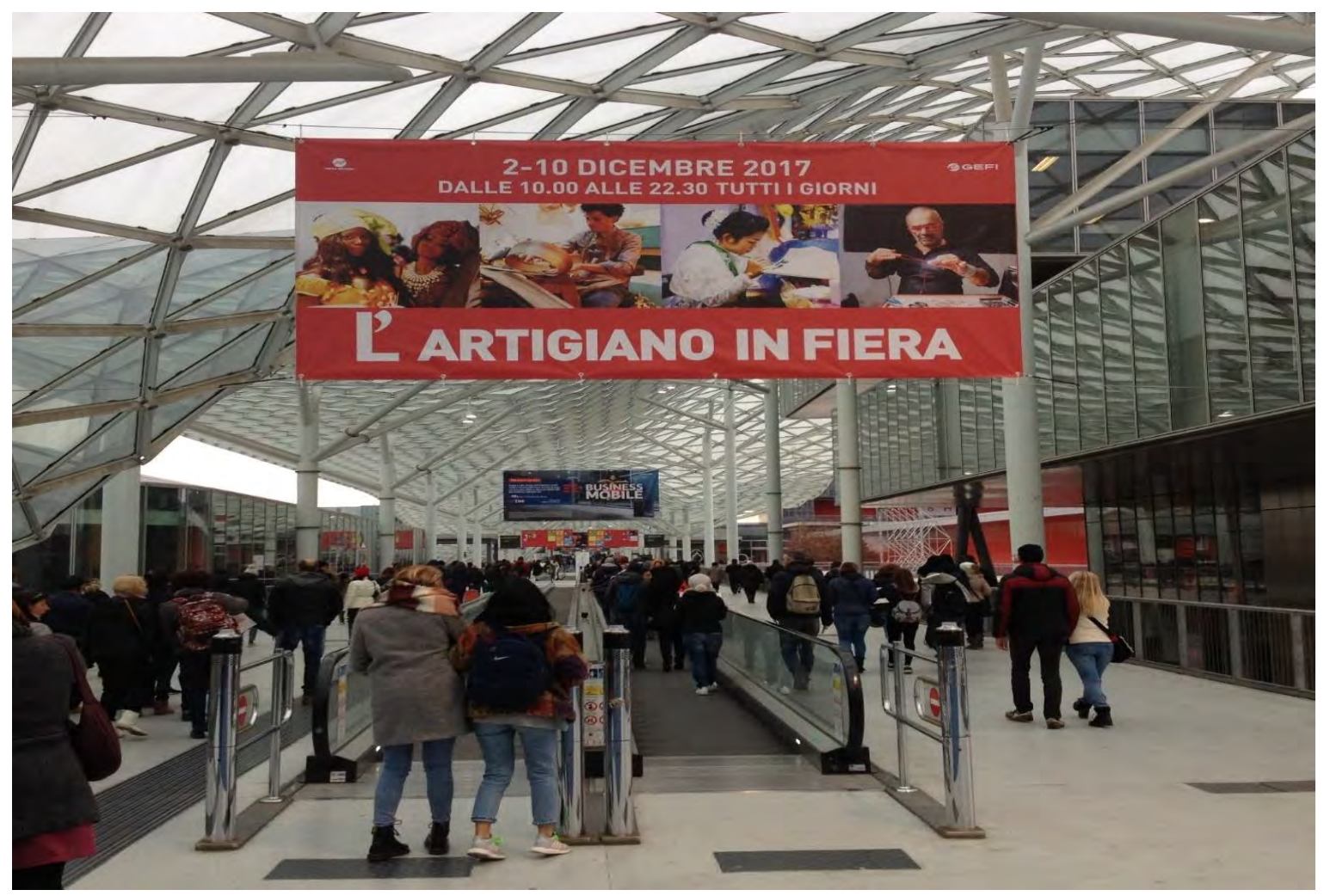

Feira L'Artigiano in Fiera - Centro de exposições Fiera Milano

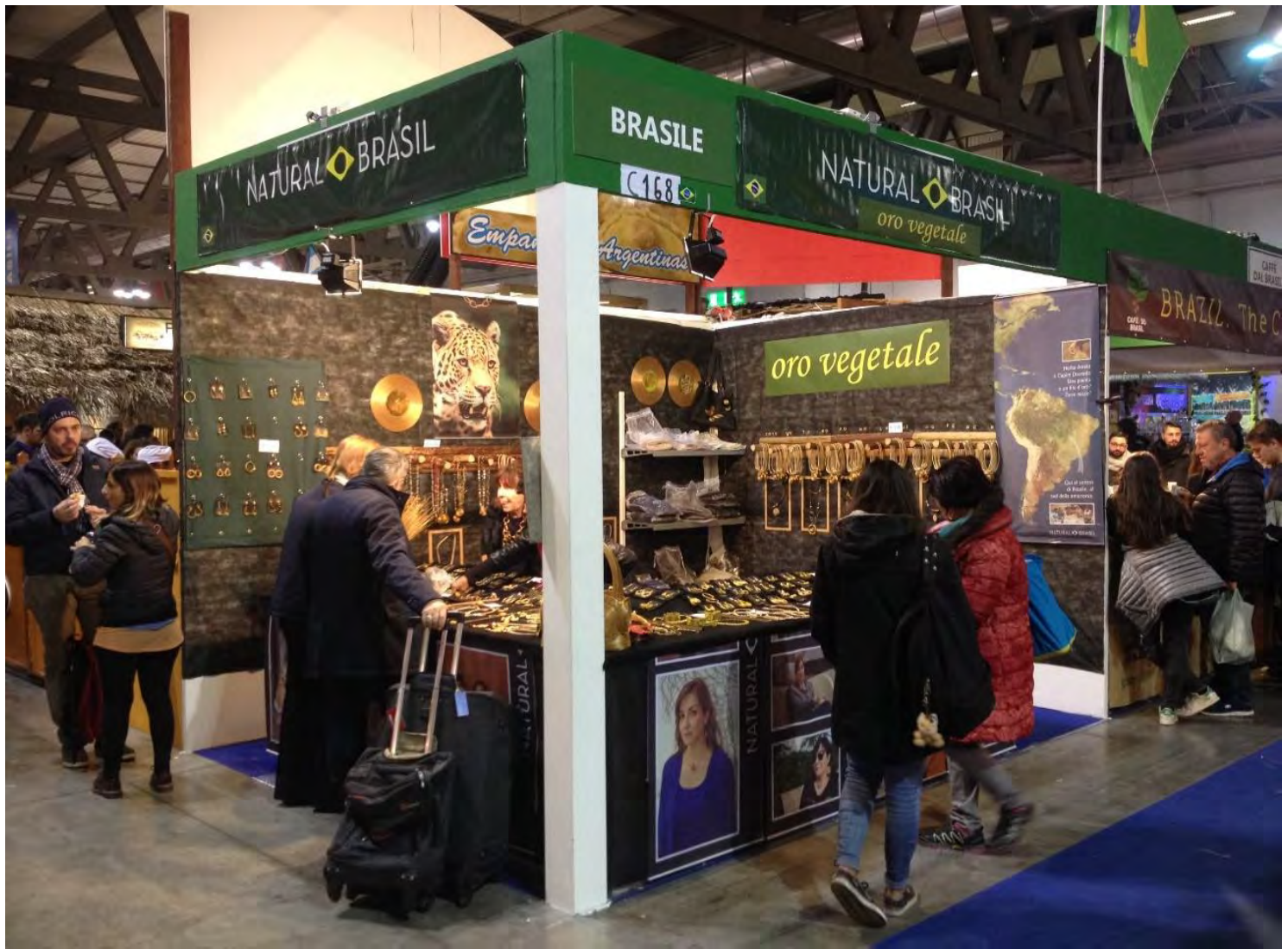

Estande Brasil (estande de esquina) 


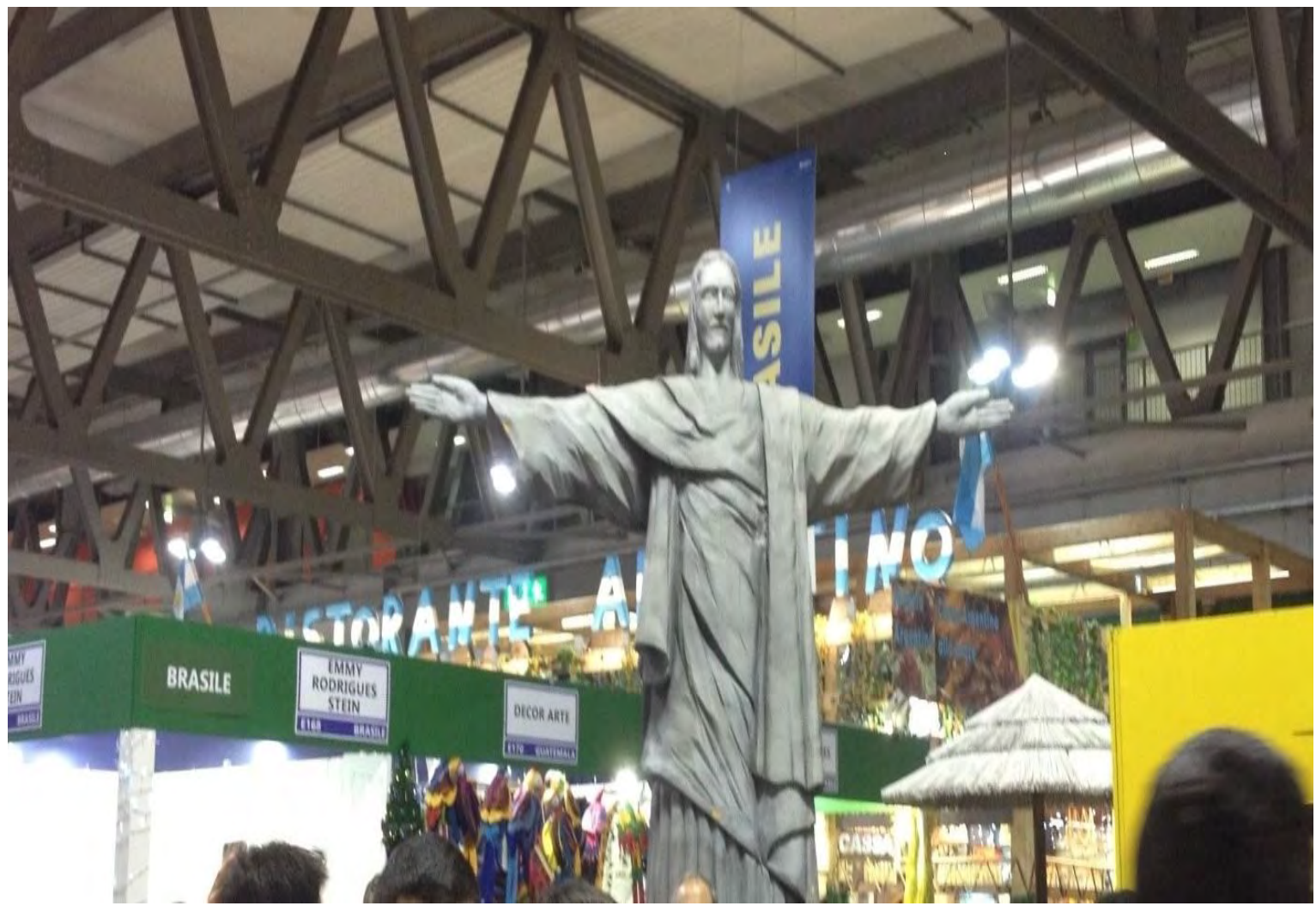

Estande Brasil

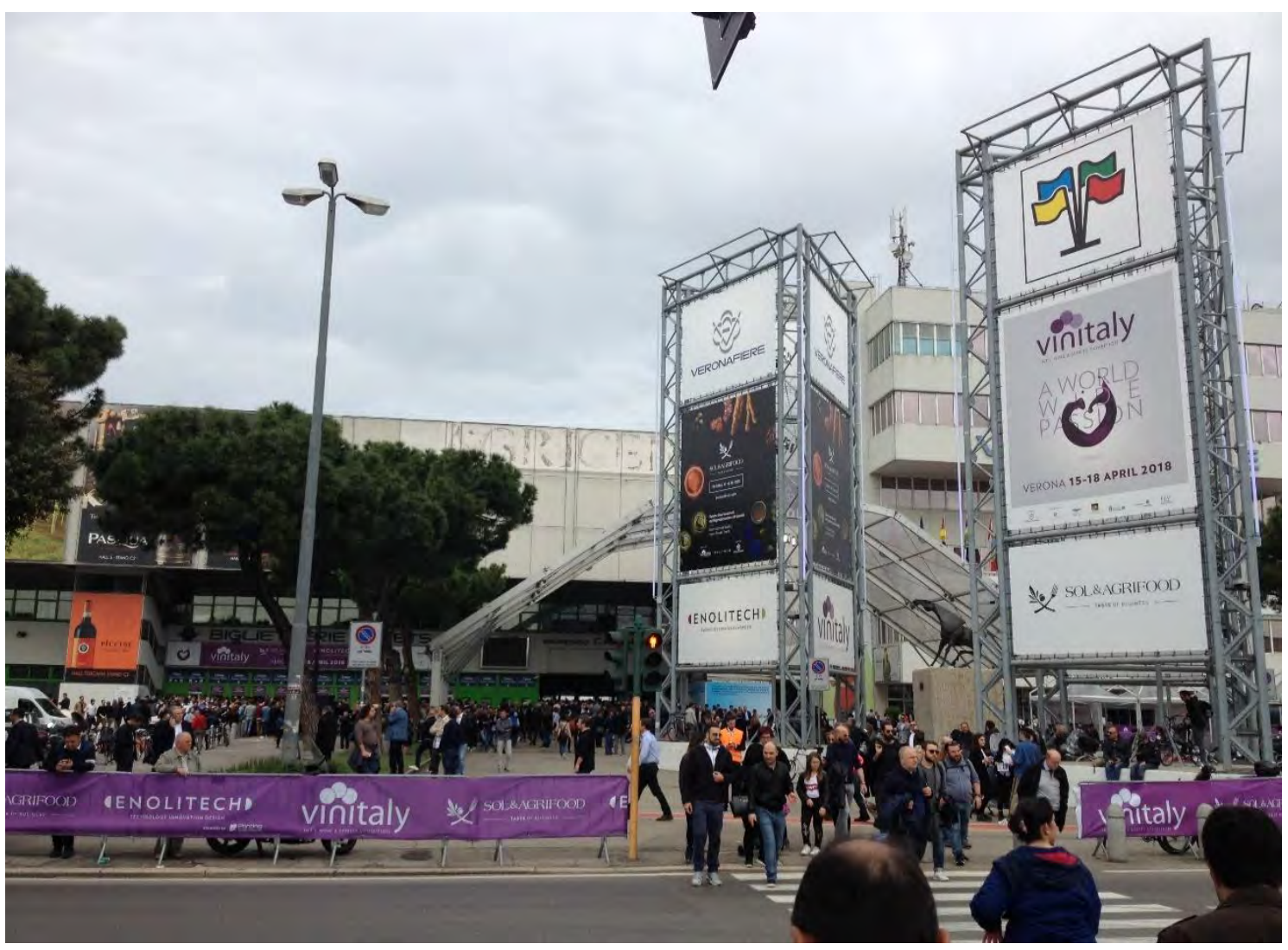

Feira Vinitaly - Verona Fiere 


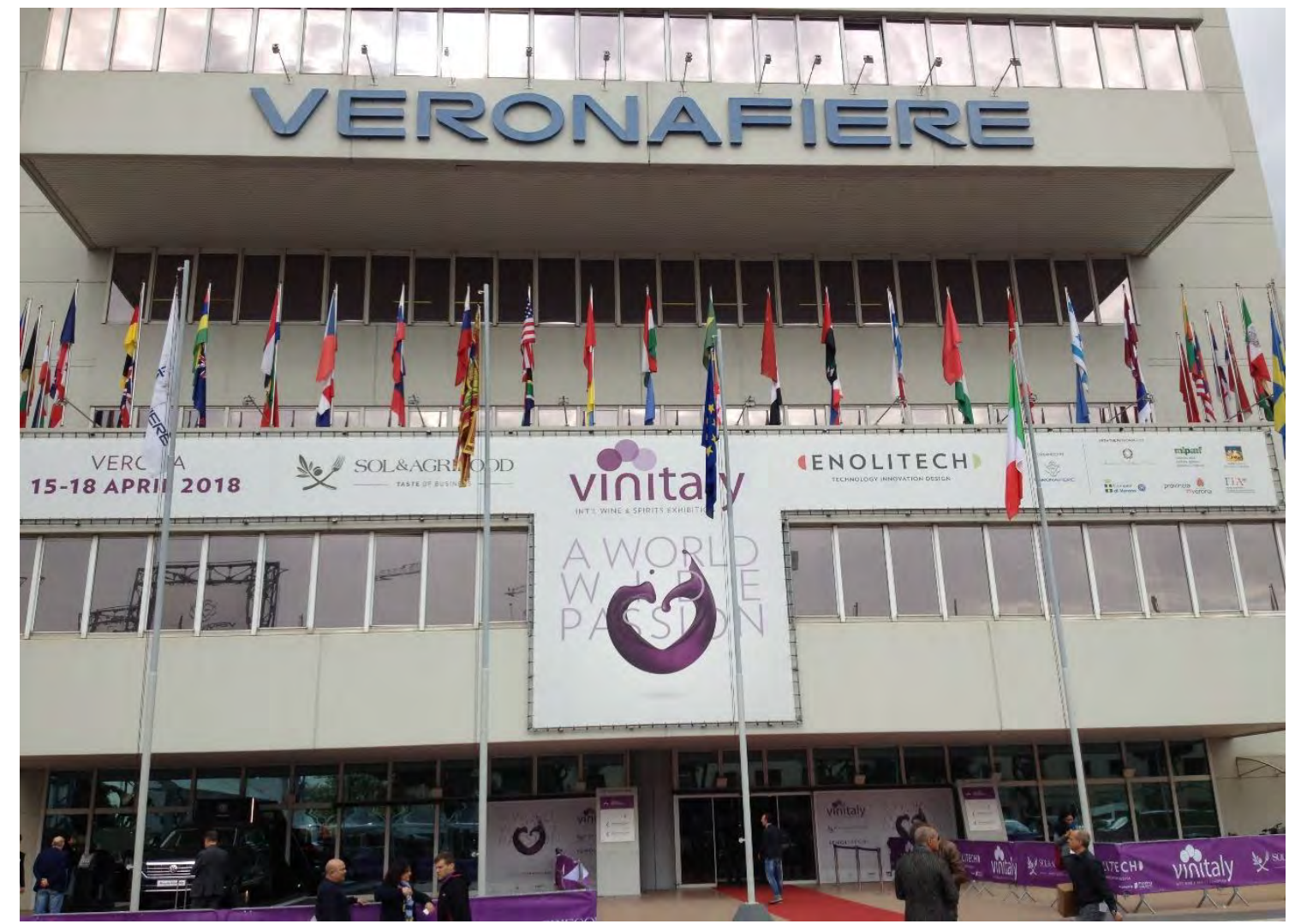

Centro de exposições Verona Fiere

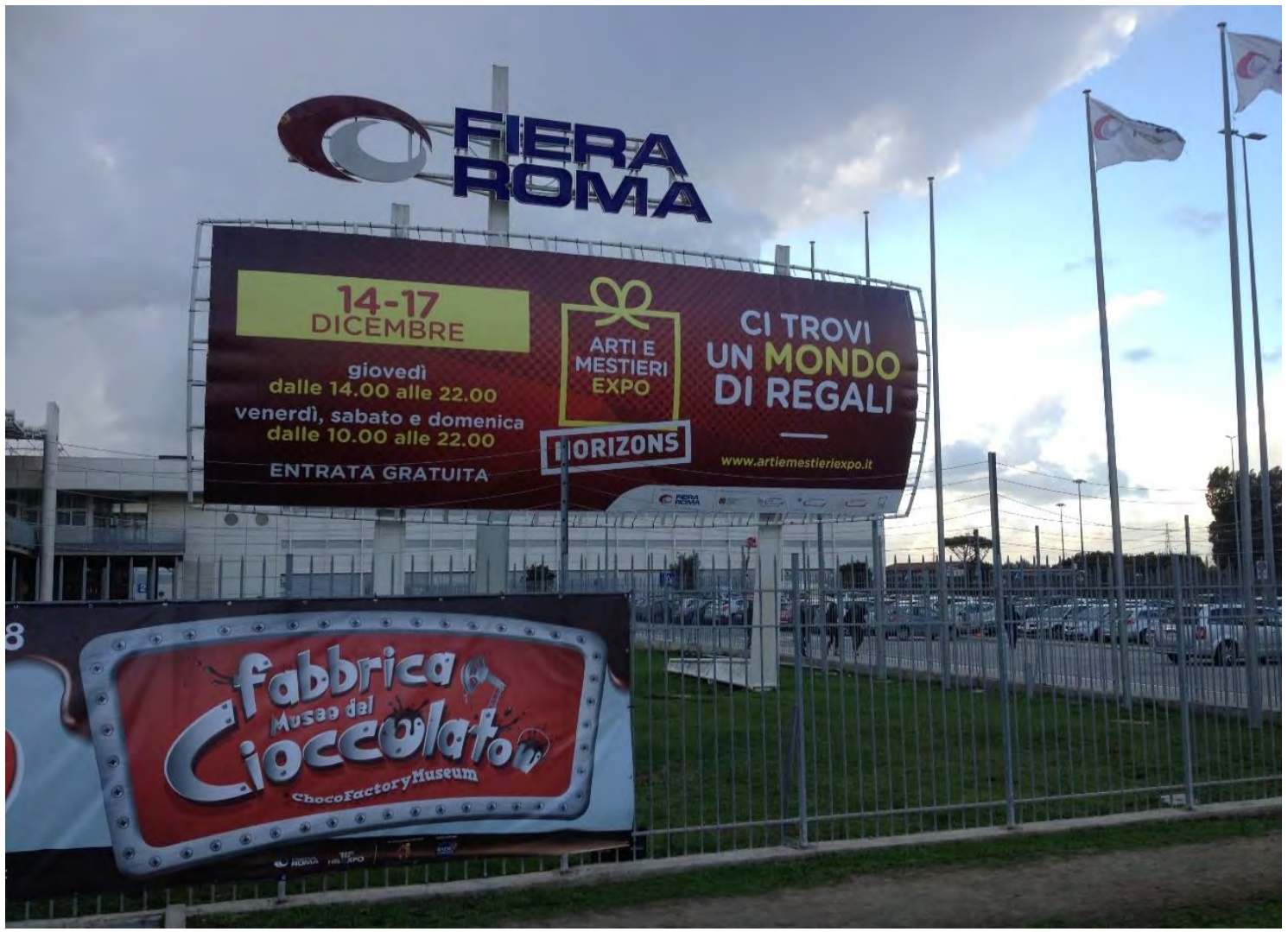

Centro de exposições Fiera Roma 


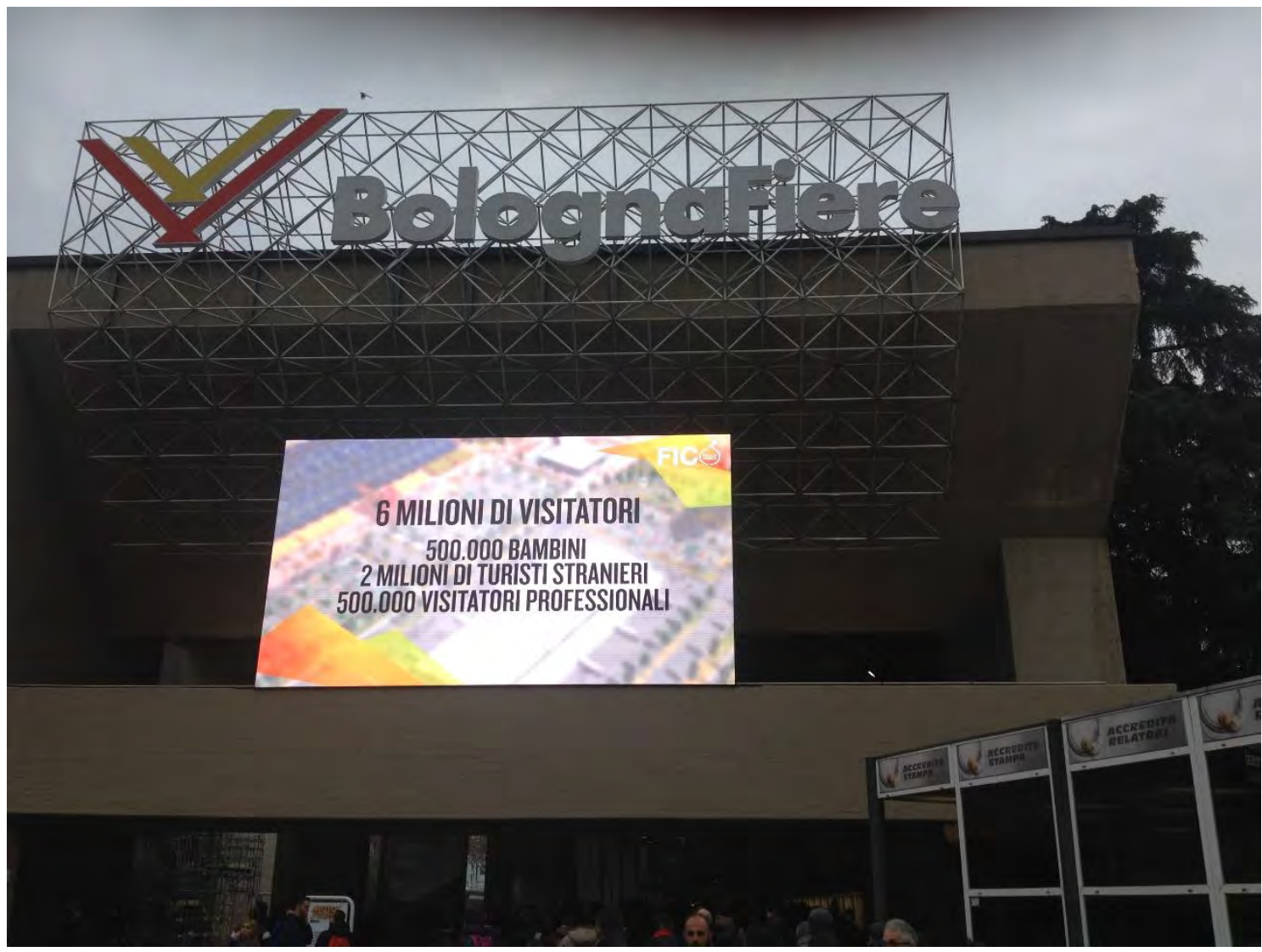

Centro de exposições Bologna Fiere

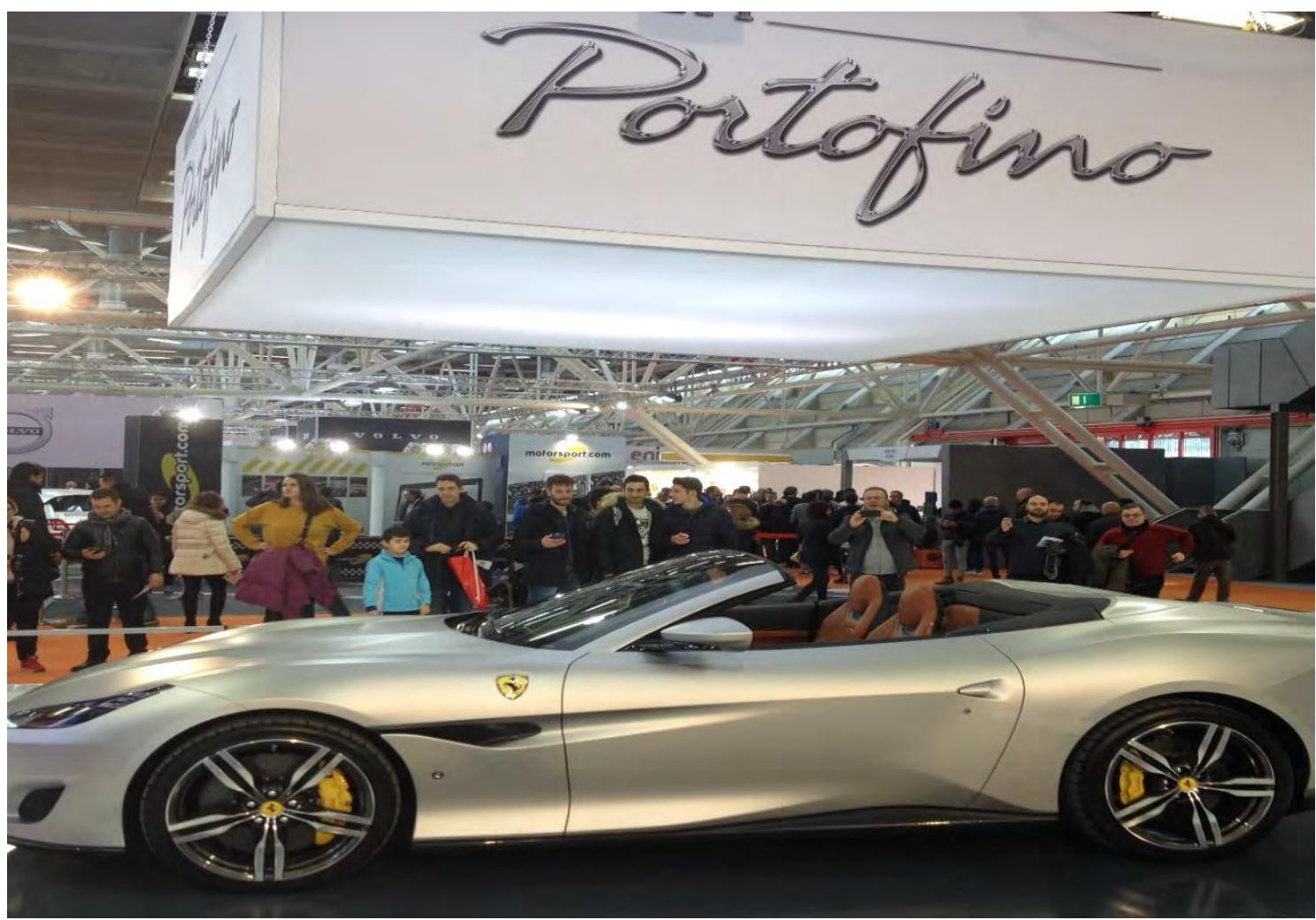

Feira do automóvel Motor Show - Bologna Fiere 2017 


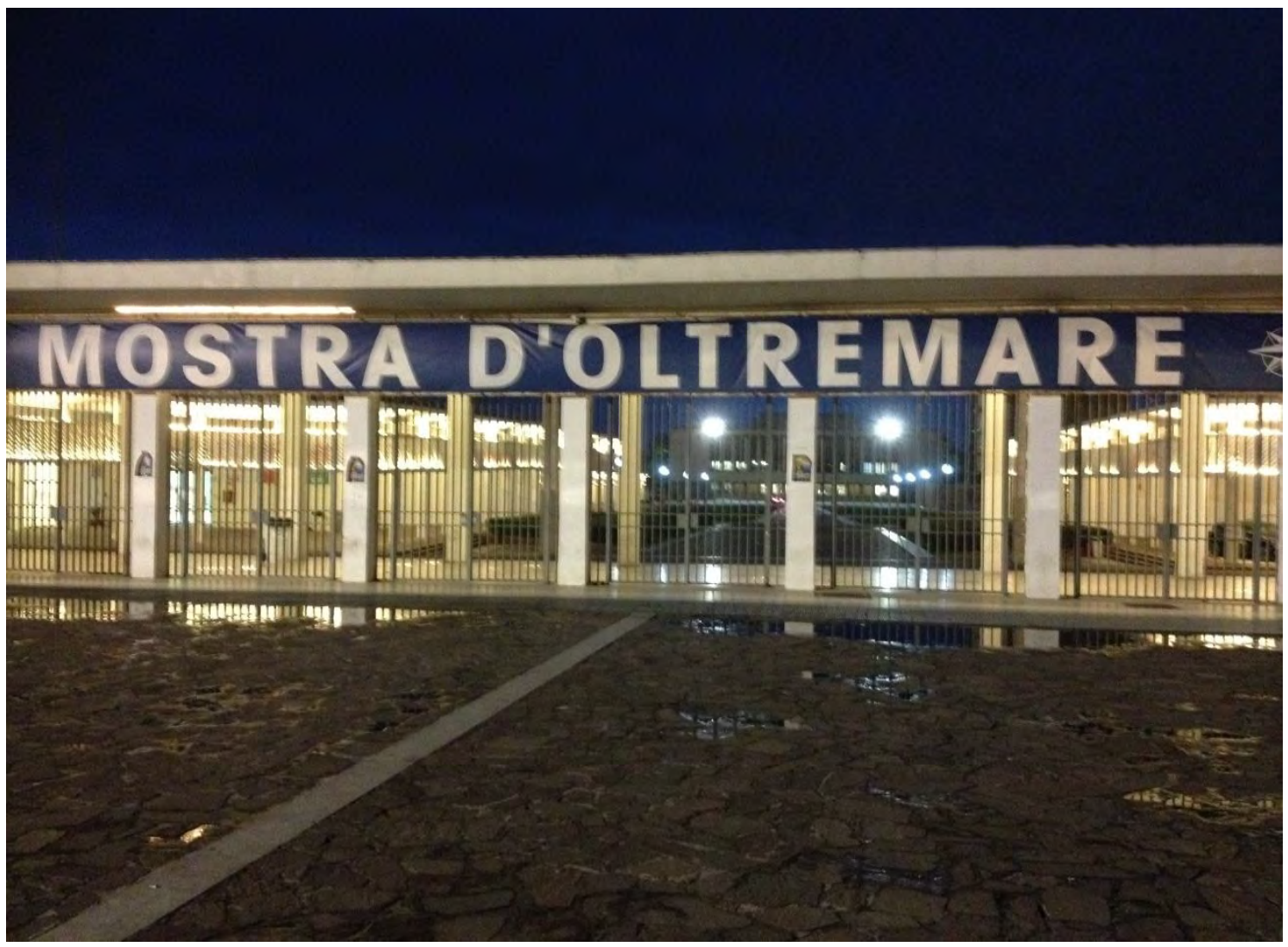

Centro de exposições Mostra D’Oltremare - Nápoles

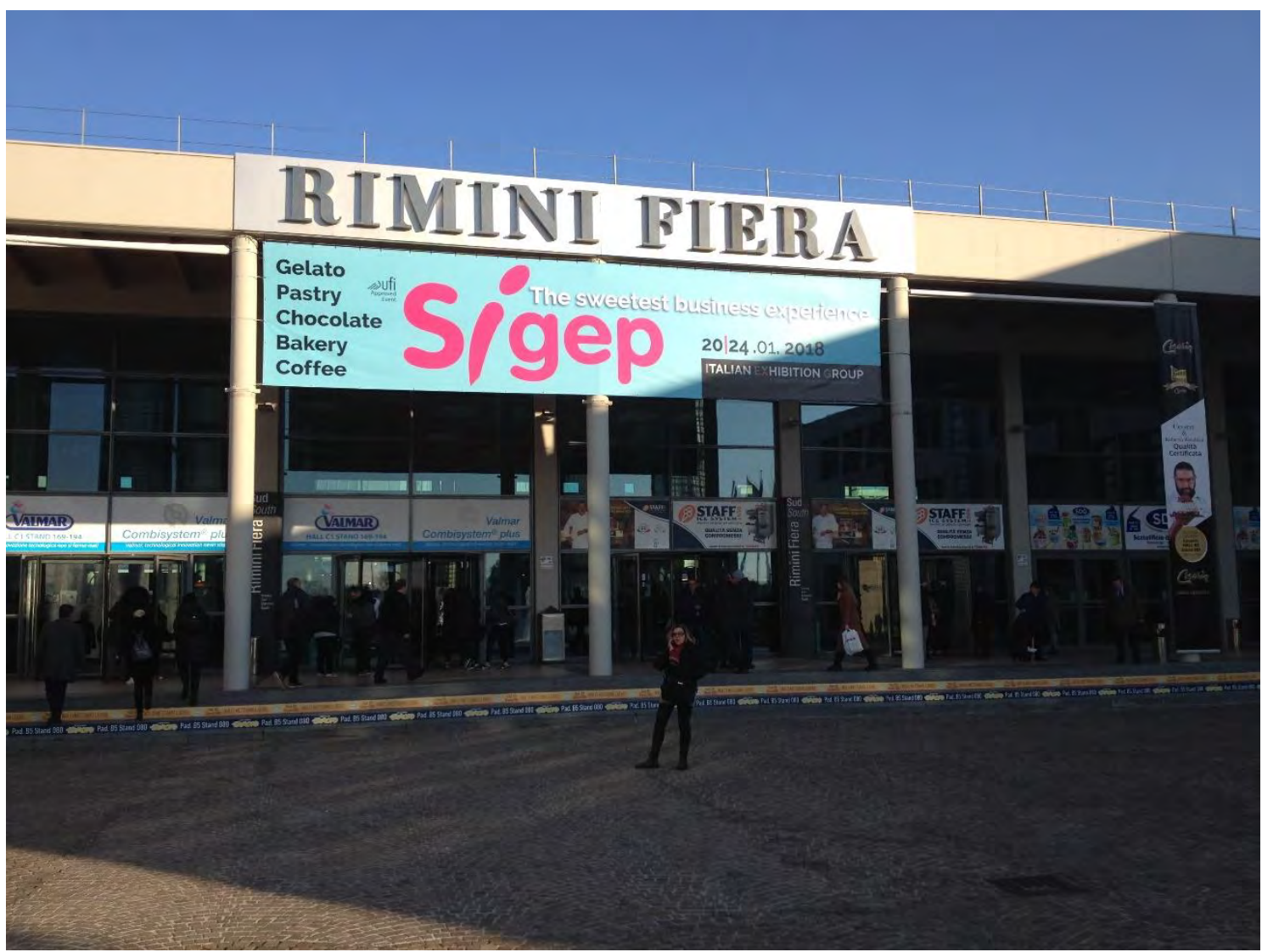

Centro de exposições Rimini Fiera 


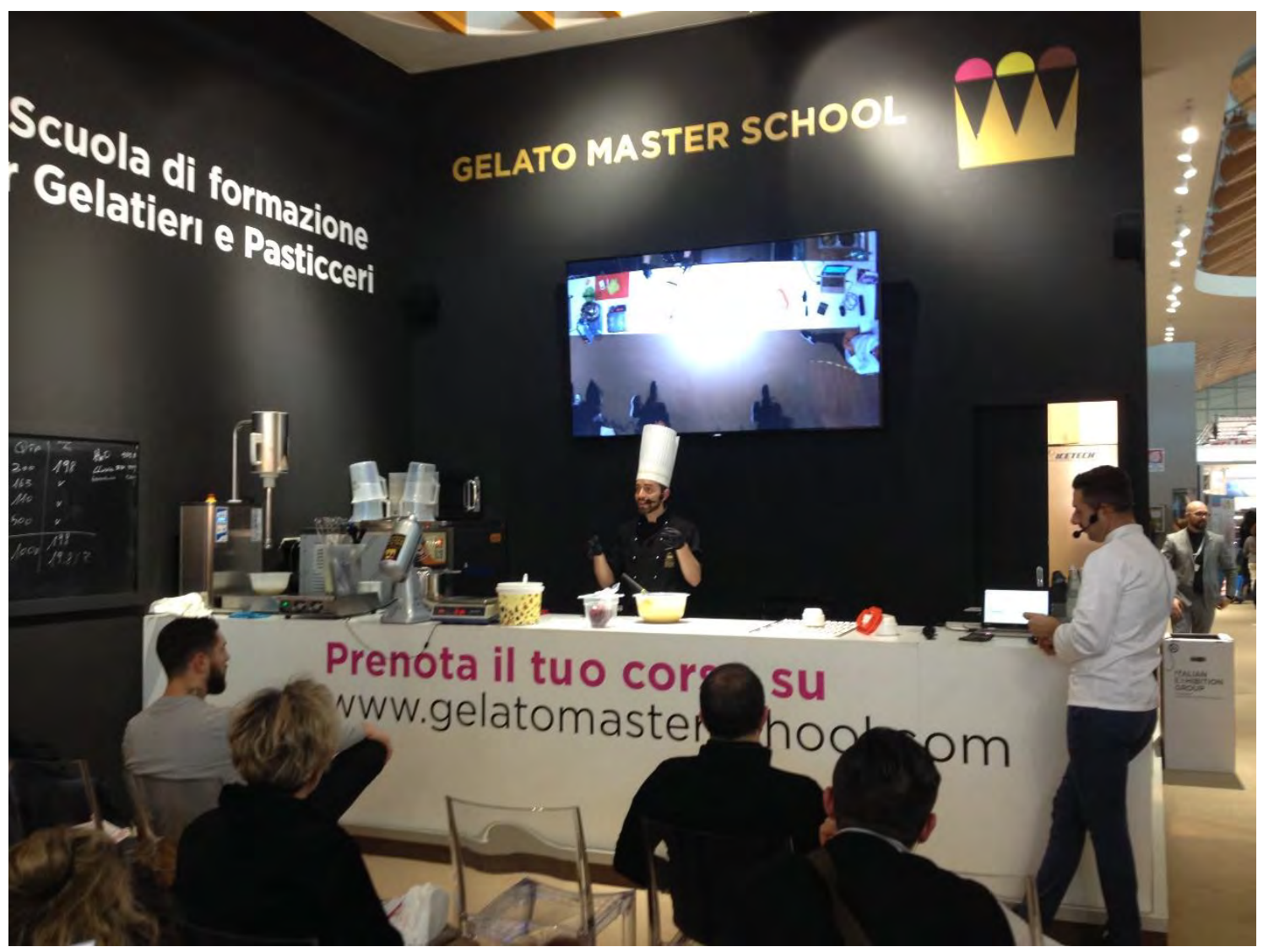

Demonstração do preparo de sorvetes - SIGEP 2018

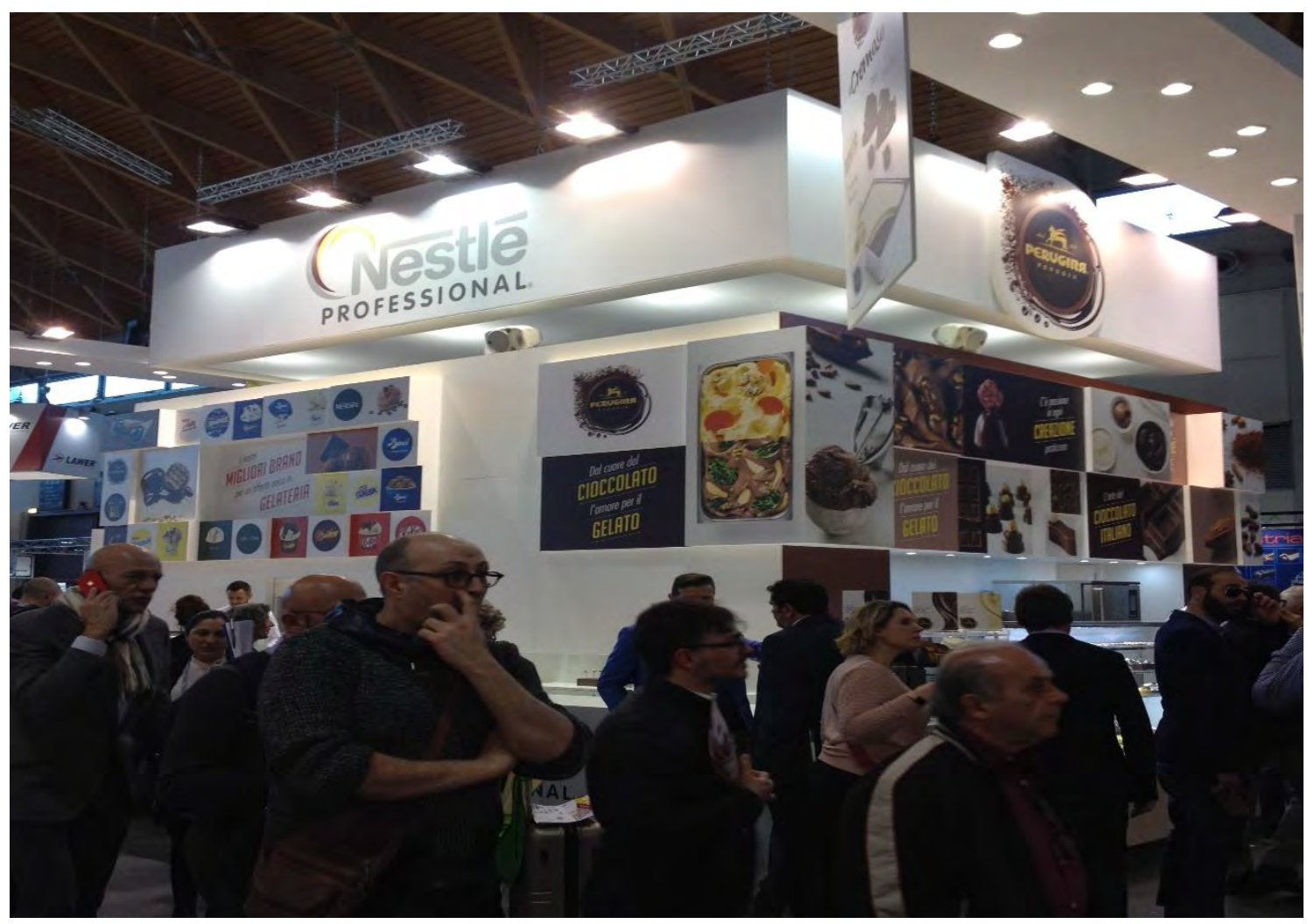

Estande com degustação de sorvetes - SIGEP 2018 


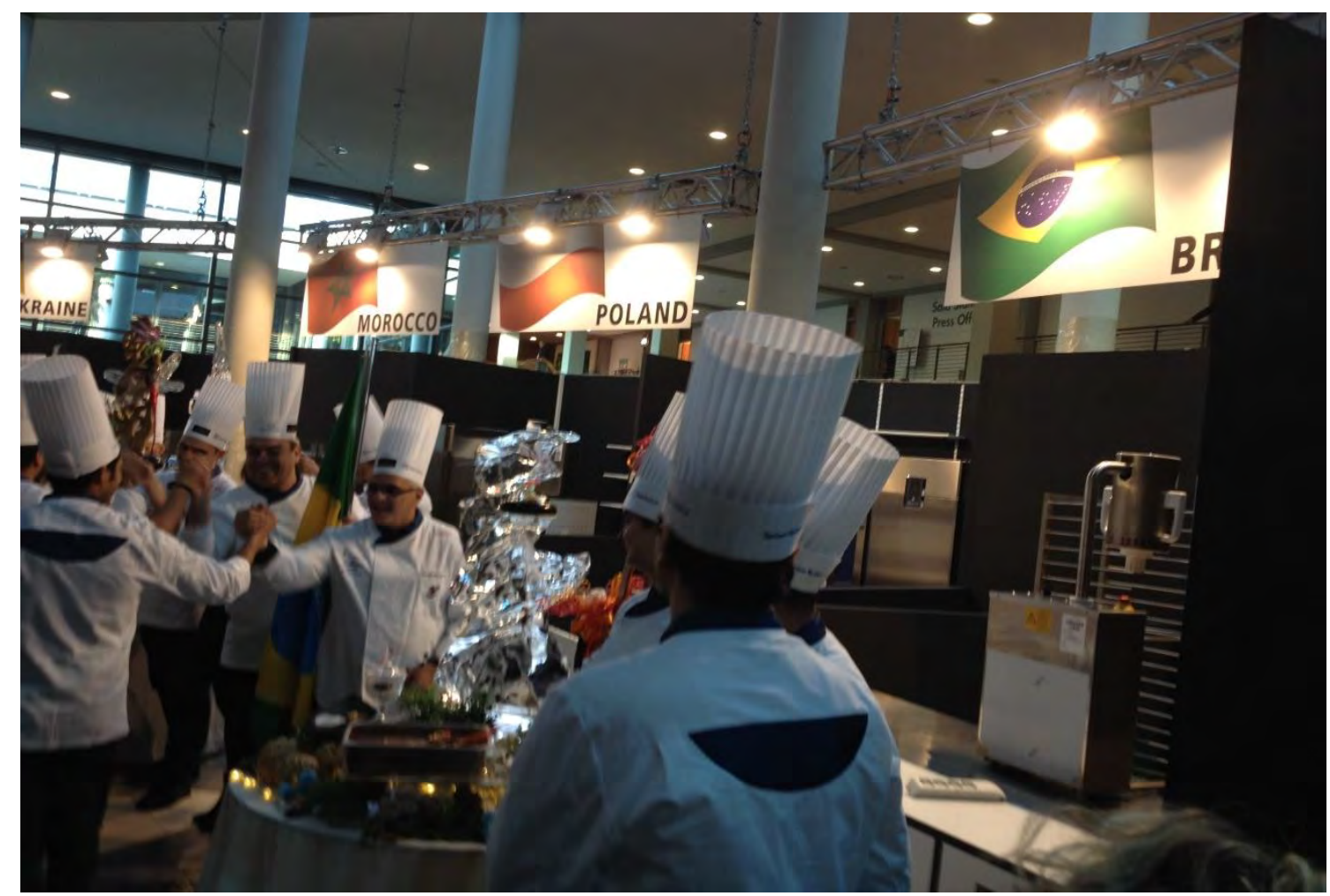

Competição de estátuas de gelo na feira SIGEP 2018 e o Brasil estava participando

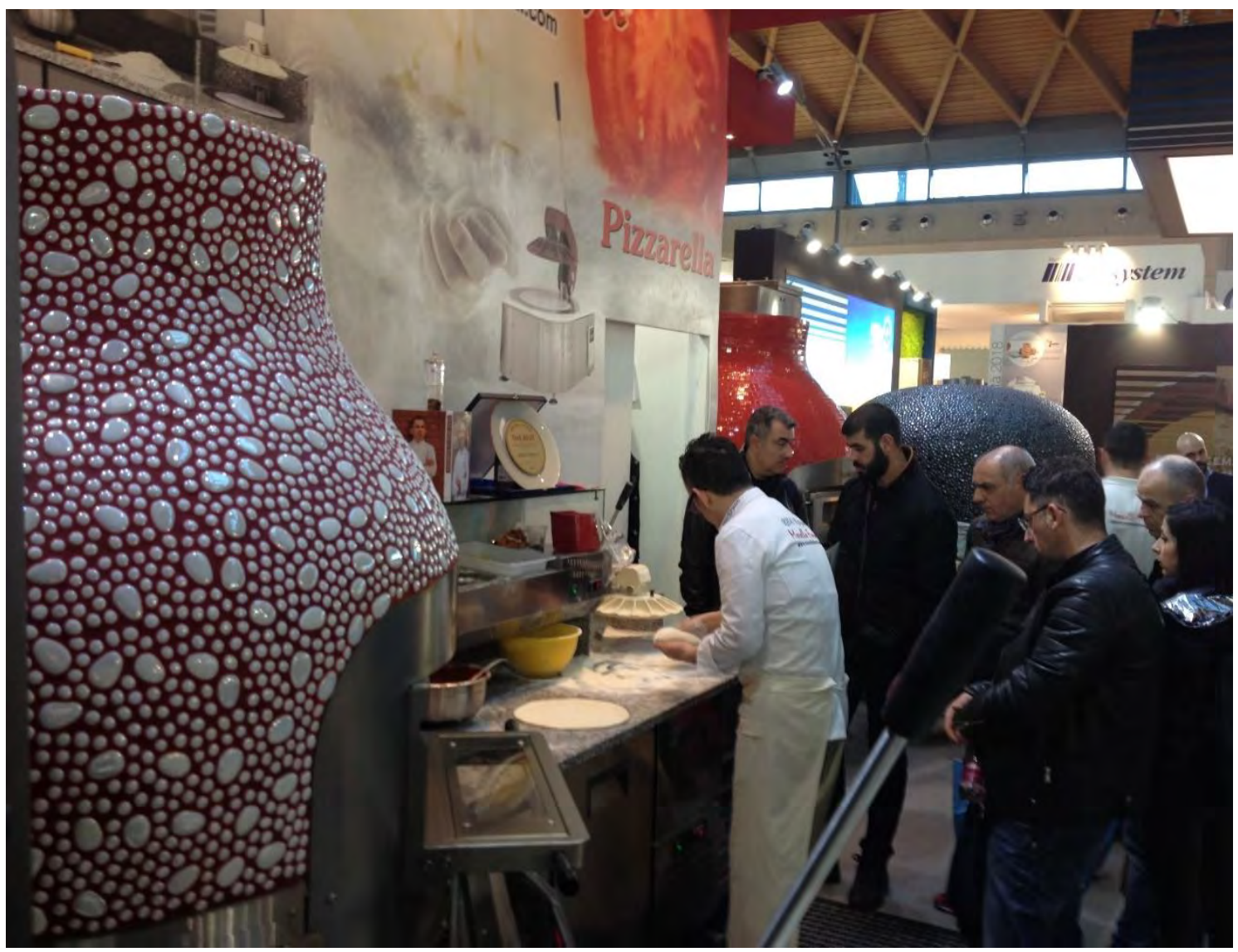

Preparo de pizzas no estande para degustação - Feira SIGEP 2018 


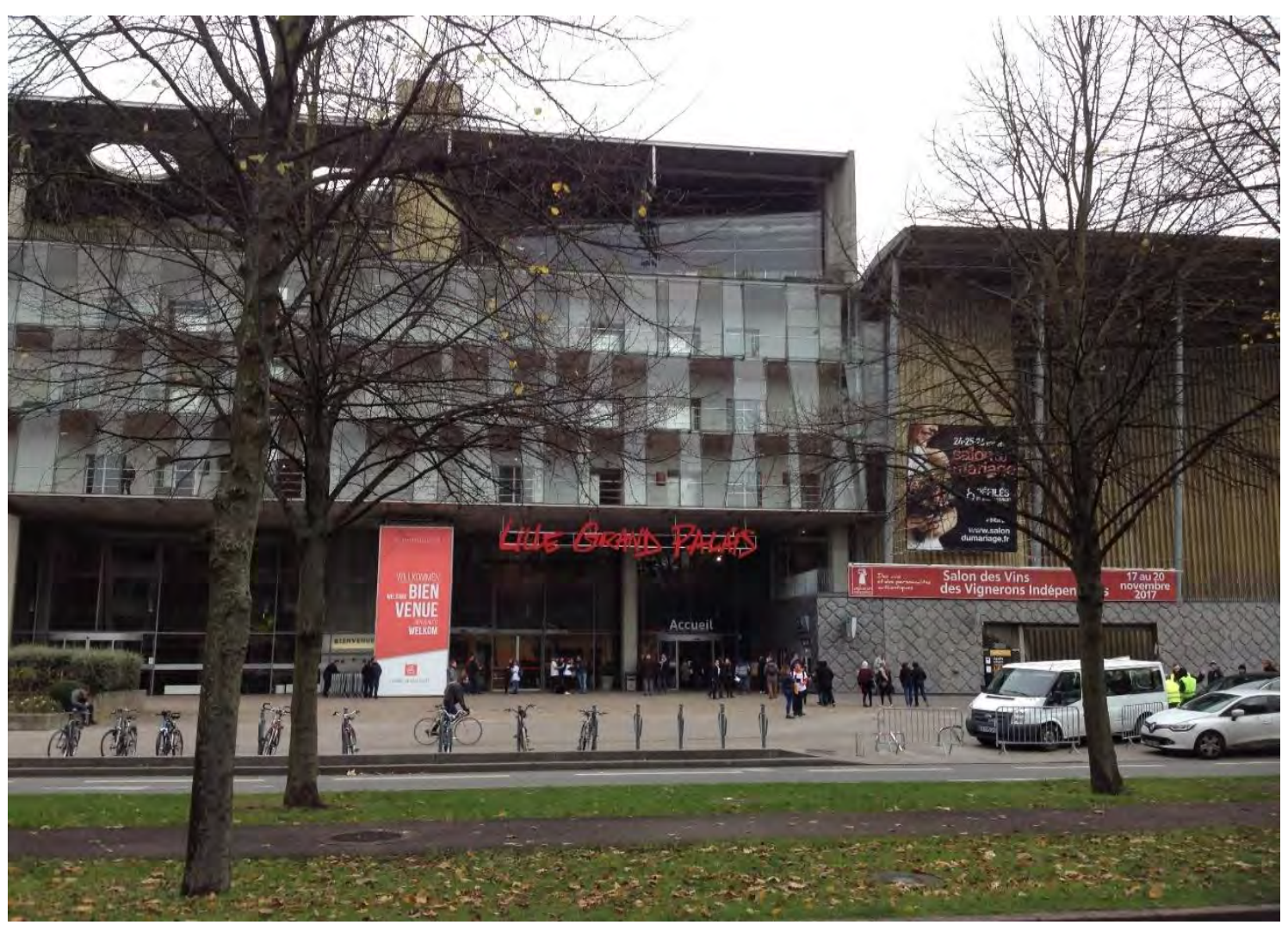

Centro de Exposições Grand Palais - Lille

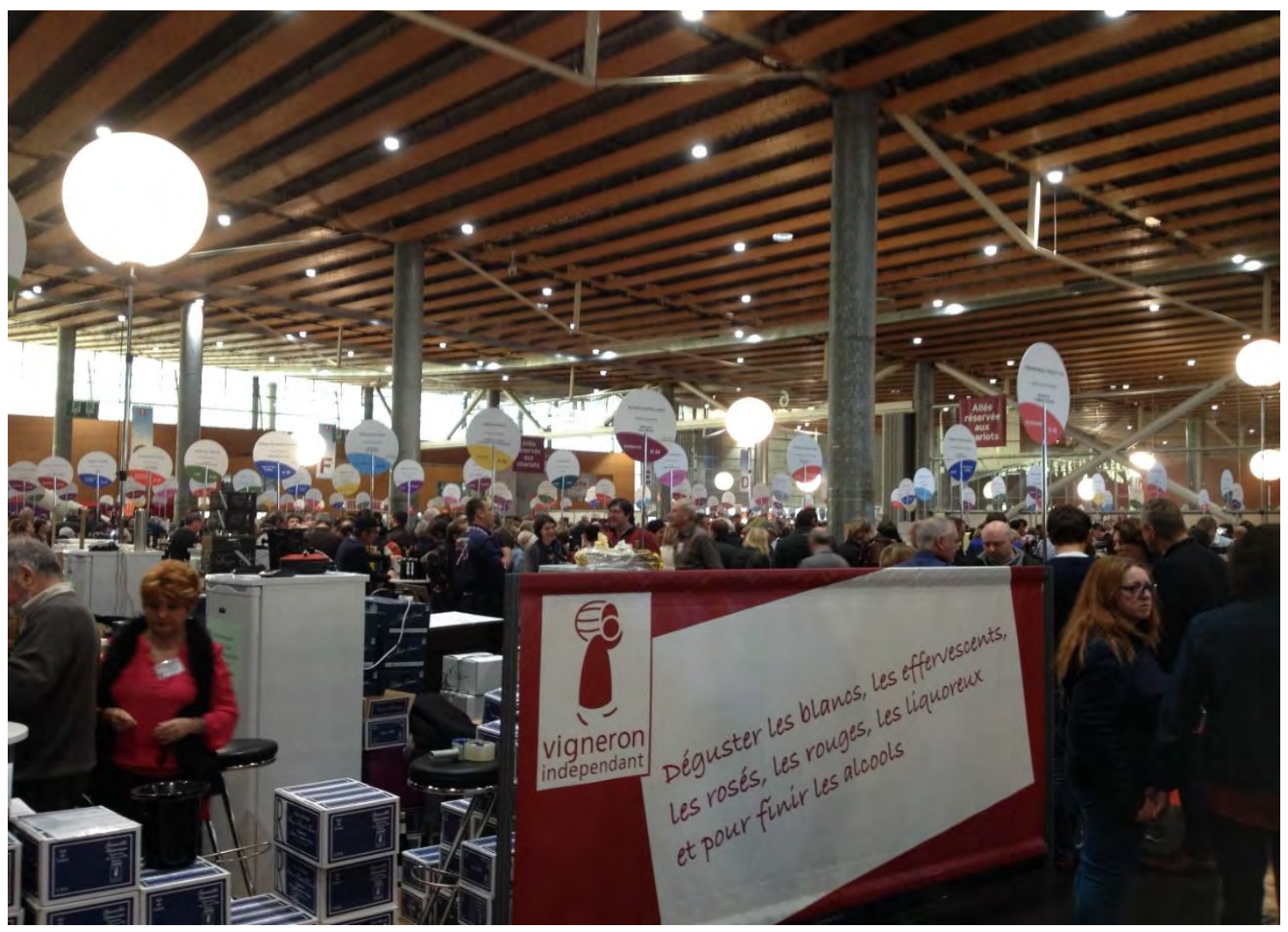

Feira de vinhos Vignerons Indépendants - Grand Palais - Lille 


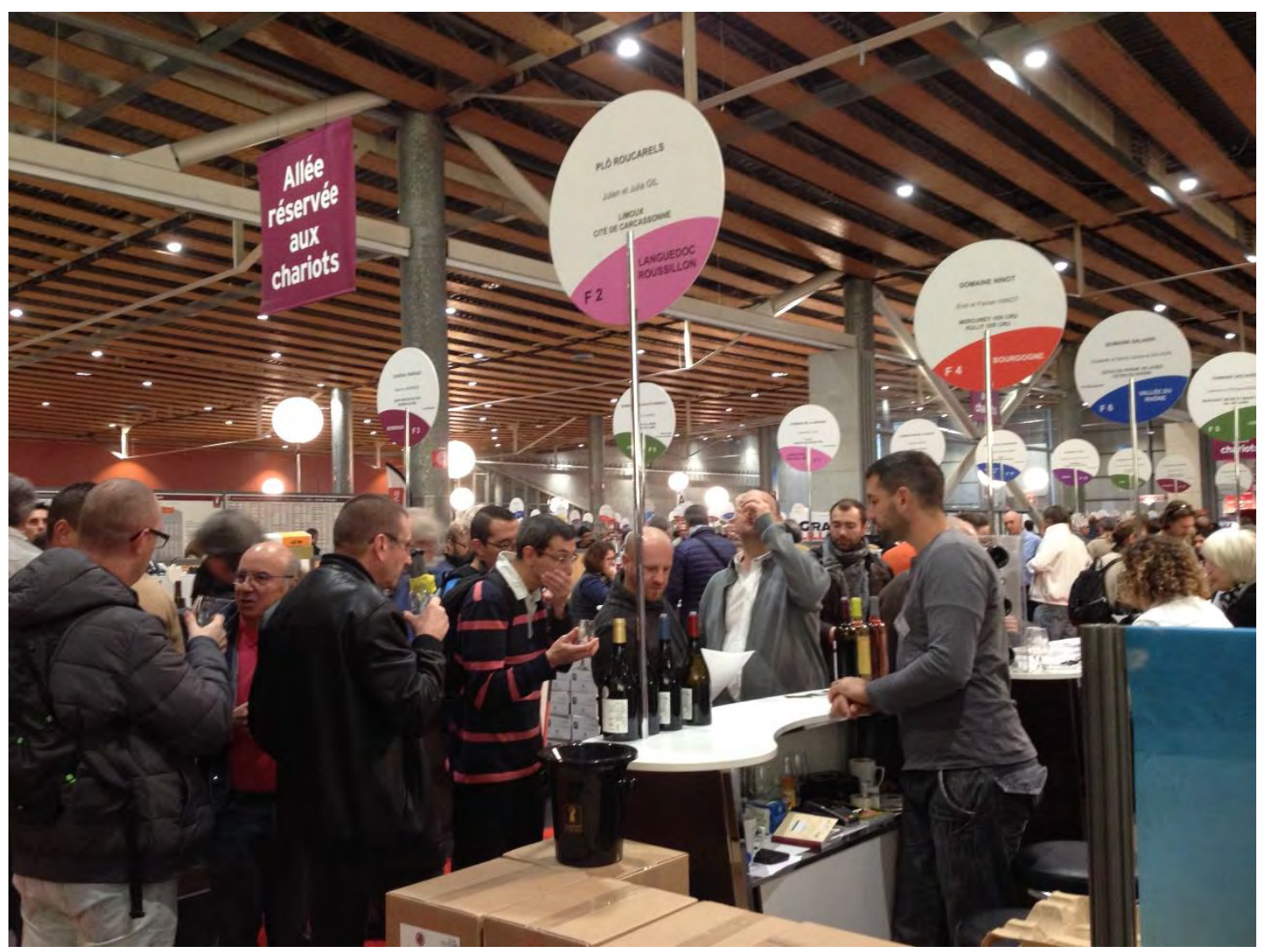

Degustação - Feira de Vinhos Vignerons Indépendants - Grand Palais - Lille

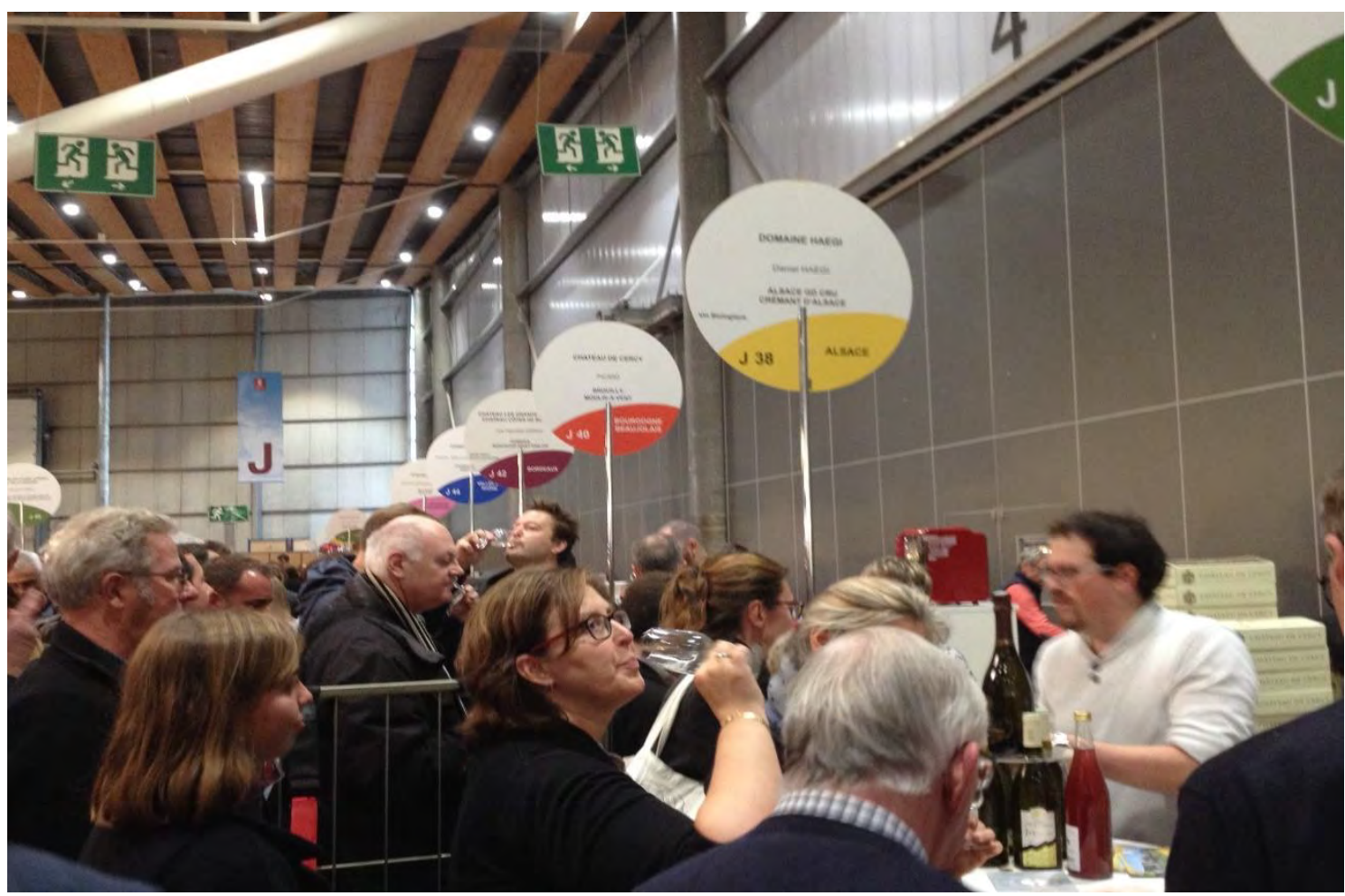

Degustação - Feira de Vinhos Vignerons Indépendants - Grand Palais - Lille 


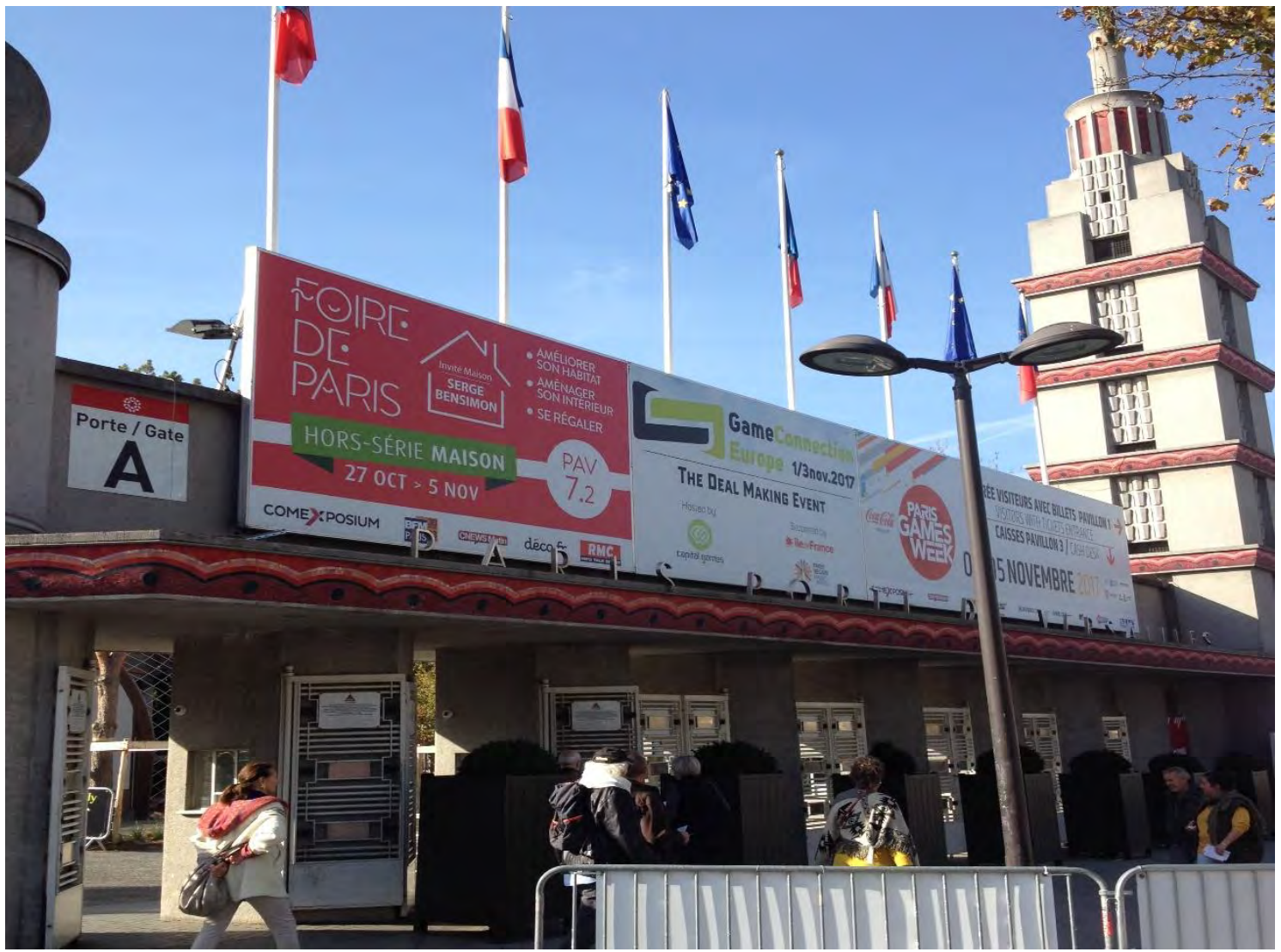

Foire de Paris - Paris Porte de Versailles

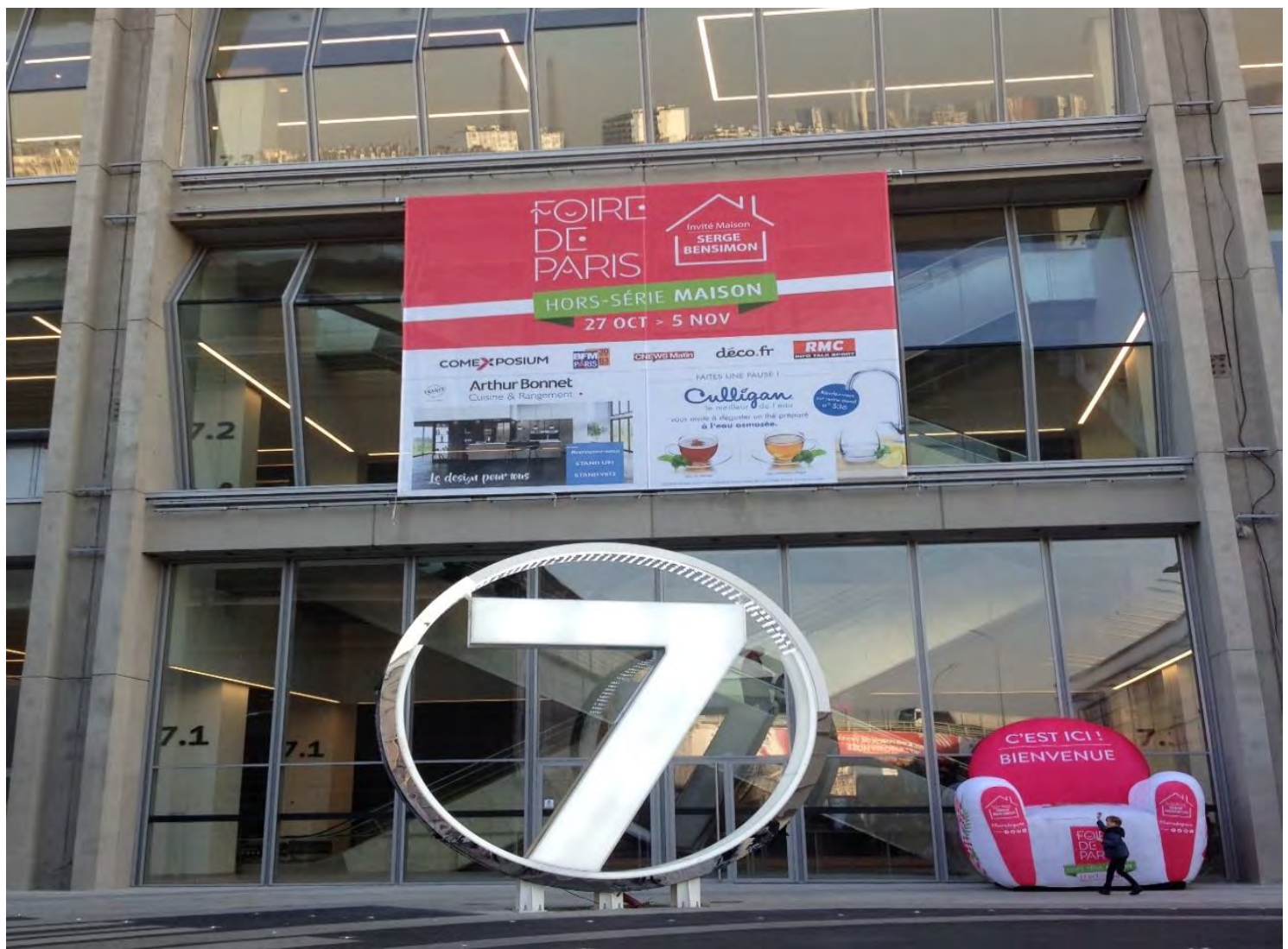

Pavilhão 7 - Paris Porte de Versailles - Foire de Paris 


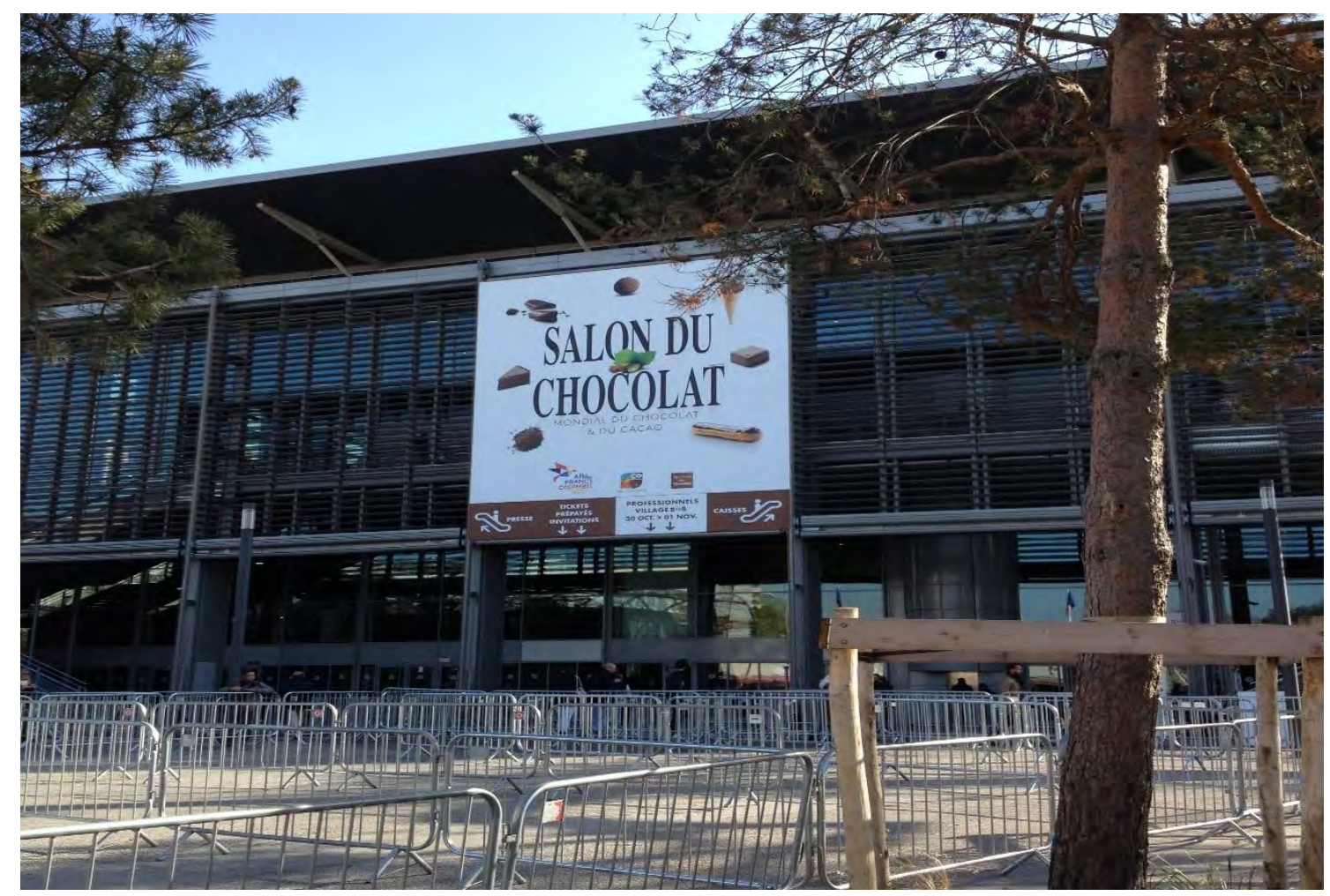

Salon du Chocolat - Paris Porte de Versailles

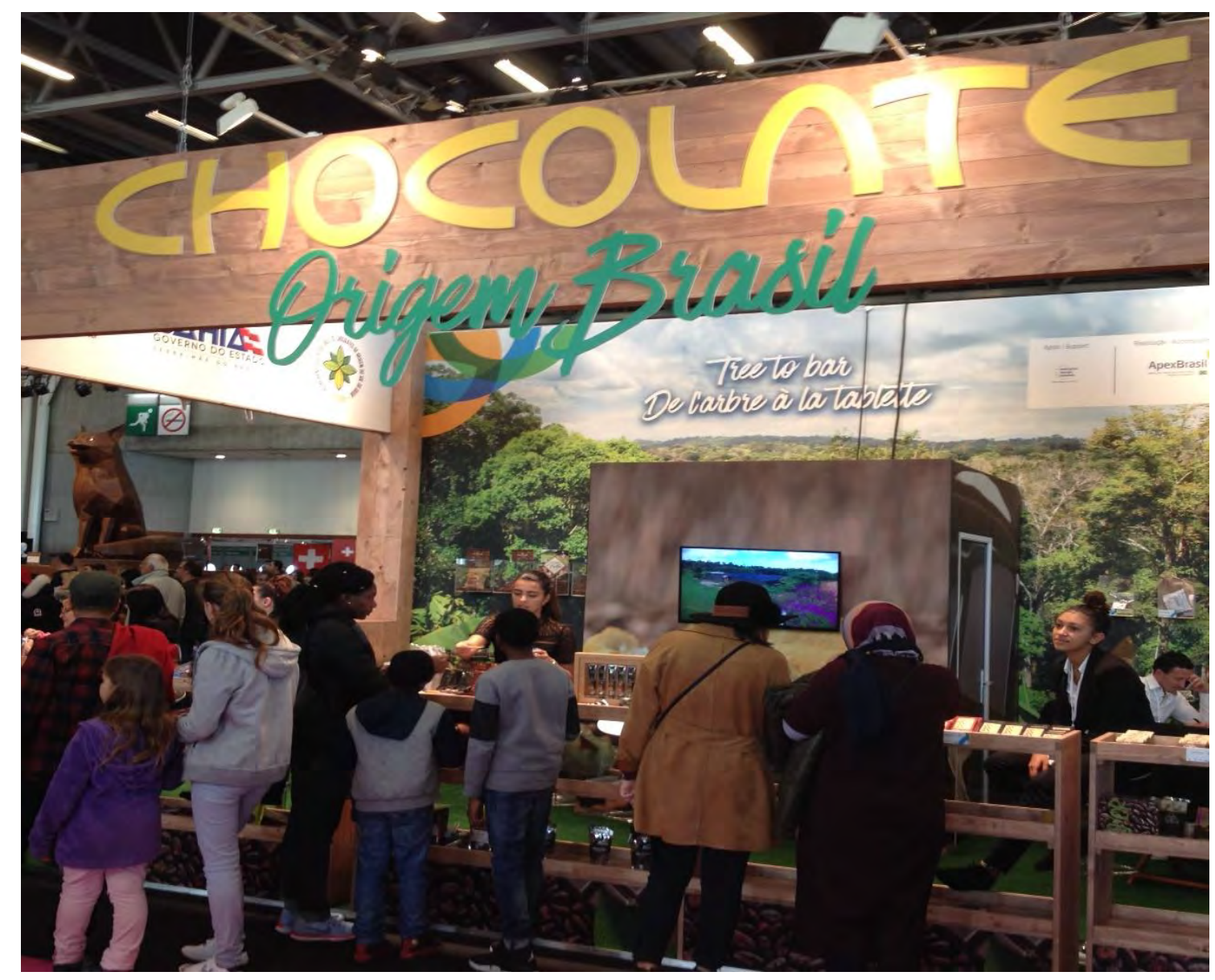

Estande Brasil 


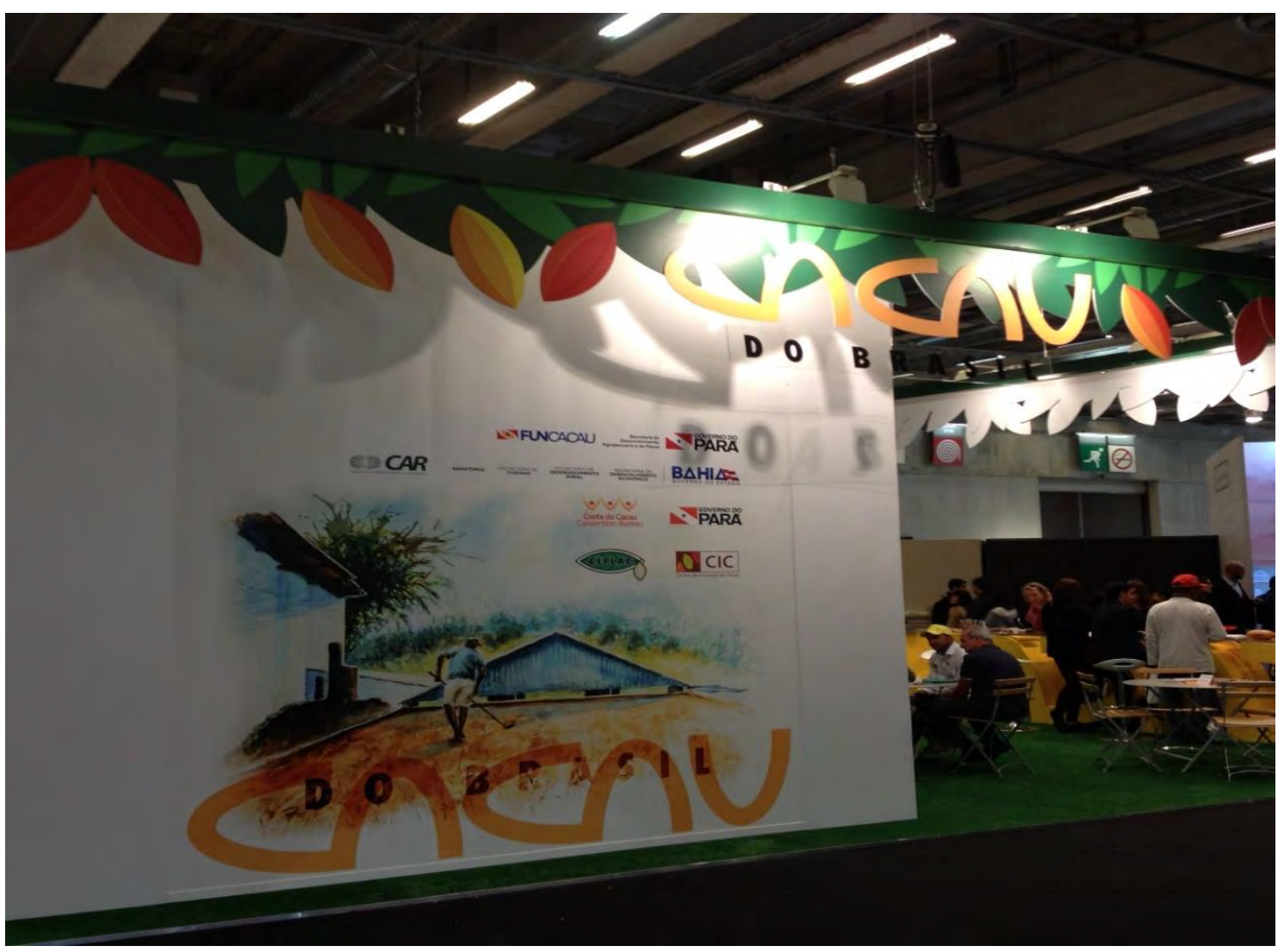

Estande Brasil

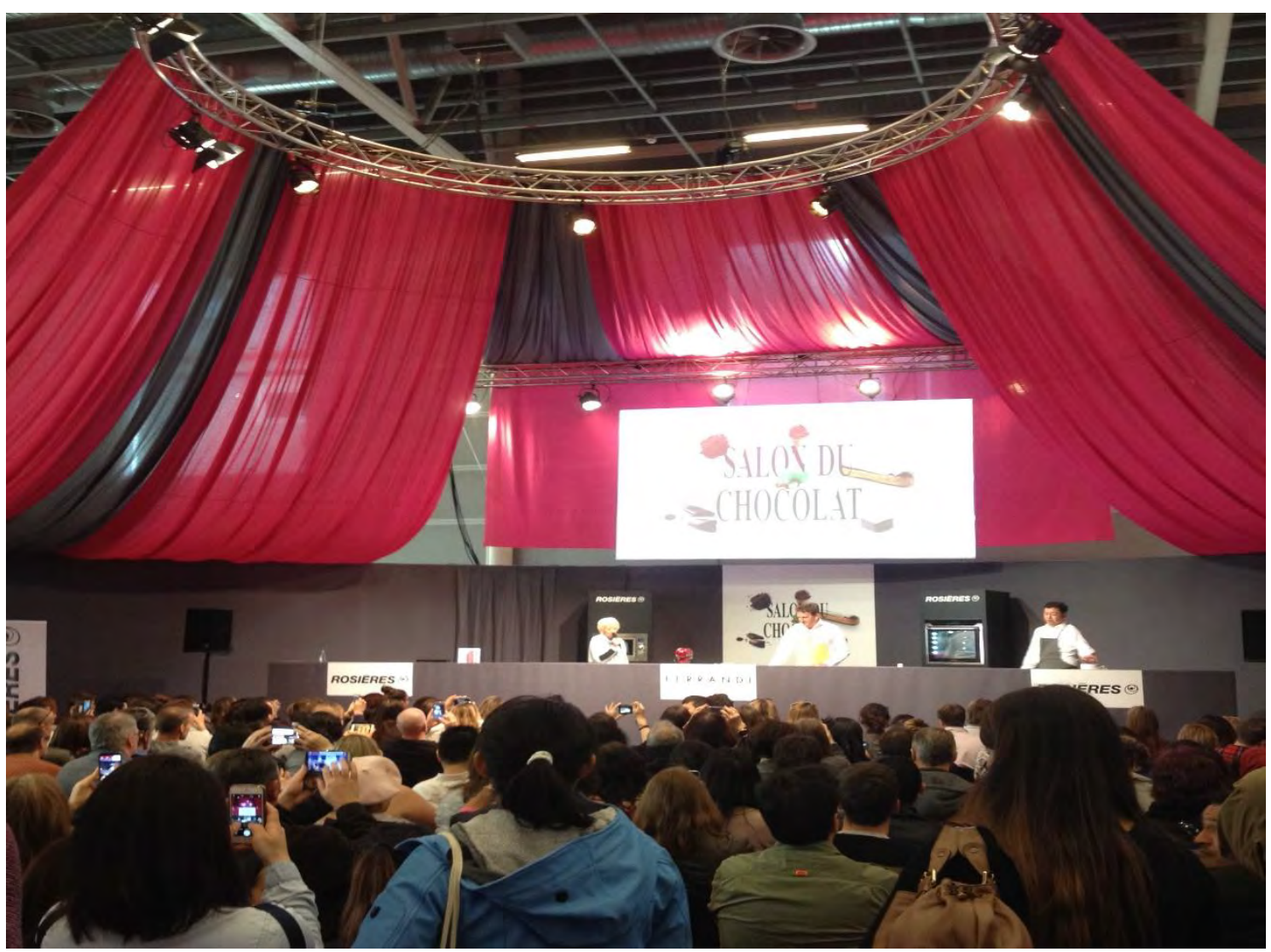

Workshop - Salon du Chocolat - Paris Porte de Versailles 


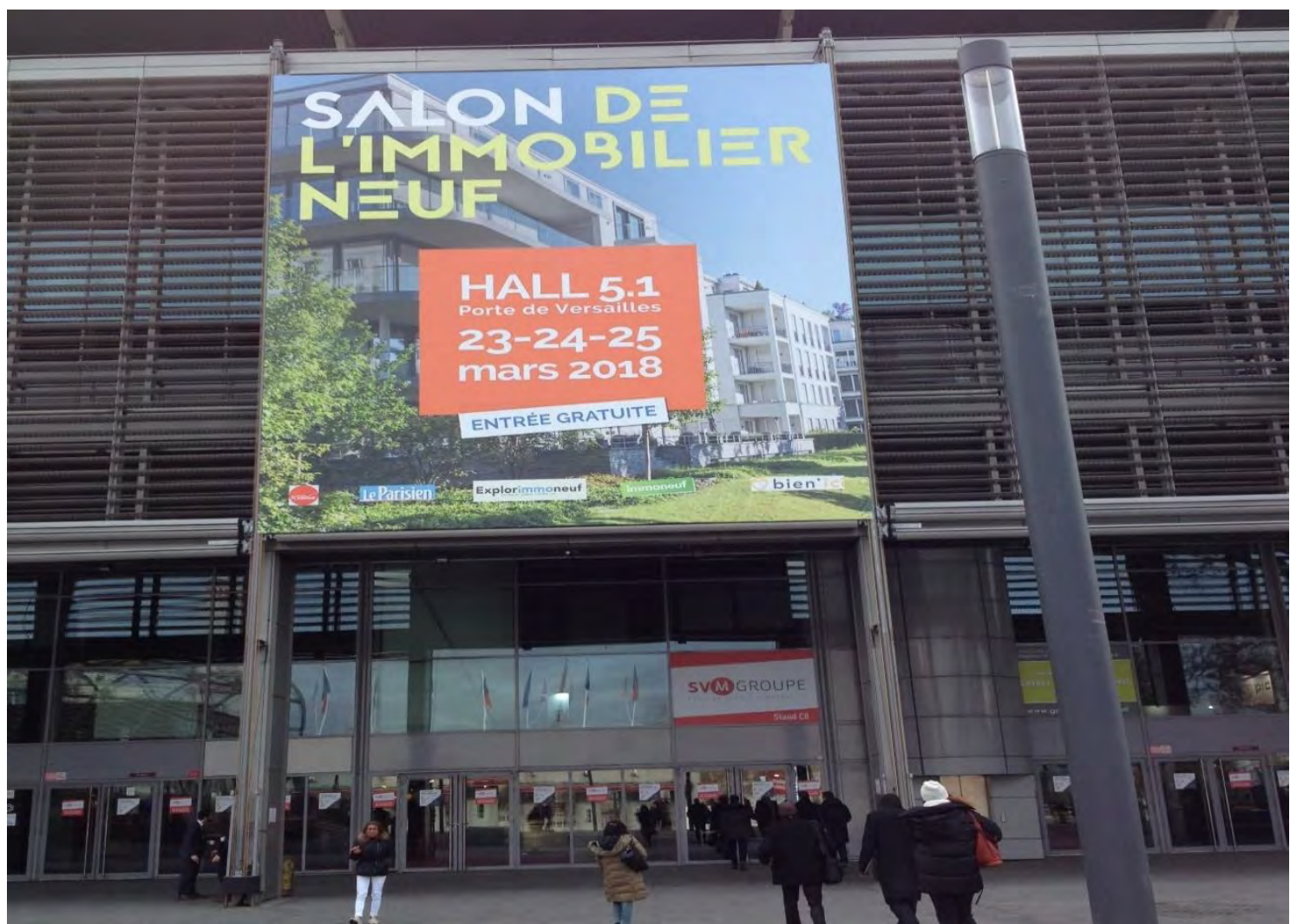

Centro de exposições Paris Porte de Versailles

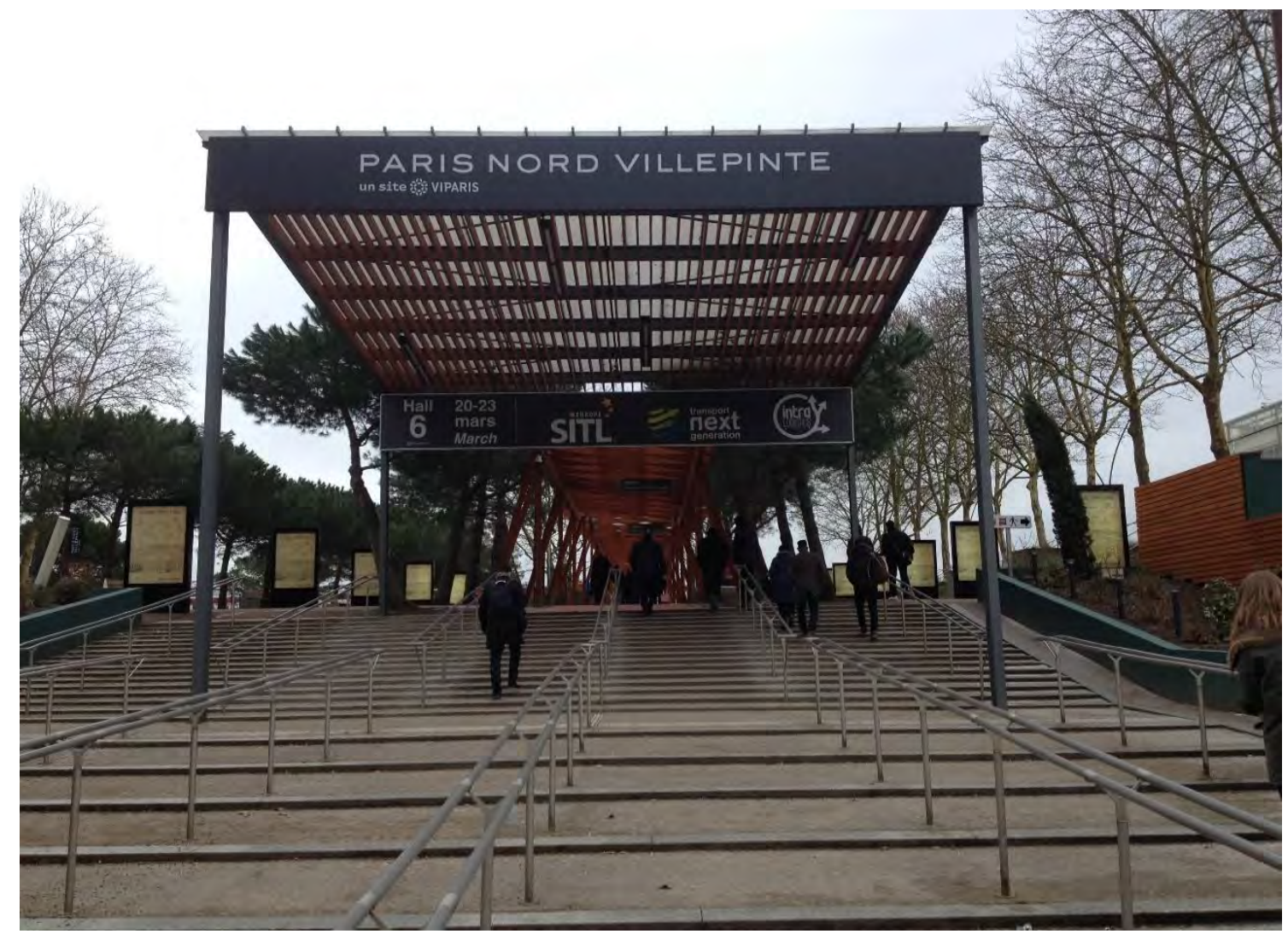

Centro de exposições Paris Nord Villepinte 


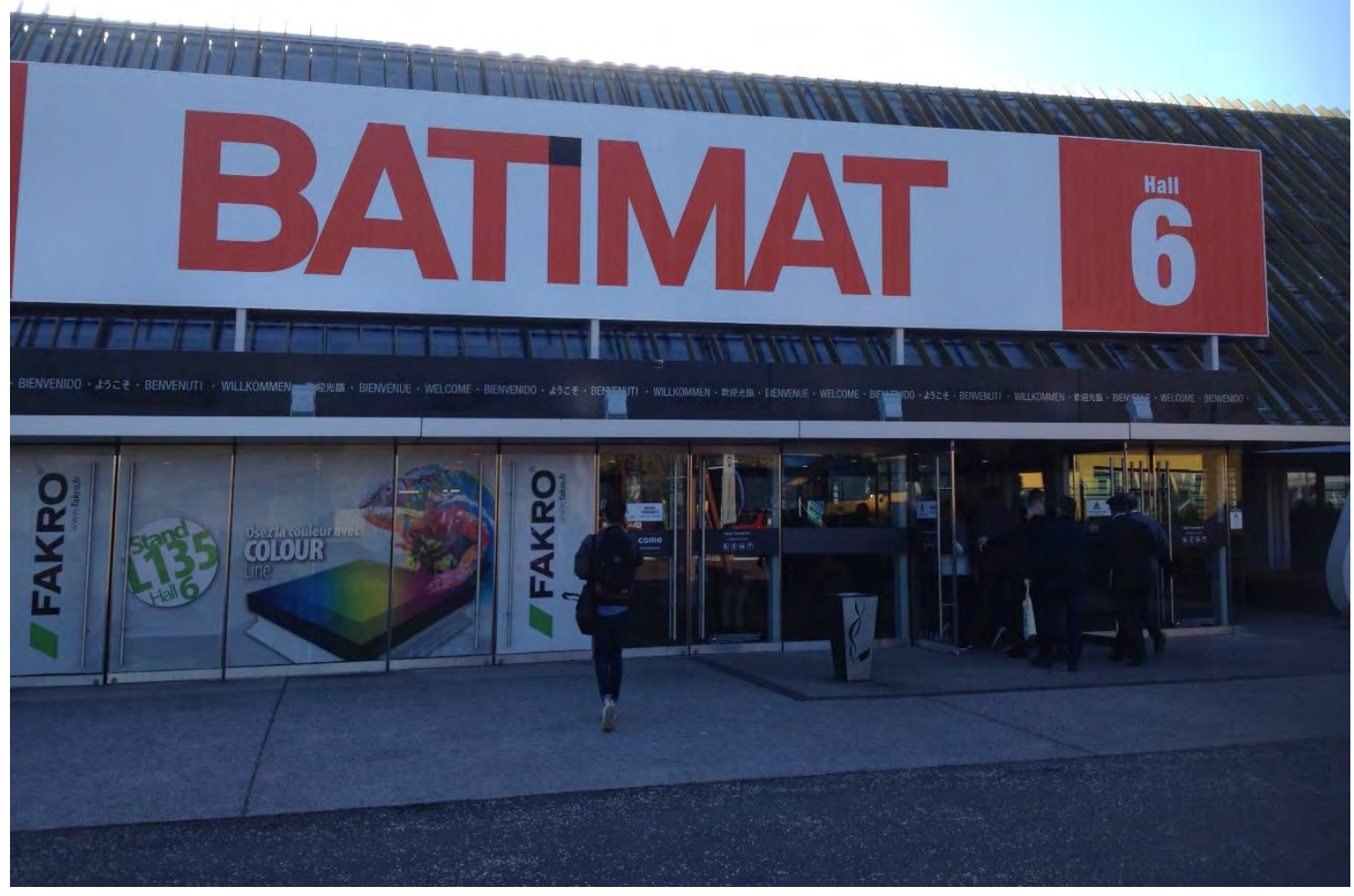

Pavilhão 6 - Paris Nord Villepinte - Salon Batimat

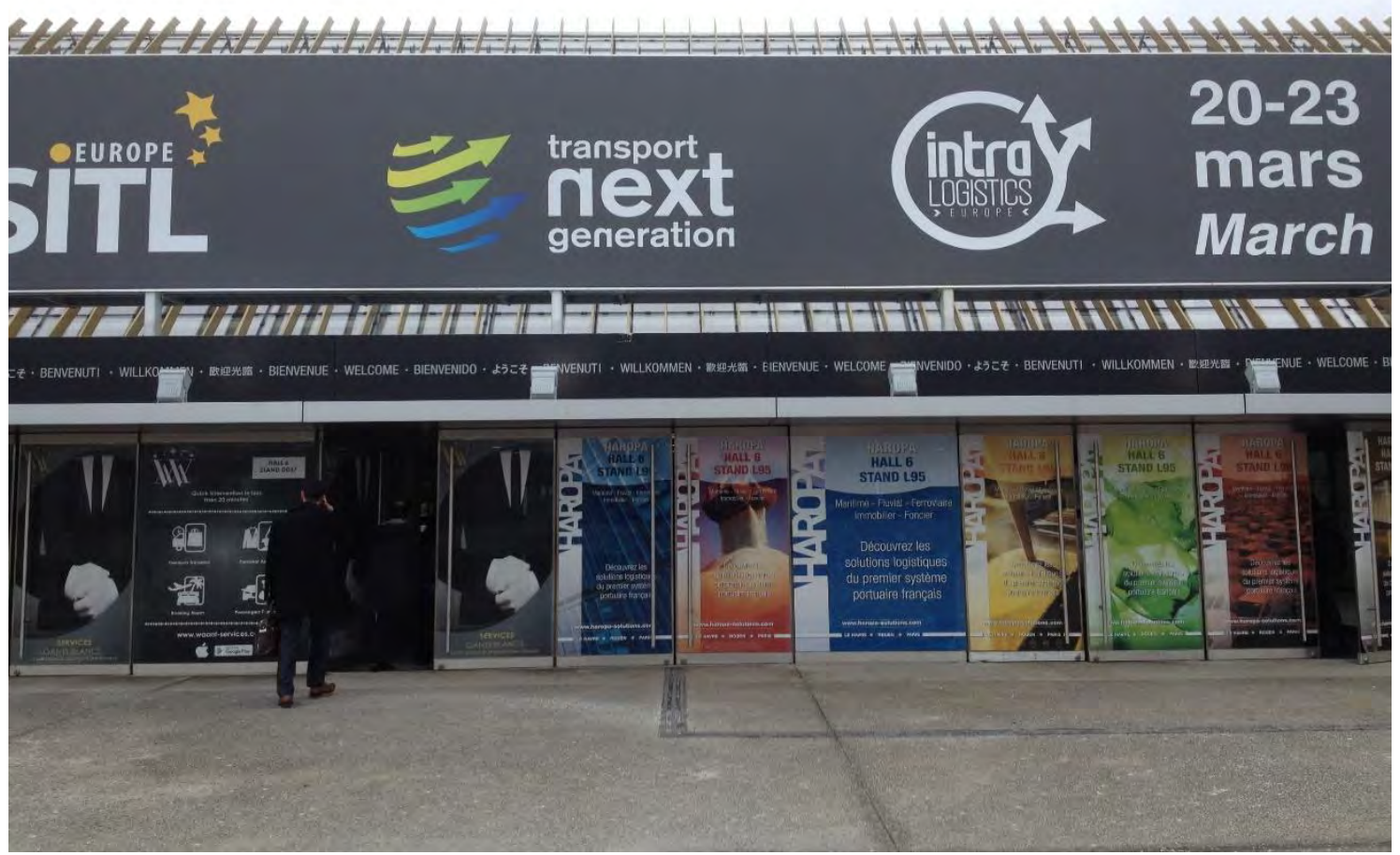

Feira de transportes SITL - Paris Nord Villepinte 


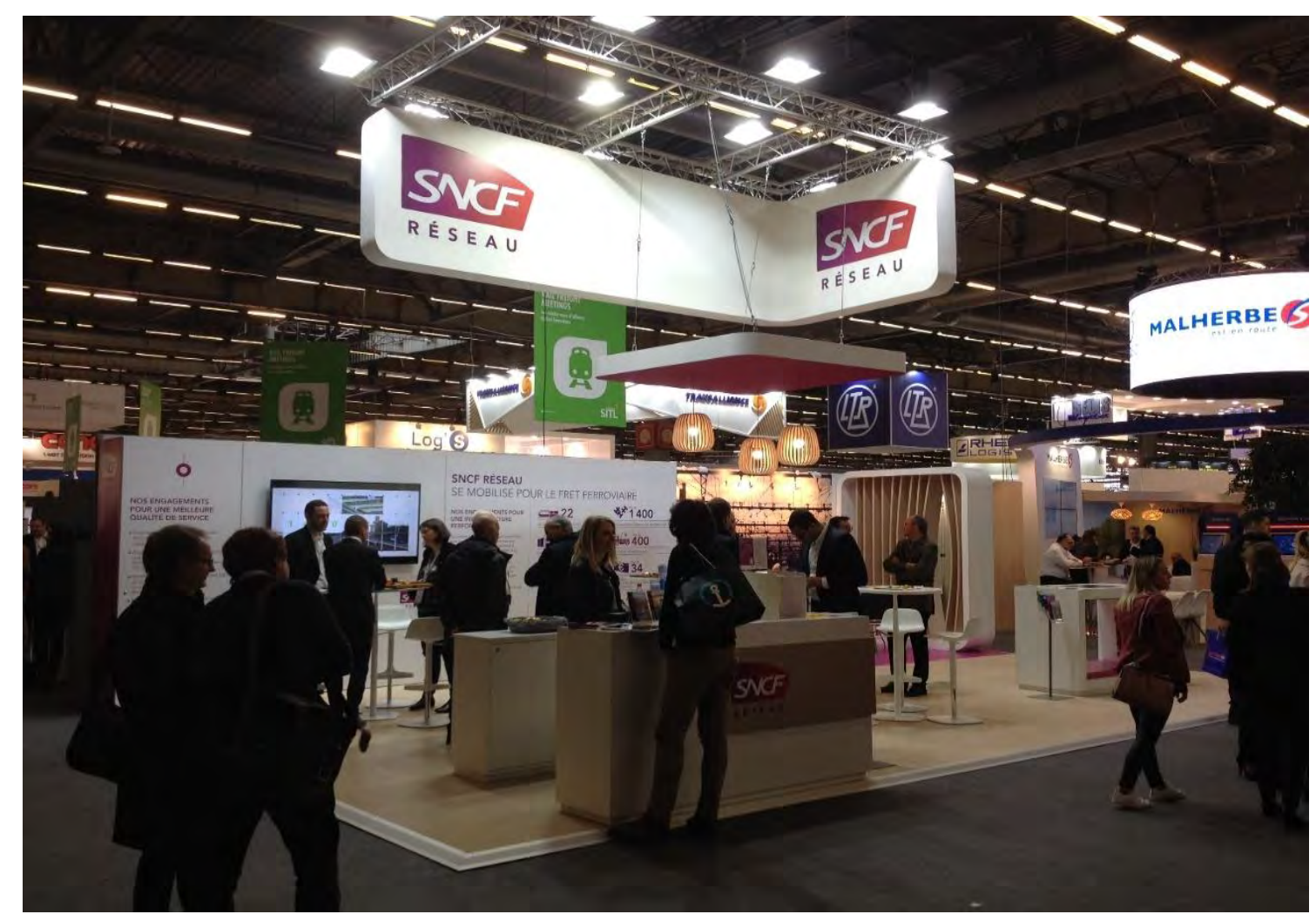

Estande personalizado

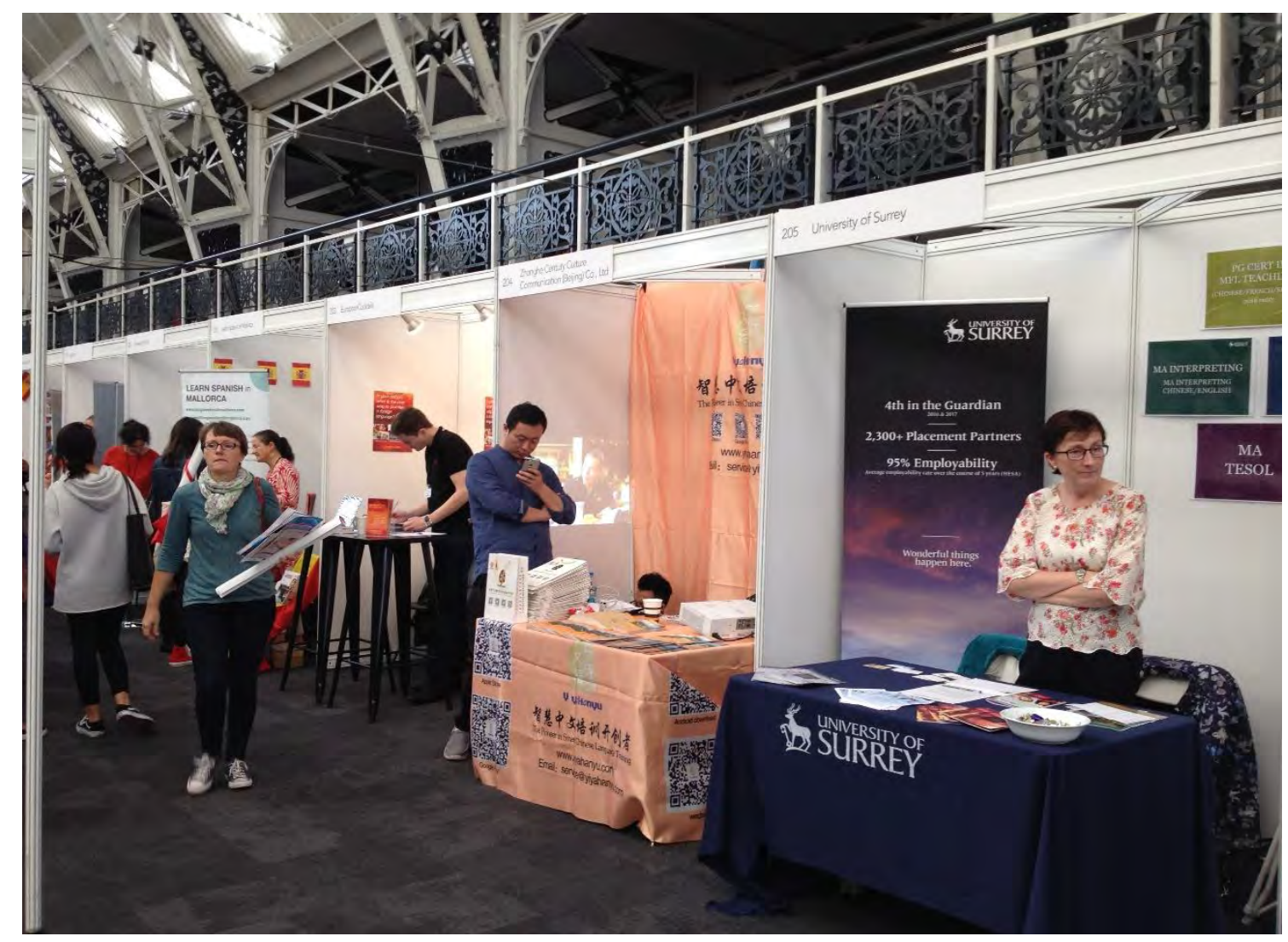

Feira Language Show - Universidade de Surrey estava presente com estande 


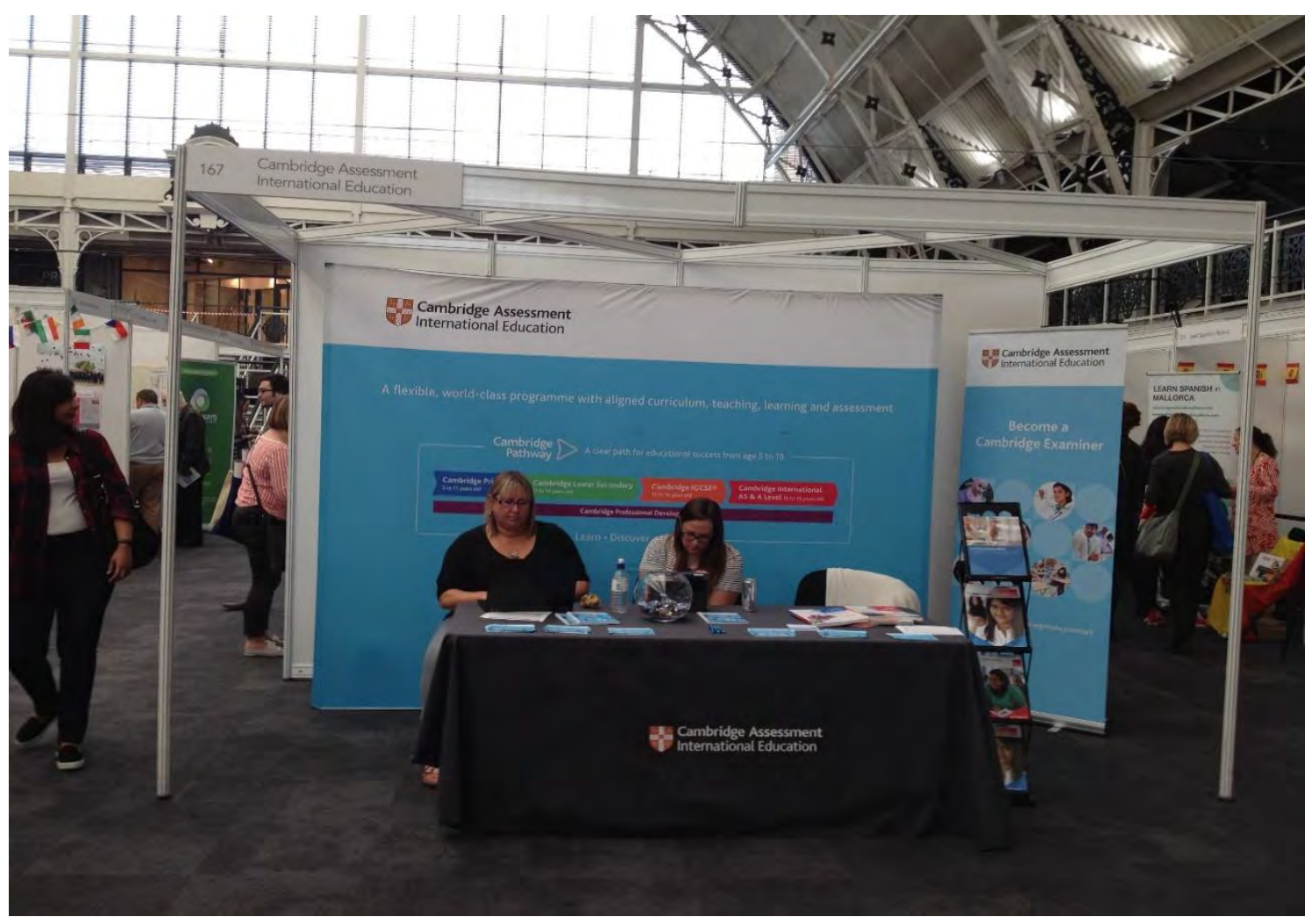

Estande básico - Language Show - Business Design Centre - Londres

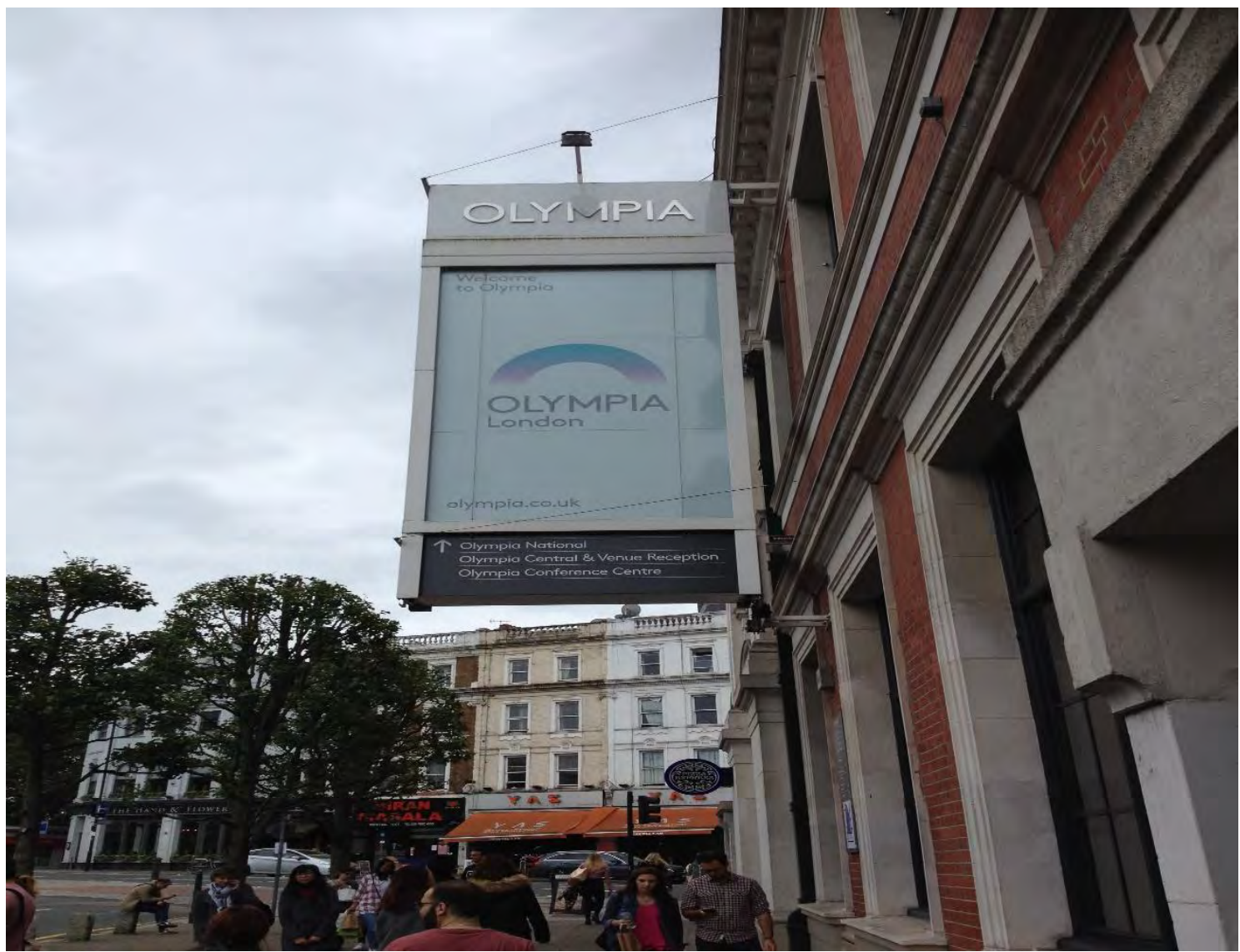

Centro de exposições Olympia London 


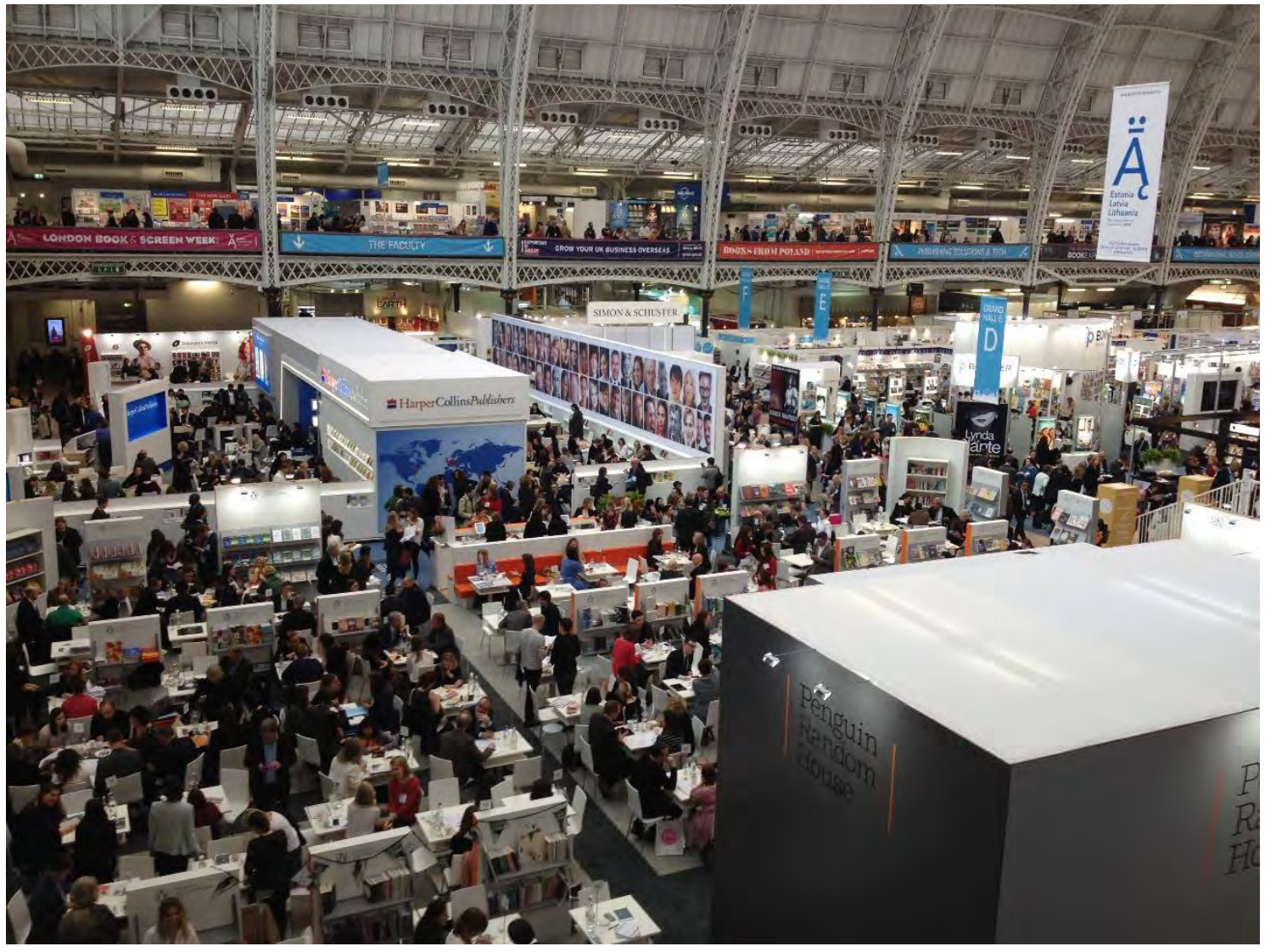

Pavilhão de Exposições da London Book Fair

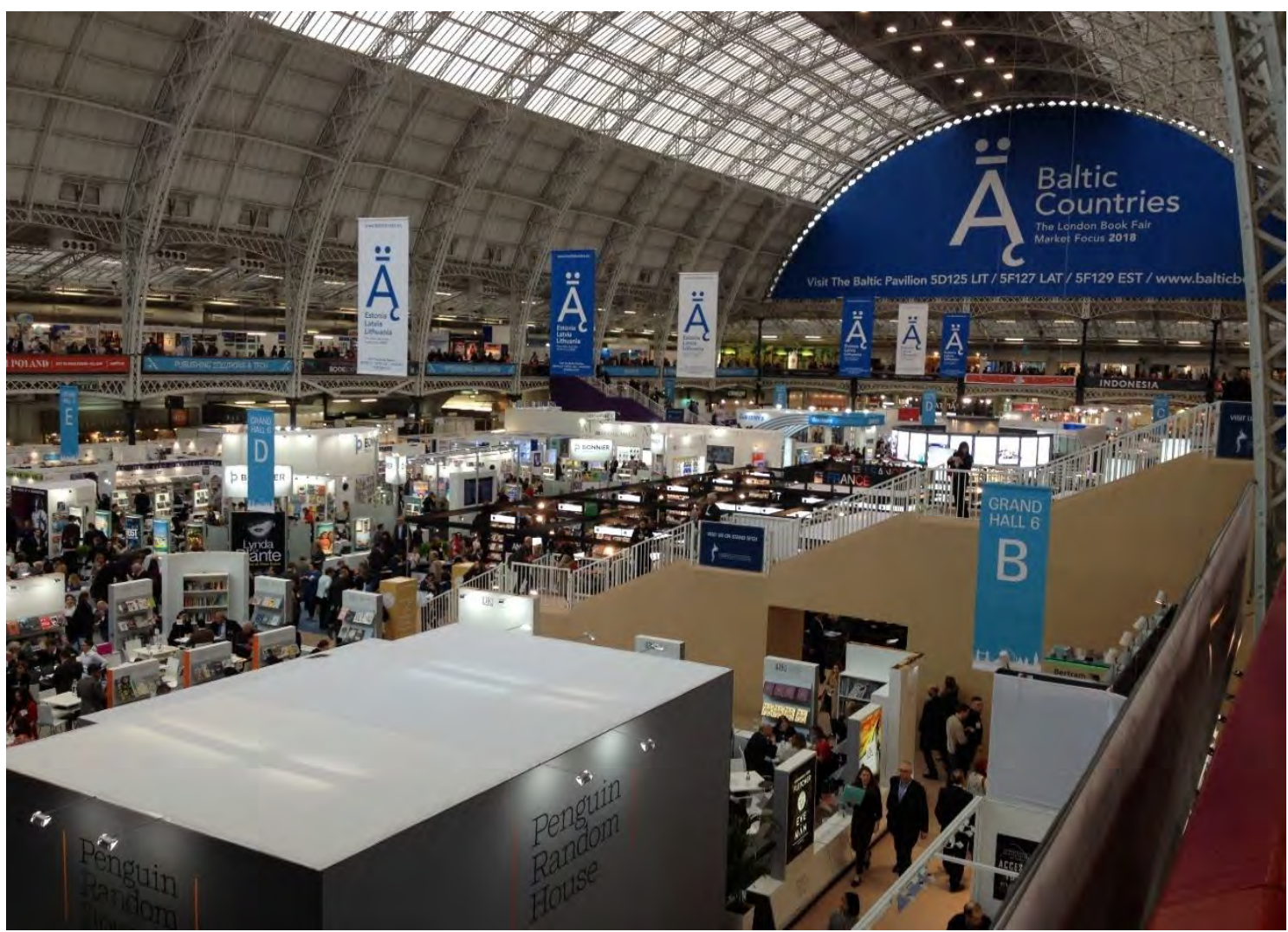

Pavilhão de Exposições da London Book Fair 


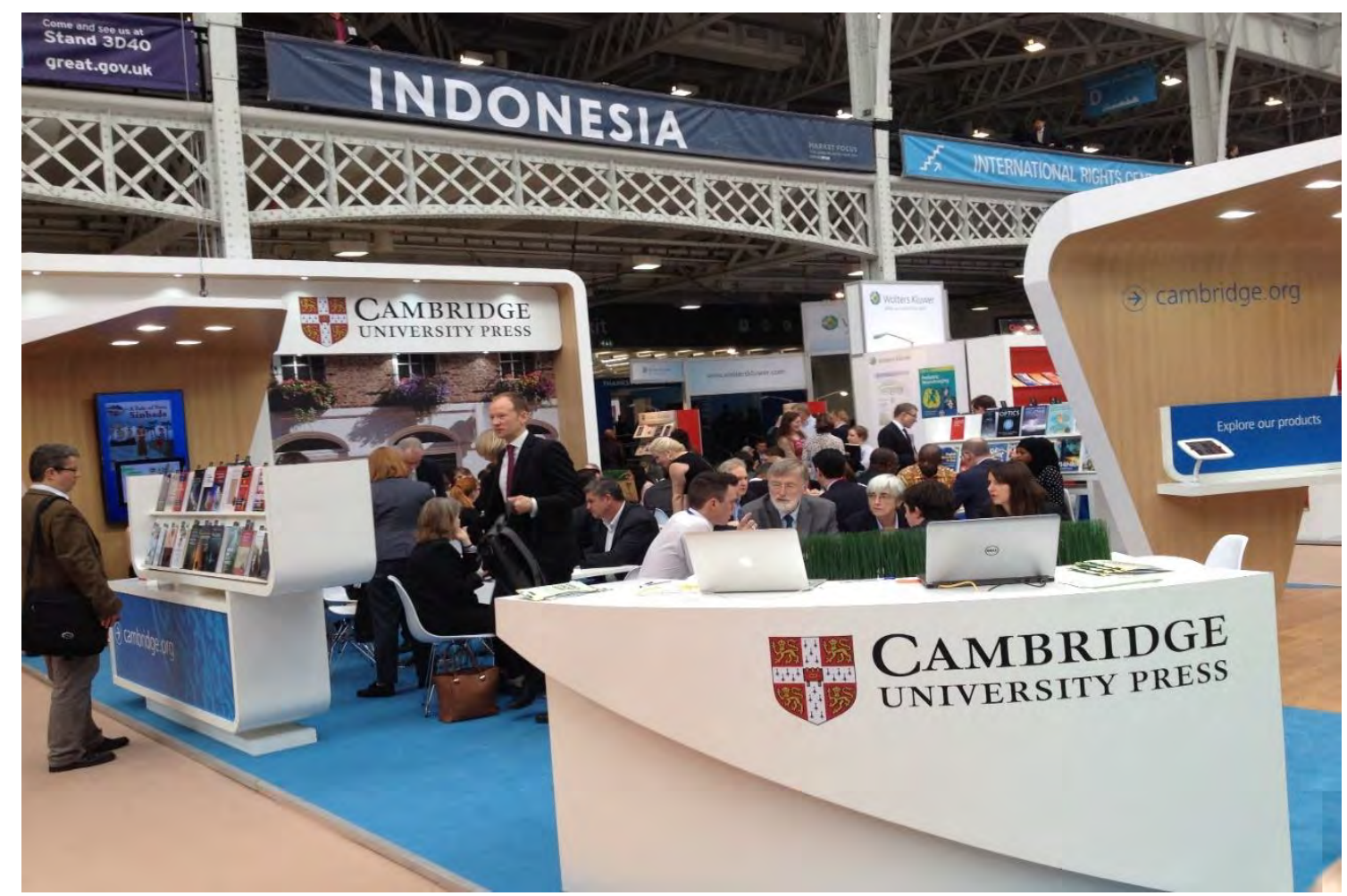

Estande ilha da Cambridge University - London Book Fair

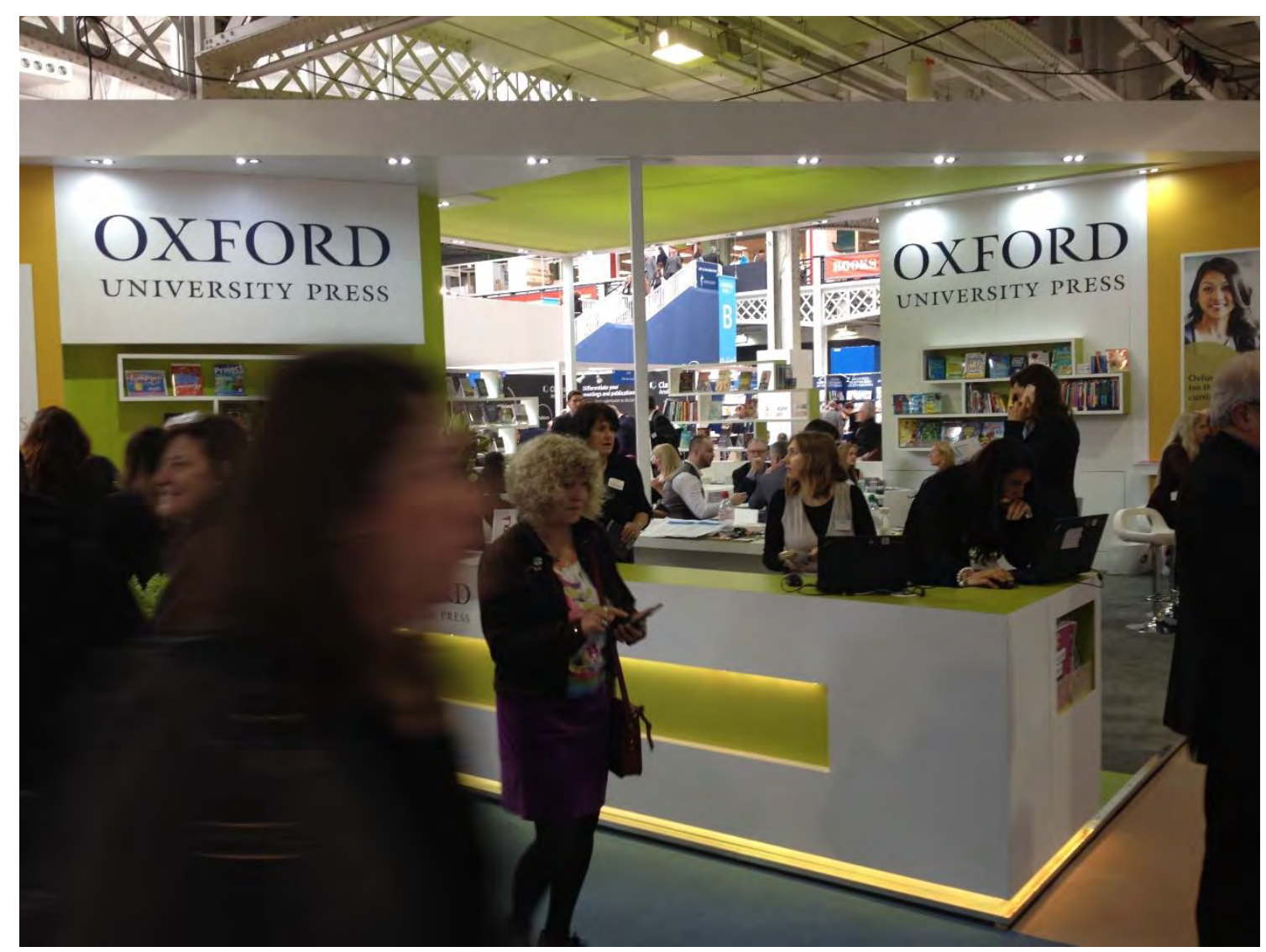

Estande construído - Oxford University - London Book Fair 


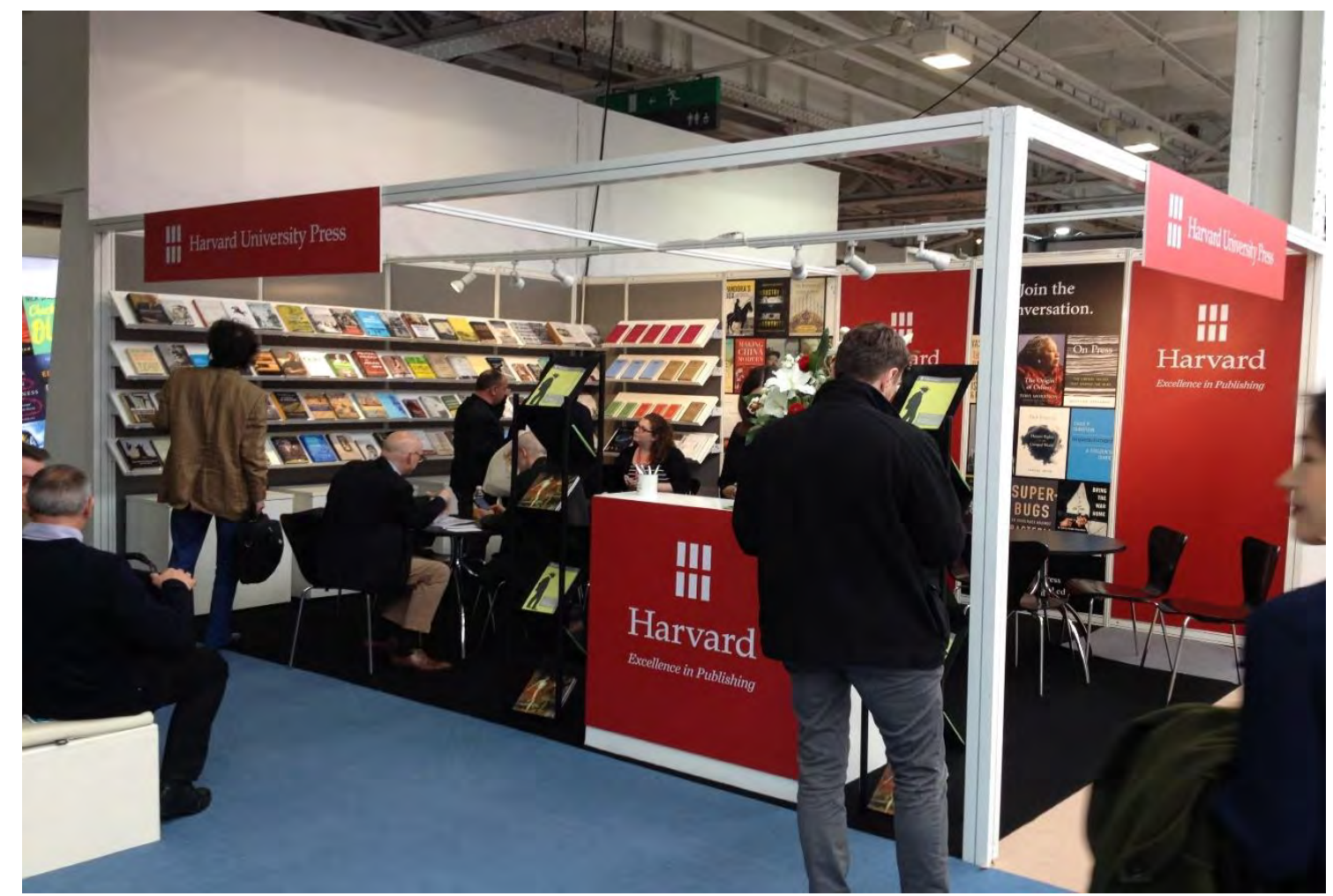

Estande básico (shell scheme) - Universidade de Harvard - London Book Fair

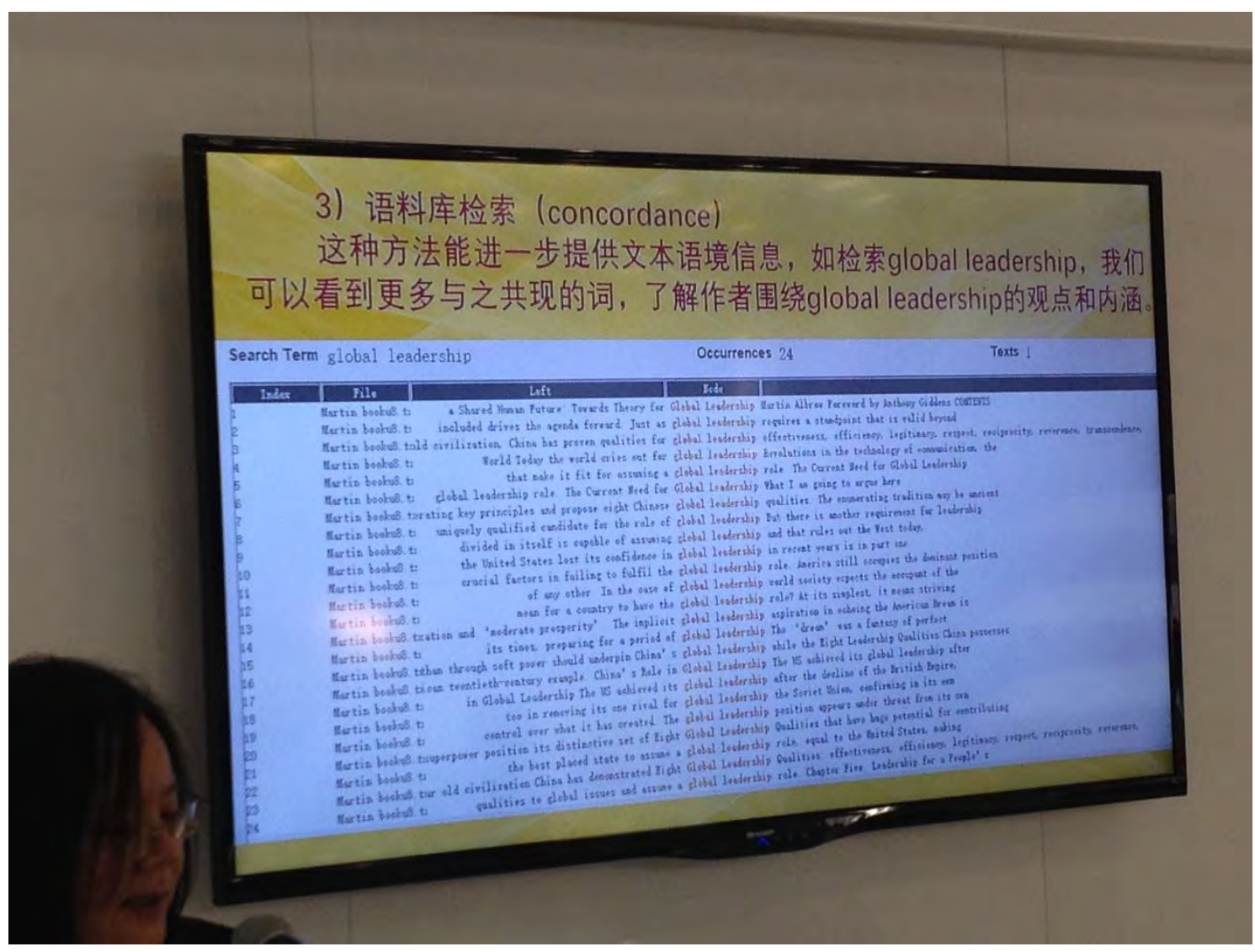

Demonstração do funcionamento de uma ferramenta (concordance) no estande 


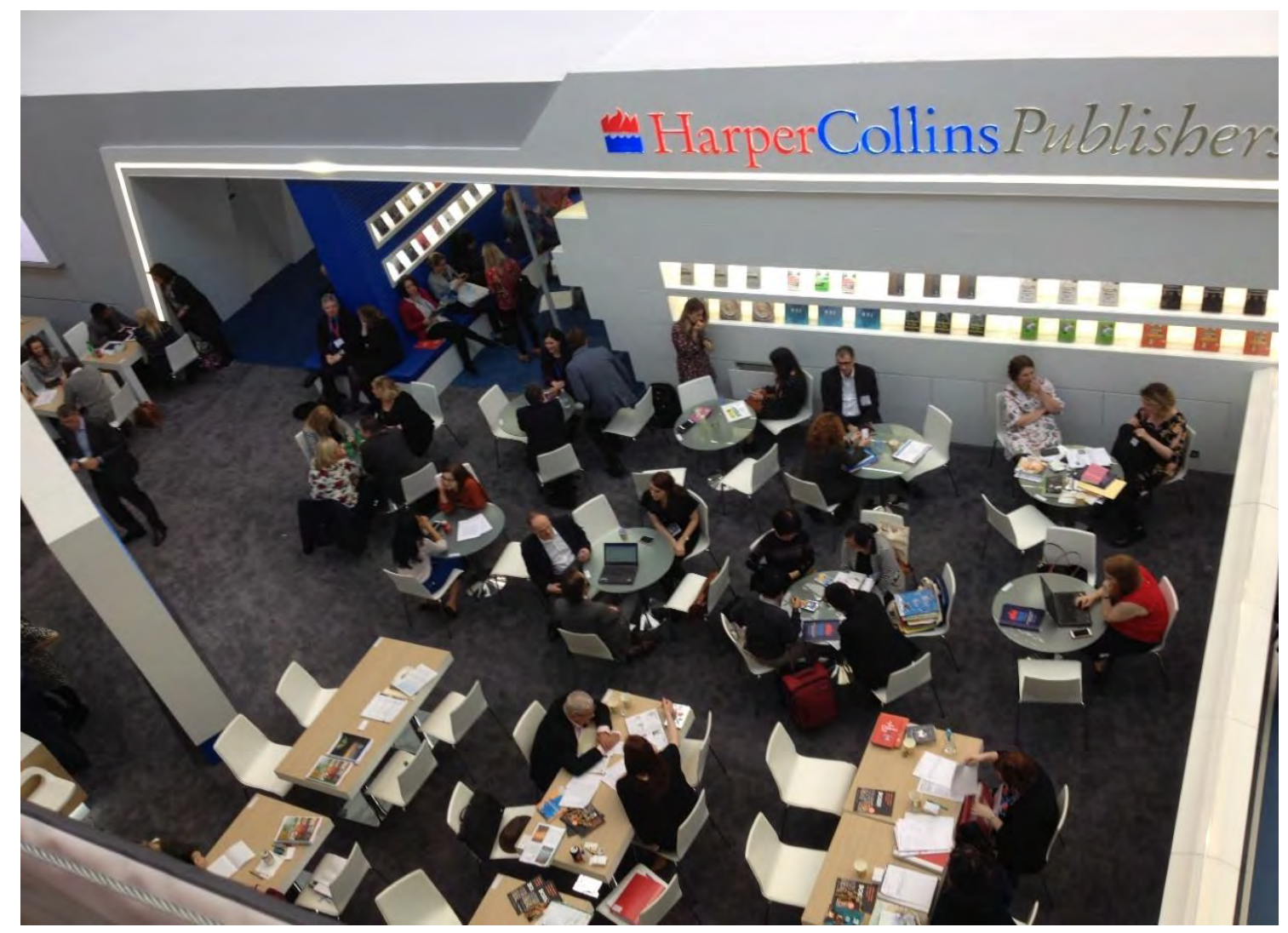

Reuniões de negócios no estande

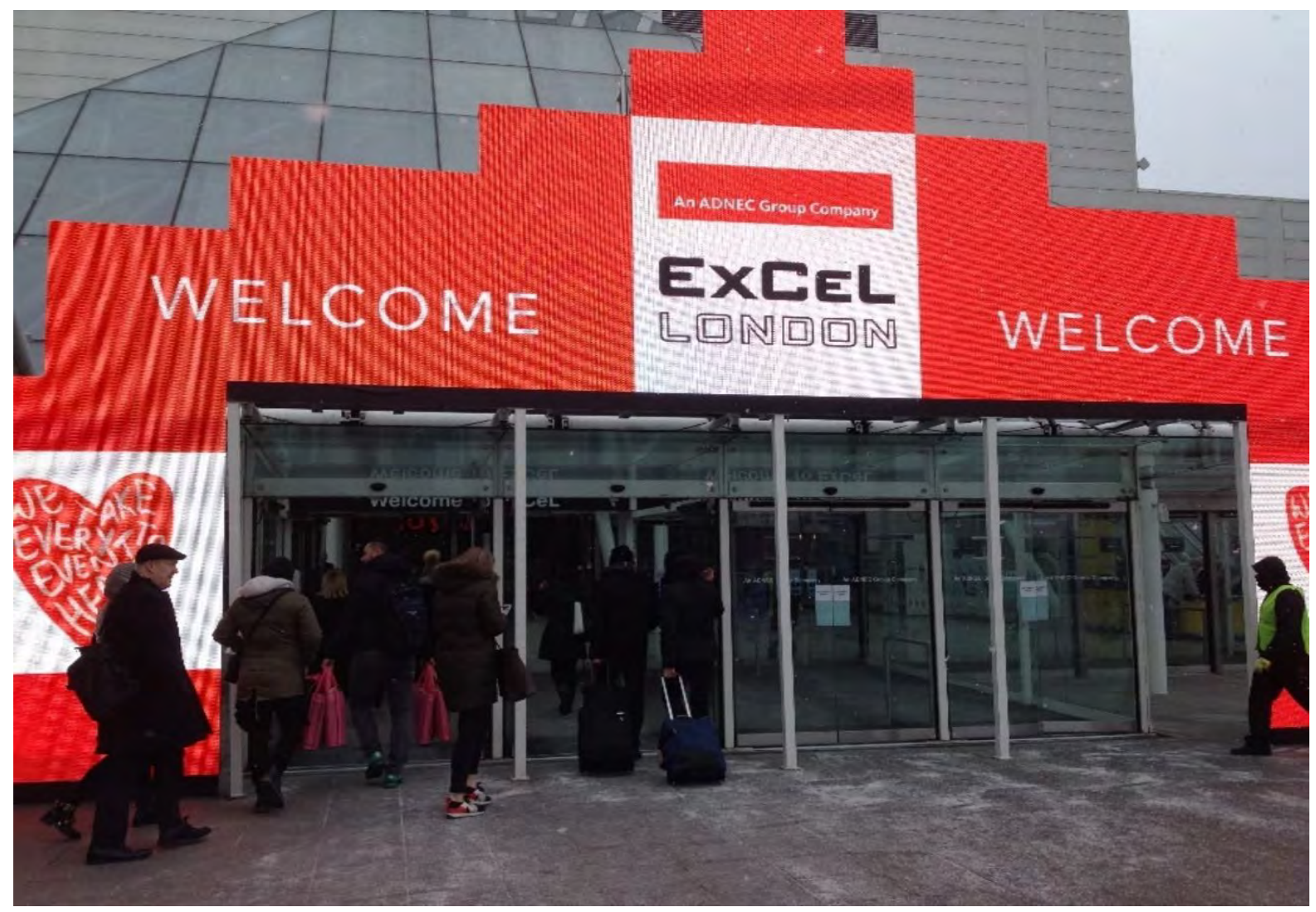

Centro de exposições Excel London 


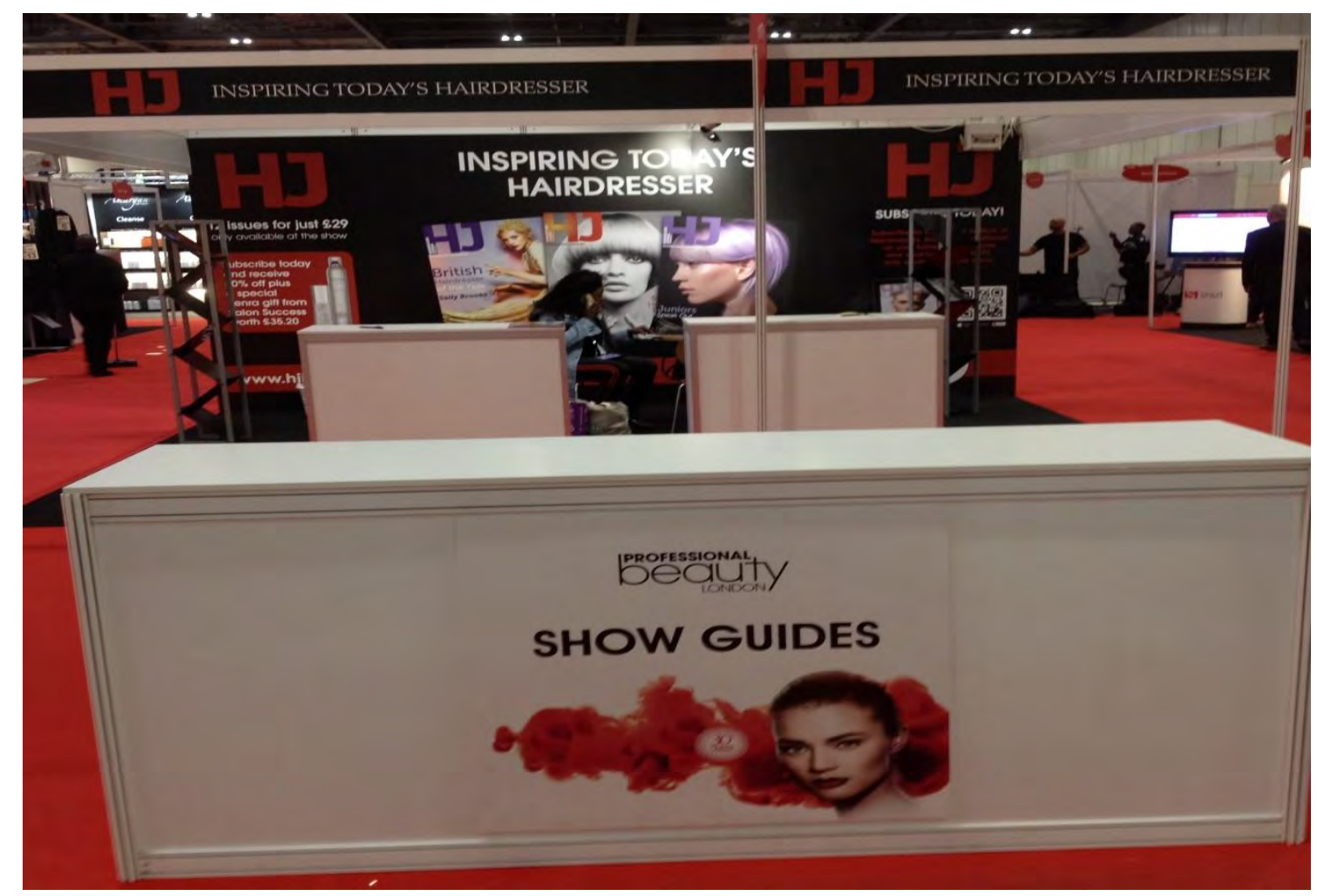

Entrada da feira - local de retirada do catálogo da feira (show guide)

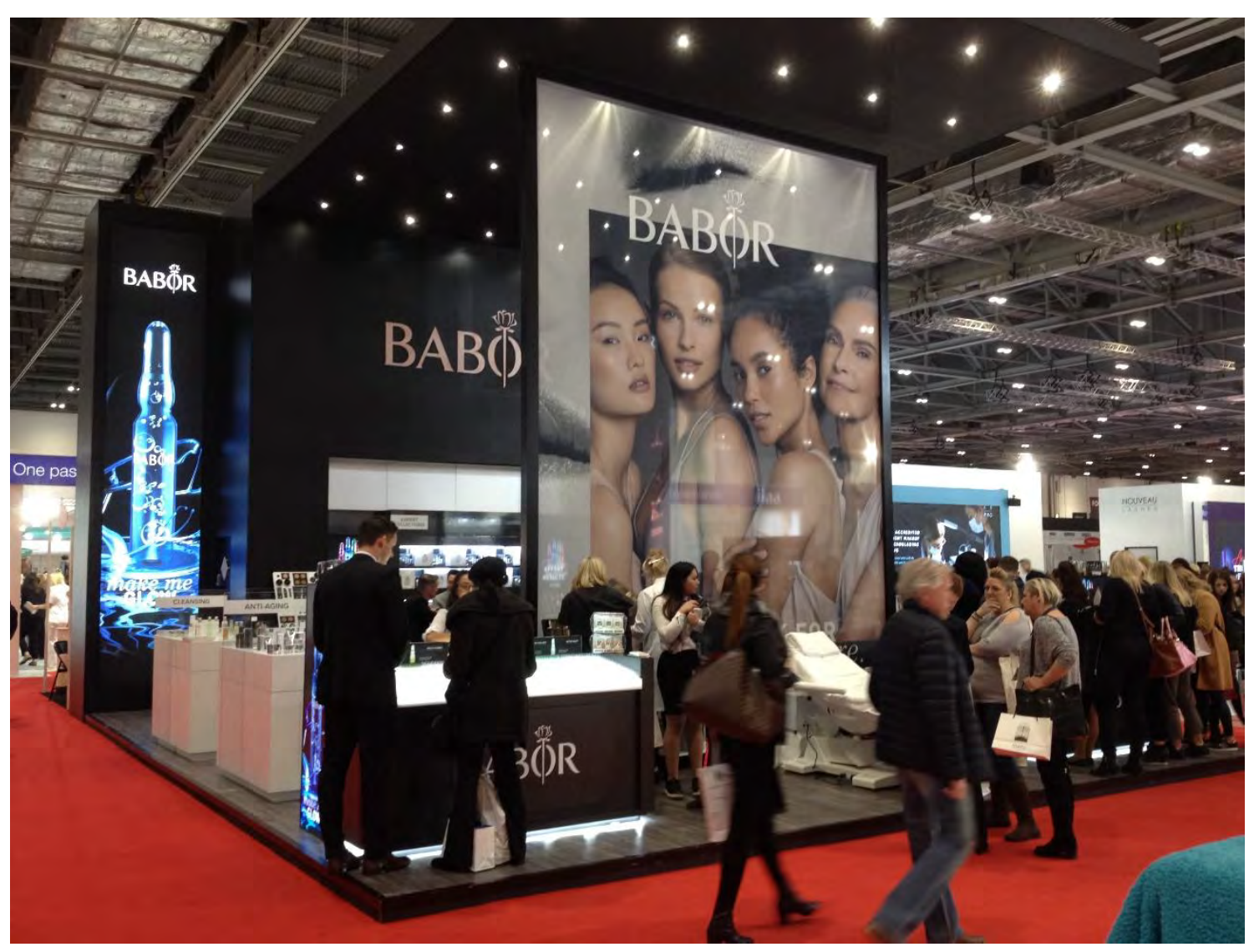

Estande construído - Feira Professional Beauty London 


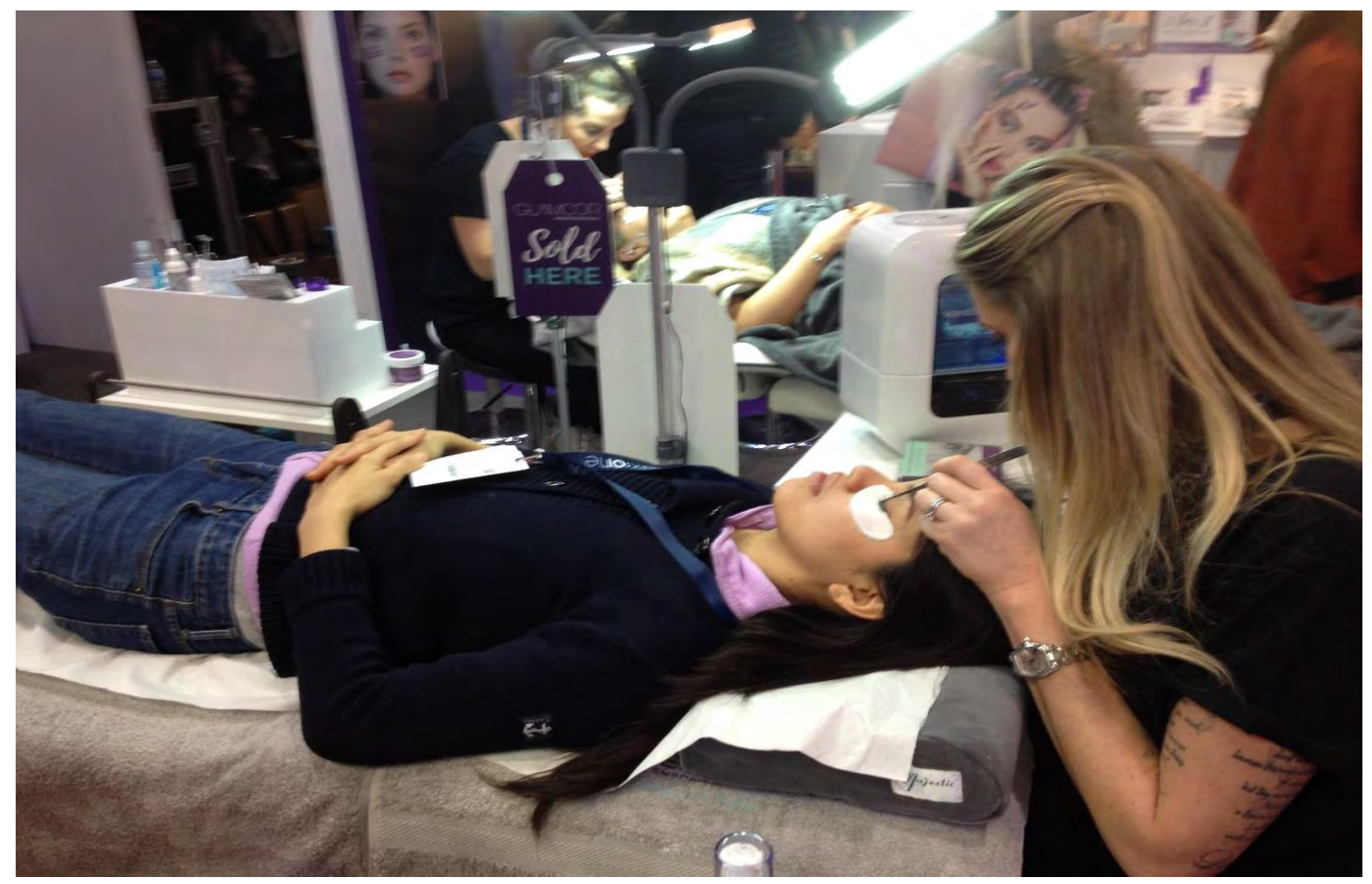

Demonstração e teste de produtos na Feira Professional Beauty London

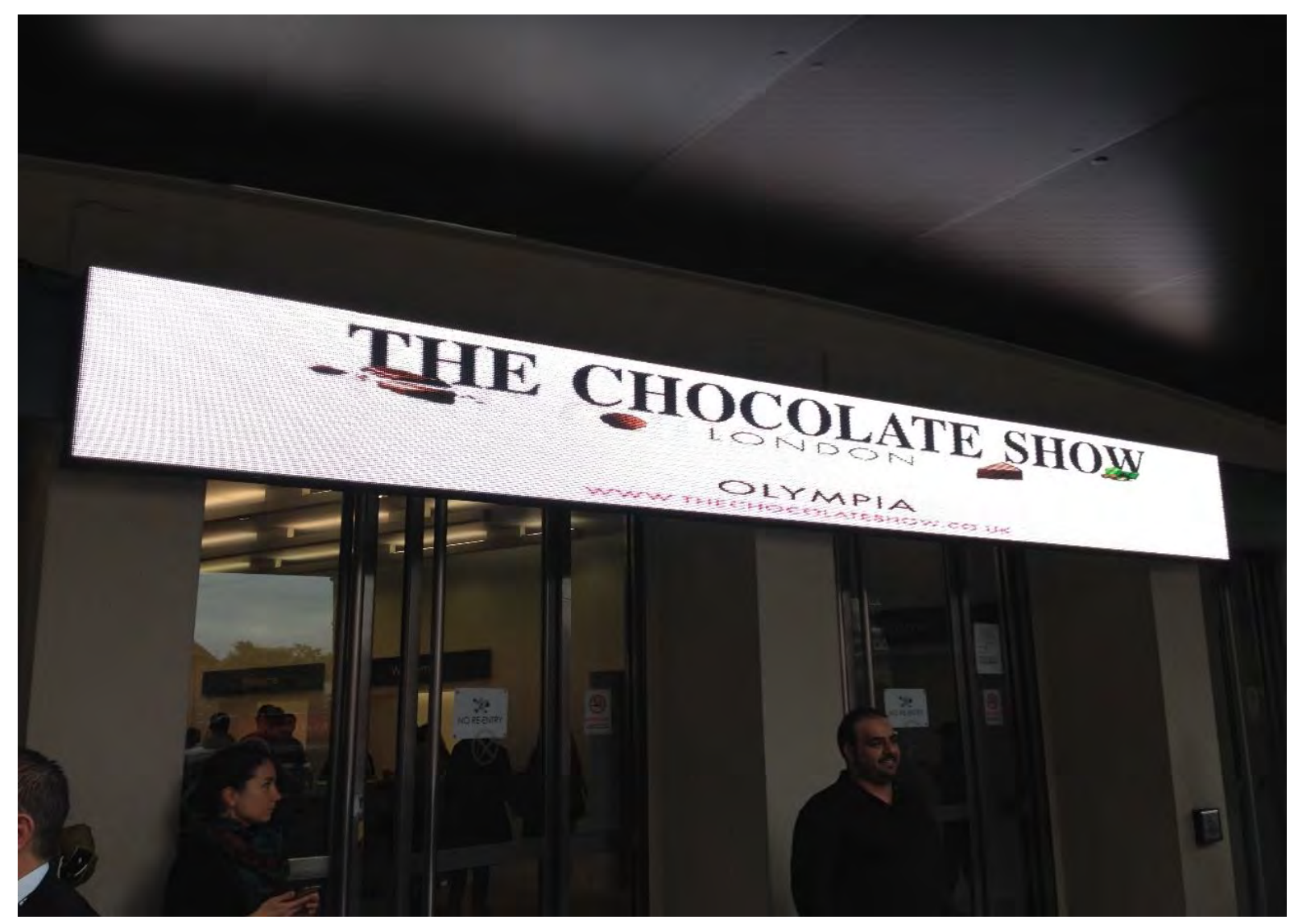

The Chocolate Show - Olympia London 


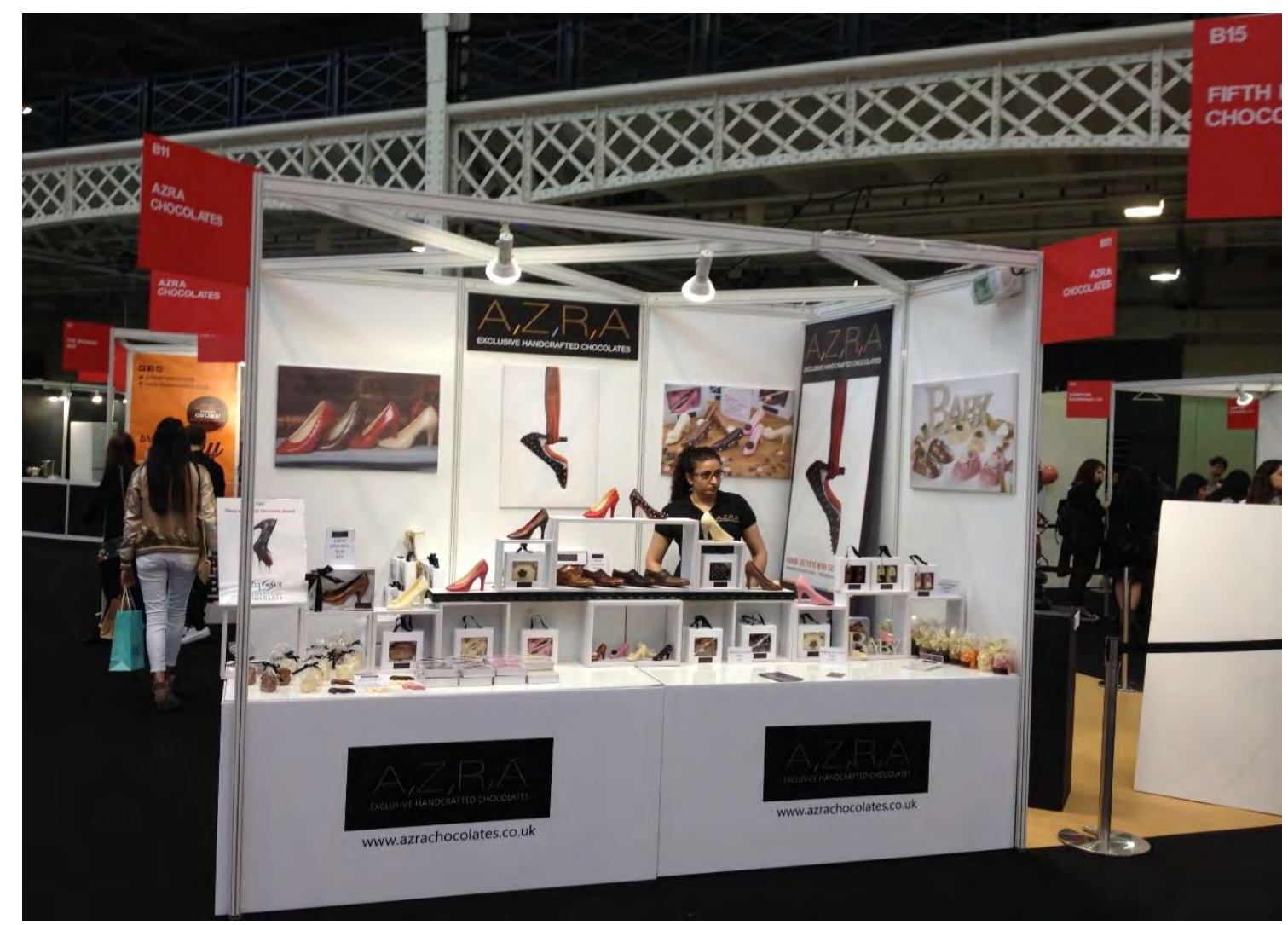

Estande básico com esculturas em chocolate

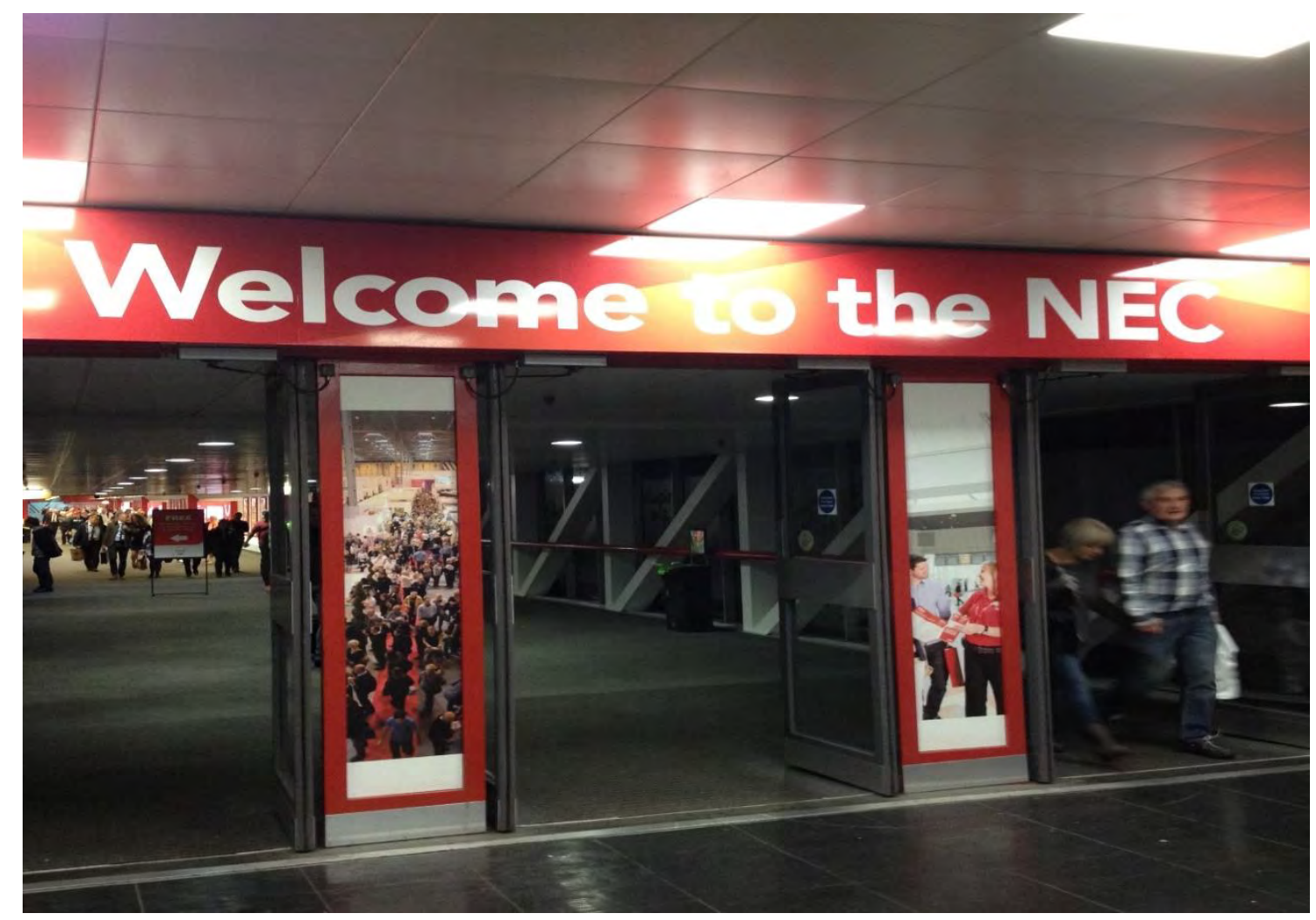

Centro de exposições National Exhibition Centre (NEC) - Birmingham 


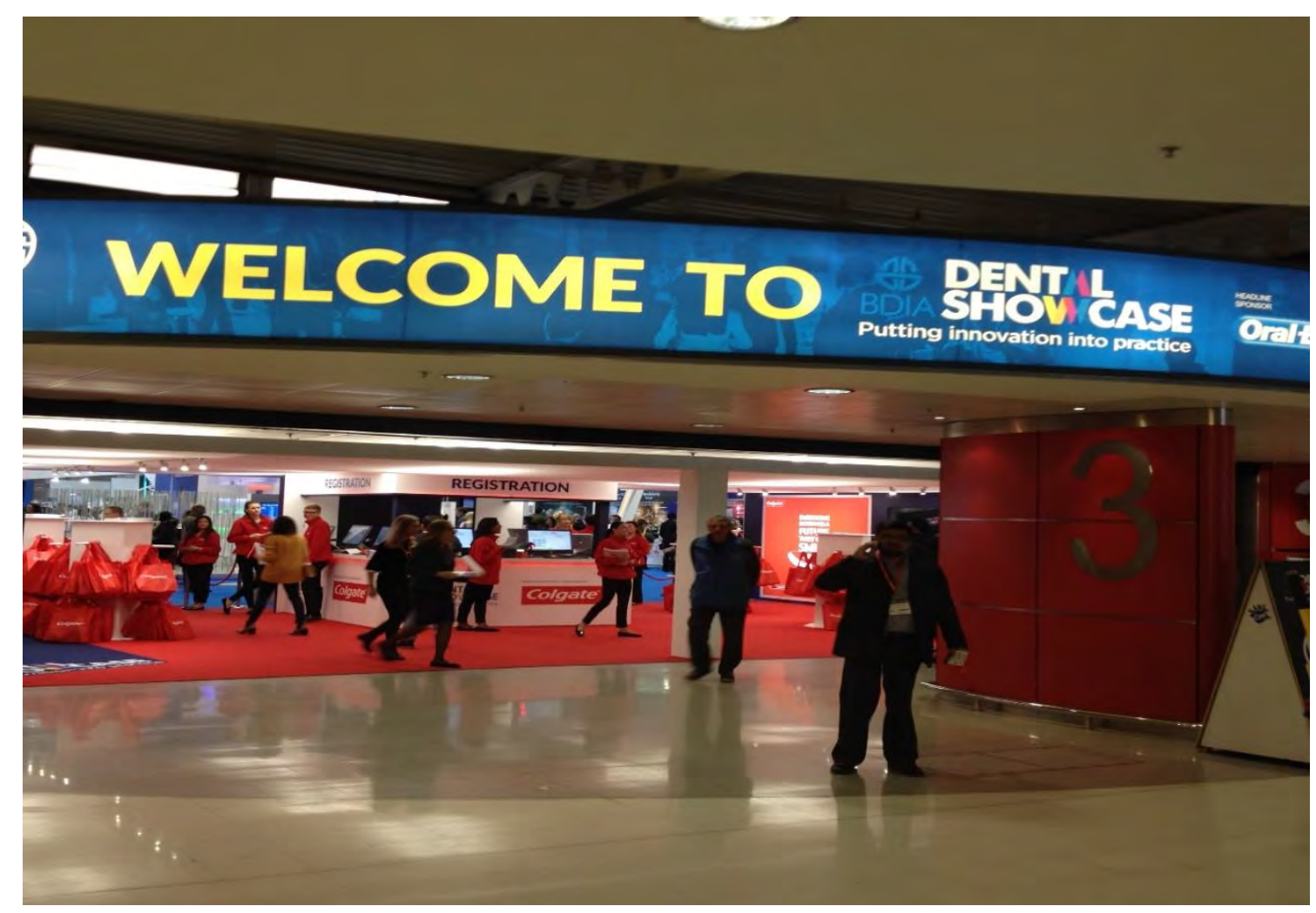

Dental Show - NEC - Birmingham

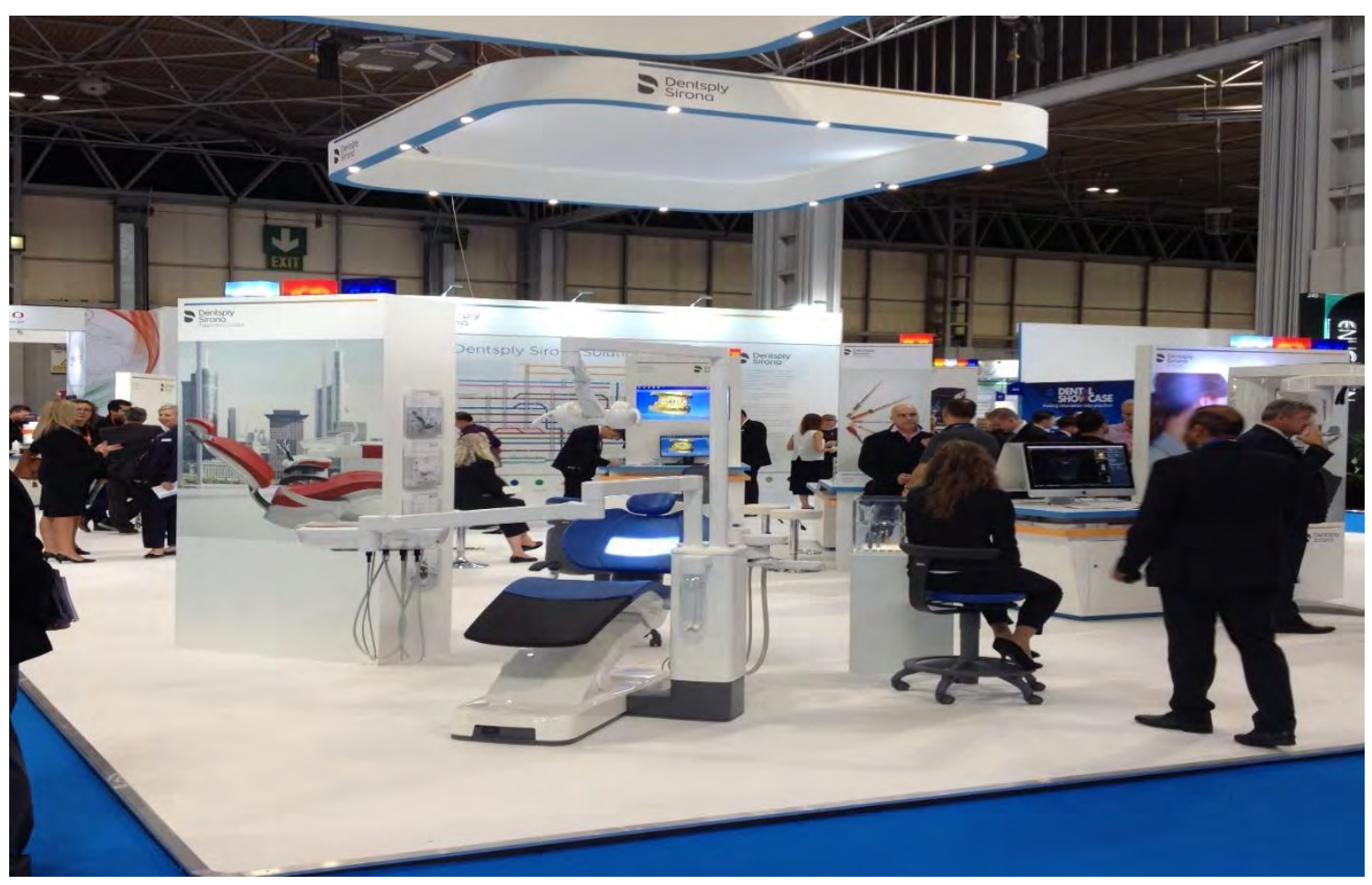

Estande ilha - Dental Show - NEC - Birmingham 


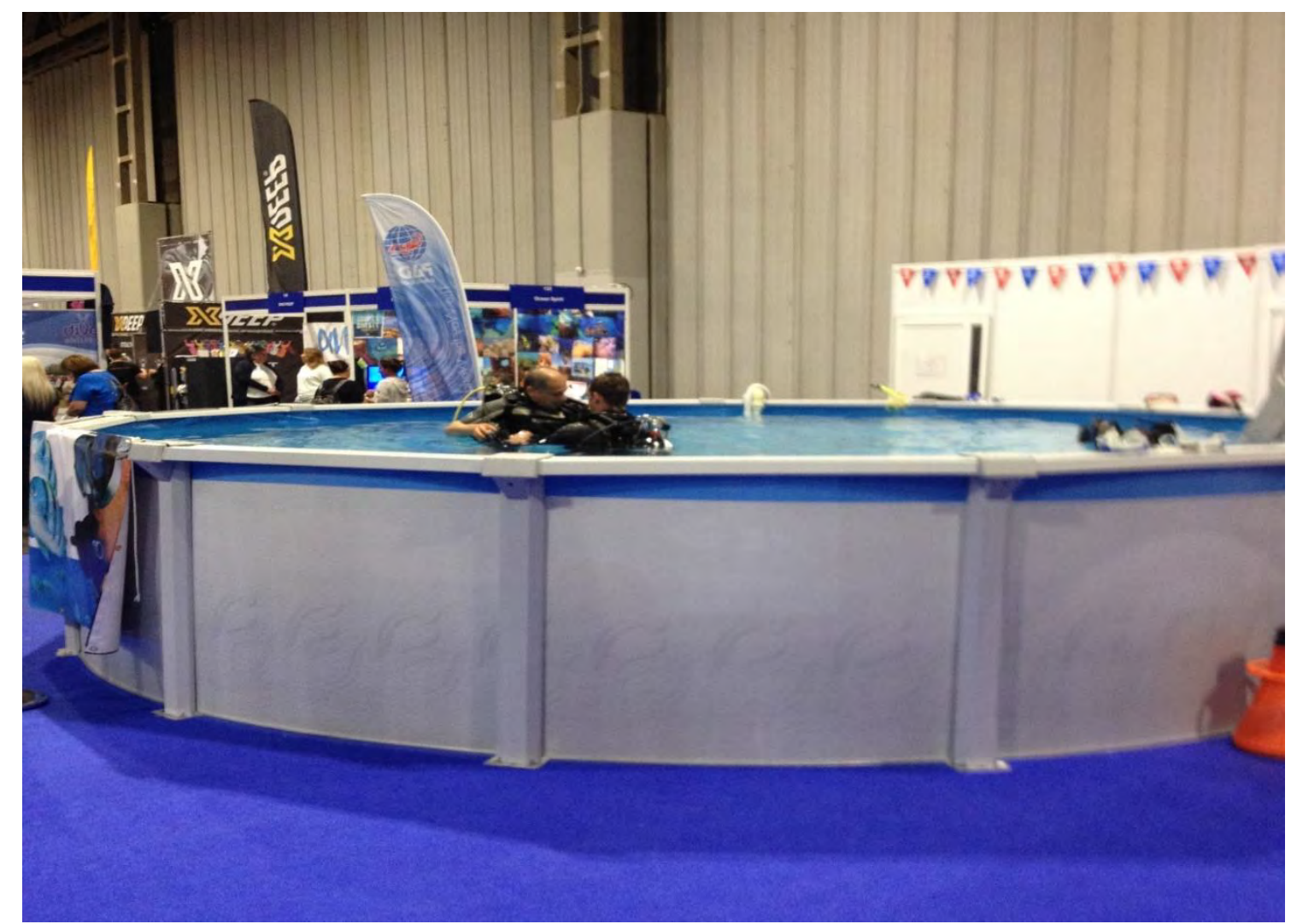

Demonstração da utilização de equipamentos - Dive Show - NEC

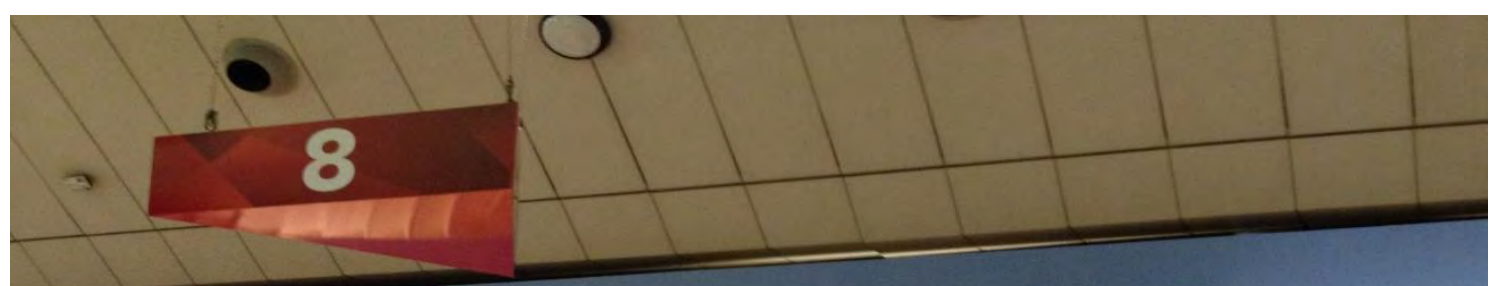

\section{WELCOME TO THE}

MOTORHOME S CARAVAN SHON 2017

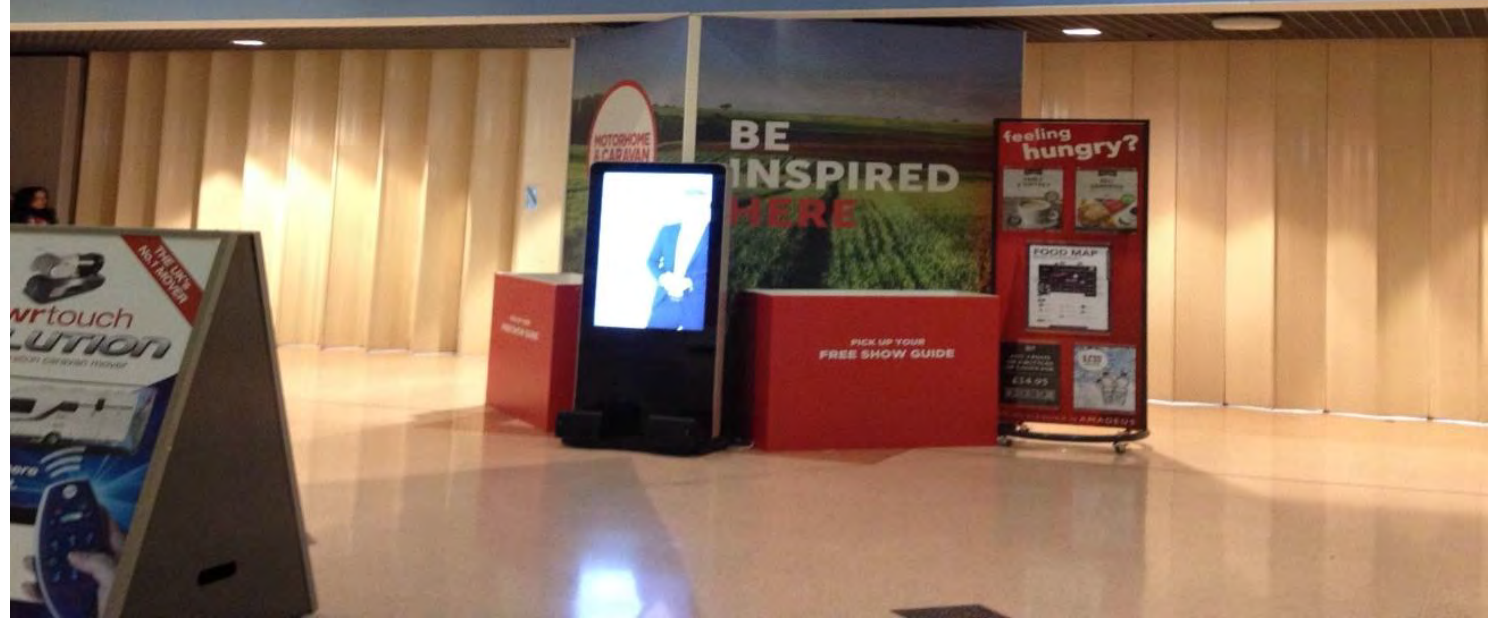

Motorhome \& Caravan Show - NEC - Birmingham 


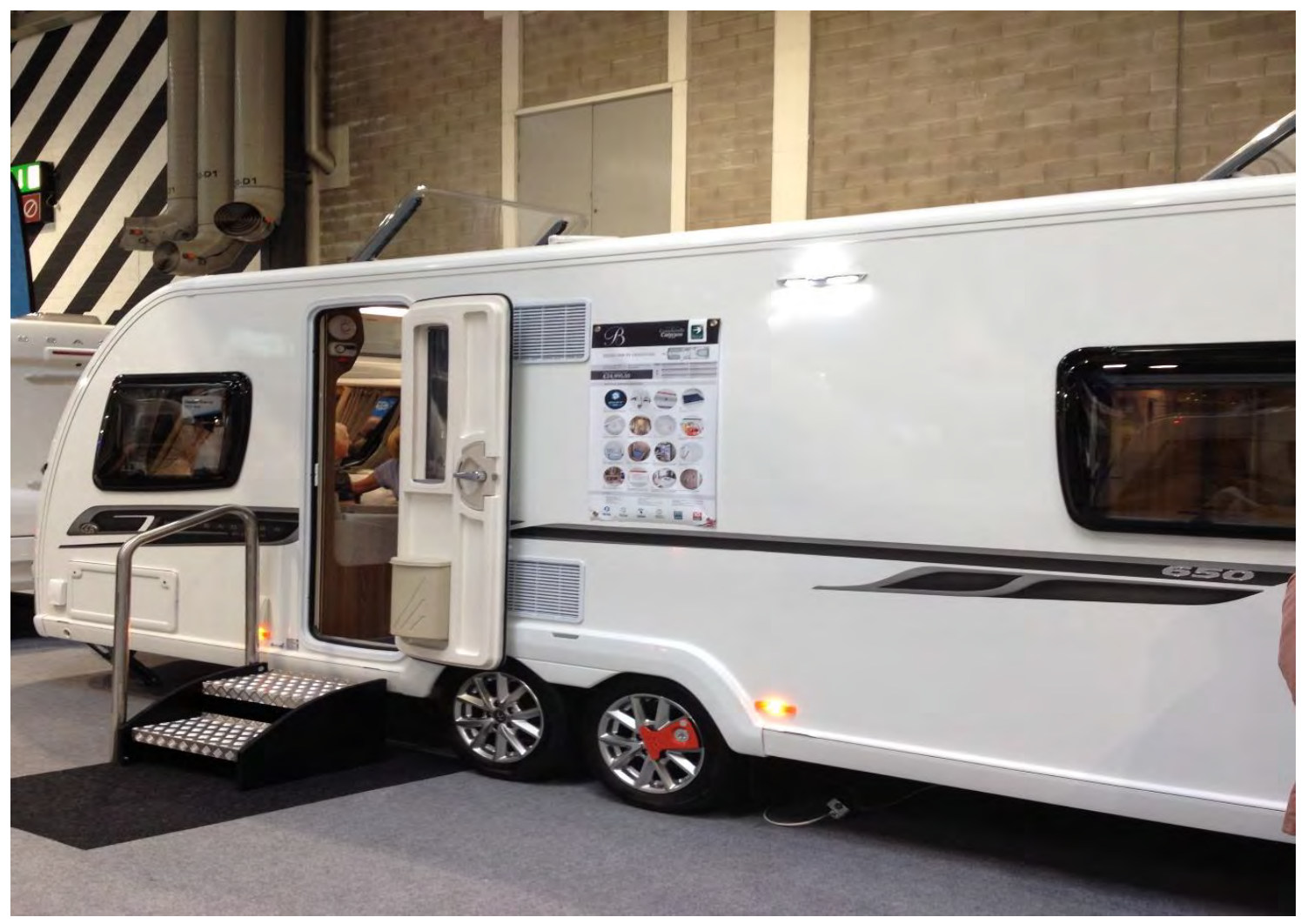

Estande de área livre - Motorhome \& Caravan Show - NEC - Birmingham

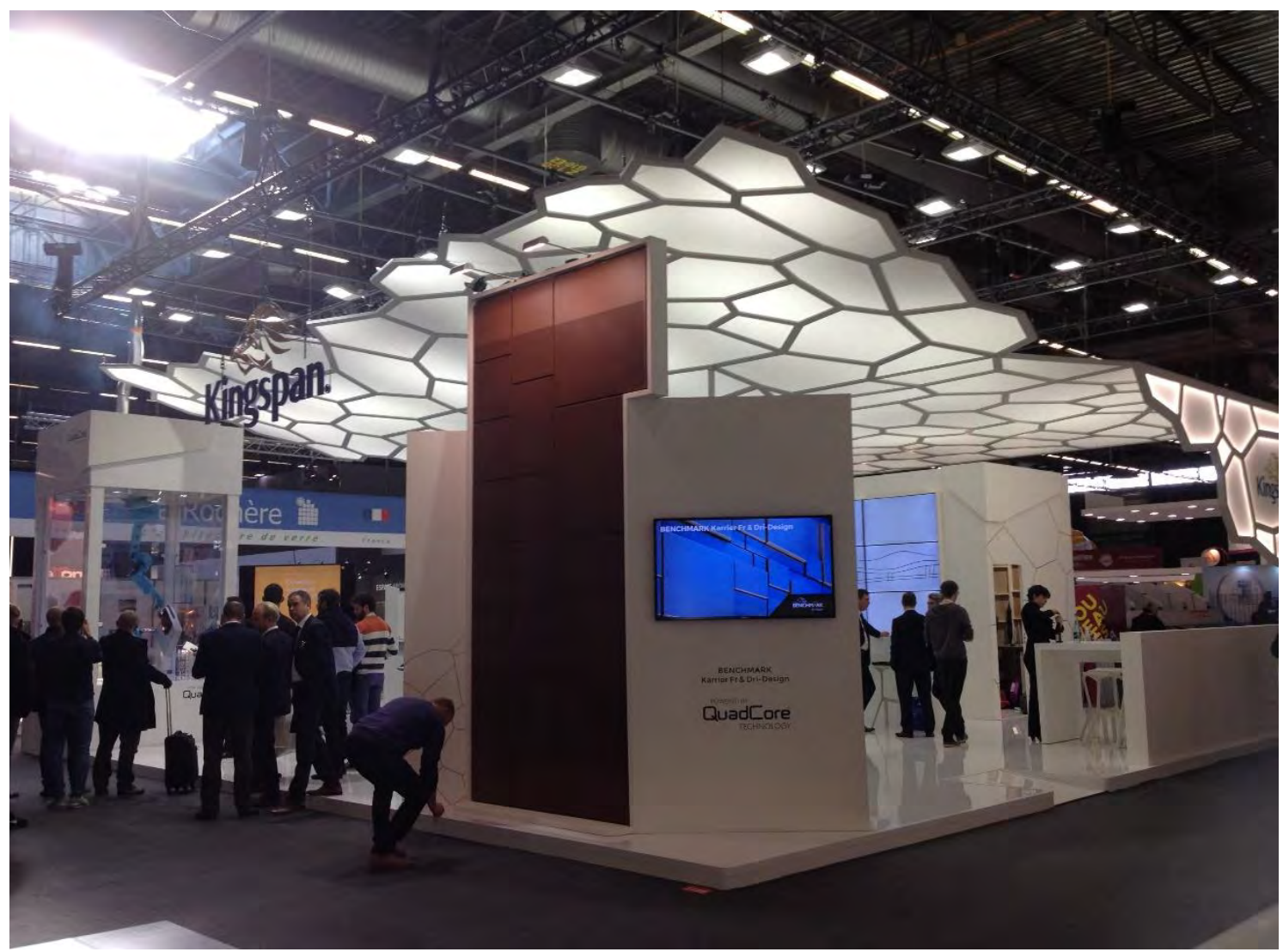

Estande personalizado 


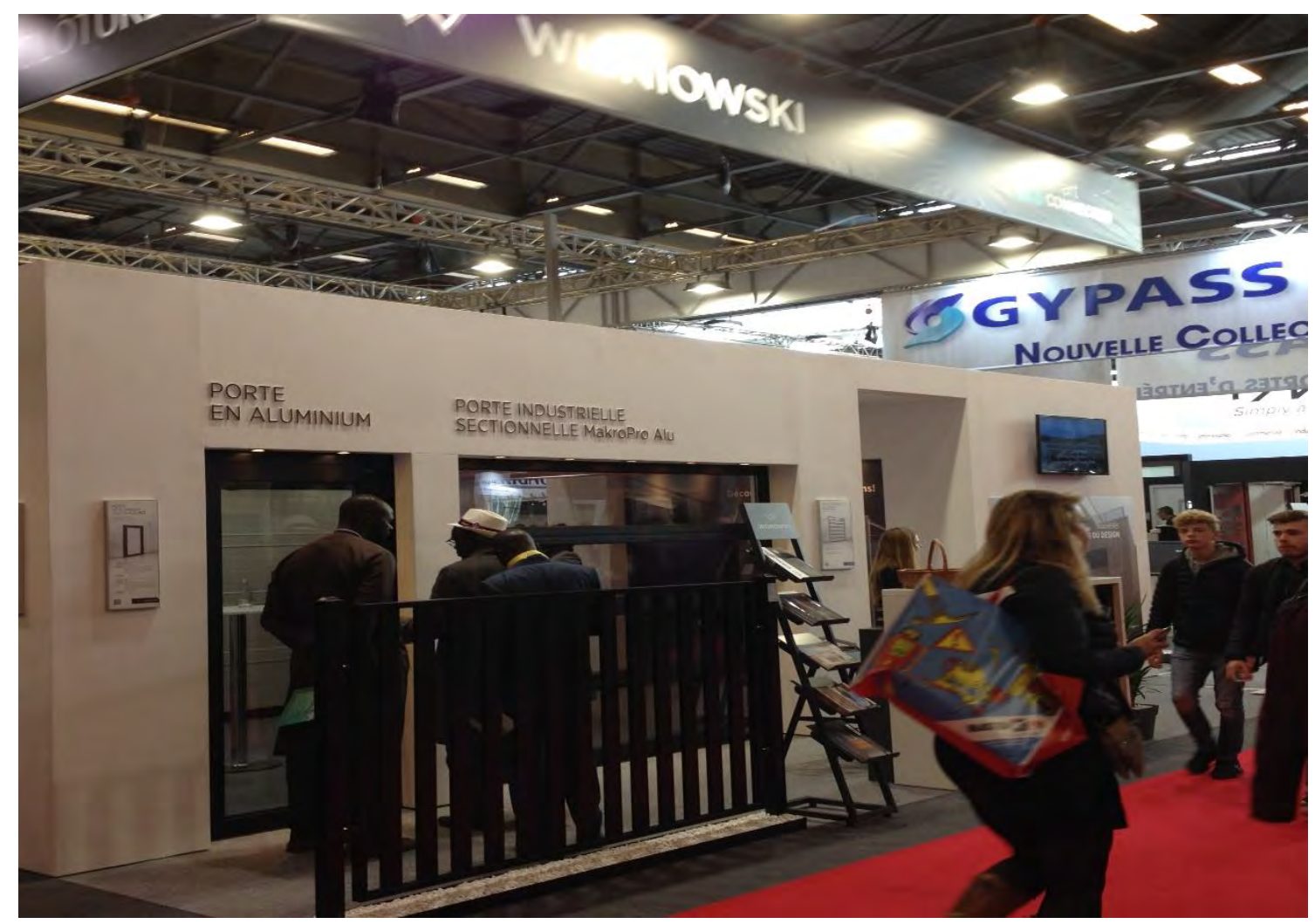

Estande fechado

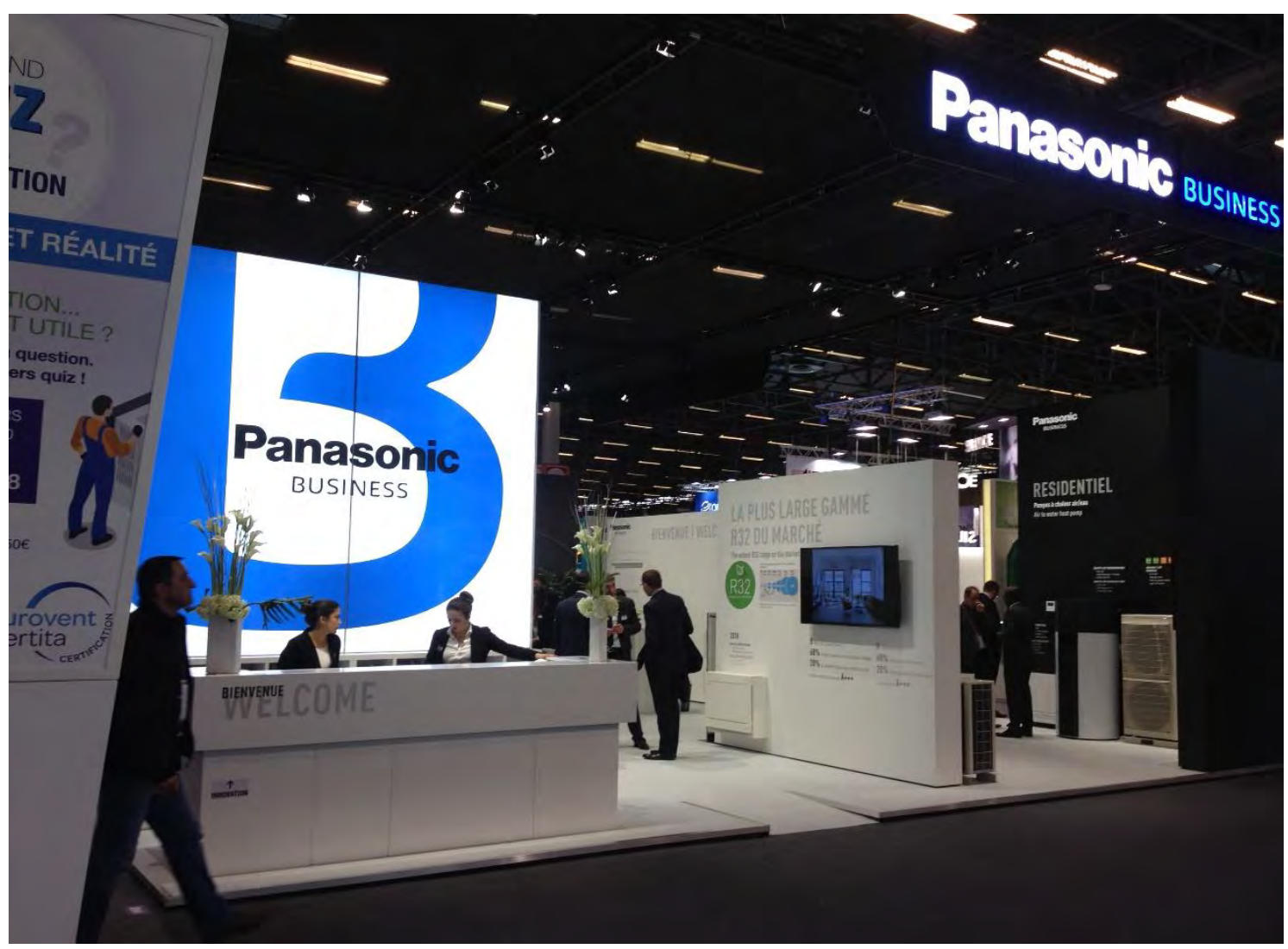

Estande personalizado 


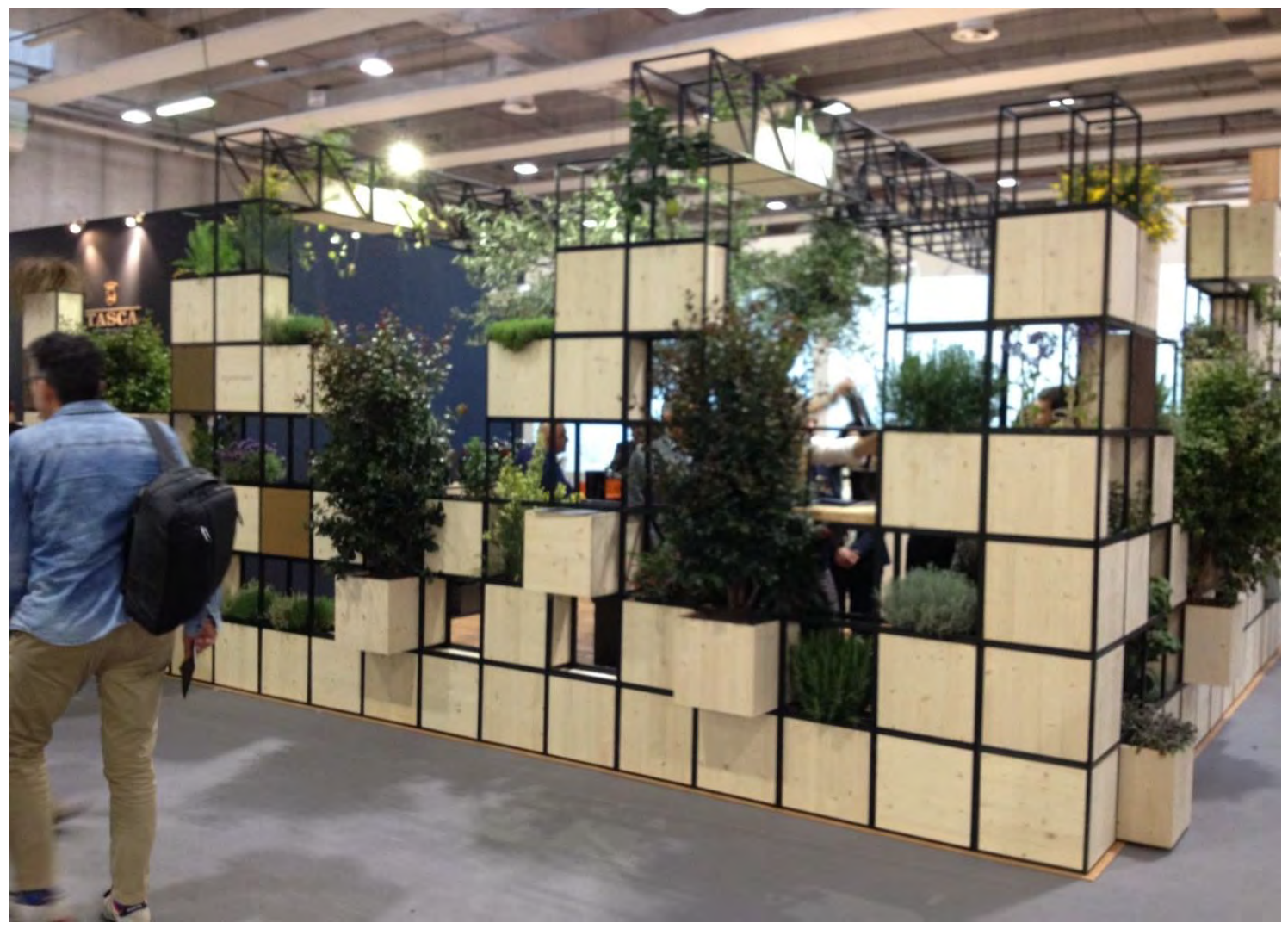

Estande sustentável

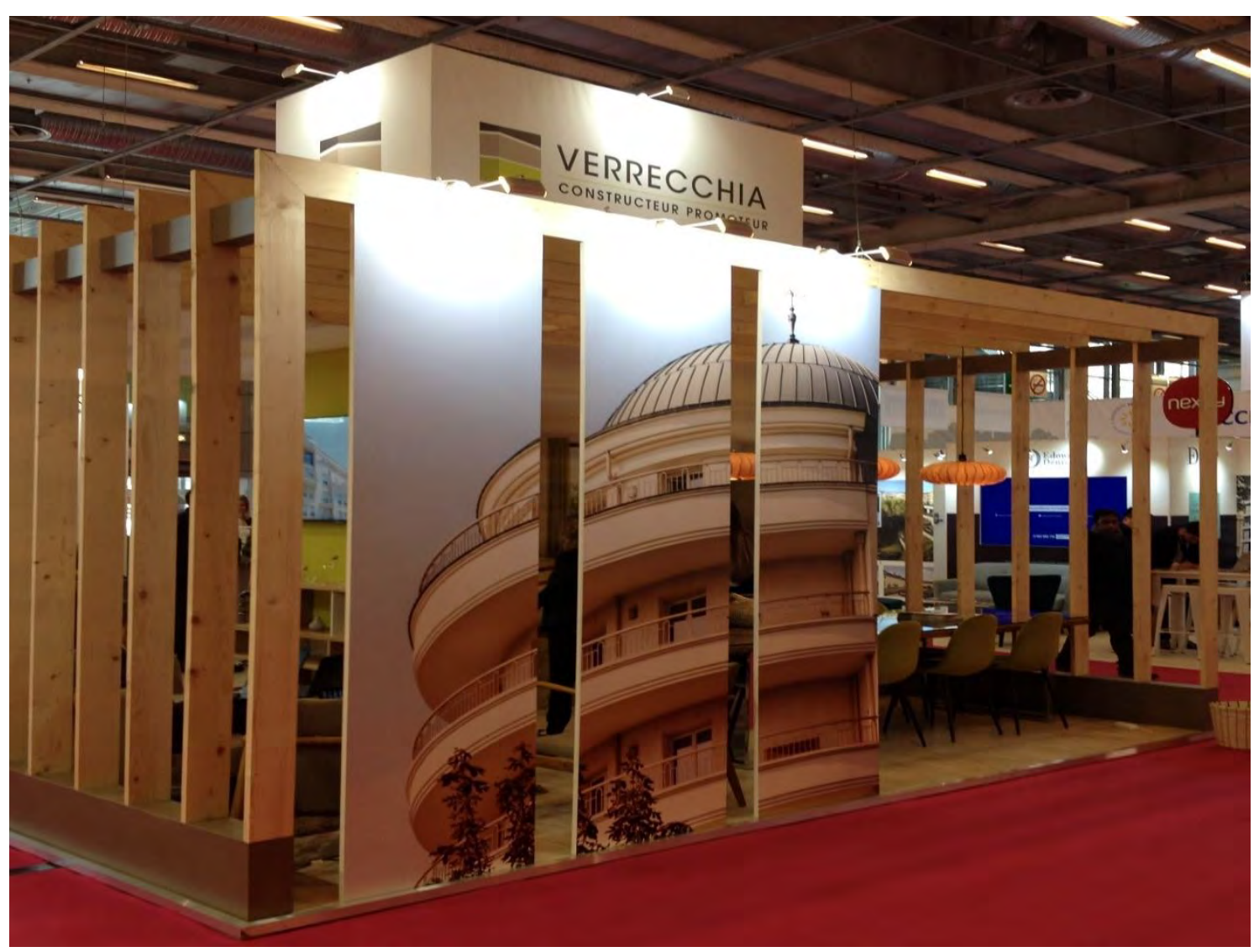

Estande sustentável 


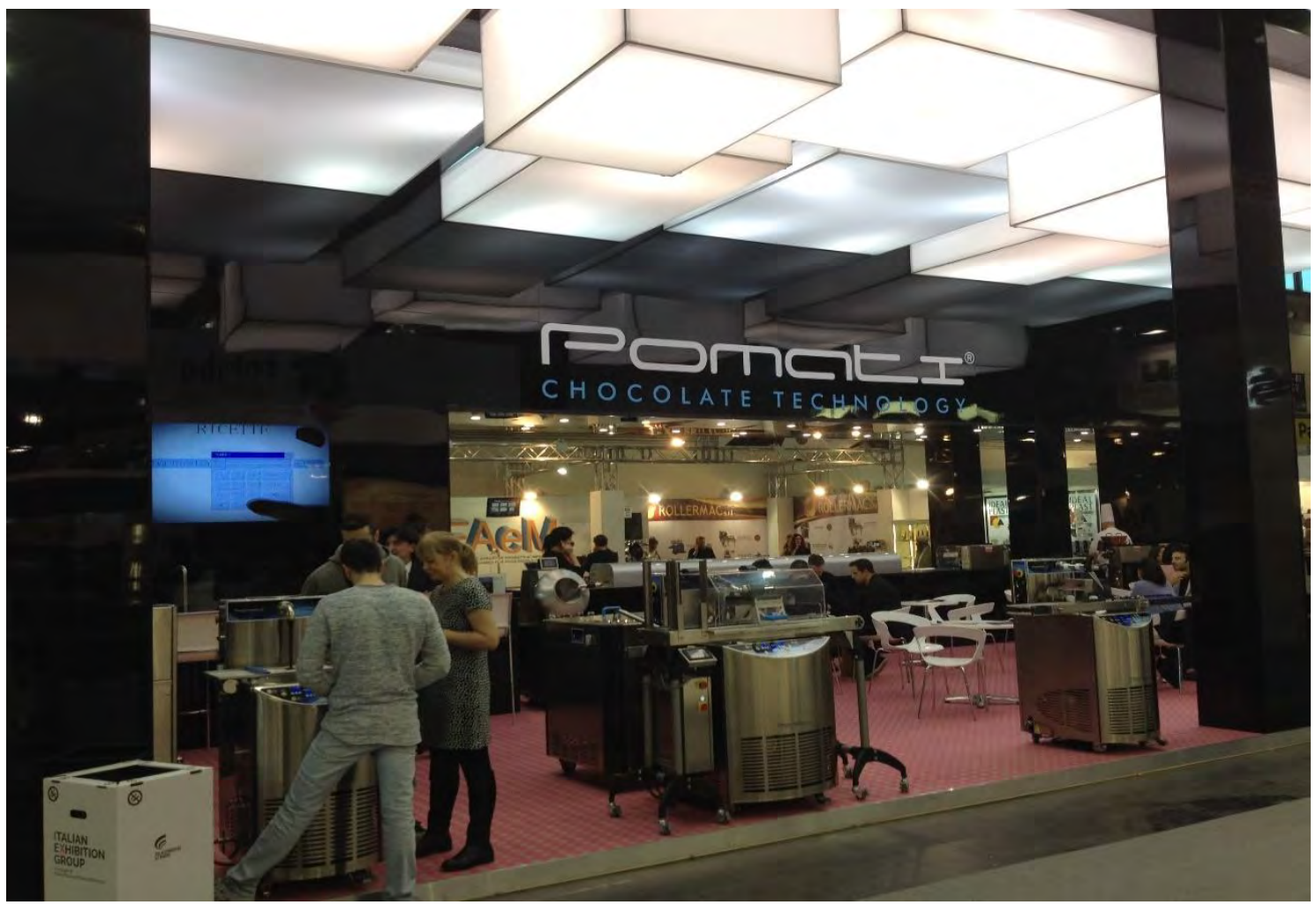

Estande construído

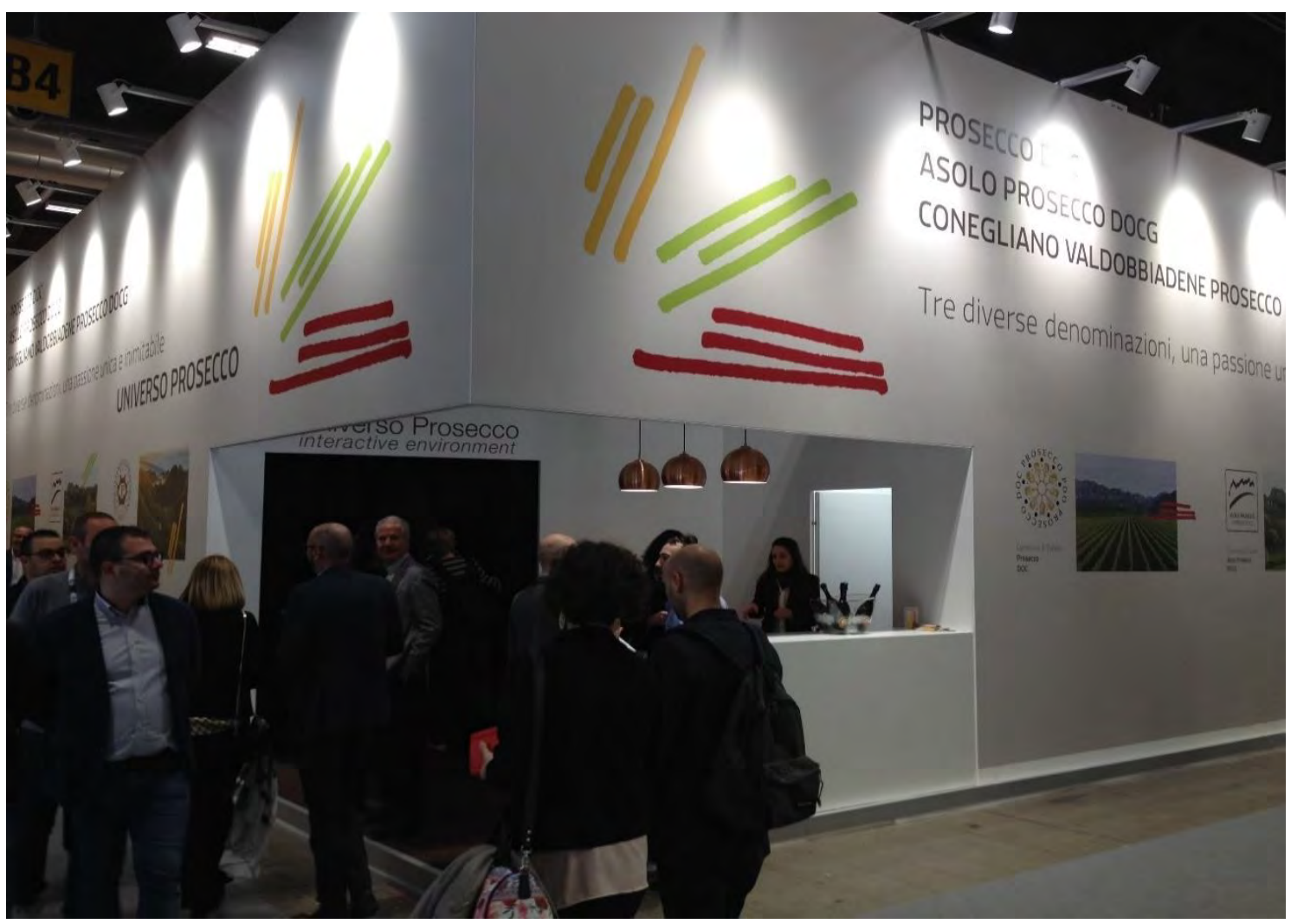

Estande semi-aberto 


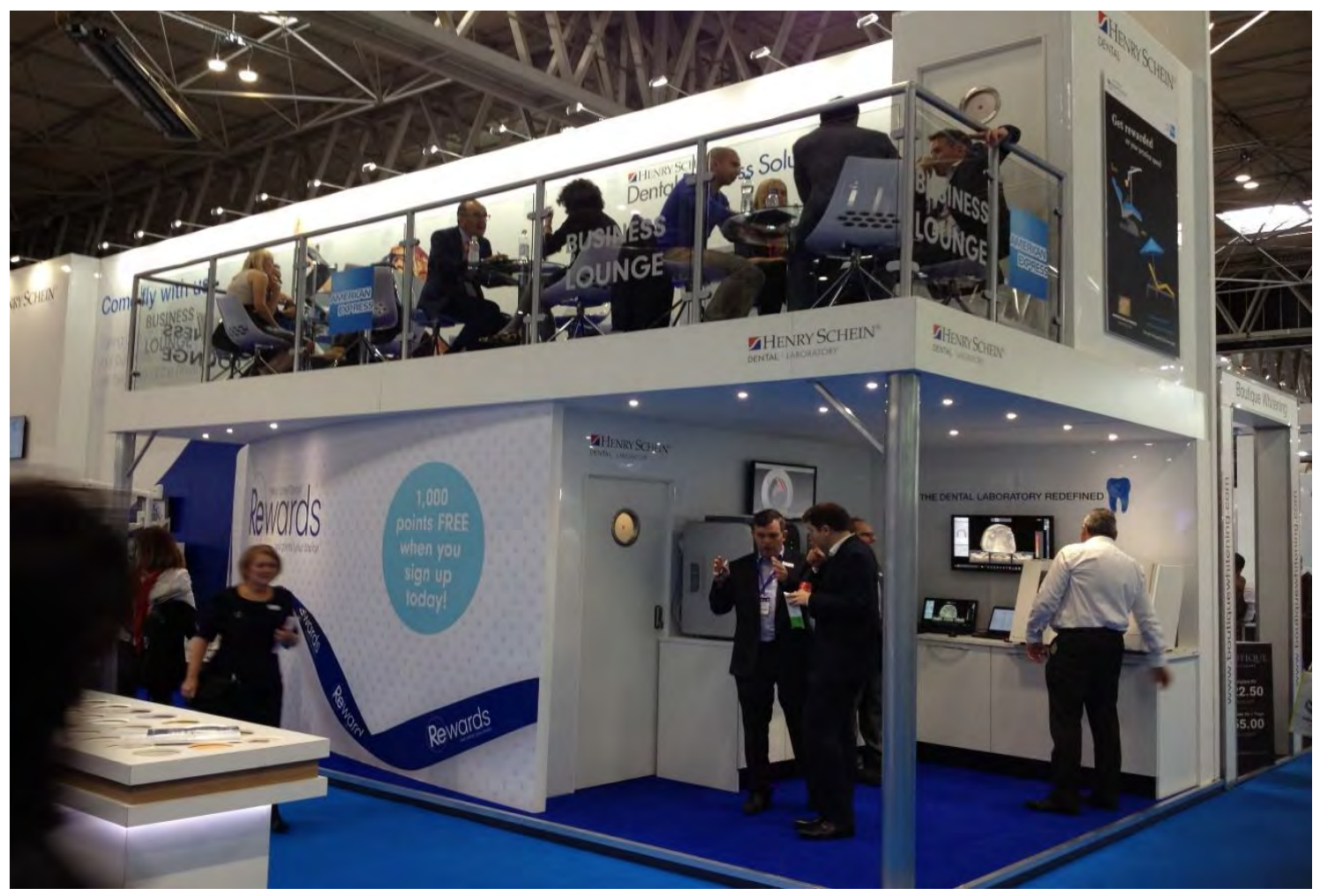

Estande com mezanino

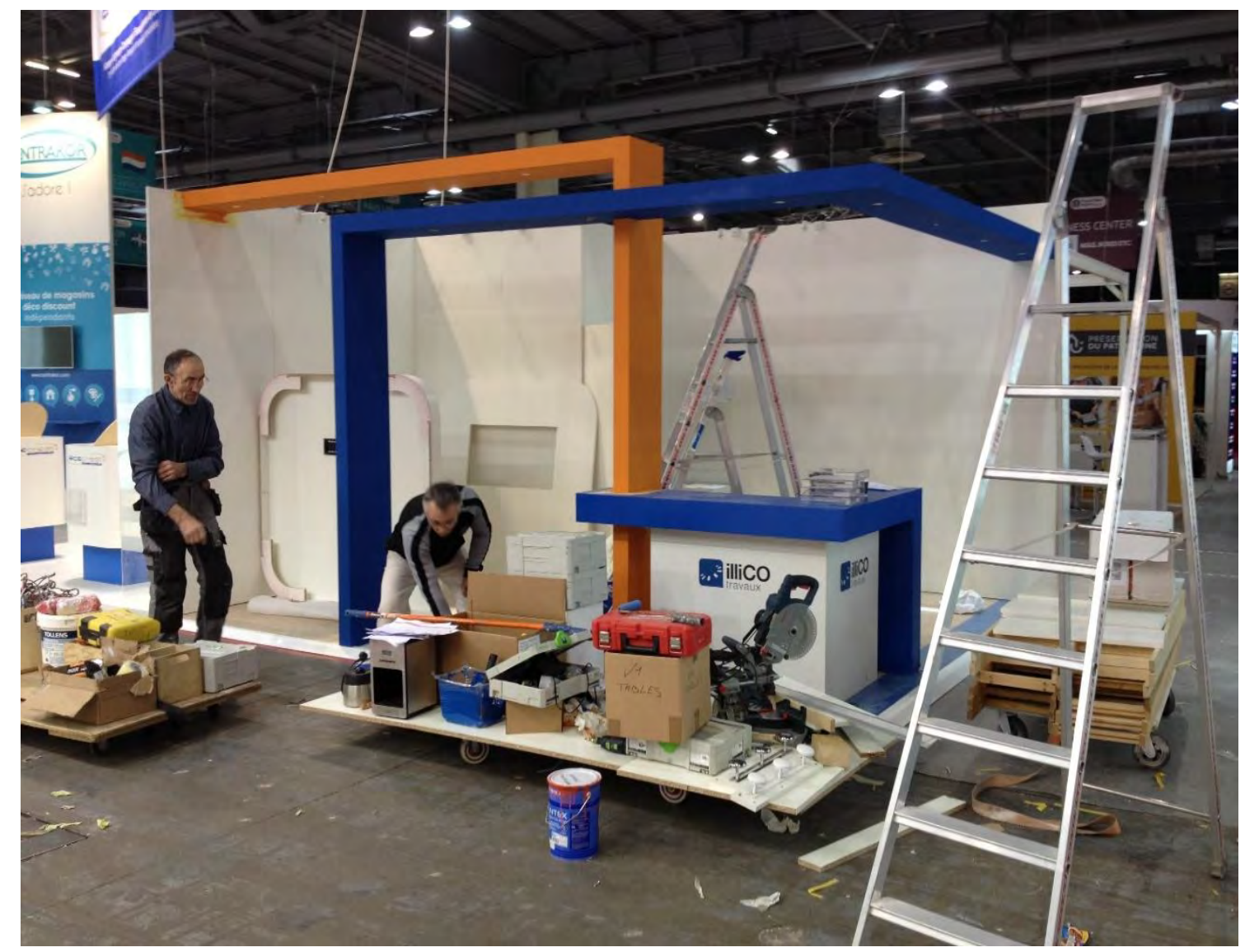

Montagem de estande 


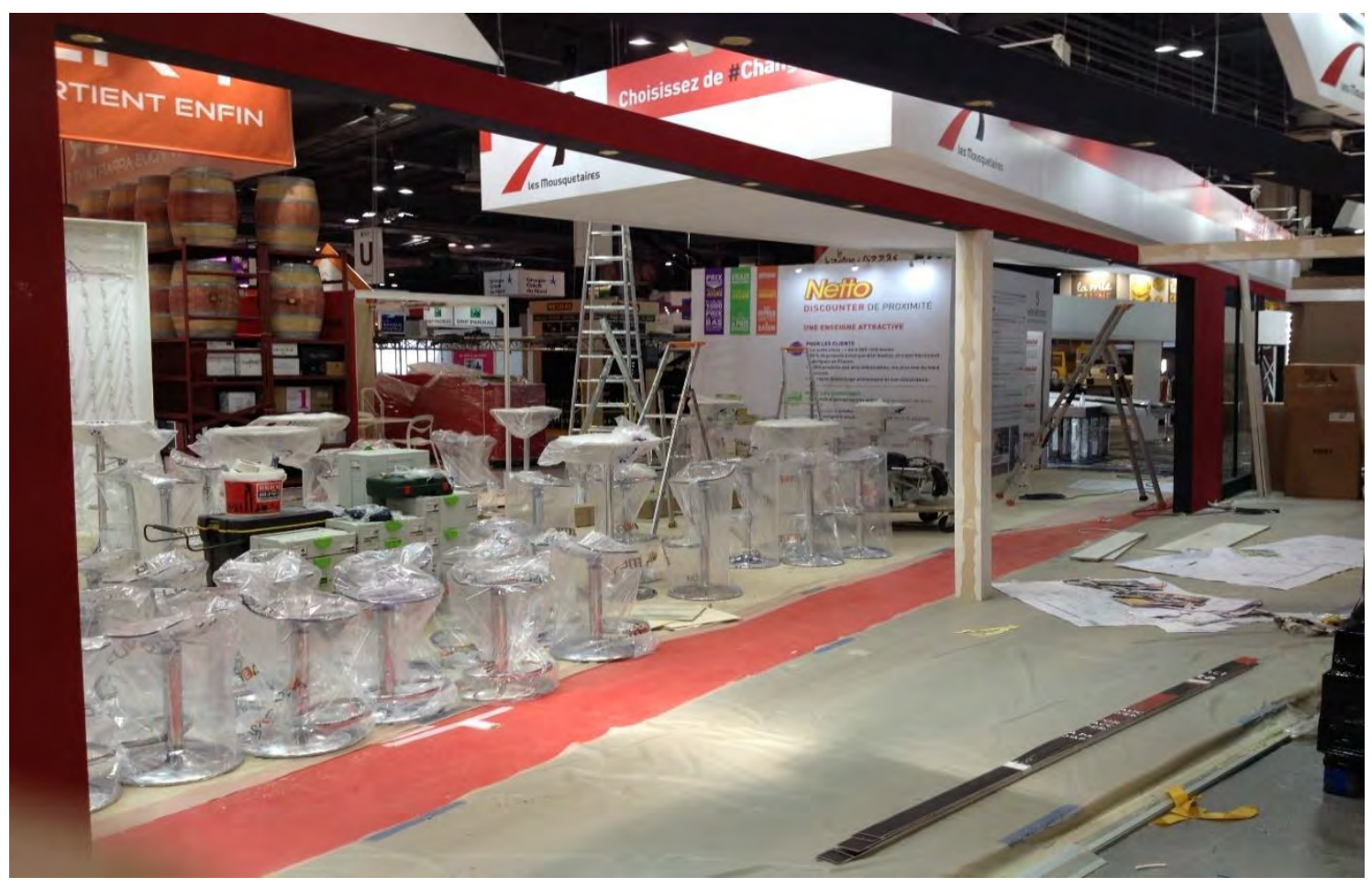

Montagem de estande

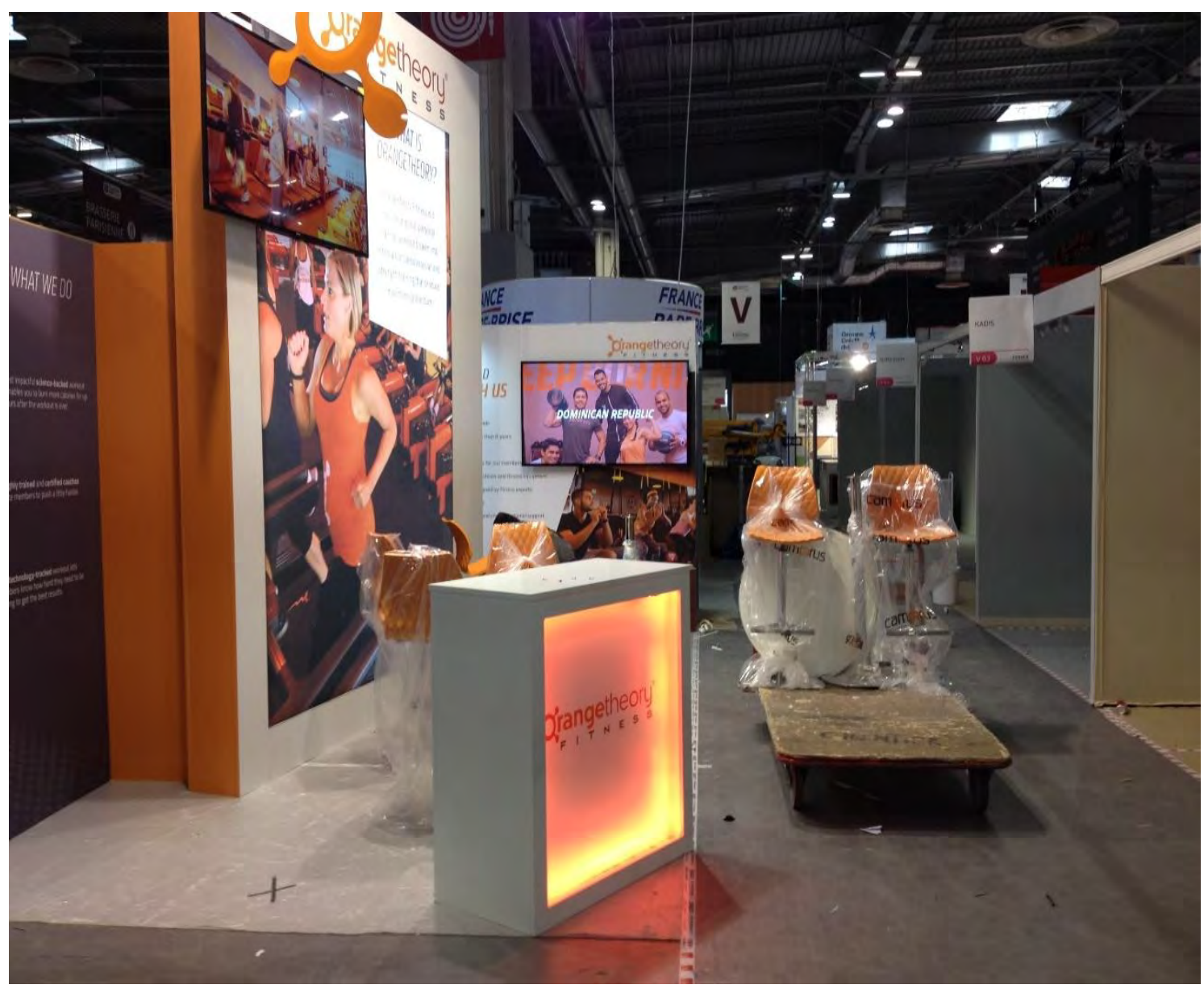

Montagem de estande 


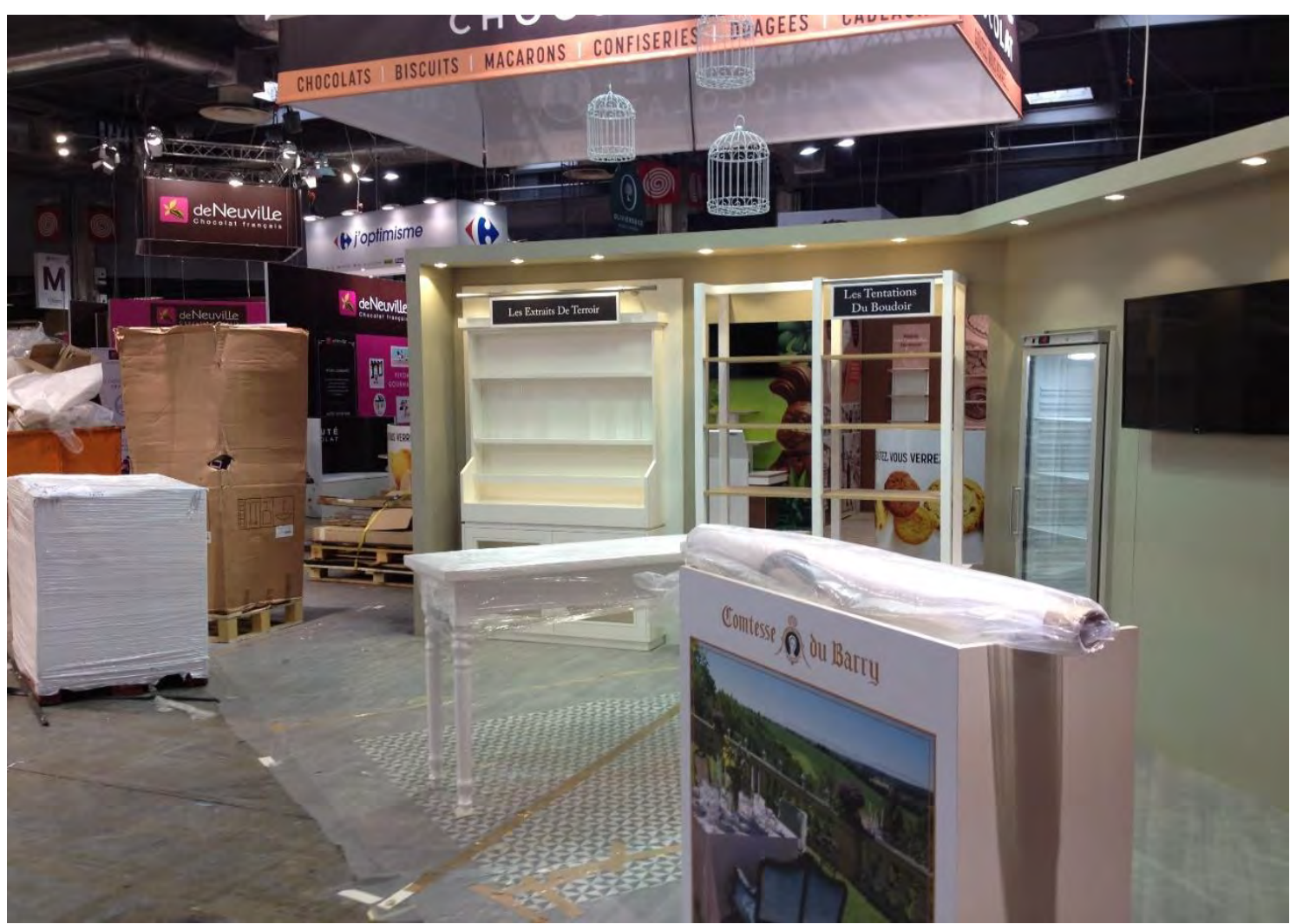

Montagem de estande

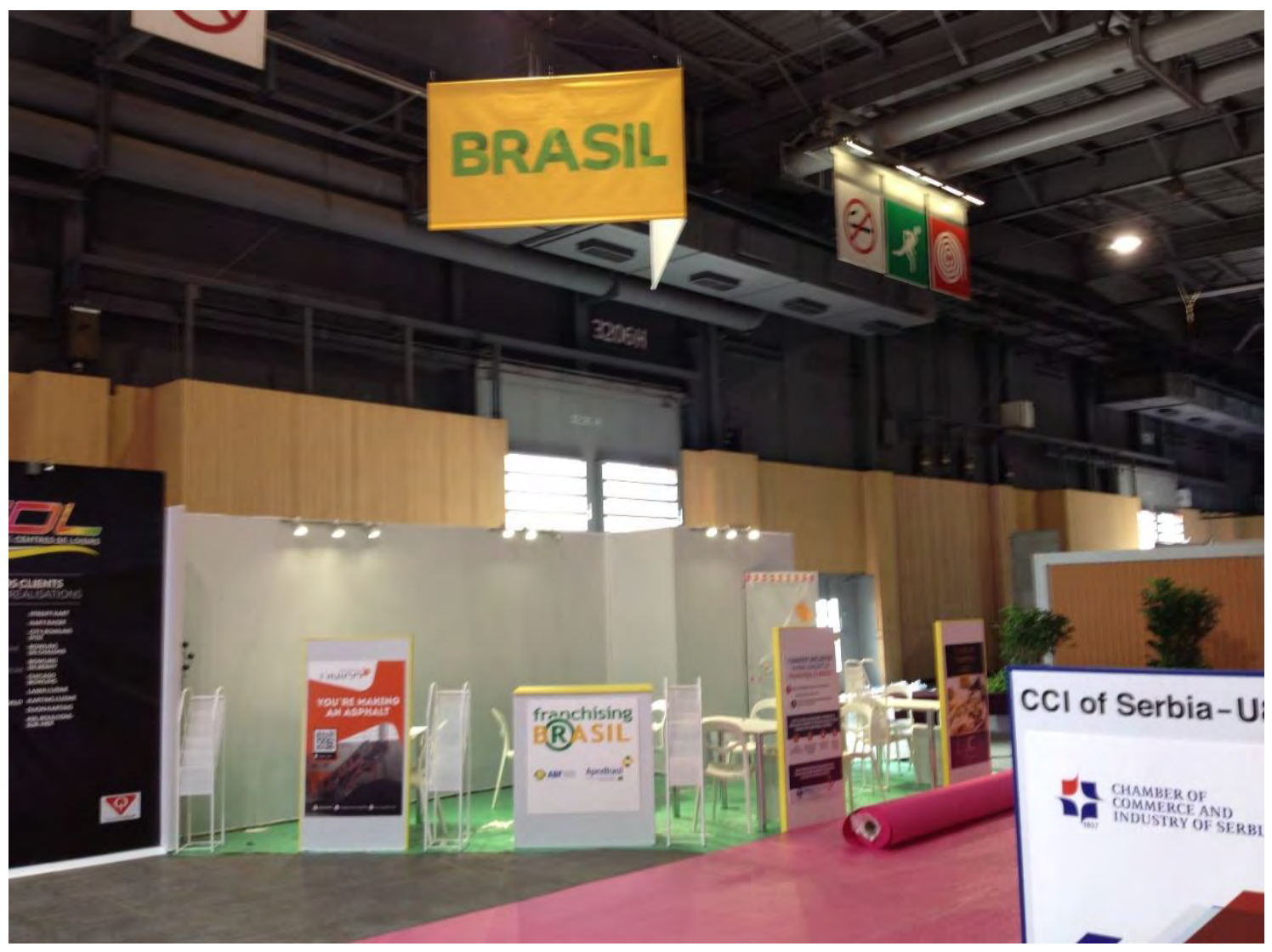

Montagem do estande Brasil 


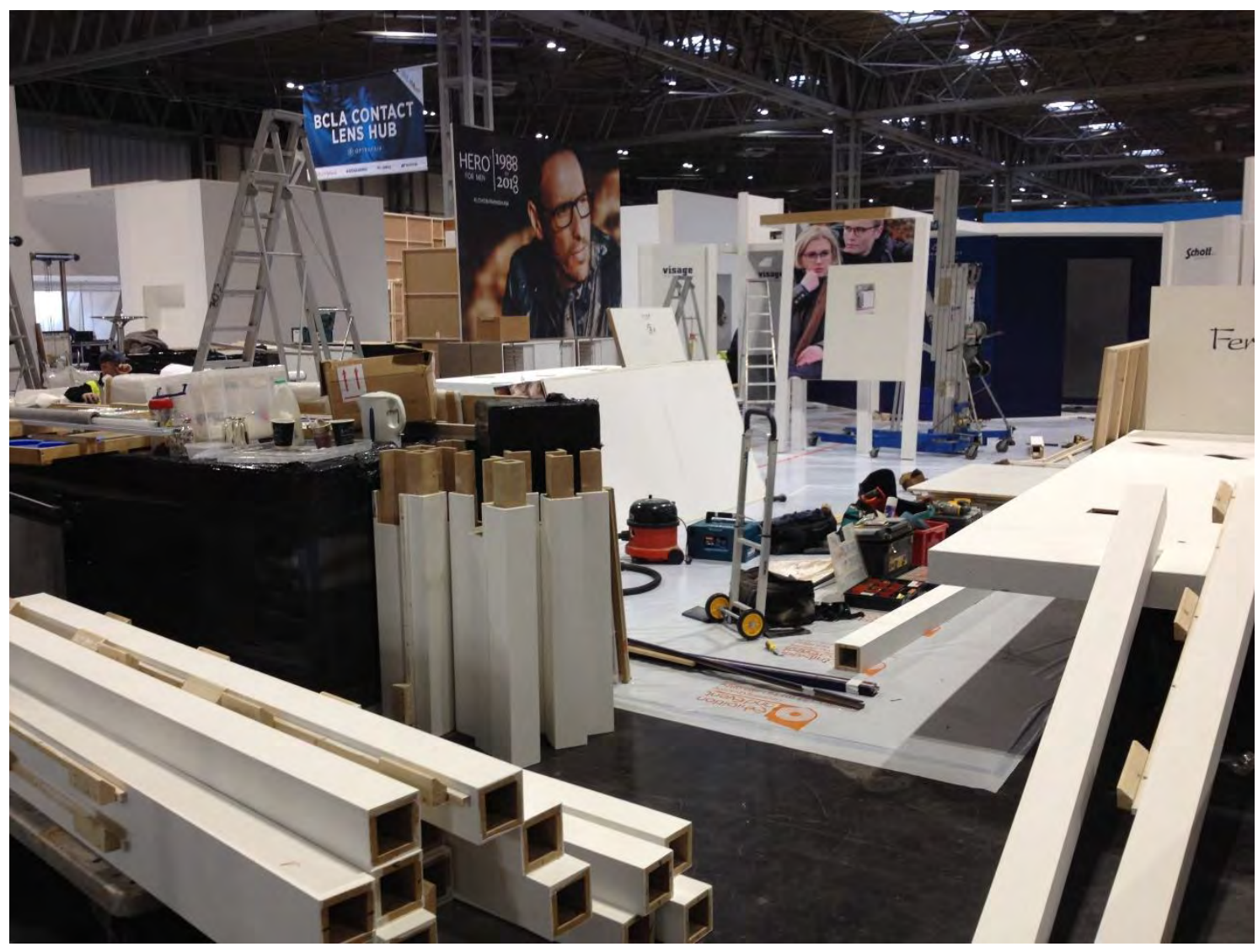

Montagem da feira

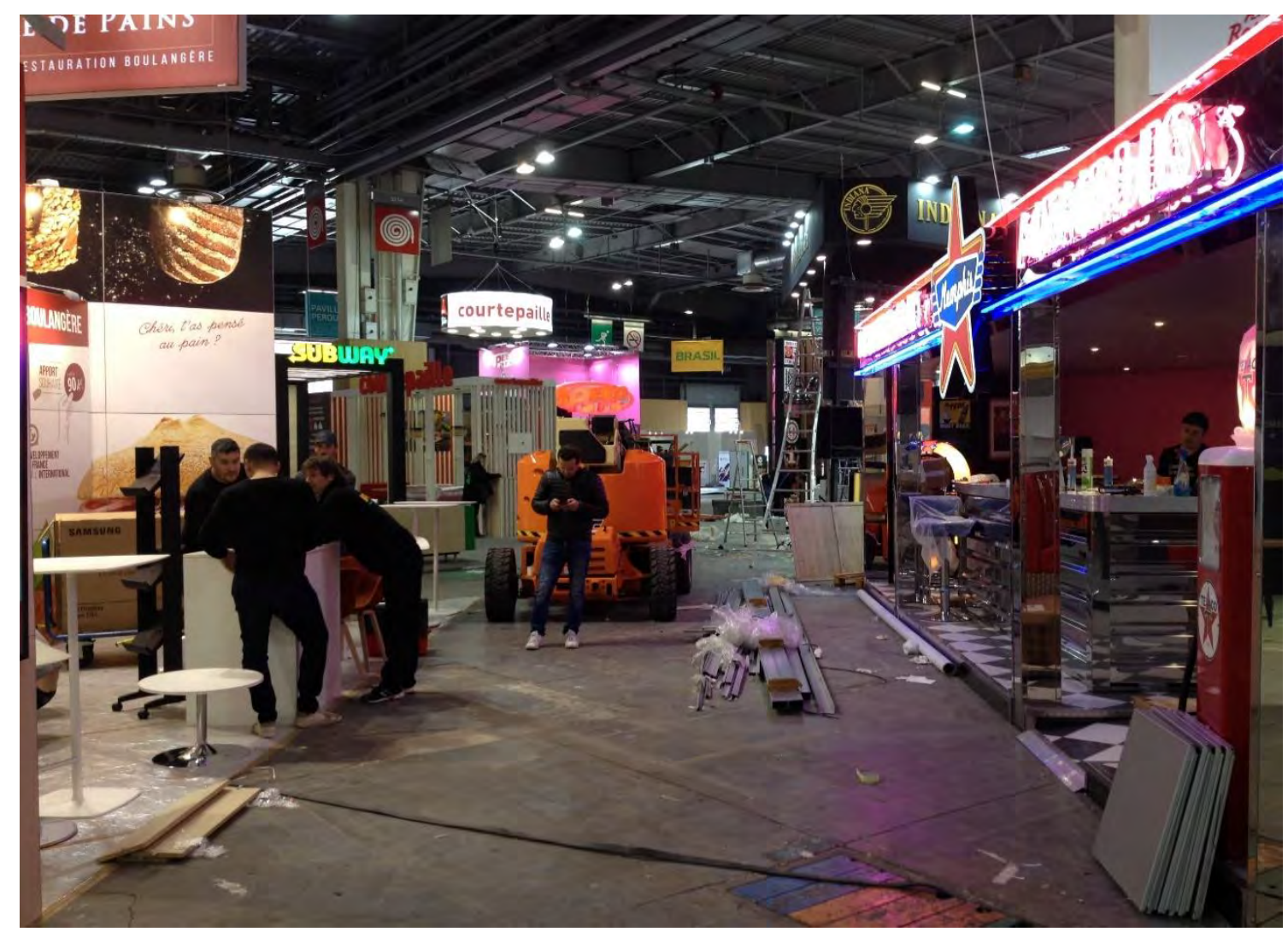




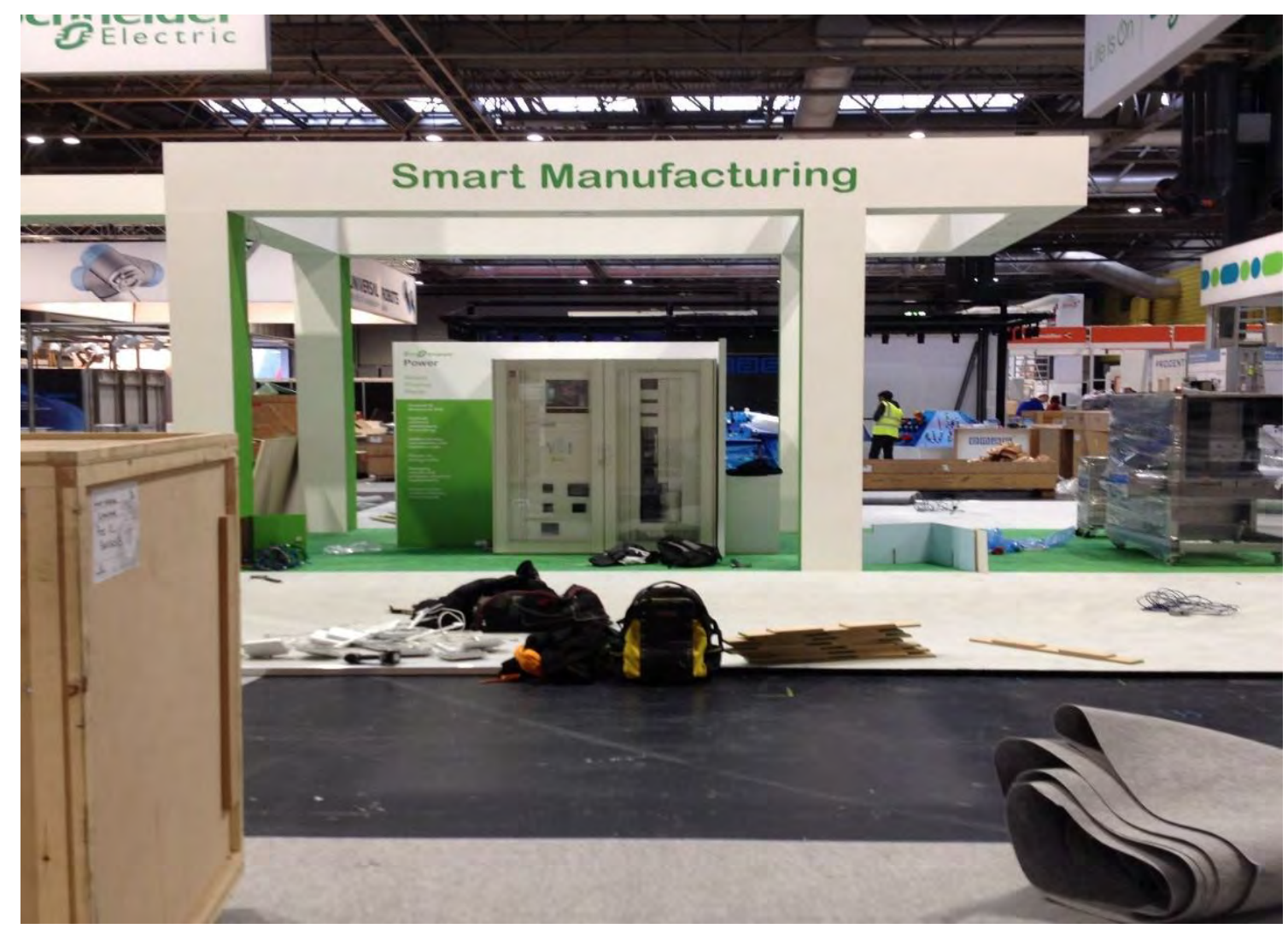

Desmontagem da feira

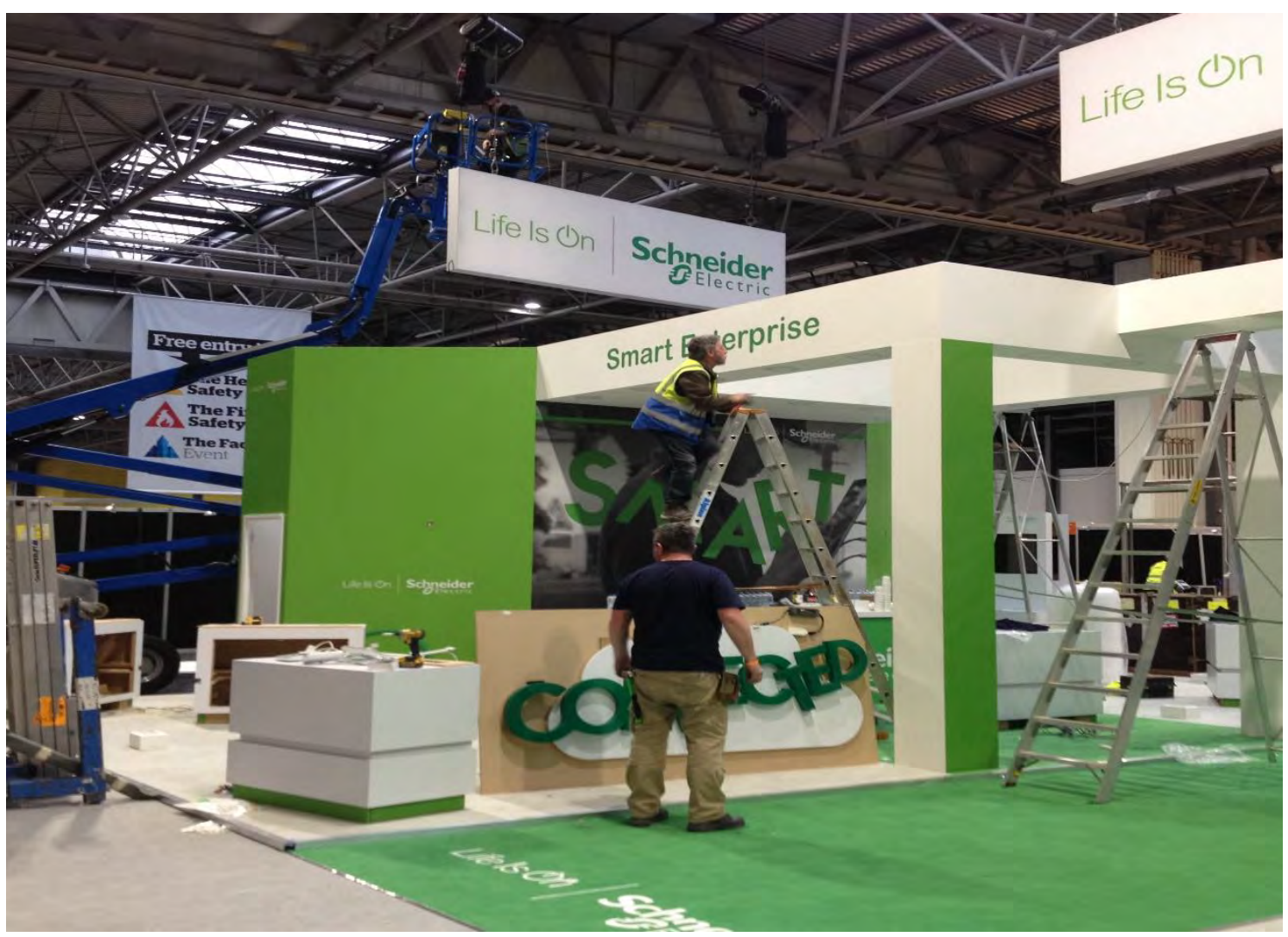

Desmontagem de estande 


\section{AGGUEIL EXPOSANTS EXHIBITOR DESK}

CATTALOGUE - PARKING DU PAGK ÉOUIPEMENT CATALOGUE - PARKING TICKETS INCL. IN EQUIPMENT PACKAG

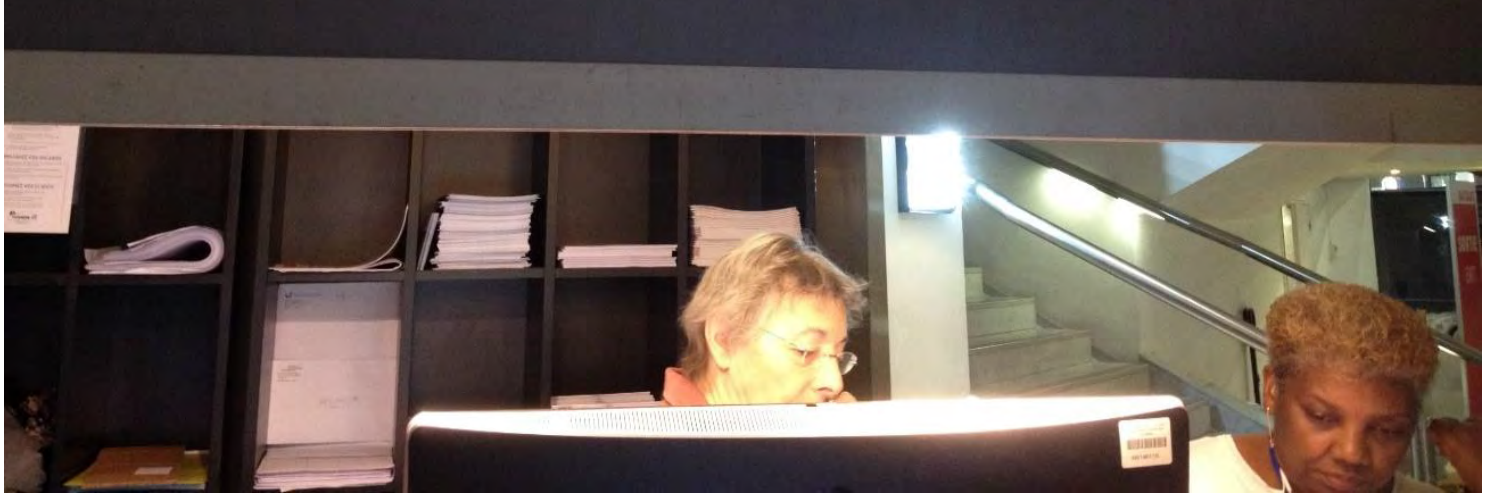

Centro de atendimento ao expositor (um dos locais dentro do pavilhão que visitava para conseguir falar com os organizadores, além, é claro, do escritório da organização da feira)

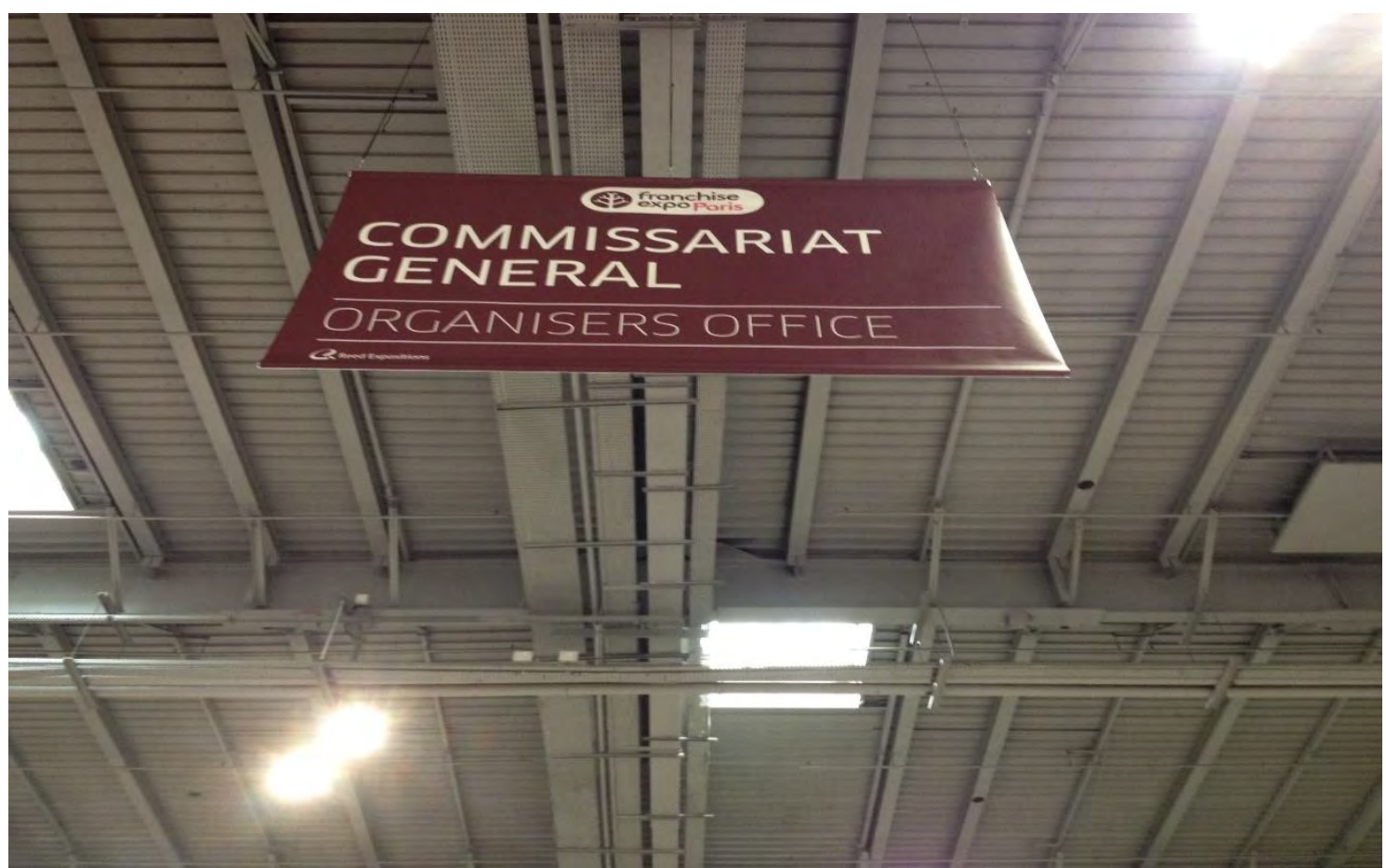

Indicação da localização do escritório da organização da feira dentro do pavilhão (era a primeira coisa que procurava quando chegava em uma feira) 


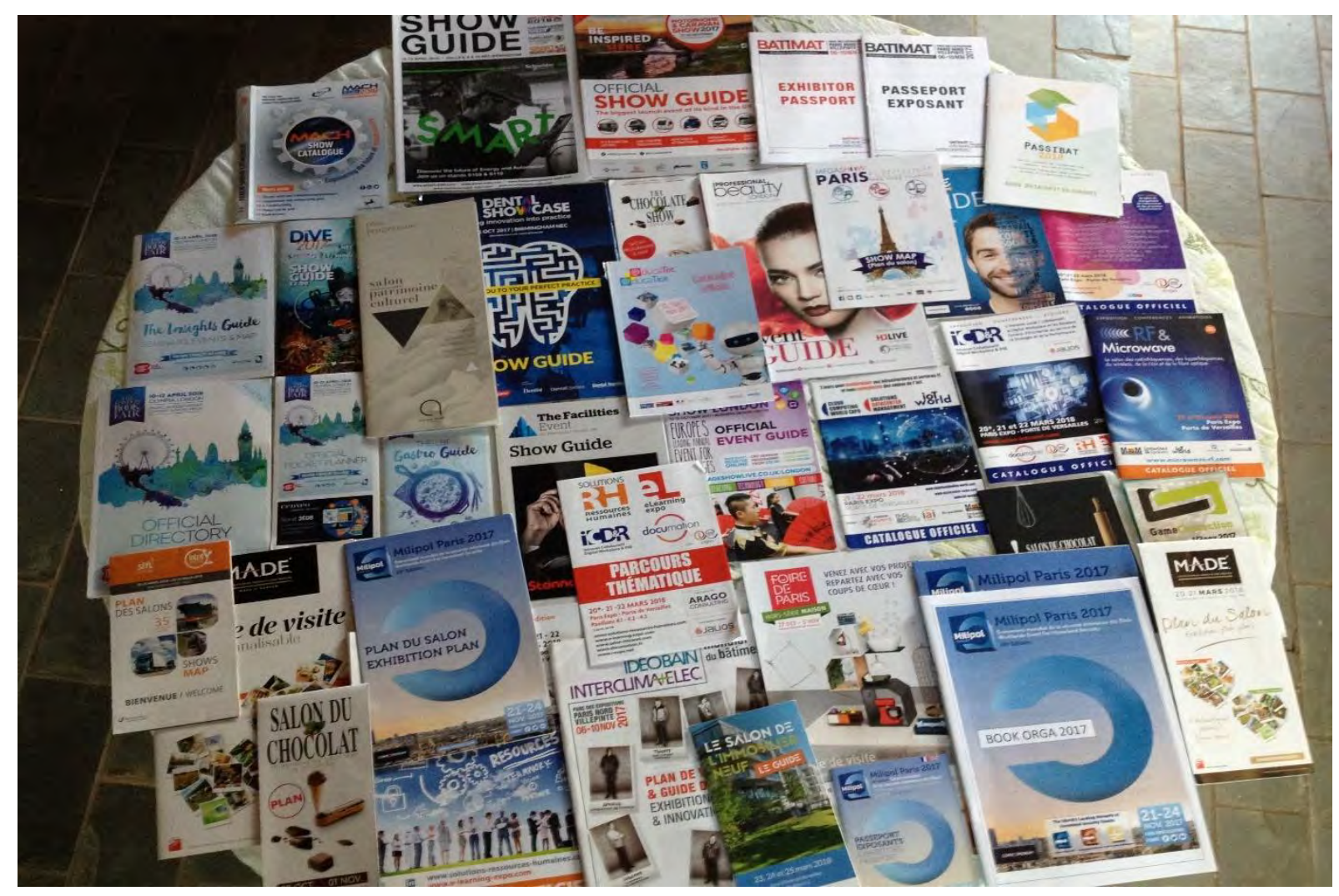

Materiais coletados durante as visitas às feiras

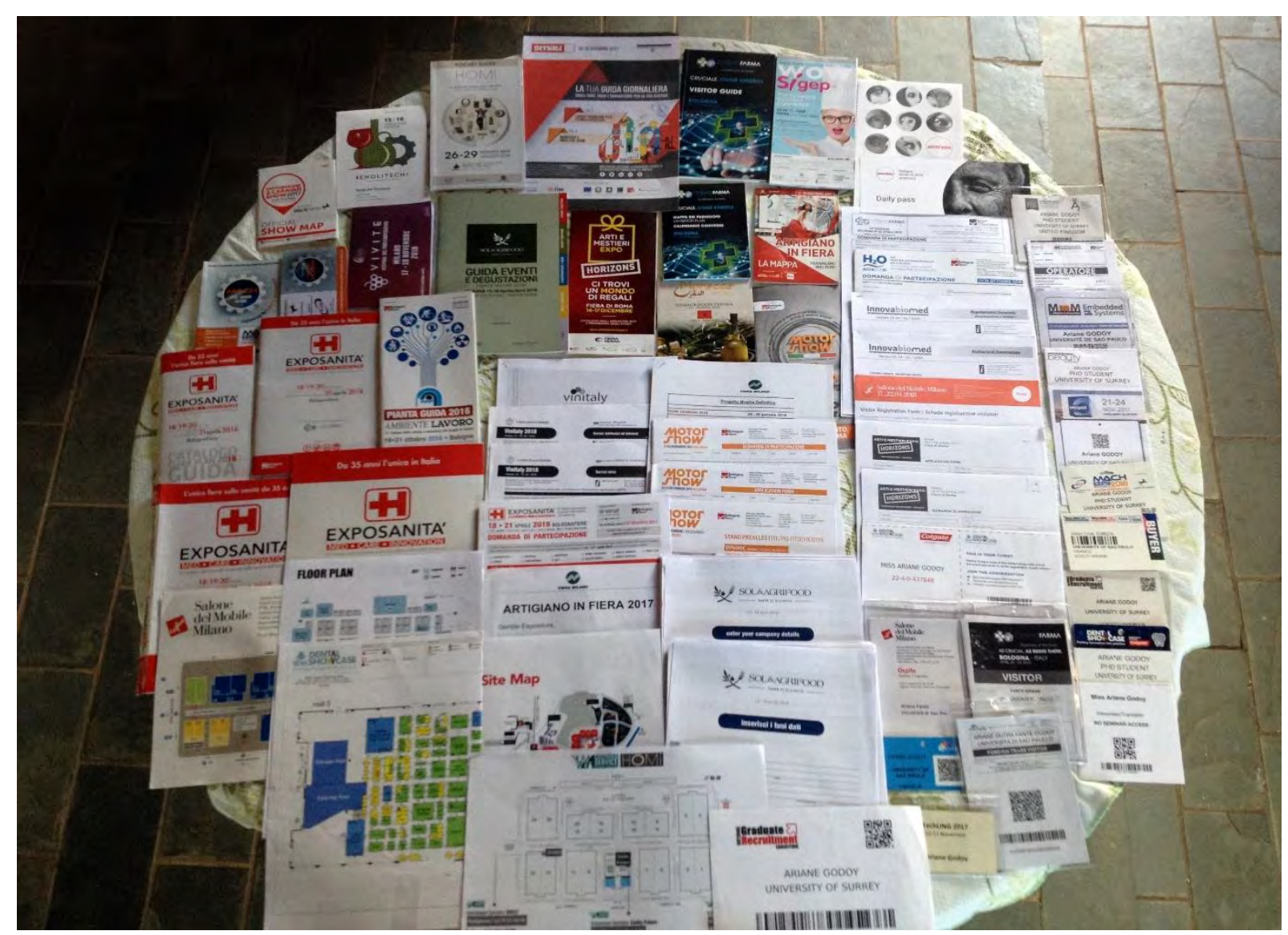

Materiais coletados durante as visitas às feiras 